
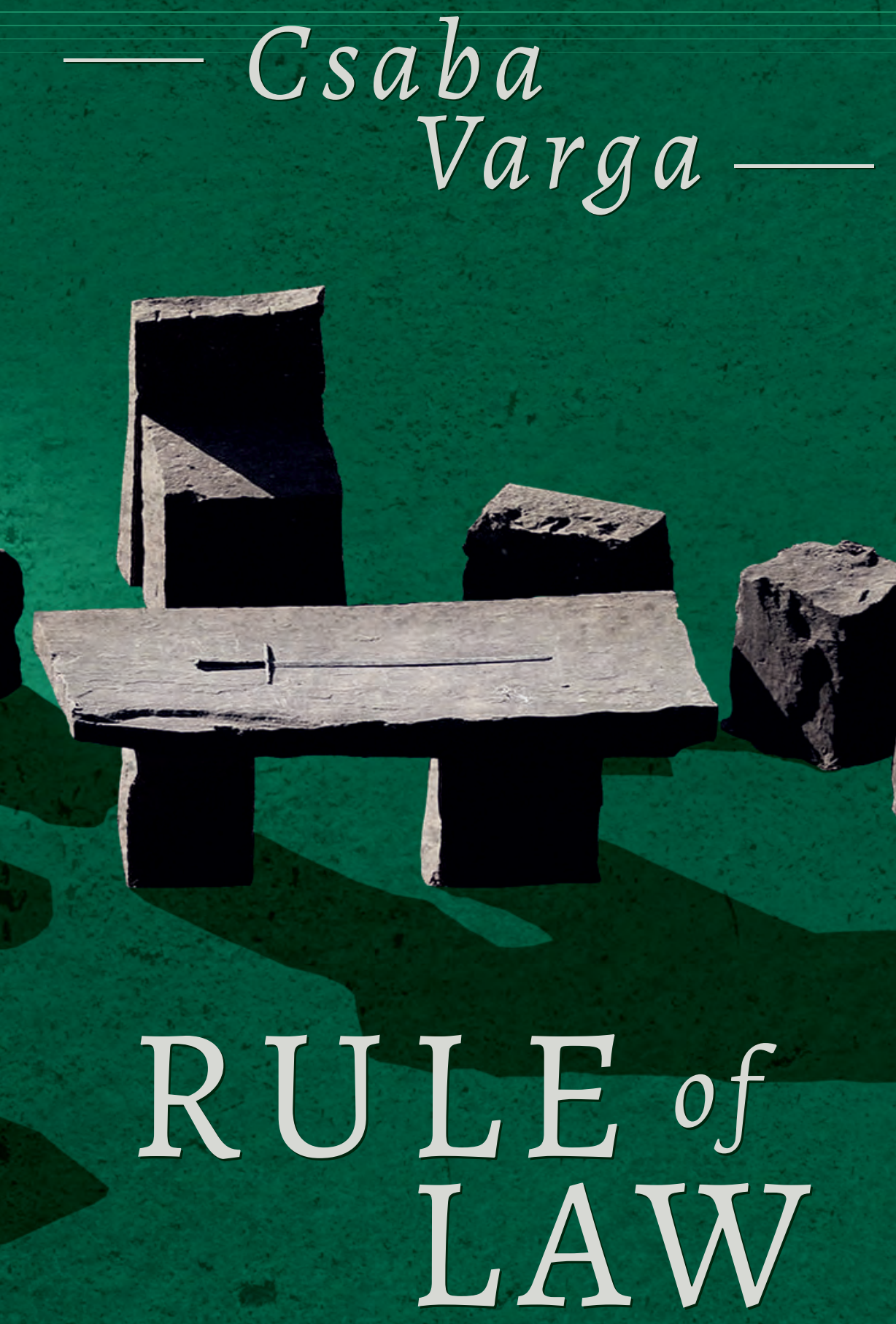

Contesting and Contested 



\section{RULE OF LAW}

Contesting and Contested

CSABA VARGA 



\section{RULE OF LAW Contesting and Contested}




\title{
Rule of Law: Contesting and Contested
}

Csaba Varga

\section{Published by}

Ferenc Mádl Institute of Comparative Law

(H-1123 Budapest, Alkotás str. 55)

\author{
ISBN 978-615-6356-02-4 \\ ISBN 978-615-6356-03-1 (eBook)
}

DOI: $10.47079 / 2021 . c s v \cdot$ rolcac

The cover photo-Oberfreistuhl in Arnsberg-has been downloaded from $<$ https://www.wikiwand.com/de/Oberfreistuhl_(Arnsberg)> under CC BY-SA 3.0 license.

(c) Ferenc Mádl Institute of Comparative Law

(c) Csaba Varga

Typeset and designed by IdeaPlus in Cluj-Napoca, Romania

Printed and bound by AK Nyomda in Martonvásár, Hungary 


\section{CONTENTS}

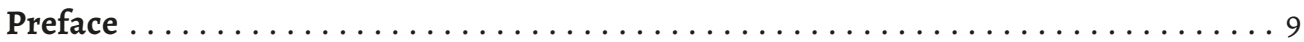

BASICS .15

'Rechtsstaatlichkeit' and 'Rule of Law': Divergent Paths of a Correlated Ideal (1993) . . . . 16 1. 'RECHTSSTAATLICHKEIT' AND 'RULE OF LAW' 1.1. Rechtsstaatlichkeit 1.2. Rule of Law 2. RECHTSSTAATLICHKEIT AND RULE OF LAW AS VARIATIONS 2.1. Rechtsstaatlichkeit and the European Continental Conception of Law (2.1.1. Logical Pattern [a) Axiomatism b) Logical Submission (b.a) Logical determination / (b.b) Normative Definition of a Legal Frame] 2.1.2. Consequences as to the Structure and Ontology of Law [a) Legal Force as the Final Criterion b) Science-and Languagephilosophical Reconsideration (b.a) Law as an Ontology of Concepts and Texts / (b.b) The Role of Logic] 2.1.3. Summary) 2.2. Rule of Law and the Anglo-American Conception of Law 3. THE ROLE OF CONCEPTUAL GENERALITY 3.1 The Paradigm of What the Concept Is 3.1.1. The Tradition of Rome 3.1.2. The Duality of the Humans' Conceptual World 3.1.3 'Concept of Order' in the Law? 3.1.4. Different Approaches to Law? An Eventual Commonality of Law?)

OUTLOOKS.

Hyperrationality Standing for Anarchy in America (A Case Study on the Pattern of the Judicial Mind) (2002) . . . . . . . . . . . . . . . . . . . . . . . 34 1. THE BACKGROUND 1.1. Transformations in Law and Legal Mentality 1.2. Changes in the Juristic Ethos 2. THE AMERICAN SCENE 2.1. Legislation through Processualization 2.2. Hyperrationalism 2.3. Example of a Genuine Query: The Lost Property 2.4. Verbal Magic 2.5. Jurispathy 2.6. Self-interest of the Legal Profession? 3. CONCLUSION 3.1. Postmodern Primitivization 3.2. The Final Query

In Want of New Balances in Transition: Lithuania Searching for Its Own Path (2004). . . 50 1. TRANSITOLOGY QUESTIONED 2. LITHUANIA 2.1. Ideal: Law and Balance 2.2. Ideal: Rights Counterbalanced by Duties 2.3. Anything Except Democracy in Outcome 2.4. Legal Personalism as a Response 3. A CALL FOR LOCAL EXPERIENCE ASSESSED

Global Changes and Challenges to Law: Immutability and Mutability in Law (2013) . . . . .61 1. Introduction 2. Challenges in Need of a Direct Response 3. New Dimensions of Law 4. Changes in Law 5. New Paradigm in Understanding Social Order

TRANSITION .

Rule of Law: Imperfectly Realized, or Perfected without Realization? (2000) . . . . . . 72 1. Declarations 2. Question marks

Rule of Law - At the Crossroads of Challenges (2002) . . . . . . . . . . . . . 79 1. Law: Values \& Techniques 2. Human-centeredness and Practical Orientation 3. Theological and Anthropological Foundations 4. An Irreplaceably Own Task 5. Recapitulation 6. A Final Remark in Comparison 
Transition Marshaled by Constitutional Court Dicta under the Cover of Rule of Law (A Case study of Hungary) (2006) ............................... 100 1. Transitions in the Age of Globalization 2. Constitutional Assessment: The Hungarian Way 3. Example: Human Dignity in Isolation and Sterility 4. Public Law Privatized with the State Targeted as the Common Enemy 5. A Future without Past 6. Legality with Justice Silenced: Crimes Unpunished 7. Rule of Constitutional Court Dicta, not of Law 8. A Self-image in Reverse

The Revolution of 1956 in the Judgment of Ethics and Law (Or the Responding Ability of

Law as a Post-totalitarian Dilemma (2006) . . . . . . . . . . . . . . . 132

1. Law and Socio-ethical Foundations 2. The Sine Qua Non of an Ethical Minimum in Law 3. 1956s Drama in Hungary 4. The Law Silenced Afterward

'Fight for Law' (Lessons from our Constitutional Debates) (2011) . . . . . . . . . . . . 142 1. 'Twenty Years of Freedom in Central Europe' 2. Globalism? Cosmopolitanism? 3. Do we Need New Law? Do we Need a New Constitution? 4. Has our 'Transition to Rule of Law' so far Proved to be a Dead End? 5. So what is the Concept of Law that is so Persistently Inculcated in Us?

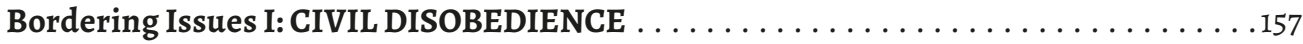

The Challenge by the Taxi Blockade (1991) . . . . . . . . . . . . . . . . . 158

1. What is Law? 2. What is the Law's Message for a Given Situation? 3. Law and its tertium non datur 4. Legal Assessments are to be Heard

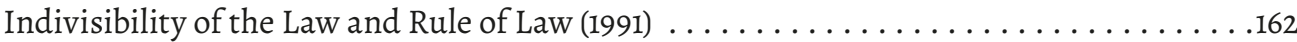

Civil Disobedience: Pattern with no Standard? (1991) . . . . . . . . . . . . . . 166 1. The Background 2. The Task 3. Civil Disobedience (3.1. Analysis 3.2. Summation) 4. Concluding Remarks

Crossroads of Civil Obedience and Disobedience (A Moment of Constitutional Impotence in Hungary) (2007) . . . . . . . . . . . . . . . . . . . . . . . . . . . . . . . . 174 1. Civil Disobedience 2. Civil Obedience

Bordering Issues II: COMING TO TERMS WITH THE PAST . . . . . . . . . . . . 183

On Setting Standards (Or the Dilemma in General (1990) . . . . . . . . . . . . . . . 184 1. Intellectual Climate and Arguments in Favor 2. Strategic Ends and Considerations of Principles 3. A Legal Solution?

The Right to Judge the Past (Or the Dilemma in Legal Particulars) (1990) . . . . . . . . . 192 1. Law is Law 2. Law is Continued 3. Rule of Law as a New Base 4. Rule of Law in Exceptional Situations 5. The Case of a State Non-abiding by its Law 6. The Variety of Paths and Ways in Law

'Radical Evil' on Trial (On the Historical Setting, Political Aspects and Legal Conditions of Transitional Justice Facing the Crimes of Dictatorial Regimes) (2002) . . . . . . . 200 1. THE QUEST 2. HISTORICAL BACKGROUND 3. NORMATIVE DIMENSIONS (3.1 Political Aspects 3.2 Moral Aspects 3.3 Legal Aspects) 4. THE TURN OF IDEAS 5. CONCLUSION

Why Having Failed in Facing with the Past? (2003) . . . . . . . . . . . . . . . 213

Coming to Terms with the Past under the Rule of Law (2009) . . . . . . . . . 221

1. When a Criminal Past is over 2. "Radical Evil on Trial" 3. Attempts at Resolution in Hungary

4. Constitutional Counterrevolution 5. Perspectives? 
Retroactivity in Law (1999)

1. Preliminaries 2. Neutrality of Legal Techniques

Bordering Issues III: HUMAN RIGHTS

The Problematics of Human Rights $(2013) \ldots \ldots \ldots \ldots \ldots \ldots \ldots \ldots \ldots$

1. Historical Outline of Human Rights 2. The Foundation of Human Rights 3. The Nature of

Human Rights 4. The Universality and/or Particularity of Human Rights 5. Conclusion

PUZZLES AND THEORIES

Rule of Law, or the Dilemma of an Ethos: To be Gardened or Mechanized? (2007) . . . . 266

1. Models of Post-dictatorship Transition: US Patterns and Understanding of the Rule of Law

2. Rule of Law: Universal vs. Particular 3. Risk of Transfers and Impositions 4. Circus Trainer and Gardener Approaches to Target Laws 5. From Nihilism to Fetishism in Constitutionalism Reviewed: German and Hungarian, Post-WWII and Post-communism Types

Transition in Hungary, Or What to Learn for Future Transformations? (2014) . . . . . . 282

1. Introduction: On the Call for Early Pre-planning 2. The Assumption 3. Post-WWII and Postcommunist Models 4. The Hungarian Case of System Transformation (No pattern to follow / Models in conflict and flux / Lack of balanced planning / Multi-party democracy with opposition: risks with stability evaporating / Prevalence of juristic considerations / Self-interest dressed as Western help / Discontinuity with the past rejected: it is more established than ever / Dividedness with media power / Academia/universitas unchallenged: Moscow vassalism changed into global universalism) 5. Conclusion 6. Policy during the Process

Ideal or Idol? Traps in Understanding the Rule of Law (2015) . . . . . . . . . . . 300 1. The Mainstream US and EU Models 2. The Genuine Message of the Rule of Law 3. Moves under the Aegis of the Rule of Law 4. The Genuine Issue: Who is to Master Whom 5. Limited Commensurability of Legal Regimes

Rule of Law, Rechtsstaatlichkeit, État de Droit - Contesting and Contested (2021) . . .

1. Post-WWII Rebirth and Transformation into a Catchword 2. Limitlessness in Today's Use

3. Roots and Development in Various Legal Cultures 4. The Genuine Content of their Referencing

Bibliography.

Index

Index of Sources of Law . . . . . . . . . . . . . . . . . . . . . . . 398

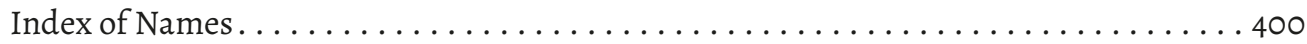





\section{PREFACE}

Almost out of nowhere, a not particularly exciting concept that has been hitherto unknown, if not exactly unknown, has burst into the international arena and into the almost everyday life of our entire global village world, which in our (mainly Austrian-German-influenced Hungarian) areas, we have been calling the legal state [jogállam] for about three and a half decades and in the last one or two decades also increasingly-if we express ourselves accurately in our terminology—-the rule oflaw [joguralom].

When we were doing our doctorate in 1965 in Pécs, where state law and state administration law, which were also subjects of the complex state examinations for the graduation from the faculty of law and was in the hands of the nationally outstandingly active scholars at the departments like OtTó BiHARI ${ }^{1}$ and LAjos SzAmel, and legal theory was taught by the equally well-read MiнÁLy Szotáczky, we hardly ever heard of such a thing, and such concepts were hardly ever mentioned. Yet it was around 1965 that the always clever and sad LÁszló SzTODOLNIK began to regularly visit our Pécs legal theory department. Right on the borderline between the history of political ideas and science of the state, he devoted the first serious paper in Hungarian MARxist scholarship to the Rechtsstaat ${ }^{2}$-and rightly so, as this topic was part of the German developments of the so-called bourgeois state theory [Staatslehre] at that time: an issue of the form of the state [Staatsformslehre], if at all. Although our discipline was then officially called Marxist state and law theory, it is precisely this first subfield that never appealed to me: as a summation of LENIN's theory of power, it had a direct political charge and could hardly be called a science.

I became a reader of its excellent library, while working in the said department as a student-assistant. I wondered why a Polish great man I got to know at the time (and later

I See Bihari, Ottó (1970) Socialist Representative Institutions. Budapest: Akadémiai Kiadó 279 pp. and Bihari, Ottó (1979) The Constitutional Models of Socialist State Organization. Budapest: Akadémiai Kiadó 371 pp., in addition to Bihari, Ottó (1967) Összehasonlitó államjog: az állami szervezet felépitése és intézményei a mai kapitalista, szocialista és felszabadult, volt gyarmati országokban [Comparative state law: the structure and institutions of state organisation in today's capitalist, socialist and liberated former colonial countries]. [Textbook.] Budapest: Tankönyvkiadó $381 \mathrm{pp}$.

2 Sztodolnik, László (1963) 'A jogállam eszméjének színeváltozásai' [The changing face of the idea of the rule of law], A Budapesti Eötvös Loránd Tudományegyetem Állam-és Jogtudományi Karának Actái, IV(1), pp. 143-163. 
became a friend) should be concerned with such an ephemeral topic, ${ }^{3}$ and I hardly understood why I should even pay attention to this concept, if even in the opinion of its classic scholar, ${ }^{4}$ it is nothing but the most simplistic generalization? Which, in the context of words, is no more than the German quintessence of Das Recht is das Recht [The law is the law]? My abstinence from this empty buzzword has remained throughout the quarter of a century, from the time I graduated until the collapse of the Soviet empire when I was researching at the Institute of Legal Studies of the Hungarian Academy of Sciences, from where I was able to make frequent trips to several countries like Australia and Japan, the two American continents, and of course, the universities of Western Europe.

It was not until the end of the communist regime imposed on us that 'Rechtsstaatlichkeit' and 'rule of law' entered the vocabulary of the critique of dictatorship. However, it changed color after the beginning of our political and social reconstruction. It was precisely as an impediment to our intention to renew the country that the newly established Constitutional Court ${ }^{5}$ turned it into a bludgeon to build roads that would impose complete legal continuity in the name of legal certainty, deterring both parliament and government from action and exposing the country to the West, which was waiting for its prey.

The term thus began its career as a rallying cry, a symbol of the rejection of "actually existing socialism." It could easily have become a flag of the transition since its popularity was crowned by against what and why. However, as soon as it became a panacea in the hands of this Constitutional Court, inspiring it to make anything that could have prevented the anarchic plunder that was robbing our country and that could have promoted a new order impossible - a confrontation with half a century of Asian depredations-it became a cuss word despite its apparent power. It was synonymous with the fact that instead of advancing public affairs, the press was full of constitutional impossibilities since this first-term Constitutional Court had always been engaged in a struggle for power to define the law, against which politics, science, and common sense could only remain irrelevant private opinions.

3 Opałek, Kazimierz (1964) 'The Rule of Law and Natural Law' in Festskrift tillägnad Karl Olivecrona. Stockholm: Almquist and Wiksell 765 pp. on pp. 497-507.

4 Dicey, A. V. [1885] Lectures Introductory to the Study of the Law of the Constitution. 1st ed. J. W. F. Allison. Oxford: Oxford University Press, 2013 xlvii+522 pp. [The Oxford Edition of Dicey I].

It is worth noting that, as was often the case at the time, the Hungarian translation was published at the same time as the major nations came up with translations of the same classic; e.g., see (1902) Bevezetés az angol alkotmányjogba. Budapest: Magyar Tudományos Akadémia xv+412 pp. [Új folyam LII] \& <http://real-eod.mtak. hu/3303/> \&<https://archive.org/details/bevezetsazangolookautgoog/page/n193/mode/2up > and (1902) Introduction à l'étude du droit constitutionnel. Paris: V. Giard et E. Brière xxxii+474 pp. [Bibliothèque internationale de droit public]; while a German translation was only produced after more than a century: (2002) Einführung in das Studium des Verfassungsrechts. Baden-Baden: Nomos 483 pp.

5 Cf. Prochazka, Radoslav (2002) Mission Accomplished: On Founding Constitutional Adjudication in Central Europe. Budapest - New York: Central European University Press xiv+358 pp. 
All this did not take place in a vacuum, of course. In the meantime, the outside world had changed, and we were faced with a completely new mentality. Because of our Soviet occupation, we were unaffected by the intellectual and moral renewal and the legal and practical impact of the postwar European legal order, just as we did not take the changes that came with earthquake-like force and devastating consequences after $1968^{6}$ as a burden on our own future. We perceived them as a sinking, a decline, but more as a byproduct of the West's wealth, recovery, and sense of security, which can afford such exaggerations and deviations, than as a symptom of crisis.

Of course, even the Soviets did not realize that in transforming the Western image of law into socialist legality with the STALINIST regime, VYSHINSKY was living a phantom that LENIN had perceived when he was in Switzerland, but which had long since been superseded by the free-law school [freie Rechtswissenschaft] and other trends. Nevertheless, even we did not realize, more than half a century later, that our expectation of the West was the result of our common experiences before the war and of our integration at the time. This, however, was already surpassed by the postwar natural law and all that had led to a change of emphasis in the relationship between ius and lex.

Some decades ago, Atlantic and Western European humanity entered a new arena:

What dominates the landscape of our contemporary law is nothing less than the immense disorder of a world fragmented to the extreme, pushed out of its proper place by an anarchic globalisation, while it has been uniformised too quickly by a hegemonic integration in the silence of the market and the clash of arms. ${ }^{7}$

What happened then? In the promise of its power, conscious of its economic and social strength, the western world began to fulfill "the end of history," relying on rationalistic selfmanagement. It has thus stripped itself of all that the historical ages had once set up as a limit

6 Cf. Varga, Csaba (2012) 'Humanity Elevating Themselves? Dilemmas of Rationalism in our Age' in Varga, Csaba Comparative Legal Cultures: On Traditions Classified, their Rapprochement \& Transfer, and the Anarchy of Hyperrationalism. Budapest: Szent István Társulat 253 pp. [Philosophiae Iuris] \&<http://mek.oszk.hu/15300/15386> on pp. 131-163, based also on a bitter summary by Bork, Robert H. (1996) Slouching towards Gomorrah: Modern Liberalism and American Decline. New York: Regan Books xiv+382 pp.

7 Delmas-Marty, Miraille (2006) 'Le pluralisme ordonné et les interactions entre ensembles juridiques', Recueil Dalloz, ${ }^{\text {er }}$ Cahier (rouge) 182(14;No.7243), pp. 951-957 \& in <http://www.ieim.uqam.ca/IMG/pdf/article_Dalloz. pdf>, p. 951 ['Ce qui domine le paysage juridique actuel, c'est le grand désordre d'un monde tout à la fois fragmenté à l'excès, comme disloqué par une mondialisation anarchique, et trop vite unifié, voire uniformisé, par une intégration hégémonique qui se réalise simultanément dans le silence du marché et le fracas des armes.']

8 Fukuyama, Francis (1992) The End of History and the Last Man. New York: The Free Press xxiii+418 pp., as well as Luzkow, Jack Lawrence (2003) The Revenge of History - Why the Past Endures: A Critique of Francis Fukuyama. Lewiston, N.Y.: Edwin Mellen Press ix+268 pp. [Problems in Contemporary Philosophy 57] and de Berg, Henk (2007) Das Ende der Geschichte und der bürgerliche Rechtsstaat: Hegel - Kojève - Fukuyama. Tübingen: Francke Verlag 285 pp. 
and restraint, as the wisdom of the limits of our free will. It has universalized, transcending the natural constraints of man, extending its own politics and making it the starting point for a universal vision of the world. Freedom, democracy, human rights, parliamentarism, constitutionalism? It rewrote the oldest known values of humanity and its aspirations for the social good based on its own liberal dogmas, by which it freed us from everything. Today, of course, it stands without a grip and is emptied of all real characteristics. It is no coincidence, then, that the description of the new us is that "at present there is no concept of European identity that is acceptable to the peoples of Europe, giving them a sense of belonging to something, like the concept of nation in the nineteenth century."

Structurally, our legal thinking has also undergone a transformation, which is, among other things, marked by

- the breakdown of the traditional balance between rights and duties, at the expense of the exclusivity of the former;

- the reform of the legal order itself and its functioning on the basis of human rights and constitutional \& rule of law criteria;

- the postmodern deconstruction of formal law's binding force in multi-factorial, multicultural democratic processes; $;^{10}$

- the replacement of rule-based judiciary by principled reasoning;

- the placement of judging into the ultimate value-instrumentalizing decision-making position.

All this is no longer part of a culture, a lesson, or a learning process but of the master pattern itself, for "the design of the future was imported." It is a design of detachment from

9 Šejvl, Michal (2008) 'European Identity and European Citizenship: the Case of Missing Polis?', International Journal of Public Administration in Central and Eastern Europe [Budapest], 2(2), pp. 49-56 at pp. 52-53.

10 Cf. Melkevik, Bjarne (1998) 'Penser le droit québécois entre culture et positivisme: Quelques considérations critiques' in Melkevik, Bjarne (ed.) Transformation de la culture juridique québecoise. Québec: Presses de l'Université Laval pp. 9-21 at p. 15 and, as a background, Varga, Csaba (2003) 'Meeting Points between the Traditions of English-American Common Law and Continental-French Civil Law (Developments and Experience of Postmodernity in Canada)', Acta Juridica Hungarica, 44(1-2), pp. 21-44 \& <https://akjournals.com/ view/journals/026/44/1-2/article-p21.xml>.

11 Offe, Claus (1997) 'Cultural Aspects of Consolidation: A Note on the Peculiarities of the Post-communist Transformation', East European Constitutional Review, 6(4), pp. 64-68 at p. 65.

It was already a frightening realization at the time how, with unscrupulous automatism, the totally ignorant of our region had shoved the democratic transition issues of Central and Eastern Europe, which were complicated in themselves, into the South American problems on which they had been working; see e.g., Linz, Juan J., Stepan, Alfred (1996) Problems of Democratic Transition and Consolidation: Southern Europe, South America, and Post-communist Europe. Baltimore: Johns Hopkins University Press $\mathrm{xx}+479 \mathrm{pp}$.

It is an anecdotal analogy that a distinguished Flemish clergyman musicologist had been researching BÉLA BARTók and his art while living in Hungary since World War II for several decades, even as director of the Bartók Archivum for a decade, and although he wrote a great deal - Lenoir, Yves (1993-1994) 'Bibliographie 
historical experience and social bondage and of what no longer matters-neither the national uniqueness we have lived hic et nunc nor the preservation of our own identity. Instead, here we have global universalization and ahistorical universality, the revelry of the perpetual honeymoon period, ${ }^{12}$ the freedom to want anything-just want it!

From its role as the world economic center, this center of power began to globalize the remnants of what was called the periphery. Its comprehensive movement of capital was based on an almost mechanical extension of its own economy-centered worldview, its political credo, its legal system, and its scientific thought, which generalized its experience. In so doing, it institutionalized a worldwide transfer of laws, from which it had to admit that it had failed everywhere because of its dysfunctional origins ${ }^{13}$ but which, in the overall effect, proved successful. For although it has dismantled everything else but itself, it has somehow managed to lay down its own foundations. By shattering the traditions that had hitherto ensured cohesion and survival, it has created a society of wreckage. ${ }^{14}$ The lesson is that the total combined effect of total pressure can ultimately prove irresistible.

I myself returned from long trips to the Australian National University (Canberra), Waseda (Tokyo), Yale University (New Haven), and finally the Institute of Advanced Studies in the Humanities (Edinburgh), practically just before the regime change, with programs in the philosophy of law. The new government had by then been formed, and I helped the new start in the Foreign Affairs and Legal Committees of the vacated party headquarters. In just one year and a half of reconstruction, the scandal of the taxi blockade ${ }^{15}$ had already demonstrated to both itself and the outside world the country's vulnerability due to the nearbankrupt financial exposure left over from communism and the complete division provoked by its opposition changing from communist internationalist to liberal cosmopolitan. Shortly after, I was appointed as a senior advisor to the prime minister's advisory council, working mainly on national strategy and its institutional security and national security aspects. In the absence of other lawyers dealing with background theoretical topics, it was in this area of interest that I began to wonder about the role of law, including the rule of law. I have traveled and published extensively on this subject. The abuse of the Constitutional Court of Hungary's

de Denijs Dille', Studia Musicologica Academiae Scientiarum Hungaricae, 35(1-3: Denijs Dille Nonagenario), pp. 7-33, at the end of his life, he had to admit that he had in fact barely been able to get to the personality and culture that surrounded him.

12 Cf. Brinton, Crane (1935) The Anatomy of Revolutions. New York: W. W. Norton 326 pp.

13 Cf. Gardner, James A. (1980) Legal Imperialism: American Lawyers and Foreign Aid in Latin America. Madison: University of Wisconsin Press xii+401 pp. and Varga, Csaba (2007) 'Reception of Legal Patterns in a Globalising Age' in Calera, Nicolás López (ed.) Globalization, Law and Economy / Globalización, Derecho y Economía: Proceedings of the $22^{\text {nd }}$ IVR World Congress. Vol. IV. Stuttgart: Franz Steiner Verlag pp. 85-96 [ARSP Beiheft 109] \{reprinted in <http://mek.oszk.hu/15300/15386>, pp. 181-207\}.

14 E.g. Gaudemet, Jean (1976) 'Les transferts de droit', L'Année sociologique, 27, pp. 29-59.

15 Cf. 'Bordering Issue I: Civil Disobedience' in the present volume. 
use of the rule of law without making it a strictly operative term for law demanded clarification in legal philosophy, and not many years later, we were confronted with the political interest blackmail of the West. The present volume is a selection of such papers.

LECTORI SALUTEM! 


\section{BASICS}




\title{
"RECHTSSTAATLICHKEIT" AND “RULE OF LAW" Divergent Paths of a Correlated Ideal ${ }^{1}$
}

\begin{abstract}
1. "RECHTSSTAATLICHKEIT" AND "RULE OF LAW" 1.1. Rechtsstaatlichkeit 1.2. Rule of Law 2. RECHTSSTAATLICHKEIT AND RULE OF LAW AS VARIATIONS 2.1. Rechtsstaatlichkeit and the European Continental Conception of Law (2.1.1. Logical Pattern [a) Axiomatism b) Logical Submission (ba) Logical determination / bb) Normative Definition of a Legal Frame] 2.1.2. Consequences as to the Structure and Ontology of Law (a) Legal Force as the Final Criterion b) Science- and Language-philosophical Reconsideration (ba) Law as an Ontology of Concepts and Texts / bb) The Role of Logic] 2.1.3. Summary) 2.2. Rule of Law and the Anglo-American Conception of Law 3. THE ROLE OF CONCEPTUAL GENERALITY 3.1 The Paradigm of What the Concept Is 3.1.1. The Tradition of Rome 3.1.2. The Duality of the Humans' Conceptual World 3.1.3 "Concept of Order" in the Law? 3.1.4. Different Approaches to Law? An Eventual Commonality of Law?)
\end{abstract}

\begin{abstract}
Rechtsstaatlichkeit, in its historical background with princely authority into which ultimate trust of the population can exclusively be placed, strives to achieve its goals through comprehensive and across-the-board regulations issued by the force of state authority. It attaches guarantee to each aspect that it wishes to protect through these regulations. Its overall conception of law postulates that we subject ourselves to the authority of a text; this accounts for the axiomatic ideal and logical pattern of legal thinking, rooted in the ideal according to which mental operation in law is basically a sequence of logical submission and, in the form of normative syllogism, also the sequence of a series of deductive conclusions. Conversely, the Rule of Law rests on the principle of all-covering justiciability, and all it institutionalizes is the right to contact a judicial forum for a definitive legal verdict via due process in any case that may have legal relevance. As an offspring of British and American historical experience, it trusts the self-reconstruction of social processes by themselves, considering both the self-organization and the permanent renewal of societal processes the foundation on which the legal system also rests. This historical experience has not elevated artificial human constructions to the role of the buttresses of continuity; accordingly, the law is not embedded symbolically in the concrete, but it rests on the natural self-organization of human processes themselves. Law is committed to the care of the continuity of organic social existence.
\end{abstract}

KEYWORDS Continental and Anglo-American understandings of law; ontology of law; structure of law; conceptualities in law; logic in law

1 Originally, the paper was commissioned as an address to the conference organized by the Section II (Philosophy and Historical Sciences) of the Hungarian Academy of Sciences on legality and morality in 1993. Earlier versions in English include (1996) 'Varieties of Law and the Rule of Law', Archiv für Rechts- und Sozialphilosophie, 82(1), pp. 61-72; reprinted in Varga, Transition, 1995, pp. 159-173; shortened as 'The Basic Settings of Modern Formal Law' in Gessner, Volkmar, Hoeland, Armin, Varga, Csaba (eds.) (1996) European Legal Cultures. Aldershot, Brookfield USA, Singapore, Sydney: Dartmouth xviii+567 pp. [Tempus Textbook Series on European Law and European Legal Cultures 1] on pp. 89-103; redrafted as (2014) 'Fight for Law; or What Does Rule of Law versus Rechtsstaatlichkeit Mean?' Central European Political Science Review, 15(No.56), pp. 16-45. 
When the countries of Central and Eastern Europe set out to achieve and institutionalize/re-institutionalize the Rule of Law on the ruins left by the local variants of Bolshevism a few years ago, they may have failed to completely understand how remote and obscure the goal was. This, of course, is justifiable to a great extent since the priority at the time was to assimilate, step by step, parts of their political and economic establishment to the ones in the Western and Atlantic world without better understanding of what those parts meant and served for because never practiced and experienced-at least since the Second World War had ended for them by the victors' shameful Yalta Agreement, giving up the region to the mercy of STALIN's regime. As known, throughout the modern times, Central and Eastern Europe have been patterned both culturally and institutionally mostly by Germany and Austria, albeit there has been strong French influence on Slavic and Romanian developments, and quite often, various Western European, British, or even American values have also reached the region, even if mostly through channels in Vienna, Munich, or Berlin.

The mainstream catchword treated in the present paper has a number of meanings, with a few shifts of emphasis having occurred mostly due-and in parallel - to the growing expansion and over-generalization of its use, from international democracy studies to comparative economic analysis and from diplomatic talks to relief project priorities. All that notwithstanding, instead of either the inevitable self-emptying of the term, subsequential to its politically motivated simplified and schematic use $e^{2}$ or the dubious attempt at using it - in vain and successful exclusively as a veil to hide the absolutism in the background-as an operative term able to define anything of a criterion in constitutional adjudication, ${ }^{3}$ the following developments are only dedicated to clear up what mentality, ideal of social order, and primitive ideas on how such an order can be best secured and what instrumentality developed for the latter's service stand behind the historical experience cumulated in the cultures of civil law and common law, respectively. One has princely authority onto which the ultimate trust of the population can exclusively be placed, and the other has lived through the success of some sort of both social civic self-organization and the testing of self-realizing organicity. Or, as the classic of the American legal thought formulated it more than 140 years

2 Cf. Varga, Csaba (2008) ‘Jogi kultúránk - európai és globális távlatban’ [Our legal culture in a European and global perspective] in Paksy, Máté (ed.) Európai jog és jogfilozófia: Tanulmányok az európai integráció ötvenedik évfordulójának ünnepére [European law and legal philosophy: Papers to the fiftieth anniversary of European integration]. Budapest: Szent István Társulat 397 pp. [Jogfilozófiák] on pp. 13-42.

3 See, from an American point of view, the variety of components with layers (in function of varying approaches) and chances of contradictions in their undifferentiated use, Fallon, Richard H., Jr. (1997) "The Rule of Law" as a Concept in Constitutional Discourse', Columbia Law Review. 97(1), pp. 1-56, and from a Hungarian viewpoint, a case of abusive misuse concealing nothing but tyrannic discretion, Varga, Csaba (2008) 'Transition Marshalled by Constitutional Court Dicta under the Cover of a Formal Rule of Law (A Case-study of Hungary)', Central European Political Science Review, 9(No.32), pp. 9-48 \{reprinted in \& <http://mek.oszk. hu/14800/14851>, pp. 117-160\}. 
ago, ${ }^{4}$ looking ahead from his local and timely perspective, defining thereby in a clear-cut manner what his own tradition was,

The life of the law has not been logic: it has been experience. The felt necessities of the time, the prevalent moral and political theories, intuitions of public policy, avowed or unconscious, even the prejudices which judges share with their fellow-men, have had a good deal more to do than the syllogism in determining the rules by which men should be governed. The law embodies the story of a nation's development through many centuries, and it cannot be dealt with as if it contained only the axioms and corollaries of a book of mathematics.

\section{1. "RECHTSSTAATLICHKEIT" AND “RULE OF LAW”}

Rechtsstaatlichkeit, with roots in the European continental traditions and especially developed through German and Austrian mediation into a culture itself, differs in its whole outlook from the concept of Rule of Law, which was conceived in and reflected the British and American legal mentality.

Succinctly expressed, Rechtsstaatlichkeit strives to achieve its goals through comprehensive and across-the-board regulations issued by the force of state authority; it attaches a guarantee to each aspect it wishes to protect through these regulations. Conversely, the Rule of Law rests on the principle of all-covering justiciability. All it institutionalizes is the right to contact a judicial forum for a definitive legal verdict via due process in any such case that may have legal relevance.

These should not be seen merely as two different legal techniques. Instead, they represent two different approaches rooted in two different cultures. Albeit both are variations within the ideal of ordo-social order- to be assured by the means of law, they are as markedly different as if they had nothing to do with each other but were differing responses to differing questions.

\subsection{Rechtsstaatlichkeit}

The conceptual culture of Rechtsstaatlichkeit rests on certain historical presuppositions. Among them, I must formulate that

4 Holmes, Oliver Wendell (1881) The Common Law. Boston: Little, Brown xvi+422 pp. \&<http://www.constitution. org/cmt/owh/commonlaw.txt> Lecture I. 
- the present is, by definition, free and unrestrained. It cannot be bound by the past. Laws are shaped by the state, which in turn is dependent on the prevailing discretion of the ruler (either prince or popular representation); and

- human activities can be regulated through their submission to normative frames by the legal enactment of orders. Consequently,

- for the law to play a controlling role, the need exists for us to introduce appropriate legal regulations, to which we can subject human and/or institutional activities.

The continental legal culture that stands behind the idea of Rechtsstaatlichkeit entails further tacitly approved inferences. On their grounds, we postulate that

- only and exclusively a written code or charter can provide guarantees in law in respect of both the one who has issued it and the one to whom it has been addressed. The lack of such a code would result in insecurity, disorder, and even chaos;

- the written code spells out all the rules of the game that the circle of addressee is expected to follow. This represents the sole and exclusive basis for the social contract on which social order rests. Consequently,

- any update or modification of this contract can only be implemented through the alteration (amendment or replacement) of the charter. Furthermore, the only possible interpretation of a shift in approach to (getting relatively stricter or more liberal) any legal situation is that we abide by the codified commands in a shifted (relatively stricter or more liberal) way.

\subsection{Rule of Law}

The conceptual culture of the Rule of Law rests on different foundations and has its roots in different historical experiences. Unlike the previous concept, here it is tacitly inferred that

- laws are coeval with humankind, and the law, which is made of the immemorial custom of the Realm having ever prevailed in the nation's history, has always been applicable and reliable. Consequently,

- under the Rule of Law, the only task is to make certain that no one can evade the jurisdiction of a judicial forum in any case to which laws are applicable. At the same time, this also implies that

- the immemorial custom that the law is a temporary expression of is not subject to changes or innovations. The questions addressed to the law can refer to its actualization only. 
Here again, the acceptance of this conceptual culture implies certain tacit theoretical conclusions. Inherent in the British and American approaches to law are the following considerations:

- confidence in social automatism backing the law's regime. In other-and rather figurative-words, it is taken for granted that in the final account, with the support of tacit traditions born in a well-developed society, the law can organize itself and its own operation based upon the channels established through generations. For this reason, it can also function by itself-only provided that the tradition is not broken, and its legal components are not stamped out (which, in fact, has never been the case in British or American legal history);

- the realization that the society's only task with law is to let it operate freely. The law will certainly organize whatever it deems necessary for its operation;

- the realization that the law must not be provoked or forced to provide answers. We, humans, must not try to influence the operation of the law. All that society needs to do is take interest in the law and heed the conclusions generated by the legal system.

\section{RECHTSSTAATLICHKEIT AND RULE OF LAW AS VARIATIONS}

It goes without saying that the above differences are rooted in the differing perceptions of situations and problems and especially of the kind of ordo that the law can implement. These perceptions are determined by the Weltanschauung and the basic conception of law developed by the legal profession, by the ideologies serving the legal profession, and consequently by the traditionally accepted and conventionalized legal techniques.

\subsection{Rechtsstaatlichkeit and the European Continental Conception of Law}

The continental conception of law, on which the ideal of Rechtsstaatlichkeit rests, postulates first and foremost that we subject ourselves to the authority-or rule-of a text. This accounts, in the background, for the axiomatic ideal and logical pattern of legal thinking. The latter is rooted in the ideal according to which mental operation in law is basically a sequence of logical submission and, in the classical form of normative syllogism, also the sequence of a series of deductive conclusions. 


\subsubsection{Logical Pattern}

a) Axiomatism

The application of logic to legal thinking means its organization into an axiomatic or quasi-axiomatic system. ${ }^{5}$

The axiomatic system separates the theses that can be established about the world within the bounds of a system (or more precisely, the logical postulates that correspond to such theses) into axioms and theorems.

In this context, theorem is defined as the logical consequence of one or more axiom(s). In other words, the theorem cannot, under any circumstances, be a vehicle for independent thoughts or statements, but it is the product of sheer application, and there is no third choice in an axiomatic system. As a result, all acts that aim to introduce innovations in the system are bound to occur on the level of axioms. An act can be either an axiom or a purely mechanical function resulting from axiom(s).

If a postulate within the system turns out to be unrelated to any of the system's axioms, we must consider this postulate an axiom itself as no system can be built on axioms that contradict each other.

The system is closed also in the sense that its axioms-its foundational theses-are codified by definition; consequently, its theorems are not discretional either. Finally, and in conclusion, the theses within the system are also pre-codified. In other words, none of its systemic elements can be incidental.

For this reason, as stated earlier, if a thesis within the system turns out to be unrelated to any axiom(s), we are bound to consider it a new axiom. However, no new axiom can enter a given system by itself. The result is that any new axiom ruins the old system, unless we can manage to eliminate the thesis in question by proving its untenability. Of course, the fact that the proven tenability of the thesis at issue creates, by definition, a brand-new system eo ipso facto remains.

5 For the approach to law as a system, cf. Varga, Csaba (1987) 'Leibniz und die Frage der rechtlichen Systembildung' in Mollnau, Karl A. (ed.) Materialismus und Idealismus im Rechtsdenken: Geschichte und Gegenwart. Stuttgart: Franz Steiner Verlag Wiesbaden 195 pp. [Archiv für Rechts- und Sozialphilosophie, Beiheft 31] on pp. 114-127 \{reprinted in <http://mek.oszk.hu/15500/15540/>, pp. 123-136\}; Varga, Csaba (1979) 'Law and its Approach as a System', Acta Juridica Academiae Scientiarum Hungaricae, 21(3-4), <http://real-j.mtak.hu/769/1/ ACTAJURIDICA_21.pdf>, pp. 295-319 \{reprinted in (1981) Informatica e Diritto, VII(2-3) \& <http://www.ittig. cnr.it/EditoriaServizi/AttivitaEditoriale/InformaticaEDiritto/1981_02-03_177-199_Varga.pdf>, pp. 177-199\}; as well as Varga, Csaba (2009) 'The Quest for Formalism in Law: Ideals of Systemicity and Axiomatisability between Utopianism and Heuristic Assertion', Acta Juridica Hungarica, 50(1), pp. 1-30 \& <https://akjournals. com/view/journals/026/50/1/article-p1.xml>. 
In other words, in the axiomatic system, all forms of creative activity focus on the very enactment of axioms. All other forms of activity are bound to remain of an executive nature, aimed at breaking down what is established as pillars of the given formation, that is, they do nothing but merely draw mechanically and logically inevitable conclusion(s). ${ }^{6}$

\section{b) Logical Submission}

There are two possibilities for the legal representation of the axiomatic pattern of thinking. These two ways differ in their concept and enforcement of logical submission.

(b.a) Logical determination Initially - for many centuries-logical submission was considered identical to logical determination. This trend culminated in the second half of the nineteenth century in the so-called conceptual jurisprudence [Begriffsjurisprudenz]. That period witnessed the ossification of codified law, during which the doctrine of legal positivism that had once shaped the European continental formation of legal concepts became simplified to statutory positivism [Gesetzespositivismus].

The tenet considering logical determination possible or inevitable has by now lost its exclusivity and radicalism. Its perhaps last definition came from GEORGES KALINOWSKI, who challenged CHaïm Perelman's view in their famous debate on formalism versus anti-formalism. ${ }^{7}$

According to this definition, all developments that occur in the law are expressible and construable through and in the formulas of logic, or "normative syllogism" is the logical manifestation of a legal event. However, it must be noted here that the mere allowance for the possibility of tracing judicial actions back to syllogistic conclusions postulates from the beginning that, on the theoretical level, the result announced in the judicial verdict is the only possible and conceivable outcome. This, and only this, is what can be logically inferred from and in the law.

From this conviction follow the ethos and the ideology of the legal profession, which considers the judge the servant of the law-or the mouth of the law, as MonTESQUieu put it. ${ }^{8}$ The word of the judge is the word of the law; the judge and their verdict are the mere outer expressions of the rule enacted by the law.

6 For deeper philosophical and methodological consequences, cf. Varga, Csaba (2012) The Paradigms of Legal Thinking. [1996/1999.] Enlarged 2nd ed. Budapest: Szent István Társulat 418 pp. [Philosophiae Iuris] \& <http:// mek.oszk.hu/14600/14657/>.

7 The debate between formalism and anti-formalism is surveyed by Horovitz, Joseph (1972) Law and Logic: A Critical Account of Legal Argument. New York, Vienna: Springer xv+213 pp. [Library of Exact Philosophy].

8 The statutory positivist definition of the judicial function is formulated in a classical way by Montesquieu [1748] De l'esprit des lois. Book XI, chapter VI. 
(b.b) Normative Definition of a Legal Frame The political upheavals and scientific discoveries of the late nineteenth and early twentieth centuries broke the rigid exclusivity of the reconstructive idea of causation and the parallel methodological notion of logical determination. 9 In the wake of groundbreaking sociological work (by MAX WEBER and EUGEN EHRLICH), the French free-law movement (FRANÇOIS GÉNY), and finally the logical reconstruction attempted by the Vienna school of neo-positivists (HANS KELSEN and ADOLF MERKL), the purport of logical submission was defined as the drawing, or filling in, of the actually available normative frames. ${ }^{10}$

The most comprehensive recapitulation of this theory came from KELSEN, according to whom the normative frame is given as blank by definition. Now, whatever is blank must be filled in by the judge's verdict on the concrete case. This verdict renders the legal judgment of the concrete case possible within the framework of legal regulations.

Regarding its conceptual construction, this theory, operating with the metaphor of the building steps [Stufenbautheorie], was construed as a normative application. This theory rendered relative the conceptual separation of law-making [Rechtsschöpfung] from law-application [Rechtsanwendung]. It considered discretion the gist of all attempts to fill the normative frame. In short, the adherents of this theory pointed out that each individual(izing) decision that points toward the concretization of the general normative tenet qualifies as application. However, seen from another perspective, the same act qualifies as creation. Seen from the angle of the general that is thus broken down into something concrete, the direction, method, and contents of this breakdown are far from determined. This move does not lack alternatives either since, in point of principle, it is always possible to act differently. Coming back to the Stufenbautheorie, however and for whatever reason this breakdown has taken place, those

9 For the relationship between fact and norm, as well as their operation, cf. Varga, Csaba (2012) The Place of Law in Lukács' World Concept. [1981/1985.] 3rd (reprint) ed. with Postface. Budapest: Szent István Társulat 218 pp. $<$ http://mek.oszk.hu/14200/14249/>, ch. 5 and Varga, Csaba (2011) Theory of the Judicial Process: The Establishment of Facts. [1992/1995.] 2 ${ }^{\text {nd }}$ \{reprint\} ed. with Postfaces I and II (Budapest: Szent István Társulat 2011) viii + 308 \& <http://mek.oszk.hu/15500/15540>; for the relationship between rule and norm, cf. Varga, Csaba (2007) 'Differing Mentalities of Civil Law and Common Law? The Issue of Logic in Law', Acta Juridica Hungarica, 48(4), pp. 401-410 \& <https://akjournals.com/view/journals/026/48/4/article-p401.xml>.

10 For the genuine role logic plays in law, cf. Varga, Csaba (1973) 'On the Socially Determined Nature of Legal Reasoning' in Perelman, Ch[aïm] (ed.) Études de logique juridique. Vol. V. Bruxelles: Établissements Émile Bruylant 296 pp. [Travaux de Centre National de Recherches de Logique] on pp. 21-78 and Varga, Csaba (1981) 'Logic of Law and Judicial Activity: A Gap between Ideals, Reality, and Future Perspectives' in Péteri, Zoltán, Lamm, Vanda (eds.) Legal Development and Comparative Law. Budapest: Akadémiai Kiadó 365 pp. on pp. 45-76 \{both reprinted in <http://mek.oszk.hu/15300/15333/\#>, pp. 317-374 resp. pp. 257-288\}; Varga, Csaba (1994) 'Kelsen's Theory of Law-application: Evolution, Ambiguities, Open Questions', Acta Juridica Hungarica, 36(1-2), \& <http://real-j.mtak.hu/784/1/ACTAJURIDICA_36.pdf>, pp. 3-27; as well as Varga, Csaba (1995) 'The Nature of the Judicial Application of Norms (Science- and Language-philosophical Considerations)' in Varga, Csaba (1994) Law and Philosophy: Selected Papers in Legal Theory. (Budapest: ELTE 'Comparative Legal Cultures' Project xi + 530 pp. [Philosophiae Iuris] \& <http://mek.oszk.hu/15300/15333/\#>, pp. 295-314. 
reasons and ways appear as given for all the subsequent concretization attempts. This is how the normative frame is filled.

This is also how the system of the sources of law is structured. The space between its vertex and medium levels (i.e., between the constitution and the centrally issued decrees) is filled by a mass of general norms characterizable as homogeneous, hierarchic, and free from contradictions. Its lower levels (ranging from the locally issued decrees to the judicial and executive decisions) contain the individual realizations or implementations of the above norms along highly varied horizontal fields.

It thus follows that the legal verdict is a fully responsible personal statement, a stand taken in person. It is simply the judge's irreplaceably individual contribution to the body of the law. It is irreplaceable and individual and also strictly creative because the actual filling in by the judge of the given normative frame can, in principle, occur in infinite forms. This infinite diversity may also produce incoherent elements and alleged inconsistencies in a given horizontal field. In terms of the diversity that manifests itself in the filling of the frame, the only common denominator of the various judicial decisions appears to be that-at least according to their own claims - they are all meant to fill in the very same and ready-made normative frame.

\subsubsection{Consequences as to the Structure and Ontology of Law}

These realizations lead us to several conclusions, which we must face and finally approve, no matter how innovative they may seem at first sight.

a) Legal Force as the Final Criterion First and foremost, as we have seen, each specific legal case allows not only one decision but rather an indefinite number and variety of competing decisions. This is why the judge's verdict is an act of genuine creation as it is law-making contribution in the strictest sense of the word, and this is why a forum is needed, which guarantees discernment and clarification, helps preserve the peculiar nature of the law, and can single out, by establishing their membership in a legally authentic manner, those decisions that are acceptable for filling the frame set by the higher norms from those others that do not qualify for that role on account of their potential to fill other-in this case, extralegal-frames only.

Legal force, which is also called the principle of res adjudicata, provides such a forum.

In such a general and rather philosophical sense, legal force is merely the execution (for the sake of guaranteeing the conformity-consistency, freedom of contradictions-of norms) of the purely procedural principle, according to which it is always the last step taken at the highest attainable level that shall be considered authoritative in the sequence of individual judicial decisions based on a set of given norms. This-and only this-step is recognized as definitive and conclusive by and in the system. 
It goes without saying that in this way, legal force assumes new meaning and at the same time, a selective power. In addition to being the symbolic emphasis of the conclusion, it also becomes the only officially recognized standard in the field of the competing potential fillers.

However, if our only criterion of judicial "truth" and "righteousness" is whether this selection, alongside its confirmation, has actually taken place-declaring thereby that there is no and there has never been an "objective relationship" or any in se and per se logical necessity between the higher norm and its frame at both ends, wherefrom and whereto the breakdown in order to concretize this higher norm has taken place-our conception is bound to change radically. In this case, legal force (together with the institutional-conventional and consensual-games conducive to it) remains the only factor that is empowered to exercise control over the judicial process.

This in turn amounts to the self-destruction of the whole formal theory, including both its logic-based and application-based angles.

b) Science- and Language-philosophical Reconsideration Here one finds themselves confronted with problems related to the philosophy of science and language as well as with paradigmatic questions inherent in the modern understanding of law.

(b.a) Law as an Ontology of Concepts and Texts Concepts and texts undeniably lack the potential to determine or control our activities. Only we ourselves can determine and control our own activities. In social life, we normally practice this by

- taking the traditions, the professional practices, and the interiorized need to preserve the existing-prevailing-conventions seriously,

- remaining responsive to the feedback by society, and thereby

- confirming and reshaping in our activities the various communal traditions and especially those that are intended for pattern-setting and roleplaying.

In relation to this ontological statement, it constitutes a different question with relevance to another kind of relationship: for regulating our activities (and/or also for having them controlled by others in a formally transparent and controllable way), we employ (refer to or interpret) concepts and texts as references, that is, merely as tools of abbreviation of the social economy.

(b.b) The Role of Logic The fact that logic is unfit and unable to address the above problem appears to buttress our conclusion. After all, a closer look at logic reveals that it deals neither with reality nor the relationships inherent in it but instead with the coherence, compatibility, consequences, and lack of contradiction of 
- the concepts, as we have defined them, as well as

- their relationships, as we have defined them.

More precisely, logic addresses these concepts and relationships only as they appear upon their application to or extension over other concepts and relationships.

\subsubsection{Summary}

Such is our intellectual heritage. Such is our tradition. Imperfect as it may be, it still manifests the historically motivated yearning of peoples and cultures of the European continent for something tangible in which they could place their confidence and through which they could demonstrate that confidence as independent of them. It is possible that we are simply witnessing a quest for a firm handhold amidst the transmutations of history. In any event, it is an effort toward something solid and concrete that could replace elusive and fluid human relationships with the promise of an objectively demonstrable, massively stable pillar-something that can be touched, held aloft, and carried around, exemplified by the symbolism of Moses' Tables of the Law.

\section{Rule of Law and the Anglo-American Conception of Law}

In a way characteristically different from what we have described above, the Rule of Law as the product of British and American historical experience trusts the social processes themselves. It considers the self-organization, reproduction, and permanent renewal of societal processes the foundation on which the legal system rests.

Contrary to the continental concepts, here the historical experience has not elevated artificial human constructions to the role of buttresses of continuity. The law is not embedded symbolically in anything concrete and objective, like a reified entity; instead, it rests on the natural self-organization of human processes themselves. Law is committed to the care of the continuity of organic social existence. This is how public opinion, which was so sensibly evaluated by Albert VenN Dicey, can serve as the ultimate foundation for law, especially proper for law. ${ }^{11}$

11 For the function of public opinion, cf., by Dicey, A. V. (1905) Lectures on the Relation between Law and Public Opinion in England during the Nineteenth Century. London - New York: Macmillan xx+503 pp. and Dicey, A. V. (1923) Introduction to the Study of the Law of the Constitution. [1885.] $2^{\text {nd }}$ edn. London: Macmillan vii+407 pp. 
As is clearly manifests in the very term of "administration of justice," the English-language civilization considers "justice" a peculiar form and manifestation of law. Surprising as it may sound for continental Europeans, this "justice" gets "administered" similarly to the way in which the governing administration operates (or at least the same term is used to describe both activities).

According to its classical interpretation, Anglo-American legal thinking is distinguished from its continental counterpart primarily by its inductive nature. As opposed to the deductive nature of continental legal reasoning, the common law approach originates from individual cases and builds its classifying network from below. Yet, for all its individualistic and case-oriented qualities, it always remains principled and proceeds by reconsidering these principles in their varying contextures.

In everyday judicial practice, this is known as the method of distinguishing-an approach that confronts the judge with all the precedents at his disposal. The judge starts from their own specific case and, while aiming for a solution that is both just and principled, directs its processing from the conceptually less general through the precedents at their disposal and the principles re-construable from them toward the doctrinal channeling of all of the concepts involved. However, if and when the judge finds it impossible beyond a certain point to identify with the suggestions and legacies of the past-that is, when they see their specific case as one lacking an archetype-the judge may create a distinctly sui generis classification scheme for their specific case, which differs from all the previously recognized patterns.

It follows that in common law legal thinking, the general does not dominate or overrule the specific. At the same time, of course, the specific is not chaotic; the particular attains its general purport not through its sheer contingency but in relation to the recognized manifestations of the general.

\section{THE ROLE OF CONCEPTUAL GENERALITY}

The evolution of science shows that the abstract general concept is a tool employed primarily by the systematizing thought to distinction. However, there is nothing to indicate that it has per se to overrule the process, and its aim is not to occupy a mercilessly superior position. It is destined-primarily in the longer run-to mark out the conceptual field that has evolved from humankind's cognitive activities. In other words, it marks out the possible choices for thinkers, and it also outlines the prospects of the thought process in the given field. It can become restrictive only in the interest of preserving cognitive traditions. This is why the abstract general concept is to be considered more a call for work than a call for order. 


\subsection{The Paradigm of What the Concept Is}

\subsubsection{The Tradition of Rome}

The idea of conceptualization appeared in the Greco-Roman legal culture at a rather early stage; however, its purpose was not to create normative systems or axiomatic hierarchies. Seen in their own abstract generality, the norms, if at all formulated, were merely the starting points for legal argumentation. MiCHEL VilLEy described their function as a springboard. The concept may have had the exclusive use of founding and generating ideas, but it was definitely not a shackle in which the heated mind was supposed to cool down. ${ }^{12}$

\subsubsection{The Duality of Humans' Conceptual World}

The dominant role of the axiomatic ideal has overarched centuries, from medieval times up to the modern age.

Today, the philosophy of modern science appears to return to earlier traditions on several points. In the field of the philosophy of law, some ancient patterns have already reappeared in the works of Paul OpPenheim, CARL G. Hempel, and Gustav RADbruch, along with the recognition — and partly as opposed to the exclusivity—of the axiomatic heritage of the purely logical treatment of concepts. ${ }^{13}$

As suggested by them, the distinction that they have introduced between the concepts of system and the concepts of order [Systembegriffe and Ordnungsbegriffe] reasserts the theoretical heritage of the axiomatic approach, in so far as the concepts of system are exclusively to mark out place and membership in a system of concepts. For this reason, our response to issues defined by a concept of systems must be unequivocal as it contains the definitive elements of either "here" or "there." The phenomenon that we identify with a concept of systems is either an element of a given generality or is not; it is either part of a given system of concepts or is not; it either contains these concepts, or it does not. There is no third chance. We cannot employ any form of dialectic uncertainty or the random indication of conceptual

12 The classical tradition is described by Villey, Michel (1967) 'Histoire de la logique juridique’, Annales de la Faculté de Droit et des Sciences économiques de Toulouse, XV(1), pp. 65-82.

13 The duality of the concepts of systems and of orders is delineated by Hempel, Carl G., Oppenheim, Paul (1936) Der Typusbegriffim Licht der neuen Logic. Leyden: Sijthoff vii+130 pp. and Oppenheim, Paul (1937) 'Von Klassenbegriffen zu Ordnungsbegriffen' in Bayer, Raymond (ed.) Travaux du IX ${ }^{e}$ Congrès International de Philosophie: Congrès Descartes. Vol. 9. Paris: Hermann [Actualités scientifiques et industrielles 530] pp. 69-76 as well as by Radbruch, Gustav (1938) 'Klassenbegriffe und Ordnungsbegriffe im Rechtsdenken', Revue internationale de la Théorie du Droit, XII(1), pp. 46-54. 
relations here. Conversely, the concept of order indicates a direction only, with reference to the frequency or scarcity (i.e., the condensation or decrease) of the similarities in contents, and it attempts to separate clubs of characteristics only. At the heart of most of those fertile ambiguities that we encounter in rational conversations, we may find such concepts of order. Wanting them to convey or express any kind of formal identity, entailment, or inclusion would be a massive misinterpretation of their peculiar nature. Whenever a concept of order is applied, our question concerning the object or notion at issue can only draw one of the following types of answers: "it is more or less similar" or "it is more or less comparable." Concepts of order cannot be used for any purpose other than indicating such an in itself obscure, scattered direction.

\subsection{3. "Concept of Order" in the Law?}

In the Anglo-American civilization, the concept of law is not identified with what has been "enacted," "made," or "issued" by the legislature; instead, law is what the court considers to be the law. The court's verdict declares the meaning of what "the law" is and has ever been in a given case.

For this reason, thinkers of common law consider their "law" to be a kind of tree accumulated out of individual judicial decisions that has been ramifying for many centuries. Each judicial decision can be used as-referred to-a precedent, which enriches law and legal culture day by day. Decision-making employs the technique of distinguishing, and therefore, it may introduce new conceptual divisions. In other words, there is a continued process of enrichment here. Owing to this chain of differentiation, the law becomes endlessly ramified; it can never reach a stage of completion because there is a never-ending repetition, with new situations generating new conceptual differentiations, which in turn may provide new answers.

It follows that any one stage in the common law understanding of "legal development from within" is only related to its preceding stage as one of the contingent generating factors (i.e., genealogically), and neither evolution nor linearity can be found in such an understanding of legal development. The system of precedents has to be conceived as a sequence of free link-ups, a kind of randomly accumulating mass. A master of liberal reasoning in law, RONALD M. DWORKIN, quite aptly used the phrase "chain-writing" to describe the Anglo-American concept of legal development for he likened this process to a literary game, that is, as a community generational game in the historical process in which each word, phrase, or paragraph in a text is contributed to by a different player. As 
they take turns, each unit will improve on its direct precedent, while it remains impossible to apply any binding rule or prediction to the way and end the chain evolves by and to. ${ }^{14}$

Thus, the Anglo-American concept of the development of the law's field is, after all, completely free of any predetermined doctrinal issues. It does not involve any problems relating to the creation of a system, and each of its steps is self-contained. It is not subjected to anything else except the order of the judicial process; yet, its structure is not anarchic. Its players are aware that it is their answers alone that promote its own future.

At the same time, this structure of legal development and this concept of the judicial process also entail the philosophical ideation and admission that-at least in theory-each decision is different and unique.

It is important to clarify at this point that, from a legal technical point of view, any decision can be described as one of three potential alternatives. Although the court is free to make its choice, the only important point is that it must be able to justify its casual choice, and through a kind of justification attached to the decision, it must also be able to defend its reasoning before any forum of appeal. Accordingly, the given decision may

- follow the previous decision(s); or, on the contrary,

- may prove to be independent and genuinely own by filling an independent conceptual slot, different and separate from the direction of the preceding decision(s); or

- may openly overrule the established precedent(s). In practical terms, this is similar to the pursuance of the previous decision(s). Here the decision also accepts the conceptual argumentation on which the preceding decision rests, but it attaches different legal considerations and/or consequences to the qualifications that originate from its stand.

Let me reiterate that the choice here is unrestrained by logic. The actual choice of argumentation and the genuine quality of its conformity to the precedents appealed is determined by the conventions applied. In theory, the court is free to defend all three alternatives indicated above in its motivation.

14 The metaphor of chain-writing has been used by Dworkin, Ronald M. (1982) 'Law as Interpretation', Texas Law Review, 60(3), pp. 527-550 and criticized by, among others, Fish, Stanley (1989) Doing What Comes Naturally: Change, Rhetoric and the Practice of Theory in Literary and Legal Studies. Durham-London: Duke University Press $\mathrm{x}+613$ pp. [Post-contemporary interventions] on pp. 89-119. 
JoHN RAWLs's descriptive concept of reflective equilibrium refers to a similar relationship between the principle and adjudication rule..$^{15}$ RAwLs's message is that no principle can be exhaustive in and by itself; it cannot rule over anything and cannot have definite contents either. Approaching the issue from another angle, we can also say that in an individual case, the rules of adjudication are never principled in themselves. Only the projection of these principles onto each other can fill the principles with definite contents at all (thus lending them well-defined meaning) and make the rule of adjudication principled (which undeniably renders this unique and contingent process a function and consequence of some previously existing general). Only the continued projection of these principles onto each other can answer the following questions: what is the principle at issue and "what does it say?"; what is the rule of adjudication and "what does it say?"

Of course, such an argument presupposes some underlying paradigmatic conviction. After all, the only thing that can make this claim rational is the presupposition that, in the final analysis, the separation of rule from principle is relative. By separating them, we differentiate between things that, on the one hand, appear directly applicable as compared to the other (this is the rule of adjudication) and on the other hand, must be taken into consideration and enforced as a condition in every practical case because they refer to fundamental considerations and requirement of coherence (this is the principle).

\subsubsection{Different Approaches to Law? An Eventual Commonality of Law?}

The above considerations suggest that the structure of judicial reasoning characteristic of the cultures of civil law on the European continent (which rests on conceptual dichotomy and polarization) is ultimately detached from the very structure of judicial reasoning characteristic of the common law (which in turn is built upon the random ramifications-i.e., branching off and out - of the potential arguments that apply to any one individual case). In the former case, the conceptual separation of $A$ from non-A serves as a starting point for conceptual areas that, in point of principle, are equal for eternity and in every sense. This is why it gives the impression of entailing the breakdown of a hierarchical construction along conceptual lines. Meanwhile, the latter kind of reasoning openly admits that it applies individual considerations to each individual case. This is why it avoids holding out the promise of any regular systemicity.

15 The explanation of reflective equilibrium can be found, as suggested by the foundational proposition of Goodman, Nelson (1955) Fact, Fiction and Forecast. Cambridge: Harvard University Press 126 pp. at pp. 65-68, in Rawls, John (1971) A Theory of Justice. Cambridge, Mass.: The Belknap Press of the Harvard University Press $\mathrm{xv}+607$ pp. on pp. $20-21,48-51$, and 120 . 
At the same time, we have every reason to suppose that this rather dramatically described gap between Civil Law and Common Law and the related fields of legal thinking and legal culture is nothing but a mere appearance, mostly of the surface. The difference is not insignificant, but it is not substantial either. The genuine difference tends to manifest itself exclusively in the conceptual reconstruction of naming rather. After all, the dichotomic structure resting on a strict conceptual differentiation, which we have described in connection with the legal thinking characteristic of civil law, carries the per force meaning only in its formal logical projection of what we are witnessing here as a separation into two areas of equal volume and extension with equal theoretical significance. In effect, all this can be just as random and unjustified by any kind of separation of contents as the common law argumentative ramifications can be determined by purely individual considerations.

If this is the case, then what we are discussing above is hardly more than a set of different verbal manifestations that have their roots in different thinking cultures.

Coming back to the dichotomy of rule and principle, our conclusion is that they are equally present in that very dichotomy at any given time. Such a dichotomy enables us to say that legal culture is more than just a mass of rules of legal adjudication. Such a law and legal regime, consisting of nothing but such a mass of rules, could only be conceived of as a mechanism operated by rule-automatons within a self-containing system of rule-automatisms.

In other words, rule and principle coexist in all legal cultures. What may differentiate one legal culture from the other is, instead, the proportion between rules and principles and also their respective potentialities. However, we must note that even this difference can only be described in the way we perceive it through our experiences. There is no difference of any kind with regard to the fact that, in both cases, it is the exclusive competence of the judge to determine which of the available alternatives they want to employ and how. This decision is normally based on necessity, on recognized interests, or simply on the accepted rules of the legal profession and its canon of juridical argumentation. 
OUTLOOKS 


\title{
HYPERRATIONALITY STANDING FOR ANARCHY IN AMERICA (A Case Study on the Pattern of the Judicial Mind) ${ }^{1}$
}

\begin{abstract}
1. THE BACKGROUND 1.1. Transformations in Law and Legal Mentality 1.2. Changes in the Juristic Ethos 2. THE AMERICAN SCENE 2.1. Legislation through Processualization 2.2. Hyperrationalism 2.3. Example of a Genuine Query: The Lost Property 2.4. Verbal Magic 2.5. Jurispathy 2.6. Self-interest of the Legal Profession? 3. CONCLUSION 3.1. Postmodern Primitivization 3.2. The Final Query
\end{abstract}

\begin{abstract}
Panoramic views on the mentality of living cultures may be edifying, for no law can be made a fetish or abstracted from the society collectively shaping it. As the present US case study reveals, there are destructive consequences if the social space vanishes from behind the law, if religion becomes inoperative instead of cementing society, if values degenerate into personal pleasure, and if social normativity is atomized. Then, law will volens nolens remain the last common denominator among the discrete members of society, with rationality elevated to the heights of omnipotence. Now, their lawyers are expected to stand for human certainty. In keeping with their view on their mythical self-belief and obsessive rationalism, the postmodern construct of "secular humanism" seems to be triumphing again, including the trouble of how to define and justify societal ends when classical foundations are refuted. Consequently, the political mind is also being patterned by the centeredness of public reason on the juridical mind.
\end{abstract}

KEYWORDS juridification; jurispathy; verbal magic; legalization through processualization; hyperrationalism; self-interest of the legal profession

\section{THE BACKGROUND}

\subsection{Transformations in Law and Legal Mentality}

Law is based on the idea of ordo, and modern formal law endeavors to enforce some kind of order built on ideal regulation that offers unambiguous application to anyone ready to draw rational conclusions from it.

1 Originally published in Hungarian in 2002. Earlier versions in English include (2010) 'Rule of Law? Mania of Law? On the Boundary between Rationality and Anarchy in America' in Nótári, Tamás, Török, Gábor (eds.) Prudentia Iuris Gentium Potestate: Ünnepi tanulmányok Lamm Vanda tiszteletére [Festschrift for Vanda Lamm]. Budapest: MTA Jogtudományi Intézete 530 pp. on pp. 492-504 and (2013) 'Legal Mentality as a Component of Law: Rationality Driven into Anarchy in America', Curentul Juridic [Tirgu Mures], XVI(1)(No.52) pp. 63-77 \& 
Historically, differing institutions and concepts of rationality (with a variety of constructions and normative expectations) were to be built in various cultures. In ways and roles characteristic of them individually, they all aimed at serving safety in application by developing a logic that may ensure inevitable conclusions, drawn with no alternatives. As is known, on the European continent, regulation was conceived geometrically as a conceptual system, logically organized and striving for completeness. Thus, continental law has for long been dominated by abstract deductions. Anglo-Saxons have always been different, preserving sensitivity toward the concretely unique features of individual cases to be assessed eventually by judicial fora, which has allowed them to consider judicial solutions applied in earlier similar cases in an analogical manner. ${ }^{2}$ American law developed from the English system, showing increasingly differing features step by step. Today, it is overwhelmingly codified based on legislation. Moreover, in the United States, the English method of distinguishing (having recourse to or excluding analogy between past cases and the present issue) has become both liberated and complemented by argumentation through principles; therefore, over the past few decades, the practice has become significantly less formal than the mere observance of rules. The selfimage of American law is contradictory from the outset. In contrast to the English, they believe that law, inasmuch as it is cognizable, can provide unambiguous guidance for whatever eventuality in principle. In consequence, present-day American regulations incessantly interfere with life relations, including the private sphere, which had been protected as free from legal intervention until now. At the same time, in the name of the rule of law and to support the enforcement of law at both the individual and collective levels, they constantly increase the range of procedural choices for action. Consequently, it may well occur that the law's final word would only be heard long after the last available procedural measure was taken (and in some cases, practically never). This is because the struggle is often tirelessly continued and resumed again, and such practice is encouraged by the domestic sense of law; consequently, as a practical matter, legal force may well be excluded from ever being reached.

Our age is characterized by legal transfers all over the world. In addition to Latin America, Asia, and Africa, Central and Eastern Europe are also especially involved in this. ${ }^{3}$ In the case

<http://www.upm.ro/facultati_departamente/ea/RePEc/curentul_juridic/rcj13/recjurid131_7F.pdf>; radically abridged as (2012) 'Mentality as a Component of Law in the Comparison of Laws (A Case-study on the Anarchy Arrived at through Rationality Maximalisation in America' in Шемщушенко, Ю. С., Тихий, В. П., Цимбалюк, М. М., Гриценко, И. С. (eds.), Кресін, О. В., Ситар, І. М. (reds.) Порівняльне правознавство: Сучасний стан і перспективи розвитку. (Збірник наукових праць.) Лвів-Київ: Львивский державий університет внутрішніх справ 619 pp. on pp. 58-61 \& in <http://new.volsu.ru/download.php?id=00000014464-1.pdf>.

2 Cf. Varga "Rechtsstaatlichkeit" and "Rule of Law"' in the present volume.

3 Varga, Csaba (2007) 'Reception of Legal Patterns in a Globalising Age' in Calera, Nicolás López (ed.) Globalization, Law and Economy / Globalización, Derecho y Economía: Proceedings of the $22^{\text {nd }}$ IVR World Congress. Vol. IV. Stuttgart: Franz Steiner Verlag, pp. 85-96 [ARSP Beiheft 109] \{reprinted in <http://mek.oszk.hu/15300/15386>, pp. 181-207\}. 
of Hungary, after half of a century of imposed experimentation with the communists' partystate and centrally planned economy, the country had to readapt itself to legal frameworks drawn by parliamentary democracy and the multi-party system, with an economy based on free competition and the market. Almost two decades ago, reintegrating into Western Europe within the European Union, Hungary had tens of thousands of pages of rules and regulations translated daily to be adopted (along with the EU's constantly forming normative scheme) in its domestic law. European law is being formed day to day, and all of the countries that have joined from Central and Eastern Europe are also taking part in forming it.

Foreign law is not easy to come to know. However, comparison among laws and legal regimes may help anyone to develop a sharper insight into the specificities of what they live through day to day. ${ }^{4}$ In particular, the compound federal and state complex (made up of a multitude of institutions and myriads of regulations and practices, with an army of practically unavoidable specialists trained expensively and employed at high costs for their procedural tricks and ingenious argumentation), which we call American law "in books and in action," scarcely reveals itself in transparent dimensions for outsiders as a lively whole, whether or not they are in search in law libraries or happen to be professional visitors of the States. This is not peculiar at all. After all, monographs necessarily treat formalizable and mostly technical details, and the visitor's eye could only be opened by a reflection both critical and endowed with self-irony if it is due-a gift that Americans as world power players since World War II, characterizable by self-closing mass socialization, ${ }^{5}$ cannot boast of in the least.

The everyday formation and experience of an arrangement, making it either livable or perhaps problematic for those living within it, can hardly be grasped from an outsider's position. Let us consider as one minor instance that the institutionalized and apparently worldconquering practice called political correctness-despite being more powerful and efficient in shaping American public discourse (within media, scholarship, and education) than the thoroughly reinterpreted Constitution itself-has not (yet) been elaborated in professional literature. Hence, in terms of transparency afforded by disciplines describing sources of social normativity, how it could have become as overwhelmingly dominant as it is cannot be taken as other than a mystery. Paradoxically, reading American tabloids offers a better chance to sense the prevalent ethos of everyday common and professional life than perhaps any thing else. Yet, it would obviously be bizarre to draw conclusions regarding considerations dominating legal life from phrases and occasional exaggerations in the press, prompted by

4 Varga, Csaba (2020) ‘Comparative Law and Multicultural Legal Classes: Challenge or Opportunity?' in Varga, Csaba (ed.) Comparative Law and Multicultural Legal Classes: Challenge or Opportunity? Cham, Springer x+212 pp. [Ius Comparatum - Global Studies in Comparative Law 46] on pp. 3-42.

5 Bloom, Allan David (1987) The Closing of the American Mind: How Higher Education has Failed Democracy and Impoverished the Souls of Today's Students. New York: Simon and Schuster xv+382 pp. 
incidental turns of mind, while the professional reader is flooded by some 50,000 pages of essays and analyses from hundreds of journals published by American law faculties and lawyers' organizations every month.

Some of the changes that took place in American legal practice over the past few decades may have also been perceived overseas. The first to be mentioned is (1) juridification, that is, the increase in both the diversity of ways through various formal procedures and the number and variety of occurrences actually resorting to them in a constantly broadening circle. The second is (2) processualization, that is, with substantive regulation being gradually pushed into the background, the growing tendency to assert law as an in-itself neutral set of rules of a formal game, presuming equality of the parties (through an emphasis slowly shifted to the protection of the individual—even if a criminal—against the state). Finally, as a theoretical achievement and also making its way into practice, the third is (3) argumentation by principles. In accordance with the Americans' widespread spirit of extending individual freedom to their personalized choice from an almost unlimited set of values and patterns of self-realization within just few decades, this creative argumentation has resulted in the thorough reinterpretation of the Constitution with such a long-term impact that, from now on, whether to follow rules is already made a function of whether or not the rule concerned encounters lawyerly counterargumentation that refers to any principle or value claimed to be constitutional. By now, all this has torn American law practically into two, duplicating the paths that can be followed as a function of the result hoped for by the client, which actually crumbles the rules' authority by relegating them to the role of mere substitutes. It is to be noted that this tendency has inspired sympathy in Western Europe and later on in Central and Eastern Europe as well, particularly in countries that were facing transition from the communism imposed upon them to the rule of law. For as a technique innocent in itself, it only suggested revitalization of one of the components of Roman law (long forgotten in our region), while also offering rehabilitation to the very wording of constitutions, neglected till then as a proper-suigeneris-source of the law.

\section{Changes in the Juristic Ethos}

Experience-especially of the Central and Eastern European region-may have clarified by the end of the millennium at the latest that almost unforeseeable consequences (deteriorating the law's prestige) may be induced if social space vanishes from behind the law, and religion (with ideas fundamental enough to cement society together and traditional enough to generate communal reproduction) becomes inoperative, that is, if values degenerate to a function of personal choice and, in the final analysis, social normativity is also atomized to 
the depth that law would remain the only common denominator among individuals, acting as a self-generating demiurge. ${ }^{6}$

For according to legal sociology, no matter how much additional burden we are compelled to put on law (out of the constraint to respond to challenges or simply to modernize), we must bear the limits of its optimum load capacity in mind because it can also collapse under its own weight.7 Speaking paradoxically, law operates with an optimum efficiency when it is resorted to only exceptionally and mostly symbolically as the ultimate authority, that is, when its regulation points to the path that the actual social movement takes anyway. ${ }^{8}$ After all, even if its eventual overburdening may increase its apparent significance, playing added roles that cannot be filled properly will unavoidably provoke changes in character in the long run.

It is a change of ethos through the challenge by our postmodern age that is seen as behind such developments by one American author whose considerations I am going to assess. ${ }^{9}$ The intention of self-revelation by providing a faithful mirror is to be highly appreciated, especially when it originates from academic circles. PAUL F. CAMPOS, Professor at the University of Colorado School of Law and Founding Director of the Byron R. White Center for the Study of American Constitutional Law at Boulder, dipped his pen into vitriol in a series of publications, of which the most overarching is taken here as an instance of case study. He did so to stir up the still water of a world in which legal professionals' business is becoming increasingly costly and increasingly complicated in technicalities with no added input/output, while

6 As already forecast, cf. Varga, Csaba (1992) 'The Law and its Limits' Acta Juridica Academiae Scientiarum Hungaricae, 34(1-2), pp. 49-56 as well as Varga, Csaba (1986) 'Macrosociological Theories of Law: From the "Lawyer's World Concept" to a Social Science Conception of Law' in Kamenka, Eugene, Summers, Robert S., Twining, William (eds.) Soziologische Jurisprudenz und realistische Theorien des Rechts. Berlin: Duncker \& Humblot xvi+381 pp. [Rechtstheorie Beiheft 9] pp. 197-215 \{both reprinted in <http://mek.oszk.hu/15300/15333/\#>, pp. 91-96 resp. pp. 43-76\}.

7 Kulcsár, Kálmán (1992) Modernization and Law. Budapest: Akadémiai Kiadó 282 pp.

8 Campos, Paul F. (1998) Jurismania: The Madness of American Law. New York: Oxford University Press x+198 pp. (with referencing to it in the paper by mere page numbers only). As he opines on p. 183, „law is always a somewhat crude and potentially destructive social steering mechanism, that works best when it remains a tacit presence in the social background."

9 A strong tone of criticisms of the legal profession is expressed, among others, by Kronman, Anthony T. (1993) The Lost Lawyer: Failing Ideals of the Legal Profession. Cambridge, Mass.: Belknap Press of the Harvard University Press viii +422 pp. at p. 1, who acknowledges that "every year produces a fresh crop of scoundrels and renewed doubts about the ability of the profession to police itself, along with familiar complaints about the undue power of lawyers (which any democratic society is bound to regard with suspicion)"; Glendon, Mary Ann (1994) A Nation under Lawyers: How the Crisis in the Legal Profession is Transforming American Society. Cambridge, Mass.: Harvard University Press 331 pp. on p. 12, who diagnoses "a significant advance of arrogance, unruliness, greed, and cynicism in the legal profession' [...] A breakdown in self-discipline among lawyers." This is further substantiated by Howard, Philip K. (1994), The Death of Common Sense: How Law is Suffocating America. New York: Random House 202 pp. as to the immensity of the legal stuff or by Rothwax, Harold J. (1996) Guilty: The Collapse of Criminal Justice. New York: Random House xiv+238 pp. as to the over-complicacy of processes. 
being unavoidably wedged in the ongoing social events, out of mere self-profit. What he describes is a pathology not only of the caste of lawyers as a postmodern super-elite but also of present-day American public speech, continuously promoted by means of the media.

\section{THE AMERICAN SCENE}

\subsection{Legalization by Processualization}

As is obvious, it is trivial that present-day America is not only the land of opposites but also of extremes, often switching into each other uncontrollably (p. vii). America happens to be undergoing a period of the law's hypertrophy: courts are flooded with 30 million cases a year (p. 178); the duration of some lawsuits extends to more than one decade, and hundredpage decisions for them are becoming usual, while articles of several hundred pages in length are devoted to analyzing them in the professional press with half a thousand notes each (p. 81). Could the Fathers of the Constitution have anticipated that both the perfection of their work and their efforts at making it accepted by the member states would be devalued as a mere trifle compared to the alleged sacrifice of time and energy detailed in the bills by $\mathrm{O} J$ SIMPSON's lawyers until they got the appointed jury entirely replaced through craftiness (p. 21)? ${ }^{10}$ Do today's taxpayers realize that the lawyers of Tiмотнy MCVEIGH, convicted for the 1995 bombing in Oklahoma City that killed 168 people, charged 10 million dollars for a trial lasting only three months at the cost of the American public, without even straining themselves to come up with serious exculpatory evidence (p. 183)? ${ }^{\text {?1 }}$

What lies behind all this? Corrupt practices? Or zeitgeist, some snobbish contemporary trend of thought? It seems that wealth and imperial dimensions may also influence socialization, in that it is difficult to stay modest. If it is rational organizational capacities (in addition to power) to which America owes its success, then it is exactly this field where temperance may encounter difficulties. Anyway, public discourse in America is mostly cut short: "problems have solutions" (p. 125) backed by the "mania for giving reasons" (p. viii). All this adds up to a culture of "juridical saturation" with almost all types of social interactions "subject to possible surveillance and regulation via the agencies of state" (p. 34), for "the best way to attack a problem is to inflict a comprehensive regulatory scheme on the social context in which the problem occurs" (p. 82) while maintaining the "belief that it is possible to both produce comprehensive regulatory regimes and to predict accurately the effects of

10 Cf. <https://en.wikipedia.org/wiki/O._J._Simpson>.

11 Cf. <https://en.wikipedia.org/wiki/Timothy_McVeigh>. 
essentially ad hoc legal decision making" (p. 179). "Legalize it!" (p. 6) and the panacea of "going to law" (p. 5) are obviously promoted as substitutes, as if lawyers (just as so-called advisors are gradually replacing priests) had a kind of inherent wisdom or learned knowledge distinguishing them from the rest of society (p. 186).

Thus, actors spanning from libraries to sports associations (no longer trusting themselves and as if having forgotten the gift of common sense) begin enthusiastically drafting regulations of several hundreds of pages each, only to insert into everyday processes something external to rely on, as a substitute for both reason and authority, afforded by both quasi-law and therapy as embodied by mediators, counselors, and psychoanalysts.

It is not "obsessive proceduralism" (p. 179) and not even the "passion for regulating" (an attribute used earlier to characterize the Prussian Enlightenment of FREDERIC II ${ }^{12}$ in themselves) that make American practice problematic. What is really confusing is the way it resorts to the law's instrumentality by making the community believe that legal professionals are more competent in value-choices as well as in defining preferences involving searchfor-compromise balancing than anyone else; so much so that they may not only overshadow policies but also have to control political alternatives as ultimate judges with their principled justifications and authoritative (judicial) approval. ${ }^{13}$ To put it briefly, nothing matters anymore but law, nothing else can create community but law, and there is no other authority than that of law.

What is at stake here is not just airy desires, intentions, or a merely ideological guise. We must reckon a change in the character of the whole legal setup with the social use of law, affecting procedures and methods, attitudes and thought patterns, and the entire ethos, which can also be traced in the judicial handling of everyday cases.

\subsection{Hyperrationalism}

For in America, "law is manifesting itself as a kind of cultural madness, whereby hyperrational modes of decision making are employed in a vain attempt to resolve rationally what

12 By, for example, Macaulay, Thomas Babington (1895) 'Frederick the Great' [1842] in Macaulay, Thomas Babington Essays. [Popular edn.] London: Longmans pp. 791-834 on p. 808 and Mann, Thomas (1933) 'Frederick the Great and the Grand Coalition: An Abstract for the Day and the Hour' [1914] in Mann, Thomas Three Essays. London: M. Secker 231 pp. on pp. 156-157. For the context, cf. Varga, Csaba (2011) Codification as a Socio-historical Phenomenon. $2^{\text {nd }}$ \{reprint\} edn. with an Annex \& Postscript. Budapest: Szent István Társulat viii+431 pp. \& $<$ http://mek.oszk.hu/14200/14231/>, in particular pp. 76-77, with notes 22 \& 28 on pp. 86-87.

13 It was Dworkin, Ronald M. (1988) Law's Empire. Cambridge, Mass.: Belknap Press of Harvard University Press xiii+470 pp. on p. 166 who ventured the claim that representation of group interests can be legitimate only provided that its message can be developed into or reconstrued through coherence established as approved by a federal justice: "Integrity becomes a political ideal when we insist that the state act on a single, coherent set of principles even though its citizens disagree about what the right principles of justice and fairness really are." 
are rationally irresolvable moral and political conflicts" (p. 182), while "the American civic life has become burdened with the widespread delusion that something called 'the rule of law' can succeed where politics and culture fail" (p. 181). Such an approach is not only dangerous in itself, but it also threatens to cause law in American practice to become extremely one-sided, that is, burdened with potentials increasingly narrowing - while increasingly imposed upon-society. This is so because

The current cultural dominance of legal modes of thought-the belief that political and ethical decisions are legitimate only to the extent they can be crammed into the conceptual categories of legal reasoning-helps reinforce a legal culture in which other modes of decision making are treated as degraded versions of law, rather than as potentially valuable alternatives to law's imperialistic grasp. (p. 187)

\subsection{Example of a Genuine Query: The Lost Property}

As a methodological illustration, what can be exemplified by the issue of ownership of lost property and reward for its finder? Well, guiding precedents ${ }^{14}$ only emphasize contradictory aspects, such as returning it to the original owner; meeting the expectations of both the finder and the owner of the place of finding; rewarding luck and honesty; or, and after all, finding any solution that is easy and rapid (p. 84). Whatever the case may be, debatable concepts such as "prior owner" necessarily emerge, and by no means as a function of competing interpretations but as one of the substantial dilemmas inherent in law. For every

legal concept of possession is of course an artifact of legal reasoning itself, which is to say it is a socially constructed concept rather than a plain fact of nature; [...] the concept will be sufficiently ambiguous to accommodate the essential tensions between the various social values the legal concept reflects. (p. 85)

This cannot be otherwise for "all rules by their nature as rules must be both over- and under-inclusive" (p. 88). The same is the reason why there evolve successive opposing movements in legal development, firstly to standardize exceptions from the rule and then, in counterreaction to the confusion emerging from this, to regulate the practice confused by those exceptions (p. 89).

14 Such as the decisions in the cases of Hannah v. Peel (1945), 1 King's Bench 509; Bridges v. Hawkesworth (1851), 21 LJ Queen's Bench 75; or South Staffordshire Water Co. v. Sharman (1896), 2 Queen's Bench 44. 


\subsection{Verbal Magic}

The question arises, therefore, of whether interpretability-controversial in itselfis an incidence of law that must be settled by lawyerly instruments. Or is it a necessity, a function, and outcome of the subject conflicting in itself, albeit concealing its very nature? In one of my earlier attempts at reconstruction, ${ }^{15}$ I reached the conclusion that no matter how sensitively the law is formed, by its very nature, it cannot be but a net of conceptual projections that reflects an ideal order according to the intention, imaginative power, and conceptualization of its designer, while, as the law is implemented, real life strives by balancing conflicting values and interests to find fulfillment within the framework of such a conceptualization. This means that discrepancy and not contradiction-that is, neither a defect of law nor a deviation in life but the very substance of any legal (or formally mediated) game-is the case. Law could not even reach more security either, this being the fate and exclusive possibility of every conceptual projection drawn from or contrasted to real life.

The argumentation referred to identifies the knot of American legal culture in the fact that domestic legal ideology has been silent on this very issue for a century, with formalists denying the failure of rational choice between conflicting interests and values on the one hand, and realists accepting it exclusively as a practical matter to be faced within individual situations at the most on the other. This explains the constant emergence of mystification, even "incantation," "verbal magic," and "delusion" in judicial discourse (p. 10), with a "bald assertion of intuitive belief masquerading as rationally compelling argument" (p. 91). That is, kinds of such "blatantly circular forms of pseudo-formal reasoning" (p. 112) and

legal artifacts are the fruit of futile, hypertrophied exercises in forms of argument that can themselves "reason", but that in fact must conclude with the assertion of axiomatic [that is, logically not following from any premises in logic] or circular [that is, drawing from and concluding with themselves] propositions. (p. 101, with added bracketed notes) ${ }^{16}$

15 Varga Judicial Process, 2011.

16 For similar developments in American phenomenological reconstructions, cf., as a somewhat MARxizing critical legal studies specimen, Conklin, William A. (1998) The Phenomenology of Modern Legal Discourse: The Judicial Production and the Disclosure of Suffering. Aldershot, etc.: Ashgate xii+285 pp., and, as reviewed, Varga, Csaba (2003) 'What is to Come after Legal Positivisms are Over? Debates Revolving around the Topic of "The Judicial Establishment of Facts"' in Atienza, Manuel, Pattaro, Enrico, Schulte, Martin, Topornin, Boris, Wyduckel, Dieter (eds.) Theorie des Rechts und der Gesellschaft: Festschrift für Werner Krawietz zum 70. Geburtstag. Berlin: Duncker \& Humblot pp. 657-676 \{reprinted in <http://mek.oszk.hu/15500/15540>, pp. 271-301\}. 
Logical positivism can easily be held responsible for such mystification ${ }^{17}$ as it creates artificial certainty with its special emphasis, while excluding real human processes from the circle of scholarly investigation. ISAIAH BERLIN could already conclude that "the notion of plurality of values not structured hierarchically [...] does not entail relativism of values," but it "entails the permanent possibility of inescapable conflict between values. ${ }^{18}$ For we can hardly "know" anything; ISAAC NEWTON himself admitted that

I do not know what I may appear to the world; but to myself I seem to have been only like a boy playing on the sea-shore, and diverting myself in now and then finding a smoother pebble or a prettier shell than ordinary, whilst the great ocean of truth lay all undiscovered before me..$^{19}$

JORGE LUIS BORGES opined that "there is no description of the universe that isn't arbitrary and conjectural for a simple reason: we don't know what the universe is." ${ }^{20}$ ALBERT EINSTEIN, addressing the Prussian Academy of Sciences in Berlin in German in 1921, concluded that "as far as the laws of mathematics refer to reality, they are not certain; and as far as they are certain, they do not refer to reality,"21 and the most we can do under such predispositions is merely to live again, by processing and improving, the tradition cultivated by predecessors and fellows, construed and reconstrued as knowledge. For human thinking is mostly tautological, even if covered by either official or scholarly speech. This is "a symptom of how the contemporary worship of analytical and supposedly scientific modes of thought can shade off into a type of dogmatic pseudo-religious belief, and eventually into the realm of a sort of intellectualized irrationalism" (p. 150).

17 Having had the opportunity to research in academic libraries from Canberra and Tokyo to Edinburgh and Berkeley, what I found the most staggering was that those tens of thousands of books devoted to "cognition" and "knowledge" considered their subject as a hypothesizing intellectual game; in other words, as a conceptual set of cases formed of other concepts out of purely analytic interest. For they actually constructed thoroughly theoretical "cognition" and "knowledge" that have almost nothing in common with cognition practiced in either everyday or professional life and knowledge acquired by humans, that is, with so-called practical knowledge.

18 Berlin, Isaiah (1991) The Crooked Timber of Humanity: Chapters in the History of Ideas. New York: Knopf xi+277 pp. on p. 80.

19 Brewster, Sir David (1855) Memoirs of the Life, Writings, and Discoveries of Sir Isaac Newton. Vol. II. Edinburgh: T. Constable ch. 27.

20 Borges, Jorge Luis (2001) 'John Wilkins' Analytical Language' in Borges, Jorge Luis The Total Library: Non-Fiction 1922-86. Ed. Eliot Weinberger. London, Penguin Books pp. 229-232 on p. 231.

21 Einstein, Albert (1922) 'Geometry and Experience' in Einstein, Albert Sidelights on Relativity. London: Methuen $\&<$ https://mathshistory.st-andrews.ac.uk/Extras/Einstein_geometry/>. 


\subsection{Jurispathy}

Translating this pattern of thought into juridical language, judicial decision-making appears thoroughly "jurispathic." This is shown excellently by judges, who, faced with the "luxuriant growth of a hundred legal traditions, assert that this one is law and destroy or try to destroy all the rest" (p. 160). This symptom once induced RoBIN WeST-sensitive and combative feminist reconstructor of the law's world—-to openly declare that

"reason alone is not going to compel agreement. [...] If we are really aiming for genuine consensus, then the experiential gaps must be bridged." Because "moral convictions are changed experientially or emphatically, not through argument [... and therefore] reason alone simply will not move us-but experience, empathy, and reflection might."22

All in all, owing to the general practice of argumentation by principles,

The Constitution has become [...] what the prophecies of Nostradamus represent [...]: an ideally vague set of oracular-sounding propositions, whose very vagueness comfort the devotee with a sense that the correct interpretation of an essentially magical text will provide insight into mysteries that would otherwise remain unknowable and obscure. (p. 169)

While

Indeed the Constitution as a whole (as opposed to judicial decisions that refer to the Constitution) appears to have nothing whatever to say about a right to abortion, or to privacy, or individual autonomy, or sacredness, or any of the other highly abstract concepts that make up the heart of Dworkin's argument. [...] For all legal rhetoric's grandiloquent talk of "reason" and "principle" we know that our law is always a contingent product of fallible human choices-choices that within interpretive equilibrium zones must remain essentially contestable. (pp. 115 and 116)

22 West, Robin L. (1994) 'The Constitution of Reasons' [a review article on Cass R. Sunstein The Partial Constitution], Michigan Law Review, 92(6) pp. 1409-1437. Moreover, decades ago, she already proposed pro-life against pro-choice activism by authentically displaying the guilt felt by those who underwent abortion, growing to unbearable degree at times, or the way foetuses killed by abortion are "hacked to pieces in a procedure difficult to distinguish visually from simple infanticide." 
It is exactly this realization that present-day American hyperrealism, striving for certainty at any price, is unwilling to recognize. For American justices are mistrustful of any decision-making based on personal responsibility; therefore, they rather prefer judicial argumentation drawn directly from the Constitution as well as from the field of practical policy to anything else reminding them of their past practices. However, according to American domestic criticism, ${ }^{23}$ this testifies to their mistrust of democracy itself-that is, as an anthropological presumption of a human considering their matters and therefore ready to choose and as a technical realization of adjusting their personal decisions to majoritarian individual opinions. In such a way, personal stance is replaced by the "expertise" of lawyers, who allegedly allow a deeper insight. After all, "voting [...] is an explicitly arational mechanism for deciding controversial issues [..., because] it doesn't require any justification of particular results beyond reference to the formal definition of the activity itself" (p. 70).

It is ironic to see development or progress as achieved by trust placed in the rational foundation of decision-making when it resorts to the panacea of comprehensive regulation and exposes itself to judicial eventualities. For such a by-chance outcome may, through side effects, both interfere with the social total motion and divert it on forced paths as "any systemic action will cause a myriad of unforeseen, and indeed unforeseeable, reactions" (p. 91). Has anyone considered that, for instance, since the due process rights of the accused had been highlighted, scarcely anyone proceeded to trial, and the majority of criminal convictions (for example, $96 \%$ of the total in Colorado in 1995) were the result of other procedures? That since the war on drugs was launched, the number of those in prison has suddenly quadrupled (without having been budgeted for such an increase) over the past 25 years? That scarcely a generation since racial segregation in schools had been declared unconstitutional, the spontaneous segregation of public schools was incomparably higher than ever? That there is a sevenfold increase in the number of legal malpractice suits only as an incidental result of technical measures aimed at reducing them? (pp. 92-93) Or that nearly two-thirds of the immense American medical care costs are incurred within the last six months of people's lives because there is no legal standard available to separate reasonable prolongations of life from unreasonable ones? (pp. 163-164). One may find substantial wisdom in the statement according to which an operable regulatory mechanism needs to be minutely sophisticated; yet, "the more it elaborates itself, the more manipulatable the system will become, and the more unpredictable the social effects of such manipulation will be" (p. 95).

23 Cf. Varga, 'Idol, Deduced from an Ideal?' in the present volume. 


\subsection{Self-interest of the Legal Profession?}

All this seems to be motivated by the self-interest of the legal profession in maintaining increasingly confused methods of regulating and decision-making. American lawyers have proven unprecedentedly successful in this, gaining increasing fields of action, prestige, and wealth in return. This also requires them to build mechanisms for self-protection by cultivating the myth of the only true knowledge that they are privileged to have acquired. The fascination of a "relentlessly rational culture" (CAMPOS) and of the "public reason" (JoHn RAWLS) accessible to all obviously brings about its own self-belief. Not too long ago, the Yale Law School Dean of the time declared as his faculty's corporate creed to become-and indeed, allegedly be-"a community united by faith in the power of reason," ${ }^{24}$ that is, "even though we now believe unicorns are solely creatures of our imaginations, we are still habituated to a cultural practice in which we talk about unicorns as if they existed autonomously from our beliefs about them" (p. 141). Thus, Americans, amazingly unfamiliar with different cultures, are convinced their law is "the best in the world" and that the rest of the globe is either ready to imitate the Americantype Rule of Law, or Bosnia and Lebanon will be the miserable end result. ${ }^{25}$

As to the triumph of rationality, the deepest truth that can be suggested to simpler minds in analogy is that water is obviously good a thing; "[t]oo much water, however, and we drown" (p. 178).

\section{CONCLUSIONS}

\section{Postmodern Primitivization}

The reason why we deal, for instance, with so-called primitive law is that it presents a system in action in an embryonic form that is yet compound and ready for sensitive responses and changes. Its already structured complexity notwithstanding, elementary contexts and operations can indeed be revealed in such primitive formations that might stay hidden to the

24 Anthony T. Kronman quoted in (1995) 'America's Best Graduate Schools', U.S. News \&World Report (March 20, 1995) p. 84. When at Yale in the academic year of 1987/88, presenting him my paper on MAX WEBER published in English in Rome, I called his attention to his conceptual misunderstanding probably due to mistranslation in the monograph he had ever published, dedicated to (1983) Max Weber. Stanford: Stanford University Press 214 pp. [Jurists: Profiles in Legal Theory]. Moreover, notwithstanding that he did master no foreign language, he seemed not to miss it either; he simply looked at me, declaring articulately that whatever was his scholarly interpretation, it had been justified by the huge number of American reviews applauding his book as simply pioneering.

25 For the interest-driven contexture of such an ideological tenet, cf. Varga, 'Rule of Law, Or the Dilemma of an Ethos' in the present volume. 
observer in its later and more developed and complex states. For large systems, powerfully developed to reach a higher degree of complexity and sophistication, do not necessarily allow cohesive system-elements as actual pillars to be easily seen and recognized—albeit their overall spirit is reflected, like an ocean in a drop, in the elaboration of details. In large systems, ramifications are also larger; therefore, the chances are greater for both functional excesses and dysfunctional, forced paths to occur. This enhances the need for various institutions, which are designed to balance and control and also to provide feedback in both planning and operative functioning, to be intersected from top to the medium level. Neither chances nor fields of action are truly closed. That is the reason why those thought patterns judiciary espouses in America are the best illustrations of the background mentality with which the US administration and the political sphere actualizing the former's services operate daily. Real-life connections between them were remarked by ALEXIS DE TOCQUEVILLE almost two centuries ago:

Scarcely any political question arises in the United States that is not resolved, sooner or later, into a judicial question. Hence all parties are obliged to borrow, in their daily controversies, the ideas, and even the language, peculiar to judicial proceedings. ${ }^{26}$

Every panoramic view of the mentality of living cultures is edifying. On the one hand, not even law can be made a fetish; or, just as when ALEXANDER ISAEvich SOLZHENITSYN was freed from bondage, he marveled at the "brave new world" consummated on the other part of the world in the meantime: "a society without any objective legal scale is a terrible one indeed. But a society with no other scale but the legal one is also less than worthy of man." ${ }^{27}$ On the other hand, law cannot be abstracted from the society that collectively shapes it, for "law and legal reason are also the simulacra of real community" (p. 194).

\section{The Final Query}

All in all, perhaps it is not by chance that classical values-wisdom, virtues, readiness to serve the public, revitalization of the statesman's old stature-are reclaimed for again, ${ }^{28} \mathrm{re}$ inforcing common sense and normality without lawyering rule and other excesses of human

26 Tocqueville, Alexis de (1839) Democracy in America. [1840.] Transl. Henry Reeve in <https:/www.marxists.org/ reference/archive/de-tocqueville/democracy-america/ch16.htm>. Book I, ch. 16.

27 Solzhenitsyn, Alexander I. (1978) A World Split Apart. (Commencement Address Delivered at Harvard University, June 8, 1978.) New York: Harper \& Row 61 pp. \& <https://www.solzhenitsyncenter.org/a-world-split-apart>.

28 Kronman, 1993 and Kronman, Anthony T. (2007) Education's End: Why our Colleges and Universities have Given up on the Meaning of Life. New Haven, Conn.: Yale University Press xi+308 pp. 
artificialness. ${ }^{29}$ This is a reaction to obsessive rationalism coupled with value relativism, achieved thanks to the triumph of political correctness threatening with the total overpenetration into people's lives and averting the everyday reformulation of what common sense would otherwise dictate. ${ }^{30}$ Prudence, fortitude, temperance, justice, faith, hope, and lovein an emergent manner, such are now the catchwords again, changing anew for an ideal of university education and professional practice no longer reducible to the type of a privately owned, hired warrior who can, at ease and please, master and win over legal processes as a merely technical match.

This is why there is criticism of "public reason" elevated to the rank of superior authority usually referred to as the last resort, showing its emptiness alongside the "shamanistic incantation of the word 'reasonable,' invoked in the same way that 'God' is in dogmatic religious argument." ${ }^{11}$

This kind of emptiness has a wide contexture and far-reaching consequences. As explained by another Colorado professor, PIERRE SCHLAG, the artificial strive for certainty and security cannot be maintained without the self-deception of the legal mind..$^{32}$ For the substitute they choose, metaphysics can only be rationality, a kind of "pathological reliance on the principle of reason" that this latter author characterizes as an epidemic. Once a deified call is made to reason, it can easily turn to be, as standing for, "a manipulative vehicle of power, faith, and prejudice" in everyday practice. ${ }^{33}$ This is a natural outcome, such as the basic alternative to select between traditional metaphysics and the position of denial by FRIEDRich Nietzsche, ${ }^{34}$ with a third option excluded. Accordingly, he continues, "it is no more possible to continue doing law in an intellectually respectable way once the metaphysic is gone, than to continue worship once God is dead. Law is like God here."35

29 Howard, Philip K. (2002) The Collapse of the Common Good: How America's Lawsuit Culture Undermines our Freedom. New York, Ballantine Books 253 pp. and Howard, Philip K. (2014) The Rule of Nobody: Saving America from Dead Laws and Broken Government. New York, W.W. Norton \& Co. $\mathrm{x}+244$ pp.

30 Schwartz, Howard S. (2010), Society against Itself: Political Correctness and Organizational Self-destruction. London: Karnac Books xiv+216 pp. and Дойчев, Момчил (2010) Политическата коректност срещулибералната толерантност: Есе за идейните битки след комунизма. [Political correctness against liberal tolerance: An essay on the ideological battles after communism.] София [Sofia]: Фабер 160 pp.

31 Campos, Paul F. (1994) 'Secular Fundamentalism', Columbia Law Review, 94(6), pp. 1814-1827 on p. 1817.

32 Schlag, Pierre (1996) Laying down the Law: Mysticism, Fetishism, and the American Legal Mind. New York: New York University Press $\mathrm{x}+195$ pp. Cf. also, as a forerunner, Smith, Steven D. (1993) 'Idolatry in Constitutional Interpretation', Virginia Law Review, 79(3) pp. 583-631.

33 Schlag, Pierre (1998) The Enchantment of Reason. Durham: Duke University Press vii+160 pp.

34 'Gott ist tot.' Cf. <http://en.wikipedia.org/wiki/God_is_dead>; more in details <http://de.wikipedia.org/wiki/ Friedrich_Nietzsche> and <http://www.sterneck.net/literatur/nietzsche-gott/index.php>.

35 Schlag, Pierre (1997) 'Law as a Continuation of God by Other Means', California Law Review, 85(2) pp. 427-440 $\&<$ http://scholarship.law.berkeley.edu/cgi/viewcontent.cgi?article $=1625 \&$ context=californialawreview $>$ on p. 440. 
Thereby, we seem to have returned to a basic situation. "American legal thinkers really do want their own desirable $X$ to exist, and so they cannot help but produce and reproduce a world of stabilized, transcendent signifiers in which the existence (a deep ontological existence) of their really desirable $X$ is authorized and maintained. ${ }^{36}$ As a matter of fact, there is nothing new in such a setting as it is an evergreen topos in any philosophizing on law. PIERRE SCHLAG also realizes that "this is what BEALE does for 'the common law, ${ }^{37}$ what FIss does for 'objectivity," 38 what RADIN, Michelman, and BALKIN do for 'the autonomous self,", ${ }^{39}$ with instances taken from contemporary American legal thought.

The conclusion is that no artificial strive for certainty and security can be upheld without self-deception of and by the legal mind. The substitution of metaphysics with rationality does not work, and the pathological reliance on the principle of reason will sooner or later serve as "a manipulative vehicle of power, faith, and prejudice" in everyday practice. ${ }^{40}$

Authors such as those referred to above start realizing that this is what predecessors have ever done with any key term actually used. As to the overall basic and genuine substance, all of this seems to be a true replica of the insoluble debate (which was never made explicit but stood for the actors' lives) between Carl SChmitt and Hans Kelsen in their parallel search for the final moment transforming judicial decision-making into a genuine act of creation.$^{41}$ Accordingly, new clothes may be used, but centuries-old ambiguities will inescapably remain. For decision needs decisio to be taken by someone somewhere somewhen, presupposing personal responsibility for it.

36 Ibid., p. 438.

37 Beale, Joseph H. (1935) A Treatise on the Conflict of Laws. Vol. I. New York: Baker, Voorhis \& Co. p. 38.

38 Fiss, Owen M. (1982) 'Objectivity and Interpretation', Stanford Law Review, 34(4) pp. 739-763 \& <http://www. law.yale.edu/documents/pdf/objectivity_and_interpretation.pdf>.

39 Radin, Margaret Jane, Michelman, Frank (1991) 'Pragmatist and Poststructuralist Critical Legal Practice' University of Pennsylvania Law Review 139(4) pp. 1019-1058 as well as Balkin, Jack M. (1990) 'Tradition, Betrayal, and the Politics of Deconstruction', Cardozo Law Review, 11(5-6) pp. 1623-1630 in <http://digitalcommons.law.yale. edu/cgi/viewcontent.cgi?article $=1282 \&$ context $=$ fss_papers $>$.

40 Schlag, Laying down the Law, 1996 and Schlag, The Enchantment, 1998.

41 Varga, Csaba (2005) 'Change of Paradigms in Legal Reconstruction (Carl Schmitt and the Temptation to Finally Reach a Synthesis)', in Peter Wahlgren (ed.), Perspectives on Jurisprudence: Essays in Honor of Jes Bjarup. Stockholm: Stockholm Institute for Scandinavian Law [= Scandinavian Studies in Law, 48] pp. 517-529 \& $<$ http://www.scandinavianlaw.se/pdf/48-31.pdf>. 


\title{
IN WANT OF NEW BALANCES IN TRANSITION Lithuania Searching for Its Own Path ${ }^{1}$
}

\author{
1. TRANSITOLOGY QUESTIONED 2. LITHUANIA 2.1. Ideal: Law and Balance 2.2. Ideal: Rights Coun- \\ terbalanced by Duties 2.3. Anything Except Democracy in Outcome 2.4. Legal Personalism as a Re- \\ sponse 3. A CALL FOR LOCAL EXPERIENCE ASSESSED
}

\begin{abstract}
The credibility of the so-called transitology is questioned worldwide as several new unbalances originating from the hardly bridgeable gap between the imported patterns and actual realizations become visible. The Lithuanian jurisprudent Alfonsas Vaišvila's Habilitationschrift on the Conception of the State Ruled by Law in Lithuania sets the law's final ideal in gaining balance on the terrain of expectations and actualizations on the field of law, including the expectation that rights be proportionately counterbalanced by duties, for according to his tenet, no healthy society can develop where balances are not secured. Without balances, anything but democracy can be the outcome. In response to the state of contemporary Lithuania with deficits accumulated, Vaišvila has advanced the so-called legal personalism in the hope of being able to outline the axioms of the legal regime of a well-balanced and duly-schemed, state-organized society.
\end{abstract}

KEYWORDS imported patterns vs. actual realizations; rule of law; Constitution of Lithuania (1928) and (1992); unity of rights and duties; legal personalism

\section{Transitology Questioned}

Having recovered from the trauma of surviving Soviet imperial socialism and being compelled to open up new paths for independent state-building in parallel to common $\mathrm{Eu}$ ropean standards with the readjustment of what is left as local economic and financial, institutional, and legal arrangement, nations of Central and Eastern Europe all have faced the same dilemma: how can they manage international encouragement to adopt foreign patterns as a promise of ready-made routes with immediate success, in a way also promoting the paths of organic development, relying on own resources and potentialities that can only

1 Originally published in Hungarian as the memory of a study trip in 2004. Earlier versions in English include (2005) 'Rule of Law between the Scylla of Imported Patterns and the Charybdis of Actual Realisations (The Experience of Lithuania)', Acta Juridica Hungarica, 46(1-2), pp. 1-11 \&<http://real.mtak.hu/45674/>; reprinted in (2006) Rechtstheorie, 37(3), pp. 349-359; redrafted as (2008) 'In Want of New Balances in Transition: Lithuania Searching for Its Own Path', Central European Political Science Review, 9(No.34), pp. 94-107. 
be gained in and from tradition? Is it feasible at all to rush forward by rapidly learning a whole series of responses that others elaborated elsewhere and somewhen in the past? Or are they expected to become one gigantic Sisyphus bearing his own charge at the price of never-ending suffering and bitter disillusionment? As a matter of fact, such questions were not raised by each country individually as not much time had been left for pondering in the rapid drift of events.

Anyhow, external cost-free solutions may easily lead to adverse results, far from being able to meet expectations. By the time of awakening, however, posterior wisdom may show that alternatives are always available, even if the practicability of either choice will prove to be nonassessable by those affected in the urgently given moment.

Three decades after the Soviet empire collapsed, we can fully realize how painful the fact must have been that each country embarking on dramatic changes was completely left in isolation to face its National Renewal Program, drifted by accidental circumstances. Neither the consciousness nor the organizational framework of the mutual dependence of those concerned relatively small and unpowerful state entities was strong enough, and Moscow, the former focus, was substituted with another center of power-the survival imperium, also interested in the target countries that were just awakening either in self-esteem or as potential counter poles. ${ }^{2}$ As a consequence, each country had to embark on separate efforts at reform, channeled by so-called Open Society agencies and other interferential exploitative benefactors; ${ }^{3}$ however, as we all know, improvisation is not likely to bear products worth consolidation.

The early and total failure of the Hungarian efforts at coming to terms with the past ${ }^{4}$ was only one among a few shocking episodes. This alone might have made us realize that we should not have attempted to respond to a considerably universal challenge on our own, and perhaps a genuine trans-national cooperation might have evolved, had not been our initiative in Hungary too early and even pioneering.

2 Cf. Varga, Csaba (2008) 'Failed Crusade: American Self-confidence, Russian Catastrophe' in Varga, Csaba Transition? To Rule of Law? Constitutionalism and Transitional Justice Challenged in Central \&Eastern Europe. Pomáz: Kráter 292 pp. [PoLíSz sorozat könyvei 7] on pp. 199-219 \& <http://mek.oszk.hu/14800/14851>.

3 See, for example, Cohen, Stephen (2000) Failed Crusade: America and the Tragedy of Post-communist Russia. New York: Norton 305 pp. and-as a by-admission-Holmes, Stephen (2001) 'Transitology', London Review of Books, 23(8)(19 April) pp. 32-35.

4 Cf., e.g., Varga, Transition, 1995, especially the part on 'Coming to Terms with the Past', pp. 119-155; Varga, Csaba (ed.) (1994) Coming to Terms with the Past under the Rule of Law: The German and the Czech Models. Budapest xxvii+178 pp. [Windsor Klub] \& <http://mek.oszk.hu/14300/14310/14310.pdf> as well as Varga, "Radical Evil” on Trial' in the present volume. 


\section{Lithuania}

A Lithuanian theoretical response $\mathrm{e}^{5}$ is outlined in the following. It is perhaps not the earliest one, but in return, its author may have learned from the experience of others. ${ }^{6}$ In general, it is remarkably rational and systematic. Its author may have reconsidered ancient wisdoms in the light of our days' ideals and may have drawn historical lessons from his Lithuanian case study by responding to the shared failures of our global new world.

\subsection{Ideal: Law and Balance}

The ideal of the Rule of Law-also formulated in the preamble of the Constitution of Lithuania (1992) after their patria had returned to the path of an independent statehood by $1990^{7}$-indicates a recognition according to which the unlimitedness of observing any law in a Rechtsstaat can be narrowed by and filtered through the value-centeredness of the Rule of Law. Moreover, such values can be implemented freely due to the principle of intervention preached by the Sozialrechtsstaat, especially when the care for "strengthening those socially weak and weakening the strong"s is on the agenda. Looking back in history, ${ }^{9}$ Lithuanians

5 Vaišvila, Alfonsas (2000) Teisinés valstybés koncepcija lietuvoje. [The Lithuanian approach to rule of law.] Vilnius: Litimo 647 pp. [with summary: 'Law-governed State and its Problems of the Formation in Lithuania: The Outline of State Ideology', pp. 611-631]. The author is chairholder of legal philosophy at the Faculty of Jurisprudence of the Law [now: Mykolas Römeris] University at Vilnius; cf. <https://www.vle.lt/straipsnis/alfonsas-vaisvila/> $\&<$ https://lt.wikipedia.org/wiki/Alfonsas_Vaišvila>. His further work on the topic includes Vaišvila, Alfonsas (2001) Conception of the State Ruled by Law in Lithuania. (Summary of the research report presented for habilitation.) Vilnius: The Law University of Lithuania 50 pp. as well as-in multiplication-his 'Rechtspersonalismus (Zusammenfassung)', 'Die Rechtsaxiomatik oder das Modell der vier Axiome als inhaltliche Grundlage des Rechtspersonalismus', 'Die geometrische Formel des Rechtes als des mehrstelligen Prädikats' and 'Das Recht als Prozess (als das Werden)'. Thanks to our personal encounter, I could invite him to clarify his theory especially as to its philosophical foundations. See now Vaišvila, Alfonsas (2005) 'Legal Personalism: A Theory of the Subjective Right' in Szilágyi, István H., Paksy, Máté (eds.) Ius unum, lex multiplex - Liber Amicorum: Studia Z. Péteri dedicata. (Studies in Comparative Law, Theory of State and Legal Philosophy. Budapest: Szent István Társulat 573 pp. [Philosophiae Iuris / Bibliotheca Iuridica: Libri amicorum 13] on pp. 557-572.

6 As a summary of the debates in Poland, see Wronkowska, Sławomira (ed.) Polskie dyskusje o państwie prawa:Zarys koncepcji państwa prawnego w polskiej literaturze politicznej i prawnej. [Polish discussions on the state of law: summary of the concepts of the state of law in the Polish political and legal literature.] Warszawa: Wydawnictwo Sejmowe 140 pp. Cf. as well Varga, Csaba (ed.) (1994) Coming to Terms with the Past under the Rule of Law: The German and the Czech Models. Budapest xxvii+178 pp. [Windsor Klub] \& <http://mek.oszk.hu/14300/14310/14310.pdf>.

7 'The Lithuanian nation strives for an open, just and harmonious civil society and a state ruled by law.' The expression 'state of law' was first used in Lithuanian literature by MYKoLAS CIMKAUSKAS (1922) and described historically and systemically by Römeris, Mykolas (1928) 'Teisinès valstybès organizacija' [Organisation of the rule of law] in Lietuvos universitetas: 1927-1928 mokslo metais. [University of Lithuania: The academic year of 1927-1928.] Kaunas pp. 6-31-, followed by interwar contemporaries like PETRAS LEONAS and others.

8 Stein, Ekkehart (1993) Staatsrecht. 14., völlig neu bearb. Aufl. Tübingen: Mohr xv+497 pp.

9 Cf., as published subsequently, Vaišvila, Alfonsas (2004) 'The Historical Input of Lithuania in the Creation of the Concept of the State under the Rule of Law', Jurisprudencija, 50(No.42), pp. 74-87. 
may now realize that in their search for a "well-organized" and "organic" state, their ancestors in the sixteenth and seventeenth centuries ${ }^{10}$ had already separated law [ius] from the laws [lex], demanding law to be simultaneously right (that is, calibrated to serve everyone's good in appropriate manner), and that the presumed original freedom that may have led to their first integrative social contract could not entitle anyone to create anarchy but only prepare for genuine balancing. Back in their past, the Lithuanian Statutes (1529, 1566, and 1588) ensured an extremely all-covering "rule of law" for the nobility alone. This became enhanced by the Polish liberum veto. ${ }^{11}$ Accordingly, the disintegration of the ruler's power and responsibility followed-a temporary situation that could only result in either the tyranny of nobles (as beneficiaries) against everyone else or the coming of foreigners to rule (and do whatever they please) with at least some promise of order. History messages that both alternatives did subsequently materialize in Lithuania.

Reconsideration is imperative for all concerned in the region, only if to avoid the traps of the past. One must escape the temptation of whatever kind of dogmatism-foremost that of absolutizing universalization-even if some of the issues crop up in global proportions due to the new role assumed by the American foreign policy after the Cold War and the end of the Soviet might. The early twentieth-century Lithuanian classic of public law, Mykolas RÖMERIS already emphasized that the rule of law is hardly more than a specifically disciplined ethos, only conceivable as the direction of a constantly renewing ambition: it never arrives at completion, for "it cannot be answered once and for all." ${ }^{\text {"12 }}$ It is not even an external pattern to be simply followed and implemented, for it is not of the kind to presume the mechanically "obedient execution or imitation" of requirements once stipulated by others. ${ }^{13}$ This is all the more remarkable now when the course of globalization, maximizing the rule by the rule of law and human rights with a growing disregard for other considerations and values, is about to stumble on disintegrating contradictions and dysfunctions. While eliminating certain threats to human rights, the state ruled by law-writes the present author-immediately originates new ones that are inherent in the notion of human rights itself, ${ }^{14}$ that is, in their abstract conceptualization, totally insensitive to their own social (pre)conditions, ways of operation, and consequences in the short as well as the long run.

10 E.g. Jonas Chondzinskis, Albertas Goštautas, Mykolas lietuvis, Petras Roizijus, Augustinas Rotundas, Leonas Sapiega, Petras Skarga, Andrius Volanas.

11 Cf. Konopczyński, Ladislas (1930) Le liberum veto: Étude surle développement du principe majoritaire. Paris: Librairie Ancienne Honoré Champion \& Varsovie, etc.: Librairie Gebethner et Wolff 297 pp. [Institut d'Études slaves de l'Université de Paris, Bibliothèque polonaise II].

12 Römeris, 'Teisinès valstybès organizacija', 1928, p. 6.

13 Vaišvila, Conception of the State, 2001, p. 11.

14 Ibid., p. 6. 
Furthermore, he inquires into the conditions of reaching states of genuine balance upon the basis of reciprocity between law and social solidarity on the one hand and between (with regards to the openness of social order) full social consent and (with regards to the openness of law and order) the inseparable unity of rights and duties on the other. He reminds that just as the downfall of the first (1572-1795) and the second (1918-1926) Republic of Lithuania was due to the over-limitation of the sovereign and thereby exposing the country to external despotism, historical breakdown may still occur today. What is currently happening is the liberalization of anti-sociality through the restriction of the executive power with reference to abstract human rights. ${ }^{15}$

Preliminary to raising any issue relating to the rule of law is the assessment of the state of actual social conditions. For this author, the acknowledgment of the priority of the human person with inborn rights, taken as the source of their autonomy, as well as the overwhelming social cooperation based on contracts and mutual concessions together with the social majority's active and organized participation, are of equally utmost importance. In contrast, what reality shows now are legal statism and the exclusivity of the dominance of formal law. Even the rule of law tenet is mostly conceived of as formal institutionalization, mere dictate of the law [lex]. However, he continues, until the Lithuanian Constitution (Article 109, Section 3) provides for the judges to proceed "exclusively according to the laws"-instead of laws "and law [ius]"—no genuine division of powers can be achieved.

\subsection{Ideal: Rights Counterbalanced by Duties}

Functionally, law is based upon the unity of subjective rights and legal duties. Rights cannot be but relative as they otherwise degenerate into privileges with aggressive use. Here and in general, mutual dependence arises as part of the natural order from the natural state of humankind, open to exchange equivalent services. Such an interconnection is not made by the state; all that any statehood can do is to make statements about it. In a democratic society, law [ius] can therefore only be built on a conception of law not reduced to mere laws [lex], and only such claims can be posited in the form of laws that are in compliance with human rights, express social agreement, and formulate as legal imperatives such provisions only-the realization of which is also guaranteed by the state's instruments (i.e., to the extent of the state's economic capacity and eventual approval by citizens; ch. 4).

Expounding theoretically, the state is not in a position to dispense justice or punish; moreover, it is not even the state that deprives anyone of their freedom. At the most, all that 
a state can do is to officially establish the new status of a person's rights when this happens to be diminished by their own action of rejecting the fulfillment of certain duties. Consequently, neither capital punishment nor its possible abolishment are within the states' discretion, but they are exclusively within that of the perpetrator. Anyone who kills by negating the right to life of others deprives themselves of the right to their own life. The act of the Lithuanian Constitutional Court that decided for the abolishment on December 9, 1998, declaring the Article 105 of the Lithuanian Criminal Code unconstitutional, can only be construed as the application of one of the following two statements: it either denied its citizens their natural right to equality as a reciprocal interpersonal relationship, or it merely granted pardon for future events, in general terms, on a legally unjustifiable basis and in a way that citizens believe could not have empowered the Court in any way. Moreover, not even the eventual failure of regulation can result in breaking up the necessary balance between rights and duties or in unpunishment because only criminal aggression could otherwise be encouraged. Therefore, the formal, exhaustive, and exclusively statutory definition of crimes needs to be complemented by the availability of judicial—casual—correction. ${ }^{16}$ Entering the twenty-first century, on the one hand, the author claims to perceive that the absolute prohibition of analogy in criminal law may have fairly been motivated by the experience of past totalitarianism. On the other hand, stemming from the data of twentieth-century international criminal practice, Anglo-American jurisprudence, and continental penalizing trends, he is ready to state, generalizing, that the actual boundaries of today's formally absolute prohibition are becoming increasingly flexible under the contemporary, well-balanced rule of law conditions (ch. 5). ${ }^{17}$

\subsection{Anything Except Democracy in Outcome}

According to the authorial vision, the concentration of capital when society is split between the rich and the poor may generate a sui generis type of authoritarianism-cum-totalitarianism under the rhetorical guise of total liberalism. For situations may come about by effects threatening the latter part, in terms of which enlarging groups of addressees must endure practical resignation of their rights and legal rights protection on the command of sheer biological survival. As far as the domestic situation is concerned, the present degree of actual poverty and defenselessness in Lithuania is already about to genuinely erode what

16 For case law is only to counterbalance the unexhaustive nature of legislation by ensuring the universality of implementation of the basic principles of criminal law. Ibid., p. 23.

17 Arnold, Jörg (1998) 'Prinzipien und Grundsätze im deutschen Strafrecht und im Entwurf des Allgemeinen Teils des Litauischen Strafgesetzbuches', Jurisprudencija [Vilnius], 9(1), pp. 62-74, using on p. 68 the expression "fließend" when surveying the German practice of Analogieverbot. 
the state can affect at all. The shameful fact that only $40-42$ per cent of the officially known criminal acts are actually prosecuted can only mean that the other 60-58 per cent of national sovereignty relating to effective crime control is lost. However, this other part should not benefit the criminals - as is the case today - but the victims, either by providing them efficient protection or by returning them the right to protect themselves against crime to a viable extent at least. It is little wonder if citizens' traditional confidence in the state is withdrawn in such situations, only to be replaced by either confidence in their own hands or in powers beyond this world instead. In 1996, only 25 per cent of the Lithuanian population claimed to trust their own parliament, yet 74 per cent claimed that they trusted the Catholic Church. After many decades of Soviet occupation, it is tragic to recall that there was a time when power in Lithuania was seized by foreigners with a promise of order against the tyranny of Lithuanian nobles. Today, Lithuanian officials do ascertain that their justice system is hardly sufficiently operable. A criminal environment can grow to be effective enough to deter injured parties and witnesses from taking part in the administration of justice. Law is no longer a protective power, and legal proceeding may have lost any sense. Criminals have in fact extended their control over law and order, practically depriving society of the chance of legal protection, degrading citizens to growingly becoming partners to the very aggression criminals are used to committing against them. It is the aggression by criminal asociality that is eventually supported by an abstract protection of human rights.

Is it conceivable at all that after a totalitarian past, democracy is to arrive at a time when the present mixture of liberalism-cum-authoritarianism will have been left behind? Is there any logic to the actual course of history in that the former (Soviet-type) lack of freedom is now being compensated by immoderate, even asocial (American-type) libertinism? ${ }^{18}$ What are the symptomatic indicators here? According to the author, the weakness of a middle class that could substantiate democratic progress; the miserable state of economy in the country, the lack of chance for any genuine civil (civic) initiative; the feeble self-assertion of the populace (e.g., when all personal bank savings of the Soviet times were frozen by the parliament once and for all on July 19, 1995 through a posterior and unilateral statutory modification of the conditions of fulfillment of contractual obligations established in the Article 471 of the Lithuanian Civil Code); the want of high state officials' respect for the law (e.g., when the President of the Republic or the Sejm [i.e., the parliament] may fail to observe their formal duties without facing any legal consequence, or the state elite defines ad hoc measures when own remuneration is at stake) as well as the undisturbed misappropriation of public property (through commercial banks and companies with a state share) are all among the first to be considered here.

18 For the term, cf. Meyer, Frank S. (1969) 'Libertarianism and Libertinism?', National Review, 21(September 9), p. 910. 
The rule of law is hardly imaginable without proper social and psychological, ideological, and constitutional foundations. As to the current political experience in Lithuania, it calls for a stronger presidency as well as a parliament with more effectivity in balancing. For what the constitutionalist RöMERIS had once written about parliamentocracy as a mere theoretical potentiality, three-quarters of a century ago seems to have by now become everyday reality since the last election in October 2000, which broke the continuation of communists' domination. In fact, pursuant to the Article 72, Sections 2-3 of the Constitution, any bill can be-even repeatedly and without the slightest alteration-passed by absolute majority, despite any veto by the president of the state. Thus, nine protests by President BRAZAuskas could be constitutionally ignored in 1997 without paying the least attention to his motives. As to historical antecedents, the Article 51, Section 2 of the Constitution of the Republic of Lithuania of 1928 followed the American model by providing a qualified two-third majority in case a bill had been vetoed against. As fairly recalled, President Roosevelt interposed official veto 631 times until the New Deal could be implemented; moreover, Lithuania itself was in favor of a tradition of strong presidency both in the far and recent past. ${ }^{19}$ Surveys show that the population still trusts a weak president significantly more than a parliament formed by random circumstances and, as the case may be, sometimes tragically exposed to the play of mere chance. This is clearly indicated by the contrasted support through varying periods and circumstances notwithstanding:

\begin{tabular}{|l|c|c|}
\hline & President Algirdas BRAZAusKaS & Parliament \\
\hline December 1993 & $60.0 \%$ & $34.0 \%$ \\
\hline June 1996 & $20.0 \%$ & $14.0 \%$ \\
\hline & President VALDAS ADAMKUS & Parliament \\
\hline June 1998 & $71.2 \%$ & $12.7 \%$ \\
\hline December 1998 & $76.4 \%$ & $13.4 \%$ \\
\hline
\end{tabular}

19 Destabilization efforts were already made in 1922, at the dawn of the young republic, under the pretext of stabilizing the legal status of the parliament. - During World War II, the partisan movement Žalioji rinktine fought against the occupying Soviet powers in Eastern Lithuania and declared as early as in 1945 that "We want a presidential republic, similar to the one of the United States of America, with a powerful president" [V. Kuročkos apklausos protokolas. (Archives manuscript.) p. 15.] - The World Congress of Lithuanian Lawyers declared on May 24-31, 1992: "Exclusively a strong presidency can ensure the stability of social processes, block the way to chaos and neutralise the destructivity of those thirsting for revenge, in order to become the buttress of the further development of democracy." Kaganas, I. (1993) Lietuvos Respublikos valdymo forma - Lietuvos valstybingumo teisines problemos: Pirmojo pasaulio leituviu teisininku kongreso straipsniu ir teziu rinkinys [The form of government of the Republic of Lithuania - Legal problems of Lithuanian statehood: a collection of articles and theses of the First World Congress of Lithuanian Lawyers]. Vilnius p. 7. - It was President AlgiRDAs BRAZAuskas who claimed, when his vetoes were ignored, that "to be able to operate efficiently, the President should also be given more power, following the introduction of the democratic pattern of governance" [Lietuvos rytas (February 14, 1997).] 
Thus, there is a contradiction that can barely be eliminated by means of mere rhetoric, namely that while the country is actually ruled by a power of a rather low esteem, the power preponderately trusted by the nation is without almost any sensible competence (ch. 8, para 2). ${ }^{20}$

In the final analysis, the exclusive way to (with some standard and criterion of) a "wellorganized" and "organic" state is now nothing but the "maintenance of comprehensive balance" on each relevant field of the entire social, political, and legal setup as the exclusively available guarantee of political stability, social equality, and legal reciprocity. ${ }^{21}$

\subsection{Legal Personalism as a Response}

This is the reason why the author has developed his theory of so-called legal personalism based on the axiomatics of the geometrical formula of law, taken as a compound predicate. I avail just to mention some of its fundamental tenets here. Accordingly, the equivalence in reciprocity of social relations is the prerequisite of any "open society." It follows that "subjective right is not the property of the individual but, as a compound predicate, is a relation established for the mutual protection of the interests of all persons concerned." Consequently, on the ground of the reciprocity having come about with the "unity of rights and duties," the individual is, depending upon their deeds, always in balance with their own respective rights and duties because "by fulfilling or rejecting the latter, he has the former recognised, legalised or annihilated" automatically. Indeed, there is no other way to choose, for "rights without obligations are nothing but downright privileges, while duties without rights can only stand for sheer violence."22

20 Vaišvila, 2001, pp. 32-36.

21 Also see Vaišvila, Alfonsas (1999) 'Место наказания в правовом государстве' [Place of punishment in a legal state] in Проблеми вдосконаления законодавства та практика його застосувания з урахуванням прогнозу злочинности. Vol. 1. Луганськ рр. 44-49 [Вісник Луганського інституту внутрішніх справ МВС Украіни] and Vaišvila, Alfonsas (2000) 'Социальное правовое государство: Приобретаемая и теряемая реальность' [Welfare legal state as acquired and lost reality] in (2000) Конституционно-правовое проблемы бормирования соииального правового государства. (Материалы международной конференции.) Минск: Белорусский государственный университет рр. 24-28.

22 ["Die Äquivalenz der Austausche [...ist...] die Einheit von Rechten (der Erlaubnis) und Pflichten (dem Gebot) zu bestimmen [.......] die Menschenrechte werden nach der Erfüllung oder der Verzicht der entsprechenden Pflichten erworben, legalisiert oder verloren." "Das subjektive Recht ist nicht die Eigenschaft des Individuums, es ist ein mehrstelliges Prädikat bzw. das Verhältnis, das für den gegenseitigen Schutz der Interessen der Personen geschaffen ist." "Das Recht ohne Pflicht gleich einen Privilegien, die Pflicht ohne Recht ist bloße Gewalt."] 


\section{A Call for Local Experience Assessed}

The oeuvre presented herewith is not a cry for help but the manifestation of a responsible scholarship gradually realizing its own strength and independence. It is rewarding to learn that the same ethos that, after the Soviet regime is over, is about introducing Western trends as desirable patterns to be followed with natural ease also indicates the need for new foundations by building up its own worldview, having left behind its earlier forms rooted in Bolshevik ideology. This is exactly what the magisterial work that has just been surveyed does: having overviewed the mostly pattern-following and more or less promising or disappointing results of Lithuanian domestic development spanning over nearly one and a half decades as givens of their history, it assesses them monographically. This very approach presumed sound skepticism as prerequisite to any responsibly constructive thought, subjecting any result to scrutiny, omitting reliance on either clearly personal [ad hominem] or exclusively authoritarian [ad autoritatem] reasons in their evaluation.

It would be a shock if the arrogance of force could define itself again in the guise of the renewed ideology of the once alleged HEgELian quote "so much the worse for the facts" this time at the overture to the twenty-first century. It is a fact notwithstanding that ideas and constructions that stream toward us from overseas are expected to find roots in a soil poor in resources while targeting a disintegrated society with distorted morals, in which only the reliance on individual surviving strategies has proven to be the exclusive adequate personal response in an economy that has fallen prey to the stronger and professionally preoccupied with the exhaustion of national property.

According to the creed of many, the principles of free market, democracy, and parliamentarism (with rule of law and human rights in the background) offer a kind of panacea curing all the ills in the world. Still, social science should be given the chance to record-if so found - that the same abstracted institutional scheme may not work here as it is used to work there in its natural surrounding, or at least not with the same cost and benefit ratio. Social science is open to ideas to both test them and reject them upon criticism. Moreover, scholarship in Central and Eastern Europe is growingly aware of the fact that what it can provide is by far not marginal feedback but the very first testing and teasing proof of the social embeddedness of the ideas and ideals exported. For whatever we think of the cultural-anthropological preconditions of such guiding stars of modernity and of the scientific verifiability of the concept

23 "If the facts do not fit to the theory, the worse for the facts" ["Wenn die Tatsachen nicht mit der Theorie übereinstimmen, umso schlimmer für die Tatsachen"] is usually attributed to GEORG WILHELM FRIEDRICH HEGEL, though it may originate from the French "Tant pis pour les faits" redrafted in German journalism; cf. <https:// falschzitate.blogspot.com/2020/08/wenn-die-tatsachen-nicht-mit-der.html>. 
of man that they postulate, ${ }^{24}$ Western social development (with the ideocracy of DworkIN, HABERMAS, and RAWLS, in terms of which values are just a random function of supporting majority, and rights are made one of the gratuitous accessories of any human existence) is by no means separable from economic capacity and reserves of such a development, or the practical operation of any societal complexity requires resources in both social organization and material production. In the Atlantic world, those preconditions seem to be presently available either through economic reproduction, by using up their own reserves, or as withdrawn or expropriated from others' assets. In any case, if a program proves to be too wasteful or costly, less powerful regions of the world may encounter problems with financing, for they are in want of reserves and of other substitute resources.

Scholarly sensitivity to such issues has developed in the Western world as well, ${ }^{25}$ even if not yet transcending purely local self-analysis. Until now, scholars have failed to address either other regions or their ideals' very preconditions. This is why the issues raised above are still question ${ }^{26}$ on and for us and why they should be tackled at least by those concerned.

24 If the presuppositions of democracy are not provable as preconditions prevailing in fact, only tradition taken from the Enlightenment credo can be the case. Cf. Frivaldszky, János (2003) 'Gondolatok az emberi jogok radikális szemléletéből fakadó problémákról' [Thoughts on problems arising from the radical approach to human rights] in Frivaldszky, János (ed.) Egy európai alkotmány felé: A nizzai Alapvető Jogok Chartája és a Konvent. [Towards a European constitution: the Charter of Fundamental Rights and the European Convention on $\mathrm{Hu}-$ man Rights.] Budapest: JTMR Faludi Akadémia - OCIPE Magyarország 99 pp. [Agóra II] on pp. 63-74.

25 Cf., for example, Holmes, Stephen, Sunstein, Cass R. (1999) The Cost of Rights: Why Liberty Defends on Taxes. New York: Norton 255 pp. as well as Posner, Richard A. (1983) The Economics of Justice. Cambridge, Mass.: Harvard University Press xiii+415 pp. and Posner, Richard A. (1998) Economic Analysis of Law. New York: Aspen Law \& Business xxi+808 pp. As an outlook, see also Sajó, András (ed.) (1996) Western Rights? Post-communist Application. The Hague: Kluwer Law International xviii+386 pp.

26 As for the author's posterior contribution to the topic, cf. Vaišvila, Alfonsas (2008) 'Dviguba Pilietybe - ne tik dvigubos teisès' [Double citizenship - not only Rights are Double] Jurisprudencija, 7(No.109), pp. 7-13; Vaišvila, Alfonsas (2009) 'Human Dignity and the Right to Dignity in Terms of Legal Personalism (from Conception of Static Dignity to Conception of Dynamic Dignity)' Jurisprudencija, 3(No.117), pp. 111-127 \& <https://search. proquest.com/openview/fadb79d2ea998601ffeoe1ed9421265d/1.pdf?pq-origsite=gscholar\&cbl=2026708>; as well as Vaišvila, Alfonsas (2012) "Other Forms of Family", or an Attempt to Tailor the Notion of Family to an Individual's Subjectivity' Socialiniu Mokslu Studijos 4(3), pp. 953-972. 


\title{
GLOBAL CHANGES AND CHALLENGES TO LAW Immutability and Mutability in Law ${ }^{1}$
}

\author{
1. Introduction 2. Challenges in Need of a Direct Response 3. New Dimensions of Law 4. Changes in Law \\ 5. New Paradigm in Understanding Social Order
}

\begin{abstract}
Confronting (2) Challenges in Need of Direct Response: how to react if, by inventing easy-touse facilities, personality can be manipulated, programmed, and changed all through? If abortion can be achieved through organic regression? If undetectable arms will be developed with long delayed or far-reaching effect? If chemical, radioactive, or cyber warfare is made available on a mass scale as operated by anyone in isolation with no chance of identification? If life expectations of human groups can be worsened or changed? Or if the reason for copyright regulation is lost as technological innovation excludes any chance of control? Facing (3) New Dimensions of Law: how law reacts if given multiplied presence, global level of orderliness (arranged "in books") and globally centralized focus (practiced "in action"), with technics intensifying scope and depth of regulation? Moreover, (4) Changes in Law also occur as a consequence of basic changes in the way humans are organized into society and the technology by which their conduct is influenced. For instance, information technology enables to process millions of opinions and calls masses for public actions, with civil society superseding politically organized society. Lastly, (5) New Paradigm in Understanding Social Order is a new phenomenon: the investigation into individual factors (i.e., causes/energies/effects) in chains of (quasi-)causality is replaced by a vision built on the average of what can be experienced in statistic masses and probabilities. For an autopoietic process, the coordinates (or laws) of ongoing operations are defined through (and while and for) the operational process itself, individually for each case. Accordingly, the "order out of chaos" idea is becoming an explanatory principle also for the field of law.
\end{abstract}

KEYWORDS normality; technological development; all-thorough change of law; principles, presuppositions, and social preconditions; mutability vs. human perspective of immutability; responding nature of law

1 Originally delivered on November 3, 2012 on the Day of Hungarian Science at the event of the Hungarian Academy of Sciences' Institute for Legal Studies, commemorating the day in 1825 when the Hungarian Parliament decided to establish a Hungarian Academy of Sciences: (2013) 'Tudományos-technikai forradalom és globalizmus - lehetséges változások a jog szerepkörében', Valóság [Reality], LVI(4), pp. 1-10 \& <http://epa. oszk.hu/02900/02924/00004/pdf/EPA02924_valosag_2013_4_001-010.pdf>. Published earlier in English as 'Global Future, Systemic Challenges: Changes in the Profiles of Law?', Central European Political Science Review, 18(No.67), pp. 62-81 and as (2017) 'Global Future, Systemic Challenges (Changes in the Profiles of Law?)' in Zapesotsky, A. S. (ed.) Global World - System Shifts, Challenges and Contours of the Future: The 17th International Likhachov Scientific Conference, May 18-20, 2017. St. Petersburg: St. Petersburg University of the Humanities and Social Sciences 242 pp. on pp. 149-152 \&<http://www.lihachev.ru/pic/site/files/lihcht/Sbor_full/2017_english. pdf> \{reprinted as 'Socio-economic Development and Global Challenges to Law' in Семенівна, Мякушко Надія (еd.) (2020) Інноваційний потенціал та правове забезпечення соиіальноекономічного розвитку України: Виклик глобального світу (Матеріали Міжнародноїнауково-практичної онлайн конференції, м. Полтава, 25-26 березня 2020 р.). Полтава: Полтавський інститут економіки і права 990, pp. 186-199. 


\section{Introduction}

Law is only distinct in so far as there is an institutional claim that posits distinctiveness to be a notional sine qua non. ${ }^{2}$ As an agent in action, however, law is never detached from the human component and the latter's sociality. Taken as an aggregate of abstract conceptual categories, law reflects intersubjective relations as universally typifiable social relations transformed into jural relations, the formulation of which serves as self-justification within its own system of fulfillment as a quasi-logical consequence with questioning excluded. Thereby, social order is mediated by legal order as the final and supreme factor of social integration.

What needs (re)solution here, according to whatever general standard, is the bunch of human interests with tensions arising among them. KARL MARX and CARL SCHMITT equally described how human interests-including the most particular ones-have ever been universalized in history ${ }^{3}$ and how laws-ancient and contemporary-have been legitimized by reference to godly roots or natural law foundations or, and especially these days, through deduction from human rights. Human manipulation and ideological detorsion notwithstanding, ${ }^{4}$ the intellectual world is ours: we are at home in and routinized within it. ${ }^{5}$ It is ceaselessly acquired through premises shaped by education and socialization, ${ }^{6}$ the framework of which is outlined by universalized moral principles and lived as the natural

2 Selznick, Philip (1959) 'The Sociology of Law' in Merton, Robert K., Broom, Leonard, Cottrell, Leonard S. (ed.) Sociology Today: Problems and Prospects. New York: Basic Books pp. 125-127 at p. 124 and Selznick, Philip (1968) 'Sociology of Law' in Sills, David L. (ed.) International Encyclopedia of the Social Sciences. Vol. 9. New York: Macmillan on pp. 50-59 on p. 50.

3 Marx, Karl, Engels, Friedrich (1845-1846) The German Ideology [Die deutsche Ideologie]. Vol. I-II. 3rd rev. ed. Moscow: Progress Publishers, 1976. In original German, <http://www.mlwerke.de/me/me03/me03_009. htm>.

4 FRIEDRICH NiETzSCHE identified Willen zur Macht in the process of how conceptualisation is made, as field of the pressure widely exercised by those stronger, worthy to rule; cf. <http://de.wikipedia.org/wiki/Wille_zur_ Macht>.

5 See, e.g., Baecker, Dirk (2001) Wozu Kultur? 2nd enlarged ed. Berlin: Kadmos Kulturverlag 203 pp.

6 This is not a reference to pre-comprehension [Vorverständnis] within the hermeneutic circle but knowledge backing whatever social consensus, seldom made conscious. Cf. Varga, Csaba (2012) The Paradigms of Legal Thinking. [1996/1999.] Enlarged 2nd ed. Budapest: Szent István Társulat 418 pp. [Philosophiae Iuris] \&<https:// mek.oszk.hu/14600/14657/>. It was Perelman, Chaïm (1968) Droit, morale et philosophie. Paris: Librairie Générale de Droit et de Jurisprudence 149 pp. [Bibliothèque de Philosophie du Droit VIII] that revealed how our opinions are based on series of conventionalisations made by the human kind on the scene of a "universal auditorium" [auditoire universelle], justifying the quest only in case of deviation or reformulation and otherwise preserving the routine by unreflected imitation. 
condition of human existence, ${ }^{7}$ although it is molded by human imagination ${ }^{8}$ within the bounds of what is conceived as normality. ${ }^{9}$

Globalism is a politically motivated process, the new potentialities of which are afforded by contemporary scientific and technological revolution. Without prophesizing on possible outcomes from the perspective of a coming world society, it can now be argued with certainty that our present law's conceptual network, axiomatized by conventionalized principles within an ideally coherent system, will be wholly or partly shaken with unforeseen consequences.

\section{Challenges in Need of a Direct Response}

Technological development ceaselessly raises challenges that humankind must respond to instantly: biotechnics, nanotechnics, and physical and chemical reconsiderations on both macro and micro levels-from armament to pharmacology and, last but not least, social explosion that may arise from new achievements of information technology. That is, a series of new actors and factors may become the source of new dangers, crying, as imminent calls, for regulation on a global scale, such as what to do with space or atomic garbage or with technologies that make information multiplication and distribution uncontrollable, for instance.

Accordingly, foundational values and basic principles are eminently targeted, with an urge to reconsider them, in their reflective equilibrium ${ }^{10}$ and the new-still tolerablebalance amongst them, even if this is only tentatively possible. How to react if, by having invented easy-to-use facilities, personality can already be manipulated, programmed, and

7 For natural law based on the anthropological presuppositions of Jewish, Christian, and Islamic theology, the human quality is defined once and for all by the act of creation. This was somewhat mitigated through realizing its historically variable contents [Naturrecht mit wechselndem Inhalt] by Stammler, Rudolf (1896) Wirtschaft und Recht nach der materialistischen Geschichtsauffassung: Eine sozialphilosophische Untersuchung. Leipzig: Veit viii+668 pp. on p. 183. For MARxism, however, albeit the human species-essence [Gattungswesen] - see <http://www.marx-forum.de/marx-lexikon/lexikon_g/gattung.html>- appears as constant for the contemporary observer, in an analytic-conceptual perspective, it is a historical product, part of the second nature of humans and derivative of underlying conditions. At the same time, MARxism holds that it is ideologically colored, in the sense that it results from human reflection in any of its given forms.

8 As for the law's preassumptions, seldom specified or defined, cf. White, James Boyd (1973) The Legal Imagination: Studies in the Legal Thought and Expression. Boston: Little Brown xxxv+986 pp.

9 Schmitt, Carl (1922) Politische Theologie: Vier Kapitel zur Lehre von der Souverenität. Berlin \& Leipzig: Duncker \& Humblot 56 pp. <http://de.scribd.com/doc/81214206/schmitt-politische-theologie> argues with normality conceived of as the natural presupposition of any conscious regulation, concluding that responding to exceptional situations needs a hic et nunc concrete norm to be found or posteriorly construed.

10 Cf. <http://en.wikipedia.org/wiki/Reflective_equilibrium>, originating in Rawls, John (1971) A Theory of Justice. Cambridge, Mass.: The Belknap Press of The Harvard University Press xv+607 pp. 
changed all through? If abortion can be achieved through (as replaced by) organic regression? If undetectable arms will be developed with long delayed or very far-reaching effect? If chemical, radioactive, or cyber warfare is made available on a mass scale, which is easy to operate by one single person in isolation, under conditions by which no genuine chance to identify the wrongdoer will remain ${ }^{11}$ If life expectations of human groups, either genetically specified or otherwise targeted, can be worsened or changed, almost at please and with no trace posteriorly successfully detectable? Or if there will be no reason any longer for copyright regulation at all as technological innovation will by itself exclude the very chance of control?

As known, technology is generally seen as merely instrumental and, as such, as having quite neutral a function. However, lessons that can be drawn from twentiethcentury brutalities show parallel development between technological achievement in producing bulldozer-like, earthmoving machines and genocides perfected on an almost industrial mass scale. It is almost as if the humans' tendencies to kill were realized as soon as earthmoving machines to clear the remains were found. ${ }^{12}$ Perhaps it is not by chance that philosophy of history visions, such as OswALD SPENGLER's The Decline of the West, have for long been associated with the fear of technological self-development, that is, with technical processes becoming autotelic as a motive force leading to the death of civilizations. ${ }^{13}$

Who is then to decide in technology issues? Following the direction of developing from post legal positivism to legal socio-positivism (transubstantiating judicial process into a

11 For the British S[pecial]A[ir]S[ervice] Gibraltar action practically executing three I[rish]R[epublican]A[rmy]/ A[ctive]S[ervice]U[nit] agents on March 6, 1988, see <http://en.wikipedia.org/wiki/Operation_Flavius> \& $<$ http://en.wikipedia.org/wiki/Death_on_the_Rock>, and for the complaint dismissed by the European Court of Human Rights, see McCann and Others v United Kingdom Series A, No 324, Application No 18984/91(1995) in $<$ https://hudoc.echr.coe.int/fre\#\{\%22itemid\%22:[\%22001-57943\%22]\}>. As to the type of practically undetectible wrongdoing, with effect of troubling (up to crashing) working systems in the base organization of present-day society, cf. <http://en.wikipedia.org/wiki/Cyberwarfare> and, from the rich literature, Rosenzweig, Paul (2013) Cyber Warfare: How Conflicts in Cyberspace are Challenging America and Changing the World. Santa Barbara, Calif.: Praeger xi+290 [Changing Face of War]; Woltag, Johann-Christoph (2014) Cyber Warfare: Military Cross-border Computer Network Operations under International Law. Mortsel: Intersentia xviii+314 pp. [International Law 14]; Jajodia, Sushil, Shakarian, Paulo, Subrahmanian, V.S., Swarup, Vipin, Wang, Cliff (eds.) (2015) Cyber Warfare: Building the Scientific Foundation. Cham: Springer International Publishing xiii +321 [Advances in Information Security 56].

12 See, for instance, Melson, Robert (1996) Revolution and Genocide: On the Origins of the Armenian Genocide and the Holocaust. Chicago: The University of Chicago Press xxi+363 pp.

13 Spengler, Oswald (1931) Der Mensch und die Technik: Beitrag zu einer Philosophie des Lebens. München: Beck v+88 pp. \{(1932) Man and Technics: A Contribution to a Philosophy of Law. Trans. Charles Francis Atkinson. New York: Knopf 104 pp.\}. 
multi-actor intercultural and multi-criterial discourse), ${ }^{14}$ decision will certainly be prepared or made by experts' panels with lawyerly assistance in channeling, drafting, and coherence testing-unless American-type re-juridification intervenes, wedging the lawyers' cast in the process again to regain monopoly of control and diverting the socially all-inclusive trend into American-specific jurispathy. ${ }^{15}$

\section{New Dimensions of Law}

Due to ongoing technological revolution, the legal phenomenon may gain new dimensions if given, among others, multiplied presence, higher level of orderliness (as arranged "in books"), and/or more centralized focus (as practiced "in action"), complementing-as the main goal or a side effect-technics that may enhance and intensify the scope and depth of regulation.

Let us just take a moment to consider how the law was objectivated and legal texts distributed in very early times. ${ }^{16}$ The Codex Hammurapi was once carved; the Leges Duodecim Tabularum was versed for and memorized by pupils (as the child CICERO was expected to do); the Magna Carta was placarded on church gates once a year; the pre-revolutionary French cahiers de doléance as penny literature were all printed and sold at markets; and the total mass of the empire's laws was card-indexed by the once All-Soviet Institute of Legislation, to allow them to establish authoritatively what exactly and with what wording had been in force, ${ }^{17}$ finally, the eGovernment of Austria ${ }^{18}$ prepared to give automated, computerized documents in public administration. What

14 Cf. Csaba Varga 'Meeting Points between the Traditions of English-American Common Law and Continental-French Civil Law: Developments and Experience of Postmodernity in Canada' [2002] in his Comparative Legal Cultures On Traditions Classified, their Rapprochement \& Transfer, and the Anarchy of Hyper-rationalism (Budapest: Szent István Társulat 2012) 253 pp. [Philosophiae Iuris] pp. 105-130 \& Varga, Csaba (2003) 'Meeting Points between the Traditions of English-American Common Law and Continental-French Civil Law (Developments and Experience of Postmodernity in Canada)', Acta Juridica Hungarica, 44(1-2), pp. 21-44 \{reprinted in $<$ http://mek.oszk.hu/15300/15386>, at p. 124\}.

15 Cf. Varga, Csaba (2010) 'Rule of Law? Mania of Law? On the Boundary between Rationality and Anarchy in America' in Nótári, Tamás, Török, Gábor (eds.) Prudentia Iuris Gentium Potestate: Ünnepi tanulmányok Lamm Vanda tiszteletére [Festschrift to Vanda Lamm]. Budapest: MTA Jogtudományi Intézete 530 pp. on pp. 492-504 \{reprinted in <http://mek.oszk.hu/15300/15386>, pp. 165-180\} as well as Varga, Csaba (2012) 'The Law's Homogeneity Challenged by Heterogenisation through Ethics and Economics', Acta Juridica Hungarica, 53(2), pp. 165-174 \& <https://akjournals.com/view/journals/026/53/2/article-p165.xml>.

16 Cf. Varga, Csaba (2011) Codification as a Socio-historical Phenomenon. [1979/1991.] 2nd \{reprint\} edn. with an Annex \& Postscript. Budapest: Szent István Társulat viii+431 pp. \&<http://mek.oszk.hu/14200/14231/>.

17 What I visited in Moscow in 1968; cf. Varga, Csaba (2021) 'Encountering Comparative Law in Hungary', Journal of Comparative Law [London, Wiley], 16(1), pp. 243-264.

18 As a break-through by the project Digital Austria, cf. <http://www.digitales.oesterreich.gv.at/site/6506/ default.aspx> \& <http://www.egov.vic.gov.au/focus-on-countries/europe/countries-europe/austria/trendsand-issues-austria/e-government-austria.html>, with an European overview in <http://en.wikipedia.org/ wiki/EGovernment_in_Europe\#Hungary>. 
about the future of laws' coherence? Of new instrumentalities globally radiating laws and legal change? With means enabling such law to rule society alone? With such exclusivity that nothing of morality, tradition, or common sense can seep into this law anymore?

It is hard to assess how much humankind retarded since JEAN-JACQUES ROUSSEAU's answer to the quest priced by the Academy of Dijon. ${ }^{19}$ Anyhow, warfare brutality and the awakening conscience have been reacted to by the birth of international humanitarian law. Here, it is not facts that legally defined constitute a case in law but the posteriorly re-construable intent and foresight, while tactical planning and commanding will be judged in law.

What role law is designed to play at all? As back in times of communist dictatorship, the sociology of law in Hungary already professed, the law's exclusively effective-optimumjob cannot be more than the reassertion of ongoing social processes by the law's specific means and authority, that is, a final, symbolic, and authoritative stamping, although law is frequently forced into the impossible role of a Mädchen für alles - to act as a demiurge, a substitute to the various means of social reform, taking on what is hardly more than political voluntarism. ${ }^{20}$ Making laws instead of all social reforms is sham action; it is bound to fail, and it degrades the law's prestige, too, at least in the long run.

In what normative environment and with which expectations is law called to work? For millennia, in more or less integral social organicity, law used to serve cementing community as (a) a frameworking ethos, (b) a prime agent of accumulating, refining and helping in the institutionalization of transcendental ideas concerning their aggregate as people, and (c) the final support of morality, later on also assisted by $(d)$ the lawyers' professional deontology. ${ }^{21}$ As known, all this has subsequently been denied by the post-1968 Western world, with the very idea of social normativity dissolved under the aegis of libertines' individualism and with only law to remain as reduced to the role of a mediator among duelers, under conditions of social atomization with neutral and unconcerned look at lawbreakers and law-enforcers alike, just as if none of them were else and more than rivaling partners in a free-time sporting event.

19 To the question posed 'Has the restoration of the sciences and arts contributed to the purification of morals?' ['Si le rétablissement des sciences et des arts a contribué à épurer les moeurs'], he responded in 1750 that 'our souls have become corrupted to the extent that our sciences and our arts have advanced towards perfection.' ['Nos âmes se sont corrompues à mesure que nos sciences et nos arts se sont avancés à la perfection.'] Cf. $<$ https://ebooks.adelaide.edu.au/r/rousseau/jean_jacques/arts/> \& < <http://classiques.uqac.ca/classiques/ Rousseau_jj/discours_sciences_arts/discours_sc_arts.html>.

20 Cf., for example, Varga, Csaba (1986) 'Macrosociological Theories of Law: From the "Lawyer's World Concept" to a Social Science Conception of Law' in Kamenka, Eugene, Summers, Robert S., Twining, William (eds.) Soziologische Jurisprudenz und realistische Theorien des Rechts. Berlin: Duncker \& Humblot xvi+381 pp. [Rechtstheorie Beiheft 9] pp. 197-215 \{reprinted in <http://mek.oszk.hu/15300/15333/\#>, pp. 43-76\} and, as monographed to the depth by case studies, Kulcsár, Kálmán (1992) Modernization and Law. Budapest: Akadémiai Kiadó 282 pp.

21 'juristische Weltbild'; cf. Engels, Friedrich, Krautsky, Karl 'Juristen-Sozialismus' (1887) in Marx, Karl, Engels, Friedrich (1962) Werke. Vol. 21. Berlin[-East]: Dietz Verlag pp. 491-509 \& <http://www.mlwerke.de/me/me21/ me21_491.htm>. 


\section{Changes in Law}

It goes without saying that both the ways in which humans are organized into society and the technology and background culture by which their conduct is conditioned and/or influenced can change over a longer period of time, which may also provoke changes in law.

By future development, we may be in possession of a kind of information technology that enables us to process and taxonomize the opinion of millions; to directly call masses for public actions; and to grow civil society up to the point of managing politically organized society with the chance of, once upon the time, perhaps definitively replacing state machinery. ${ }^{22}$ Nowadays, some American research shows that the random representation of civic opinion may prove to be more prudent, grounded, responsive, and responsible as compared to the level of commissioned expert opinions. Though random reaction is characteristically fuzzy or, properly speaking, spread and scattered, their effect in statistical probability is by far foreseeably certain.

Anyone can hardly foresee now what technics for channeling and influencing human behavior will be operated in the future. However, perhaps, it is enough to recall how many modifications in the implementation of social changes have been assisted by the mass media as a new phenomenon and how extensively the wide instrumentality of mass manipulation has been used in dictatorial and democratic regimes since the beginning of the twentieth century. Practically the same holds for social normality and abnormality as well, at least in so far as the changing formation and possible transubstantiation of our presuppositions and criteria of what they are and how we feel them are concerned. For even our present (self-) image of personality has already been shocked by such innovations as organ transplantation and biotechnics. At the same time, the sheer technical ability to create mass danger, perhaps mortal to the Earth itself, thanks to means that can perhaps be made easily available now or in the future, also has to challenge classic freedoms to be heavily narrowed or limited as they are by now required by antiterrorist measures, among others. ${ }^{23}$

Still in its quality of a distinct phenomenon, law, which also tends to preserve its own systemicity, develops mostly by changing the volume or extension of its rule-based regulation

22 See, for example, the variety of claims formulated in (2001-) Global Civil Society Yearbook, I-, London \& New York: Oxford University Press.

23 Cf. the author's memory sitting just after the New York World Trade Center collapsed on September 11, 2001, with his friend Professor BJARNE MELKeviK at the latter's home in Québec, watching US TV channels for news, to learn, among others, how a terroristic disaster is responded to by those responsible to take a stand on and select priority between prompt necessity and traditionalized routine, involving, if at all, usual limits set by law, Varga, Csaba (2012) '...csak múlásunk törvény...' Varga Csaba jogfilozófussal beszélget Mezei Károly ['...only our passing away is a law...' The legal philosopher is interviewed...]. Budapest: Kairosz Kiadó 142 pp. [Magyarnak lenni CIII] \& <https://mek.oszk.hu/19800/19835/>, pp. 128-129. 
through analogically narrowing or enlarging the scope to which it applies. Any of its provisions with the principles underlying them and the background philosophy in the foundation of the principles concerned can easily be shaken once ongoing scientific-technical revolution will improve organic reproductive processes, disperse information in the electronic space, create further virtual realities by projection (including any kind of artificial reasons that already master us from the field of finances, via economic organization, to rule by law and rule of law, and so on), or scatter our human environment with chemicals or radioactive materials, making life on Earth impossible.

Human will and ability, of course, are also necessary to draw the consequences in law. However, at the same time, we must be aware that it is the law that provides this opportunity, with its structures and the concrete conceptual framing of the variables of changes. When any of these or other processes or consequences become problematic, it is the law that can build new and new channels of influence, restriction, or prohibition in response, and again, within the limits drawn by the law's general structure and abstract conceptuality. ${ }^{24}$

\section{New Paradigm in Understanding Social Order}

In the meantime, a change of paradigms has occurred in our very understanding of the nature of sociality, of the way action is followed by reaction in the social space of normativity. Until the middle of the nineteenth century, the physical world outlook (once built by NicOLAUS COPERNICUS and ISAAC NEWTON) was adapted to the social world: we, too, were to search for causes and effects (and isolate them for analytic purposes as much as possible) in the chain of processes. However, by the turn of the twentieth century, the investigation into individual factors (i.e., causes/energies/effects) in those chains of (quasi-)causality was replaced in thermodynamics and the sciences of elementary particles by a vision built on the average of what can be experienced in case of statistic masses on their probabilities. This led to the imagination of systems that are half closed and half open, named as autopoietic processes, in case of which the coordinates (or laws) of any ongoing operation are defined through (and while and for) the operational process itself, that is, individually in each case. Accordingly, the idea of "order out of chaos" - unthinkable beforehand for both scientific and theological reasons-became the theoretical framework with explanatory force for micro-physics and

24 Legal machinery permits both discretionary answers and mutually contradictory conclusions to be drawn from the same wording, once it is supported by sufficiently motivated legal reasoning, digging deep enough in what is meant by law; cf. Varga, Csaba (2008) 'Judicial Black-box and the Rule of Law in the Context of European Unification and Globalisation', Acta Juridica Hungarica, 49(4) \& in <http://real-j.mtak.hu/763/1/ ACTAJURIDICA_49.pdf>, pp. 469-482. 
step by step for anthropology, sociology, and law as well. ${ }^{25}$ Moreover, treating law as just one of the considerations rather than the sole definitivum in living processes, ${ }^{26}$ this "order out of chaos" vision became identified as the operational principle that also makes the European Union work: the union and the national states, or in other words, union laws and domestic laws challenging and responding to one another and eventually creating an unprecedentedly high level of the desired and patterned law and order (at the macro-level) from apparent diversity (close to sheer anarchy for micro-analysis). ${ }^{27}$

Accordingly, oriented toward individual actors and acts as well as their inherent teleology, classical legal positivism is a response by the classical physical world outlook, while the "order out of chaos" vision (extending its idea of order from the micro-physical world to the universe of humans) is a stand taken by contemporary anthropology, sociology, and jurisprudence. Once in neo-KANTianism, methodological purity was a sine qua non. Now, in the legal regime of the European Union, member states continue following the old paradigm, while their interaction both among them and with the European Union law properly exhibits the features of the new paradigm. ${ }^{28}$

It might be seen as symptomatic that in the series of the Internationales Rechtsinformatik Symposia at Salzburg, there is a standing section devoted to Science Fiction \& Utopia. ${ }^{29}$ For since the time of AlDous HuXley's Brave New World (1931), the world may have changed, and the avenging spirit in ARTHUR KoEsTLER's Darkness at Noon (1940), so much as the totalitarian technicality of intimidation as foreseen by GEORGE ORWELL's Animal Farm (1945), ${ }^{30}$ have proved to be underestimated when compared with the hidden moves behind the façade of contemporary historical reality.

25 Cf. Varga, The Paradigms of Legal Thinking, 2012.

26 According to Teubner, Gunther (1998) 'Legal Irritants: Good Faith in British Law or How Unifying Law Ends up in New Divergences,' The Modern Law Review, 61(1), pp. 11-32, especially on p. 12, any imposed texture in law is going to become a factor of trouble so long as finally it will either be rejected or made to function properly. See also Varga, Csaba (2007) 'Reception of Legal Patterns in a Globalising Age' in Calera, Nicolás López (ed.) Globalization, Law and Economy / Globalización, Derecho y Economía: Proceedings of the $22^{\text {nd }}$ IVR World Congress. Vol. IV. Stuttgart: Franz Steiner Verlag, pp. 85-96 [ARSP Beiheft 109] \{reprinted in <http://mek.oszk. hu/15300/15386>, pp. 181-207\}.

27 Varga, Csaba (2011) 'The Philosophy of the Construction and Operation of European Law', Rivista internazionale di Filosofia del Diritto [Roma], LXXXVIII(3), pp. 313-344 \{reprinted in <http://mek.oszk.hu/15400/15409>, pp. 307-354\}.

28 Or, some normative information is issued by a union agency and then reacted to by some domestic agency, which then gets reacted/disputed/retorted to by any union or (foreign) state level agency calling on domestic/ union reconsideration, which later will be responded to by a second piece of normative information issued by a union agency - a process that looks like a game itself, playable and perhaps also played to infinity.

29 Cf. $<$ http://www.univie.ac.at/RI/IRIS2013/>.

30 Cf. <http://en.wikipedia.org/wiki/Brave_New_World>, <https://en.wikipedia.org/wiki/Darkness_at_Noon> $\&<$ https://en.wikipedia.org/wiki/Animal_Farm>. 
Law tends to be conservative, but within its own system of justification, optional technics with all kinds of contradictory outcomes tolerate, permit, and sometimes expressly call for complete turns, with genuine volte-face, in judicial interpretation and construction. In accordance with it, possible renewals of law may mostly be the result of what we perceive of as prerequisites of social/societal existence. This is to say, our present-day preference of preserving free choice on behalf of entities-either the state or individuals-will necessarily be counterbalanced (if not overruled) by the priority of what the security of the bare community existence will demand under new conditions. Perhaps, the millennia-old fight for the liberty of humankind will also be remembered with resignation and nostalgia, as a failed Golden Age Two.

In contemporary public speech, buzzwords such as "natural law," "constitutionality," "human rights," and "the Rule of Law" are highly popularized and defended as highest-valued goals themselves, although none of them can be an exception to the main—ontological—rule. For they stand for nothing but instrumental values within the realm of law. Consequently, their genuine value is a function of what fundamental values they mediate, or, in the subsequent era of scientific-technological revolution, they may also be exposed to transformation hitherto unimagined and plainly unimaginable..$^{31}$

Summing up, even some decades ago, visions of the future could be outlined through tendencies extrapolated from the present, for the future was only contemplatable as the extension of present tendencies in accumulation of the variations in their shifts of emphasis. As to the present dénouements - the fact notwithstanding that the twentieth-century interwar period was already imprinted with the widespread feeling of Weltkrise $e^{32}$ - not event directions can be taken as granted. ${ }^{33}$ The future will emerge from actions still to be performed. In conclusion, a long series of alternatives is the only help to preview anything-and necessarily, less than something-from the future.

31 Varga, Csaba (2003) 'Buts et moyens en droit' in Loiodice, Aldo, Vari, Massimo (eds.) Giovanni Paolo II: Le vie della giustizia-Itinerari per il terzo millennio (Omaggio dei giuristi a Sua Santità nel XXV anno di pontificato). Roma: Bardi Editore - Libreria Editrice Vaticana pp. 71-75 and, as expanded, Varga, Csaba (2005) 'Goals and Means in Law: or Janus-faced Abstract Rights', Jurisprudencija [Vilnius: Mykolo Romerio Universitetas], 68(60), pp. 5-10 \& <https://intranet.mruni.eu/en/mokslo_darbai/jurisprudencija/archyvas/?l=120712>.

32 For a Hungarian approach with international bibliography, cf. Hamvas, Béla (1938) A világválság [World crisis]. Budapest: Budapest Székesfóváros Házinyomdája 69 pp. [=(1937) A Fôvárosi Könyvtár évkönyve, VII, pp. 39-105]. The very crisis of "human existence" is treated by the sociologist Hankiss, Elemér (2016) 'Europe between Two Worlds' in Jensen, Jody, Miszlivetz, Ferenc (eds.) Reframing Europe's Future: Challenges and Failer of the European Construction. New York - London: Routledge pp. 237-248. \{in German: (1990) 'Zwischen zwei Welten. Wertewandel in Ungarn' Transit, (1), pp. 167-184\}.

33 Noticed by the Hungarian Prime Minister VikTor Orbán, who raised the issue in a private discussion with the author during a closed meeting at Saloon Hermina on November 30, 2012. 


\section{TRANSITION}




\title{
Rule of Law Imperfectly Realized, or Perfected without Realization?
}

\section{Declarations 2. Question marks}

\begin{abstract}
Our transition to the rule of law has brought the domination of appealing slogans but not a law and order of which the promises could serve as a basis for a well-balanced, orderly society with peace and security. The nihilation of law by communism has in fact been replaced by a letter-of-the-law fetishism emptied from values; public interest has become unprotected in the shadow of the exclusive tribute to the individual; human rights have transformed into generators of deviancy; the rule of principles taken as mere abstracts has made social integration contentless; and in this renewal, the fact that everyday practical experience has become legally irrelevant has risen to a barrier to any critical insightall the more so because public affairs are no longer served by any single state body as each of them in this realm of rights is only preoccupied with optimizing its own powers.
\end{abstract}

KEYWORDS rule of law; human rights; public affairs; rights vs. duties; values

\section{Declarations}

Communal values should have their social prestige restored in the civilian society of Hungary.

The perfection and inviolability of the rights of men should not overshadow the citizens' simultaneous respect for their moral obligations towards their community, to their allegiance and legal responsibility as well as the unquestioned assumption of the latter. Social and economic activity has to be governed by the full consciousness of the law's value and the impact public rules may exert in any societal game.

Rights have to be referred to in order to resist despotism, to redress and prevent actual grievances. They are not meant to be invoked for just tyrannising others by misusing

I Originally, the paper served as a series of questions raised to Minister of Justice IBoLYA DÁvid when invited to talk at the Batthyány Circle of Professors' meeting on "What is the law like under an administration committed to responsible policy-making?" in Budapest in 2000. Published already in English in Varga, Csaba (2008) Transition? To Rule of Law? Constitutionalism and Transitional Justice Challenged in Central \& Eastern Europe. Pomáz: Kráter 292 pp. [PoLíSz sorozat könyvei 7] \& <http://mek.oszk.hu/14800/14851> on pp. 50-58. 
own superior position or exploiting others' inferior situation, or to strengthen supremacy or financial position by the unscrupled over-use of the legal machinery. Public life and the legal arrangement marking out its framework have to be governed by a mentality that encourages the natural rewarding of honesty and the observance of rules.

We have to achieve that our country really serves as a homeland, offering the sense of familiarity for the honest majority of the fellow compatriots. Therefore, the civic virtue respects law and order, supports the feeble, while it is benevolently tolerant towards the forms unfolding personal talent and self-realisation. However, thereby it is not to relinquish national past, present and future, tradition and habits, as well as proven experience with the knowledge accumulated throughout generations, for the sake of ephemeral fads, meagre and modish ideas, individual or collective initiatives dividing society or breaking up the ties binding together the community. Showing openness to others, to the particular features of otherness in opinion or attitude, is implied in civic tolerance, without limiting the community's natural right to preserve and strengthen its own identity.

The reforms civic tolerance supports must not threaten the basic structure of society and, in the guise of any principle or principled attitude, must not promote self-profiting from gaps in law or trickery difficult to defend community interest against on legal fora, but have to encourage the shared building of our future for what we shall bear undivided responsibility.

Aware therefore, that law and morality operate differently on differing fields, this is not an excuse for any of them to be played off against the other.

No rule of law can be based upon cynical and self-centred individual attitudes hardly refraining from the open trampling of common good: rule of law is simply inconceivable without the very idea of social solidarity, imbued with the collective ethos of and interest in co-operation.

Therefore, it can neither be built on ethically intolerable or unjustifiable foundations, nor serve aims considered morally repulsive or unacceptable by the social majority. Freedom is not anarchy; it is not designed either to encourage the uninhibited fulfilment of inferior instincts.

Just like human dignity, freedom is also built on order and in order.

In the delicate balances cementing social order, proper consideration must be given to the lawful desire for the respect of public interest in preserving law and order, for the clear definition of the law's institutional frames and for the responsibility to be taken for its foreseeable functioning. 
Accordingly, rights shall not be asserted to the detriment of common good and public interest but, just to the contrary, in order to serve law and order at a higher level. The difference between victims and victimisers, that is, between those who suffered and those who benefited from causing undue sufferance, must not be obscured. The technicality of legal proceedings and the overall extension of social care cannot be taken as a pretext for diminishing personal responsibility to be taken by individuals and their collectivities in shaping their own fates.

Common goals, frameworks encompassing large portions of society, the mutually complementing interaction of law and morality, furthermore, security, foreseeability and calculability of institutional operation, as well as the encouragement of personal and collective initiative in harmony with the overall ethos of common good in one order of shared values-all these are worthy of support in order to reactivate forces dormant in society and to overcome apparent lethargy.

This is what successful nations had inherited from their ancestors and they also owe their luck to the ability of its continuous building.

This is exactly what Hungarian history teaches us and what had nourished social harmony and speedy development in course of the nation's consolidation following the Great Depression as well as the post-WWII economic and intellectual recovery and the glorious days of 1956.

The manifestation above was my own formulation in October 1997, and it expressed a personal concern and anxiety within the Batthyány Circle of Professors, which finally issued a Declaration on Responsible Policy-making and Governance on December 1, 1997. It formulated, among others, that

We share the liberal principles of parliamentary democracy. We think that the principle according to which the liberty of any individual can exclusively be limited by the liberty of others shall be fully taken as a guiding principle in societies where the traditional ethics of obligations is respected by the great majority. For the perfection of individual liberty is to be complemented by the care for and promotion of the collective traditions of society.

In the civic society of Hungary, the esteem of common good has to be restored. The inviolability of individual rights should not overshadow the citizens' moral and legal obligations towards their collectivity. An ethos based on the observance of applicable laws is a prerequisite for a society in which security for the honest majority is guaranteed by law and not by force. 
Corruption, hypertrophied "black" and "grey" economies, criminality and social lethargy may excel in destabilising law and order, especially if they are not adequately addressed by the law. For, actually, corruption is not faced to the depth by the law, the law-enforcing machinery fails in controlling crime effectively, and the society is helplessly exposed to criminals.

The citizens of Hungary want order and security in terms of civic equality. In order to reach it, a government committed to public interest, an effective policy of law enforcement, a machinery of justice with reliable and expeditious functioning, able to eliminate mafia-type social operation, are all needed. Those having unduly allotted or expropriated public property and public funds are to be called to account.

More than two years have passed since. At that time, parliamentary elections were imminent, and now, half of the mandate of the then-incoming government has almost expired. How satisfied can we be if faced with those concerns now? Are they solved? Do they have a solution at all? Have our expectations been founded at all, or have they been taken away by utopianism or sheer desires?

\section{Question marks}

What is the value of constitutionality, democracy, and rule of law, if they are accompanied, even a decade after their reestablishment, by social disorder, the wasteful management of resources, the segmentation of the country and its exposition to external forces, the reluctance to fulfill rightful expectations, the devaluation of millennial values of morality and justice in the name of some allegedly supreme principles of, and the unscrupulous domination of private motives stealthily creeping in through the well-designed gaps in, the law, demoralizing and intimidating the rest of the community?

What is the purport of constitutionality, democracy, and rule of law, if they are accompanied by the growing impotence of the state's institutional machinery (which is the actor primarily responsible for social order, for the concentration of the nation's forces, wealth, and resources as well as for the available social balance), while they are mostly used to, heralding the brave "new world" of our "global village," uncritically applaud whatever individual and collective deviance?

Where can the ideal of law lead us if, deprived of millennium-old foundations, it does not commit itself to genuine values but transforms traditional virtues of moral ennoblement into a function of momentary reactions by faceless masses and degrades law and order to the 
merely procedural framework of bellum omnium contra omnes again, thereby proclaiming the scrupleless, merciless, and tireless specialists of fighting, the new heroes of law?

When shall we reach an epoch of constitutionality, democracy, and rule of law, ready to consider (in addition to its own abstract and universal self-projections) the very basics of the operation of our world as well, namely the genuinely (cultural-anthropological, historical, demographic, and sociological) preconditions of its overall reasonable desirability as well as the depth of complexity it is to mediate in, with both empathy toward the values of human associations (families and nations) and readiness to balance if they are in conflict? Is it too daring to hope for a genuine constitutionality, democracy, and rule of law, in which honesty is usually awarded and whose privileges are not designed to be firstly benefited by either political murderers and torturers or looters of the nation's fortune?

Is there law and order where anyone may feel encouraged, with reference to some abstract entitlement, to dispute their duties instead of fulfilling them as they are due? Can the new-old anarchy that results from the individual's limitless self-assertion offer us a genuine perspective for the future? Is it good for the nation if everyone must be given but not give, if rights as freed from the burden of duties abound unlimitedly (for ambitious rights-protecting activity may generate practically anything and anything else at wish out of mere words)? Is order not emerging as a delicate balance between rights and duties? Is it not necessarily to be paid by someone if any right is narrowed or extended, for everything has a price? Can a right be asserted without charging others with its cost?

What will remain for the individual to live in, if the public disappears from behind? What will law and order be reduced to, if there is no community supporting it? What is the measure for the individual, if there are no longer "common good," "public interest," "public order," "public security," "public morality" in law that could serve as a framework? Can smaller nations (national entities) be successful in fighting for their collective legal personality to be recognized, if they simultaneously excel themselves in liquidating anything public?

What has the noble ideal of human rights been degraded into, if the martyrdom of a hundred of millions is treated with the cynicism of double standards, while it serves as an invocation justifying individual and group aggressivity demoralizing existing communities? May the alleged protection of rights prevent the lawful resolution of actual situations? May rewarding the lack of honesty, of inactivity, or of parasitism or a criminal way of life (at the cost of a by-chance neighborhood) be qualified as a protection of rights? May those intervening at the cost of others without own responsibility to take be genuinely called as defenders of rights? Whose rights do we advocate when we, in our enlightened zeal, merely watch the fight between victim and victimizer, investigator and criminal, law enforcement agencies and jailbirds impartially, as if they were optional roles in, say, a sport match? 
Are we expected to glorify what just crops up to prevail? Is the current state of domestic law at the same time also necessarily unchangeable? Why is it not clear and unambiguous to the public what ideas are being promoted by the various political forces and with what consequences?

Why is there no governmental program available to enlist practical shortcomings and failures with feasible responses both in the short and the long run, recording actual gaps, errors, and miscalculations in regulation-whether due to legislation or constitutional adjudication-especially if they can be cured within governmental competence or simply with majoritarian vote? Why are we resigned to the legislator having once neglected their duty to interfere? Abuses in privatization, smuggling covered by banking consolidation, globalized profiteering, tax exemption for foreign financiers and entrepreneurs, value-added tax frauds, corporate fraudulence, industries based on car and metal stealing, and manipulations with wine-production and oil business may proliferate without anyone ever openly declaring whether regulatory blindness, lack of determination, or governmental complicity have allowed them to "flourish" for a time undisturbed.

Are we ready to sacrifice the future of our nation for the mere sake of abstract principles, instead of striving for a decent and prosperous civic life? Is it, for instance, constitutionally unconstruable that the legality of enrichment should be proven by those who make a fortune strikingly quickly? Is it inevitable that illicitly obtained properties cannot any longer be questioned in law? Is it inevitable that murderers and torturers remain unnamed as exempt from any proceedings just because they could maintain their terror long enough for the period of statutory limitations to pass and be eventually over? Is it tolerable that those having formerly operated the dictatorial regime (excelling also in denouncing and looting) are now given the opportunity to become masters of the new regime, designers and teachers of an allegedly democratic attitude? Is it necessary that, from among the sufferers of the grievances of the twentieth century, only the victims of socialism are neglected among those offered some remedy?

Is it due to incompetence, past burdens, or some mysteriously obscure principle that quite a few affairs, falling within state competence and financing, are now channeled away into segmented self-governing bodies and deprived of responsibilities? As known, oppositional leftist veto has blocked the subordination of the attorney general's office (and, with it, the monopoly of criminal charge) to the government. The machinery of the administration of justice is now governed by a self-generated, self-governing body, dedicated mainly to our country's own interests (even questioning others' right to query about the state of and access to justice, the respect of procedural deadlines, the uniformity and consequentiality of judicial practice, and the level of actual indifference to political interests). Research is mostly administered and controlled by self-nominees within the Academy of Sciences. Public health 
and institutional education are for the time being within governmental competence, but public opinion is marshaled by irresponsible commercial media. The official safeguarding of citizens' rights is institutionalized to a hypertrophied extent, no longer resembling its original pattern, the single ombudsman.

Given the present conditions, what are the genuine factors that we are ruled by within this rule of law? Quis custodiet ipsos custodes?

With the first period of eight years behind us, our constitutional justices have recently switched over from their hyperactive interventionism (suggested by the "invisible Constitution" they hypothesized) to the proper enforcement of constitutional provisions. As to the Court's first period, enforcing anything in law without prior adequate entitlement and competence is usually considered sheer arbitrariness in a constitutional state. Were they ever once empowered to infer decisions with effects dramatic upon the actual purport of the entire transition process and the paths of law beaten in Hungary from either their own discretion or foreign standards, instead of keeping silent in cases when the Constitution itself fails to provide suitable guidance?

Policing and crime control are also rather discretionary. The violation of a rule in itself is often not enough for measures to be taken and for proceedings to be instituted-albeit the very fact that further substantive reason has to be given for persuading the agent of law to react does encourage corruption. Moreover, law in action may vary from branch to branch in central government and from county to county, district to district in local government, and finally also from agent to agent. Measures are eventually taken (if at all) also in consideration of convenience, fashion, and routine as easy and guaranteed ending, as if legal officials took it for granted that only a tiny minority can afford formal proceedings confronting their arbitrary selection.

After all, should our legal ideals be taken as a sheer constraint imposed upon the populace from above or as a way rather helping us to become more noble, sophisticated, and gentle, that is, more mediated and patterned, in our handling of human affairs and social management? Do they indeed help us in achieving our professed goals, or are they simply wedged in as external limitations, alien to the respect for the Natur der Sache and detouring us therefrom? Are they indeed designed for us or rather for someone's "world spirit" still imposed upon us, after we have already experienced the ignominious and bloody adventure, ending in a crushing defeat, of some other contemporary ideologies? Should our nation not also be involved-as an interested partner-into this noble venture, by giving it a share in its blessings? Do those presumptuous minds have the faintest idea that people judge practice by facts of practice, instead of taking part in sheer intellectual adventurism? 


\title{
RULE OF LAW -AT THE CROSSROADS OF CHALLENGES ${ }^{1}$
}

1. Law: Values \& Techniques 2. Human-centeredness and Practical Orientation 3. Theological and Anthropological Foundations 4. An Irreplaceably Own Task 5. Recapitulation 6. A Final Remark in Comparison

\begin{abstract}
Law is a composite structure of values and techniques. As final motives, it is human-centeredness and practical orientation that form its changing shapes. At the same time, the eventual theological and anthropological foundations of its ideal, culminating in the very notion of the rule of law, circumscribe some aspects and features of the latter's generalizability and even universalizability. As a primordially practical category, however, it is faced by recurrent challenges, and as a consequence and in point of principle, it is always situated amidst a flux of feasible crossroads. Moreover, as an ideal, it can never be perfected but only humbly served through a variety of means and techniques, which are to reflect and respond to acute societal needs, or the definition of any particular form of it, suitable to meet the varying demands of the always actual and socially concrete hic et nunc, is an irreplaceably own task of any society at any stage of its development. Otherwise speaking, none of its models are to be taken by societies not having generated them, if not within a continuous learning process. A recapitulation and a final remark in comparison draw some parallel to dramatic situations in which some decision is to be taken even if the borderlines of the good and the bad are not plainly visible.
\end{abstract}

KEYWORDS theology \& anthropology on axiology \& human ordering; practicality; neutrality of techniques; self-emptying of law; interdependence of rights and duties; cost of rights; transferability of patterns

\section{Law: Values \& Techniques}

Human history is not only the field of new recognitions but the scene of adapting experiences gained from failed revolutionary innovatory zeal as livable practice and thereby,

1 Commissioned as a closing address to the workshop on 'Nation and the Rule of Law' organized by the Deputy Speaker of the Parliament SÁNDOR LezSÁk and Professor Tibor KirÁLY of the Hungarian Academy of Sciences in Kossuth Klub in Budapest in 2002. Earlier versions in English were published in (2005) Iustum, Aequum, Salutare, I(1-2), pp. 73-88 \& <http://ias.jak.ppke.hu/hir/ias/20051sz/20051.pdf> \{reprinted in <http:// mek.oszk.hu/14800/14851>, pp. 59-84\} as well as in Sadakata, Mamoru (ed.) (2007) Legal and Political Aspects of the Contemporary World. Nagoya: Nagoya University Graduate School Center for Asian Legal Exchange pp. 167-188, and as (2009) 'Rule of Law: Challenges with Crossroads Offered', Central European Political Science Review 10(No.35), pp. 42-68. 
also the stage of the sobering test of their acceptability, when their implementation is also assumed. After the euphoria of "We can achieve everything!" in the so-called honeymoon period-having grown from infantile disorder into the destructive plague during the French Revolution-was over, the jurisprudent PORTALIs addressed the French National Assembly to present the code civil as a first step in the path of consolidating some balanced social progress under stabilized conditions as follows:

In these modern times we were too much fond of changes and reforms. If the centuries of ignorance are the scenes of abuses as regards institutions and laws, then the centuries of philosophy and Enlightenment are perhaps much too often nothing else than scenes of exaggerations. [...] Change is needed, when the most perilous of changes would be if we did not make the change. Because we must not fall prey to blind prejudice. All that is old was once new. The essential thing is, therefore, to put the stamp of stability and permanence on our new institutions, which ensures them the right to grow old. It is profitable to safeguard all that we do not have to destroy; the laws must spare habitudes, if they are not harmful. ${ }^{2}$

Our days' fashionable catchwords and endeavors, channeling our everyday actions by commanding us to get along, are yet to be tested in practice. At present, it is not even clear whether their vague terms are at all more than just random (or consciously constructed) products of enlightened minds, issued from occasional constraints (or political calculations), which may have once been generated either by humility toward values or by professional intellectualism reduced to a mere parrotry of slogans.

All this notwithstanding, our subject can hardly be addressed otherwise than in a tone of respect and pathos. "Rule of law?" A momentous notion implying dramatic human experience, a concept of great traditions and significance regarding its theoretical foundations and historical dilemmas, implying both ambiguities ${ }^{3}$ and heavily labored responses fought through and out: a notion which refers to a similarly noble series of further concepts such as "human rights," "constitutionality," "parliamentarianism," "democracy," and so on. Yet—or exactly for this very reason-we must continue the train of thought commenced above. For

2 Portalis, Jean-Étienne-Marie (1836) 'Discours préliminaire' in Fenet, F. A. Recueil complet des travaux préparatoires du Code civil. Vol. I. Paris: Videcoq pp. 11 and 481.

3 See, on the one hand, for the suitability of the very notion of "Rule of Law" for almost nothing except the mapping out of the routes on which one has to start searching for own solutions, and on the other, for the impossibility of giving any adequate and exhaustive definition of it, the recent debate in the US as overviewed by Fallon, Richard H., Jr. (1997) “'The Rule of Law” as a Concept in Constitutional Discourse', Columbia Law Review, 97(1), pp. 1-56. 
all these catchwords present themselves as if they spoke from the past. However, we cannot know for sure whether or not they always and everywhere convey indeed nothing but the message of the past, embodying an elementary search of humans for ways out from one-time tensions, with adherence to values and institutional paths of responding to challenges of the time, all crystallized through and at the cost of the hard experience of past generations. For although the words themselves may be rather old terms, what they imply are genuinely new strivings, and all that we may realize about them is that presently, and with all our efforts, we do pursue them but have no theoretical proof as to why. Moreover, we do not even have an idea about the world that would emerge as a result of them as no one has experienced that so far.

On the European continent and for centuries, the culture of Rechtsstaatlichkeit has stood for the statutory regulation of given fields with enforceable guarantees prescribed the prevailing law and order (i.e., under the protection of state power), while in the Anglo-American world, the ideal culture of the "rule of law" has meant just the opposite to any rule by humans, the ultimate guarantee of which is justiciability of any issue, that is, the availability of conflicts subjected to the decision by judicial fora. While continental Europe puts its trust in the force of enacted rules, in the very fact of the issuance of rules, the English-speaking civilization relies upon the sheer independence of the judiciary and the trust in the strength of undefined principles ${ }^{4}$ as its historical experience may have built a chain of confidence reposed on processes themselves, if operated by good will, socialized within a network duly fed back in historical continuity. ${ }^{5}$ Now, the question may arise: what has become of all this by today, among our circumstances called postmodern? The tentative answer may hold that, in the final analysis, nothing but the cult of endless disputability has pervaded the scene when statutory law and order no longer matters, apart from providing the opportunity for practicing lawyers to argue according to the demands and at the money of their clients and also for the growing number of those professional defenders of human rights, whose exclusive ambition is steadily shifting from making the rules observed to questioning the rules themselves, regardless of how textually clear they are otherwise. As we may learn from the contextual dependence of premises in legal logic, any rule can be circumvented from both below and above. It is by far not logic itself (taken as the mathematics of thinking, elevated sometimes to mythical heights in the absolutism of rationality) that is positioned either to challenge or counteract this-as logic in itself is faceless and mute and can only be asserted through

4 Cf., Varga, "Rechtsstaatlichkeit" and "Rule of Law"', in the present volume.

5 Within a revealing context, cf., as classic, Dicey, A. V. (1923) Introduction to the Study of the Law of the Constitution. [1885.] $2^{\text {nd }}$ edn. London: Macmillan vii+407 pp. and Dicey, A. V. (1905) Lectures on the Relation between Law and Public Opinion in England during the Nineteenth Century. London - New York: Macmillan xx+503 pp. 
roles designed for it by those having a recourse to it-but only an external power, seemingly melting away in our hands: the strength and culture of the actors' commitment to the respect for rules. ${ }^{6}$ If this is missing or becomes a secondary consideration in the routinized handling of ordinary cases-only showing that a decision made upon the strict following of a given rule did not interfere with any implied interest for the sake of which the rule would have been worth questioning - the lawyer of our age may come up practically in any procedural stage at any time. This would be done either to find a gap in law, allegedly blocking the proper adjudication of the case, or to recourse to constitutional review for the reassessment of the rule's questioned constitutionality-in both cases, only to justify the client's accidental claim to reach a specific solution as necessarily concluding from the law itself. That is, the end result of such lawyering is the practical mockery of law in either case: the avoidance of the applicability of an otherwise applicable rule.

This abstractly dry formulation may seem hard to grasp for everyday thought due to the harsh but concealed reality behind it. However, the point at stake is that law can at most sanction values that are, if at all, only approximated after they have been translated into the instrumental language of statutory texts. At the same time, even the most accurately drafted rules are inevitably exposed to the objection-no matter how strikingly artificial (and practically interest-driven) - that, given a gap in the law, they do not apply to the case. After all, neither the rule nor its allegedly implied logic can help us decide whether we should opt for applying the rule, after having construed a similarity between the rule and the case or disapplying it because their dissimilarity is construed.

Let us now return to the two basic legal cultures familiar to us. In the Anglo-American common law, the method of distinguishing among precedents, known for long periods, might have caused a judicial revolution or practical renovation of law on a daily basis and frequency; in fact, it has not, just because both the conservatism of the judiciary and the hierarchical structure of appeal were equally capable of controlling jurisprudence, keeping it tightly in check. In the realm of civil law, built on the application of statutory texts as a logical ideal, in point of principle, the legal instruments designed to fill gaps in law could also have resulted in a fluctuating judicial practice (with as startlingly ${ }^{7}$ discretionary solutions as, for example, in Switzerland, where the judge may openly and directly take over the casual role

6 See, for example, Varga, Csaba (2012) The Paradigms of Legal Thinking. [1996/1999.] Enlarged 2nd ed. Budapest: Szent István Társulat 418 pp. [Philosophiae Iuris] \& <http://mek.oszk.hu/14600/14657/>.

7 Cf. the revolted echo to the news of its draft even by Benjamin N. CARDozo (USA) as well as Rudolf StamMLER, Eugen EhrLich and Hermann Kantorowicz (Germany). 
of a legislator as a last resort $\left.{ }^{8}\right)$. Yet they have not because the same professional pathos-here appearing under the aegis of the exclusivity of an ideally logical application, resulting in deductive conclusion-has eventually prevented the techniques (reserved for limiting situations of exceptional cases) from spreading and becoming destructive.

After all, what is given in law is nothing but a set of techniques. It is true that certain limitation in the practical application of techniques can be achieved by other techniques; however, effective limitation can only be secured-instead of techniques themselves (that is, by rules institutionalizing techniques through their linguistic formulation in the normative ordering) - by the entire culture operating and also by substantiating law: primarily, by the culture of the legal profession and secondarily, by general social culture. It is to be noted that the latter may counterbalance the former, while the former may supersede the latter, for societal life is composed of the endless alternation of tensions and loosening of such a kind. However, a variety and also a mutuality of segments, layers, and sets of norms interacting in social integration have arisen in all societies to provide for social identity, defining the framework of social reproduction-a complex network of regulations with mechanisms of check \& balance-in a medium of tensions balanced amongst various challenges to preservation and change.

"God is dead." Although doubt and negation in final issues had become trivial long before NiETzSCHE, I wonder whether we have ever thoroughly reflected upon what a society no longer knowing neither transcendency nor supra-human authority would be like. Could it mean more than ORTEGA Y GASSET's rebellion of the masses ${ }^{10}$ or the raving mob once cherished with enlightened intentions, based on the scenario of Viridiana? ${ }^{11}$ In a society where the dignity of the person is replaced by the mere self-assertion of the individual, where the concern for a nation's destiny is substituted by the undoubted right to the free choice of domicile and marriage by occasional partnerships, where citizens are reduced to consumers, and conscience gets cared for by sheer mass media control, could there remain any bond other than merely procedural frameworks and rules of game arising from optional agreement, similar to contracts between individual parties but projected now as a universal

8 Schweizerisches Zivilgesetzbuch (1907), \$1 (2): "In the absence of a provision, the court shall decide in accordance with customary law and, in the absence of customary law, in accordance with the rule that it would make as legislator."

9 Nietzsche, Friedrich (1891) Thus spake Zarathustra. [(1883) Also sprach Zarathustra.] Trans. Thomas Common. $<$ http://eserver.org/philosophy/nietzsche-zarathustra.txt> Prologue, para. 2.

10 Ortega y Gasset, José (1930) La Rebelión de las masas. Madrid: Revista de occidente 315 pp. In English, see (1932) Revolt of the Masses. Authorized trans. London: Allen \& Unwin - New York: Norton 204 pp. and (1985) Revolt of the Masses. Trans. Anthony Kerigan, ed. Kenneth Moore. Notre Dame: University of Notre Dame Press xxxi+192 pp.

11 Buñuel, Luis Viridiana (1961); cf. <https://en.wikipedia.org/wiki/Viridiana>. 
minimal maximum (as hypostatized in the very idea of an underlying social contract)? Religion and morals are no longer in a position to support; consequently, there are no duties any longer known, only rights. The law itself (if at all formulated in rules' structure) is less material than processual now, serving as a mere rule of the actual game no longer guiding on the substance of what to do or what to refrain from, as exclusively the guaranteed procedural frameworks of how to proceed on are mapped out by it. Law is mostly reduced to the issue of how and with what legal claim we can act successfully when addressing either the state we have opted for or another self-asserting individual (e.g., when demanding material support by reference to some human rights after the only ascertainment of the bare fact that we, as humans, exist is made).

Since its conception as a discipline committed to social criticism, legal sociology has proven countless times how unfounded and illusive the lawyers' normativism embodied by their traditional professional mentality is, presuming that law has strength by itself. Only legal sociology teaches that the force of law is nothing but symbolic, in so far as it can at the most attach the additional seal of a particular social authority on tendencies already asserting themselves in society. ${ }^{12}$ Indeed, in our postmodern era, it seems as if common sense were replaced by simple-mindedness. Ideologically, we have endowed law with a mythical might and authority, while in fact we have emptied it. ${ }^{13}$ By tearing it away from moral and social traditions, we have detached it from its millennia-old exclusively organic medium, thereby depriving it of its only genuine foundations; what is more, we no longer respect it. ${ }^{14}$

12 See Varga, Csaba (1981) ‘Towards a Sociological Concept of Law', International Journal of the Sociology of Law, 9(2), pp. 157-176.

13 Cf. Campos, Paul F. (1998) Jurismania: The Madness of American Law. New York \& Oxford: Oxford University Press xi+198 pp. and, as reviewed, Varga 'Hyperrationality Standing for Anarchy in America' in the present volume.

14 It is noteworthy that while the consensus of anthropology, sociology, political science, and of course, jurisprudence was based on a normativist model until the last decades of the twentieth century-"society after society was depicted primarily in terms of the consistency, regularity, and continuity of its system of rules and of the power of these rules to bring about behavioral conformity," as summarised by Reynolds, Noel B. (1994) 'Rule of Law in Legal and Economic Theory' in Kotsiris, L. E. (ed.) Law at the Turn of the Twentieth Century: International Conference Thessaloniki 1993. Thessaloniki: Sakkoulas v+404 pp. on pp. 357-376 on p. 373-, it now had to be replaced by a new explanatory framework, in terms of which-as Edgerton, Robert B. (1985) Rules, Exceptions, and Social Order. Berkeley: University of California Press ix +328 pp. on pp. 13 and 14 formulates-"The essence of human life did not lie in following rules and in being rewarded by one's virtue but in making the best use of rules for one's own self-interest, depending on the situation'. For 'rules are seen as ambiguous, flexible, contradictory, and inconsistent; [...] they serve as resources for human strategies, strategies that vary from person to person and from situation to situation... Order is never complete and never can be." That is, instead of a clear hierarchical structure, a multi-factor and unpredictable - but along its main determinative forces-stochastic, mass-generating order was created thereby. This is rather similar to the scheme based upon the idea of "order out of chaos," by which I represented the functioning of the law of the European Union. Cf. Varga, Csaba (2011) 'The Philosophy of the Construction and Operation of European Law', Rivista internazionale di Filosofia del Diritto [Roma], LXXXVIII(3), pp. 313-344 \{reprinted in <http://mek.oszk.hu/15400/15409>, pp. 307-354\}. 
We only use it as a field of operations in our unscrupulous battle, repeatedly re-launched with no end, transubstantiating brute force (or substitutive pressure) into so-called inventive legal reasoning.

Rule of law? When I am discussing here the role of society and societal culture in support of law, I do not mean only to allude to the facelessness of legal techniques taken in themselves. They are indeed neutral in themselves as they can be used to serve different and conflicting values as well. Just as law is not simply a pyramidal aggregate of abstract rules posited in a given hierarchy but the living total of meanings and messages getting concretized in one way or another at any time, following generations' efforts at both refining them so as to build them into a systematic dogmatics and transforming them into some livable practice by filtering them through conventionalizations contextualizing formal regulation in the materiality of practice, it is not backed simply by a hierarchical structure of values but by a sensitively changing compound of a huge variety of aspects and considerations of values. For it is always a responsible decision with a personal stand taken in pondering values and balancing among them that the formalism of the mere observance of rules disguises in law. After all, when we, giving official reasons for our decision, subsume facts under a rule through logical inference or reject a claim in want of subsumability, ${ }^{15}$ we do balance between values. Apart from few truly exceptional cases, we usually do not negate (or exclude from supporting) some specific value to implement some other value(s) instead, but quite the contrary. Being skilled in the judicial "art" (made up of empathy, intuition and ingenuity, among others), we strive to find solutions that may ensure the optimum realization of values (by allowing to serve important values without the disproportionate detriment to other values), which can be duly justified and resulting from (with no similarly arguable alternative in) the given normative and processual contexture. This is exactly the reason why we are used to proudly recall the "ars" used by ancient Romans when referring to law, ${ }^{16}$ denoting, in Latin, proper "art" and "craftsmanship" alike.

\section{Human-centeredness and Practical Orientation}

When I am speaking about historical experience, as well as truth and justice fought out through the lives of generations, I mean testing by everyday practice. Nevertheless, it must

15 For a reconstruction, cf. Varga, Csaba (2011) Theory of the Judicial Process: The Establishment of Facts. [1992/1995.] $2^{\text {nd }}\{$ reprint\} ed. with Postfaces I and II (Budapest: Szent István Társulat 2011) viii + 308 \& <http://mek.oszk. $\mathrm{hu} / 15500 / 15540>$.

16 "ius est ars boni et aequi" Celsus in D 1.1.1. pr. Ulp I Inst (Pal. 278). 
be noted that accepting the test of everyday practice as a criterion is theoretically far more honest and demanding than today's ahistorical, neo-primitive absolutism growing into the present mainstream of Atlantic thought. For even MARxism, among others, by emphasizing the moment of praxis, the principle of historicity, and the role of the hic et nunc particularity in the overall complex of historical (self-)determination, has made a standard out of the actual practice itself, taken as an accumulation of human experience and self-reflection. As opposed to it, the current time-spirit replaces responsible human actions with the forging of hectic programs, offering hardly anything more than feeble life-substitutes, ready to present even immature whims and varieties of otherness (sometimes bordering on deviance) in an ahistorical universality. It is known from reconstructions from the history of ideas that the very notions of rule of law, human rights, constitutionalism, parliamentarianism, as well as democracy are also products of endeavors, recognitions, successes, and failures accumulated through thousands of years, to which meditative pagan Antiquity, the Christian Middle Ages as well as modern and contemporary times (striving for anthropo-centrism) may have equally contributed. Notwithstanding the fact that they may seem relatively completed and solidified as abstracted in a series of theoretical statements from the Enlightenment up to the present age, they are in a constant process of refinement and further shaping. It is exactly the Christian tradition that once laid the foundations for all these, with the transcendence of divine law and the human commitment to values, by substantiating the inviolable and unquestionable dignity of the human person. More importantly, it is also the Christian tradition that marked out the dependence of human institutions (as mute instruments in themselves) upon a given destination designed for value implementation. ${ }^{17}$ This is the reason why Christianity has set internal barriers for these institutions to prevent them from growing self-centeredly predominant, that is, from growing into a self-definingly independent power with the eventual chance of turning against humans themselves, by the eventual risk of destroying the rest of their dignity. ${ }^{18}$

In the Western hemisphere-or in the North (to use the term of financiers regularly convening in Switzerland at Davos)-humankind has started writing a new history since postwar reconstruction. What are its characteristics? Self-confidence, success, devaluation

17 Cf. Varga, Csaba (2003) 'Buts et moyens en droit' in Loiodice, Aldo, Vari, Massimo (eds.) Giovanni Paolo II: Le vie della giustizia - Itinerari per il terzo millennio (Omaggio dei giuristi a Sua Santità nel XXV anno di pontificato). Roma: Bardi Editore - Libreria Editrice Vaticana pp. 71-75 and, as expanded, Varga, Csaba (2005) 'Goals and Means in Law: or Janus-faced Abstract Rights' in Jurisprudencija [Vilnius: Mykolo Romerio Universitetas], 68(60), pp. 5-10 \& <https://intranet.mruni.eu/en/mokslo_darbai/jurisprudencija/archyvas/?l=120712>.

18 In terms of alienation, cf. Varga, Csaba (2013) 'The Contemporaneity of Lukács' Ideas with Modern Social Theoretical Thought: The Ontology of Social Being in Social Science Reconstruction with Regards to Constructs like Law' Archiv für Rechts- und Sozialphilosophie, 99(1), pp. 42-54 \{reprinted in <http://elib.sfu-kras.ru/ bitstream/2311/19820/4/01_Varga.pdf>\}. 
of human labor (as if it were a postmodern correction of the burden of labor to be carried by humans since their expulsion from Paradise upon divine punishment), haughtiness of learning, the rule of reason, and abstract planning with guarantees of calculability and predictability: all in all, trends disregarding God, trying to substitute Him by the individual self and also burying Him more and more vociferously and provocatively day to day. Here is the Individual entering the scene alongside a few billion fellows, with each and every one representing their selves as the center and last meaning-in other words, the axiomatic zero point-of the Universe; moreover, as a key to its hermeneutics and, in their ephemeral lives, also as the immoderately unrestrained consumer using up whatever goods to be found on Earth. Now, the Individual's incidental pleasure constitutes the exclusive criterion of values. Their rather shapeable psychical disposition is the gauge for the existence of whatever institution. "Rule of law," "human rights," "constitutionalism," "parliamentarianism," as well as "democracy"-just like the once revolutionary thought of the res publica itself-serve, from now on, as the framework of random motions (maybe sometimes pulled in idiotism pouring on us from the media) for these few billion creators of the world as plenipotentiary carriers and users of the ever-growing catalog of nothing but rights and also as the guardians sanctioning the momentary state of this world, finalizing or further shaping it.

A future for Hungary? The outcome into which the sublime ideas of the rule of law, human rights, constitutionalism, parliamentarianism as well as democracy became (de) formed since the Atlantic revival after World War II (and especially in hands of radical leftist anarchists, marking the generation of 1968) is only now becoming visible, showing the apotheosis of irresponsibility, the cult of unworthiness with chanceless chances in full blossom; strictly speaking, no one can eventually fail since by the very biological fact that we are born as humans, we may start reclaiming full catalogs of rights for ourselves with no obligation to return anything. Our ideals are still floating in the air, challenged but not shaken, when the Atlantic world starts facing the outcome. Now, when the underlying societal texture has fallen apart, the hearth of families has cooled out, and citizens thoroughly programmed have become robots and media-controlled consumer-units, everyone fights against everyone in an endless battle in the name of law-with women snarling at men, minors turning against their parents, those infatuated with the same sex incited against those attached to the other one-all loathing the state and the church as public enemies from a cloud of daze. Indeed, has there been anything left to be respected in anyone who still dares to set standards and values and who longs for adherence to them? We do not yet know what tomorrow's Western world would be like if irresponsibility, environmental destruction, human sinning without punishment, glorification of licentiousness, and life-substitutes offered by simulated virtual worlds had already grown to global proportions halfway through our near future, as they are doing in our day. 
Neither do we know how much and how far our everyday sense and experience, having proven unfailing so far in our human history of thousands of years, will be able to adapt to this world when its reserves will exhaust, and what final impetus will-if at all—provoke humans to revolt for reclaiming their human dignity. For, enthused by the success story of the Atlantic world, we may have scarcely realized that the uninhibited universalization of rights is not only a gesture by our own enlightenment but also a burden that we mostly generously (but effectively) pay at mostly the cost of others.

For sexual licentiousness is also a budget and social capital item (just like AIDS) in the households of nations, and an economy based on free labor market squanders the resources just as the retirement at the meridian of life does at the cost of offspring born in decreasing numbers. The global division of labor (when even toothpicks may be produced within transcontinental cooperation in Europe) also imposes a tremendous burden on the energy household of the Earth, just like dumping prices resulting from the rivalry of airlines competing for the market of leisure do. This is to say that rights, too, cost. As the extension of the sheltered sphere of privacy results in increasing costs and decreasing efficiency in the maintenance of public order, massive malpractice litigations also imply costs rocketing in health and social care. ${ }^{19}$ This may be a vicious circle, for the richer a nation, the more resources it can spend to meet the standards set by its own enlightenment. However, the more unlimitedly it provides rights, the more reserves it inevitably has to spend on overall societal reproduction.

It may be intellectually exciting an experience to watch the game of some wealthy nations from a distance, if they are self-destructive and counterproductive beyond a certain extent; however, it is by far not worth risking our own modest existence among the small states of the Central European region with no giant reserves in this game. Strategic planning is mostly undertaken by big states because there is more for them to win or lose by predicting the future. Conversely, nevertheless, smaller states run a relatively bigger risk, because it is their sheer existence with their chance for survival that is eventually at stake, for they not only risk a relatively greater part of their financial chances (or channel it on a forced track) but may also seriously risk their moral reserve and future prospects. Let us contemplate, for instance, the disproportionately huge costs to be borne by Hungary, due to its geographical location, to enforce the internationally renowned high standards of human rights to manage its part in the global migration, pushed by the misery in a number of ruined societies in either our neighborhood or major parts of Asia and Africa. Let us also consider the additional

19 Cf. Varga, Csaba (2012) 'The Law's Homogeneity Challenged by Heterogenisation through Ethics and Economics', Acta Juridica Hungarica, 53(2), pp. 165-174 \& <https://akjournals.com/view/journals/026/53/2/article-p165. $\mathrm{xml}>$. 
obligations arising from the necessity widely felt as vital to re-socialize parts of the Roma population.

Nowadays, it is popularly held among those considering themselves enlightened that the state is growingly losing ground, whereas the operation of the rule of law, human rights, constitutionalism, parliamentarianism, and democracy presume the unquestioned operability of the state. Although the state of the future may not be a powerful one, it ought not to be a weak one either; it shall be an organization strong enough despite its relatively modest extent. ${ }^{20}$ What else has been built for decades now under the aegis of the United Nations, the North Atlantic Treaty Organization, or the European Union? What else is the political game all about? Any of our large-scale decisions require a firm conception, and as soon as mental anticipation is replaced by resolution, a readiness to act is also required, so that deeds can no longer be prevented by further hesitation. For any administrative action to become effective, determination is needed, which in turn presupposes smoothly functioning communication channels to spread information. It is firmness and readiness to act that are a sine qua non for the maintenance of public order. The prerequisite of administering justice is a sense of responsibility, mature enough to morally face the consequences of a decision.

Now, let us examine from the other-positive-side all into which our catchwords must not degenerate. We must serve the dignity of the human person with humility and moral commitment, striving for justice and equity, aware of the truth of our belief in the basic honesty of humans as filled with a sense of responsibility, in a way that our behavior can serve as a pattern for others. We must serve human dignity to be able to live in a social community, in the natural bonds of family and nation, with equal sensibility for rights and responsibilities, building law and order invested with all authority as may be needed.

The assumption of responsibility, personal commitment, and the inevitability of making decisions do not apply to everyday life-situations only. Even if we should find ourselves to have no spouse, to be childless, jobless, or homeless, or to have no honesty or self-control, we should not act as vegetative beings, resorting to accusing others, trying to find excuses and raise pity for ourselves as innocent victims of some social disease that is easily identifiable anywhere at any time on principle. One of the most noble objectives of training lawyers now is to convince future generations of the inevitability of personal commitment and of the necessity of accepting one's own personal fate when defining and undertaking our individual

20 Cf., e.g., Utz, Arthur Fridolin (1975) Zwischen Neoliberalismus und Neomarxismus: Die Philosophie des Dritten Weges. Cologne: P. Hanstein 184 pp. [Gesellschaft, Kirche, Wirtschaft 8] and Nojiri, Taketoshi (1999) 'Values as a Precondition of Democracy' in Zacher, Hans F. (ed.) Democracy: Some Acute Questions. (The Proceedings of the Fourth Plenary Session of the Pontifical Academy of Social Sciences, 22-25 April 1998.) Vatican City 450 pp. [Pontificiae Academiae Scientiarum Socialium Acta 4] on pp. 89-113 on p. 105. 
life missions. ${ }^{21}$ It is obvious that the responsibility for any choice and decision must be shared by those who make the law and also by those who merely apply it.

One and a half decades ago, after the collapse of communism in the middle part of Europe, there were only sporadic voices warning against possible damages by a purely mechanical extension of the patterns taken from the Western routine of the rule of law, and the Western law exporters themselves rejected these fears in outrage. ${ }^{22}$ By now, it has become obvious that our vast Euro-Asiatic region of Central and Eastern Europe, spanning from Vladivostok to Tallinn, to Dresden, and to Ljubljana, was reduced to a field of experimentation by the rhetorical champions of tolerance, imbued by merciless uniformization and theoretical arrogance. ${ }^{23}$ After their "Law and Development" program, propagated and implanted as a panacea by the wishful American liberal doctrines, had failed all through Latin America, they decided to test it again in a by far more difficult terrain: on the ruins of communist dictatorial regimes. It is no wonder that this missionary zeal has all but aggravated the bankruptcy in a number of ex-Soviet countries (maybe except for the Baltic states ${ }^{24}$ ) and also in Albania. ${ }^{25}$ Meanwhile, in the heart of the Hungarian capital and as housed in the building of the onetime communist National Planning Office, the so-called Central European University was

21 Cf., for example, Varga, Csaba (2012) The Paradigms of Legal Thinking. [1996/1999.] Enlarged 2nd ed. Budapest: Szent István Társulat 418 pp. [Philosophiae Iuris] \& <http://mek.oszk.hu/14600/14657/> and Varga, Csaba (2003) 'Búcsúírás' [Farewell letter] in Boros, Emese, Ohlendorff, Nóra (eds.) Pázmány Péter Katolikus Egyetem Jog-és Államtudományi Kar: 2003-ban végzettek évkönyve. [Yearbook of the class graduating at the Faculty of Law of Pázmány Péter Catholic University in 2003.] Budapest: Alumni pp. 119-122 \{reprinted in <http://mek.oszk. $\mathrm{hu} / 18900 / 18995 / 18995 . \mathrm{pdf}>, 563-566\}$.

22 "Laws [...] were made for people and not people for the laws; and they have to conform to the character, the customs and situation of the people for which they were made; [...] and it would be absurd to indulge in the absolute ideals of perfection in things that are only suitable to realise the relative good [...]." Portalis in Fenet, 1836, pp. 466-467. As one of the case-studies, see Cohen, Stephen F. (2000) Failed Crusade: America and the Tragedy of Post-Communist Russia. New York - London: W. W. Norton \& Company xiv+304 pp. and, as reviewed, Varga, Csaba (2008) 'Failed Crusade: American Self-confidence, Russian Catastrophe' in Varga, Csaba Transition? To Rule of Law? Constitutionalism and Transitional Justice Challenged in Central \& Eastern Europe. Pomáz: Kráter 292 pp. [PoLíSz sorozat könyvei 7] on pp. 199-219 \& <http://mek.oszk.hu/14800/14851>.

23 See, for instance, Mattei, Ugo (1997) Introducing Legal Change: Problems and Perspectives in Less Developed Countries. [Manuscript of a lecture delivered at the Session of World Bank Workshop on Legal Reform in Washington D. C. on April 14, 1997.] Berkeley - Trento 19 pp.; Brietzke, Paul H. (1994) 'Designing the Legal Frameworks for Markets in Eastern Europe', The Transnational Lawyer, 7, pp. 35-63; Höland, Armin (1993) 'Évolution du droit en Europe centrale et orientale: Assiste-t-on à une renaissance du "Law and Development"?', Droit et société, (No.25), pp. 467-488; Ajani, Gianmaria (1994) 'La circulation des modèles juridiques dans le droit postsocialiste', Revue internationale du Droit comparé, 46(4), pp. 1087-1105 [or Ajani, Gianmaria (1995) 'By Chance and Prestige: Legal Transplants in Russia and Eastern Europe', The American Journal of Comparative Law, XLIII(1), pp. 93-117].

24 Cf. Varga, 'In Want of New Balances in Transition' in the present volume.

25 See, for instance, Shlapentokh, Vladimir (1995) Russia: Privatization and Illegalization of Social and Political Life. Michigan State University Department of Sociology [September 25] 44 pp. [NATO CND \{Chris Donally\} (95 459)]. 
established with a missionary dedication to theoretically promote abstract universalism in the entire former socialist bloc.

Since the euphoria of the transition's honeymoon period in Central Europe is over, public opinion (fed by accumulating practical experience) is already more critical concerning the adoption of ready-made recipes and wonder-working gestures, miracle-expecting attitudes, and the like. ${ }^{26}$ More importantly, those in parliament and government are more about to realize, as a truth of our landmarking present, that simplistic and rapid methods smuggled from somewhere by elitist groups as showing the exclusive road most probably have no potential to become organically integrated into ongoing social processes and can therefore scarcely serve our own interests with optimum effectivity in the long run.

Needless to say, foreign models can be useful as raw material, as an emphatic notification about solutions developed elsewhere by others at another time-maybe and mostly even under different conditions-only provided that they operated with reliable success there and then. ${ }^{27}$ We should be aware that no reference to outside authorities can substitute for own decision on principle. Being necessarily partial and selective as conceived within differing paradigms, such references are unsuitable to replace a personal stand to be taken.

No matter how such international fora and world powers may represent twenty-firstcentury Atlantic civilization (self-closing in its underlying individualistic ideology and therefore by far not safe from the threat of a crisis some day), it is just their absolutizing universalism that makes them not only dated but reminiscent of the ages before modern science. For in their underlying approach, they mistake the edifice of (any) society, continuously rebuilding upon traditions, convictions, collective and personal beliefs, for a primitive system made up of interchangeably ready-made, mechanically connected elements (such as, for example, the standard engine blocks of a motor vehicle). ${ }^{28}$

26 'The State of Law is Not a Gift'-this is how the first ombudslady of Poland summarized her sobering experience half a decade after the expiry of her office term; cf. Łętowska, Ewa (1996) 'Poland: In search of the "State of Law" and Its Future Constitution' in Łętowska, Ewa, Łętowski, Janusz Poland: Towards to the Rule of Law. Warszawa: Wydawnictwo Naukowe Scholar 176 pp. on p. 11.

27 Cf., as a global overview with theoretical backing, Varga, Csaba (2007) 'Reception of Legal Patterns in a Globalising Age' in Calera, Nicolás López (ed.) Globalization, Law and Economy / Globalización, Derecho y Economía: Proceedings of the $22^{\text {nd }}$ IVR World Congress. Vol. IV. Stuttgart: Franz Steiner Verlag, pp. 85-96 [ARSP Beiheft 109] \{reprinted in <http://mek.oszk.hu/15300/15386>, pp. 181-207\}.

28 Cf.-reviewing Glenn, H. Patrick (2000) Legal Traditions of the World: Sustainable Diversity in Law. Oxford New York: Oxford University Press xxiv+371 pp.-Varga, Csaba (2005) 'Legal Traditions? In Search for Families and Cultures of Law', Acta Juridica Hungarica 46(3-4), pp. 177-197 and in Moreso, José Juan (2007) Legal Theory: Legal Positivism and Conceptual Analysis (Proceedings of the $22^{\text {nd }}$ IVR World Congress Granada 2005). Vol. I. Stuttgart: Steiner 263 pp. [ARSP Beiheft 106] on pp. 181-193 \{reprinted in <http://mek.oszk.hu/15300/15386>, pp. 77-97\}. 


\section{Theological and Anthropological Foundations}

As an axiomatic starting point, it has always been obvious that "all the balance of the CHRISTian thought is based on two antinomic statements. On the one hand, the person is prior to society. On the other, public good is superior to personal goods. ${ }^{29}$ Not only recognitions based upon natural law-drawing conclusions, in addition to connections obvious for common sense, also from theological truths-but also insights drawn from social sciences (based on anthropological, psychological, sociological as well as criminological investigations and empirical data) are growingly definite in concluding that

- ordo, ${ }^{30}$ that is, human order in society, is inconceivable without the agreed-on practice based upon the acknowledgment of some kind of authority. Unless this authority contents itself with a new fist law, ensuing from actual anarchy and deviance and tolerated as normal by now, disguised with some minimum and superficial maintenance of public order, ${ }^{31}$ it must be founded through collective experience and traditions with a commonly shared vision of future and an ethical worldview; ${ }^{32}$

- any way of life accepted with procedural techniques in society must be based on values originating from the unalienable entirety of human persons. Therefore, not even democracy can embody values without genuine eternal values to implement, that is, on the sheer foundation of ethical neutrality and the total relativization of values; ${ }^{33}$

29 Bigo, Pierre (1965) La doctrine sociale de l'Église: Recherche et dialogue. Paris: Presses Universitaires de France 540 pp. on p. 168 ['Tout l'équilibre de la pensée chrétienne tient dans deux affirmations antinomiques. D'une part, la personne est antérieure à la société. D'autre part, le bien commun est supérieur aux biens particuliers.'].

30 'But it must not be imagined that authority knows no bounds [...].' Pacem in Terris Encyclical of Pope John XXIII [1963], 47.

31 "A person who is concerned solely or primarily with possessing and enjoying, who is no longer able to control his instincts and passions, or to subordinate them by obedience to the truth, cannot be free." Encyclical Letter Centesimus Annus issued by the Supreme Pontiff John Paul II [1991], 41.

32 Most expressly-first of all, from the aspect of social psychology and sociology—see Nisbet, Robert (2010) The Quest for Community: A Study in the Ethics of Order and Freedom. Wilmington, Del.: Isi Books xxxiii+330 pp. It must be noted that the same objection is formulated in criticism of the new doctrine in formation on the practice of precedents. For a theoretical context, cf. Varga, Csaba (2003) 'Meeting Points between the Traditions of English-American Common Law and Continental-French Civil Law (Developments and Experience of Postmodernity in Canada)', Acta Juridica Hungarica, 44(1-2), pp. 21-44 \& <https://akjournals.com/view/ journals/026/44/1-2/article-p21.xml>, para. 1.

33 "With regard to civil authority, LEO XIII [in the Encyclical on the Condition of Workers (1891), 48], boldly breaking through the confines imposed by Liberalism, fearlessly taught that government must not be thought a mere guardian of law and of good order, but rather must put forth every effort so that 'through the entire scheme of laws and institutions [...] both public and individual well-being may develop spontaneously out of the very structure and administration of the State." Pius XI Quadragesimo Anno [1931], 25. "Hence, before a society can be considered well-ordered, creative, and consonant with human dignity, it must be based on truth [...]. And so will it be, if each man acknowledges sincerely his own rights and his own duties toward others." John XXIII Pacem in Terris [1963], 35. 
- dignity and responsibility are inseparable because the former arises from the autonomy of the person, and the latter from the freedom of man. Therefore, no form of social care or generous provision of rights can reduce the minimum responsibility to be irrevocably borne by the person for their decisions and actions and for the development and exploitation of all their potentials (that is, for their conduct in private, in family and professional life as well as in their larger communities); 34

- as a result of the inviolable dignity and undiminishable responsibility of the human person, rights and obligations go hand in hand. ${ }^{35}$ Otherwise, reciprocity and balance would be unthinkable, ${ }^{36}$ and the societas as a whole would fall apart. ${ }^{37}$ Therefore, in the last analysis,

- our social achievements are-as human freedom itself is (if valuable at all) also a historical achievement and not simply the product of a mere declaration of right ${ }^{38}$-by no means built on the sand randomly formed by momentary taste, delight, and fancy but upon the awareness of the cognizability of our world and upon the belief that a sensible order can be developed in it, at the heart of which one finds the vocation

34 A Jesuit professor-Schooyans, Michel (1999) 'Droits de l'homme et démocratie à la lumière de l'enseignement social de l'Église' in Zacher (ed.), Democracy, pp. 50-51-has termed the process by which newer packages of human rights are acknowledged (and responsibility for them is shifted upon the state) through global lobbying and pressurizing via international organizations as a "tyranny of consensus," which, due to its positivistic voluntarism and by trampling on the principle of subsidiarity itself, results in the end to any genuinely democratic thought.

35 "[M]an's awareness of his rights must inevitably lead him to the recognition of his duties. The possession of rights involves the duty of implementing those rights, for they are the expression of a man's personal dignity. And the possession of rights also involves their recognition and respect by other people." John XXIII Pacem in Terris [note 31], 44.

36 "Since men are social by nature, they must live together and consult each other's interests. That men should recognize and perform their respective rights and duties is imperative to a well-ordered society. But the result will be that each individual will make his whole-hearted contribution to the creation of a civic order in which rights and duties are ever more diligently and more effectively observed." Ibid., 31.

37 See, for the comparative criminological analysis of the individualistic vs. communitarian backgrounds of the policing in the USA vs. Japan, concluding in a dazzling difference between the expenses invested and the results achieved, Szabo, Denis (1995) Intégration normative et évolution de la criminalité. \{Lecture at a conference on value, behavior, development, modernity, or the cultural factors of development and backwardness in development, as organized by the Institut de France [Paris] on September 16-17; manuscript [with the same title published in Boudon, Raymond, Chaunu, Pierre (eds.) (1996) Valeurs et modernité autour d'Alain Peyrefitte. Paris: Odile Jacob pp. 202-230]\}, as based upon the research by D. H. BAYLEY. For a Central European stand on the complementarity of rights and obligations, cf. Vaišvila, Alfonsas (2005) 'Legal Personalism: A Theory of the Subjective Right' in Szilágyi, István H., Paksy, Máté (eds.) Ius unum, lex multiplex - Liber Amicorum: Studia Z. Péteri dedicata (Studies in Comparative Law, Theory of State and Legal Philosophy). Budapest: Szent István Társulat 573 pp. [Philosophiae Iuris / Bibliotheca Iuridica: Libri amicorum 13] on pp. 557-573.

38 For one of its latest formulations, see, for example, Grant, Robert (1990) Oakeshott. London: The Claridge Press 128 pp. [Thinkers of our Time] at p. 63. 
of humans to both recognize the values dormant in them and then carry them into effect in their environment. ${ }^{39}$

This being the case, would it not be acutely necessary to reconsider what follows therefrom in terms of state organization? Should we, responsible citizens, not try to find answers to our concerns through this realization instead of just relying (with vacuous idleness, by shifting responsibility on others) upon patterns devised by others under differing conditions, which can only result in our failure? By claiming this, I do not mean alone anomalies, excesses, and disproportions (by, for example, one-sided extension of rights and competencies, which can only lead to dysfunction and irresponsibility as well as to irradiating chaos), recurring abundantly in our transition process, ${ }^{40}$ which—even if heralded mostly in the majestic robe

39 "Authentic democracy is possible only in a State ruled by law, and on the basis of a correct conception of the human person. It requires that the necessary conditions be present for the advancement both of the individual through education and formation in true ideals, and of the 'subjectivity' of society through the creation of structures of participation and shared responsibility. Nowadays there is a tendency to claim that agnosticism and sceptical relativism are the philosophy and the basic attitude which correspond to democratic forms of political life. Those who are convinced that they know the truth and firmly adhere to it are considered unreliable from a democratic point of view, since they do not accept that truth is determined by the majority, or that it is subject to variation according to different political trends. It must be observed in this regard that if there is no ultimate truth to guide and direct political activity, then ideas and convictions can easily be manipulated for reasons of power. As history demonstrates, a democracy without values easily turns into open or thinly disguised totalitarianism." John Paul II Centesimus Annus [note 27], 46. It should be remarked that on pp. 55-56, Schooyans [note 33] sees our days' developments-maybe in sign of an impending Apocalypse-as the beginning of a "total war waged against man" because the so-called "anthropological revolution" (p. 53)(de)grading humans from genuine persons to sheer individuals, utterly free to choose any truth, value, and ethics they please-eradicate from the human being exactly what is divine in them, depriving them of their being an imago Dei (i.e., an image of God). The human being practically becomes incapable of survival when their own reason and will are eliminated.

40 Cf. Varga, Csaba (1995) Transition to Rule of Law: On the Democratic Transformation in Hungary. (Budapest: 'ELTE Comparative Legal Cultures' Project 190 pp. [Philosophiae Iuris] \& <http://mek.oszk. hu/14700/14760/>; Krawietz, Werner, Varga, Csaba (eds.) (2003) On Different Legal Cultures, Pre-Modern and Modern States, and the Transition to the Rule of Law in Western and Eastern Europe. Berlin: Duncker \& Humblot xi+139-531 pp. [=(2002) Rechtstheorie, 33(2-4): II. Sonderheft Ungarn]; Varga, Csaba (2008) Transition? To Rule of Law? Constitutionalism and Transitional Justice Challenged in Central \& Eastern Europe. Pomáz: Kráter 292 pp. [PoLíSz sorozat könyvei 7] \& <http://mek.oszk.hu/14800/14851>. Focusing on one single issueconcealing in the guise of constitutional principles the politically motivated rejection of coming to terms with the past in criminal law by constitutional justices as legally irresponsible professional defenders of abstract constitutionalism in Hungary-cf. also Varga, Csaba (ed.) (1994) Coming to Terms with the Past under the Rule of Law: The German and the Czech Models. Budapest xxvii+178 pp. [Windsor Klub] \& <http://mek.oszk. $\mathrm{hu} / 14300 / 14310 / 14310 . p d f>$. As a kind of diagnosis of the problems of our age, see also Varga, Csaba (2012) 'Humanity Elevating Themselves? Dilemmas of Rationalism in our Age' [2000] in Varga, Csaba Comparative Legal Cultures: On Traditions Classified, their Rapprochement \& Transfer, and the Anarchy of Hyper-rationalism. Budapest: Szent István Társulat 253 pp. [Philosophiae Iuris] \& <http://mek.oszk.hu/15300/15386> on pp. 131-163. 
of the defense of constitutionalism ${ }^{41}$-are only apt to eventually shake the foundations of collective order, undermine its reliability and cohesive force, shattering its foreseeability and, in the final analysis (even if sometimes dragged out of the cloak of constitutional justices or ombudsmen), subjecting it to the "logic" of fist law, where only the stronger, more persevering, and uninhibited of us are awarded - those who resort to the arbitrament of a perhaps merely legalistic war.

Let us contemplate: if the ideal of the rule of law analogon developed in the European continental (German) idea of Rechtsstaatlichkeit preserves the maintenance of law and order by means of statutory regulation (and through judicial decision-making guided by principles) at its focal point, binding those governing and those governed alike, and if its smooth and safe realizability is the purpose of the separation between the (executive) power of the government, the legislative (regulatory) power of the parliament, and the (decisional) power of the judiciary - the latter two controlling the former-then, how can our present scheme of the rule of law respond to challenges regarding which the classical system of checks \& balances, developed nearly two centuries ago in a classical way, is now hardly able to operate functionally and efficiently? That is, how can it react to the power (or sheer monopoly) of the printed press and electronic media, the pressure by large organizations, the financial extortion by the international agents of globalization and the crime organized without frontiers-acting sometimes with assistance of the state, asserting themselves increasingly arrogantly with no responsibility, on a field practically freed from whatever regulation but actually assisted by worldwide economic trends and newest high technologies? The classical regime of the rule of law offers neither regulation nor ideas ${ }^{42}$ to control the interference on behalf of such new powers weighing down heavily on our future. Even by a benevolent comparison, all that is available does not even reach a fraction—say, one thousandth—of the European regulation standardizing (for example, the size of holes in cheese). Since we keep proudly and imperturbably thinking in terms of stubborn principles, our eyesight still does not reach farther than the hand-operated printing press of heroes of classical liberty such as MiнÁLY TÁNCsics (preparing the bourgeois revolution by means of mass journalism from the $1830 \mathrm{~s}$

41 As a case-study, cf. Dupré, Catherine (2003) Importing the Law in Post-communist Transitions: The Hungarian Constitutional Court and the Right to Human Dignity. Oxford \& Portland Oregon: Hart Publishing xx+217 pp. [Human Rights Law in Perspective].

42 Although focused mostly on considerations of legal policy in present-day Hungary, Pokol, Béla (1995) Médiahatalom: Válogatott írások [Media Power: Selected writings]. Budapest: Windsor Kiadó 198 pp. is a refreshing exception in this respect. Another remarkable fact is that a professor once at Yale, a constitutionalist, and not long ago the acting Attorney General of the U.S. identifies two main moments as having led to the present-day situation in the United States of America, notably, the liberal reinterpretation of the Constitution led of the Supreme Court and the limitless destruction by television (having also brought about virtual illiteracy as a side effect). Bork, Robert H. (1997) Slouching towards Gomorrah: Modern Liberalism and American Decline. New York: HarperCollins xiv+382 pp. 
in Hungary) or the channels of communication between Pest, the then capital, and Szolnok, a town by the river Tisza in the Great Plain, hardly a hundred kilometers from the capital-a distance that could be run in a post-chaise muddling through marshes, often threatened by highwaymen yet allowed, at times of good weather, by carriageable trails to reach its destination within two to three days in the 1860 s. ${ }^{43}$ Thus, it is no wonder that we cannot rise above the shortest reassertion of the freedom of press by a total lack of its regulation.

\section{An Irreplaceably own Task}

If such is the case, what are we to do? We are not likely to serve with a solution here and now. The most our message can convey is that we must contemplate about history, and if we already know what we want, we must look for paths, draw lessons from human experience, take responsible decisions, and go along the road that we have chosen. No one shall take decisions instead of us, and whatever we have once sowed, it will be us who shall have to reap it. We must assume responsibility for our people, our age, our fate, our conviction, and our rule of law in the undivided collectivity of humankind but also individually, for the talent entrusted to each of us for which we are accountable in person.

\section{Recapitulation}

To summarize the issue, the relationship between rights and duties cannot be but logically complementary as they necessarily supplement each other. As none of them can be posited without the other, no one is entrusted to select only rights from them.

What we have claimed about the role of legal culture in general also applies to the law's practical action. Notably, most decisive changes in the law's life may occur amazingly often through considered (re)interpretation, without the slightest modification of the law's posited wording. Only such silent (yet practically irresistible) shifts, such as in prevailing ideas, can explain how the ordering concepts of "common good," "public interest,"

43 This is a reference to the artists' colony at Szolnok, actually born in result of a nostalgy tour in 1851 by an Austrian officer of the emperor's army after the defeat of the Hungarian bourgeois revolution of 1848. The officer, painting as an amateur (August von PETtenkofen), had been so enchanted by the landscape of the Hungarian Great Plain that he later started inviting friends to this end point of "Far East"-for this was then the farthest South-East reachable at all by railroads on the European continent, changing over the then rather inconvenient land communication. Cf. (1975) Die Szolnoker Malerschule. Wien: G. Gistel 126+40 pp. and Strasser, Christine (1983) August von Pettenkofen: Die Szolnoker Bilder. Salzburg 185 pp. [Salzburg Universität, geisteswissenschaftliche Dissertation]. 
"public order," "public security," "public health" (etc.) that had once set the boundaries of rights provided for by basic codes to the individual from the early nineteenth century on (serving as a general basis of interpretation and also as general clauses in limiting cases, restricting, or refusing the enforceability of rights in given situations, thereby justifying a legal exception), ${ }^{44}$ seem to have gradually disappeared from our juridical discourse. For what my generation used to learn (back in the mid-1960s in both Western Europe and socialist Hungary) as a joint heritage of European civilization has suddenly become dated, no longer referred to by anyone. This has also resulted in a dramatic change in relations between the public and the individual. In our new cult of nothing but rights, public affairs can at most take hold in the periphery of, or gap in between, our increasingly expanding individual entitlements.

Although in its social teaching, aware of the danger of such dubious age-dependent fashions, the church has been declaring its stand more and more firmly from the last third of the nineteenth century on, according to which (1) also secular institutions must be built on the recognition and in service of the person; in consequence, (2) no civilizational achievement has its value in itself (i.e., even democracy is only valuable through the values implemented and materialized by it); (3) the dignity of human person presupposes the undertaking of responsibility through the unity of rights and duties, among others. Rule of law, human rights, constitutionality, parliamentarianism, and democracy? No achievement of Western development, however sublime and enlightening it may be, is free from criticism: their given form and output (as a few papal encyclicals do remind us) may suffer from infantile disorders with various excesses, that is, from mistakes and false emphases as well.

In addition, the principles of (4) representation and (5) participation are to be mentioned, particularly to understand the genuine foundations of democracy. For democracy in a Christian view is not something merely happening to us but rather a chance of getting realized through true representation and participation. ${ }^{45}$ It costs a lot, requires sacrifice and may involve the potential of errors in addition to its demand of time, which is another potential source of short-run disillusionment.

44 Cf., first of all, by the Hungarian émigré scholar, Bolgár, Vera (1963) 'The Public Interest: A Jurisprudential and Comparative Overview of the Symposium on Fundamental Concepts of Public Law', Journal of Public Law [Emory University Law School], 12(1), pp. 13-52.

45 Cf., as theoretical synthesis in general, Utz, Zwischen Neoliberalismus und Neomarxismus, 1975 and, as one of the applied fields in particular, Millon-Delsol, Chantal (1993) Le principe de subsidiarité. Paris: Presses Universitaires de France 127 pp. [Que sais-je? 2793]. In a historico-comparative context, cf. Millon-Delsol, Chantal (1992) L'État subsidiaire-Ingérence et non-ingérence de l'État: le principe de subsidiarité aux fondements de l'histoire européenne. Chicago-London-Toronto: Encyclopaedia britannica 232 pp. [Léviathan], in addition to Endo, Ken (2001) Subsidiarity and its Enemies: To what Extent is Sovereignty Contested in the Mixed Commonwealth of Europe? San Domenico/Firenze: European University Institute 42 pp. [EUI Working Paper RSC 2001/24]. 


\section{A Final Remark in Comparison}

Let us consider the issue once again, this time by recalling the dilemma of the American supreme command in 1944, when the deployment of the first atomic bomb in warfare had to be decided. For the radical ending of World War II in the Far East by such a bombing would have forecast and also involved a certain-yet immense but limited—number of civil and uniformed victims on the enemy side. In case of any other option, destroying the enemy in a protracted jungle war would have inevitably presumed a far greater number of victims both on the enemy's and the own side, in a number and time schedule both uncertain and unlimited. Which option is more humanitarian? Which one should have been resorted to in this fatal and tormenting dilemma, to be decided unambiguously anyway in this superhumanly dramatic choice faced by both the politicians and the relevant general staff? ${ }^{46}$ Not too far away in time, let us continue our reconsideration with the example of the termination of World War II, which, dividing the world into defeaters and defeated, had the task of pacifying the latter with the former. A naive question may arise as to whether this has perhaps meant that the victors' democracy was just extended to the liberated one? We know the answer: not in the least, for it would have been at the formers' own costs and by risking their own human lives; therefore, they actually chose the continued use of their armed forces. What followed included military occupation and the suspension of basic freedoms as well as occupying administration with unlimited foreign power intervention and reckoning with the past through military tribunals by the suppression of principles of the rule of law. Finally, it also forced a "re-education to democracy" process which was originally designed to span about one decade of transition before anything like democracy could be implemented. ${ }^{47}$

46 Cf., from the literature, Weyden, Peter (1984) Day One: Before Hiroshima and After. New York: Simon and Schuster 414 pp., on the contexture, Baker, Paul R. (ed.) (1976) The Atomic Bomb: The Great Decision. 2nd rev. ed. Hindale, Ill.: Dryden Press viii+193 pp. and Giovannitti, Len, Freed, Fred (1965) The Decision to Drop the Bomb. New York: Coward-MacCann 348 pp. and Bernstein, Barton J. (ed.) (1976) The Atomic Bomb: The Critical Issues. Boston: Little, Brown xix+169 pp., and with archives' background, Bernstein, Barton J., Matusow, Allen F. (1966) The Truman Administration: A Documentary History. New York: Harper \& Row viii+518 pp. and Morton, Louis (1960) 'The Decision to Use the Atomic Bomb' in Greenfield, Kent Roberts, Office of the Chief of Military History (ed.) Command Decisions. Washington: U.S. Army viii $+565 \mathrm{pp}$.

47 Cf. Varga, Csaba (2006) 'Transition to Rule of Law: A Philosophical Assessment of Challenges and Realisations in a Historico-comparative Perspective' in Varga, Csaba On Transfers, Transition, and Renovation of Law. [Papers in Sadakata, Mamoru (ed.) Hungary's Legal Assistance Experiences in the Age of Globalization. Nagoya: Center for Asian Legal Exchange \{of the\} Graduate School of Law, Nagoya University] \& <http://mek.oszk.hu/17500/17543> on pp. 185-214 in general and Varga, Csaba (1993) 'Transformation to Rule of Law from No-law: Societal Contexture of the Democratic Transition in Central and Eastern Europe', The Connecticut Journal of International Law, 8(2), pp. 487-505 in particular. For the background, see, for example, Montgomery, John D. (1957) Forced to be Free: The Artificial Revolution in Germany and Japan. Chicago: The University of Chicago Press xiii+21o pp. and Friedmann, Wolfgang (1947) The Allied Military Government of Germany. London: Stevens x+362 pp. 
By now, we may have realized that in the Central and Eastern European region, transition after the downfall of the red dictatorship (distinguished favorably by the Western mainstream double measure from the brown one) took place differently. Could any decisionmaker have, one and a half decades ago, presented an alternative to the democratic jungle war, to its tiresome roughness, pitfalls, costs, and even its disillusioningly meager and counter-effective self-prolonging performance? Everything considered, it seems that there has been no genuine alternative. Thus, this is to be taken by us as acquired and to be fought through as our way, fate, and mission. The sequence of generations to come has to assume the task of incessantly caring for, protecting, and eventually perfecting it within the given frameworks but not without the sight of the once contemplated ends. 


\title{
TRANSITION MARSHALED BY CONSTITUTIONAL COURT DICTA UNDER THE COVER OF RULE OF LAW (A Case Study of Hungary) ${ }^{1}$
}

\begin{abstract}
1. Transitions in the Age of Globalization 2. Constitutional Assessment: The Hungarian Way 3. Example: Human Dignity in Isolation and Sterility 4. Public Law Privatized with the State Targeted as the Common Enemy 5. A Future without Past 6. Legality with Justice Silenced: Crimes Unpunished 7. Rule of Constitutional Court Dicta, not of Law 8. A Self-image in Reverse
\end{abstract}

ABSTRACT In the age of globalization, diverse types of transitions can be observed, all of which need differentiation in assessment and classification. One of them is the case of Hungary, with a strongly emphasized, formalistic understanding of the rule of law reduced to certainty and thereby to foreseeability in law. In the beginning, the main actor shaping ongoing processes in Hungary was the new Constitutional Court with politically partisan over-activism, annulling the measures needed to heal the economic, social, and political wrongs caused by the communist regime. It was also instrumental in the exclusion of morality and material justice from the law's working considerations. The necessary result was the emptying of law from ultimate standards. Mostly staffed with civilists, the Court's constitutional adjudication eventually privatized public law; moreover, driven by the contractualist's mind, it treated the state as a common enemy. All this may have contributed to the atomization of society. In consequence, even human dignity deformed to treatment in isolation and sterility. All this could only end in a future without past and in legality silencing justice with crimes left unpunished.

KEYWORDS idolatry of the West; rule of law as panacea; certainty of law vs. material justice; judicial activism; legal continuity; autotelism in law; borrowing of legal models; pondering and balancing in adjudication

1 Originally published in Hungarian in 2006. Earlier versions in English include (2006) 'Legal Renovation through Constitutional Judiciary?' in Varga, Csaba On Transfers, Transition, and Renovation of Law. [Papers in Sadakata, Mamoru (ed.) Hungary's Legal Assistance Experiences in the Age of Globalization. Nagoya: Center for Asian Legal Exchange \{of the\} Graduate School of Law, Nagoya University.] on pp. 287-312 and (2008) 'Creeping Renovation of Law through Constitutional Judiciary?' in Varga, Csaba Transition? To Rule of Law? Constitutionalism and Transitional Justice Challenged in Central \& Eastern Europe. Pomáz: Kráter 292 pp. [PoLíSz sorozat könyvei 7] on pp. 117-160 as well as (2008) 'Transition Marshalled by Constitutional Court Dicta under the Cover of a Formal Rule of Law (A Case-study of Hungary)', Central European Political Science Review, 9(No.32), pp. 9-48. 


\section{Transitions in the Age of Globalization}

Having reached the twenty-first century, we live in the age of legal transfers that tend to be increasingly unidirectional as practically aimed at societies exposed to the influence of globalism and temporarily proving to be open in orientation by countries playing a primary role as central control agents of globalism. Just as in case of the United Nations, this unidirectional legal effect is primarily caused (i.e., initiated, effectuated, and also rewarded) by large worldwide international organizations and institutions following their own agenda (of world banking, of free trade, of human rights, and/or others), to which various regional structures can be associated (at their own levels but with not negligible comprehensive force). For us (from Iceland to Portugal, also keeping Israel and Turkey, as well as the successor states of the one-time Soviet Union, in mind), the European Union itself as well as the great powers are destined to play distinctive roles in a classical sense (at least in their areas) - as the United States of America in world dimensions or, in their continental environments or broader neighborhoods or geopolitical zones of influence-Japan, ${ }^{2}$ Germany, or Turkey, ${ }^{3}$ to mention just a few examples. Those significant legal effects radiating from the Atlantic world-be it a par excellence American or quite an international initiative on globalism with a center in New York or Washington, or just Swedish governmental support to legal assistance-are now being sharply criticized in general and not quite without reason. ${ }^{4}$ In most cases, it is merely universalistic projections that take place under the aegis of transferring legal patterns, on the one hand, and solely mechanic insertion of texts as acquisition in reception of legal patterns, on the other-and often without proper efficiency and the slightest effort by either of the two sides at coping with the delicate yet lengthy and tiresome job of their internalizationthrough rendering those patterns organic as adjusted to local conditions, that is, by fulfilling the task of accommodation day to day. It should be noted, however, that although such a criticism may be precise and verified by experience, it is far from being complete as it lacks a comprehension of the whole process as well as proper distance in time and perspective. In itself, it can scarcely express the impact en masse, namely that such a transfer, having become a daily

2 See the state-financed program of the Nagoya University Centre of Asian Legal Exchange, aimed at rebuilding traditional laws destroyed in the Asian successor states of the Soviet Union (Azerbaijan, Kazakhstan, the Kyrgyz Republic and Uzbekistan) as well as of Cambodia, Iran, Laos, Mongolia, Thailand and Vietnam. Cf. Matsuura, Y[oshihasu] (ed.) (2005) The Role of Law in Development: Past, Present and Future. Nagoya: Nagoya University viii+113 pp. [CALE Books 2].

3 In addition to the numerous higher education institutions of the Turkish Republic of North Cyprus, see the Turkish universities in Azerbaijan and Kazakhstan with their proper legal aid effect.

4 Cf., for example, Varga, Csaba (2007) 'Reception of Legal Patterns in a Globalising Age' in Calera, Nicolás López (ed.) Globalization, Law and Economy / Globalización, Derecho y Economía: Proceedings of the $22^{\text {nd }}$ IVR World Congress. Vol. IV. Stuttgart: Franz Steiner Verlag, pp. 85-96 [ARSP Beiheft 109] \{reprinted in <http:// mek.oszk.hu/15300/15386>, pp. 181-207\}. 
occurrence solely by virtue of its mere quantitative proportions, may still prove to be effective. For all the failures in individual details notwithstanding, it may perhaps be effective indeed in the specific way in which-as contrasted to German and English fighting styles in World War II (built on the professional excellence and mental preparedness of the fighters) or to the Soviet one (based singly on the massive number of those exposed to the destruction, soldiers and civilians alike) - the American type of warfare may have been: relying in every respect on the mass-scale deployment of military techniques put into action, while protecting its human staff (rarely characterizable by individual excellence) to the utmost. For it was characteristic of exactly that type that the Americans first demolished everything they could with air force and armored troops, and then-and exclusively then - they invaded the area at a time when not so much the defeat of the resistance was at stake as was the organization of the territorial control that they could exert. That is, in principle, it is conceivable that the process (or the lack) of these legal effects being internalized could only be depicted as a failure in the mirror of individual case analyses. However, on the whole, and taken as an aggregate regarding their mass effect, those legal transfers may perhaps still have brought about a kind of irreversible change and may thus have proven profitable from the financier's aspect in a pure cost \& benefit analysis.

It seems as if it were just the reproduction of the above global trend that took place with merciless consistency under the aegis of the so-called constitutional (re)building in the classical Central European and Balkan region of the once socialist empire in general as well as on the core territories of the classical Russian empire in particular, primarily through an economic and financial policy urged by American economic exploitation ${ }^{5}$ - with a difference that struck us as strange and frightening then. Notably, the very same network of experts and institutions and the same staff of specialists could be seen in this region, in which network and staff had started law modernization in Latin America in a "social-scientific" manner decades ago only to fail miserably afterward due to their ethno-centric blindness and liberal universalism in the background; they had thought to fulfill the mission of their "Law \& Development" project only through the simple transfer and/or extension of their American domestic daily legal routine. Hungary was no exception to this either. Of course, it may take years or decades until we can establish the reason with scholarly certainty, why it was exactly us-despite having beaten paths of pluralism that once required courage in socialism; despite having belonged to the vanguard by developing a state-of-the-art economic and financial system and an adequate legal structure, with an advanced scholarship that also adopted Western results of the time; and

5 Cf., for example, Varga, Csaba (1995) Transition to Rule of Law: On the Democratic Transformation in Hungary. (Budapest: 'ELTE Comparative Legal Cultures' Project 190 pp. [Philosophiae Iuris] \& <http://mek.oszk. hu/14700/14760/> as well as—collecting experiences gained abroad-Varga, Csaba (ed.) (1998) Kiáltás gyakorlatiasságért a jogállami átmenetben [A cry for practicality in transition to the rule of law]. Budapest: [AKAPrint] 122 pp. [A Windsor Klub könyvei II]. 
despite having been perhaps the first among the firsts with our network of economic-political relations rather open even in worldwide comparison - who happened to fall back, within a few years' time, into the fatigue of the lack of perspective and hopelessness, facing the threat of the practical loss of the nation resulting from the country's selling off and the consequently pursued policy of surrender. That is, why we fell back into the self-generating spiral of indebtedness, dependence, and helplessness; into the drab, cheerless, and monotonous toil of dayto-day drudgery for sheer individual and community survival. Our path is scarcely exemplary and - as we have known for years now—-far from being attractive to the surrounding world.

The reasons are presumably mostly political and sociological, and (in addition to international contexts) they also certainly come from our particular socio-psychological state above all. However, all these have legal aspects as well, either inherently or as a consequence. As the first of these-namely idealism-is concerned, I opine that our law's practical formation was achieved along idealized conceptions and principles as watchwords and with academic doctrinarian purism and unrestrained resolution, which the actors involved thought to be a simple reception of Western patterns and constructions. Meanwhile, they had no thorough knowledge of the everyday life and the practical action of the law of Atlantic societies as well as of the deep structure and real components thereof, so to speak-neither of the actual sources of the latter's occasional successes nor of what self-examination attempts at restarting and of the uncertainty that the latter may have felt in case of occasional domestic failures. Therefore, our present is mostly the product of idealists, reminiscent of belated revolutionary utopians having lost ground, who operated with ideals thought to be real and actuated them as a panacea, while the people relied on hopes for a more livable and viable future, also promising moral replenishment as opposed to the denounced immorality of the past. ${ }^{6}$ Secondly-as fragmentation of responsibility-I see another factor of a similar significance in the circumstance that, with the downfall of dictatorship when the first free parliamentary elections were made, the institutional representation of the responsibility to be taken for the country as a whole practically ceased to work. For just like in feudal particularism, the country actually fell apart in a dramatic period when it was determinative of its future. All this is to mean that what was going on-following principles such as the separation of powers and other ideals and practices-was nothing but the totalization of partial interests and competences (etc.) by expanding one's political authority to the detriment of others, in diverse fora (mostly of the

6 It was almost comical to see how the Hungarian State Radio president's program lionized the Constitutional Court's first president, albeit there was in fact no topic for them on which to agree. Namely, the external observer searched for public goods as fruits of the Rule of Law, which the interviewee reduced to nothing spectacular, as a mere structuring principle of the state organization that itself cannot be held accountable for anything else. Kondor, Katalin (2005) Névjegy 2: Válogatás Kondor Katalin músorából [Name card: selection from her \{radio\} programme]. Budapest: Masszi Kiadó 397 pp. 
state) in constant competition with one another in the overrepresentation and fight for selfassertion. As if everyone had been against everyone, no one acted aware of one's irreducible responsibility for the whole: for the country's future, for the actual cause or-in cooperation with others-for the sake of a common purpose at least. The Constitutional Court, ombudsmen as well as agents of the public order from police via public prosecuting to courts (often extinguishing the effect of each others' efforts), human rights activists, and others were all busy to implement and enforce their particular agenda, instead of cooperating as parts of a shared whole. All may have acted in the name of and through the instrumentalities offered by the Republic of Hungary but for a new Hungary that may successfully cope with its difficult task of transition. Some behaved as if they had existed in another world, failing to recognize that the actual impact they hoped of their actions would also be worth of their attention. Instead of assuming some humility recommendable common causes, the Constitutional Court expected the parliament and the government to set up additional offices for its practical extension, designed exclusively to try to detect the allegedly deep and mostly hidden motives behind the otherwise inscrutable action of constitutional judiciary.

Thus, taking international trends into account, it is no mere chance that the issue of global legal effects has produced a particular literature of its own. The first decade of the Constitutional Court of the Republic of Hungary has become one of the key instances for it, serving as a unique example in the thousands of years of the history of legal transfers, for it was legal importation without authorization (i.e., definitely arbitrary in a legal sense) on behalf of a constitutional court, performed tacitly and stealthily (because by resources activated that could only be identified as a result of some subsequent analysis of the products), by the deliberate use of its sphere of competence usurpingly extended. This legal transfer was devised by one of the supreme state organs acting with power that could not be appealed against and as part of authoritative practice that excluded both control and responsibility for this operation in either a legal or a political sense.

\section{Constitutional Assessment: The Hungarian Way}

If a career-starter young researcher attempts to write a monograph ${ }^{7}$ on the peculiarity of such a very species of legal transfer to raise scholarly interest in the challenging topic, choosing a self-marketing subject may indicate good sense. For us Hungarians, this might

7 Dupré, Catherine (2003) Importing the Law in Post-Communist Transitions: The Hungarian Constitutional Court and the Right to Human Dignity. Oxford \& Portland Oregon: Hart Publishing xx+217 pp. [Human Rights Law in Perspective 1] (references to it are by page numbers in brackets in this paper's text). 
indeed be very edifying, for in any case, it is noted if the country is closely approached from the outside through a kind of thorough analysis. Even if the case is of an inexperienced first experiment at interpretation, it is obviously the French (and Western European and, more broadly, Atlantic) worldview of the author that will provide a filter; therefore, the mirror offered undoubtedly renders a remarkable value judgment upon us.

According to the author's basic viewpoint, transitions in Central and Eastern Europe were characterized by the "unprecedented level of exportation and importation of law" in general and "law importation was a deliberate strategy carried out by the Hungarian Court" in particular (p. i). The circumstance that "although the Constitutional Court used the language of globalisation or ius commune, the law it imported was more specific" ${ }^{\prime 8}$ even enhances the uniqueness of this as "the background of the importers determined the choice of German case law" (p. i). It is this realization that will from now on serve as a starting point for the whole elaboration as it genuinely provides us with "a unique field of experimentation and of reflection" (p. 62) in the examination of the complex multitude of present-day legal transfers and effects. Within this, it is taken as a widely known fact that academics are mostly "eager to test their hypotheses and to extend their empirical field of studies" (p. 3), even if they look for specific experience and background knowledge of the field of such an expanded new experiment. Accordingly, at the most, they are guided by some presuppositions that they are to inflict (extrapolate) on new fields, instead of the humility of getting to cognize the given hic et nunc ; thus, it is no mere chance that "[c]ountless experts [...] flooded Eastern Europe" at the time (p. 50). ${ }^{10}$ As to the contemporary widespread opinion, Hungary was the best and earliest prepared for transition and could thus be the first to embark on its own path. For this reason, it is all the more puzzling how all this could be reverted into a negative or even counterexample and whether any international intention could play any role in this. Even the author holds it as commonly known that we, in the whole Central and Eastern Europe, were in the focus of the world community, as "[n]ever before in history had the drafting of

8 Harvey, Colin (2003) 'Series Editor's Preface' in Dupré, Importing, p. vii.

9 As a telling example to the extrapolation by experts of Latin-America, see Linz, Juan J[osé], Stepan, Alfred (1996) Problems of Democratic Transition and Consolidation: Southern Europe, South America and Post-Communist Europe. Baltimore: Johns Hopkins University Press xx+479 pp.

10 As ironically observed, "Allegedly, planeloads of frustrated Western law professors brought to Eastern Europe their pet private draft codes that had been ridiculed back home. These were sold to the new democratic regimes as inevitable." Sajó, András (1997) 'Universal Rights, Missionaries, Converts and »Local Savages«', East European Constitutional Review, 6, pp. 44-49 on p. 45. Moreover, as an early perception, Dorandeu, Renaud (1993) 'Les Pélerins constitutionnels: Éléments pour une sociologie des influences juridiques' in Mény, Yves (ed.) Les politiques du mimétisme institutionnel: La greffe et le rejet. Paris: L'Harmattan 285 pp. [Logiques politiques] on pp. 83-112 on p. 83-remembers salesmen having toured Central Europe with catalogues of "flat pack constitutions" offered for the price of US $\$ 250.000$ (Dupré, p. 51). 
constitutions and the adoption of national legal systems attracted so much attention from outside the countries concerned" (p. 10).

What distinguishes Western (American-type) interventionism or decisive interference from Eastern (Soviet-type) imperialism is definitely the way that it takes place: instead of direct or indirect military or police-controlled occupation, the former creates an economic and/or financial situation to be exploited by it. That is, it applies control by the capital which is-if at all-very rarely noticeable in the language of the applied rhetoric, even in the most obvious cases of a dictate. ${ }^{11}$ It is true that reassuringly nice words were then spent with regard to the whole region-for example, by LAWRENCE S. EAGLEBURGER as US Deputy Secretary of State as early as in 1991 at the annual conference of the US Export-Import Bank, messaging that "one thing we in the West should not do is sit in judgment on our East European friends, or attempt to dictate choices which are theirs to make." Of course, he also added at once, for the sake of clarity (as always, both before and after Iraq and Iran) that

However, there are certain things which the West, particularly we in the United States, can do to help ensure that the difficult economic transition on the way does not destabilise either the fragile new democratic institutions or peace in the region as a whole..$^{12}$

The author also considers it as a fact that "as a result of the external involvement in the reconstruction [...], these countries were flooded with advice and guidance" (p. 10), and in this, the European Union, the Council of Europe, the International Monetary Fund as well as the World Bank played equally cardinal roles (p. 11), even more so as "the universalistic liberal ideal was used as a yardstick to judge the preparedness of the new democracies to join first the Council of Europe, and then the European Union." ${ }^{\prime 3}$

In connection with such an unprecedentedly powerful mechanism of influencing and direct or indirect international interference, ${ }^{14}$ the Hungarian Constitutional Court became

11 As an edifying case study concerning the ex-Soviet Union, see Varga, Csaba (2008) 'Failed Crusade: American Self-confidence, Russian Catastrophe' in Varga, Csaba Transition? To Rule of Law? Constitutionalism and Transitional Justice Challenged in Central \& Eastern Europe. Pomáz: Kráter 292 pp. [PoLíSz sorozat könyvei 7] on pp. 199-219 \& <http://mek.oszk.hu/14800/14851>.

12 Quoted by Hyde-Price, Adrian G. V. (1994) 'Democratization in Eastern Europe, the External Dimension' in Pridham, Geoffrey, Vanhanen, Tatu (eds.) Democratization in Eastern Europe: Domestic and International Perspectives. London: Routledge xiv+274 pp. on pp. 220-254 on p. 245 (Dupré, p. 51).

13 Sadurski, Wojciech (2005) Rights before Courts: A Study of Constitutional Courts in Post-communist States of Central and Eastern Europe. Dordrecht: Springer xix+377 pp. on p. 232.

14 As to the nature and operation of the agents of globalism in a Latin American (Brasilian) perspective, see Schooyans, Michel (1991) La dérive totalitaire du libéralisme. [Paris]: Éditions universitaires 358 pp. \{\& (1997) The Totalitarian Trend of Liberalism. St. Louis, Mo.: CCVA Central Bureau xi+262 pp.\} and Schooyans, Michel (2000) La face cachée de l'ONU. Paris: Le Sarment 283 pp. $\{\&$ (2001) The Hidden Face of the United Nations. St. Louis, Mo.: CCVA Central Bureau xv+188 pp.\}. 
worthy of the international professional community's attention, having itself proven to be a tacit legal importer. For it acted within its own competence, that is, under the pretext of constitutional adjudication and thus, albeit not authorized to creeping legislation or constitution-writing, exploiting the consequences of the fact to the extent that their founding constitutional statute placed no forum of control or appeal above it, and consequently, each and every act taken by it would be built into the Hungarian constitutional order with inevitably legal (or more precisely, constitutional) force. Otherwise speaking, in want of any legal possibility to be held responsible politically or legally, the activity of its justices is only limited by their own moderation and self-control. As the decisions of the Constitutional Court become themselves-until a new constitution is framed or until they are overruled or perhaps reinterpreted, not to mention their tacit desuetudo (this being presumable at present only as a theoretical chance) - parts of the constitutional foundations of the legal order, they had the possibility, as a law-repealing authority over the parliamentary legislature (what HANS KELSEN, having constructed the very idea of constitutional adjudication in Europe, described as negativer Gesetzgeber), both to define the pattern and the limits of the transition and to draw the constitutional standards and confines of the legal order in formation after socialism ended.

Although the Constitutional Court consequently denied this back then, ${ }^{15}$ it already caught the public eye at the beginning that the Constitutional Court was in fact "the most powerful and perhaps even the most active specimen of its kind in the world"16 as "perhaps the most powerful in the region in that it encompasses all the known powers of Western constitutional courts" (pp. 6 \& 34). In addition, this was noticeable not only as regards its competence and political over-activism but also in the nearly total lack of regulation of its procedure (in what it starts proceeding, when, by whom, and in which way), within which-including also its own staff, literally and lavishly - "anyone can file a petition about virtually any constitutional issue, with subsequent proceedings being very informal" (p. 6). All in all, this court proved to become "a very prolific importer of foreign law [...] in a systematic way" (p. 46).

15 The Constitutional Court president intervened with the succession of justices unduly but temporarily successfully in so much as he played off parties against one another in a tactical game of the personal selection. When I happened to be the governing conservative parties' joint candidate against the communists and the free democrat liberals, at the Court's unofficial plenary session on succession (for which they did not even have the power to comment), he argued against me that I dared both to mention their overstanding competence in international comparison and to criticize some of their decisions even in an international publication. For its echo in the press, see (1996) 'Alkotmánybírák: kivonulók kérték' [Constitutional justices: leavers] and Sólyom, László [interviewed] (1996) 'Teljesen átpolitizált lett a választás' [The elections became totally politicised], Magyar Narancs, VIII(November21), p. 47 in <http://www.mancs.hu/index.php?gcPage=/public/ hirek/hir.php\&id=653>.

16 Brunner, Georg (1992) 'Development of a Constitutional Judiciary in Eastern Europe', Review of Central and East European Law, 18(6), pp. 535-553 on p. 539 (Dupré, p. 37). 
The circumstance that "the Hungarian Court imported German law" (p. 9) and "routinely relied on imported law as an adjudication strategy" (p. 11) not only played an incidental auxiliary role, but it also determined its entire strategy in that it "provided the new values and constitutional benchmarks" (p. 12) in a way that, in the last analysis, "importing the law from German constitutional case law enabled the Hungarian Court to introduce a new concept of fundamental rights" (p. 54).

If we consider that in the devotion to a genuine transition in Hungary, "the 'rule of law' had a particularly strong appeal" because "it was the law that people had demonstrated for and fought for" (p. 21), this explains the contrast and paradoxical contradiction that the catchword "rule of law" became incontestable (and not only legally but also socially and politically), while it was exactly under its pretense that, according to a growing number of analyses, the sense and the merit of the entire transition process was lost (i.e., the country's rebuilding and its chance to take a new start, integrating the nation in a manner ethically acceptable for generations). For at every crossroads, the hypnotizing siren's voice of a "revolution led by the rule of law" could be heard, and indeed, "the role of law was primordial in that each step in this process, no matter how unexpected, was controlled and accompanied by a legal response" (p. 29).

The provision of the new, effective Constitution announcing the transition is rather laconic as its Article 2 reads: "1-The Republic of Hungary shall be an independent, democratic state under the rule of law. ${ }^{{ }^{17}}$ However, it was this on which the Constitutional Court relied, or "ii]t is from this one word, alternatively interpreted as promising a 'rule of law' or 'constitutional' state, that the court construed"18 -in the dramatically decisive first epoch of its existence and in its decisions of bringing the system change back to being a legitimate extension of the past's legal continuity. As the first president himself put it later on, "of all constitutional principles, the rule of law played a special, symbolic role: it represented the essence of the system change,"19 and in practice, this could mean nothing else than that "the

17 The version adopted in 1989- "The Republic of Hungary is an independent, democratic state under the rule of law [...]"-was amended by Act XL (June 19, 1990). For details, see Schanda, Balázs (1995) 'Rechtsstaatlichkeit in Ungarn' in Hofmann, Rainer, Marko, Joseph, Merli, Franz, Wiederlin, Ewald (eds.) Rechtsstaatlichkeit in Europa. Heidelberg: Müller viii+340 pp. [Motive, Texte, Materialien 75] on pp. 219-235 and Kilényi, Géza (1989) 'Ungarn schreitet in Richtung Rechtsstaatlichkeit', Europäische GrundrechtsZeitschrift, (No.23-24), pp. 513-518. Such a formulation is not peculiar to Hungary and raised worries elsewhere as well in the region. For example, Article 1 of the Czech Constitution holds that " $1-$ The Czech Republic is a democratic state ruled by law." Cf. Hanuš, Libor (2007) 'Jsou obecné právní principy pramenem práva v právním řádu ČR?' [Are general principles of law a source of law in the legal system of the Czech Republic?], Právník, CXLVI(1), pp. 1-12.

18 Teitel, Ruti (1994) 'Paradoxes in the Revolution of the Rule of Law', Yale Journal of International Law, 19(1), pp. 239-247 \& <https://digitalcommons.law.yale.edu/yjil/volis/issi/13/> on p. 244.

19 Sólyom, László, Brunner, Georg (2000) Constitutional Judiciary in a New Democracy: The Hungarian Constitutional Court. Ann Arbor: University of Michigan Press X+417 pp. on p. 38. 
Hungarian Constitutional Court adopted a formalistic and neutral approach to the rule of law that focused on legal certainty" (p. 31). However, from the well-schemed stand that

the rule of law-as the key concept for the transition and also in a technical sensegained a meaning identical with legal safety that is regarded by the Constitutional Court [...] as the "conceptual element" of the rule of law, ${ }^{20}$

the practice followed that "the rule of law [...] is construable as exclusively a formal rule of law." ${ }^{21}$ Accordingly, in the jurisprudence of the Hungarian Constitutional Court "the general clause of the rule of law [has become] [a]n own standard of constitutionality, on the one hand, and the source of rights and constitutional principles, on the other," which the Court did not hesitate to "break down into requirements in merit" at once, ${ }^{22}$ proceeding from case to case and judging various issues at hand by pronouncing upon their merits with a constitutional force. That is, the Constitutional Court selected one single partial element at random and endowed this with a general, somewhat nearly good-for-all role, from a complex and collective concep $\mathrm{t}^{23}$ that is undefined and therefore unsuited for formal inference, being construable only as the living ethos of a given active culture and interpretable exclusively as the direction of continuous striving for reconciliation among in-themselves opposing or even contradictory tendencies.

The result is disputable, above all because the unsuitable method (that is, suited exclusively to conceal the arbitrariness-or falsity-of the derivation) itself is disputable. Moreover, our scholarship agrees that a normative construction based on the exclusivity of "not entirely normatively definable" concepts and principles can prove nothing else than the "political hypertrophy" of constitutional judiciary ${ }^{24}$ —exactly the end result against which (notably, against the activism in the immoderate expansion of the playing field of free discretion and the assumed political role inevitably involved by this) HANS KELSEN (the one who

20 Sólyom, László (2001) Az alkotmánybiráskodás kezdetei Magyarországon [The beginnings of constitutional judiciary in Hungary]. Budapest: Osiris 799 pp. [Osiris tankönyvek] on p. 686.

21 Decision no. 31/1990 (15 December) of the Constitutional Court in Alkotmánybirósági Határozatok (1990), 136 on 141 .

22 Sólyom, Azalkotmánybiráskodás kezdetei, 2001), p. 464.

23 As an example, cf. Fallon, Jr., Richard H. (1997) '"The Rule of Law« as a Concept in Constitutional Discourse', Columbia Law Review, 97(1), pp. 1-56. The very fact that "the meaning of the rule of law is contingent in nature" with "multiple rule-of-law values competing" within its reach, in which eventually "no one rule-of-law value is essential" in and by itself, is emphasized rightly and just in this specific Hungarian context by Teitel, Ruti (1997) 'Transitional Jurisprudence: The Role of Law in Political Transformation', The Yale Law Journal, 106(7), pp. 2009-2080 \& <https://digitalcommons.law.yale.edu/ylj/volio6/iss7/2/> on p. 2025.

24 Přibáň, Jiř́i (2001) 'Moral and Political Legislation in Constitutional Justice: A Case Study of the Czech Constitutional Court', The Journal of East European Law [Columbia University East European Law Center], 8(1), pp. 15-34 on pp. $28 \& 16$. 
once sowed the seeds of the very notion of constitutional adjudication and then also took part in implementing it in its early practice) tried to warn constitutional judiciary. ${ }^{25}$

Drawing from the Constitution's laconic formulation-Article 32 reads that " $1-$ The Constitutional Court shall review the constitutionality of laws [...]" and "2-The Constitutional Court shall annul the statutes or other legal norms that it finds to be unconstitutional"the Hungarian Constitutional Court rose to be the highest-level political body on the pretext of interventionist activism. For example, already in the period before the amendment of the Constitution on June 20, 1990, it would have had an excellent opportunity for modestly waiting in the background, but instead, as the author claims, it used the transitory state of constitutional regulation as a strategic stepping-stone. Notably, back then,

the Constitutional Court could have shield away from its role and waited for the adoption of a new constitution but instead, it seemed that the interim Constitution encouraged the Court to use its powers to the maximum of its creativity and capacity under SóLYom’s presidency. (p. 34)

For this very reason, it is no mere chance that an analysis from the first years of the Court's operation (in 1992) already states,

Therefore, it is not surprising that the Constitutional Court has in no time become one of the key actors on the stage of Hungarian constitutional life whose performances are thoroughly watched and hotly debated, and both criticised and praised by the general public. ${ }^{26}$

I remember my Viennese colleague being amazed (and somewhat perplexed) when telling me about their prior invitation extended to the Hungarian Constitutional Court president in Vienna-an occasion which had solely been attributable to the mystery that had kept them all confounded; namely, they wondered what this newly founded institution trusted.

25 Kelsen, Hans (1931) Wer soll der Hüter der Verfassung sein? Berlin-Grunewald: Rotschild 56 pp. and Kelsen, Hans (1942) 'Judicial Review of Legislation: A Comparative Study of the Austrian and the American Constitution', The Journal of Politics, 4(2), pp. 183-200. Cf. Vinx, Larx (2015) The Guardian of the Constitution: Hans Kelsen and Carl Schmitt on the Limits of Constitutional Law. Cambridge: Cambridge University Press ix+279 pp. [Cambridge Studies in Constitutional Law]; Hinghofer-Szalkay, Stephan G. (2019) 'The Austrian Constitutional Court: Kelsen's Creation and Federalism's Contribution?' Fédéralisme Régionalism, 17, <https://popups.uliege.be/13743864/index.php?id=1671> and Moreso, J. J. (2012) 'Kelsen on Justifying Judicial Review' in Ramírez, Gonzalo Ecos de Kelsen: Vidas, obras y controversias. Bogotá: Editorial Universidad Externado de Colombia pp. 354-378 \{\& $<$ https://ssrn.com/abstract=2595560>\}.

26 Brunner, 'Development of Constitutional Judiciary', 1992 on p. 540 (Dupré, p. 37). 
Did this Court indeed suppose that the entire institutional system, the lawyerly elite, and the people in great expectation of the Republic of Hungary would further tolerate its continuous reprimand and persistent constitution-writing? Yet, as my friend had gone on smiling, the invitee had come in and heralded their victory with perfect tranquility.

True, for more than a decade the literature has now described the phenomenon of "transjudicial communication" as the globalization of the process in which "courts are talking to one another all over the world, ${ }^{27}$ but this does by far not alter the formal obligation that "constitutional courts are meant to refer only to provisions of positive constitutional law"-in the same way as it does not provide exemption from the requirement of the division of powers, whereas in our case, "constitutional courts are strictly prohibited from acting as legislators" (p. 45). Given its lack of authorization, how can we qualify such a proceeding of the Hungarian Constitutional Court, compelling the whole state apparatus? While judging on issues of constitutionality, by what right does this Constitutional Court demand consistency and proportionality with openness and transparency from all norm issuers and from all norms issued, while it may lack such properties? Because the non consequitur in the field of law-in fact the synonym of political activism here-denotes, also in this case, that the constitutionality criteria postulated in the transition's dramatic period by the Constitutional Court of the Republic of Hungary (which it unyieldingly enforced as the measure for its constitutional adjudication) does not derive from the Constitution of the Republic of Hungary with any logically compelling force. For the kind of constitutionality that it has enforced is presumable at the most as one of the Constitution's numerous and equally feasible interpretational alternatives-although, as it shall be seen, the Court broke away even from the consolidate and reliable Western models of constitutionality, sometimes diametrically opposing them and denying their major values. This is to say that the operation of the Constitutional Court (with its outputs from official inputs in a black box) proved to be more inextricable and unforeseeable than, for instance, the activity of ancient Delphic oracles or antique Rome soothsayers (who observed the flight of birds or the intestines of animals). This operation might have followed from a deep insight of constitutional justices themselves but by no means from the exclusive constitutional basis of such an operation, notably, the textual frame of the Constitution as a supreme source of the law. The Constitutional Court was set up by its founders in the alleged transcendence of socialism, blocking its survival. In this socialism, we could already experience the exaltation of certain materialistic values (as, for example, "the cause of socialism") as the first rule, while usually the proverbial principle of la loi du plus fort as the second rule prevailed.

27 Slaughter, Anne-Marie (1994) 'A Typology of Transjudicial Communication', University of Richmond Law Review, 29(1), pp. 99-137 \&<https://scholarship.richmond.edu/lawreview/vol29/iss1/6/> (Dupré, p. 43). 
Thus, the question is the following: who has authorized the Constitutional Court to such an over-accomplishment? If it authorized itself to nothing more than allowed by its original (and until now, the only one) statutory assignment of a constitutional force, then what is at stake here is nothing more than what is called usurpatio in jurisprudence. This raises the dilemma, at least in principle, of whether decisions made this way are valid, irrespective of whether or not the legal order of the Republic of Hungary knows any invalidating mechanism or sanctioning form for establishing the invalidity that must result from the abuse-via overuse-of power. It is an axiom known in every material doctrine starting from ancient Roman wisdom (only confirmed by the KELSENian doctrinal reconstruction of our times' modern formal law) that nobody can transfer more rights and entitlements than they themselves have. ${ }^{28}$ In other words, misuse is no source of law but, on the contrary, a quality depriving of rights and annulling alleged entitlements.

What is more, not only slogans such as the "rule of law" but also the (detested but existent) West-idolatry arising from a lack of actual knowledge about the West ${ }^{29}$ captured the minds of Hungarians. This was also true for circles of the intellectual elite as well as the peaks of authority occupied by it (even - or even more so-if their ideas were rooted in postmodern, cosmopolitan, a-historic universalism). In the final account, this ignorantia proved a bad counselor: a false and, above all, self-deceiving one. As characterized by the author cited, "a glorified and idealised vision of the West and of liberal law" replaced the

28 'Nemo plus iuris ad alium transferre potest, quam ipse haberet.' Ulpianus in D.50.17.54, and cf. also 170.

29 Of the 11 constitutional judges involved in the first nine-year cycle in question (eight with university and three with judicial backgrounds), six were civilists, and one public administration, one criminal, and one international lawyer, in addition to two professors of state law (the Bolshevik alternative to constitutional law) who were formerly communist party functionaries at their universities; none of them had had any reading on their freshly sworn profession before, for which there was hardly any Hungarian literature. Alone in the Soviet empiredom, I could edit a number of classic twentieth-century opuses that are the cornerstones of Western legal literacy. Varga, Csaba (ed.) (1977) Modern polgári jogelméleti tanulmányok [Studies from modern western legal theory]. Budapest: Magyar Tudományos Akadémia Állam-és Jogtudományi Intézete 145 pp. and Varga, Csaba (ed.) (1981) Jog és filozófia: Antológia a század első felének polgári jogelméleti irodalma köréból [Law and philosophy: Anthology from Western legal theory of the first part of the 2oth century]. Budapest: Akadémiai Kiadó 383 pp. involve excerpts from Rudolf Stammler, MaX Weber, Hermann Kantorowicz, Eugen EHrLich, Hans Kelsen, Gustav Radbruch; François Gény, Giorgio del Vecchio; Roscoe Pound, Benjamin n. Cardozo, Jerome Frank; Vilhelm lundstedt, Axel Hägerström, Alf Ross, Karl Olivecrona; Felix Somló, Leo Petrazycki. Moreover, thanks to the European Economic Community's two TEMPUS projects (1990-1993 and 1995-1998), I was in a rush to publish as soon as possible such basic works as GEORG JELLINEK's Allgemeine Staatslehre [1894], CARL SChmitT's Political Theology [1932], Hans Kelsen's Pure Theory of Law [1934], JeROME Frank's selection, H. L. A. HART's The Concept of Law [1961/1994] as well as topical volumes on constitutional review, Rechtsstaatlichkeit and Rule of Law, natural law, historical jurisprudence, Scandinavian legal realism, BARNA HoRváTH's legal sociology, autopoietic theory of law, anthropological approach to law, language and law, in addition to collected works in philosophy of law in foreign languages by FeLIX SomLó, Julius Moór, István Losonczy, JózSEF Szabó, Tibor VAs, István Bibó, and ended this endeavor by Saint Thomas Aquinas' Summa theologiae (I-II, qq. 90-108 \& II-II, qq. 57-62) parts relating to law as well as by natural law by ALEXANDER HORVÁTH, the interwar Dominican natural lawyer. 
missed opportunities of "direct knowledge or experience" and, as a result, "a cultural image of the West developed which did not correspond much to the reality" (p. $57^{30}$ ). Thus, not only the local past, tradition, and arrangement (and therewith also the nation's endeavor and potentialities) were mostly ignored but also the mechanical transfer of partial solutions, torn (by way of some mere technicality) out of the sociopolitical complex of an entire working law and order, suggested an in-itself false and distorted image of the benefits promised by it. In addition, the total lack of adaptation, that is, a ceaseless drive to meet some external (foreign) standards, also pushed decision makers to extreme responses, eliminating the chances for any "in-between solution" conceivable (p. 58). In today's state of Hungarian public speech, this author's self-assured judgment appears appalling, notably that back at its very beginning (ascertainably back to quite a few decades ago, that is, so to speak, as a defect from birth), "a procedural and minimalist conception of democracy" was adopted and enforced by the political elite ${ }^{31}$ - perhaps because the genuine social foundation was missing, and there was nothing onto which anything else (even a bit reminiscent of the daily operation of usual Western arrangements) could have been built. Paradoxically speaking, in want of any civil society established and functioning, there is a structure operating dysfunctionally, which should have in fact evolved exactly from this civil society but is instead imposed upon it from above, as ideally ready-made, in a sort of vacuum. ${ }^{32}$

30 For example, an ex-MARxist in emigration published on the "West is best" absurd Utopianism—Fehér, Ferenc (1995) 'Imagining the West', Thesis Eleven, 42(1), pp. 52-68-and, in parallel, a special issue was dedicated to the topic -(1995) 'Ex occidente lux?', Transit: Europäische Review, (9) \{for the contents, cf. <https://www. iwm.at/publication/transit/heft-09-ex-occidente-lux>\}, formulating similar doubts. Cf. also Kende, Pierre (1992) 'Reflexion sur l'optimisme institutionnel des élites postcommunistes' [Communication présentée au $4^{\text {ème }}$ congrès de l'Association Française de Science Politique, 23-26 septembre] 16 pp. \{\& Kende, Péter (1993) 'L'optimisme institutionnel des élites postcommunistes' in Mény (ed.), Les politiques du mimétisme, 1993, pp. 237-2483 on the probable pitfalls of "institutional optimism."

31 Dawisha, Karen (1997) 'Introduction' to Dawisha, Karen, Parrot, Bruce (eds.) The Consolidation of Democracy in East-Central Europe. Cambridge \& New York: Cambridge University Press xx+389 [Democratization and authoritarianism in post-communist societies 1] on p. 40 (Dupré, p. 58, note 51).

32 See, as first disclosure, Lomax, Bill (1997) 'The Strange Death of Civil Society in Post-communist Hungary', Journal of Communist Studies and Transition Politics, pp. 41-63, while others, too-such as Linz \& Stepan, Problems of Democratic Transition, 1996, p. 314-establish that "political society after 1989 effectively demobilised civil society." In other words, the transition chased the best forces of society into party-like organizing activity, which, however, paralyzed the chances of the emergence of civil society for about one and a half decade, owing to the society's tragic splitting into two constituencies that divided both the political and socio-intellectual elite of Hungary. Transcendence, promising the end of division, presumably started at last as an unexpected and certainly not intended byproduct of the movement of so-called civic circles ['polgári körök'], firstly and primarily in rural Hungary (in villages and small towns). Cf. Greskovits, Béla (2017) Rebuilding the Hungarian Right through Civil Organization and Contention: The Civic Circles Movement. San Domenico di Fiesole: European University Institute Robert Schuman Centre for Advanced Studies 30 pp. [EUI Paper RSCAS 2017/37]. 


\section{Example: Human Dignity in Isolation and Sterility}

Then, what is at the heart of such developments? "The period 1990 to 1998, which corresponds to the first term of the Hungarian Constitutional Court, was characterised by an abundant use of foreign law in judicial reasoning." Within this, the construction of "human dignity interpreted as being the source of other fundamental rights" was framed with the intermediary role of a general personality right, "which the Court imported from German law" (p. 6333).

However, doing so to justify its actions, our Constitutional Court adopted an encoded speech, pretense, and insincerity aimed at reassuring, in contrast to the clarity it preached and the ethos it expected from everyone else on its behalf. To reach a kind of approval on the fact that its "decisions are based not on partisan political considerations but on neutral, objective law, even when the issue in dispute obviously has very contentious political origins and consequences," ${ }^{34}$ the "imported law [was] used [...] as a modern substitute for natural law [...] couched in a discourse of globalisation or ius commune" (p. 157, similarly on p. 12). Thus, no matter how modern, defendable, and maybe even justifiable it was (as the Court must have thought it to be), in its actual application, our Constitutional Court did not even assume the openness of the relatively confined realm of positive (constitutional) law rules having been brought into a broader circle of principles-to the same extent that had once proven to be instrumental in the legal founding of how to face with the past after the World War II, to surpass all the difficulties of making progress across obstacles ${ }^{35}$ and eventually to successfully cover the affair with the additional ethical splendor in result of the greatness of the goal and the obvious necessity of reaching it. Whenever it had a way to conceal, it did not assume

33 See also Dupré, Catherine (1995) 'Le droit à la dignité humaine, emblême de la transition constitutionnelle?' in Tóth, Károly (ed.) System Transformation and Constitutional Developments in Central and Eastern Europe / Changement de régime politique et le développement de la constitution en Europe centrale et orientale. Szeged-Kecskemét: József Attila Tudományegyetem - Károli Gáspár Reformed University Press 298 pp. on pp. 51 et seq. and Dupré, Catherine (2000) 'Importing German Law: The Interpretation of the Right to Human Dignity by the Hungarian Constitutional Court', Osteuropa-Recht, 46(2), pp. 144-157 as well as Dupré, Catherine (2000) 'Importing German Case Law: The Right to Human Dignity in Hungarian Constitutional Case Law' in The Constitution Found? The First Nine Years of Hungarian Constitutional Review on Fundamental Rights. Budapest: INDOK pp. 215 et seq.

34 Schwartz, Herman (2000) The Struggle for Constitutional Justice in Post Communist Europe. Chicago: University of Chicago Press xx+347 pp. [Constitutionalism in Eastern Europe] at p. 5 (Dupré, p. 158).

35 Rommen, Heinrich (1959) 'Natural Law in the Decisions of the Federal Supreme Court and of the Constitutional Courts in Germany', Natural Law Forum, IV, pp. 1-25 \& <https://scholarship.law.nd.edu/nd naturallaw_forum/37/> on pp. 5 et seq.; Friedmann, Wolfgang (1955) 'Übergesetzliche Rechtsgrundsätze und die Lösung von Rechtsproblemen', Archiv für Rechts- und Sozialphilosophie, 41(3), pp. 348-371; Schneider, Peter (1956) 'Naturrechtliche Strömungen in deutscher Rechtssprechung' Archiv für Rechts- und Sozialphilosophie, 42(1), pp. 98-111. 
sincerity or openness, for the Court had enough power, and it did not want to really convince anyone. Instead,

in order to maintain the semblance of an exclusively legal-that is, politically neutral - way of reasoning, while of course it practised a political and ideological activity in order to promote a new system of values [...], it used German law as a timeless and incontestable natural law [...] only to present its own legal novations and ideological choices as an enterprise of catching up with Western countries and the harmonisation of Hungarian law with norms and standards supposed as shared on the basis of consensus by the international community (although in reality there was no global legal practice about human dignity). ${ }^{36}$

Aware of its legally unquestionable power raising it above criticism and therefore convinced that it was formally enough for it to communicate with society only one-sidedly and from above without feedback, the Constitutional Court contented itself with mere declaratory rhetoric, in fact with the falsity implied by referring to nothing but "modern constitutions" and similar unspecified generalities (p. 160).

It is this very complex in which what the author characterizes with the three qualities of exteriority, anteriority, and universality was accomplished (p. 163). Indeed, they stand for the fact that the renovation of the Hungarian legal system was performed by an unauthorized and (in want of any legal mechanism superordinate to it) unsupervised agent by adopting patterns in the guise of universality from outside, as elaborated earlier by others and for others. Of course, everyone knows that there is no global pattern in abstracto: what we operate with is always concrete. Although "this was never made explicit by the Court," it took place in silent reception from the Federal Republic of Germany (p. 171), the arrangement (linguistically, culturally, and by virtue of earlier study trips) most familiar for the influential president of the Constitutional Court. All this was done on a scale that may resemble neo-colonialism for the external observer, with parallel underestimation of their own, exclusively binding constitutional background (p. 173). According to this author's illustration, in its decision on the

36 Delpeuch, Thierry (2005) [compte rendu], Droit et Société, (No.60), p. 593 [„de maintenir l'apparence d'un mode de raisonnement uniquement juridique-donc politiquement neutre-, alors même qu'ils se sont livrés à une activité politique et idéologique de promotion d'un nouveau système de valeur. [...] à faire passer le droit allemand pour un droit naturel, intemporel et incontestable [...] de présenter ses propres innovations juridiques et ses propres choix idéologiques comme une entreprise de rattrapage des pays occidentaux et de mise en conformité du droit hongrois avec des normes et des standards supposés consensuels au sein de la communauté internationale (bien qu'il n'existe en réalité aucune jurisprudence globale sur la dignité humaine)"]. 
death penalty, ${ }^{37}$ only the International Covenant on Civil and Political Rights could qualify as an official source of law in Hungary. Even this could hardly serve as a normative foundation for it: what it exclusively established was no more than the "recognition of a development towards the abolition of capital punishment" as a mere factual tendency; moreover, this same covenant, valid in Hungary from 1976, had also served the proactive capital punishment policy of the socialist People's Republic of Hungary with no difficulty. On the other hand, the Sixth Additional Protocol to the European Convention on the Protection of Human Rights and Fundamental Freedoms (1983) and the Declaration on "Fundamental Rights and Fundamental Freedoms" as adopted by the European Parliament (1989) had, at the time of the actual decision-making, no legal effect whatsoever in Hungary. The fact that the Hungarian Constitutional Court's reception policy was in fact "disguised" by the hiding formula of "modern constitutions" and other unidentified empty generalities (p. 67 and ch. 4, para. 1.1) could only help its actual path to an overall achievement, which this author can now illustrate through tables showing German stands that might model the Hungarian formulation of "human dignity" (pp. 69 et seq. \& 76 et seq.)—constitutional provisions, constitutional court decisions, the latter's ground motivation, and scholarly opinions ${ }^{38}$ Enthusiasm and routine prevailed in that the Constitutional Court resorted-again, in a legally unauthorized manner (i.e., arbitrarily) - to external authority even in cases when perfectly adequate provisions might have been available in the very wording of the Hungarian Constitution (p. 86). Moreover, reference to "modern constitutions" served as an enchantment, a mere captatio benevolentiae so that a desired solution could be justified, as if it were also backed by international practice (p. 164): "In fact, the Court often had in mind a very particular legal system and interpretation of a right and presented it as if this particular interpretation and use were recognised by all legal systems in the same manner" (p. 165).

Lastly, a question arises as to the kind of authorization, if at all, upon which the process of universalizing the decisions of various constitutional courts was based, in result of which it could be presented as "globalisation of constitutional jurisdiction." What may have been the basis of the fact that "as a study by the Hungarian Constitutional Court has shown, even the diversity of constitutions does not necessarily lead to different results in constitutional case law" and that constitutional justices are adjudicating the conformity of domestic laws

37 Hungarian Constitutional Court decision no. 23/1990<https://hunconcourt.hu/dontes/decision-23-1990-oncapital-punishment>.

38 Above all, Dworkin, Ronald M. (1977) Taking Rights Seriously. London: Duckworth xv+293 pp. and Dworkin, Ronald M. (1986) Law's Empire. London: Fontana xiii+470 pp. [Fontana Masterguides] referred to in the decisions nos. 9/1990 and 21/1990 (Dupré, p. 91). In more detail, see Sólyom, László (1994) 'The Hungarian Constitutional Court and Social Change', Yale Journal of International Law, 19(1), pp. 223-237 \&<https://digitalcommons. law.yale.edu/yjil/volig/issi/12/> on pp. 228 et seq. 
to relevant domestic constitutions until they arrive at an "independence of constitutional justice from the constraints of national laws"? ${ }^{39}$ Maybe with the effect that a not too distant future would bring about "an unprecedented movement of export/import of law in which states were no longer essential actors, ${ }^{340}$ perhaps making continuous and undisturbed concessions to the individual, to the cult of entitlements without obligations at the expense of the state (i.e., of the rest, the taxpayers)?

It seems unambiguously ascertainable by today that mainly in those dramatically decisive times establishing the legal frameworks of our later development, "most of the cases decided by the Court [...] were not simple cases of interpreting the Constitution [...but...] political, or more precisely ideological rulings" (p. 159). As such, one may mention the inventionthrough "the artificiality of its argument stretched to its limits [...] at its most absurd"41 —of "[t]he concept of constitutional criminal law, whose aphoristic formulation-

The traditional basic principle of criminal law, according to which a deed is a crime once made so by the law, has become a rule of guarantee (protecting rights and liberties) in our present legal system by adding to it the additional formula of nullum crimen sine lege constitutionalit ${ }^{42}$

-has permeated the practice of the Constitutional Court so far. ${ }^{43}$

\section{Public Law Privatized with the State Targeted as the Common Enemy}

The end result is quite thought-provoking. The jurisprudence of the Hungarian Constitutional Court's first term is probably the first in Europe to acknowledge the right to a healthy environment, to relations between people of the same gender, and children's right to identify their fathers by blood. What is more, it provided unprecedentedly one-sided, absolute, and

39 Sólyom, László (1996) 'Sur la coopération des cours constitutionnelles: Introduction à la X ${ }^{\text {ième }}$ conférence des cours constitutionnelles européens' in Rapports généraux sur la séparation des pouvoirs et la liberté d'opinion dans la jurisprudence des cours constitutionnelles [Budapest, 6-9 mai] [ms] (Dupré, p. 165).

40 Grugel, Jean (1999) Democracy without Borders: Transnationalisation and Conditionality in New Democracies. London \& New York: Routledge xv+189 pp. [Routledge/ECPR Studies in European Political Science 10].

41 Sadurski, Rights before Courts, 2005 on pp. 254-255.

42 Szabó, András (2000) 'Alkotmány és büntetőjog' [Constitution and criminal law. Budapest: MTA 11 pp. [Székfoglalók a Magyar Tudományos Akadémián].

43 Majtényi, László (2002) 'Lesz-e magánéletünk?' [Will we have a private life?] Élet és Irodalom, XLVI (29March), p. 13. 
interventionist liberties in the field of personal data protection, making it exclusively dependent on the individual concerned. ${ }^{44}$

However, in its striving for recognition and ultimate legitimization by the West, it may have also become vulnerable by making itself, in its self-built ivory-tower as a hidingplace, both disinterested in and unapproachable to sensitive social issues, by having become content-if heard at times-mostly in form of unilateral declarations. Withdrawn in invisibility, like a snail in its shell, in self-inflicted isolation, and incapable of dialogue, as if abhorring the human warmth of sociability, it became the lonely fighter to merely be admired, so much so that it passed up initiating integration into the state structure, into the lawyering community-either academic or practicing — and into the very societal feedback underlying any law and order, that is, of all which constitutional judiciary itself is just one of the serving parts. Thus, adding that it has not even started dialogue with ordinary courts either (p. 178), to ease a relation characterized by "a certain rivalry rather than constructive co-operation" (p. 182) seems only hypercriticism, ${ }^{45}$ but it sheds some light on its autotelism. For, in terms of a decade-old criticism,

the court's assertion of exclusive interpretive power is highly problematic; in a constitutional democracy, understandings of legality and constitutionality are best promoted not by judicial monopoly over constitutional interpretation, but by a system

44 Notably, their control of monitoring the entire route of data processing, thereby guaranteeing the right to know who used the data and when, where, and for what purpose (decision no. 15/1991).

In contrast, the resolution of the German Constitutional Court from nearly one decade earlier (1983) was a circumspect, balanced decision assessing the personality's role in social contexts at any time. In terms of this-BVergGE 65, 1 in Kommers, Donald P. (ed.) (1997) The Constitutional Jurisprudence of the Federal Republic of Germany. 2nd ed. Durham \& London: Duke University Press [xxi]+620 pp. on p. 325 (Dupré, p. 90, note 7)-, "However, the right to 'informational self-determination' is not unlimited. The individual does not possess any absolute, unlimited mastery over 'his' data; rather, he is a personality [...] developing within the social community. Even personal information is a reflection of social reality and cannot be associated purely with the individual concerned. The Basic Law has resolved the tension between the individual and society by postulating a community-related and community-bound individual, as the decisions of the Federal Constitutional Court have repeatedly stressed. The individual must in principle accept certain limits on his right to informational self-determination for reasons of compelling public interest."

Again, in contrast, the decision of the French Conseil constitutionnel (December 29, 1998)-serving the values of common good-did not find it unconstitutional for the state to cross-reference personal data on different databases for double-checking tax declarations submitted by citizens without informing them.

45 Let us consider what is suggested by a style (with a corporative character behind it) that starts from a doctrinal point of view while pondering upon the nature of the Supreme Court's guiding (abstract) decisions aimed at the unity of judicial practice for that they can be subdued to the control by the Constitutional Court; initiates a statutory amendment to extort this from above; and finally—of course, without even trying to agree with the branch of the judiciary-simply surpasses again the Constitutional Court's competence stipulated by the charter founding it with a constitutional force, and with noble simplicity, it just starts to bring these decisions under constitutional control by judging unconstitutional and annulling some of these. 
allowing for simultaneous and parallel interpretation by the political branches and by the people. ${ }^{46}$

Thus, instead of becoming anything more markedly sociable, it retracted into a position of standing outside and above everything, into the mist of clouds, from the sublime heights of which it is only to communicate if it wants to, in the way it wants to. Consequently, it became the embodiment of dysfunctionality of our new post-socialist state organization, of the competition over rule of law claims on human rights with actors rivaling one another to the detriment of their respective competence, in which no public interest is relevant to the fighters as each and every one functions self-centered and self-propelling, inattentive of others, with over-activity or extension of competences destroying other's efforts mutuallyignoring responsibility, dialogue, moderation, and control.

The scene is the paroxysm of rule-normativism, distorted from late nineteenth-century parsimonious statutory positivism into socialist legality, idealizing the mechanical automatism enforcing rules exclusively and with no responsibility for the humane order to be formed and for practical outcomes in general. Thereby, relinquishing the issue of the nation's survival while suggesting the apotheosis of irresponsibility under the seal of the rule of law, it may prove to be even more destructive than the socialist dictatorship. This strange dialectic of idolization presents where fetishes are created from what socialism annihilated in law.

All in all, the decade after the bitter half century of socialism was permeated by miracle expectation, wrapped in supra-historicity of some magical utopianism. What was to follow was indeed another trap, notably, the one of becoming "guinea pigs" of neo-liberalism, ${ }^{47}$ imbued with the "faith in the ability of law alone to create and foster democracy [...] and in the power of words to achieve this" (p. 187). In this enchantment process, the "[r]epetition of legal definitions, in a manner similar to some magical incantation, [which] was part of the reification process through which words became law" (p. 188) contributed to the overall degeneration.

Was anyone in our domestic or external environment outraged that parts of the state may act totally at will, pursuing self-departmentalized idols exclusively at the cost of selfgenerated practical anarchy, by losing all control while abandoning the indivisibility of national sovereignty? A vision by ALFRED JARRY (1873-1907) may come into view—or the queen's cricket that LEWIS CARROLL ${ }^{48}$ schemed in Alice in Wonderland-if rule of law is substituted with the octroi of judicial arrogance.

46 Teitel, 'Paradoxes...', 1994 on p. 245.

47 Kovrig, Bennett (1995) 'Marginality Reinforced' in Barany, Zoltán, Völgyes, Iván (eds.) The Legacies ofCommunism in Eastern Europe. Baltimore \& London: Johns Hopkins University Press pp. 23-41 on pp. 37-38 (Dupré, p. 179). 48 Pen name of Charles Lutwidge Dodgson (1832-1898). 
The worst in the whole process may have been that all of it actually both presupposed and reproduced the atrophy of the inner forces of law development as a side effect, and this resulted-in internal relations - in the incapability of adaptation and-in external relations - in the uncritical attitude toward Western solutions, ending in mechanical text transplantations.

To sum up, the Constitutional Court must have been motivated by an ahistorical utopistic universalism when it "grounded on a sort of tabula rasa fiction" by practically "negating the [...] 'legal culture"' (p. 192) as it acted under what it euphemistically meant-insensitive of domestic milieu and needs, heedless of local traditions and conditions, never as a partner in a common cause but always from the heights of supreme uncriticizability, and treating the country as a bunch of addressees - autocratically and arbitrarily_of the "rule of law."

However, inspiration from outside did not lead to the unconditional reception of imported patterns. The result was often different (p. 104) as it sometimes instrumentalized the model (ch. 5). Therefore, it challenges the following questions: in what direction did the Hungarians make their decisions to differ from the German arche-formula, usually copied in topics and doctrinal structuring, if not letter to letter? In terms of what philosophy did the Hungarian disciple overwrite the German master? The Hungarian Court practically denied the social rights acknowledged by the regime of socialism and postponed the full recognition of human dignity before birth-in contrast with the Germans but exclusively making concession to public opinion in this $\operatorname{case}^{49}$ (ch. 5, para 1.2/a). Most conspicuously, ignoring the balanced (although rather categorical) perspective offered by the German Basic Law"everyone shall have the right to the free fulfilment of his personality in so far as he does not violate the rights of others, or offend against the constitutional order or the moral code" (Article $2^{50}$ ), whereas, according to their doctrinal substantiation, "human dignity resides not only in individuality but in sociality as well. Such dignity requires the protection of the personality and freedom of the individual, but must also promote the goods of relationship, family, participation, communication, and civility"51 - the Hungarian partner took over the first part of the entitlement alone as an "all-powerful provision" without bothering about limitations, preconditions, complementing obligations, or the risk of injury of others' rights (pp. 120-122). Even in the motives of the decision declaring the capital punishment

49 Commenting on the death penalty case, the president, who once was the rapporteur, notes that "according to the receptivity of the people to such slogans and the repeated attempts to organise a referendum on the reintroduction of the death penalty, it would appear that a large majority of the population remains in favour of it." Sólyom and Brunner, Constitutional Judiciary..., 2000 on p. 53, note 20.

50 "Jeder hat das Recht auf die freie Entfaltung seiner Persönlichkeit, soweit er nicht die Rechte anderer verletzt und nicht gegen die verfassungsmäßige Ordnung oder das Sittengesetz verstößt."

51 Kommers (ed.), The Constitutional Jurisprudence..., 1997 on p. 305 (Dupré, p. 125). 
unconstitutional in Hungary, the Court did not reckon with the rest of people with human dignity, too, in society, who should in parallel be entitled to some protection against the wrongdoings of inhumane perpetrators (p. 124).

It can be concluded that while the German wisdom looked at rights due to all humans objectively and in the context of a well-balanced social interdependence between society, the individual, and the latter's rights, the Hungarian ambition rendered the entitlement absolute. As echoed later on, "such an individualistic vision is dissonant to the general spirit of the German law [...]. It has become an absolute [...], unconditional and unlimited right" ${ }^{\text {"52}}$; or, on the ruins of communism, in a society practically fallen apart, the Hungarian Court did not perceive any guiding star except itself. Coming down from the mountain and looking around-like FRIEDRICH NIETZSCHE's Zarathustra paraphrasing les fleurs du mal of his epoch philosophically - they saw nothing but individuals "in isolation and fighting against the state to protect their rights" (p. 122), because, as their revelation held, "human dignity surrounds the individual in a sort of protective sphere, and thus isolates individuals from each other." This reductionist—negative and MANIchean' (p. 126) - approach, drowned in its deep inner alienation (scarcely transcending childish defiance in the early phase of man's societal development), sees antagonism from the outset: the irreconcilability between the good individual, worthy of absolute human dignity, on the one hand, and the bad and therefore to be tightly controlled state, on the other (p. 126). Perhaps this is nothing more or else than just a consequent privatist vision, but as a "selfish picture of human beings as solely preoccupied by the realisation and protection of their own interests and achievements" (p. 125), if lifted into a public law contexture, ${ }^{53}$ it atomizes society and pushes it onto the path of a libertinist anarchy.

The notabilities of the Constitutional Court declared themselves to be the St STEPHEN of our times, that is, re-founders of the Hungarian statehood. They may have been right as their decisions massively and dramatically predefined the whole path of the transition process. As a result of the fact that "the Hungarian Court [...] was seeking to import values or principles on the basis of which the Court could lay the foundations of a new constitutional order" and thereby "used imported law as a source of new criteria for constitutional justice" (p. 154) under the pretext of nothing but constitutional adjudication, it took effective control of the entire political dénouement, predetermining basic directions. It meant, in practice, that it subjugated the whole society-with political classes, parties and governments, involving the original intent at a genuine transition—-to self-inflicted amateurish philosophies

52 "Un telle vision individualiste est dissonante avec l'esprit général du droit allemand [...]. Elle devient [...] un droit absolu, [...] inconditionnel et sans limitation." Delpeuch, [compte rendu], 2005 on p. 592.

53 Teitel, 'Transitional Jurisprudence', 1997 on p. 2023 simply regards it as indefensible and trappy. 
and convictions, detouring an entire society to forced paths with ensuing coercions and prohibitions.

\section{A Future without Past}

This same exposure and helplessness, that is, being at the mercy of the West, also appears in the impossible experiment of building a future without a past. In brief, "this unease with the past is palpable" as "the Court [...] never really addressed the past directly" (p. 192). When its over-politicized role-playing forced it yet to do so-as their collective self-image permeated by the drive to activism dictated from the beginnings that their "constitutional court is one of the major actors of political system so it cannot do as if it worked in the sphere of sheer theory"54 - the result was simply a catastrophe: lifeless as quite a doctrinarian deduction can at all be; "in fact the Court seemed to make a point of considering that there was nothing particularly special nor problematic with this past and that its adjudication function was as normal as in any other Western country" (p. 192). As a Polish analyst from Australia recapitulates,

by repeating the mantra of the rule of law (without a textual anchor in the constitution, and under a highly arbitrary interpretation of the concept) [...] the Court decided that its own highly arbitrary interpretation of the rule of law should prevail over politically defined understandings of the right mix of legalism and substantive justice. ${ }^{55}$

This is just the attraction to extremity with sui generis fundamental differences effaced, about the mistaken partisanship of which ${ }^{56}$ he is to conclude that

not much is gained, and much is lost in terms of comprehending the complexity of the issue at hand, by "normalizing" such dilemmas through analogizing them to various routine constitutional dilemmas faced by consolidated constitutional systems in their day-to-day operations. ${ }^{57}$

54 LÁszló Sólyom [as interviewed by] Sereg, András (2005) Alkotmánybírák talár nélkül [Constitutional justices without robe]. Budapest: KJK-Kerszöv 299 pp. on pp. 165-197 on p. 171.

55 Sadurski, Rights before Courts, 2005, p. 256.

56 E.g., Posner, Eric A., Vermeule, Adrian (2004) 'Transitional Justice as Ordinary Justice', Harvard Law Review, 117(3), pp. 761-825 \&<https://chicagounbound.uchicago.edu/journal_articles/1742/>.

57 Sadurski, Wojciech (2003) "Decommunisation", "Lustration", and Constitutional Continuity: Dilemmas of Transitional Justice in Central Europe. Badia Fiesolana, San Domenico [Firenze]: European University Institute Department of Law 50 pp. [EUI Working Paper Law No. 2003/15]. 


\section{Legality with Justice Silenced: Crimes Unpunished}

The decision of the Constitutional Court, by terms of which the chance of processing the past murders' "travesty of legality"s8 through correctional procedure law is blocked by the "constitutionalisation of criminal law," 59 distinctly shows the Court's corporate determination for formal interpretation, by indeed reducing the very idea of the Rule of Law to an understanding of legal certainty that assumes unbroken continuity with the past-a continuity that cannot any longer be either challenged or intervened with by legislatorial or other means. At stake was no less than the issue of whether, after the inglorious collapse of a state having become criminal itself by having offenses committed which had been qualified as crimes by its own properly enacted criminal code (such as homicide and torture), then gratifying such deeds while also criminally preventing any eventual social initiative at their effective prosecution, the successor state had to formally complete criminal proceeding of deeds previously made time-barred, that is, of their adjudication according to the law of the place and time of perpetration, or it has, in the name and with the seal of its "rule of law" but by belying any sound ideal of law, assumed and enforced, in this new constitutional democracy, the MACHIAVELLIan cynicism of the dictators' murderous logic. This would suggest that one can safely continue "doing the dirty work," taking care of one thing only: to erect a power that is oppressing enough to last until the deeds implied by such a dirty work can be declared prescribed or pardoned.

Nonetheless, this decision of a stunning logic that would be directly and disproportionately beneficial for the perpetrator's side came into the focus of critical debate at once.

The legitimacy of the different (political) systems during the past half century is irrelevant from this perspective, that is, from the viewpoint of the constitutionality of laws, it does not comprise a meaningful category. Irrespective of its date of enactment, each and every valid law must conform with the new constitution.

For in its decision no. 11/1992 (March 5), the Hungarian Constitutional Court stipulated repeatedly and with an unprecedented sharpness that

the old law retained its validity. With respect to its validity, there is no distinction between "pre-Constitution" and "post-Constitution" law. The legitimacy of the different (political) systems during the past half century is irrelevant from this

58 Ibid., p. 2.

59 Szabó, 'Alkotmány és büntetőjog', 2000 on p. 9, in terms of which "the reference of the principle of nullum crimen sine lege [...] to a domain transcending the criminal law proper is the genuine provision for a guarantee" (p. 6). 
perspective; that is, from the viewpoint of the constitutionality of laws, it does not comprise a meaningful category. Irrespective of its date of enactment, each and every valid law must conform with the new Constitution.

What obviously follows from this-since, from now on, "constitutional review does not admit two different standards for the review of laws"60-testifies to an utter "constitutional indifference" toward the legal actualities of the communist dictatorship.

From the correct description of what the statute of limitations is about (i.e., "the statute of limitations in the criminal law guarantees lawful accountability for criminal liability by imposing a temporal restriction on the exercise of the State's punitive powers") as reflected by the bill just voted for by the parliament, which had declared the legal passing of the prescription's time interrupted (in so far as, as termed by the bill, "State's failure to prosecute for criminal offenses was based on political reasons"), the Court concluded that "failure to apprehend [the criminal] or the dereliction of duties by the authorities which exercise the punitive powers of the State is a risk borne by the State." Thus, according to the judgment, in want of previous express statutory provision to the opposite, the period of limitations can also expire through a lapse of time relieved from official procedure by a dictatorial (i.e., again, criminal) rétorsion of any victim's legal initiative during prosecution. Consequently, no subsequent differentiation whatsoever and no comprehension detached from the dictatorial past can now affront the reassessment of the cynicism implied by such an insensitively disnatured logical formalism, which may even degrade the future becoming captive of complicity, trampling from the outset the ethical foundation and humanity of the new scheme parading by its "rule of law." For, as the verdict continues, "if the statute of limitations has expired, the person has a right to immunity from criminal punishment." ${ }^{\prime 1}$

A monographic stand overviewing issues ranging from lustration to facing with the past in criminal law in the region ${ }^{62}$ describes this decision as a veterinary horse for the presentation of all that is wrong, as it casts doubt on everything while galloping freely forward, floating in its own formalism, but losing touch with everything that can only be meaningfully real.For, as its author deems, "it is rather hard to see what values underlying the principle of legality support such a conclusion." Namely, the conditions referred to by the decision above-notably, the "failure to apprehend or the dereliction of duties" — do let the limitations

60 Sólyom and Brunner, Constitutional Judiciary..., 2000 on p. 220.

61 Idem., p. 223.

62 Sadurski, "Decommunisation"..., 2003 \& as reconsidered in Sadurski, Rights before Courts, 2005, ch. 9, pp. 223262. 
expire as accidental occurrences (practically due to incidental negligence or percentage of failure) in a society operating normally as due under the Rule of Law. However, in our case concerned, it was the system itself that degenerated, silencing its own law and order. With its flagrantly unlawful intervention brutally retaliating any potential lawfully retaliating intention, the past system annihilated, with its own law-related activity, the very normality that the Constitutional Court's discretion now claims to have existed. As was well known and can be proved to the smallest point, all these limiting conditions were not in the least due to accidental circumstances - "as if the 'risk' in question were a matter of the negligent behaviour of the state"-but to the contrary, they "were part of the purposeful policy of the Communist state."

Irrespective of the transition's story traced back to negotiations, a legal equation such as this one between the dictatorial past and the alleged constitutional present is simply unfounded, deeply unjust, and morally intolerable. Moreover, instead of seeing the opposites, the Constitutional Court mixes them up, albeit

here the non-identity of the "state" before and after the transition is most crucially relevant, and the fiction of continuity at its most absurd. For, in terms of the Communist state, it was not a matter of a "risk" at all but rather of deliberate and lawless protection of offenders, whiles on the part of the successor state the "price" in the form of non-prosecution is unrelated to its negligent criminal policy. ${ }^{63}$

The legally equated situations are not only incommensurable but mutually excluding in both ethoses and value contents that stretch between the democratic proclamation of the Rule of Law ideal and the dictatorial negation of any rule of law. Similarly, the decision equated human intentions and responsibilities involved while disregarding the presumable fate and afterlife of victims and innocents alike.

Situations of unspeakable brutal depravity, assassination, and torture are at stake here, whose judicial processing is by now asserted all over the world by human rights activists as well, who are rather cautious otherwise-though the other day they professed a political fiction presenting the successor state as suspicious from the point of view of human rights once they had dared investigating the legacy bequeathed. However, now, as masses of skeletons from Latin America to Africa have begun to fall out of the various cabinets, they have realized that something must be done, for inaction itself would otherwise become a barrier to any successful democratization process. Slowly changing their focus, these same activists 
have now started making a radical backward face, proclaiming the successor state's duty to face the past, even as an internationally acclaimed formal obligation. ${ }^{64}$

Of course, nobody thinks in terms of principles being excluded but of the necessity of pondering and balancing values-whether complementing or conflicting with one another. For each of them is to be respected in its own way-as dichotomized, for example, in the tension between prospectivity and equal justice, ${ }^{65}$ legality and substantive justice, ${ }^{66}$ or (using the terminology of the Hungarian Constitutional Court) legal security and material justice, and preferably none of them to be absolutized in a sober judgment. It is more so as

a lawless and reprehensible refusal by the old regime to punish those who committed some of the most severe crimes as defined under the law valid at the time, seems to effectively vitiate the general moral reprobation of various forms of retroactivity in criminal law. Put simply, it would seem perverse if the crimes committed in the past were to go unpunished solely because those who committed them were part of the system that protected them, and made sure that, as long as the system lasted, their crimes would remain unpunished. ${ }^{67}$

Viewed from the perspective of end-results, the stand taken by the decision in question can indeed be interpreted (even if wrongly) as an encouragement to crime because it places the grace into the perpetrator's hand, allowing the latter to absolve itself, by administering that by due way and in due time with effect at its own discretion. The successor

64 Cf. especially Méndez, Juan E. (1997) 'Accountability for Past Abuses', Human Rights Quarterly, 19(2), pp. 225$282 \&<$ https://digitalcommons.wcl.american.edu/facsch_lawrev/1696/>.

65 In the case of Ruti Teitel. For Teitel, 'Transitional Jurisprudence...', 1997 on p. 2024 reminds of the fact that "for the Berlin court, the controlling rule-of-law value was what was 'morally' right, whereas for the Hungarian Court the controlling rule-of-law value was protection of preexisting 'legal' rights." However, to have any moral foundation, some commonly shared values are presupposed, and-as Sadurski, Rights before Courts, 2005, p. 231 ascertains-"moral homogeneity [...] is anathema to a liberal [...] state." This is what may have motivated the rejective position of liberals such as Ackerman, Bruce (1992) The Future of Liberal Revolution. New Haven: Yale University Press viii+152 on p. 71, by rightly realizing that "an emphasis on corrective justice will divide the citizenry into two groups-evildoers and innocent victims." In his recollection, the Constitutional Court's president refers exactly to the TeITELian moral/legal duality, presenting his once stand as a paradox: "This debate is morally insoluble. I find it right to have, as a constitutional judge, put legal security first. It is a different issue that I shall never be able to reassuringly settle the question of conscience that I have not fulfilled the rightful claims of several victims." LÁszLó SóLYOM in [as one of those interviewed by] Takács, Péter (2001) "A morális alkotmányértelmezésnek a szöveghez kötöttnek kell lennie"' [Moral constitutional interpretation has to be bound by the text], Fundamentum, 5(1) \&<https:/epa.oszk.hu/02300/02334/00005/ pdf/>, pp. 68-73 on p. 71 .

66 For example, in the case of WoJCIECH SADURSKI.

67 Sadurski, Rights before Courts, 2005, p. 255. 
state (innocent of the predecessor dictatorship's crimes in fact) is thereby inevitably made an accomplice to crime whether or not it wants this; in terms of the above, it can have no other choice than declare the wrongfully unprosecuted offenses unprosecutable as legally final.

At the same time, it is obvious that such a profoundly artificial solution that would be destructive to the very chances and ethical foundations of a genuine restart from the outset was not inevitable; at least, it did not follow from the texture of the valid constitution. Because

by non-prosecution of these crimes, and by thus allowing them to become timebarred, the old regime successfully brought about a state of affairs practically identical to what it could have achieved by conferring upon itself and its members a blanket amnesty. Consistently with what has just been suggested, there is no special, conclusive obligation deriving from the principle of legal continuity to meticulously observe those privileges, and no obvious reason why to prosecute despite them would be an outrage to the principle of non-retroactivity of justice.

The malady that can be referred to here is the categorical and inflexible nature of the response, with no search reserved for in-between solutions or compromise. For " $t$ the range of options is much broader than either full observance of all the entitlement-conferring rules of the predecessor system or a revolutionary rupture with the legal past." ${ }^{\prime 68}$ This is why "the intervention of the Court [...] can be seen as an arrogation of the power, by the Court, to dictate the terms of the transition." ${ }^{\prime 69}$

The simplifying extremism raises a dilemma: what is more important? Is it the case that the human being exists for the rule of law, or vice versa, the rule of law for the human being? Or tertium datur, in which case the rule of law exists for itself? What we have encountered here has been by far sheer incidence-a sign of cultural misery rather than predestination. Unfortunately, "[o]ur society was judged unsuited to face with the past by the Constitutional Court with its decisions from 'above', while in Germany the wise and precise legal thought addressed the problem itself, thereby allowing space for social debate as well."?o

68 Idem., pp. $261 \& 262$.

69 Idem., p. 256.

70 Rumi, Tamás (2005) 'Szembenézés a jogállam előtti múlttal - a német példa és tanulságai, különös tekintettel az elévülés kérdésére' [Facing with the prior-to-the-rule-of-law past: lessons drawn from the German instance, with special regards to the issue of limitations], Collega [Budapest], IX(4), pp. 45-51, quotes on 46 $\& 51$. 


\section{Rule of Constitutional Court Dicta, not of Law}

According to a past self-characterization, "the criterion of the integrity of the new system was to constantly demonstrate the rule of law." Demonstration assumed conflicts from the very start, as " $[\mathrm{t}] \mathrm{he}$ possible contradiction between justice and the guarantees of the positive law is programmed into this paradox concept ['revolution through the rule of law']."

On the one hand, "no interest can break through the formal requirements of the rule of law." "11 $O n$ the other, what is meant by this "rule of law" can only be what the Constitutional Court itself has established as its own "invisible constitution" worked out from its own vision. ${ }^{72}$ This alone can generate new developments. For instance, "the Hungarian Court posited a new constraint on the state: an individual right to security"73; "mother rights" were produced as generated from foreign jurisprudence, and with further derivation of rights, justices will be free to operate in an unrecognizable distance from the very wording of the valid Constitution and able to master any event. In sum, and as an upper goal, "it is this approach with which the Constitutional Court could transform the great political-ideological debates of the transition into problems of constitutional law and thereby neutralise them. ${ }^{74}$

This is exactly what allowed the Constitutional Court to prescribe, by compelling its own vision and will, the kind of distance from past dictatorship while enforcing continuity with it. The nature of the "velvet revolution" privileged the old forces in transition and hamstrung any definite action to be undertaken for the sake of a genuine transitionbeyond the daily routine that was also usual in old, established, and well-balanced Western democracies. All these may have contributed to the undisturbed survival of past power

71 Sólyom in Takács, “'A morális alkotmányértelmezésnek...”', 2001, pp. 69, 69 \& 71.

72 "[T]he starting point is the totality of the Constitution. The Constitutional Court has to continue determining in its interpretations the principled bases of the Constitution and the rights laid down thereby and establishing a coherent system by means of its judgments, which as an 'invisible Constitution' serves as a standard benchmark of constitutionality above the Constitution which is nowadays being amended in everyday political interest" [concurrent opinion to the decision No. 23 of October 31, 1990]; cf. also Sólyom, László (2000) 'Introduction to the Decisions of the Constitutional Court of the Republic of Hungary' in Sólyom and Brunner, Constitutional Judiciary... pp. 41 et seq. as well as Sajó, András (1995) 'Reading the Invisible Constitution: Judicial Review in Hungary', Oxford Legal Studies, 15(2), pp. 253-267 \& <https://academic.oup.com/ojls/article/15/ 2/253/1446818?login=true> and Füzér, Katalin (1997) 'The Invisible Constitution: The Construction of Constitutional Reality in Hungary', International Journal of Sociology, 26(4), pp. 48-65 \& <https://www.researchgate. net/publication/310757509_The_Invisible_Constitution_The_Construction_of_Constitutional_Reality_in_ Hungary>.

73 Teitel, 'Transitional Jurisprudence...', 1997 on p. 2023.

74 Sólyom, $A z$ alkotmánybiráskodás kezdetei..., 2001 on p. 689. This key sentence was translated into English with another message given: "The existence of the Constitutional Court during the transition [...] allowed the transformation of political problems into legal questions that could be addressed with final, binding decisions”; Sólyom, 'The Hungarian Constitutional Court...', 1994 on p. 223. 
relations, including whatever goods and privileges now resealed by this rule of law; all these are inaugurated as achievements of our local constitutional democracy. What they actually recognized was nothing but continuity with the past, with the inviolability of past relations-if once established-and the absolutization of guarantees idealized as civic rights and forever untouchable..$^{75} \mathrm{An}$ American liberal constitutional scholar felt perplexed by the realization that the Court's genuine concern may have been with the rivalry in the race for the ultimate power in Hungary. According to her, "the ZÉTÉNYI case stands for the proposition that the authority to assess the legality of the prior regime does not lie with Parliament, but instead with the Constitutional Court" and as "a controversial power grab" that "enables the court to operate in a counterrevolutionary fashion while increasing judicial power," "the ZÉTÉNYI case could be less about the rule of law than about institutional distrust. ${ }^{76}$

Accordingly, all this also relates to the burning issue of legitimacy. For "the court's emphasis on certainty of the law masked its own interpretive leaps and exercise of discretion" and thereby "[n]agging questions underlie the court's formalism." It is even more so as the concerns of whether and to what extent the court's activity may in fact "imply a moment of illegality, a glitch in the rule of law as the court has defined it" have only been addressed by its very "clinging to the fiction that a state under the rule of law cannot be-and was not in the case of Hungary-created by undermining rule of law," and eventually, "the court [...] dismissed questions about its own legitimacy." ${ }^{77}$

\section{A Self-image in Reverse}

The Hungarian Constitutional Court has never confronted its own self openly. As if with some strange modesty, it has always presented its own creature here and now as an evident choice with no alternative at all. ${ }^{78}$ For instance, in the beginning, the president attributed

75 Sólyom, Azalkotmánybíráskodás kezdetei..., 2001, pp. 542-544. Cf. also Bragyova, András (2005) ‘Constitutional Law as Limit to Legal Change: The Constitutional Court and the Backward-looking Laws in Hungary' in The Role ofJudicial Review Bodies in Countries in Transition. [International Symposium, Nagoya University Center for Asian Legal Exchange, 29-30 July.] [multipl.] pp. 1-10.

76 Teitel, 'Paradoxes...', 1994, pp. 246, $244 \& 246$.

77 Ibidem., pp. 245-246.

78 It is precisely such a context about which Sadurski, Rights before Courts, 2005, pp. 262, 259 \& 260 could establish that "the asserted necessity [...] is highly problematic. It is a non sequitur to say that if a new legal system wants to observe the rules of legality, it must adhere to prior settled law no matter what its content." Therefore, independently of whether or not the Court concealed its "arrogation" by "presenting the matter as a simply dichotomy," the very fact of its artificiality "tend[s] to blur rather than clarify the real dilemmas raised." 
only "a shaping of competence" to his Court, ${ }^{79}$ then circumscribing the unspoken, namely by stating that

"I am a convinced activist, unless we mean by activism someone transgressing his competence. Activism means that the court undertakes a decision even in border situations" ${ }^{\prime \circ}$

- as if he were not to see any contradiction, in that his Court realized the "direct participation in the normative creation of the constitutional order of the law-based state" ${ }^{\text {81 }}$ by erecting a rule of law and order arbitrarily, with no due authorization, thereby destroying the goal through the means. Today, a kind of fait accompli is declared by the silence: parties in the parliament with the left-wing majority of scribes simply take note of what has happened for short-term political interests..$^{82}$ As avowed by its president, the Court's output "appears as real amendments to the Constitution," "83 "implementing a trend of positive norm-formulation" by "transforming their construction of the Constitution into rules [which] constitute a specific layer of material constitutional law." Accordingly,

it depends on the choice of the Constitutional Court when and by means of which general clause and according to how strict criteria of basic rights it adjudicates. If it

79 Sólyom, László (1995) 'Az Alkotmánybíróság hatáskörének sajátossága' [The specificity of the competence of the Constitutional Court] in Tanulmányok Benedek Ferenc tiszteletére [Festschrift for Ferenc Benedek]. Pécs: [Janus Pannonius Tudományegyetem Állam- és Jogtudományi Kar] pp. 5-34 [Studia Iuridica Auctoritate Universitatis Pécs publicata 123] as well as Sólyom, Az alkotmánybiráaskodás kezdetei..., 2001, pp. 157-182.

80 Mihalicz, Csilla (1998) 'Interjú Sólyom Lászlóval, az Alkotmánybíróság volt elnökével' [Interview with László Sólyom, the ex-president of the Constitutional Court], BUKSz [Budapesti Könyvszemle], 10(4) \& <https://epa. oszk.hu/00000/00015/00012/09int.htm>, p. 437.

81 Přibán̆, 'Moral and Political Legislation...', 2001, p. 17.

82 Reviews on DuPRÉ's book—Lévai, Imre (2003) in Central European Political Science Review, 4(No.12), pp. 177-179; Pribán, Jiri (2003) in Legal Studies, 23(4), pp. 721-723; Jakab, András (2004) in Zeitschriftfür ausländisches öffentliches Recht und Völkerrecht, 64(1), pp. 243-246; H[almai], G[ábor] (2004) 'Alkotmány és alkotmánybíráskodás a rendszerváltozások után' [Constitution and constitutional judiciary after the political transitions], Fundamentum, (1), pp. 211-215 and Uitz, Renáta (2004) 'Az emberi méltósághoz való jog és a magyar demokratikus átmenet' [The right to human dignity and the Hungarian democratic transition], Fundamentum, (1), pp. 216-220; Sanderson, M. A. (2004) in The Modern Law Review, 67(4), pp. 537-540-passed by the cardinality of the difference between Civil Law and Common Law and were disinterested in what this paper is about. They were content to record-Duprat, Jean-Pierre (2006) in Revue internationale de Droit comparé, 56(3), pp. 734-737 on p. 736 ["Pour la Cour hongroise, il s'agissait de réorienter la théorie des droits héritée de la période communist, dans un sens libéral"] - that "for the Hungarian Court, it was a question of reorienting the theory of rights inherited from the communist period in a liberal direction." Interestingly, the author herself did not thematise this anymore, not even in her last workshop paper [Dupré, Catherine (2003) 'Anticipating Membership: Importing the Law of the West' <http://www.iue.it/LAW/Events/WSWorkshopNov2003/Dupre_paper. $\mathrm{pdf}>$ ].

83 Sólyom, Az alkotmánybíráskodás kezdetei..., 2001, p. 258. 
starts out from the general clause of the right to human dignity, it can declare new rights, thereby elevating them to the quality of basic rights,

for "indeed, the rule of law is the most suited as a basis of reference for the Constitutional Court to establish rights and principles which are missing from the Constitution itself." ${ }^{84}$

One of the fellow justices-a scholar of administrative law who had once rivaled for the first presidency of the Court-declared in an early dissent that

at this time, from among the constitutional courts operating in the world [...] the Constitutional Court of the Republic of Hungary has the broadest authorisation and store of instruments linked to such an authorisation for enforcing the Constitution. However, not even this extremely broad statutory authorisation is unlimited: it does by far not mean that the Constitutional Court can do anything it finds necessary in the interest of the Constitution. ${ }^{85}$

To conclude, the contrast is sharp between the claim of "system transformation [to be achieved] within the framework of law and by the law"86 and, then, implementing it in Hungary by a kind of "elegant flying to and fro above the legal system," as one of the justices of the Court remembered.$^{87}$ All that notwithstanding, this body, as its own performance, was proud of all that we have shown in our analysis that its oldest member had to add to it charismatically: "Even if we received it without our intervention, it will not make us happy without our own efforts." ${ }^{n 8}$

84 Sólyom, László (2002) 'Alkotmányértelmezés az új alkotmánybíróságok gyakorlatában' [Constitutional interpretation in the practice of the new constitutional courts], Fundamentum, 6(2), pp. 18-28 on pp. 22,23 \& 24.

85 Dissenting opinion of GÉZA KILÉNYI to the Constitutional Court's decision no. 57/1991 (November 8).

86 Wyrzykowski, Mirosław (1995) 'Selected Problems of System Transformation' in Aregger, Josef, Poczobut, Jerzy, Wyrzykowski, Mirosław (eds.) Rechtsfragen der Transformation in Polen: Schweizerisch-polnisches Kolloquium. Kraków: Wydawnictwo Baran i Suszczyńsi 317 pp. on pp. 9-33 on p. 10.

87 IMrE Vörös in [as interviewed by] Halmai, Gábor, Tordai, Csaba (1999) '»kevesebb lesz az elegáns röpködés a jogrendszer fölött «' ['There will be less elegant flying to and fro above the legal system'], Fundamentum, 3(2), pp. $60-68$ on p. 68.

88 Zlinszky, János (2003) 'Nyertesek és vesztesek a rendszerváltás során' [Winners and losers in the political transition] in Kiss, Daisy, Varga, István (eds.) Magister artis boni et aequi: Studia in honorem Németh János. Budapest: ELTE Eötvös Kiadó 1071 pp. on pp. 1015-1027 on p. 1027. 


\title{
THE REVOLUTION OF 1956 IN THE JUDGMENT OF ETHICS AND LAW Or the Responding Ability of Law as a Post-totalitarian Dilemma ${ }^{1}$
}

\begin{abstract}
1. Law and Socio-ethical Foundations 2. The Sine Qua Non of an Ethical Minimum in Law 3. 1956 Drama in Hungary 4. The Law Silenced Afterward

ABSTRACT It is a shame for law and order built upon the ruins of communism that by referring to the Constitution's introductory clause on Hungary as "an independent democratic country ruled by the law," the new regime's privileged legal protection was extended to the criminal deed of the dictatorial past as the Constitutional Court equated the physical passage of time of the phase of lawlessness, on the one hand, and legal time under consolidate conditions, on the other, for its calculation of the expiry of the period of statutory limitations. Although it was the dictatorship that had made crimes committed and then rewarded them, it was its machinery of justice that had been schemed normatively to block persecution and to retaliate any lawful initiative to launch criminal inquiry. If it is so, once the perpetrator state can remain in power so long as it can declare that the period of limitations it has granted for itself expired, then law and order in Hungary as a successor state will remain disinterested in political murder and the torture of the past. Such a moral insensitivity and upside-down logic undermines the rule of law and impairs popular support.
\end{abstract}

KEYWORDS total social complex unity; ethics; foundation of law; 1956 Pécs; constitutional adjudication activism; rule-positivism

\section{Law and Socio-ethical Foundations}

From an ontological perspective, the societal totality and the commonality of all the constructs developed within it are to limit law as well, excluding contingency (albeit not

1 The paper originally served as a presentation at the conference dedicated to the half-century anniversary of the Revolution of 1956 at the Faculty of Law of Pázmány Péter Catholic University in 2006. Earlier versions in English include '1956 Judged by Ethics and Law, Or the Moral Unity of the Law's Responsiveness as a Post-totalitarian Dilemma' in his (2008) Transition? To Rule of Law? Constitutionalism and Transitional Justice Challenged in Central \& Eastern Europe. Pomáz: Kráter [PoLíSz sorozat könyvei 7] on pp. 178-196 and (2010) 'The Revolution of 1956 in the Judgment of Ethics and Law, Or the Responding Ability of Law as a Post-totalitarian Dilemma', Central European Political Science Review, 11 (No.40), pp. 42-61, reprinted in the (2017) Central European Political Science Review special issue dedicated to 1956, 18(No.69), pp. 51-87. 
variability) to some extent. These parts do have some autonomy to exert influence up to the point that they are about to run against the overall movement of social totality, messaging that such a self-sufficient state cannot be but relative. At the same time, those parts in question - termed in ontologies by their differentiation between heterogeneity and homogeneity, or as total and partial complexes or kinds of processes within Ausdifferenzierung-is that at least tendentially, in fundamental directions, some unity has to be reached among them. ${ }^{2}$ Needless to say, what I mean here is an ontological statement with no normative expectation or preference. The demand for functional optimization and the various roles in society that need to be taken necessarily lead to internal differentiation. Grand systems with distinctively particular features developed presuppose a relatively independent operation that can also manifest itself in eventual discrepancy, deviance, or counteraction. Nevertheless, all this is expected to move within the terms of final unity with the total movement. In any other case, the whole process can only result in disorganization ended by self-destruction; this will necessarily be the case unless suitable corrective mechanisms are built in in due time with required optimization effects. ${ }^{3}$

The question may only be answered retrospectively and in a system-specific way by subsequent description of the result of concrete analytical exploration, whether in the respective field of economy, politics, law, science, morality, and so on, (1) what kind of autonomy, (2) what strength and profundity of tension and (3) what type and depth of deviation may be produced by own operation with the overall effect that the underlying system can no longer simply tolerate but also accept it as stirring in overall functionality or, in a reverse formulation, when it already ends by becoming destructive in its totality. For it is to be taken as granted that there is a limiting value somewhere in each and every case (even if it remains theoretically disputable), beyond which what will already be at stake is just the case of one of the parts overcoming the rest by (de)forming the overall totality.

2 See Lukács, György (1976) A társadalmi lét ontológiájáról [Zur Ontologie der gesellschaftlichen Sens]. Vol. III: Prolegomena. Budapest: Magvetô pp. 296, respectively Varga, Csaba (2012) The Place of Law in Lukács' World Concept. [1981/1985.] 3rd (reprint) ed. with Postface. Budapest: Szent István Társulat 218 pp. \& <http://mek. oszk.hu/14200/14249/>, ch. 5, pp. 101-156.

$3 \mathrm{~A}$ biological comparison is perhaps needless. Yet it is well known that the most destructive organic anomalies and sources of danger to our survival do result from our organization's casual limitation in its ability to selfregulate. From such a point of view, the cancer as an endemic of our age is just the outcome of the overgrowth of the organism - in other words, of cell reproduction having become unrestricted so as to even destroy organic identity, ending by the termination of its underlying final tendential unity and eventually destructing the whole underlying system. Cf. Varga, Csaba (2012) The Paradigms of Legal Thinking. [1996/1999.] Enlarged 2nd ed. Budapest: Szent István Társulat 418 pp. [Philosophiae Iuris] \& <http://mek.oszk.hu/14600/14657/>, especially para. 5.1. 


\section{The Sine Qua Non of an Ethical Minimum in Law}

Law is rooted in society as one of the main performers of its moral expectations. This is to mean that the law's proper instrumental values are exclusively of a mediatory nature. They channel and refine legal processes, but they cannot serve to deform the law's basic function or make its fulfillment impossible since, only provided that they could do this, it would be exactly as if humans were diverted from their nature or common sense or rationality. In this case, what would all of it be worth?

It is to be known that law is abstract and formal as it is matched to each and every addressee in principle; however, it can only remain effective until its sanctions are actually meted out among a fragment of those addressees. ${ }^{4}$ Otherwise, once it runs counter an entire society or a massive practice no longer manageable by law, it will necessarily collapse.

It is also known that until law is not yet actualized, some may be able to withdraw themselves from its timely control. This fact, however-and this is the essential point here-does not affect the validity of the law's operation at all since it may influence them for long, and the law's sanctioning power will also operate in their case.

Nevertheless, law cannot-and simply must not-tolerate that entire groups or nets of important relationships in, and concerns for, society to prove simply untouchable by and irrelevant to it. What is meant here is the overall result, that is, the responding potential of the law in operation rather than the depth of regulation it offers. For it is simply not true to state that law either addresses or keeps silent: it addresses even when it keeps silent. Consequently, providing that it declares its irrelevance and thereby a total lack of specific message, then it is only indifference that it enunciates.

If that were to occur, law would cut itself off from its vital roots and essential embeddings in the life of society, weakening its patterning power in conflicts that may threaten societal integration and its ability to guarantee overall order. ${ }^{5}$ Then, it would degenerate into

4 Cf. Lukács, A társadalmi lét..., 1976 at p. 18 and Lukács, Georg Prinzipienfragen einer heute möglich gewordenen Ontologie. [The last MS typed with autograph corrections in the Georg Lukács Archives of the Hungarian Academy of Sciences in Budapest; <https://konyvtar.mta.hu/index_en.php?name=v_1_4_lukacs_archivum>], LAK M/153, p. 17, respectively Varga, The Place of Law..., 2012, para. 5.2.1 on p. 114 ["erst einer relativ kleinen Minorität gegenüber muß und kann der Rechtszwang effektiv wirkungsvoll werden"].

5 According to the recognition concluded partly from cultural anthropological and partly from legal ontological analysis—cf. Varga, Csaba (1988) 'Anthropological Jurisprudence? Leopold Pospíšil and the Comparative Study of Legal Cultures' in Law in East and West: On the Occasion of the $30^{\text {th }}$ Anniversary of the Institute of Comparative Law. Tokyo: Waseda University Press pp. 265-285 \{reprinted in <http://mek.oszk.hu/15300/15333/\#>, 437457\}, and Varga, Csaba (2012) The Paradigms of Legal Thinking. [1996/1999.] Enlarged 2nd ed. Budapest: Szent István Társulat 418 pp. [Philosophiae Iuris] \& <https://mek.oszk.hu/14600/14657/> on pp. 311-312-“(1) Law is a global phenomenon embracing society as a whole [...]. (2) Law is a phenomenon able to settle conflicts of interests which emerge in social practice as fundamental [...]. (3) Law is a phenomenon prevailing as the supreme controlling factor in society." This is not only a kind of definition but also an indication both of the 
mere coercion —an arbitrarily imposed external measure that settles on it from the outside and above.

This would be a bad law, a false instrument excluding defensibility from the very start.

If this occurred, then it would be a greater a problem than any damage to or violation on society because law may answer this latter, and society may recover from it. However, this can deform a whole society, for falsity may lead to the widely shared feeling of self-abandonment which, if untreatable, may even push society into disorganization, that is, into retro gradation, loss of forces, decline, and eventual decomposition.

\section{1956 Drama in Hungary}

What do we mean when we talk about the drama of 1956, its judgment by ethics, and law? Some years or decades passed as microseconds in world history; yet, these rather dense moments can be decisive for a whole nation's destiny, and the events of 1956 proved to be just that.

At that time, I was a secondary school student at Pécs. My father had by then been expropriated from the factory that my grand-father had once founded for coach-producing, which then had planted the first fuel station in provincial Hungary, and we had also been expelled from our house. In the successive years, my father had transformed the factory into a body manufacture (of automobiles, trucks, and buses) known all over Transdanubia, also selling, supplying for, and servicing especially DKW and BMW cars. In terms of the so-called nationalization (a predatory and in our case also illegal industry destruction, in fact by far not beneficial to the country), we as a family were also compulsorily moved to a miner colony on the outskirts of the town. By the morning of October 24, we looked, as usual, for news coming from Radio Free Europe in Munich again ${ }^{6}$; then, due to the consternation by news from abroad, we listened to the short statement of the Hungarian broadcast, which advanced the power of the revolt in the capital. I at once understood it in all its dimensions and selfmultiplying effects. Then, having become conscious of the fact that, from then on, all of us

law's hic et nunc relativity (that can exlusively be described retrospectively) and its demand for totality (only assessable concretely) as absolute sine qua non preconditions for it to truly function as law.

6 Against the artificial waiver disturbance practiced as a counteroperation by the communist state security, one had to search for leaks. However, it was advised not to leave the radio program finder button rightly adjusted to the wave as an abrupt police visit or search of premises might have qualified the fact as a corpus delicti. The official biographies accompanying us as children (prepared unilaterally and secretly by the communist party organs of the local soviets) categorized us with the sign "X," standing for "class-alien: ex-exploiter" from the beginning. Such a corpus delicti might have immediately aggravated our status to "class-enemy," with direct inclusion of official revenge), e.g., ban on secondary education already. 
happened to become witnesses and participants of momentous events with the prospect of either living a miracle or some even more terrible downfall, after a few moments of thinking, I immediately went to our closet where our old things were kept safe. I took some still empty hardcover registration books with sealed and numbered pages of the old factory-one of the most luxurious ones- to record broadcasts word for word, except when I went to the town to observe events and collect leaflets and newspapers. ${ }^{7}$

After World War II, the red dictatorship that defeated the brown dictatorship became the counterpart-but still the partner-of the Western powers victorious in the rivalry and mutual threats of the so-called Cold War. Hungary shared the cynically meted out fate of hundreds of millions in Central Europe: a country occupied, the Bolshevik rule of which was assisted by local communists who rivaled each other in proselytism and in the hatred of everything Hungarian and drawn from national history. It is in this way that our homeland became a defenseless colony of a barbaric Asian power-a ruler whose empire was not only civilized differently, but simply undercivilized.

The red dictatorship could do whatever it aspired to within its mighty competence in complete indisturbance as the superb West tolerated it in a most opportunist way. Among

7 By the middle of November, the big book was filled, and I developed a rich collection from printed materials. I could also complete it with a few amateur photos of the metropolitan silent demonstration against the reprisal by the pufajkás [Russian word for those uniformed in short warm quitted jacket] in the one-month day of November 23, 1956. My interest in the fuller truth was so much irresistible that I finally stole a number of documents (émigré journal Nemzetôr [National guard] and Új Látóhatár [New visionary frontier] issues as well as Western leaflets) exhibited under the title of "Counter-revolution in Hungary" in the once Korzó Coffee House's two stories (then Palace of the Trade Unions, besides the theatre of Pécs) in order to prove "imperialistic subversion" in an evening moment by moving the covering glass, when the pufajkás guards were already tired-although feared for but luckily having passed undetected. These remained my secret treasures for years. On February 6, 1961 en masse arrests throughout the country revenged hundreds of priests and monks for clandestine youth pastoring. State security considered the "Black Ravens" case an "illegal organisation for the subversion of the state and societal order of the people's democracy." I got involved, and political police interrogations and investigations followed (mostly in the premises of the Faculty of Law at the University of Pécs room of the communist party secretary). After some tormenting nights with apocalyptic visions instead of sleep and after having dug this collection several times, eventually I burned all of them and even scattered the ashes on Mecsek Hill. Cf. Aczél, Zsongor László (2005) Parázs a hamu alatt Dokumentumok és visszaemlékezések a pécsi cserkészek katakombaéletéből, (1947)-1951-1965... [Brand under ash: Documents and memories from the scouts' catacomb life at Pécs]. Budapest: Új Ember - Márton Áron Kiadó 339 pp.; for my involvement, BÁRDFALVY FERENC inverviewed by Bükkösdi, László (2003) 'Az egyház nem rehabilitál' [The Church is not to rehabilitate] [originally: (1989) A Helyzet (September 15)] in Bükkösdi, László Szeressétek a macskát! Egy öregember emlékiratai [Love the cat! Memoirs of an old man]. Pécs: Pro Pannonia 357 pp. [Pannonia] on pp. 99-107, and as affected in person, Jillek, Ilona (2002) 'A világot nem tudom elképzelni Isten nélkül' [I cannot imagine the world without God], Uj Ember, LVIII(February 24,8[No.2795]); for a complete record, Ivasivka, Mátyás, Arató, László (2006) Sziklatábor-A katakombacserkészet története: Visszaemlékezésekés dokumentumok, (1945-)1948-1988 [Rock camp: History of catacomb scouting; Remembrance and documents]. Budapest: Új Ember - Márton Áron Kiadó 517 pp. at pp. 125, 126, 414 and 492; as monographised, Wirthné, Diera Bernadett (2015) Katolikus hitoktatás és elitképzés a Kádár-korszakban: Az 1961-es 'Fekete Hollók' fedônevü ügy elemzése. [PhD Diss.] Budapest: Eötvös Loránd Tudományegyetem Bölcsészettudományi Kar 249 pp. 
others, they ignored the workers' rebellion in East-Berlin in 1953. The never-ending series of intimidation, retortion, indoctrination, and submission to common rituals indeed had a totalizing effect with no chance of retreating into privacy: in contrast to its brown parallel, ${ }^{8}$ the red variant destroyed (or penetrated into) the smallest mouse-holes of withdrawal or hiding (as portrayed by Doctor Zhivago's total defenselessness'). The home, the "church and school,"10 the associations made by artistic expressions and well-coded scientific or historical textures-all of them dictated closed mouths. To speak out, to express opinion, or to call anything/anyone by the name it or they preserved might prove to be life-threatening. However, happily and rapturously, to agree by signs was already easier: we knew whom we should honor and why, although we did not name them except for rare and intimate occasions.

In our neighborhood of miners, warrant officers were mostly new settlers who had arrived from rural ignorance after being quickly retrained for the people's army within the plan of minister MiHÁLY FARKAS to assist the Soviets when they would overrun Tito's Yugoslavia. Dark, small-minded men, with corpulent women and many healthy children, with whom I played soldiers on the outskirts of town (sometimes equipped with weapons loaded with balls "borrowed" from their fathers) at a time when I was dreaming of a heroic life (inspired by youth novels with irresistibly timely messages written mostly by Jesuit fathers between the two wars), ready for intelligent self-sacrificing to fight down this barbarism-an ultimate secret target nurtured for a whole life.

In contrast to all that modern historiography explores, and unlike all the sophisticated intricacies of the contemporary movements, I always aimed to hear the unanimous flat rejection of "Them" (or Они, as the Poles expressed it with an ostracizing overtone in Russian ${ }^{11}$ - the barbarian invaders and their local henchmen who had so proudly distinguished themselves from the rest of the submitted nation.

8 The earliest self-description of the Third Reich-Fraenkel, Ernst von (1941) The Dual State: A Contribution to the Theory of Dictatorship. Trans. E. A. Shils. New York \& London: Oxford University Press xvi + 248 pp., resp. (1974) Der Doppelstaat. Frankfurt am Main: Europe Verlag-Anstalt 257 pp. [Studien der Gesellschaftstheorie]-describes a Janus-faced policy: quasi-normality for "us" and legally precisely implemented revengeful machinery for "them," according to the categorization by CARL SCHMITT) of the friend [Freund] distinguished from the enemy [Feind]. However, all that notwithstanding, the dismissed Mayor of Cologne, KonRAD ADENAUER, representative of the latter class, could retire to his estate and manage it, and the legal philosopher GUSTAV RADBRUCH, expulsed from the Heidelberg University, could continue researching criminal law doctrinal history in pace-only provided they really disappeared from public sight.

9 Pasternak, Boris (1957) Доктор Живаго. Milan: Feltrinelli.

10 Reményik, Sándor (1941) 'Templom és iskola’ in Reményik, Sándor Összes versei [Complete Poems]. Vol. II. Budapest: Révai p. $334 \&<$ <ttp://www.geocities.com/erdelyilobby/htm/remenyik.htm\#nehagyd >: 'Don't give up the church and school!' in <http://www.hungarianreview.com/article/20200121_a_nation_dismembered_ selected_poetry_part_i>.

11 E.g. Toranska, Teresa (1987) Oni: Stalin's Polish Puppets. Trans. Agnieszka Kolakowska. London: Collins Harwill $384 \mathrm{pp}$. 
There, in our direct neighborhood, two children of a coal miner's family (one trainee boy and one truck-pushing boy) were the first who, shot from behind the neck by the Soviet, with their hands tied up with wire and twisted in the back and wearing Schichta ${ }^{12}$ dresses (i.e., returning to home from work, just having directly joined the armed resistance of the "invisibles at the mountain Mecsek"), were unloaded from lorries by agents of the ÁVH [State Defence Authority] in front of the Forensic Institute of the University of Pécs on a November night, with a few further companions murdered. These young men, genuinely proletarians and educated by the regime to become its supposed favorites as uncorrupted representatives of the Hungarian Youth, became heroes, while I could bitterly cry at most.

The events of 1956 electrified and downright shook the world. The idea of communism was pushed off the altar of the idealism built by the self-fulfilling utopianism of the salooncommunists of the Western world. The communist feeling was deservedly filled with guilty conscience; the Soviets' dependence on sheer might and expediency was to change over with rational calculation within some Realpolitik, and, last but not least, the revolutionary fight for liberty in 1956 made the light shimmering in darkness of the tunnel of barbarism visible, or at least wished, by those who had made themselves half-blind until then by calculation of interest.

\section{The Law getting Silenced Afterward}

Due to the European traditions of several thousands of years of the doctrine justifying tyrannicide ${ }^{13}$ and to its doctrinal and casuistic natural law background forged especially by

12 Schicht in Hungarian miners' language, derived from the German for "shift," standing for a day's work.

13 Cf., for instance, Baxter, Simeon (1782) Tyrannicide Proved Lawful: From the Practice and Writing of Jews, Heathens, and Christians. (A Discourse delivered in the mines at Symsbury, in the colony of Connecticut to the Loyalists confined there by order of the Congress; On September 19, 1781.) [London]: Printed in America: reprinted for S. Bladon 31 pp.; (1828) De la doctrine du tyrannicide. Paris: chez Mlle Carié de la Charie 129 pp.; Landor, Walter Savage (1851) Tyrannicide. [Published for the benefit of the Hungarians in America.] Bath: Meyler and son, printers [3 pp.]; Drahomaniv, Mykhǎlo Petrovych (1881) Le tyrannicide en Russie et l'action de l'Europe occidentale. Genève: Rabotnik et de la Hromada 16 pp.; [Kárpáthy-]Kravjánszky, Miksa Mór (1914) Tanulmányok a zsarnokölés tanának történetéhez [Studies to the history of tyrannicide]. Nagyvárad \{now: Oradea in Romania\}: [Szent László Rt.] 155 pp.; Coville, Alfred (1932) Jean Petit: La question du tyrannicide au commencement du XV siècle. Paris: A. Picard xi+613 pp.; Mirot, Léon (1933) L'assassinat de Louis duc d'Orléans et la théorie du tyrannicide au XVe siècle. Paris: A. Picard 14 pp.; Jászi, Oszkár, Lewis, John D. (1957) Against the Tyrant: The Tradition and Theory of Tyrannicide. Glencoe, Ill.: The Free Press ix+288 pp.; Mousnier, Roland (1973) The Assassination of Henry IV: The Tyrannicide Problem and the Consolidation of the French Absolute Monarchy in the Early Seventeenth Century. Trans. Joan Spencer. London: Faber and Faber 428 pp.; Lutaud, Olivier (1973) Des révolutions d'Angleterre à la Revolution française: Le tyrannicide \& Killing no murder: Cromwell, Athalie, Bonaparte. La Haye: Martinus Nijhoff xvi+463 pp. [Archives internationales d'histoire des idées 56]; Jed, Stephanie (1982) Tyrannicidae Imago: Lorenzino de'Medici and the Imprint of Human Action. [Microform dissertation.] Connecticut: Yale University Department of Italian 
the Spanish Jesuits, ${ }^{14}$ I do not feel particular need to give the reason why all that had happened in 1956 was legitimate also in a moral sense. I do not feel specific need to justify why even those limited atrocities were hardly avoidable in the given situation, the occurrence of which many (including myself) have thought to be tragic. As known, those taking part in the events and subsequently stricken dead by the pufajkás ${ }^{15}$ or by ÁVH agents (perhaps just because the latter's shame had become thoroughly known by the former) or summarily executed had endeavored, with all their might, to forestall such atrocities as all they fully understood how much brutal antecedents might have motivated similar reactions in mass activities individually and mass-psychologically. However, since the thought of any lynch law or popular verdict truly deviates from our moral sense, as a responsible Hungarian, I still feel rather proud that our revolution had been started, pursued, and maintained all through with clear morality, totally and in parts-whatever the official historiography of socialism had wanted us to believe in re of the Revolution and Fight for Freedom in 1956.

Revenge en masse with narrow-minded brutality is only a continuation of the antecedents and origins of twentieth-century communism that implemented the methods of Bolshevism. It will be hardly reparable a shame of our newly built law and order after communism that under the aegis of a vague constitutional declaration-"The Republic of Hungary shall be an independent, democratic state under the rule of law"16-legal protection has firstly privileged the dirt of a guilty past which, by criminal deeds committed against its nation, disregarded even the laws its own dictatorship had enacted by the fact that it has lifted physical time passing in the hell of inhumanity to legally acknowledged status, making the time of statutory limitations run, as if the whole regime was under the conditions of the Rule of Law.

Moreover, this is not simply one minor affair, nor may we even claim that helplessness, impotence, or perhaps incidental moves extinguishing each other may have been instrumental in producing such an effect. For the Constitutional Court, as the highest representative of

Language and Literature; Ford, Franklin L[ewis] (1985) Political Murder: From Tyrannicide to Terrorism. Cambridge, Mass: Harvard University Press xii+440 pp.; Lewis, Anna Lisa Merklin (1990) Tyrannicide: Heresy or Duty? The Debates at the Council of Constance. Dumbarton Oaks vi+223 pp.; Zhu sha bao jun, Lu (1990) Diquan li: Bao jun fang fa li lun xin tan [The right of tyrannicide]. Chu ban / Taibei Shi: Shi ying chu ban she: zong jing xiao San min shu ju, Min guo 79 10+250 pp.; Turchetti, Mario (2001) Tyrannie et tyrannicide de l'Antiquité à nos jours. Paris: Presses Universitaires de France 1044 pp. [Fondements de la politique: Essais].

14 Here it is usual to refer, first of all, to the doctrine of FRANCISCO DE VITORIA (1480-1546) and-in parts-to JUAN MARIANA De rege et regis institutionae (1599), banned by the Jesuits when, following the Jesuit assassination of HENRY IV (1610), the author was also sued. Interpretation in modern times draws mainly from JOHN of SAlisbury Policraticus (1159) (III, 15) with popularization mostly due to positive summaries by JEAN CALVIN (1590-1564), HUGo DE GROot (1583-1645), and JÁNos CSERE APÁCZAI (1625-1659) [Magyar Encyklopaedia.

Utrecht 1665].

15 For the word, cf. a former note.

16 Section 2, paragraph 1. 
the institutionalization of the Rule of Law in Hungary, after long deliberations, declared it as the message of the Republic of Hungary that the chance of judicial processing of criminal deeds that had once been committed-and also the persecution of which had once been blocked-by agents of the dictatorial state for the sake of the same state are excluded from the rule of this law for pure reasons of the Rule of Law-if these deeds were either cynically self-pardoned by the same regime or expired the prescribed period of statutory limitations, that is, the legal institution that has ever been devised to conditions of the normal functioning of the state machinery.

In our region, and especially in the period of a heroically began reconstruction from economic and societal wreckage as left here by communism, no other nation sank as low in a misunderstood Rule-of-Law servilism.

Nowhere else has such a pairing occurred, as to our shame, that the highest judicial forum of a given country not only excludes the possibility of proceedings under domestic law in respect of the same subject matter, but also declares that only international law can provide any possibility of proceedings therein. Nolens volens, it has been ruled that the law in force in Hungary does not extend any interest in and sensitivity to the chance of processing murderous deeds of the past in law, committed as fore-planned systematically (out of sheer considerations of tactics and mere purposefulness in flat disregard at own laws) by the then agents of the state. In the same way, it is quite alien to it to take account of either the human loss caused by those past deeds or the demands of the social sense of justice by differentiating between the total denial of law in dictatorship and the unconditional affirmation of the law in a constitutional state. ${ }^{17}$ At the same time, if independently of the Constitutional Court dictum there is some international law provision notwithstanding, which is superior to domestic control in its capacity to overwrite domestic law, then the Court is ready to

17 "Legal certainty based on formal and objective principles is more important than necessarily partial and subjective justice." "Failure to apprehend or the dereliction of duties by the authorities which exercise the punitive powers of the State is a risk borne by the State." "[T] he statute of limitations [...] extinguishes punishability irrespective of the reasons for not prosecuting the offender; the offender cannot be burdened by the State's dereliction of its duty." "Retrospectively, the criminal legal policy of an epoch can as well be qualified as unconstitutional without, however, substantiating the claim to posteriorly declare selected parts of the punitive power operating contrary to the Rule of Law principles as non-existent, by concluding therefrom that, within the given circle, the period of limitation has not had even a start." Decision no. 11/1992 (March 5) of the Constitutional Court. In such a narrowly rule-positivist stand-modeled by the nineteenth-century German "das Recht ist das Recht" [law is nothing but law] position—-neither natural human reason nor values of life at the foundation of law or any principle respected as immutable for thousands of years can penetrate: nothing is to complement or substantiate mere positivation. As the said decision also stated, "With regard to the Act under review, the statute of limitations for the criminal offences committed between 21 December 1941 and 2 May 1990 could have been tolled only on the basis of reasons which were recognized by the law in effect at the time the offences were committed. That 'the State's failure to prosecute its claim to punish was based on political reasons' did not exist as a justification for tolling the statute of limitations." For quotations, see Sólyom, 
acknowledge to not be in a position to uphold it. All in all, the Hungarian Constitutional Court dictate has prevented and excluded the past to be faced in law; however, if there is a superpower, that of the international community, which can force its determination upon the country, then its path can be-nolens volens, that is, involuntary but freely-followed. This is indeed a rare occasion for a nation to offer such a miserable self-picture of being proud of its own disability.

Obviously, in the meantime, this negative solution has become a standard component of our rule of law proclaimed by the highest state authority. Namely, how law can be cut away from its societal embeddings, from its underlying ethos accompanied by functional expectations, and at last but not the least, from the need encountered for centuries by countries in the Western hemisphere that has the Rule of Law as both a distant ideal and everyday reality in formation cries for continued organic formation from the bottom, with growing popular participation as pushed by the demand of democratic self-building instead of some grace from above, from mere voluntas or power dictate, or out of anyone's pleasure or tyranny.

Have we missed the road somewhere? In the year 1956, we showed a respectable road, and we must hope that one day we will overcome this strange change of regimes that questioned the ontologicum of law itself and let our God grant us that we no longer live and survive similar cataclysms.

László, Brunner, Georg (2000) Constitutional Judiciary in a New Democracy: The Hungarian Constitutional Court. Ann Arbor: The University of Michigan Press X+417 pp. on pp. 221, 226 \& 228.

The President of the Republic denied what he, as President of the Constitutional Court, had done a decade earlier in his address at the Hungarian State Opera gala performance on 22 October 11, 2006, dedicated to the 50th anniversary of the Revolution and Fight for Freedom in 1956: "In the way the revolution in 1956 had immediately eliminated the legitimacy of RÁKOsı's regime, the legitimacy of KÁDÁR's regime was ceased in 1989 by the restitution of the name and honour of the revolution. [...] There is no continuity between 56 and KÁDÁR. There is no continuity between KÁDÁr and the democratic state under the rule of law as established in 1989/90." 


\title{
"FIGHT FOR LAW" (Lessons from our Constitutional Debates) ${ }^{1}$
}

\begin{abstract}
1. 'Twenty Years of Freedom in Central Europe' 2. Globalism? Cosmopolitanism? 3. Do we Need New Law? Do we Need a New Constitution? 4. Has our "Legal Transition" so far Proved to be a Dead End? 5. What is the Concept of Law that is so Persistently Inculcated in Us?
\end{abstract}

\begin{abstract}
The first two decades of transition may have been rich in external successes, but the transformation of law was in fact predominantly mastered by the Constitutional Court. By its absolutistic excesses, hostility to the state, and overemphasis on building new safeguards into the law, the Court deprived law of some of its best promoting chances. Instead, it provided legal continuity with the criminal ante-regime, replaced the past nihilism of law by fetishizing the letter of the new law, absolutized the rights of the individual and, in the final analysis, made it impossible that goals that might give meaning alone to the new state-building could be reached. The excesses of its individuum-centered liberal worldview, showing a cynical disinterest in justice, enforced its own variation of an arbitrarily, usurpatorily, and formalistically rule-based Rule of Law, by which it discredited the law itself, including the popular support for the very idea of Rule of Law. Any move forward from here is hardly conceivable without reconsidering the importance of the common-sense, practical components of law.
\end{abstract}

KEYWORDS re-education to democracy vs. democracy instituted; practicality vs. doctrinairism; constitutionalism and constitutional review; interdependency of rights/duties; collectivity and the individual

With the collapse of communism, the fate of the transition became a topical theoretical issue. The only previous example that came to mind was the lesson of the path of the dictatorships defeated in World War II, and we were reminded that it is not in our celebrations that our true selves can only really be revealed but in overcoming the agonizing difficulties of our everyday lives, in standing our ground in a crisis. It is therefore interesting to learn that, for example, the real story of Romeo and Juliet, in the way and sequence of events that

I Introductory speech at the international conference "Twenty Years of Freedom in Central Europe" in Budapest in 2010. The title is borrowed from Rudolf von Jhering's classical (1872) Der Kampfum's Recht. Wien: Manz vi+100 pp. It was published earlier only in Hungarian language within the proceedings of Simon, János (ed.) (2011) Húsz éve szabadon Közép-Európában: Demokrácia, politika, jog [Twenty years of freedom in Central Europe: Democracy, politics, law; international conference, 25-26 November 2010]. Budapest: Konrad Adenauer Alapítvány 576 pp. on pp. 482-489 and reproduced in Varga, Csaba (2011) Válaszúton - húsz év múltán: Viták jogunk alapjairól és céljairól [At a crossroads - twenty years from now: Debates on the foundations and goals of our law]. Pomáz: Kráter 256 pp. [volumes of the PoLíSz series 7] \&<http://mek.oszk.hu/15100/15175> on pp. 147-162. 
SHAKESPEARE's setting has made us familiar with it, has not even begun because the dramatic failure of the marriage has obscured the prose that the daily drudgery of later days could have transformed the former flamboyance of the lovers' love affair. ${ }^{2}$ This thought is critical here and now to carry forward to our own reflection on the problem since the law can show its true capacity to bear the burden best in extreme situations. Historically, the distortion of the dictatorships we have lived through and the failed regeneration of the wrecked societies that emerged from them have offered a rare opportunity for this-for most of our problems today are rooted in the past and in its stubborn continuity, which is still emerging from its depths.

By defining the themes of public discourse, politics and the press can easily take the attention away from what is neuralgic and pathological. In such cases, a breakthrough of some kind is needed to bring the latter issue to the fore. It is as if this is precisely what happened in our transition, when the way in which we have seen regime change and in which continuity has taken over has been the most striking example of the king's folly. It is now easy to conclude that the law we have today is not the solution but the source of the problems.

\section{1. "Twenty Years of Freedom in Central Europe"}

If this title is to be believed, it was around 1990 that we were declared capable of determining our national destiny. Did we really have the chance? Are we capable of living it?

Until recently, the human world of our twentieth century was threatened by two great dictatorships. The world empire of the red version, rooted in Asian cruelty, survived the demise of the brown version for nearly half a century. How did the world power that emerged victorious from the demise of both, the American one, view their legacy? The answer is thoughtprovoking, for although it always acts as a mouthpiece for liberal values, its practical response suggests not the crippled but rather its own naked self-interest as an outsider victor. The brown dictatorship had a decade or more to impose some form of world domination on itself through its totalitarianism, the economy of which was transformed into a kind of state capitalism; however, its wartime conquerors had grown weary over the years: they no longer wanted to risk the lives of their own soldiers or waste their strength as occupiers and therefore condemned the whole society behind the dictatorship as utterly rotten. They wanted to compensate for a decade of brown dictatorial influence with a program of re-education

2 Cf. Łetowska, Ewa, Łetowski, Janus (1996) 'Poland: In Search of the "State of Law" and its Future Constitution' in Łetowska, Ewa, Łetowski, Janus (ed.) Poland: Towards to the Rule of Law. Warszawa: Wydawnictwo Naukowe Scholar 176 pp. [Institute of Legal Studies, Polish Academy of Sciences] on pp. 10-22. 
to democracy, planned for the same period, by establishing the new society through social engineering and by depriving the defeated of the possibility of democratic self-organization, replacing this with their own military command. In our case, as a huge territory and population that could only be exploited politically and economically, when the fall of the Soviet empire meant that they were only interested in their own capital accumulation and market acquisition and immediately unleashed a so-called democracy on us as a people on half a continent which, under more consolidated conditions, the peoples of the Atlantic and Western Europe had been building for centuries and had adjusted for themselves in response to their own challenges to secure their ultimate influence once and for all by masterfully mastering its techniques, while we ourselves were barely able to even grope in it. $^{3}$

After World War II, many recognized the danger that the effects of decades of brown power subterfuge might continue to exist in the countries concerned, and subsequent developments have indeed proved this to be the case. A special explanation is therefore needed as to when the red totalization of the entire political, economic, and social organization and the destruction of souls had been going on for almost half a century; how could they have thought that society there was ready for this democracy? Could they really have been guided by a childish belief in an absolute panacea, the success of which did not depend on any precondition? Thanks in part to our Western friends, we had the full-blown rights apparatus of these democracies up and running before communism was even dead. Lawyers were crowding the road to change then, just as they are today at Open Society agencies. Of course, they flocked here not to fight for our goods but to wrest from politics its most sacred taskthe creation of law itself, to impose their own image on the "mystery of law-making."4

The strategic aim of the western hemisphere was surely to extend globalism and to secure a space of domination with a big size perspective, both in business and in market creation. This may indeed have required our region to be seamlessly integrated into a larger whole, while its capacity for self-assertion remained weak, and even the possibility of a common regional action (i.e., uniting Central and Eastern European interests) was inevitably shattered by making individual countries dependent on any kind of favor by competing with each other. The side effect of the uniformization of national laws by adopting external models was clearly meant to have the effect of stifling the internal forces of law development.

With all this, despite the fact that the quarter of a million communist Party members considered as families showed their significant involvement in Hungarian society and

3 Cf. Varga, Csaba (1993) 'Transformation to Rule of Law from No-law: Societal Contexture of the Democratic Transition in Central and Eastern Europe', The Connecticut Journal of International Law, 8(2), pp. 487-505.

4 'das große Mysterium von Recht und Staat' in Kelsen, Hans (1911) Hauptprobleme der Staatsrechtslehre entwickelt aus der Lehre vom Rechtssatze. Tübingen: Mohr xxvii+709 pp. on p. 411. 
already indicated the confusion of one tenth of society, yet en bloc, our whole society was assumed to be ripe for democracy. By implication, it was assumed that our people had survived several generations of dictatorship in moral integrity. Their logic thus foundered, for according to this view, a decade or more of the brown dictatorship could have wiped out the sense of democracy from Europe's dominant elite-the Germanic peoples. Here on the Balkan fringes, however, having experienced the misery of late feudalism and the late onset of civilization, have almost five decades of totalitarian brainwashing by Eastern barbarism ${ }^{5}$ not changed our capacity for democracy at all? The taxi blockade ${ }^{6}$ at the very beginning of the transformation to the rule of law showed how vulnerable we are as in Hungary we can bring down governments with promises, destroy trust with hysteria, and derail the nation's search for self-discovery with a disunity that mimics a "democratic" public life.

To no small extent, we are still living off the skills we learned under socialism. The practice of generations of socialist legalism is still evident today. The continuity of socialization can pass on the unchanged routine in our old and new institutions even to the young lawyers entering the profession from today's Catholic or Protestant law faculties. The survival of the old in its mass is so visible that, in the bosom of the European Union, it is thistogether with the fact that our region has a different past from the majority and its own historical experience, which is almost a millennium old - that continues to set us apart from the countries that joined the Union earlier.?

However, can we really write on our flag "Twenty Years of Freedom?" Freedom is multifaceted, experienced in the most diverse relations of the individual and the community. It can also be understood in terms of the relationship against which it is historically contested, which in our case was obviously the imperialism of the Soviet empire. It was in this spirit and for this purpose that everything was done: it was a distancing from it, out of fear of the nation and for reasons of one's own values. However, it was only a supposition, or more accurately a dream, for what this distancing was made as in the process, we had to realize that the other world that we had thus entered, in relation to the image of the West in our dreams and also to its own past, was already dissolved and that the world that we had therefore

5 Cf., among others, by a 'Russian-born Hungarian Jewish historian' (1925-1972) (<https://en.wikipedia.org/ wiki/Tibor_Szamuely_(historian)>), Szamuely, Tibor (1974) The Russian Tradition. Ed. Robert Conquest. London: Secker \& Warburg xi+443 pp.

6 See the part a 'Bordering Issues I: Civil Disobedience' in this volume.

7 Concerning the first statement, see Fleck, Zoltán (2010) Változások és változatlanságok: A magyar jogrendszer a rendszerváltás után [Changed and unchanged: Hungarian legal system after the change of regimes]. Budapest: Napvilág 162 pp. [20 év után], and for the second one Varga, Csaba (2009) Jogrendszerek, jogi gondolkodásmódok az európai egységesülés perspektívájában (Magyar körkép - európai uniós összefüggésben) [Legal systems and legal mentalities in the perspective of European unification: Hungarian overview in a European Union context]. Budapest: Szent István Társulat 282 pp. [Philosophiae Iuris] \& <http://mek.oszk.hu/15100/15173>, in particular ch. VII, pp. 179 et seq. 
actually entered was, for us, already divided. It was not in statu nascendi (i.e., a space that could be shaped further with an open chance) but a completely shaped and filled space with the actual impossibility of an alternative-namely, we would either fall into it or end up in a vacuum. ${ }^{8}$

All this, therefore, meant a constraint for assimilation. Anything that did not fit was immediately turned into a ballast, including the knowledge that we ourselves had enthusiastically acquired as a Western cultural acquis at the university law schools of socialism"sovereignty," "self-determination," "parliamentary omnipotence," "national self-determination," "freedom of speech and of the press," and so on, in a then still unspoiled sense. By then, they had already transformed their brave new world from the other side of the Atlantic, where all this had suddenly become irrelevant and a mere dream, if not a new enemy, or at least a vestigiality, a child disease, or utopianism escaping into obsessive thoughts of insecurity-pathological symptoms that we would do well to leave behind as soon as possible for our own sake.

It is true, of course, that we have become equal members of the great organizations we have long coveted and that we are now ourselves also responsible for the future fate of NATO and the European Union. We wanted this, but could we have gone elsewhere? Could we really have stayed outside? Because there was no space to the east and west other than this closed and divided world, and in the situation of our country and our region, we could hardly have followed the Swiss example. ${ }^{9}$

\section{Globalism? Cosmopolitism?}

In themselves, these and similar slogans are also natural and noble goals and directions; they only become controversial when they involve the oppression of something/someone else. A particular case of this might be when they are confronted with national interest protection because serving the interests of our narrow communities is also natural and noble. Moreover, it is only us, and hardly "humankind," who can do the latter service.

8 Let us remember Lenin, V. I. (1996) Imperialism, the Highest Stage of Capitalism (A Popular Outline). [1917.] London: Junius \& Chicago: Pluto lviii+132, and the reactions from different quarters which were rightly provoked when, at the height of its power, Germany, also at the beginning of that century, could sense that the British expansion had taken over everything and that there was no more space left to colonize.

9 In company of Professor AULIS AARNIO, I was coorganizing a conference in Finland, at the universities of Helsinki and Turku at the end of the 1980s, when the Finns were already engaged in a heated debate about European accession. It was perhaps the last time that there were still open opportunities to be explored here and there. 
Creating any antagonism between the two is therefore artificial. It is as if some kind of established balance ${ }^{10}$ was upset, ${ }^{11}$ and only one side remained active, which in turn would force everyone else to tolerate "all or nothing!"

At the time, however, the change of regime was about the failure of our socialism, indebtedness, and the need for privatization as a way out-total sell-outs to petty Western buyers and, as it later turned out, the acquisition of markets for their own goods by scrapping and stripping the acquired firms. Hence, there was no real balance then, nor has there been since. Perhaps, we do not even know what it could be like, for before the real cause could be formed, it was already betrayed by the succession of forced compromises.

However, some of our old scientific convictions have been revived, such as the summingup of our sociology of law's modernization research on the fact that, in the absence of anything else to do, we stumble from one forced path to another; or in social philosophy, the lesson of the posthumous social ontology experiment by LukÁcs, by which there are so many alternatives in every system, even totalitarianism, and corrective (system-reforming) movements can be initiated with sufficient planning. ${ }^{12}$

\section{Do we Need New Law? Do we Need a New Constitution?}

I have made a number of references so far, but the question remains: can we build a comprehensive picture around the law? Assuming the normal course of our work, we should surely answer no. Nevertheless, a yes is appropriate because we started with a disturbed mind-so much so that we may not even know for sure whether the necessary social normality ever existed at any time.

10 Medicine defines the term "health" as a dynamic state of equilibrium and describes it as having somatic, psychological, and social dimensions. It is revealing that the Hungarian language also derives it from the word "completeness" (i.e., "az egész" [what is complete]).

11 Can a shaped order, a homeostasis, be inherently pathological? After all, each of its existing states was livable. However, if there is a paradigmatic shift, this leads to a new problem.

12 On the former, see Kulcsár, Kálmán (1992) Modernization and Law. Budapest: Akadémiai Kiadó 282 pp., and for the latter-in full Lukács, György (1976) A társadalmi lét ontológiájáról. \{On the Ontology of the Social Being\} Vol. I-III. Budapest: Magvető, or as two-thirds: Lukács, Georg (1984-1986) Zur Ontologie des gesellschaftlichen Seins. Vol. I-II. Darmstadt: Luchterhand [Georg Lukács Werke 13-14]-Varga, Csaba (2012) The Place of Law in Lukács' World Concept. [1981/1985.] 3rd (reprint) ed. with Postface. Budapest: Szent István Társulat 218 pp. \& <http://mek.oszk.hu/14200/14249/>, and in topical exposition Varga, Csaba (1986) 'Macrosociological Theories of Law: From the "Lawyer's World Concept" to a Social Science Conception of Law' in Kamenka, Eugene, Summers, Robert S., Twining, William (eds.) Soziologische Jurisprudenz und realistische Theorien des Rechts. Berlin: Duncker \& Humblot xvi+381 pp. [Rechtstheorie Beiheft 9] pp. 197-215 \{reprinted in <http://mek.oszk. hu/15300/15333/\#>, pp. 43-76\}. 
As a first preliminary question, let me refer to the well-known fact that the world of law (or more precisely, its professional ideological framing) is also filled with mystifications. WEBER described this a century ago as the enchantment of the world when he clarified the assumptions of modern formal law. ${ }^{13}$ Such is the absolute domination of the system, of principles, of logical consequence, and such is the formal necessity of any decision taken. Last but not least, the covering of all these procedures in a logical automatism (which is inevitably linked to the agent and is therefore theoretically viewed, also governed by their personality and social, political, and other contexts). However, not least, it is also the case that law consists of "law" - that is, of what is assumed to be law (i.e., ius or lex).

Instead, however, the only justifiable legal reality is the existence of this and other components in interaction - where, for example, one side is what is objectified (posited), ${ }^{14}$ while the other is its understanding and interpretation (i.e., the hermeneutics of community and individual). Thus, "law"? Actually, there is nothing of the sort, for it is merely an allusion. I asked for a word, and I answered by a word as, in principle, when we refer to law, we are only talking about virtuality. We construct it all in words and in our practice, which comprises and is layered by these references, and constantly conventionalize and re-conventionalize it. At most, things can have an identity, but understanding, whatever it is, is a process in constant motion; it is thus doubtful whether it has any core at all through which it can have an identity.

Law can be shaped by any of its components as well as by the sum of them. Consequently, we may necessarily need, for example, to have a "new" law for our current transformation. Nevertheless, the only empirical fact is the constant change of law, and the logic of succession in this is something that is hardly debatable from within, in the system's own terms, but which must always be accepted in the spirit of continuity. Nevertheless, it is perhaps true to say that if, according to the rules of the game of democracy, a new player replaced the winner, it would be counterproductive since it is against the logic of things, if the person leaving were to try to discourage or threaten their successor from acting. It would be even more perverse, and even tempting to ridicule, if in their restless arrogance, someone who was both the

13 'Entzauberung der Welt' in Weber, Max (1919) Wissenschaft als Beruf. München \& Leipzig: Duncker \& Humblot 38 pp. reprinted in Weber, Max (1988) Gesammelte Aufsätze zur Wissenschaftslehre. [1922.] 7. Aufl. Tübingen: Mohr xi+613 pp. on p. 594; cf. also Lehmann, Hartmut (2009) Die Entzauberung der Welt: Studien zu Themen von Max Weber. Göttingen: Wallstein 149 pp.

14 This is characteristic only of the continental European branches of former Roman law. For a comparison with Anglo-Saxon law, classical Jewish and Islamic traditions, and Far Eastern (Chinese and Japanese) legal concepts, see Varga, Csaba (ed.) (1992) Comparative Legal Cultures. Aldershot, Hong Kong, Singapore, Sydney: Dartmouth \& New York: The New York University Press xxiv+614 pp. [The International Library of Essays in Law \& Legal Theory, Legal Cultures 1] and Varga, Csaba (2012) Comparative Legal Cultures: On Traditions Classified, their Rapprochement \& Transfer, and the Anarchy of Hyper-rationalism. Budapest: Szent István Társulat 253 pp. [Philosophiae Iuris] \& <http://mek.oszk.hu/15300/15386>. 
author and the beneficiary of what the successor has just done were to try to put pressure on their successor as a returning ghost. ${ }^{15}$

Whether it is sympathetic to define the electoral victory in 2010, which was overwhelming because it gave a two-thirds majority, a revolution is then a non-theoretical question. However, even if we contrast this as a predecessor with, for example, JózsEF ANTALL's avoidance of radicalism - because "If only you had made a revolution!"16 - it is nevertheless apt as a sign of the legitimacy of the new governmental party power as well as a rare opportunity for a breakthrough.

\section{Has our "Legal Transition" so far Proved to be a Dead End?}

In order, as a preliminary question, a dry reckoning should also make itself aware that twice (but since then, until the next election in 2022, three more times) we have had/can have four years of national, civic, Christian, conservative tailwinds and thrice four years of postcommunist looting accompanied by destructive liberal doctrinarism. Of all this, the balance of the 20-year period from 1990 onward was clearly negative: a deplorable state of strength and moral—even by the standards of the unlamented days of communism. The nation's economic potential and indebtedness became not only unsustainable but downright irreversible. It is no coincidence that many have also entertained the notion of losing the nation. ${ }^{17}$

Our Rule of Law, our scenario of statehood, was set up by the Constitutional Court in such a way that any governmental declaration could be considered legally impeccable. Even if a head of government happened to be declared guiltless for technical legal reasons. For what else could one read from the fact that President LÁszLó SólYom (also as the former first President of the Constitutional Court) condemned a government of lies and deceit merely

15 However, if "as invisible president I will always stand by you"-as the first president of the Hungarian Constitutional Court, who became the first president of the republic, declared to the successor president (also a civil law professor, FERENC MÁDL) at the handover ceremony (<http://www.solyomlaszlo.hu/aktualis20100805_ atadasi_ceremonia.html>, no longer available) — this means the same thing (though not from the same perspective but rather as a farce of it) as the once natural identity of king and state. Cf. Rowen, Herbert H. (1961) “'L'État c'est à moi": Louis XIV and the State', French Historical Studies [Duke University Press], II(1), pp. 83-98.

16 <https://de.wikipedia.org/wiki/József_Antall>; this was his laconicism toward his own party, which, from behind him, demanded radicalism; in German 'Hätten Sie doch eine Revolution gemacht!' or 'Warum haben Sie denn keine Revolution gemacht?'

17 If only to remind us of the founding potential of two decades that have now been virtually wasted in terms of the country's actual development, we should mention our country between the two world wars. It started with a lost world war, unprecedented dismemberment and a laborous process of a global economic crisis. Yet, in the same period of peace, the industry, economy, institutions, and architecture of a modern Hungary were created under MiKLós HORTHY's government and, among other things, Kunó KLEBELSBERG's vision on education, culture, and science to build a brand new and modern network of respective institutions. 
by using the generalized phrase "moral crisis," while the same content in the most insignificant private matter would lead to a declaration of void? It is neither communists nor some "against" or an external enemy that has forced such a stage upon us: we owe what we have, what we have created, to our best-a select few of our Christian middle class and the combination of their eloquence and impracticality, their liberal doctrinarism, and the mundane destruction of the airiness of the beautiful souls growing up behind university desks.

Our current Prime Minister, VIKTOR ORBÁN, once perceived that they first learned from us, their teachers at the time, the sublime principles of our civilization. With open helmets, they took to the field with expectation to work in the House of our country to shape our common destiny. In retrospect, they had to admit that they were wrong because parliamentary sovereignty does not really exist. A new supreme authority, a Constitutional Court, has risen above it, deciding for them at any time and in private, without transparency or record: irresponsible as regards its own fate but unappealable as regards the fate of everyone else. It is also the Court's own business, so that it alone decides what to judge based on whatif you like, as a magician pulling a pigeon out of their pack. Our former students' knowledge of democracy, power-sharing, and everything else will be tested accordingly.

They will have learned from the workings of the Constitutional Court that the people sitting there are not politicians; they are not judges, and they are not skilled in shaping people's lives and destinies, nor are they responsible for their communities. Therefore, they are not statesmen because their strengths are not practical wisdom, moderation, a sense of proportion, or openness to compromise. They are of the cool and alarmist, smart-alecky professor type and think in terms of a system, with only a concern for its rigor and consistencya kind of conceptualists or, as they used to say in other ages, sophists. ${ }^{18}$

18 This is the observation of the drafter who moulded the French Code civil, when, escaping to northern Germany in revolutionary times, he experienced the good and bad uses of the "esprit philosophique." He saw the tragedy of his country in the sterile intellectualism of the system-thought, which tempted contemporary intellectuals to irresponsibility and extreme consistency.

It was the men of genius, of character and of vision, and not the Sophists who founded societies, built cities, and taught things to peoples. Sophists always appear at times when morals are corrupted. They are born therefrom and they are hardly suitable to raise, with their miserable influence, those degraded spirits and hearts. As soon as they formulate an idea, they believe they have brought about a kind of institution. But, as the ideas formulated do not, by themselves, capture people, they neither take roots where they were sown. They just keep multiplying the laws, whereby they exactly achieve the debasement of legislation. And meanwhile everything gets lost: the false philosophical mind is like a deaf shell enclosing everything.

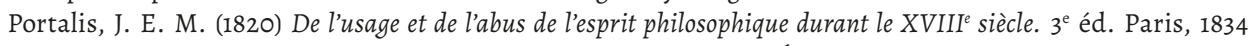
lxiii+404 pp. on pp. 403-404, respectively Portalis, J. E. M. (1988) Écrits et discours juridique et politique. AixMarseille: Presses Universitaires d'Aix-Marseille 406 pp. on pp. 398-399. A French classic in the sociology of law summed up the guiding thought of a wise legislator: 'no system, only adaptation, that is, the adaptability 
Our Constitutional Court's mandate is purely for the application of law, yet it is fructified by uncertain ideals. ${ }^{19}$ It builds on external alien law as it judges, it imposes international recommendation, and it creates "an invisible constitution" from mere abstractions. ${ }^{20}$ Like Molière's hero, it takes his wealth from where it knows it. ${ }^{21}$ This is not only usurpation of power [usurpatio] but also unconstitutional, claiming in vain to defend the constitution since it is itself and without authority that it creates the standard by which the sovereign will of the nation will be destroyed..$^{22}$

The result is pathetic: unlivable, impractical law with doctrinal rigidity in the background. It is a contrast to the way in which communism once annihilated law, but it goes to the opposite extreme, which becomes just as damaging. Although it misleadingly claims to be law-centered, it does nothing more than fetishize a literal law. It is therefore a mystification, wrapped in a sublime pathos. ${ }^{23}$ Finally, it itself is a convert to the new doctrine it proclaims - a new catechesis, the main doctrine of which is that our existence will find its ultimate meaning in the fact that our procedure will always be constitutional.

Because seeing such a practice, where does the profession in Hungary stand? What is behind it? Because how big, what kind, and how developed is a philosophy of state and law, and of course the constitutional jurisprudence that rests on its foundations? Because the latter's millennial past is dead, thanks to the half of a century of communist indoctrination. Even the history of ideas has not been processed since academia and universitas could only create a socialist "state law" with the Soviet occupation, with Bolshevism, and that which became its present-day substitute after the fall of communism was only taken from here and

of thought to the different requirements of the moment.' Carbonnier, Jean (1981) 'Le Code Napoléon en tant que phénomène sociologique', Revue de la Recherche juridique: Droit prospectif, (3), pp. 327-336 on p. 335.

Such is also expressed in the conventional wisdom of the British government. There, the schools of philosophical rhetorical excellence are Cambridge and Oxford, but the knowledge needed for imperial leadership is prepared elsewhere.

19 It made genuine regime-changing decisions solely on the basis of the introductory provision of the Constitution (1989), which says no more than that 'Die Ungarische Republikistein unabhängiger, demokratischer Rechtsstaat' (the official English translation is hardly instructive here: "The Republic of Hungary is an independent, democratic constitutional state."]

20 Cf. Varga, Csaba (2008) ‘Creeping Renovation of Law through Constitutional Judiciary?' in Varga, Csaba Transition? To Rule of Law? Constitutionalism and Transitional Justice Challenged in Central \& Eastern Europe. Pomáz: Kráter 292 pp. [Books in the PoLíSz series 7] on pp. 117-160 \& <http://mek.oszk.hu/14800/14851>.

21 "je prends mon bien où je trouve" in Molière (1668) L'Avare. Act II, Scene 11.

22 Historically, usurpatio has always been one of the most serious crimes against the state since it corrupted the very foundations of its existence, and the punishment was correspondingly severe. That is why the ancient legal maxim remains alive: no right can arise from illegality.

23 This is why I had to emphasize in a conversation with disciples in 2009-Varga, Csaba (2009) 'Kényszeredetten bolyongunk' [Constrained, we are wandering], de Jure, X(11-12), pp. 2-7 \{reprinted in <http://mek.oszk. $\mathrm{hu} / 15100 / 15175>$, pp. 163-174\} - that "Let us not forget: we live in a global world, so there are too many selfglorifying calls. Their role is that of AEsop's fox. That's why we need science and publicity, so that we can draw the fairy-tale cheese down to its true core." 
there. Its founding opuses and classics could not yet have been written in this country, and its heroes of the new breed of constitutional judge could at best cultivate themselves. They were once civilists, cultivating private law, and therefore their constitutional jurisprudence was also of a noble dilettante kind since they came from a private law tradition that did not focus on community-oriented public law but on the will of isolated individuals. That is why, in the first nine years, their constitutional jurisprudence was distorted and decidedly anti-social: for them, the individual was everything, and the state was nothing; at the very most, it was a suspicious source of danger that had to be limited in the name of liberalism.

We know that private law everywhere is a multiply distilled, highly complex network of concepts and institutions with millennial education and continuous refinement. However, at least in our country, the discipline of public law is still little more than a sheer mass of constitutional court decisions. These are discussed today in such a dependent and casual mode, even in works that are called academic, that they abstract the irreplaceable uniqueness of their case law without not only empathy but also critical detachment. ${ }^{24}$

\section{What Kind of Legal Concept is being Hardly Planted into us?}

Even if we do not attempt to unravel the decades of our constitutional jurisprudence to date, we will still be able to defend our summarized picture of the first two decades since the decisions they took were intended for the future and, in principle, incorporated into the Hungarian legal system with constitutional force and irrevocability.

This proved to be a counter-formation that was incomparably harmful even in the face of the destructive experience of socialism. With its excessively puritanical and uncompromising principled liberalism, it was based on a firm denial of the advances of the new state-building but without any vision of the future. ${ }^{25}$ Its signs were accordingly these and similar:

24 In a debate a couple of decades ago, the civil law academic Lajos VÉKÁs, criticizing the very style of constitutional writing described above, said that it is in itself reverse to overwrite a millennium-old (public law) tradition in a short time and then to transfer it like a parent law on a (private law) tradition that has been continuously cultivated and refined for a millennium. However, such a public law can be contradictory in itself. It must be based on the contradiction of two principles that are now diametrically opposed to each other since the integration of society is necessarily broken up when the Constitutional Court absolutizes the individual.

25 At times, it was only a shocking experience that revealed the limits of our thinking. Such a surprise came in 1988, on the ocean sands of Punte del Este (Uruguay), where, as a guest researcher at Yale Law School, I was invited to present a paper at the International Conference on Constitutionalism of the American Council of Learned Societies. I was spouting to a Harvard Hungarian, Dov RonEN, who fled Jewish persecution as a young child, about the faltering of our socialism, when he asked me about the future, a program of self-government to be regained. I had little to answer beyond generalities. He then trumpeted that only then would we have real difficulties, as if we had not had them before. Because we ourselves had become STALinists, albeit in a negative sense; because we have had to build on naked denial, striving to do the opposite of what 
- the balance of rights and obligations has been upset by the uncompensated excess of rights; ${ }^{26}$

- absolutized the rights of the individual by granting them unrestricted control; but in doing so

- made the state a public enemy, against which the individual must be protected by all means and in all ways, lest they fall victim to the abuse of state supremacy; ${ }^{27}$

- emptied the law, insofar as it elevated formal legal certainty to the sole criterion of their rule of law by eliminating any consideration of justice; ${ }^{28}$ with which

- it has taken morality out of the law; ${ }^{29}$ and finally ${ }^{30}$

- in its presumption of the continuity of law, it rehabilitated the law of the past, which was the subject of the law, by recognizing the past, conceived and maintained in sin, as a mere antecedent of the Constitutional Court's own rule of law.

In this way, the alleged rule of law, the preservation and even the construction of which is being debated, or the rejection and abandonment of which, leaving behind its remnants, is in fact

- primarily defended the legal status quo of the past regime, its actors with the rights they had acquired, and by conceiving of the present as the next in an unbroken continuity of the past, it only helped the legal, political, social, sociological and economic survival of the forces of communism;

we are being oppressed with. Our struggle is certainly a moral stand, but we have also become its intellectual captives. Although I was offended by this truth at the time, he was right. For in every rigid compulsion to confront, such a threat lives on at all times.

26 For example, it disintegrated the population by re-socializing the Roma people in a program imposed by the Free Democratic Interior Minister GÁBOR KUNCZE based on the recognition of "crime for subsistence" and its lack of legal consequences.

27 In everyday life in America, the population-and sometimes its scribes-now notoriously see the duel of a police officer and criminal from the same plane and with the same chance; see, for example, the 'Rule of Law? Mania of Law? Rationality and Anarchy in America' in this volume.

28 For democracy, this is the procedural versionò for the Rule of Law, it is the reduction of everything to a single formal factor-the letter of the law.

29 It was instructive to see how a young constitutional lawyer was fertilized by the logic of the Constitutional Court. Criticizing the third court ruling in the case of the success fee of MÁRTA TocsiK, which was a corruption scandal (1996) and was based on the composition of new and new facts in each case, he proposed that the possibility of the expost declaration of the nullity of an "immoral legal transaction" should be removed from the Hungarian Civil Code because if there is no closer legal definition of its conditions, it would, in his opinion, result in legal uncertainty. Tilk, Péter (2003) 'A jogállamiság és a jóerkölcs viszonya a Ptk. semmisségi szabályában' [The relationship of the rule of law to good morals in the nullity rule of the Civil code], Cég ésjog, V(12), pp. 4-6.

30 It should be noted that the features listed so far are also contrary to the social teaching of the Church; cf. Curran, Charles E., McCormick, Richard A. (eds.) (1986) Official Catholic Social Teaching. New York: Paulist Press xi+459 pp. [Readings in Moral Theology 5]. 
- by formally fetishizing the law of letters as the Court understood it, it limited the necessary flexibility of the administration of justice, in particular the possibility of enforcing general legal principles, clauses and uncertain but common legal concepts in marginal cases, ${ }^{31}$ and in so doing, the Court itself encouraged the scandal of recognizing the "unjust but lawful" to take root in the soil of the home country, while at the same time encouraging the growth of the de facto evasion of the law by business law, based on the construction of legal gaps, into a professional practice; ${ }^{32}$

- by imposing, by means of ruthless absolutism, principles that had been illegitimately accepted by the Constitutional Court without legal authority. It also imposed on the community the anti-national consequences of such artificial reliance on reason, by silencing the right of reason to decide freely on the fate of itself and its nation; ${ }^{33}$

- by its deskilled, principled treatment of the law and its proud insensitivity to the consequences of its own actions, the Court has driven the virtue of experience and practical wisdom out of law; and finally

31 The lawyer concentrates on typifiable occurrences: these are the classification places defined by the particular factual features of the codes. Mostly, it is at most mentioned, in addition, that there may sometimes be situations that cannot be classified in this way. In such cases, the judge moves up a level from the general; for example, the presumption of danger to society in criminal law or the presumption of the proper exercise of rights in civil law. However, in doing so, he has already logically assumed an order and a special order [Ordnung/Sonderordnung] — the latter being separated from the former. In other words, on average, the judge will follow rules covering all details, but when an exceptional situation is detected and officially established, they will simply set aside any such constraints.

32 It was not for the first and last time during the Reformation that lawyers were accused of being Talmudists and hairsplitters, and MARTIN LUTHER even spoke in his statements of the conflation of 'Juristen, böse Christen' [Jurists, bad Christians]. Stintzing, Johann August Roderich von (1875) Das Sprichwort »uristen böse Christen « in seinen geschichtlichen Bedeutungen (Rede gehalten beim Antritt des Rectorates der Universität Bonn am 18. October 1875). Bonn: Adolph Marcus 32 pp. and Herberger, Maximilian (1978) 'Juristen, böse Christen' in Erler, Adalbert (ed.) Handwörterbuch zur deutschen Rechtsgeschichte. Vol. II. Berlin: Erich Schmidt pp. 481-484 on pp. $482 \&<$ http://rechtsgeschichte-life.jura.uni-sb.de/Herberger_Juristen.htm>.

33 All the imperatives of our social existence-its watchwords, its ideals and its goals-are presupposed; they are therefore also relative. However, this is mostly only visible when examining great historical arcs. Such has been the case in our recent history, with the economic rise of the Asian little tigers and China, to see that democracy and the Rule of Law in the Western sense are not the sine qua non of economic success; that the Rule of Law, although already accepted in global dimensions, has become empty by extension; that the legal framework of self-defense and the legal limits of national security action in the United States had to be rethought after September 11; that both market self-regulation and state non-intervention have been called into question by recent crises; or that a study by the German Bundeswehr had to testify to the inconsistency of free trade and democracy in the event of the actual depletion of energy resources. On the transformation of the legal concept of "Rule of Law" into a diplomatic weapon, see Varga, Csaba (2008) 'Jogi kultúránk - európai és globális távlatban' [Our legal culture in a European and global perspective] in Paksy, Máté (ed.) Európai jog és jogfilozófia: Tanulmányok az európai integráció ötvenedik évfordulójának ünnepére [European law and legal philosophy: Papers to the fiftieth anniversary of European integration]. Budapest: Szent István Társulat 397 pp. [Jogfilozófiák] on pp. 13-42 \{reprinted in <https://mek.oszk.hu/15100/15173>, pp. 5-32\}. 
- in contrast to its own self-image, it did not serve our transformation by "Transforming the great political-ideological debates of the regime change [...] into constitutional law problems and thus neutralising them" ${ }^{\prime 3}$ but derailed the whole process from the outset, by setting it on a blind track. In the name of a fashionable phantom of "constitutionalism,"35 it was engaged in a pure fog-slinging exercise, forcing an entire country to debate this-and thus the importance of a Constitutional Court body inexhaustible in its ideas - while the nation was already close to ruin in the moral and financial state it had itself brought about.

Democracy, a multi-party system, parliamentarianism, human rights, rule of lawagainst the falsehood of artificially inflating them, these idols are all instrumental values, expressions of our human nobility as civilizational goods. They are not entities in their own right, nor can they be set against the state and the very foundations of the country. Moreover, they are not values in themselves since their value embodiment, as Pope JoHN PAUL II, formerly a professor of philosophy in Poland, has also stated, is due solely to the fundamental values they serve. ${ }^{36}$ They have no absolute nature-their defense can only be conceived and advocated within the general culture of the country and thus within its particular development..$^{37}$

34 Sólyom, László (2001) Az alkotmánybirráskodás kezdetei Magyarországon [The beginnings of constitutional judiciary in Hungary]. Budapest: Osiris 799 pp. [Osiris tankönyvek] on p. 689.

35 The English 'constitutional' 29,000,000/125,000,000 and 'constitutionalism' 686,000/3,490,000; the French 'constitutionnel' 6,180,000/12,200,000 and 'constitutionnalité' 185,000/1,280,000; the German 'verfassungsmässig' 32,000/518,000, 'Verfassungsmässigkeit' $141,000 / 1,390,000$, 'konstitutionell' 215,000/618,000 and 'Konstitutionalität' 1,000/2,800; at the same time, the Hungarian 'alkotmányos' 286,000/1,940,000, 'alkotmányosság' 43,000/50,000 and 'alkotmányossági' 161,000/58,000 times were found on December 7, 2010 resp. March 13, 2021 in Google searches.

36 Cf. Varga, Csaba (2003) 'Buts et moyens en droit' in Loiodice, Aldo, Vari, Massimo (eds.) Giovanni Paolo II: Le vie della giustizia - Itinerari per il terzo millennio (Omaggio dei giuristi a Sua Santità nel XXV anno di pontificato). Roma: Bardi Editore \& Libreria Editrice Vaticana pp. 71-75 and, as expanded, Varga, Csaba (2005) ‘Goals and Means in Law: or Janus-faced Abstract Rights' in Jurisprudencija [Vilnius: Mykolo Romerio Universitetas], 68(60), pp. 5-10 \& <https://intranet.mruni.eu/en/mokslo_darbai/jurisprudencija/archyvas/?l=120712>.

37 One such question is illustrative and just for thought: would our country be better off with thousands or even millions of constitutional judges and ombudsmen protecting its population of 10 million? What is it really that a court of law finds when it finds a violation of law or of the constitution? Is it a degenerate substance, like an abnormal but inoperable cell in the body, or is it merely some compositional structure or mode of functioning of the organism, on which one can form an opinion but against which a whole range of medical opinions can obviously still be conflicted? In law, actions can only take place between parties authorized to proceed and only in the prescribed procedural order, according to KELSEN's reconstruction, and such an opinion can only be the final decision with a legal force by a body competent to do so in a procedure prescribed for that purpose. It is a constitutive (and not declarative) act-in the language of KELSEN: Zurechnung, 'ascription'which exists only because and as it is constituted. Cf. Varga, Csaba (1994) 'Kelsen's Theory of Law-application: Evolution, Ambiguities, Open Questions', Acta Juridica Hungarica, 36(1-2) \& <http://real-j.mtak.hu/784/1/ ACTAJURIDICA_36.pdf>, pp. 3-27. 
If we are out of line on such and such a question, it is probably just a case of falling victim to the smuggling of appealing but false ideas from someone else. The general lesson is that

at a global level, democracy (and any asset value), when exported, is forced to choose between the exclusive object of a circus trainer, the aggressiveness of forcing an animal to perform like a trainer, and the humility of a gardener merely for the natural good of his beloved plant; ${ }^{38}$

and for those of us who think systematically, whether living here or there, we must be aware that social science is always and only local: it is a function of place and time-since it is itself hardly more than the collection, ordering and somewhat generalized methodical processing of a set of particular historical experiences (because they are acquired here or there in time and place). This also means that any event or experience of which one acquires knowledge immediately becomes the subject of a continuous learning process. Of course, nothing is mechanically acquired; if only because, in a new medium, nothing old is valid in the same old way; no legality or constitutionality, no rule of law or jurisdiction, in whatever form, could have come into being other than as a response to its own challenge. Therefore, such virtualities (i.e., institutionalities operating by projection and within the framework of their conventionalization) can only be understood within the paradigm of historically always specific challenges/responses. There is no royal road that can be applied as a panacea in all times and circumstances, only one that is more or less appropriate to the given situation. In our social affairs, in our public affairs, and above all in our external relations, we must always act with this in mind. We must reject any exaltation of the superiority/primacy of others or any suggestion of our own inferiority, whether suggested by wise men from wherever they come or by the magic of temporary Ubu kings. ${ }^{39}$

38 Cf. 'Rule of Law, Or the Dilemma of an Ethos: to be Gardened or Mechanised' in this volume.

39 Jarry, Alfred [1896] Ubu roi, Drama in 5 Acts. In French \& English, transl. Barbara Wright. ${ }^{\text {rd }}$ ed. [1961.] London: Gaberbocchus P., 1966 xi+175 pp.; cf. also Cooper, Judith (1974) Ubu roi: An Analytical Study. New Orleans: Tulane University Department of French and Italian 120 pp. [Tulane Studies in Romance Languages and Literature 6]. 


\section{Bordering Issues I}

\section{CIVIL DISOBEDIENCE}




\title{
THE CHALLENGE BY THE TAXI BLOCKADE (Troubles Surrounding the Functions of Law) ${ }^{1}$
}

\begin{abstract}
1 What is Law? 2 What is the Law's Message for a Given Situation? 3 Law and its Tertium non Datur 4 Legal Assessments are to be Heard

ABSTRACT By October 25, 1990, taxi blockade responded to an urgent government measure. To offer a quick clarification of the legal situation, the present author coauthored a stand debated by political journalism. Defending this position, some foundational issues of law needed to be explained on the institutional, normative, and working features of law.
\end{abstract}

KEYWORDS taxi blockade; law as an institution; law as a normative pattern; law's working system

The columnist reveals some uncertainties related to the law's functioning in his leading article in a Hungarian daily newspaper. ${ }^{2}$ He seems to feel uncertainties following the "taxi blockade when the legal experts of the largest governing party meticulously collected those facts that could constitute a case in law, and which were in fact broken in the weekend in question by half of the country." He adds that in the meantime, "nobody mentioned that the law is not and cannot be a panacea, that it is effective only in relatively stable situations."

For the sake of historical accuracy, let me recall that the expert opinion of the legal committee of the governing party Hungarian Democratic Forum was drafted and issued in the early afternoon of October 27 , Saturday, in the midst of the events. By this time, the capital was almost deserted. The opinion was meant to respond to the events of the previous day, when the country had been completely debilitated and the blockaders' triumphant declaration of "We are in control!" had been heard. Though expressed differently and with varying intensity, all the three opposition parties aligned themselves with and for the blockade. In

1 Responding to the pending issue of the legal nature of the blockade in early 1991, it was published in a leading newspaper, (1991) Magyar Nemzet [Hungarian nation], LIV(19January)(16), p. 14. In English, it was published already in Varga, Csaba (1995) Transition to Rule of Law: On the Democratic Transformation in Hungary. (Budapest: 'ELTE Comparative Legal Cultures' Project 190 pp. [Philosophiae Iuris] \& <http://mek.oszk.hu/14700/14760/> on pp. 103-106.

2 Balla, Péter (1990) 'A jog funkciói körüli szerepzavar' [The trouble of roles around the functions of law], Magyar Nemzet [Hungarian Nation], LIII(29 November), p. 1. 
addition to pressing for the dismissal of the minister of the interior, who allegedly threatened the use of force, the resignation of the government was also demanded. The support by certain political forces was explicitly shown from their organizing contribution, statements they published in newspapers, declarations they made on the public radio, and incitements they spread through leaflets. Even non-activist forces expressed their sympathy by refraining from open condemnation.

The leading governing party's assessment of the situation ${ }^{3}$ was sent to two television channels informing them "for internal use," as marked. It was therefore quite surprising when the document was published in a special edition of the Free Democrats' weekly, Beszélö, the next morning, with the tacked-on and evocative subtitle "Crimes and Sins," suggesting moral condemnation of the assessment and thereby emphasizing the difference in approach.

It is beyond my task to examine whether the legal stand taken by the Hungarian Democratic Forum may have had an effect on that the parties involved eventually refrained from further escalating of the situation. The limiting nature of the events, as the journalist has sensitively recognized it in his article, calls for the close examination of the relationship between the function of law, on the one hand, and the differentiation of the normal conditions from the extraordinary ones, on the other. Allow me to consider it.

\section{What is Law?}

Above all, law is a system of references. In that respect, law is similar to morality and any other system of rules based on conventions. Law is a network of references to which I can relate real-life events, so that I can find their place in the related conceptual system. The primary aim of law is, therefore, nothing but conceptual classification. In the cases when this network is normative, the pigeon-holing of life events entails, by the same stroke, a normative judgment of the whole situation.

Though widespread popular opinion may suggest that law is associated with courts, law enforcement, and jail, this is as false as if I were to say that the fruits I buy at the market are law (because I have previously contracted for them), or the decades I have spent with my wife are law (because our common life was preceded by a ceremony called "marriage"). Similarly, morals are not equal to the cutting of women's hair (as the French did with female

3 On behalf of the party itself, it was the only quick reaction. It was drafted by four of us, two of us representing and two of the rest contributing to its Legal Committee. Cf. (1990) Beszélő [The Speaker], special issue (October28)(6). 
compatriots who had entered into sexual relationships with the occupying Germans soldiers ${ }^{4}$ ): at most and at best, it is one of the possible consequences of moral judgment.

Law differs from morals in many respects, and it is superior to morals, especially in forms. It is strictly formalized in its identifiable sources, procedures, and consequences; above all, the law is not flexible but calibrated to allow only black-and-white-type answers within the conceptual categories of the normative system. The law's answer is either "yes" or "no" and tertium non datur. Furthermore, as its procedure follows normative patterns, a decision of exclusively "yes" or "no" must be made. Finally, the law is stuffed with institutionsamong others, public prosecutors-whose explicit task is to initiate proceedings.

\section{What is the Law's Message in a Given Situation?}

One feature of the networks of normative reference is common to all the fields structured by logic, namely in every sphere where the network is relevant, this is valid as well. In contrast to logic, notwithstanding, where a given connection can be said "to prevail" and "to be the case" irrespective of whether we are aware of it or not, the same cannot be formulated in respect of law. On the one hand, statements in law are strictly formalized as they are determined by the rules of and steps taken in a formal—legal—procedure. On the other, the answer to the question of "What is law?" presupposes interpretation by legal authorities. Thus, the answers to the questions of "What is stated in law?" or "What is the law's message for a given situation?" can only be construed from within the normative system through normative means. In the final analysis, they can only be afforded by competent legal authorities.

\section{Law and its Tertium non Datur}

Having in view the formalized nature of law (and also the fact that since post-feudalist times, legal formalism has been considered the achievement itself for being able to foster

4 Cf. Aron, Robert (1967-1975) Histoire de l'épuration. Vol. 1-3(1-2). Paris: Fayard; Bourdrel, Philipe (2002) L'épuration sauvage: 1944-1945. Paris: Perrin 698 pp. [Collection Tempus 227]; Novick, Peter (1968) The Resistance versus Vichy: The Purge of Collatorators in Liberated France. New York: Columbia University Press xv+245 pp.; (2001) La justice des années sombres: 1940-1944. Paris: La documentation française 335 pp. [Collection Histoire de la justice 14]; Cointet, Jean-Paul (2008) Expier Vichy: L'épuration en France (1943-1958). Paris: Perrin 522 pp.; (2008) La justice de l'épuration: À la fin de la Seconde Guerre mondiale. Paris: La Documentation française 285 pp. [Collection Histoire de la justice 18]; Jean, Jean-Paul (ed.) (2018) Juger sous Vichy, juger Vichy. Paris: La Documentation française $451 \mathrm{pp}$. [Histoire de la justice 29]. 
development), when speaking in terms of the law, points of view and games' rules cannot be freely changed. For law functions mainly through judgments by the law, and each of us must accept legal judgments if we do not intend to discard the idea of the Rule of Law. We must let the law function undisturbed if we want to refer to it in the future (without ulterior or hidden motives and without using a position of strength) as something whose validity and general applicability are granted and not questioned again.

One must also be aware of the fact that once one has created a situation in which the law is muted, then the case is not simply an individual occurrence of the infringement of the law, but it necessarily involves that its very foundation, namely its validity, has also been knocked from underneath it, which in principle can only be restricted by legal means.

If I were in the position to authoritatively state that the law, as opposed to its letter, does not apply to some given matter, this, as to its form, would be by itself an act of revolution latently completed. The example formulated by the journalist in his article, in which he qualifies the demolition of the Bastille as destruction, illustrates my point well. For after a successful revolutionary breakthrough, I would remain psychologically captive of the old regime if I had insisted on qualifying it as destruction. However, in want of a revolutionary success, I would also be denying the continuity of any law and order if I did not allow the question of destruction to be raised. There is no third choice: again, tertium non datur.

All in all, there is no valid reason to argue against legal relevance. In addition, properly speaking, it is not just the law but something else that can at all be rendered muted. Law only means the availability and the duty of that concrete situations shall be related to the pigeon-holing network of normative conceptual references, and law is only identical to itself; it cannot be identified with the presence and/or the effective use of the means of enforcement that it may define. As it is known, law employs a complex qualification system spanning from basic, general principles to concrete rules, applicable in details. This is the reason why preliminary qualifications do not necessarily preempt final decisions. Thus, in spite of the qualification of an action as an infringement of the law, one can reach the conclusion notwithstanding that no practical reaction (compensatory damage or enforcement in civil law, or police officers, the dock or prison in criminal law) is required, for this could only turn to be harmful or socially unacceptable. Naturally, such a conclusion can only be reached and justified by arguments taken from within the prevailing system of law and only after the acknowledgment of the fact that an infringement of the law has been committed. In this respect, too, tertium non datur. 


\section{Legal Assessments are to be Heard}

There is a widespread opinion in Hungary, expressed by many-from politicians to journalists, and occasionally upheld by legal experts as well-according to which the matter of the blockade requires an assessment that is not legal but political. Provided that social problems can only be approached in a complex manner, I am in full agreement, for it is important that also the voice of the law is allowed to be heard and that a legal assessment of the issue is allowed to be formulated. Needless to say, the legal approach can only be one of many.

Law is indeed not a panacea, and it has never been. It is unrealistic to expect social change exclusively from law. Such a statement, however, does not limit legal validity at all, but it only describes the law's working mechanism more realistically. As far as the validity of the law is concerned, the experience of the imposed socialist regime-namely, the practical limitation of the law's proper sphere of validity according to varying political considerations of the day - already led to the conclusion that socialist law, in the final analysis, did not function as law. Consequently, the achievement of which the socialist ideology has been so proud can only be qualified as an atavistic, pre-law state of existence.

I believe that our aim, irrespectively of which side of the future barricades we may stand on, is to surpass past conditions and their predicament.

\section{INDIVISIBILITY OF THE LAW AND RULE OF LAW ${ }^{1}$}

In the past, either far away or recent, dreaming about the Rule of Law meant its German version because of our natural inclination toward and intimate knowledge of neighborhood cultural influence and experience. The Rechtsstaat as a characteristic product of the continental European tradition is based on regulation by law and on the precondition that the operation of the state and the guarantees of legal protection are institutionally regulated. This is in accordance with its history as in continental Europe, the law [ius] has ever been defined by the laws [lex] and the administration of justice based upon the application of laws. By way of contrast, the Anglo-American pattern was for long a distant phenomenon for the whole Central and Eastern European region. Today, it seems to be more familiar; according to it, the law is rooted in traditions of the past. The casual declaration of the essence of the law is

1 Originally drafted to the leading dailies (1991) Magyar Hírlap [Hungarian Newspaper], (May13.), p. 7 and (1991) Magyar Nemzet [Hungarian Nation], LIII(June3), p. 7 in clarification of the legal situation after the taxi blockade in late October 1990 ended. Published already in English in Varga, Csaba (1995) Transition to Rule of Law: On the Democratic Transformation in Hungary. (Budapest: 'ELTE Comparative Legal Cultures' Project 190 pp. [Philosophiae Iuris] \& <http://mek.oszk.hu/14700/14760/> on pp. 107-110. 
a task of the courts. The Rule of Law is confined primarily to secure that debatable questions can be decided by a court of justice. Both patterns presuppose certain minimum conditions for the Rule of Law: one, it is necessary that the operation of the state and the guarantees of legal protection be subjected to proper regulation; two, it is also necessary that all matters that may have of legal relevance can be taken for decision before a court of law. Only together can these two conditions guarantee that the Rule of Man is replaced by the Rule of Law.

Historical studies on Western ideals reveal that the formation of modern Europe has been fundamentally influenced by the theories of social contract. In their light, we ourselves create our social institutions as a result of mutual agreement to provide orderly circumstances for ourselves. Thus, we are responsible for them, and law is also our own product. We created it to be the medium of social mediation, to play the role of common denominator when various forces confront one another. This mediating equivalent is nothing other than the formulation of faceless rules for society. The main demand is the provision of a framework; this does not require self-supplication to a predetermined goal but the establishment of a system in which the future is capable of anything. We must remember István BiBó's popular writings in the short-lived coalition period after the Second World War: the main issue was not choosing a particular party program but the institutionalization of a political culture enabling party programs to develop freely. ${ }^{2}$

What could a politician understand of the values of the West, who preaches about the importance of those values but, on the first occasion, sings the praises of a situation that suspends laws? Let us think about the reasons for the difference between life in the West and here. Is it because they have laws? Is it because they have courts? We have both, and they function properly. However, our feeling of being different is distressing, despite, speaking about Eastern Europe - that is, beyond east and south to the Carpathians surrounding usnot even Czars being assassinated weekly in Russia and politicians not shooting at one another every year in Belgrade or Sofia. We know and experience, however, that even actions taking only seconds can stiffen into tradition, simply because they may happen. For order there is not unconditional, and tolerance exists in such scarcity that order may be overturned at any time-perhaps only exceptionally. This is sufficient, however, for all of us-also in our intermediate region between West and East-not to be able to foresee when a state of exceptionality will find us again.

The main differences between the West and its Eastern epigones, therefore, are stability, reliability, and predictability. Naturally, there are rebellious, criminal, and insane people also in the West. The difference lies not in that the West is protected from these people but in

2 For István Bı́ó, see Papp, Zsolt (1980) 'Társadalomelemzés és politika' [Social analysis and politics], Kritika, (11), pp. 11-15. 
how it reacts to challenges; it reacts with dignity and with the awareness of the supremacy of order. It forgives deviancy but does not neglect breaches of law, and it does not indulge itself with ideological negotiations that can undermine the very foundations of law.

We may accept, then, that our parties have so far been unable to articulate the needs of the people and that mistakes committed by governing forces are judged severely. We may also accept that the more society is broken down, the more it is atomized. In the heat of the moment, however, I cannot allow myself to react purely on instinct as I might get burned. Thus, my standpoints and the arguments on which they are based require careful consideration as situations may arise when the next step can only be the breaching of the law. In this case, the conclusions must be drawn. For example, statutory conditions that are no longer sustainable are to be deleted. Alternatively, special regulations concerning a course of action when a regulation is not sustainable must be adopted, for lawfulness is only reached as a condition when exceptions to it can also be legally treated.

The European culture knows two possible answers to those situations in which law conflicts with other values. One, law may turn out to be powerless, but as soon as the opportunity arises to speak, legality is going to be confirmed (what is important is that the law be symbolically confirmed and not that retaliation be instigated.) Two, it is also feasible that the law will finally extend a helping hand to what otherwise would inevitably happen. In this case, the law eventually gets violated because it performs the task that should be otherwise performed by a constitutional convention, namely the legislative separation of the normal from the extraordinary. One of the classic examples is Magnaud, Le bon juge, ${ }^{3}$ who worked in southern France at the turn of the last century. As a justice, he was unwilling to convict starving street children for stealing bread. With this, he did not open the gates of lawlessness, for he only tried to avert the criminalization of those events that would occur inevitably. He acquitted the broken down, those who were compelled to steal because they were starving, who had no other means of alleviating their need, but convicted those he found too lazy to search for a law-abiding solution to their problems.

Therefore, the question of what to do is a burning issue. In finding an answer, legislature can do only little. Legislators may enlarge the circle within which a deed is lawful, but a limit will in any case be reached. Once it is actually reached, they cannot go further. It is judicial

3 The turn-of-the-century exaltation of Paul Magnaud (1848-1926), "the good judge," originally served as a practical model of free law adjudication. Cf. Leyret, Henry (ed.) (1900) Lesjugements du président Magnaud. Paris: P.-V. Stock 346 pp. [Recherches sociales 4] and Leyret, Henry (ed.) (1903) Les nouveaux jugements du président Magnaud. Paris: Librairie C. Reinwald-Schleicher 246 pp. [Eklitra 84], as well as Foucart, Jacques (2000) Le mythe du 'bon juge' de Château-Thierry: Le Président Magnaud. Amiens: Bibliothèque municipale d'Amiens 286 pp. [Eklitra 84] and Sadoun, Mohamed (2011) Paul Magnaud, Ou le bon juge au service du pot de terre. Paris: Riveneuve $153 \mathrm{pp}$. 
practice that must find the answers. By solving borderline cases, the judiciary may try to demarcate the boundaries of lawfulness, but they cannot offer a helping hand to unlawful deeds or crimes. They cannot even add interpretation to cases only to unjustifiably elevate them into the domain of the lawful.

Is it possible that there is no intermediate area between complete lawfulness and complete unlawfulness? Would it not be too practical to find a borderline for those swaying between these two poles? Though these questions are beyond the law, the responsibility of legal experts remains high because they can only effectively contribute to preventing lawbreakers from complete denial and rejection of the law. Those who directly deal with the situationfor example, the police or the court that can review police procedure-can surely provide this mediatory service. However, it is necessary that all intermediate conditions that can later serve as patterns, precedents, or bases of reference be made conventional. Is the application for permitting a demonstration just about acceptable? In what circumstances will a social act call for the involvement and/or intervention of the police? Can an orderly counter-demonstration be permitted? What is the responsibility of those whose demonstrations violate the constitution by trespassing the limits law and order set?

No mediatory service is entitled at making the unlawful lawful; mediation is not even capable of doing so. Its main task can only be to help start communication between the conflicting parties. In making the responsible parties establish a dialogue, it should attempt to direct their reasoning toward channels characteristic of the realm of the law, to recall the accepted rules of the game and to keep in mind the common interest in preserving all these rules by recalling the danger that necessarily awaits in their breach. 


\title{
CIVIL DISOBEDIENCE Pattern With No Standard? ${ }^{1}$
}

1. The Background 2. The Task 3. Civil Disobedience (3.1. Analysis 3.2. Summation) 4. Concluding Remarks

\begin{abstract}
The government's measure, which was forced to raise radical gasoline prices immediately in the public interest, led to a nationwide blockade of taxi drivers, crippling all traffic in the country. The political opposition tried to ride this as a government overthrow, and its intellectual background immediately attempted to legitimize it, heralding it loudly as a mature case of civil disobedience common in living Western democracies. The author's clarification at the time shows its deception and conceptual falsification, using American forensic analyses. In light of these, the blockade was, from a legal point of view, nothing more than a violation of the law which, under the same law, has to entail legal consequences.
\end{abstract}

KEYWORDS civil obedience/disobedience; conceptual clarity; rule of law; treason of intellectuals; right/ wrong in public affairs

\section{The Background}

Considerable intellectual courage is needed to formulate and present something as completely new. It also requires intellectual honesty to introduce an idea that is already known from the past or elsewhere. Though there are instances crowned with success for both, they may sometimes cover merely irresponsible, impromptu, or dishonest ventures.

I was inspired to reflect and also distressed by the chorus-like concurrence among parties in opposition, alleged liberals in both academic positions and the news who were proud of their professional qualities, who, during the taxi drivers' blockade at the end of October 1990, ${ }^{2}$ glorified their product as an outstanding instance of civil disobedience

I " Originally, the paper served the clarification of the legal situation for the ruling party Hungarian Democratic Forum's Legal Committee during and after the events with a definition of key terms and later on, also as an address to a conference dedicated to the scholarly assessment of the same events. It was already published in English in Varga, Csaba (2008) Transition? To Rule of Law? Constitutionalism and Transitional Justice Challenged in Central \& Eastern Europe. Pomáz: Kráter 292 pp. [PoLíSz sorozat könyvei 7] \& <http://mek.oszk. hu/14800/14851>, pp. 111-118.

2 "Angry taxi drivers and truck drivers blockaded the streets and bridges of Hungary's capital today to protest the government's decision to raise gasoline prices by 65 percent" - as one of the reports states; cf. <https:// www.nytimes.com/1990/10/28/world/evolution-in-europe-gas-price-protest-cripples-hungary.html> in addi- 
and of the ius resistendi. Their stories have been repeated many times since then, and they have highly appreciated the main elements-only to forget about the basic component. This was the following sequence of events: shock by the news of an unexpected hike of gasoline price; masses flocking to the street in protest; erection of blockades closing the roads of the country; cut off of traffic from factories of public importance; limitation of freedom of movement for millions; and finally, public broadcasting of political statements amounting to a case of incitement to revolt. Many representatives of the domestic cultural elite joined the choir, welcoming and justifying this sequence of events and greeting it as the first successful experimentation of transplanting Western civic virtues on the Hungarian soil.

They were cocksure in considering their variant of truth being beyond dispute, preaching this case of successful, genuine "Westernization" with a missionary fury. They declared that the day of the liberty had thereby finally come and that it was already high time for all of us to learn how we should live together with the manifestation of civic virtues; moreover, that all what had happened was not in detriment but in reinforcement of democratic culture and procedures. Academics and essayists of the newborn Hungarian liberalism - those with firsthand experience relating to the everyday and intellectual life of the Atlantic nations, who had claimed for long to import the culture of "the West"- taught a nation by praising this very specific move. To be sure, they have had no reference at all to the thorough and sometimes bitter debates that have for long revolved around the issue throughout the Atlantic world. They have been disinterested in the contradictions as well as the dangers and limited (i.e., exceptional and partial) acceptability of those manifestations of civic resistance that are sharply opposed to-albeit fought through within - a democratic establishment. They have failed mentioning the fact that as a result of such debates, American and European scholars have reached a basic agreement upon the terms by which civil disobedience can be justified, its limits can be drawn, and the consequences partners in disobedience may face can be foreseen.

After the blockade, intellectuals from the academic world in Hungary presented their conjecture as if the blockade were the case of an objective description of one established form of popular behavior, known from all Western-type civilizations around the world. Although they were representing nothing but own dreams, coming out of wishful thinking, their arrogance was hardly counterbalanced by the cool detachment of a true interpreter that they apparently took. What they were interpreting was in fact a series of fragments in theory which, except for the type of anarchists in 1968 and doctrinaires of extreme left-wing terrorism, nobody was ready to accept in the Western world. It seems to be of a paradigmatic feature that these

tion to, for example, <https://bbj.hu/budapest/culture/history/taxi-blockade-a-chronicle-of-four-remarkable-

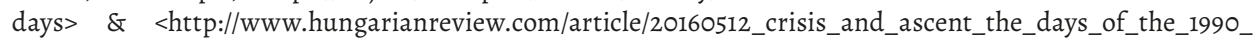
taxi_blockade>. 
partisan writings - their detached scholarly stance notwithstanding - did not even mention the legal approach, as if it were again suspicious of standing for hidden motives or second thought despite the collapse of STALINism. They did not reckon that it was the legal profession that in the United States and Europe, following the cataclysms of recent decades, eventually answered the sophisticated legal philosophical, political philosophical, constitutional, and moral issues that civil disobedience may raise in a rare theoretical agreement.

In the midst of the events, I felt that the characteristic reaction of a huge part of the intellectual elite in Hungary was a self-repetition of La trahison des intellectuels as described by JULIEN BENDA ${ }^{3}$ in interwar Europe. As a matter of fact, never before have I come across theories resembling those partisan views since the time I surveyed the topic of obedience/disobedience two decades ago. ${ }^{4}$ For it can also be taken as a characteristic feature that I began working on this problem during the heyday of the socialist era, when it was still expected to endure for a long time. This was the very reason that I was interested in the boundaries and actual borderlines of law to extend and also delimit legal imagination.

\section{The Task}

It is common knowledge in philosophy that concepts are conventional. Therefore, what must be justified first is not why one follows established prevailing traditions but why one attempts to reject or change them.

We are free in judging the way in which civil disobedience was understood in the United States of America and impregnated political and legal philosophy and practices of Europe. There is only one thing we must not do, providing that we intend preserving professional integrity. Namely, we should not replace an established and conventionalized concept with the outcome of merely wishful thinking without simultaneously taking notice of what we are doing. Accordingly, we are expected not to present own conjectures as objective descriptions of a state of affairs that is known to have been established or institutionalized elsewhere.

In the following, I shall summarize some key elements of a theoretical approach to civil disobedience as it was developed in the American literature pioneering the scholarly treatment of the topic. The aspects of civil disobedience that can be conceptualized in law,

3 Benda, Julien (1928) The Great Betrayal. [(1927) La trahison des clerks. Paris: B. Grasset 306 pp.] Transl. Richard Aldington. London: Routledge $\mathrm{x}+188 \mathrm{pp}$. / The Treason of the Intellectuals. Transl. Richard Aldington. New York: W. Morrow 1928. xii +244 pp.

4 By chance, among many contemporary foreign and comparative law items, I reviewed the papers of FrANK M. Johnson, Wilson Carey MCWilliams and PaUl F. Power in a (perhaps first) professional overview on the topic in (1970) Jogi Tudósitó [Legal reporter] [Budapest], I(13-14), pp. 27-32. 
that is, mainly the juristic efforts at distinguishing it from ordinary violations of the law, are primarily targeted. Therefore, the analysis concentrates on a juristic (and partly legal philosophical) description of the notion of civil disobedience, or rather, of some of its sine qua non minimum conditions, and it will not be concerned with the moral, constitutional, or political philosophical issues associated with it.

\section{Civil Disobedience}

\subsection{Analysis}

Civil disobedience is a concept born outside the law; however, it can gain meaning only as opposed to the law. This is the basic source of its inherent Janus-facedness. The origins and inspirations of civil disobedience are partly pre-law and partly extra-law. Nevertheless, we can only define its meaning by clarifying what it denies, why, and how as well as what is that distinguishes the denial involved from other violations of the law.

Civil disobedience is a concept that refers to law but is outside its structure. It is unjustifiable to draw its inherent unlawfulness into the very structure of the law. ${ }^{5}$ Adventuring the same under a moral pretext is no more than empty sophistic exercise. ${ }^{6}$

The judgment of cases related to civil disobedience, therefore, does not raise any specific problem from a jurisprudential point of view. Once we have decided that we resort to civil disobedience, we can freely discuss from any non-legal point of view who, when, and how to take a course of action, but this "raises no substantial or even interesting questions for the lawyer qua lawyer." Furthermore, we may even venture as far as to formulate a paradox here: the pure legal point of view cannot play a part in the legal judgment of civil disobedience. For it can be rightly said that

[m]oral decisions concerning civil disobedience certainly ought to take relevant legal considerations into account, but it is a mistake to look for a legal defence of an illegal

5 For example, Freeman, Harrop A. (1966) 'The Right of Protest and Civil Disobedience', Indiana Law Journal, $41(2)$, pp. $228-254$ on p. 228 claims that "the theory is not anti-law but within the law."

6 "But as long as the law is dealing with men as rational beings, it cannot command simply do this or do not do this; it must say do this or do not do this-or else," as RUCKER argues. By tracing imperatives back according to the formula "-or else," he concluded that "[a]nd the 'or else' provides an essential alternative within the structure of law.” Rucker, Darnell (1966) 'The Moral Grounds of Civil Disobedience', Ethics, 76(2), pp. 142-145 on p. 143. 7 Allen, Francis A. (1967) 'Civil Disobedience and the Legal Order', University of Cincinnati Law Review, 36(1), pp. 1-38 on p. 2. 
act. Since such acts fall outside of law in every sense, civil disobedience cannot be treated as a legal category or classification. ${ }^{8}$

Therefore, in cases of criminal violation, no reference to civil disobedience can ever justify a special assessment or treatment upon the basis of legal criteria.

This is the reason why legal experts, who may otherwise be socially sensitive, do protest the smuggling of purely moral or political considerations into the forms of legal reasoning proper, for the intermingling of dissimilar concepts may result in the undifferentiated treatment of that what requires social differentiation. This is why it must be stressed repeatedly and unambiguously that "[v]iolations of our criminal laws are criminal violations, not civil disobedience." 9

Providing that for one or another reason we take notice of a case of civil disobedience in a legal context at all, we have to clarify from the very beginning that civil disobedience can only be directed-temporarily-against a rather partial and limited measure (or provision) of the law and must the same time distance itself from both the negation of the prevailing law and order as such (which is already anarchy) and the questioning of its legitimacy (which, on its turn, is revolution). ${ }^{10}$

When violations of the law are judged, an act can be recognized as a case of civil disobedience-if there are several sound reasons supporting this choice-only within the discretionary sphere of the application of law by the given legal forum. This is available only provided that its basically illegal character crying for sanctioning has been acknowledged. The legal assessment can in no case lead to even a symbolic authorization of an act of civil disobedience. ${ }^{11}$ Therefore, not even the eventual discretionary postponement or cancellation of retaliation can alter the principle according to which

[t]here is no immunity conferred by our Constitution and laws of the United States to those individuals who insist upon practising civil disobedience under the guise of

8 Hall, Robert T. (1971) The Morality of Civil Disobedience. New York, etc.: Harper \& Row xiii+162 pp. [Torchbook Library Edition] on p. 18.

9 WhitTAKeR in Whittaker, Charles E., Coffin, Jr., William Sloane (1967) Law, Order and Civil Disobedience. Washington, D.C.: American Enterprise Institute for Public Policy Research viii+156 pp. [Rational Debate Seminars 2] on pp. 3, 52, and 2.

10 Hall, The Morality of Civil Disobedience, 1971 on p. 20 states that

his objection, and consequently his moral rationale, is directed toward only a part of the positive law of the state. Objection to law as such (anarchy), or an opinion that the state itself is immoral and ought to be overthrown (revolution), would therefore be unacceptable as a moral reason for an act of civil disobedience.

11 Cf. Dworkin, Ronald M. (1968) 'On Not Prosecuting Civil Disobedience', The New York Review of Books, X(June 6), p. 14 . 
demonstrating or protesting for "civil rights." The philosophy that a person may-if his cause is labelled "civil rights" or "states rights"- determine for himself that laws and court decisions are morally right or wrong and either obey or refuse to obey them according to his own determination, is a philosophy that is foreign to our "rule-of-law" theory of government..$^{12}$

Again, it is a conceptual precondition of an act of civil disobedience that its unlawful nature will be unconditionally acknowledged. Consequently, partners in civil disobedience must be prepared to submit themselves to punishment. ${ }^{13}$ In other words, as civil disobedience can only originate from an individual's moral and political conviction, and as a result, it can only be intentional and fully conscious, it does by far not challenge the legal situation according to which "[i]t is the state's duty to arrest and punish those who violate the laws designed to protect the private safety and public order."14

It is worth emphasizing here that the threat of punishment and/or its practical implementation - notably that it does not remain a rhetorical substitute or a symbolic act but will in fact be meted out—does not originate from the judges' so-called "tunnel-vision" or their obstinate insistence on retaliation. The inner logic of the act itself demands this, so that the merits of the moral and political dilemma inherent in the internal logic of civil disobedience are demonstrated. Thus, it cannot, and should not, be eliminated. This is what makes the act dramatic, enhancing its effect and substantiating the moral commitment of resorting to it. The moral commitment gives the reason why - at least at the level of a general political judgment-the partner in civil disobedience may expect balanced, moderate—and to some extent liberal—treatment. ${ }^{15}$

Everything considered, the American jurisprudence offers the following definition for civil disobedience: "an open intentional violation of a law concededly valid, under a banner of morality or justice by one willing to accept punishment for the violation."16

12 Frank M. Johnson in Forman v. City Montgomery 245 F. Supp. 17, 24-5 (M.D. Ala. 1965) [Middle District of Alabama], quoted in Johnson, Frank M. (1969) 'Civil Disobedience and the Law', Tulane Law Review, XLIV(1), pp. 1-13 on pp. 2-3.

13 "A willing submission to arrest," as Hall, The Morality of Civil Disobedience, 1971 on p. 146, states.

14 Fortas, Abe (1968) Concerning Civil Disobedience and Dissent. New York: The New American Library 64 pp. [Signet Special Broadside 3] on p. 63.

15 As McWilliams, Wilson Carey (1969) 'Civil Disobedience and Contemporary Constitutionalism: The American Case', Comparative Politics, I(2), pp. 11-27 on p. 226 opines,

Yet whatever concessions may be made to civil disobedience, on the most vital of issues it cannot be protected from the threat of punishment. In fact, precisely because civil disobedience may be a vital part of constitutional order in our times, there are limits to how much it may be shielded from penalty. Punishment is often essential to the disobedient himself: it provides a dramatization of his concerns, an instance of his sincerity, and a challenge to complacency which may be essential if he is to command the attention of those "good citizens" who may be moved by the "spectacle of courage [...] taking its own path."

16 Johnson, 'Civil Disobedience and the Law', 1969, p. 2. 


\subsection{Summation}

It seems to be a matter of course that the more we proceed in the analysis, the more essential limiting factors and considerations we find. As "it is not characteristic of the moral point of view to determine what is right or virtuous wholly in terms of what the individual desires or of what is to his interest, ${ }^{{ }_{17}}$ and since exclusively " $[t]$ he intent of the criminal is to gain benefit for himself at the expense of the interest of other people," in recognizing acts as, and assessing cases of, civil disobedience, the emphasis will inevitably be placed on the unselfish character of the act and on its refraining from violating or harming others' interest. ${ }^{18}$

Finally, though we cannot exhaust thereby all analytic possibilities, the necessary balance between the acts of civil disobedience, on the one hand, and the aims sought and the direct damages inflicted thereby, on the other, must be mentioned. Judicial practice sanctions that the means of achieving what the act of civil disobedience aims at be just. ${ }^{19}$

All in all, summarizing the whole diversity of the components of civil disobedience-and also, to some extent, paraphrasing the criteria enlisted by the literature ${ }^{20}$-we may set the sine qua non conceptual elements of civil disobedience as follows. The act of civil disobedience is expected to be

17 Frankena, William K. (1963) Ethics. Englewood Cliffs, N.J. xiii+109 pp. [Prentice-Hall Foundations of Philosophy Series] on p. 6.

18 Hall, 'Civil Disobedience and the Law', 1971 on p. 24. "[A]n obvious limitation of the act to non-violent practices." Ibid., pp. 146-147. Cf. also Kunstler, William (1969) 'Dissent and the Jury' in Berrigan, Daniel et al. (eds.) Delivered Into Resistance. New Haven, Conn.: The Advocate Press pp. 50-59 on p. 57.

19 "To qualify as an act of civil disobedience, an action would have to be appropriate to the agent's stated purpose, and the purpose should have to be of a socially responsible nature." Hall, 'Civil Disobedience and the Law', 1971 on p. 146. "Here as elsewhere civil disobedience requires a measure of political prudence." McWilliams, 'Civil Disobedience...', 1969, p. 226. As Justice Johnson stated in Williams v. Wallace 240 F. Supp. 100, 106 (M.D. Ala. 1965),

[I]t seems basic to our constitutional principles that the extent of the right to assemble, demonstrate and march peaceably along the highways and streets in an orderly manner should be commensurate with the enormity of the wrongs that are being protested or petitioned against. [...] In this case, the wrongs are enormous. The extent of the right to demonstrate against these wrongs should be determined accordingly.

Johnson, 'Civil Disobedience and the Law', 1969 on p. 4 added to the above that 'There must be [...] a "constitutional boundary line" drawn between the competing interests of society.'

20 According to the definition of Power, Paul F. (1970) 'On Civil Disobedience in Recent American Democratic Thought', The American Political Science Review, LXIV(1) pp. 35-47,

1) The act must be performed openly-secrecy is prohibited. 2) It must be a deliberate, not an accidental step. 3) The action is clearly unlawful, i.e. not permissible under existing laws and court interpretations of civil rights and liberties. 4) The illegal act is voluntary, not induced by others. 5) The conduct proceeds from "conscientious" dissent, inspired by moral or religious beliefs. 6) The objective sought is a concrete, public reform. 7) Legal remedies must be exhausted before disobedience is undertaken. 8) The disobedient is obligated to use "non-violent" means. 9) Throughout his challenge he demonstrates concern for the right of others. 10) A proximate relation exists between the rule under attack and the reason for dissent. 11) The disobedient must submit to the legal consequences of his act. 
- clearly unlawful

- as a deliberate step

- in the realization of a given plan

— proceeding from "conscientious" dissent,

— inspired by moral or religious beliefs

— with motives unselfish and

- with public reform as the objective sought,

- performed openly

- after legal remedies are exhausted,

- using "nonviolent" means

- with concern for the right of others

- by maintaining a proximate relationship between the goal and the means

- while submitting to the legal consequences of the act.

\section{Concluding Remarks}

In the light of the events of the taxi drivers' blockade, we can only be sure of one thing: it was not a case of civil disobedience, assuming that we do not have a special reason to deviate from the term's established and conventionalized meaning. This statement in the negative, however, does not render it unnecessary (but on the contrary, it expressly presupposes) that further research on the characteristic features and the genuine meaning of civil disobedience will be conducted.

In its present-day culture, civil disobedience is aimed at improving the constitutional system through the individual's exceptionally dramatic acceptance of responsibility. ${ }^{21}$ By doing this, the disobedient undertakes a creative contribution to the development of the constitutional system by the simultaneous reassertion of the system's underlying basic values. Therefore, we may anticipate that cases of civil disobedience will occur in one form or another also in the future. For

[i]f society is going to exist in dependence upon man's moral nature, on his ability to choose the right course from the wrong-on his conscience-then society is also going to have to recognise man's right and duty to follow his conscience even if it leads to civil disobedience. ${ }^{22}$

21 Bay, Christian (1967) 'Civil Disobedience: Prerequisite for Democracy in Mass Society' in Spitz, David (ed.) Political Theory \& Social Change. New York: Atherton Press pp. 163-183.

22 Freeman, Harrop A. (1966) 'Moral Preemption Part I: The Case for the Disobedient', Hastings Law Journal, 17(3) pp. 425-437 on p. 437. 


\title{
CROSSROADS OF CIVIL OBEDIENCE AND DISOBEDIENCE (A Moment of Constitutional Impotence in Hungary) ${ }^{1}$
}

\author{
1. Civil Disobedience 2. Civil Obedience
}

\begin{abstract}
The two cases compared show the political partisanship of both the intellectuals and the media in situations of political divide, the taxi blockade of October 1990-falsely qualified to be an instance of civil disobedience but enforced to end by granting blockaders mercy-and the dismantling of the cordon fencing around the parliament building in February 2007-falsely refuted to be an instance of civil disobedience but unreacted in law to this very day. In the first one, the gasoline price policy of the government was at stake; in the second one, the constitutional impasse of popular protest against police restrictions. The legal analysis of civil disobedience performed in 1990 and in 2007 as well is contrasted by weighing the chances of civil obedience under the conditions of constitutional impotence. The outcome is to show that the rule of law committed on paper and used in official rhetoric does not imply automatically that claims under the rule of law can easily be implemented in practice.
\end{abstract}

KEYWORDS Rule of Law; majority and minorities; logicum of and ethicum in civil disobedience; law as instrument; law in service of human community; fight for rights and continuity; public opinion; Bible

\section{Civil Disobedience}

Civil disobedience is an idea that stands for confrontation and moral rebellion, describing one of the feasible ways of enforcing our conscience's word. This is one of the historically developed choices for self-sacrificing for others in human altruism with implied risk taken, which exerts its impact mostly in particular manners on the by-pass roads it channels.

1 Originally published as a contemporary background note-[Civil disobedience and the voice of morality (Especially abusive if the moral rebellion is labeled by public authority)]-in the leading daily 2007), $\mathrm{Ma}$ gyar Nemzet [Hungarian Nation], LXX(February8), 6 \& <http://mandiner.hu/cikk/20170615_varga_csaba_a_ polgari_engedetlenseg_es_az_erkolcs_szava_2007>; earlier versions in English published in Varga, Csaba (2008) Transition? To Rule of Law? Constitutionalism and Transitional Justice Challenged in Central \& Eastern Europe. Pomáz: Kráter 292 pp. [PoLíSz sorozat könyvei 7] \& <http://mek.oszk.hu/14800/14851>, 262-271 and as Varga, Csaba (2008) 'At the Crossroads of Civil Obedience and Disobedience (A Case Study of a Moment of Constitutional Impotence in Hungary)', Central European Political Science Review, 9(No.31), pp. 68-77 \& in <http://www. academia.edu/1948089/Institutions_and_political_regime_in_Putin_s_Russia_an_analysis>. 
Every element of it is thoroughly imbued with an underlying moral stance, and this is its most distinctive characteristic. The first time, the expression had been used by the moral hero THOREAU (1817-1862) in his conscientious rebellion against American slavery, ${ }^{2}$ then by GANDHI (1869-1948) launching a movement that conceptualized it as a programmatic tenet after more than half a century33; certainly, it is not for antipathetic or cynical outsiders and even less for those counter-interested to qualify it. When the actor identifies their deed as civil disobedience, in abbreviated form, they simply refer the intended reason and target back to a given tradition.

Civil disobedience is not a legal concept. Moreover, it is not part of the law's concept in a larger sense either as it merely denies the compulsory force of some valid law in the light of the superior validity of some higher order to change this very law. At the same time, not even the expression itself is a legal concept as the law has no reference to it, or civil disobedience is an external event, either heterogeneous or differently homogeneous as compared to the law's field, in the course of which some provision of the valid law is broken and to the perception of which the law can only react by meting out the prescribed sanction.

At this point, it is high time to reveal the subtly complex network of mutual impacts in operation between morality and law, when civil disobedience challenges both, for on the one hand, civil disobedience is a moral challenge to law. It is an open declaration of conflict in terms of which the law is intentionally broken under some moral demand. On the other hand, the law, which is calibrated to sense the outside world through the lenses of its own categorial system exclusively, may not and will not perceive anything else in this than the mere breach of some legal provisions. At the same time, considering that civil disobedience usually achieves its target by forcing the legal machinery to response, the offense is mostly made publicly and with defiant unambiguity, for its provocative gesture is just aimed at excluding, on behalf of that machinery, any insensitivity, evasion, quibble, or compromise solution by avoiding a definite answer to be offered by the law. On the law's side, all this is simply taken as an injury as law has no access or path to sense the moral gesture or tradition called civil disobedience in the deed, just because no such concept is provided for and by

2 Thoreau, Henry David (1966) Walden, and Civil Disobedience. Authoritative Texts, Background, Reviews, and Essays in Criticism. Ed. Owen Thomas. New York: W. W. Norton vi+424 pp. [A Norton Critical Edition]; cf. also Lee, Leon H. (1990) The Historical and Literary Context of Henry David Thoreau's 'Civil Disobedience'. [D.A. thesis.] Murfirsboro, TN: Middle Tennessee State University 190 pp. [HOLLIS number: 990049006270203941 ] and Howe, Daniel Walker (1990) Henry David Thoreau on the Duty of Civil Disobedience: An Inaugural Lecture Delivered before the University of Oxford on 21 May 1990. Oxford: Clarendon Press $32 \mathrm{pp}$.

3 Cf. Bakshi, S. R. (1985) Gandhi and the Civil Disobedience Movement. New Delhi: Gitanjali 230 pp. and Patil, V.T. (1988) Mahatma Gandhi and the Civil Disobedience Movement: A Study in the Dynamics of the Mass Movement. Delhi: Renaissance Publishing House vi+224 pp. 
the law. Consequently, instead of the merits or moral connotations of the deed, only the act through which the injury was committed will be named by the law. Accordingly, not even the fact that the offender acted magnanimously as pushed by moral considerations to provoke a change in law can be part of the officially established facts of the case, unless there is a specific provision on all the concrete individual circumstances of the deed to be both recorded and considered for the judgment to render. Otherwise, such moral motive is to be noticed within the proceedings as personal feature at the most, without its chance to add to the legal qualification itself.

It follows that not even the conceptual expression itself is normative but merely descriptive, as conventionally established. Although its moral motive offering self-sacrifice may be accompanied by pathos in its societal perception, this is hardly a reason to stint civil disobeyers this quality by disqualifying them, if we happen not to agree with them or their deed. It is somewhat awkward to see representatives of state power qualify for civil disobedience practice. For those against whom moral rebellion (culminating in intentional law breaking) is directed are from the original losers in the moral dilemma having led to a case of civil disobedience: it was the civil disobedient and not them who first came out against some insupportable condition. Their acquiescence would be covered by the holy gown of the rule of law in vain; at most, the conceptual level would be mistaken as the mere fact of having had recourse to civil disobedience is to testify to that the institutional rule of law network has failed-or proved to be helpless-in the given situation.

The operational mechanism of civil disobedience lies in dislocating state and legal practices from daily routine. They have either to punish (with furiously grinding teeth and bitter taste in the mouth) or to acknowledge their own defeat, looking for ways to support the underlying moral cause. Civil disobedience is by definition exceptional and spoiling everyday peace by having irrevocably declared a conflict. It also has a polarizing effect by announcing a split made in society: the more divisive the more alive it is, with the stake being the fate of moral considerations shared by powerful sectors of society.

Therefore, it is understandable (although hardly sympathetic) to encounter power reactions these times-particularly when the official stand is not shared by the social majoritydamping down the merits by either over-dimensioning the injury or rolling down the original intent to disqualify the disobedient or their case.

The world must be an abject one in which such huge amount of insensitivity, stubbornness, life-strange causeless conceit, or simple power game may be compressed into symbolic values by gratuitous gestures that will either force the community to prostrate itself before the state's altar or lead to explosion. It is abject to encounter such a rule of law that in addition to repeating own mantras, there is no sensitivity left to cure actual troubles. 
Situations of unlimited power are also dangerous for being both challenging and exciting. For the Rule of Law remains an empty framework and mere procedural frame until it will be impregnated with contents worth of being lived in a democracy asserting ultimate human values. It happened to be a one-sided official act exercised as a symbolic gesture that the action of the so-called cordon removal called to account. ${ }^{4}$

It was strange to perceive continuity in that the same intellectual class of media that had once greeted past disorder (called taxi blockade) as part of the widely acclaimed movement of civil disobedience and heated it further in order to eventually overturn the government, ${ }^{5}$ now, as an unconsecrated prelate of omniscience, deprived the event of its quality of civil disobedience by identifying it with a party action instead of a moral cause. At that timeand now as well-the media mainstream failed to cover its political judgment with objective knowledge or relevant arguments. For we may remember that taxi-blockaders, taken away by merely pecuniary self-interest, brought millions of humans into a situation of necessity, while its rousing fighters fled as rats from assuming the consequences of their unlawful acts.

Accordingly, it is not an issue of political likes or dislikes whether or not we had to qualify the event as a case of civil disobedience or just as common lawbreaking. In case we had called it civil disobedience, we would have deprived its concept of its differential sense by identifying mob reactions with the self-sacrificing moral espousal of HENRY DAVID Thoreau, Mahatma Gandhi, Martin Luther King, and others, putting the state in an insoluble conflict: either excusing resistance with no sanction (risking the state's moral collapse) or meting out sanctions to a mass self-reproducing endlessly (unfeasible in any long run as threatening with institutional collapse). The self-qualification is hardly to contest from those having dismantled the cordon yesterday, if accompanied by the risk of getting sanctioned. Today's wisdom of mainstream journalism announcing its "contravention, not civil disobedience" sneaks on total ignorance as to its genuine nature. It is their old self that can psychologically motivate such a stand, which once channeled political decision

4 "FIDESz removes illegal police cordon [...]. The cordon was erected by the police as the entire area around the buildings of Parliament was declared 'operational field' by the head of the Budapest Police following anti-government street protests last October”—starts Prime Minister VIKTOR ORBÁN’s self-report on the February 2 action in <http://2010-2015.miniszterelnok.hu/in_english_article/fidesz_removes_illegal_police_cordon>. For the event on February 2, 2007, cf. <http://www.budapestsun.com/cikk.php?id=12083>, <http://www. budapestsun.com/cikk.php?id=12083> and <http://www.eppfrakcio.hu/en/new/96/>.

5 Cf. Varga, Csaba (1995) Transition to Rule of Law: On the Democratic Transformation in Hungary. (Budapest: 'ELTE Comparative Legal Cultures' Project 190 pp. [Philosophiae Iuris] \& <http://mek.oszk.hu/14700/14760/>, part on 'Skirmishes and the Game's Rule', pp. 91 et seq., and for the historical contexture, Swain, N[igel] (1992) Hungary: The Rise and Fall of Feasible Socialism. London: Verso 264 pp.

6 For example, Halmai, Gábor (2007) 'Ez nem polgári engedetlenség’ [This is not civil disobedience], Népszabadság [People's Liberty: a daily], (February 3). 
makers to reconcile with the taxi blockade as civil disobedience and also granting blockaders mercy. For civil disobedience is one of the plain violations of the law which-speaking in terms of moral intention or the logic of a political action-as committed intentionally, without violence, in public, with the penalty (which is by all means to be meted out) undertaken from the beginning, does serve ideal (not material) targets to induce change to be effected in law. This time, discussing whether each and every procedural path in law has previously been exhausted is highly irrelevant. On the one hand, no such condition is implied by such an utterly a-legal concept, and on the other, its long tradition refers this to those taking the risk to deliberate on the alternatives, if any; that is, if (even in a blank cost/ benefit analysis) there are further ways open to them, leading to comparable outcome with less risks. In policing and judicial reaction to such injury, the government must also face this challenge by making it clear for anyone's daily practice of constitutional civil rights, namely what will separate civil governance from a police state, proceeding with unquestionable autocracy.

It is worth wondering about chances, sense, dilemmas, and limits of civil disobedience. One has to remember the forerunners, emphasize the seriousness of offering themselves to punishment and unconditional sacrifice, recall that the contemporary, well-developed doctrine of civil disobedience is due to a past when many heroes languished in long-term prison for their espousal. We must also learn that civil disobedience as a pattern implies the danger of spreading; therefore, it must be kept as an exception not to easily allure to anarchical attitude—once we have actually reached legal normality.

\section{Civil Obedience}

What remains to society if it chooses the way of civil obedience? Hardly more than what can at all be met as coming from increasingly alienated, reified structures. It might have already been a squealing sign to observe how much our society expected its own salvation to materialize from the all-curing idol of Law and of the Rule of Law after the fall of communism. Instead of common sense and well-planned responsible action not shrinking even from risks, it shed its hopes in rules and judgments made by others (as if the blind was to lead the blind). It resigned to the death of the deed once the magic words of prophets promising a brave new world from idleness got in its ear, and it became even more squealing a sign, when a major part threw away its natural sense of justice, when it was made to believe the superiority of alleged "lawfulness" and "constitutionality" said to derive from formal ideal operations with unmistakable automatism. After the socialist regime had annihilated law, society began to adore it as a fetish. Although nothing other 
than what Comenius had already reported on happened," watching "distinguished men" in the Labyrinth of the World, who, pushing mysterious linkages here and there on tables and monologuing about connections and separations to make and made, did in fact allocate fate of properties and empires, in a manner "founded upon the mere whim of a few men." This is to reach what MARx had rightfully grieved about in a classical age, namely how much artifacts generated by humans for their own welfare can turn against humans by ruling the world. As dazed from poppy seeds, we ourselves also act as cussed. ${ }^{8}$ One may remember Russia as having fallen in crushing chaos and misery due to the fury of mostly Americans chasing after profit, when less than some decades ago those profiteering from

7 Komenský, Jan Amos (1663) Labyrint sveta a ráj srdce. Amsterdam ch. 15 in <http://www.oldlandmarks.com/ labis.htm>:

The Pilgrim Observes the Legal Profession 1 FINIS JURIS In the last place, they led me into still another very spacious lecture room where I saw a greater number of distinguished men than anywhere else. The walls around were painted with stone walls, barriers, picket-fences, plank-fences, bars, rails, and gate staves, interspersed at various intervals by gaps and holes, doors and gates, bolts and locks, and along with it larger and smaller keys and hooks. All this they pointed out to each other, measuring where and how one might or might not pass through. "What are these people doing?" I inquired. I was told that they were searching for means how every man in the world might hold his own or might also peacefully obtain something from another's property without disturbing order and concord. "That is a fine thing!" I remarked. But observing it a while, it grew disgusting to me. 2 JUS CIRCA QUID VESETUR For, in the first place, I noticed that the barriers enclosed neither the soul, the mind, nor the body of man, but solely his property, which is of incidental importance to him; and it did not seem to me worthy of the extremely difficult toil that was, as I saw, expended upon it. 3 FUnDAmentum JURIs Besides, I observed that all this science was founded upon the mere whim of a few men to whom one or another thing seemed worthy of being enjoined as a statute and which the others now obsesrved. Moreover (as I noticed here), some erected or demolished the bars or gaps as the notion entered their heads. Consequently, there was much outright contradiction in it all, the rectification of which caused a group of them a great deal of curious and ingenious labor; I was amazed that they sweated and toiled so much upon most insignificant minutiae, amounting to very little, and occurring scarcely once in a millenium; and all with not a little pride. For the more a man broke through some bar or made an opening that he was able to wall up again, the better he thought of himself and the more was he envied by others. But some (in order to show the keenness of their wit) rose up and opposed him, contending that the bars should be set up or the gaps broken thus so. Hence arose contentions and quarrels, until finally separating, they painted each his case in his own way, at the same time attracting spectators to themselves. Observing this tomfoolery sufficiently, I shook my head, exclaiming: "Let us hurry away! I feel distressed here!" "Is there anything in the world to your liking?" my interpreter angrily retorted. "You find fault even with the noblest of callings, you weathercock!" "It seems that he is religious-minded; let us take him to see the clerical professions; perhaps he will find it to his liking," Mr. Ubiquitous suggested.

8 Cf. Varga, Csaba (2012) '»Thing and Reification in Law' [1978.] in Varga, Csaba (2012) The Place of Law in Lukács' World Concept. [1981/1985.] 3rd (reprint) ed. with Postface. Budapest: Szent István Társulat 218 pp. \& <http:// mek.oszk.hu/14200/14249/> in Appendix, pp. 160-184 and Varga, Csaba (2013) 'The Contemporaneity of Lukács' Ideas with Modern Social Theoretical Thought: The Ontology of Social Being in Social Science Reconstruction with Regards to Constructs like Law' Archiv für Rechts- und Sozialphilosophie, 99(1), pp. 42-54 \{reprinted in <http://elib.sfu-kras.ru/bitstream/2311/19820/4/o1_Varga.pdf $>$ \}. 
all this shouted: "More shock therapy!" As if we had nothing left except "still more law! More Rule of Law!"

Should we eventually return to the naturalness and rationality of common sense to eventually clear it, who is to serve whom? Is the fate of our nation for the law's sake, or is the law for human beings' sake? Were we born, and do we live and die only to have an ideal legal perfectionism been fulfilled? Or since we live, in our life we slowly build culture-then and therein law as well-to improve them and being thereby improved?

Our system of election raised an unusually high threshold to get in popular representation, thereby merely excluding a differentiated representation of the variety of life relations and historical experiences. We speak about morals with dandy affectation, and we do not have any remedy only against taking over power through false means. Although our Constitution encourages people to direct participation, today's descendants of those "distinguished men" limit it to a low-grade implementation. Our rush in human rights' defense has managed to become so perfect that real humans on Earth can hardly survive it. For reassurance, we may also take notice of the right of resistance that was already protected in the Golden Bull throughout our "dark" Middle Ages, ${ }^{10}$ but in our postmodern Enlightenment we-as alleged by the mainstream press ${ }^{11}-$ proudly assigned it to Constitutional Court justices. Thus, we have arrived at one of the best possible worlds, in which we have succeeded in making ourselves totally defenseless and unprotected. Not much is left from the property of the nation, however, and even less from self-esteem and readiness to act-not even pearls were received in return for our renunciation of the future.

I remember how it seemed to be astoundingly brave and frivolous to learn, when I was young law student, from DICEY, ${ }^{12}$ genius of British constitutionalism, that all the achieve-

9 Cohen, Stephen F. (2000) Failed Crusade: America and the Tragedy of Post-Communist Russia. New York \& London: W.W. Norton \& Company xiv+304 pp. Cf. also Varga, Csaba (2008) 'Failed Crusade: American Self-confidence, Russian Catastrophe' in Varga, Csaba Transition? To Rule of Law? Constitutionalism and Transitional Justice Challenged in Central \& Eastern Europe. Pomáz: Kráter 292 pp. [PoLíSz sorozat könyvei 7] on pp. 199-219 \& <http:// mek.oszk.hu/14800/14851>.

10 Cf., as a first orientation, <http://www.britannica.com/eb/article-9037229/Golden-Bull-of-1222> and <http:// en.wikipedia.org/wiki/Golden_Bull_of_1222>. The text in Italian, English, Latin, and Hungarian is in Besenyei, Lajos, Érszegi, Géza, Gorlero, Maurizio Pedrazza (eds.) (1999) De bulla aurea Andreae II regis Hungariae, 1222. Verona: Valdonega 253 pp. In an wider context, cf. Rau, Zbigniew, Grajewski, Przemysław Żurawski vel, Tracz-Tryniecki, Marek (eds.) (2016) Magna Carta: A Central European Perspective of our Common Heritage of Freedom. Abingdon, Oxon: Routledge xix+233 pp. and, for a bibliography proper, Horvath, Michael J. (1972) Golden Bull (Bulla aurea), 1222, of Hungary and the Magna carta, 1215: A Selected Bibliography Commemorating the Former One's 750 th Anniversary. College Park, University of Maryland Library 28 pp.

11 Nagy, Péter N. (2007) 'A tőkétől a kerítésig' [From the capital to the fence], Népszabadság [People's Liberty - a daily], (February11) in <http://nol.hu/cikk/434884/>.

12 Dicey, A.V. (1885) Lectures Introductory to the Study of the Law of the Constitution. London: Macmillan vii+407 pp. and Dicey, A.V. (1905) Lectures on the Relation between Law and Public Opinion in England during the Nineteenth Century. London: Macmillan and Co. $\mathrm{xx}+503 \mathrm{pp}$. 
ments for what his nation had fought and made it a principle of everyday practice are based on the force of public opinion instead of formulas committed to paper. That is, for a mature nation, the genuine soul is not hidden in stones, rules, or other reified entities. Strength is not to be drawn from such tangible ephemera but from cultural continuity. What anyone thinks today is merely a daily affair. Successive days are not derived from stones or texts concluded the previous day - and certainly not cut out by geometric compasses and rules-but from what the nation will draw up out of itself in the challenge of the next day, actualizing its own primordial tradition. In this type of culture, people are never tired because they are always ready to continue their cultural adaptation further, trusting in the continuality of such a culture and having matured enough to undertake responsibility themselves.

From a social science perspective, the Bible is a corpus of historical wisdom on man. It tells us what is worth knowing about those having populated the Earth, although others may regard it as dated, unable to meet the new profane requirements of political correctness since it reports on us as a herd to be kept driving by shepherds, who needs both birdlime and lash not to lose the way. We may discover to be destined to become easily tired as unwilling to work; at the same time, we are easily tempted by the voices of sirens, although we should eventually realize that we can only arrive at that for which we have labored.

The collection of historical data on Europe is a profusion of results due to bloody battles only. As our populous minorities, Hungarians (having lived where they do live now for almost a thousand years) are humiliated day to day in so-called successor states in our direct neighborhood (in continuation of the territory taken from Hungary); however, instead of launching a real fight, we sublimate our anxiety to the self-discipline of dictions and artistic mourning. As a consequence, our noble heart is adequately praised as we are busy with ourselves and do not give anybody much trouble. As known, national entities that matter at all with a firm determination to reach anything are used to actually do it, albeit voices of sirens attempt to reduce the desire to act and discourage the assessment of interests, and mostly those who already hesitate to act and are dissuaded from following their own paths even if rough are tempted. Reading newspapers reveals who listens to such voices and who listens to everything else because there is hardly anything to write about those enchanted by others.

Is law anywhere else better? Yes or no, but readiness to act may be greater. Those who listen to themselves and their articulated interests are ready to act, and they know what law is for. Namely, it is to use it since we have created it as part of our culture; it is not a fetish, and we do not idolize it. It is not our supranatural commander, and we do not throw our fate in front of it as mere spoil. Law is what I live with to pursue our collective life in a nobler way, and as we live our culture on a daily basis, we aim to implement all that is left to us in the potential of our law and see its fruits materialize in our everyday life. 
Law is not a goal but only a means. ${ }^{13}$ To live merely for means, one would lose perspectives. A goal may derive only from values resulting from our being Godly creatures and attached to our personal dignity. Our means may exclusively serve us as humans. Even if hindered, they could not divert us from the goal.

Have we resigned from forming our law? Have we abandoned the dignity born with us to respect the law not as our reified lord but as our servant, formed as an artifact from ourselves? Have we declined to such an extent that we place law-any law-as fetish to the altar of the highest reason of existence instead of God? As a last resort, we should at least notice that no law formed by others is formed for us, or the sequence of MADÁcH describing the Tragedy of Man is by far not contingent: we must strive to create an anabasis upon which we can already nurture trust by having faith $\mathrm{in}^{14}$; no plant will result, and no solid soil inviting to pass on will emerge from miracle expectation as neither personality mature for struggle is likely to grow.

Our law has been formed by elites for their own pleasure. This is not simply good or bad, even if we are urged to observe that it is alien to genuine needs, too doctrinal and weak, and avoids real problems to be faced. ${ }^{15}$ Albeit with readiness to act, we could shape it: this is the reason why we had better to develop an own civil society.

13 See Varga, Csaba (2003) 'Buts et moyens en droit' in Loiodice, Aldo, Vari, Massimo (eds.) Giovanni Paolo II: Le vie della giustizia - Itinerari per il terzo millennio (Omaggio dei giuristi a Sua Santità nel XXV anno di pontificato). Roma: Bardi Editore - Libreria Editrice Vaticana pp. 71-75 and, as expanded, Varga, Csaba (2005) 'Goals and Means in Law: or Janus-faced Abstract Rights' in Jurisprudencija [Vilnius: Mykolo Romerio Universitetas], 68(60), pp. 5-10 \& <https://intranet.mruni.eu/en/mokslo_darbai/jurisprudencija/archyvas/?l=120712>.

14 Madách, Imre (1860) The Tragedy of Man ending by The Lord's words as trans. George Szirtes in <http://mek. oszk.hu/00900/00918/html/madach15.htm>: "Man, I have spoken: strive on, trust, have faith!”; as trans. Ottó Tomschey in <https://mek.oszk.hu/00800/00876/00876.htm>: "I told you, man: fight, trust and be full of hope!"; as trans. J. C. W. Horne in <https://mek.oszk.hu/00900/00915/html/madach15.htm>: "O Man, strive on, strive on, have faith; and trust!"

15 Cf., for example, as a compendium of contemporary Western criticism, Varga, Csaba (ed.) (1998) Kiáltás gyakorlatiasságért a jogállami átmenetben [A cry for practicality in transition to the rule of law]. Budapest: [AKAPrint] 122 pp. [A Windsor Klub könyvei II]. 


\section{Bordering Issues II}

\section{COMING TO TERMS WITH THE PAST}




\section{ON SETTING STANDARDS (Or the Dilemma in General) ${ }^{1}$}

1. Intellectual Climate and Arguments in Favor 2. Strategic Ends and Considerations of Principles 3. A Legal Solution?

ABSTRACT After the fall of communism, crucial questions emerged in Central and Eastern Europe that prompted early answer. These were challenges never met before as ones to be responded adequately in the proper assessment of Rule of Law considerations. One of such issues is whether or not and how to come to terms with the past under the Rule of Law. The issue is partly philosophical-why settling accounts by setting standards is a moral quest and why it must be taken seriously as a preliminary agenda - and partly strictly legal—exposing basic queries for which a solution may then be found.

KEYWORDS recurrent affirmation of truth; eliminating Bolshevik ideology and practice; ex post facto justice; physical time; limitation period; legal institutions

\section{Intellectual Climate and Arguments in Favor}

Let me start this essay on a rather skeptical note: it is always a potentially catastrophic practice to administer justice in the aftermath of basic political changes. At the same time, it would be likewise disastrous to eliminate the possibility of jurisdiction in such often turbulent periods of history. We are clearly on the horns of a dilemma as our choice is between the Devil and the deep sea.

I In 1990, the Open Society network started mastering topics of transition as political and scholarly agendas as well, launching international conferences in the region and publishing the quarterly of East European Constitutional Review [Chicago \& New York], I (1992) - 12 (2003), among others. In Hungary, the philosopher GYöRGY BENCE (1941-2006), who became political adviser (1990-1994) to then liberal VIKTOR ORBÁN, launched a conference practically deterring new forces from holding accountable old murderous crimes by propagating the false analogy of reconciliation, which had kept Spain from drifting into civil war. Originally, the present paper addressed this meeting (January 12, 1990), which was provocatively called 'Retroactive justice in new regimes', as if it were ab ovo standing for order suspended. Its earlier version in English was 'On Setting Standards' in Varga, Csaba (1995) Transition to Rule of Law: On the Democratic Transformation in Hungary. (Budapest: 'ELTE Comparative Legal Cultures' Project 190 pp. [Philosophiae Iuris] \& <http://mek.oszk.hu/14700/14760/> on pp. 121-128 and amalgamated with 'The Right to Judge the Past' in the present volume, was also published in (2016) Central European Political Sciences Review 16(No.62), pp. 72-93. 
We must put it on record right here that irrespective of the prevailing circumstances, conformity with the law is a fundamental asset of every viable society, which must not be sacrificed on the altar of any real or presumed cause. Of course, we are always free to cogitate upon the actual meaning of lawfulness-if only to proclaim our deep-seated convictions but never to give reason to fetishism. We must also be aware that as to the elements or ingredients that constitute our complex social existence, each have their own particular sphere, whose integrity we are all obliged to respect. Law is nothing more or else than one of such ingredients, and lawfulness is a mandatorily enforced organizing force within its sphere. In this sense, law and lawfulness represent a peculiar approach and a set of standards that can hardly ever be ignored. It means that in cases when the law has relevance to our life, we must remain within the bounds of its authority.

In general, it must be stated that the implementation of what is frequently (inaccurately and reprovingly) catchworded as "ex post facto political justice" to reprove and ban it from the beginning ${ }^{2}$ is indispensable for launching a new social or political regime. Since we cannot draw a clear dividing line between past and present, there is no other choice left for us but to postulate continuity. In this process, the desire for and also the need for moral standards become clearly manifest, if only as a result of the logical sequence of events.

Let me recall a personal experience here. About 40 years ago, I was busy elucidating GEORGE LUKÁCs' posthumous social ontology from the point of view of legal philosophy. ${ }^{3}$ Pretending that I had been working on some kind of official assignment, I traveled to Transylvania (a territory belonging to Romania since the peace treaty concluded after World War I) in the hope of learning more about his early intellectual activity as a law student in Kolozsvár. ${ }^{4}$ One specific goal of mine was to track down the doctor iuris dissertation he had submitted to the famous jurisprudent of the age, FELIX Somló (1873-1920).5 During my stay, I was able to meet some outstanding scholars, including science historian SAMU BENKő (1928-). Not long ago, in Budapest, the renowned poet GyUla ILlyÉs (1902-1983) published a rather scathing article regarding the timeliness of HERDER's once prophecies

2 GYöRGY BENCE's term in his invitation to the said conference; cf. Bence, György, Chambre, Ágnes, Kelemen, János (ed.) (1990) Visszamenő igazságszolgáltatás új rezsimekben. [multipl.] Budapest: ELTE BTK Társadalomfilozófia és Etika Tanszék 53 pp. [Fil2 gyorsszimpózium].

3 Varga, Csaba (2012) The Place of Law in Lukács' World Concept. [1981/1985.] 3rd (reprint) ed. with Postface. Budapest: Szent István Társulat 218 pp. \& <http://mek.oszk.hu/14200/14249/>.

4 Or, in traditional Saxonian, Klausenburg, but since CEAUȘESCU's time exclusively Cluj-Napoca.

5 Cf. Varga, Csaba (ed.) (1999) Felix Somló: Schriften zur Rechtsphilosophie. Budapest: Akadémiai Kiadó xx+114 pp. [Philosophiae Iuris: Excerpta Historica Philosophiae Hungaricae] \& <http://mek.oszk.hu/14800/14830/index. phtml>, including CV and Bibliography on pp. xiii-xx. 
on the disappearance of Hungarian language in the sea of surrounding peoples ${ }^{6}$ in the 1977 Christmas issue of the daily Magyar Nemzet. True to their old habits, the rulers of Rumania spared no time in taking revenge on the Hungarian minorities there. Aware of those developments, I was shocked to have heard BENkő's words in Kolozsvár's main square café.

Listen - he told-we have to heed the message of the Old Testament. We must be familiar with the deeds and motives of the prophets. They duly went about their business, as Scripture says. Time and again they raised their voice, as it was their calling to set standards. Accordingly, they established certain moral limits, and they never cared for the consequences of their actions. After all, this was their calling.

In time, we must publicly proclaim and reassert the basic common values of society. Furthermore, we must revitalize the ancient example of periodically reciting and reestablish what is in force with laws. ${ }^{7}$ Of course, how the job is done makes a difference; for example, reestablishing basic values cannot end in lynching. Otherwise speaking, justice has a potential worth considering, which would be a shame to either ignore or just put off.

\section{Strategic Ends and Considerations of Principles}

It is a sine qua non of any such process to grant, at least in principle, a minimal redress to victims and to ensure that those measures have a preventive effect on the society at large as well as on the offenders. Likewise, it is a must to learn the details of the past and to denounce the negative developments in history - at least symbolically. Strategically speaking, it is important to rule out communism (whose ingrained practices still appear to linger) as an acceptable political alternative. That is to say, one must prevent communism from sneaking back in through the back door in the guise of a democratically legitimate political alternative.

6 "There they are now among the Slavs, Germans, Wlachs, and other peoples, the smaller part of the country's population, and after centuries one may hardly find their language" (1791) Ideen zur Philosophie der Geschichte der Menschheit. in Herder, Johann Gottfried (2002) Werke. Ed. Wolfgang Pross. Vol. III/1. Munich: Carl Hanser Verlag Book 16, ch. II, p. 633 ["Da sind sie jetzt unter Slawen, Deutschen, Wlachen, und andern Völkern der geringere Teil des Landeseinwohner, und nach Jahrhunderten wird man vielleicht ihre Sprache kaum finden"].

7 According to the archaic institution of the living voice of the law, well-known from Iceland to ancient Israel, the lagsaga [or lögsögumađur] was the first law professional, fulfilling the service of reciting the law while standing on a rock, in the absence of any written code. Cf. Líndal, Sigurđur (1993) 'Law and Legislation in the Icelandic Commonwealth', Scandinavian Studies in Law, 37, pp. 55-92 and Varga, Csaba (2011) Codification as a Socio-historical Phenomenon. $2^{\text {nd }}$ \{reprint\} edn. with an Annex \& Postscript. Budapest: Szent István Társulat viii+431 pp. \& <http://mek.oszk.hu/14200/14231/>, p. 28 and p. 40, note 2 . 
Preventive effect? After a quarter of a century, the accounts are still to be settled. One can even make an allegation that this process has hardly started. Is this not a shameful development in itself? Breaking the decades of cowardly silence that had accompanied stately criminal deeds, a lone journalist writing in a virtually unknown weekly publication ${ }^{8}$ undertook the impossible mission of identifying the files of at least some public figures in the archives of the previous regime's secret services. For a long time, this was practically the only attempt to address the job, which I would call an absurd situation. We still have silenced victims and one-time torturers, and the latter are granted the right to successfully prevent their own identification. ${ }^{9}$

The dawn of freedom tends to give rise to practices that are commonly considered as spontaneous delivery of historical justice. This is but a response coming from historically coherent, small communities. In the specific case of Hungary, this process manifested itself in the rejection, by villagers, of those social outcasts and pariahs who had been recruited by the communists in the early 1950s and again after 1956 for repressive service. This rejection is a textbook pattern for cultural anthropologists since it was executed by subtle signals and gestures that were hardly perceptible to outsiders and hardly attributable to any individual either. Yet, these signals and gestures unmistakably identified those with whom responsibility was believed to lie, and all this was performed without hurting anyone. People were to silently pass by these outcasts, thereby ostracizing the most inhuman of themselves from their society. On the other hand, those rejected were always to receive the messages sent and encountered no mercy when struggling with their shame. For it is a basic truth of legal anthropology that in societies where the members' prime consideration is their belonging to a definite community, there is hardly anything more important than to preserve such an identity. This is why both stigmatization and ostracism are sensed as more hurtful than corporal punishment; for an outcast, life is bound to lose meaning and perspective. ${ }^{10}$

Contrary to the practice accepted elsewhere, no official lists or memoranda have been compiled in Hungary about the legal violations that occurred during the half of a century

8 For example, Ferenc Kubinyi in the periodical Kapu [The Gate]. Cf. also Kubinyi, Ferenc (1994) Fekete lexikon: 1945-1956 [Black lexicon]. Budapest: [Malomfalvi] 303 pp., a biographical lexicon which has remained, without continuation, in the shadow of him being intimidated by perpetrators' lawyers to sue him because he would not be able to prove the details involved with the libraries and archives prepared for the job.

9 There is a Historical Archives of State Security Services in Budapest-<http://www.abtl.hu/>-but with insufficient service.

10 Cf. Pospíšil, Leopold (1974) Anthropology of Law: A Comparative Theory. New Haven: HRAF xiii+385 pp. on pp. 87-95 and Varga, Csaba (1988) 'Anthropological Jurisprudence? Leopold Pospíšil and the Comparative Study of Legal Cultures' in Law in East and West: On the Occasion of the $30^{\text {th }}$ Anniversary of the Institute of Comparative Law. Tokyo: Waseda University Press pp. 265-285 \{reprinted in <http://mek.oszk.hu/15300/15333/\#>, pp. 437-457\}. 
after World War II. Apart from isolated attempts at addressing that past, we still do not have comprehensive documentation on the destructive policy that the communist state targeted at our communities for nearly 50 years.

"Ex post facto political justice": indeed, what specifically does retroactivity mean in this specific context? At a basic level, every criminal case is ex post facto by default. Someone commits something, the relevant act is subsequently qualified with reference to the laws in force, and certain procedures are eventually launched. In other words, every standardized, normative judgment is based on previously established norms by definition. Consequently, the term carries no specific additional meaning here. It merely creates a dismissive, condemning mood with rhetorical means from the beginning.

What does the adjective "political" stand for in this expression? Let us not forget that the situation in law is unchanged. Once any issue is unambiguously settled from a legal point of view, the legal aspect of the same issue can no longer be approached politically. This is to say that any attempt to punish acts that were not considered punishable by the laws in force at the time when the given acts were committed would lead us into the very same trap in which the ill-famed (so-called) people's tribunals found themselves in Hungary after World War II. For those tribunals became dominated by a thirst for revenge at a fairly early stage and out of any noble motive. This is why we believe that to use such tribunals as a model would be self-defeating and ultimately suicidal. No matter how valid the historical study may be on the procedures of delivering political justice, ${ }^{11}$ one must not forget that the relationship between jurisdiction and political jurisdiction is similar to that between democracy and its past socialist caricature, when the adjective negates-or at least restricts-the qualified word. That is, political jurisdiction falls beyond the realm of the law, as does it the gruesome rite, wrapped in a kind of legalese rhetoric, which was resorted to while executing Romania's Nicolae and Elena CeAuşescu. ${ }^{12}$

In any legal procedure, the legally available means are to be utilized exclusively with regard to their specific legal peculiarities. A question arises: is it feasible to regard as legal what will otherwise qualify as negating anything legal? The gist of statutory limitations is the following: once the normally functioning state machinery fails to initiate proceedings against people committing acts qualified as criminal according to the law in force, the power of initiating prosecution expires after a certain period of time. As to the philosophical consideration underlying statutory limitations, it is not acceptable to keep people at bay with the threat of proceedings for

11 Kirchheimer, Otto (1961) Political Justice: The Use of Legal Procedure for Political Ends. Princeton, New Jersey: Princeton University Press $452 \mathrm{pp}$.

12 Cf. <https://en.wikipedia.org/wiki/Trial_of_Nicolae_and_Elena_Ceauşescu> and Livezeanu, Irina “Transcript of the closed "trial" of Nicolae and Elena Ceausescu, December, 1989' Making the History of 1989, Item \#690 $<$ https://chnm.gmu.edu/1989/items/show/690>. 
a discretional length of time. Otherwise speaking, in the absence of proceeding, law and order are considered as automatically restored after a certain period. Still, statutory limitations does not rely on the mere physical progress of time, but it presumes law and order as functioning under social normality when, for instance, individuals who have suffered from criminal acts are entitled by law and also enjoy the real position to seek legal remedy. In fact, in socialism, legal proceedings were recurrently and systematically ruled out or prevented in given classes of cases. Such a practice was started by those who, all that notwithstanding, ventured to report to the police and were to face subsequent harassment, labeled as "provocateur." Meanwhile, the state's criminal authorities went out of their way to prevent these state crimes from being prosecuted at all, sometimes even issuing amnesties for certain categories.

Let me cite here a situation of paradigmatic import from Belgium. During World War I, when Belgium was occupied by the Germans, the king and the government were forced to move to The Hague in neighboring Holland and continued to exercise their authority there. However, under the Belgian Constitution, the legislature serves as the foundation for the government's operation, and the legislative power is shared by the king, the House of Representatives as well as the Senate. Since the latter two bodies could not move into exile in full, they were legally no longer existent. After the war, attempts were made to legally interpret the king's decision to leave the country and to decide whether his decrees could be regarded as valid and legally acceptable. No matter how patriotic and dramatically heroic the king's personal fight may have appeared to the public, his constitutional status remained questionable since the law did not recognize the institution of exceptional power and by default precluded the possibility of its own abeyance. To avoid the abyss of considering the kingly preservation of statal continuity simply as abuse of power, the solution came from Belgium's Cour de cassation, upholding their validity as laws in force while establishing that "the law can contain provisions for normal, predictable situations only." Accordingly, providing that "life takes such turns which are not explicitly foreseen by the law, the conclusion cannot be that there is an absence of relevant stipulations, as this would lead to anarchy and the negation of a legally organised society."

Instead, in such cases, either the legislator or the judicial authority is obliged to fill in those gaps in the law, or, since normality did not prevail there and then, the case was peculiar and exceptional, which called for a discretionary approach. Consequently, as the Cour de cassation promulgated, the gap in the law could not be covered by explicit constitutional regulations, and the king's conduct was therefore in conformity with the Constitution. ${ }^{13}$

13 Vanwelkenhuyzen, A. (1968) 'De quelques lacunes du droit constitutionnel belge' in Perelman, Ch[aïm] Le problème des lacunes en droit. Brussels: Bruylant pp. 339-360 [Travaux du Centre de Recherches de Logique] on pp. 347-350 and Perelman, Ch[ä̈m] (1976) Logiquejuridique-Nouvelle rhétorique. Paris: Dalloz 193 pp. [Méthodes du droit] in para. 41 , pp. $76-78$. 


\section{A Legal Solution?}

Returning to our issue, I would propose a similar solution to our dilemma. If the previous regime automatically averted criminal impeachment, statutory limitations could not even start on the field involved. After all, social normality and orderly functioning are obviously a sine qua non for that statutory limitations can have its effect.

It is certainly advisable to frame criminal proceedings in refutation of recognizing the very start of statutory limitations in respect of cases when the crime has enjoyed illegal support by the state-proceedings that enforce the substantive rules of the law in force at the time of the commission of the given offense and which, for example, may even exercise the prerogative of pardoning due to humanitarian considerations. Based on the provisions of the substantive (and perhaps also the procedural) laws, the court can even declare remission to relate not to the committed act but only to the execution of a non-recidivist's punishment on account, perhaps, of the elapsed time.

It appears likewise feasible to frame some social-cum-legal procedure of investigation that can directly fill the prophetic function described in the Old Testament.

In any case, in the absence of clear-cut and unchallengeable verdicts on the legal status of all the committed acts, even the justification of socialism's crimes and the nostalgic treatment of its terror may stand a chance at being recognized as acceptable. In the final analysis, this is why the quest for a socially acceptable framework within which the past can be settled at long last must be continued. After all, what is looked for is not punishment itself; moreover, punishment could even be ruled out as a possible conclusion of the court proceedings, thereby settling for the drama of public identification as being the ultimate climax. However, it remains that the procedure of identification must assume some kind of publicly recognized form.

Everywhere, expectation prevails for legal security and particular care of fundamental legal values without fetishizing any of their aspects in themselves. At the same time, it is known that no legal text has the potential of guaranteeing positive foresight, definitions, or security by itself. It is a fundamental principle of cognitive sciences today ${ }^{14}$ that meaning is by definition conditional on the practical use of quasi-contractual communicative conventions in typical everyday situations. Consequently, both principles and rules may always entail exceptions as diverse inferences do generate diverse conventionalizing situations, each

14 Cf. Varga, Csaba (2011) Theory of the Judicial Process: The Establishment of Facts. [1992/1995.] $2^{\text {nd }}$ \{reprint\} ed. with Postfaces I and II (Budapest: Szent István Társulat 2011) viii + 308 \& < http://mek.oszk.hu/15500/15540> and Varga, Csaba (2012) The Paradigms of Legal Thinking. [1996/1999.] Enlarged 2nd ed. Budapest: Szent István Társulat 418 pp. [Philosophiae Iuris] \& <https://mek.oszk.hu/14600/14657/>. 
of which entails its own value assumptions. Accordingly, all our concepts represent an exceptionally rich and complex collection of tools, by the help of which we have the intellectual justificatory power to get to wherever we wish. Of course, such an apparent freedom also has its own limitations. For all its contextual openness, the law entails clear short-term and long-term standards. The law entails restrictions in the sense that it is rooted in permanent feedbacks, that it perpetually provokes us to justify ourselves with convincing (canonized) arguments, that it may only adopt innovations through the filter of established traditions of the legal profession, and that the social context of the relevant juristic processes is embedded by the common acceptance of some foundational values. 


\title{
THE RIGHT TO JUDGE THE PAST (Or the Dilemma in Legal Particulars) ${ }^{1}$
}

\author{
1. Law is Law 2. Law is Continued 3. Rule of Law as a New Base 4. Rule of Law in Exceptional Situations \\ 5. The Case of a State Non-abiding by its Law 6. The Variety of Paths and Ways in Law
}

\begin{abstract}
For society to face up to the serious crimes against life committed by order of the communist dictatorship not allowing their prosecution either, for justice to be done, and for the victims to be at least vindicated, legal foundations must be clarified. Being a theoretical approach based upon considerations in legal philosophy and experience gathered in legal anthropology, its truth is independent of whether or not, and to what degree, conclusions have been implemented in practice either in Hungary or elsewhere.
\end{abstract}

KEYWORDS continuity of the law; rule of law; ordinary/extraordinary situations; nature and preconditions of statutory limitations; combination of state's legal and extralegal instruments

In Hungary, after communism, the recommencement resulting from the new political conditions, the urgent need for reconsidering both national past and present to finally meet the challenge of an overall intellectual and moral reconstruction, and the judgment relating to the past equally force thinkers to face yesterday by drawing the boundaries dividing it from today.

In this regard, two questions urge prompt preliminary answers: (1) was the regime just left behind one governed by law? (2) what is our relation to this past like? Are we heirs or only happy survivors of this past, who can at best build upon its ruins? Once answers are given, further dilemmas will immediately crop up, such as (3) what kinds of requirements have the Rule of Law and its proclaimed constitutional democracy imposed on the builders of such

1 In March 1991, a shortened version of the paper was presented to the Committee for the Investigation of Unlawful Benefits (consisting of senior law professors of the Loránd Eötvös University in Budapest). We were commissioned by the prime minister of the Republic of Hungary in issuance of the Government Decision No. 1025 of August 30, 1990 to clarify jurisprudential foundations. After the government had discussed the individual stands and the Committee's statement, the Committee dissolved. This allowed the texts to be made public, my contribution being first published in the daily (1991) Reggeli Pesti Hirlap [Pest Morning News] II(November4)(258), p. 8. Earlier versions in English were published in (1992) Rechtstheorie, 23(3), pp. 396-404, reprinted in Varga, Csaba (1995) Transition to Rule of Law: On the Democratic Transformation in Hungary. (Budapest: 'ELTE Comparative Legal Cultures' Project 190 pp. [Philosophiae Iuris] \& <http://mek.oszk. hu/14700/14760/>, pp. 129-135. Amalgamated with "On Setting Standards," it was also published in (2016) Central European Political Sciences Review, 16(No.62), pp. 72-93. 
a new state? (4) How can we draw a distinction between ordinary and extraordinary conditions? Is there, or is there not, a connection between the universal validity and obligatory nature of the law, on the one hand, and the tacit assumptions and social preconditions of the constitutional state, on the other? (5) What is the genuine meaning of statutory limitations, and how do they operate? Is there any complementary effect on the limitations' action if the state has persistently been unwilling to execute its own laws or if the state itself has obstructed any implementation of own laws and punished those who may have dared to live by those laws? Finally, (6) what is the relationship between the legal and extralegal instruments at the disposal of the state, of the society at large, and of the citizen? Can they also be used in parallel?

\section{Law is Law}

In dramatic situations, when a completely new start becomes a political necessity, the issue of the continuity of law and legal conditions is often raised.

For judging the law upon the basis of values challenging it, we may be inclined to simply declare that laws serving despotism, inhumanity, and moral destruction are at best mere abuses of the very idea of law. This is a position characteristic of natural law. From a legal philosophical point of view, we can also declare that the laws of abusive power-mongering are not laws at all but faint precursors to any law at best. This statement can be concluded from the ontological assessment of the genuine roles that law may have ever fulfilled. ${ }^{2}$ However, neither of these two approaches can afford any valuable answer here, for their criteria fall outside the law.

From a legal point of view, we can state that law is an aggregate of rules with regulative power which do (a) embrace the whole society by (b) providing order to its underlying fundamental living conditions and which are (c) supreme by taking effect as the final authority in the community. ${ }^{3}$ In consequence, Bolshevik and Fascist and Nazi legal arrangements are to be equally regarded as varieties to the law. They can be deprived from their legal character exclusively in an extralegal sense. Nevertheless, such a negative statement has no practical purport whatsoever. Exceptionally, all that notwithstanding, such a denial was resorted to

2 Cf. Varga, Csaba (1989) 'Liberty, Equality, and the Conceptual Minimum of Legal Mediation' in MacCormick, Neil, Bankowski, Zenon (eds.) (1989) Enlightenment, Rights and Revolution: Essays in Legal and Social Philosophy. Aberdeen: Aberdeen University Press pp. 229-251 \{reprinted in <http://mek.oszk.hu/14700/14760/>, pp. 38-61\}.

3 Varga, Csaba (1988) 'Anthropological Jurisprudence? Leopold Pospíšil and the Comparative Study of Legal Cultures' in Law in East and West: On the Occasion of the $30^{\text {th }}$ Anniversary of the Institute of Comparative Law. Tokyo: Waseda University Press pp. 265-285 \{reprinted in <http://mek.oszk.hu/15300/15333/\#>, pp. 437-457\}. 
in view of either to annul legal innovations made by short-lived subverter regimes (e.g., the Hungarian Soviet Republic during its 133 days of action in 1919) or by legal cultures developing under retrograde conditions (e.g., the Bolshevik revolution in 1917 or Tiтo's takeover in Yugoslavia in 1944).

In sum, regardless of how much alien the so-called socialist law was to Western legal values, from the point of view of the criteria of modern formal law, ${ }^{4}$ it was, however, law.

\section{Law is Continued}

Legal continuity is one of the issues to be answered by the state in one way or another. In principle, the state can choose between recognition and repudiation at will, but none of the options can be selected free of charge, that is, without bearing proper, well-defined consequences. Therefore, the alternatives need to be weighed in light of their side effects.

A similar query was already formulated by those nations which had lost World War I, when the victorious powers presented the bill of waging the war to the common folk-themselves forced to war, instead of their elite-by demanding them to grant the winners territorial concessions, reparations, and so on. Why should they pay those debts, which their own former oppressor managed for its own sake? Irrespective of the merits of the answer, it must be consequential. One cannot deny legal continuity by repudiating responsibility for some selected burdens while actually acknowledging continuity by taking advantage of privileges. The choice cannot be situationally selective; eventually, one of the alternatives has to be selected, and the selection made has to be justified by the law.

That is to say, in terms of the ratio between costs and benefits, it may happen that it is too expensive to be freed from specific burdens. Notwithstanding, the law's call for internal coherency allows only principled choices and exceptions to be made. In consequence, it authorizes neither legally nonconformist choices nor ones which do not logically proceed therefrom. Legal validity is either recognized, or it is not; no third option can be taken.

Needless to say, internal coherency and legal justifiability are strong calls in international law as well. In the final analysis, and in the long run, the validity of any domestic order is the function of its international setting, that is, its formal recognition. Domestic orders can become parts of the international order through their mutually cooperative support. That is the reason why breaking continuity can also result in losing international recognition.

4 Cf. Varga Csaba, (1984) 'Moderne Staatlichkeit und modernes formales Rechts', Acta Juridica Academiae Scientiarum Hungaricae, 26(1-2), pp. 235-241 \{reprinted in <http://mek.oszk.hu/15500/15540>, 116-122\}. 
Therefore, from a legal point of view, the change of regimes in Central and Eastern Europe is not qualified to have been a revolution. For this very reason, and since the nations concerned have the advantage of legal continuity, their laws were not discontinued in a technical sense.

\section{Rule of Law as a New Base}

Declaring revolution will necessarily imply the fracturing of legal continuity. In case of discontinuity, the chain of legal validity is broken, and the state must apply anew for international recognition. In case of non-revolutionary transition, it will remain at the discretion of the new establishment to decide how much and in which respect to depart from and amend-if at all-old conditions.

In Hungary, the transition was rather peaceful and gradual, resulting in gapless continuity. Hungary could therefore profess the ideal of parliamentary, constitutional democracy from the first moment of its renewed existence and not simply for mere ideological legitimization.

Accordingly, the topical question is the following: what is the message of accepting the Rule of Law after 40 years of communist dictatorship, the annihilation of European and national values, the brutal reprisal against opponents and the intimidation of the rest, the destruction of economy, the waste of reserves, the corruption of morals-eventually all having pushed the whole nation into a kind of total bankruptcy? Surely, the ideal of the Rule of Law is indivisible. Certainly, it includes respect for prevailing law, recognition of previous conditions as legal ones, and the reference to nothing but the law in force at the time when those past incidences that need legal assessment have occurred.

Thus, if anyone is removed, denied an unlawful benefit, identified in relationship with, or reprehended for past action, all such acts can only be done through common legal procedures and according to the law in force when the act was committed.

The ideal of the Rule of Law has been made the touchstone of the new regime. Accordingly, the state can only act through and justifiably within its available legal mechanisms.

\section{Rule of Law in Exceptional Situations}

The requirements of the Rule of Law have been historically formed under certain preconditions and assumptions. First, historically, they fitted the development pattern characteristic of the West of Europe, rooted in its socially somewhat balanced and consolidated conditions. That is to say, those requirements have never been challenged to cope with 
limiting cases and extraordinary conditions that are to characterize the Central and Eastern European transition.

The Rule of Law offers a set of principles for consideration and requires that action is channeled through legally justifiable procedures. The demand is absolute but not for its own sake. Legal procedures cannot threaten the chance of bare societal survival, and the exceptional handling of exceptional conditions cannot be precluded. Despite ts practical implementation, the Rule of Law is not to be used for that it will be used for legitimating illegal situations.

Ideas are a function of the foresight of effects. ${ }^{5}$ In law, assumptions are usually backed by the vision of some well-ordered ordinary processes. This also holds for exceptional cases such as the regulation for emergency conditions, born out of the crisis of the Weimar Republic, differentiating between ordinary and extraordinary conditions. Nevertheless, the vision of exception is also built on the foresight of what can actually be envisaged upon the experience of normality, and those departures from and deviances to it which are collected in historical memory. The claim for the law to be universally valid and obligatory can only be made absolute within the frame of such an understanding.

In a conflicting situation, if there is no statutory resolution, a gap is usually construed in the law, only to be filled by the proceeding legal authority. General principles can justify that law stipulations do not apply and that there can be no legal solution within their reach; thus, a second, subsidiary order, the one defined by the general principles, will come to the forefront to decide. This is a case of the failure of regulation rather than the rejection thereof. Within the reach of general principles, the judicial filling of the gap will justify that, notwithstanding the failure, the case is covered by the law, and the general principles will offer a solution.

The Rule of Law requires the use of available procedures and observation of principles. With regard to itself, however, it cannot make assumptions as to the preconditions of its own relevance and obligatory nature. This may result in conflicting situations. With respect to the Rule of Law, these must also be resolved within the boundaries of law.

\section{The Case of a State Non-abiding by its Law}

The Rule of Law requires that legal proceedings only be launched with reference to the original legal situation and according to the available legal instrumentality. At the same time, however, the requirements of the Rule of Law do not provide any criteria for their own foundations, presuppositions, and relevance. 
The law's inability to stipulate on its own foundations, however, cannot be taken as a burden upon or an internal contradiction of it, ones to be resolved once and for all. The dilemma involved is a paradox of formal legal cultures, arising from the conflict between the formalism legal procedures take and the substance that the practice of law has to offer. In the final analysis, it results from the self-referential nature of law, continually positing and reestablishing what it is but not what preconditions it. ${ }^{6}$

Let us take the issue of statutory limitations ${ }^{7}$ as an example. This is a kind of institutional guarantee that after a given period, no further action will take effect, unless certain actions in law that can break its continuation are instituted. Under well-balanced social conditions and legal implementation, statutory limitations establish a time-based limitation on the state's prerogative to inflict punishment and the citizens' right to instigate legal proceedings. However, what is the consequence if the state does not use this instrumentality for fulfilling its punitive responsibility but rather as a perspective for avoiding fulfillment? What if the state itself becomes the perpetrator? What if the politics of the state are backed only by committed crimes and rewarded state criminals?

Let us take an example-apparently extreme but by far not unrealistic-from World War II and its aftermath in Central European history. Regarding incidences of rape, when an official notice was made, the commanders of the occupying forces reacted abruptly under military law by shooting the offender. It could only be established subsequently that this was the exception. The normal practice was to expose those making complaint (i.e., the victim and/or their relative) to immediate brutal, often murderous destiny. The invaders preferred to eradicate the trouble itself once and for all, and only if proved not to be feasible for any reason, they resorted to kinds of legal or quasi-legal proceedings. In any case, the roles of the victim and the guilty were in fact mixed, and the only secure way was not to take cognizance of the crime committed. Is it then reasonable, fitting within the morality of the Rule of Law, that those transgressing any law and order would be the first beneficiary of the protection extended by a new law and order? That the new Rule of Law must be tested (and corrupted) from the very beginning by granting unpunishability for state-organized murderers, all this simply because the running amok did not last for a shorter period of time? Simply because they were unscrupulous enough to make their crimes officially unnoticeable? Because they held on long enough so that both their self-granted statutory limitations could pass and grant a pardon to make the rest unpunishable?

6 Cf. Varga, Csaba (1991) 'On Judicial Ascertainment of Facts', Ratio Juris, 4(1), pp. 61-71 \&<https://booksc.org/ book/9571753/a26400>.

7 Or Verjährung, or péremption; prescription; extinction d'un crime. 
In law, there is no unobjectionable answer to limiting questions. In borderline cases, the law is always ambivalent, providing foreseeable patterns to foreseeable events in society, with its routine covering only routine conditions.

Nevertheless, a routine answer to a non-routine question has no stronger argument to defend than a non-routine answer to such a question. With the legal aspects in the background, the built-in sequence of principles, rules, and exceptions to rules, and the eyes of the Goddess of Justice can equally be seen as impartial objectiveness and blindness. That is, from the available legal stuff another response can also be construed based upon principles and the merits crying for exception.

In the name of law, a response can be formulated according to which (a) reference to the formal system of available rules is no longer relevant and applicable to the case; therefore, (b) it must be judged by the principles that justify departure from routine ruling.

Law is not a decision-exacting automaton, as statutory positivism may have believed. As classics taught, ius is the profession and art of the materialization of justice, which must prevail under changing conditions. That is, law is a medium of justice to prevail, with only stepping stones and channels and methods of reasoning afforded for a process to identify it, having neither ready-made answers nor definite choices at the beginning. This is why, in developed legal cultures, literature relating to the general principles of law is as large as the doctrinal treatment of statutory instruments. Thus, we should know more of the old principles, such as what the deep message of the maxim "nobody may profit from his wrong" is.

In the final analysis, once the routine is questioned, the insistence on routine is just as much one of the choices for a genuinely creative, responsible, and responsive decision as the one based upon substantive argumentation. Eventually, any of them are only justified by a political position.

Accordingly, statutory limitations assume that the state abides by its laws, and crime is usually followed by prosecution. If this is not the case, one may doubt whether the mere physical passing of the time can eventually lead to legal extinction.

\section{The Variety of Paths and Ways in Law}

In addition to legally formalized procedures, there is a variety of other available means. We can choose any and many at will, for what is not forbidden is permitted in law. ${ }^{9}$ Our free

8 Corresponding to what is known as <https://en.wikipedia.org/wiki/Ex_turpi_causa_non_oritur_actio>, treated by Yale, D. E. C. (1971) 'Ex Turpi Causa Non Oritur Actio', The Cambridge Law Journal, 29(1), pp. 17-19.

9 Cf. <https://en.wikipedia.org/wiki/Everything_which_is_not_forbidden_is_allowed>. 
scope of action can only be limited by the instruments of human rights-both domestic and international.

Differing types of action, the fulfillment of which (a) is a legal obligation, (b) is specifically allowed by the law, (c) is only regulated by the law in a specific relation, connection, or domain, or (d) falls entirely outside the law, can equally be undertaken, following parallel tactics and ways as well. Legalized and non-legalized modes of action can equally be instrumental in the achievement of the desired result, successfully complementing one another.

Legal considerations can only delimitate the choice that we make from among actions procedurally protected by the law. The variety of paths and ways that can also be chosen is certainly larger. Considerations of principles and practical insights can nevertheless suggest that, for coming to terms with the wrong and injustices of the past, in whatever form and option of it is selected, legal instrumentality is also to be used. 


\title{
"RADICAL EVIL" ON TRIAL (On the Historical Setting, Political Aspects, and Legal Conditions of Transitional Justice Facing the Crimes of Dictatorial Regimes) ${ }^{1}$
}

\begin{abstract}
1. The Quest 2. Historical Background 3. Normative Dimensions (3.1 Political Aspects 3.2 Moral Aspects 3.3 Legal Aspects) 4. The Turn of Ideas 5. Conclusion

ABSTRACT Reconsidering the historical overview given partly posthumously by the late liberal criminal lawyer and legal philosopher CARLOS SANTIAGO NINO, while reassessing a few political dilemmas about, as well as moral motives and legal arguments for and against, the judicial way of coping with the criminal legacies of dictatorial regimes by their successors under the Rule of Law, it is concluded that the usual excuses (referring to lack of agency, necessity, lawful defense, due obedience, statute of limitations, selectivity of punishment, and/or act of self-amnesty) hardly represent any irrefutable defense value. The genuine issue is the priority of practical problem-solving - a vivid quest also in law that can only be the result of careful pondering and balancing, in which the representative of the legal profession should not side with limiting position without sober assessment of their own when conflicts of values and/or interests are at stake, or the law's instrumentality is always much richer than any particular formula actually applied in everyday routine.
\end{abstract}

KEYWORDS post-WWII trials in Europe and Japan; political and moral aspects of transitional justice; due obedience as self-defense; statute of limitations; international involvement in transitional justice

\section{The Quest}

Carlos Santiago Nino, professor of legal philosophy in Buenos Aires and author of books on the philosophy of rights and liberal criminal theory, ${ }^{2}$ spent the 1980 s as an ad-

1 The book was bought and the paper written during my official visit in Canada, which ended by joining my friend, Professor BJARNe MELKEviK, in his home in Québec as a weekly extension under duress, when the US 9/11 events forced all planes to the ground. First published in Hungarian in 2002. Earlier versions in English do include (2007) "Radical Evil" on Trial (On the Historical Setting, Political Aspects and Legal Conditions of Transitional Justice Facing the Crimes of Dictatorial Regimes)', Central European Political Science Review, 8(No.29), pp. 146-161 reprinted in Varga, Csaba (2008) Transition? To Rule of Law? Constitutionalism and Transitional Justice Challenged in Central \& Eastern Europe. Pomáz: Kráter 292 pp. [PoLíSz sorozat könyvei 7] \& <http:// mek.oszk.hu/14800/14851> on pp. 220-235.

2 (1943-1993); cf. <https://es.wikipedia.org/wiki/Carlos_Santiago_Nino> \& < http://www.stafforini.com/blog/ carlos-santiago-nino-a-bibliography/>. 
vocate of the civil resistance against the regime of generals and then as a special advisor to President ALFonsín, ${ }^{3}$ especially in matters of facing the past. His writings from this early time-moderate and responsibly balanced, yet definitely raising the dilemmas of historical justice-provoked a storm among his one-time friends from Yale Law School, protagonists of the abstract protection of rights. ${ }^{4}$ NINO may have therefore felt the necessity of a summation (to be taken by us also as a posthumous message), borrowing IMMANUEL KANT's moral philosophical term (re-formulated by HANNAH ARENDT in a symbolic sense) ${ }^{5}$ for its title. ${ }^{6}$ The book provides some orientation in the prolific debate between the extremes of the principled stand of legal incompetence ${ }^{7}$ and the one extending protection to victims of criminal abuses

3 Cf. <https://en.wikipedia.org/wiki/Raúl_Alfonsín>.

4 Cf. Nino, Carlos Santiago (1985) 'The Human Rights Policy of the Argentine Constitutional Government: A Reply', Yale Journal of International Law, 11(1), pp. 217-230; Nino, Carlos Santiago (1991) 'The Duty to Prosecute Past Abuses of Human Rights Put into Context: The Case of Argentina', Yale Law Journal, 100(8), pp. 2619-2640 $\&<$ https://digitalcommons.law.yale.edu/ylj/volioo/iss8/11/> [with comments by Orentlicher, Diane F. (1991) 'A Reply to Professor Nino', ibid., pp. 2641-2643 \& <https://digitalcommons.law.yale.edu/ylj/volioo/iss8/12/> as well as Nino, Carlos Santiago (1993) 'When Just Punishment is Impossible' in Teitel, Ruti et al. (1993) Truth and Justice: The Delicate Balance (The Documentation of Prior Regimes and Individual Rights). Budapest: CEU Budapest College Legal Studies Program: The Institute for Constitutional and Legislative Policy 164 pp. [Working Paper 1] on pp. 67-74.

5 From "radix malorum" to "das radikal Böse"; cf. <https://en.wikipedia.org/wiki/Radical_evil>, as well as Bernstein, Richard J. (2002) 'Reflections on Radical Evil: Arendt and Kant', Soundings: An Interdisciplinary Journal, 85(1-2), pp. 17-30; Formosa, Paul (2007) 'Is Radical Evil Banal? Is Banal Evil Radical?', Philosophy \& Social Criticism, 33(6), pp. 717-735; Botero, Adolfo Jerónimo, Granobles, Yuliana Leal (2013) 'Radical Evil and Banality of Evil: Two Faces of Horror of Totalitarian Regimes from Hannah Arendt's Perspective', Universitas Philosophica, 30(No.60), pp. 99-126 <http://www.scielo.org.co/scielo.php?pid=S0120-53232013000100005\&script=sci_ abstract\&tlng=en>; Newman, Jeffrey (2014), 'Hannah Arendt: Radical Evil, Radical Hope', European Judaism: A Journal for the New Europe, 47(1), pp. 60-71.

6 Nino, Carlos Santiago (1996) Radical Evil on Trial. New Haven \& London: Yale University Press xii+221 pp. (in case of reference in the text, with page numbers only).

7 E.g., Huntington, Samuel P. (1991) The Third Wave: Democratization in the Late Twentieth Century. Norman \& London: University of Oklahoma Press xvii+366 pp. and Ackerman, Bruce (1992) The Future of Liberal Revolution. New Haven \& London: Yale University Press viii+152 pp. I was somewhat startled by the unanimity with which renowned scholars (ranging from the one-time Vice-President of the Spanish Constitutional Court to the acting Foreign Minister of Poland) still advocated, without further ado, the Spanish way to be adopted as a master pattern by the huge Central \& Eastern European region (conquered by a foreign army and kept in tight check through puppet governments) at a recent academic event, proposing a definite break with the past without having ever faced it, that is, total and mutual oblivion, equaling to amnesia. It appeared only from the concluding word by the President of the Open Society Foundation that the organizers considered, tellingly, facing the past and democracy building not in terms of synonymity or mutual complementation but as concepts eventually neutralizing and excluding one another. Rosenfeld, Michel, Guerra, Luis López, Geremek, Bronislaw, Neier, Aryeh (et al.) (1998) 'Conference on Peaceful Transition to Constitutional Democracy: Jacob Burns Institute for Advanced Legal Studies, April 8, 1997', Cardozo Law Review, 19(6), pp. 1891-1985. 
as well. ${ }^{8}$ In their last meeting in Latin America, Professor OwEN FIss of Yale had been given the manuscript to prepare it for publication; eventually, he had also edited it subsequent to the author's death. This is a magisterial work by a great mind, by far not critically exploited ever since, ${ }^{9}$ although this very contribution was among the first to raise the torturous issue, having become topical after the end-of-the-millennium collapse of contemporary dictatorships again, recalling the spirit of the Nuremberg and Tokyo trials in facing kinds of state-organized genocide: what is to be done, if at all, with those representatives of state power who had degenerated to perpetrating crimes and abuses of human rights? Early, in pondering the availability of an honest response, ${ }^{10}$ he became one of the firsts who went on unnoticed, eventually crowded out of the professional debate of the master minds of our new civilization heralding the mainstream trend of "constitutional revolution," rich in logical consequentiality but imbued with practical irresponsibility because they were deduced from principles but hardly harmonized with responsive compromises to those truths that had been suffered through by the very lives of generations.

\section{Historical Background}

When surveying pieces of experience gathered from mid-twentieth century historical scenes, the first task is to overview the actual purports of the challenge with factors of both failure and success named.

8 For example, Garro, Alejandro M. (1993) 'Nine Years of Transition to Democracy in Argentina: Partial Failure or Qualified Success?', Columbia Journal of Transnational Law, 31(1), pp. 1-102 and Malamud-Goti, Faime 'Punishing Human Rights Abuses in Fledgling Democracies: The Case of Argentina' in Roht-Arriaza, Naomi (ed.) (1995) Impunity and Human Rights in International Law and Practice. New York: Oxford University Press xiii+398 pp. on pp. 160-170.

9 For reviews, see de Castro, Marcus Faro (1997) in The Law and Politics Book Review, VII(6), pp. 262-265; Presa, Conceptión Gimena (1998) in Droit et Société, (No.38), pp. 145-149; Jones, D. (1998) in Ethics \& International Affairs, 12(1), pp. 227-228; Elshlain, Jean Belhhe (1998) in Political Theory, XXVI(3), pp. 419-422; Jones, Drolay (1998) in Ethics and Jal's Affairs, XII, pp. 227-228; Millán, Juan A. (1999) in The American Journal of International Law, 93, pp. 548-551; Chaffee, Wilber A. (2000) in Hispanic American Historical Review, LXXX(1), pp. 217-218; Jupine, Joseph, Helmke, Gretchen (2002) in Comparative Political Studies, 34(2), pp. 120-126; in addition to Pereira, Anthony (1998) in The Americas: A Quarterly Review of Inter-American Cultural History, 54(3) as well as Jones, Dorothy V. (1998) in Ethics $\&$ International Affairs, 12 and also Cardenas, Sonia (2000) in Latin American Research Review 35(2).

10 Having spent two semesters as an American Council of Learned Societies fellow at Yale Law School in 1987 to 1988, I had ample opportunities to get acquainted with Professor Nino in person, then visiting and lecturing there. Subsequently, he regularly mailed me press cuttings on attempts in Argentina to come to terms with the past. Later on, serving as political adviser to the prime minister in the first freely elected government of Hungary, I turned to Professor Nino from 1990 on, asking for background literature-and only receiving news about his impaired health as reply, accompanied by a few documents, as remembered in his book (p. 24). 
In Germany, the Nuremberg trials may have hardly been deemed successful by the then prevailing public opinion. The allegation according to which National Socialism was a good idea - though badly implemented - was found to be correct by $53 \%$ of the German population before 1946 and by $40 \%$ in 1946. Nevertheless, increase in support followed, with $53 \%$ agreeing to it in 1947 and with $55.5 \%$ in 1948. Later on, by own jurisdiction, German courts imposed less than 100 life sentences and less than 300 imprisonments between 1959 and 1969, and 157 life sentences (out of 6,000 convictions) between 1970 and 1982-as opposed to the approximately 26,000 executions during the HITLERite regime (p. $\left.9^{11}\right) .^{12}$

In Austria, a governmental decree addressed those strongly and weakly implicated in the regime. Former Gestapo and SS members as well as anyone honored by the party and/or having financially benefited from the regime had to face severe punishment. The rest had to face mostly a loss of public functions and homes; half of the judges were replaced or not reappointed, with criminal procedures instituted against many. All in all, people's tribunals proceeded against a total of 17,500 people, 43 of which ended with capital sentences and 29 executed. Nevertheless, before the elections in 1949, an amnesty was granted to those who had only been weakly implicated, and everyone blamed exclusively for having adhered to the party was exonerated by $1957\left(\mathrm{p} \cdot 10^{13}\right)$.

In Italy, following the ceasefire concluded by PiEtro BADoglio, a series of decrees was passed to conduct a purge and prosecution as well as to appoint Count CARLO SFORZA as the High Commissioner for Defascization. The chances of prosecution were further strengthened in 1944 by some vague definitions of crimes (as the author remarks, with the aim of "hitting high and forgiving below") and by reintroducing the old penal code that had been once annulled by the Fascists. However, in the long run, judicialization turned into a fiasco, the High Commissioner's Office was later dissolved, and the Minister of Justice had to finally announce an amnesty. It serves as a bitter piece of experience that private revenge offered itself to be the only way having worked at all, officially targeting 1,732 lives (according to neofascists, 3,400,000, with literature estimates of around 30,000; pp. 10-11 $1^{14}$ ).

11 Cf. Herz, John H. (1982) 'Denazification and Related Policies' in Herz, John H. (ed.) From Dictatorship to Democracy: Coping with the Legacies of Authoritarianism and Totalitarianism. Westport, Conn.: Greenwood xii+311 pp. [Contributions in Political Science 9] on pp. 15-38 on p. 20.

12 Rückert, Adalbert (1980) The Investigation of Nazi Crimes 1945-1978: A Documentation [Die Strafverfolgung nationalsozialistischer Verbrechen 1945 bis 1978]. Hamden, Conn.: Achron Book 145 pp., especially on p. 117, recalls, from official data by the Ministry of Justice, about 85,802 cases heard by German judicial fora between May 8, 1945 and December 31, 1978, among which 6,440 were concluded finally. These included 12 death and 156 life sentences, 114 fines, and one case remitted to a juvenile court.

13 Cf. Engelmann, Frederick C. (1982) 'How Austria has Coped with Two Dictatorial Legacies' in Herz (ed.), From Dictatorship..., on p. 144.

14 Cf. DiPalma, Giuseppe (1982) 'Italy: Is there a Legacy and is it Fascist?' in ibid., pp. 119 et seq. 
In France, treason was redefined in $\$ 75$ of the code pénal with a retroactive effect in such broad terms that practically everyone not having expressly adhered to CHARLES DE GAULLE or joined the armed resistance could have been accused. Later, the facts that may constitute a case of collaboration in penal law were also redefined retroactively, rendering even indirect moral support of the Vichy regime liable to prosecution. As the third measure, a specific crime called "national indignity" was ex post facto defined so as to include any participation, production, or distribution of propaganda, membership in either the Commissariat for Jewish Affairs, or any organization supporting collaboration. All in all, 120,000 to 150,000 internments were ordered administratively, and 200,000 indictments took place with 100,000 sentences and 65,000 condemnations, as a result of which - until the amnesty in 1953-899 out of 7,000 death sentences were executed, 2,750 convicts were sentenced to life imprisonment, and 13,000 were condemned to forced labor. In addition, and mostly in the initial times, deliberately held ex-lex, at least 40,000 people were murdered as collaborators, mostly within kinds of private revenge either organized by left-wing groups or carried out spontaneously by the mob (pp. 11-12 $12^{15}$.

In Belgium, the Supreme Court declared all the orders by the exiled government to be valid. Approximately 400,000 persons ( $7 \%$ of the population) had to face prospects of trial, with tens of thousands condemned for collaboration. Its ex post facto broad formulation was also to cover those 60,000 having volunteered to work in Germany, so the socialist government had to issue an explanatory order in 1945 requiring additional proof of intent to help the German war machine, until the charges against the workers were eventually dropped (pp. 12-13).

In Japan, 5,500 proceedings were initiated within the personal competence of the Supreme Commander of the Allied Powers (with the exclusion of acts committed by the Japanese to the injury of the Japanese). Altogether, these resulted in 900 capital sentences and 3,500 imprisonments, less than 6,000 removals from office, and special military proceedings against a further 28 soldiers. From among the latter, seven were concluded with death sentences, 16 with life sentences, and two with imprisonment until November 1948. However, these trials had been received rather dubiously: seen as the issue of the victor's justice, the Japanese eventually placed the ashes of the seven executed into a memorial urn; later, a state monument was also erected above it in 1959 with the laudatory inscription "For the seven patriots." One of those convicted for war crimes even became a foreign minister later, and by 1950, all war criminals were freed and exonerated (pp. 13-14 $4^{16}$ ). 
In Spain, after more than 200,000 died in the prisons of the regime of FRANCISCO FRANCO between 1939 and 1942, Prime Minister Adolfo SÚAREZ promised not to purge, while the opposition urged an amnesty for the so-called dissidents and terrorists. Finally, in October 1977, SÚAREZ had to announce a general amnesty for all politically motivated crimes (pp. 16-17 $7^{17}$ ).

In Portugal, in 1976, the constitutional president, General Antonio RamalHo EANES and Prime Minister MARIO SOARES initiated purges and expulsions and even imprisonments against some leaders held responsible, yet the unfolding sharp political controversies had practically blocked any actual progress (pp. 17-18).

In Greece, in response to the soft measures of the interim government of Constantine KARAMANLIS, popular actions led to the declaration in a specific decree that legal offenses committed during the dictatorship would never be favored by an amnesty. A coup followed in reaction, but the government arrested the involved military leaders under the charge of high treason. Finally, in 1975, a parliamentary declaration manifested with retroactive force that the crimes of the dictatorship would be exempted from prescription. Proceedings were instituted against 18 former leaders, with governmental intervention subsequently reducing all of the imposed death sentences to life sentences. Then, 100 to 400 more proceedings were initiated under popular pressure (pp. 18-2018).

\section{Normative Dimensions}

Political, moral, and legal considerations encouraging or discouraging trials in facing the past instances of "radical evil" need to be overviewed as well.

\subsection{Political Aspects}

Within the range of political aspects, Nino criticizes the claim according to which facing the past, whatever it is, amounts to either a limitation of constitutionality or mere injustice. He argues the contrary, substantiating why this is exactly the fulfillment of lawful expectations through which any constitutional trust can be founded and reinforced at all.

17 Cf. Santamaría, Julian (1982) 'Transición controlada y dificultades de consolidación: El ejemplo español' in Santamaría, Julian (ed.) Transición a la democracia en el sur de Europa y America Latina. Madrid: Centro de Investigaciones Sociologicas vii+421 pp. [Colección 'Monografias' 49] on pp. 371-417, pp. 387 et seq. In broader contexts, cf. also Pérez-Díaz, Victor (1999) Spain at the Crossroads: Civil Society, Politics, and the Rule of Law. Cambridge, Mass.: Harvard University Press $\mathrm{x}+214 \mathrm{pp}$.

18 Cf. Psomiades, Harry J. (1982) 'Greece: From the Colonels' Rule to Democracy' in Herz (ed.) (1982) From Dictatorship..., pp. 257 et seq. 
[T]rials for human rights violations may be much closer to what ACKERMAN labels "constitutional moments"19 than many attempts at formal or informal constitutional reforms. (p. 131) For 'The result of [...] the educative effect of the trials [...] is a process of collective deliberation that [...], despite all the tensions and bitterness, will facilitate a convergence around certain basic values or create, in RONALD DwORKIN's terms, a "community of principles", ${ }^{20}$ so vital for democracy. (p. 133)

Both the diffusion of responsibility through society and the proper dissociation of the victims (with retributive feelings among the society at large) may have a crucial role in this respect. All this can, at times, easily result from the logic of events themselves. We have known, after all, from historical examples taken from World War II and its aftermath, that while the Germans and Austrians considered their victims as aliens, the French and the Belgians circumscribed and separated the perpetrators as collaborationists from the rest of society after the end of the war. The State of Israel identified itself, for obvious reasons, with the victims and dissociated itself absolutely from the perpetrators. As far as the Argentineans are concerned, they isolated those responsible from the common people first as subversive elements and then as uniformed. In contrast, writer, resistance fighter, and then President of the Czech Republic, Václav HaVel, asserted a counter-ideology for the entire Central and Eastern European region, excluding any calling to account even conceptually. According to him, "all of us are responsible, each to a different degree, for keeping the machine running. None of us is merely a victim of it, because all of us helped to create it together" (p. 201, note 11).

\subsection{Moral Aspects}

As to conceivable moral aspects (para. 4), the author finds it relevant to reassert SHKLAR's position: ${ }^{21}$ settling accounts (including Nuremberg) in terms of legalism as ideology is thoroughly unlawful. It is justifiable only in terms of legalism as social policy, using law as a political phenomenon. After all, there are sufficient grounds for it, as administration of justice sets a triple target here: (1) officially recording what actually happened, (2) strengthening the rule of law procedurally, and (3) appeasing the thirst for private revenge. In addition, trials

19 Ackerman, Bruce (1991-2014) We the People. Vol. I-III. Cambridge, Ma.: Belknap Press of Harvard University Press.

20 Dworkin, Ronald (1986) Law's Empire. Cambridge, Ma.: Belknap Press of Harvard University Press xiii+470 pp. on pp. 208-224.

21 Cf. Shklar, Judith N. (1986) Legalism: Law, Morals, and Political Trials. Cambridge, Ma.: Harvard University Press xiv +246 pp. 
may (4) help victims recover their self-respect as holders of legal rights while also (5) promoting public deliberation in a unique manner ${ }^{22}$ (pp. 146-147).

Hence, Professor Nino argues that, from a moral point of view, settling accounts raises no particular problem at all. He summarizes his stand as follows, also taking into consideration the exposition of NAGEL ${ }^{23}$ :

In the end, I believe that trials for massive human rights violations can be justified on preventionist grounds provided the trials will counter those cultural patterns and the social trends that provide fertile ground for radical evil. (pp. 145-146)

\subsection{Legal Aspects}

As far as legal aspects are concerned (para. 5), the issue of legality is the prime question, to be followed by the excuses that can be brought forward at all.

According to his basic position, the usual discussion of the entire problem complex is mostly biased by a conceptual misunderstanding, for "what is really at stake is not the option of either law or morality but the confrontation between different moral values" (p. 157). Deciding whether or not a case is prosecutable, the possible circumstance that a preliminary law satisfying the requirements of nulla poena sine lege [no punishment without law] and nullum crimen sine lege [no crime without law] is sometimes not available is not in itself considered absolutely decisive-only provided, of course, that there is some adequate prior regulation available.

As soon as the validity of the laws authorizing these acts, like the anti-Semitic Nuremberg laws of the Nazi regime is shaken, the atrocities are clearly crimes according to the previous layer of valid laws! [...] These deeds should have been judged according to the crisp rules of the criminal code that was in force before being modified by the totalitarian regime, which legitimized the human rights violations. The deeds should be tried, to the extent possible, under the substantive and procedural laws, and by the judges provided by them, that would have been in place at the time of the deeds if it were not for the totalitarian enactments endorsing the abuses. This approach was followed for the most part in Greece and Argentina and could be

22 The latter two have been connected to the previous ones by Goti, Jaime Malamud (1991) 'Punishment and a Rights-based Democracy', Criminal Justice Ethics, 10(2), pp. 3-13.

23 In Weschler, Lawrence (1990) A Miracle, A Universe: Settling Accounts with Torturers. New York: Pantheon ix+293 pp., quoted by Nino, pp. 145-146. 
applied in the former communist countries in Eastern Europe. [...] The laws authorizing the abuses should be held void ex nihilo, for their undemocratic origin allows an examination of the obnoxiousness of their content. (p. 163)

Legal defense may possibly be founded upon one or more of the following claims: (1) lack of agency; (2) necessity; (3) lawful defense or self-defense, or state of war; (4) due obedience; (5) statute of limitations; and finally, (6) the selectivity of punishment. It should be borne in mind, however, that the author does not find any of them to be an unsurpassable obstacle, excluding the judicial settling of accounts from the very beginning. What they may imply is rather a reference for the lawyerly rhetoric to be rejected $a b$ ovo as a mere pretext.

Accordingly, ad (1), reference to lack of agency cannot raise any difficulties as the chain of commanding and ordering is in principle unbroken, and in practice, any reference to it equals to doubting why to call to account. For example, "the decision convicting some of the Argentine junta members [...] held each of the commanders responsible for the deeds of his subordinates without limiting or undermining the responsibility of the latter" (pp. 166-167).

$A d(2)$, revoking necessity may in itself sound conclusive. However, its judicial proof may scarcely be successful in any particular situation, as

the defense of necessity requires three conditions: (i) balance: that the evil prevented be greater than the evil caused; (ii) efficacy: that the necessary action effectively prevents the expected evil; and (iii) economy: that there be no other means less harmful for preventing the expected evil in an at least equally efficacious way. (p. 171)

$A d$ (3), invoking lawful defense or self-defense, or state of war, is not much use for excuse either. If there is no specific law available that provides such an entitlement in a democratically framed and constitutionally defendable way, its mere lack does by far not necessarily implicate the legality of the deed debated. ${ }^{24}$ Otherwise speaking, referring to any of them has no proper content, foundation, or reserve in a legally relevant context.

24 According to Alchourrón, Carlos E., Bulygin, Eugenio (1971) Normative Systems. Wien \& New York: Springer xviii+208 pp. [Library of Exact Philosophy 5] at pp. 119 et seq., law is anything but a closed system. Consequently, the lack of prohibition can imply permission only if an explanatory definition is also added: "That means that the legality of an act is not a question of logic but rather depends on evaluative questions which the courts can hardly avoid" (p. 178). I deem this conclusion worthy of consideration, although it is obviously a result of the American constitutionalizing way of argumentation. Nonetheless, I have been of the opinion (cf. Varga 'The Right to Judge the Past' [1991] in the present volume) that "what is not forbidden is permitted in law"-conceding that forbiddance can also be achieved by principles and other standards and kinds of guidance. It is to be noted that I have suggested exactly this in a paper-Varga, Csaba (1979) 'Law and its Approach as a System', Acta Juridica Academiae Scientiarum Hungaricae, 21(3-4), <http://real-j.mtak.hu/769/1/ ACTAJURIDICA_21.pdf>, pp. 295-319 \{reprinted in (1981) Informatica e Diritto, VII(2-3) \& <http://www.ittig. 
$A d$ (4), referring to due obedience or to the obligation of the subordinate, can only be based on a misunderstanding:

Insofar as due obedience is a derivative excuse based on duress or mistake, it can be regulated retroactively without affecting the principle against retroactivity of the criminal law. Because excuses are irrelevant to the lawfulness of an act, previous knowledge of such excuses should not be a prerequisite to their applicability vis-à-vis those acts. (pp. 181-182)

$A d$ (5), statute of limitations is again an easily transcendable pseudo-object as the objection itself, its weight, and most of its prerequisites make it only of rhetorical use. In the light of NINO's reasoning - albeit the personality of the perpetrator may have in the meantime changed - with easy provability elapsed and old emotions stormed anew,

these arguments in favor of a statute of limitations are weighty, but those who have committed criminal acts should not be allowed to profit from the fact that they, or the regime to which they belong, impede justice. Therefore, legal rules that suspend the statute of limitations when prosecutions are impossible also appear attractive. This may be accomplished by retroactively extending the statute or declaring it to have been suspended during the dictatorship. Initially, this seems to clash with the principle which prohibits the retroactivity of criminal legislation, and this would be illegitimate under a liberal system of criminal law. This appearance, however, is deceptive. The prohibition of retroactive criminal laws is linked to the requirement that one must consent to assume the liability of punishment. [...] But consent is tied only to knowledge of those circumstances which are relevant to the unlawfulness of the act - the fact that this is one of the acts that the law seeks to prevent by way of punishment-and not to knowledge of other factual or normative conditions for actually imposing punishment. The statue of limitations is not relevant to the legality of the act. Prevention by way of punishment is in no way qualified by the delineation of a term during which the state's claim to punishment would expire. [...] People should decide whether or not to commit an act according to norms of unlawfulness and consequently run the risk of relying on factors which are irrelevant to such norms. If

cnr.it/EditoriaServizi/AttivitaEditoriale/InformaticaEDiritto/1981_02-03_177-199_Varga.pdf>, pp. 177-199referred to for the refoundation of the consciousness of rights in opposition to the prevailing socialist regime by Sólyom, László (1985) 'Mit szabad és mit nem? Capriccio polgári jogi témákra' [What is permitted and what is not? Capriccio for civil law topics], Valóság, XXVIII(8), pp. 12-24, which stood for a key position then, in an early phase of some hoped-for transition. 
somebody commits a crime because he hopes that before he is caught the statute of limitations will run out, he must bear the burden of relying on factors alien to the legality of the act, just like the person who hopes that he will not be punished because all the prisons in the country will burn. Therefore, I do not believe that the principle prohibiting retroactive criminal legislation is an obstacle to extending or abolishing statutes of limitations for massive human rights abuses. The only issue that may legitimately arise is whether it is just to punish somebody for acts done in the distant past when that person has changed significantly in the interim. (pp. 182-183)

$A d$ (6), the selectivity of punishment (with the ways to select for prosecution from among those involved) cannot erect any major obstacle either, for

nobody has a right that certain persons be punished and, consequently, nobody has a right not to be punished because others are not. Punishment does not call for equal treatment because it is not a benefit which is the object of positive rights. Punishment is the object of positive goals and only of negative rights. Punishment may therefore be selectively relinquished through persecutorial discretion, amnesties, or pardons without raising claims of equal treatment. ${ }^{26}$ This selectivity, of course, should not be arbitrary but rather aimed at efficiently achieving legitimate goals. (p. 183)

Let us add one more conceivable defense, notably (7) the act of self-amnesty, noticed by just one of the reviewers, as follows:

Persons should not benefit from their own wrongs-that is, those who have contributed to the suspension of democratically enacted laws that made human rights abuses criminal acts should not benefit from that decision by successfully claiming that no law criminalized their conduct or that non-democratic laws sanctioned or pardoned such acts. This interpretation is consistent with the current trend under

25 For example, Laquièze, Alain (2000) 'Le débat de 1964 sur l'imprescriptibilité des crimes contre l'humanité', Droits, (No.31), pp. 18-40, and especially on p. 25, declares-inspired by Glaser, Stefan (1964) in Le Monde (December 17), p. 10: "Prescription [...] does imply a benefit but not constitute a right"-that "prescription is not a fundamental right." In terms of practice, Roht-Arriaza, Naomi (1995) 'Special Problems of a Duty to Prosecute: Derogation, Amnesties, Statutes of Limitation, and Superior Orders' in Roht-Arriaza (ed.), Impunity and Human Rights... on pp. 57-70, identifies the disregard of limitations for the period of the practical denial of access to justice in the case initiated by the United States against an Argentinean general having fled to its territory in Forti v. Suarez-Mason, 672 F. Supp. 1531, 1550 (N.D. Cal. 1988).

26 Retributionism is self-destroying from the very start as it can only lead to the utterly unprincipled exemption of "everyone has to be punished, so no one is" (p. 183). 
international law-as evidenced by reports of the UN Human Rights Committees and the Inter-American Commission on Human Rights to the effect that domestic laws, such as self-amnesties, that grant impunity to perpetrators of abuses should be denied legitimacy. ${ }^{27}$

\section{The Turn of Ideas}

After all, there have already been signs of a shift of opinion since the turn of the millennia, with the international community to decide in the dilemma of whether or not to face past injustices in law, in which way and upon the initiative of whom, and with which distribution of its costs and burdens of proof in their resolution. ${ }^{28}$ The dogmatically merciless indifference of human rights activists toward past victims by reassessing the perpetrators' unilateral rights may have, in the meantime, corroded their chance in democratic institution building, compelling them to reconsider why the memory of the unburied dead is alive after decades and why unhealed wounds are opening up again.

While earlier, those professionally committed to the cause of human rights were suspicious of limitation of rights whenever a posterior government attempted to examine past legal offenses-thereby breaking the continuity of a prior dictatorship smoothly transiting to an arrangement based upon the rule of law-they are now almost inclined to impute the downright obligation to the successor government to legally face the major injustices committed by the prior dictatorship. If they now hesitate at all, they do so in selecting the justifiable means-whether or not also involving the judicial path or any other channel considered satisfactory there and then in the given case. For instance, the suggestion of DianE F. ORENTLICHER fits in well with this change of attitude. According to her, the prosecution of crimes committed and left unpunished for political reasons by the past regime should be made a duty of the successor state, as prescribed formally by international law. This is what even Nino finds an exaggeration, suggesting a more moderate solution which may well accord to his own sense of responsibility. He opts for international proceedings under international law, conducted by and upon the responsibility of an international actor or at least for domestic attempt at settlement and/or proceedings as supported by international fora. For

27 Millán, [review], 1999 on p. 549.

28 Cf. Varga, Csaba (ed.) (1998) Kiáltás gyakorlatiasságérta jogállami átmenetben [A cry for practicality in transition to the rule of law]. Budapest: [AKAPrint] 122 pp. [A Windsor Klub könyvei II], part on 'A múlt meghaladása' [Overcoming the past], pp. 73-117 as well as Varga, Csaba (ed.) (1994) Coming to Terms with the Past under the Rule of Law: The German and the Czech Models. Budapest xxvii+178 pp. [Windsor Klub] \& <http://mek.oszk. $\mathrm{hu} / 14300 / 14310 / 14310 . p d f>$. 
him, this is the proper way to prevent a situation in which the domestic democracy-building by a successor state might get disadvantaged or simply blocked against a formal international obligation, providing for administration of justice in previously codified forms and procedures (pp. 188-189).

\section{Conclusion}

The posthumous message of NinO's stand in such a sensitive topic is exemplary for the united treatment of social and lawyerly responsibility. In his principles and theorizing, Professor CARlos SAntiago Nino was drawing from Western liberal traditions, and in his practical responses, he searched for a path through laborious work to eventually reach optimum compromises within the bounds of justifiability. His oeuvre is all along imbued with the pathos of taking seriously the instrumental values to be implemented through legal mediation-aware of the priority of practical problem-solving that can only be the result of careful pondering, sensing, and balancing, convinced that the lawyer must not act as a sales agent or hawker, siding with any limiting position in conflicts of values and/or major interests without own sober assessment. Therefore, he was also aware of the fact that the law's instrumentality is by far richer than any particular procedural formula actually applied in everyday routine.

Law is a complex (and never fully exploited) aggregate of instrumental values, of working principles as well as of ways of (re)establishing coherences and inferences (linkages and connections, imputations, and ascriptions)-in brief, paths and ways, forms, and modes of procedure-which we both serve and reproduce by each act of procedure through our intellectual operations and reconstructions by mentally and also formally confronting available kinds of reasoning and argumentation when substantiating the final decision.

Accordingly, practical challenge and conceivable legal response are not simply meant to qualify (by judging, criticizing, or even destroying) each other. Discourses in law are to strengthen them to dialogue and encounter; within the (formally perfected but never exhaustively actualized) bounds of social acceptability and legal justifiability, they are to be ascertained and redefined at any time in sociolegal continuity, taken -instead of strict formalism-in an exclusively widened macro-sociological (cultural and civilizational) sense. 


\title{
WHY HAVING FAILED IN FACING THE PAST? ${ }^{1}$
}

\begin{abstract}
The fact that caesura had been drawn after the fall of the brown dictatorship led to the exigency of calling to account after the red dictatorship fell. However, there is no automatism, only the responsible foundation and development of a due procedure. Having no "royal path" to reach the goal, our own culture is expected to work out its own due response.
\end{abstract}

KEYWORDS coming to terms with the past; statutory limitations; rule of law; constitutional adjudication; duty and responsibility of action

Taking a look in general at the progress of your professional life, one can see that it has been steadily advancing ever since. You have achieved almost every peak in scholarship in your own field of study. Mastering several languages, you have taught and conducted research in Australia, in Japan, in Scotland, and America. As an active member in various scholarly associations and author as well as editor of a great number of publications, you are a regular participant at international congresses. You are a professor at the Faculty of Law of the Pázmány Péter Catholic University of Hungary and the director of its Institute for Legal Philosophy.

How would you describe the family background, the school, and the intellectual milieu that have contributed to this outstanding accomplishment? How did you endure the decades of communist rule?

- My father shifted from the family tradition of manufacturing coaches to the construction of cars, earning professional, human, and social authority in the fields of automobilism, motor sports, and both civil and military aviation. I was born into a harmonious, hardworking family with a responsibility for the public as well. When the communists took power in Hungary, I was a young child going to elementary school. Church schools were liquidated, and our family company fell victim to nationalization. Under the communist regime, I got to know barbarism, crude simplism, and blinded narrow-mindedness. Our commitment to the nation's fate with the cause of Catholicism and the fact that we could, even amidst various but continued kinds of persecution, help others who were even more

1 An interview given to the Hungarian leading daily Magyar Nemzet [Hungarian Nation] in 2002 but that was not published until a year later due to political controversy in the background. In English, it was published already in Varga, Csaba (2008) Transition? To Rule of Law? Constitutionalism and Transitional Justice Challenged in Central \&Eastern Europe. Pomáz: Kráter 292 pp. [PoLíSz sorozat könyvei 7] \&<http://mek.oszk.hu/14800/14851> on pp. 107-116. 
miserable than us gave our life a deeper meaning and a feeling of integrity. I certainly met impressive people, especially in church and at times at school, but it was my stubborn resistance that determined my development. In parallel with my secondary school, I served as a cantor of a suburban church while studying as an enthusiastic organist at the Pécs Conservatory. My early interest in technical (mechanical) construction was soon replaced by defiant self-expression, primarily in writing poems and aphorisms. Having finished secondary school, I had to spend 13 months working as a miner in the neighborhood of my native town to be able to attend university at all. This was the only way to "pay the penalty" for the "original sin" of having belonged to the "exploiting class" (according to the stigma of the age). Just when I finally managed to return to my hometown and the Faculty of Law at the University of Pécs from the far-away Faculty of Mine Engineering of the Technical University in Miskolc, a political police action was to be launched against the Regnum Marianum clerical community dedicated to the education of the youth. Priests were unlawfully arrested on trumped-up charges of alleged "adulteration" of the youth and conspiracy against the state and social order of the peoples' democracy. As part of the action, the secret police started to threaten and harass me: I was subjected to interrogation, accused of "subversive activity" aimed at "overthrowing" the socialist order. What they longed for was obviously a spectacular lawsuit. Such a conflict with the authorities of the Ministry of the Interior, of course, rendered it inconceivable for me to remain at the university after completing my studies. Fortunately, help arrived soon in the person of Professor KÁLMÁn KulCSÁR, who used to lecture at Pécs at the time and was an acclaimed authority in legal sociology, which, as a subject in socialism, he had recently re-founded. ${ }^{2}$ He rescued me from my desperate situation by offering me a position in the stronghold of socialist jurisprudence, the Institute for Legal and Administrative Sciences of the Hungarian Academy of Sciences, where genuine scholarship was cultivated (in contrast with the mediocre provincialism of universities) by an excellent staff at a level that was also competitive by international standards. Of course, due to my intellectual disposition, I encountered some hardships there, but the unconditional respect for the performance of my director, academician IMRE SzABó, helped me through them.

As a member of the Advisory Board of Prime Minister JózSEF ANTALL from 1991 to 1994, you extended your intellectual work to the field of politics in practice. What inspired you, as a theoretical

2 (1928-2010); cf. <https://en.wikipedia.org/wiki/Kálmán_Kulcsár> \& <https://www.munzinger.de/search/ portrait/kalman+kulcsar/o/19225.html>, as well as Varga, Csaba (2016) '2oth-century Legal Philosophy in Hungary' in Pattaro, Enrico, Roversi, Corrado (ed.) Legal Philosophy in the Twentieth Century: The Civil Law World. Tome 1: Language Areas. Dordrecht: Springer xxxix+1062 pp. [A Treatise of Legal Philosophy and General Jurisprudence 12] $\{\&<$ https://b-ok.xyz/book/2742951/573fcd $>\}$ on pp. 635-651 on para. 19.4.3, p. 647. 
professional, active basically in the field of legal philosophy, to such a step? As far as I know, you have not engaged in politics ever since. Back at that time, you worked on the legal foundation of one of the issues affecting society most deeply, that is, on how to face with past injustices. How far have you got on this issue personally?

- Theoretically, I have always been interested in the potential of law and in its possibilities and limits. This may manifest itself, first of all, in the legal handling of exceptional situations, differing from social normality and therefore unforeseeable by the legislator. Having examined the efforts at facing the past on the ruins of dictatorships abolished after World War II, which is necessary to found any future, I have contemplated the tasks ahead of law following communism, the other greatest evil of the twentieth century. I had to realize that although many of the answers offered by law are of a merely symbolical force (laying down an ideal without changing anything directly), they can launch or legalize dramatic social changes of directions. This may be one of the reasons why historical justice could become a key issue for us-above all, as the symbol of a new start concluding the past. The realization that no future can be built out of such a criminal past was declared by the Allies at the end of the World War II. What their "white doves" brought to Germany and Japan was not parliamentarism, constitutionalism, and rule of law but armed occupation, military occupying administration, censorship, abolishment of working self-governing institutions, breaking with earlier local authorities, dissolving prevailing social ties, and enclosing the past into penal sentences. The Allied Powers tried to create normality by "education to democracy" planned for decades to make any democratic arrangement workable at all. As one of the primary tasks of jurists is to ensure consistency in justice and in the social order alike, I had to ask myself: is there any rational explanation for the difference between the transitions following the various (brown and red) dictatorships, or had it been some unspecified vested interest in the background that compelled the Atlantic world to forbear from acting in the considered way in which it once did in the past, after World War II?

So this is how far you got in thinking?

- To apply the institutions of the Atlantic world directly onto a society deformed by nearly half a century of Soviet rule was a naive idea to say the least, especially after the attempt at adapting American law to Latin America had failed less than a decade before. ${ }^{3}$ However, what else could you expect from a country influenced by ideologies to the extent that even a few years before SAMUEL HunTINGTON's prediction of the clash of civilizations 
was formulated, ${ }^{4}$ any reference to the difference between historical cultures had been denounced with the label of social determinism as the negation of liberalism? ${ }^{5}$

What legal obstacles prevented the fulfillment of the natural social demand to close down the past in a reassuring way? Why were the bills aimed at facing the past rejected in Hungary?

-We have to recall, in connection with the efforts of MP Zsolt ZÉTÉNYI, that neither Lord KIRKHILL, recognized then as a leading legal authority of the Council of Europe, ${ }^{6}$ nor HANS-HEINRICH JESCHECK, the great representative of continental criminal jurisprudence (and intellectual mastermind of all established criminal lawyers in Central Europe as well) ${ }^{7}$ or the American professor CHERIF BASSIOUNI, having pioneered in eventually setting up international criminal jurisdiction, ${ }^{8}$ and SIMON WIESENTHAL, internationally respected for having fought for facing past crimes, ${ }^{9}$ perceived that any circumstance prevented the actual settling of accounts by which a dictatorship allowed prescription to pass its period without prosecution. Lapse of time undoubtedly actuates prescription; however, with a sound sense of law, it can hardly be said that the merely mechanically measured time in a physical sense is meant by statutory limitations. Law being a conventionally coded expression of social practicality, the result will be contrary to the very idea of law in a cynical and self-destroying way if the authority sees no legal relevance in the socialist statehood having not only degenerated into a perpetrator but also having left common crimes (murder, torture, and so on) unpunished all along as well as having punished exactly those initiating prosecution by reminding the jurisdiction of its legal obligation.

In 1992, during a conversation, you believed society would spontaneously stigmatize-by casting out-the perpetrators who had operated the dictatorship. This might have been a slow process, but in

4 Huntington, Samuel P. (1996) The Clash of Civilizations and the Remaking of World Order. New York: Simon \& Schuster $367 \mathrm{pp}$.

5 A personal memory of the professorial seminar I held at Yale Law School in the mid-1980s, when local greats who had already traveled extensively to the Soviet Union but lacked background and language skills returned with enthusiastic faith in the ultimate historical unification of West and East. I explained to these professors the complete difference between historical development, way of thinking, background conditions, a low degree of institutional structure, and, in consequence, the groundlessness of such hopes, which they in turn rejected with the jerk of their liberalism.

6 (1930-), rapporteur of the Council of Europe Committee on Legal Affairs and Human Rights; cf. <https:// en.wikipedia.org/wiki/John_Smith,_Baron_Kirkhill>.

7 (1915-2009) criminal law professor of Freiburg, director of the Max Planck Institute for Foreign and International Criminal Law; cf. <https://de.wikipedia.org/wiki/Hans-Heinrich_Jescheck>.

8 (1937-2017) criminal law professor of the Chicago DePaul University, initiator in international criminal law matters; cf. <https://en.wikipedia.org/wiki/M._Cherif_Bassiouni>.

9 (1908-2005) as a Holocaust survivor, founder of the Documentation Centre of the Association of Jewish Victims of the Nazi Regime in Vienna; cf. <https://en.wikipedia.org/wiki/Simon_Wiesenthal>. 
fact, it has not even taken place. In the meantime, the Constitutional Court declared the prescription passed and the deeds no longer touchable in law. Thereby, accountability has also become restricted and made almost impossible.

- Now the old criminal regime may even establish its innocence. All that our new regime of the Rule of Law is capable of is the indirect encouragement of future dictators: if they can keep their positions at any price until their deeds pass the period of limitations, then the succeeding constitutional state can no longer say anything about their atrocities. Meanwhile, it is known that the sentences of Nuremberg and Tokyo have, exactly half a century ago, already shaken this kind of anti-human positivistic narrow-mindedness.

Your book Transition to Rule of Law published in Budapest in 1994 considers a number of issues raised in the process of transition from quite unusual aspects. One of the remarkable ideas is, for instance, the obligation of collective deliberation with open chances, together with all the likely benefits and pitfalls. What does this mean? Can classical principles of law be questioned? Can anyone claim to be entitled to dispute the role played by the law in the maintenance of order?

- The Hungarian response to the legal nihilism in socialism is an equally destructive fetishism. In an international comparison, we have become a pitiable model of the kind of helplessly self-destructive doctrinarianism. With more experience, maturity, and balance, the German Constitutional Court has, for example, always regarded the Rule of Law as something that must not only be waved above our head as some stick. As the mediator of social order, the culture of what is known as "the Rule of Law" needs to also be nourished by the people's elementary sense of justice; therefore, the latter's widely held rightful expectations should not be trampled upon.

Law is not an inanimate object but something that operates through its institutional interpretation, and this is a function of all social culture. It is the reason why different practices can be built upon the same text in differing cultures. The reason why it is doubtful whether or not National Socialism or Bolshevism can easily be transcended is exactly that such regimes may have completely re-educated society by dictatorially extorting adjustment in almost every sphere of life, having formed background cultures in addition to legal texts. Now, by the push of such fetishization, we tend to attribute demiurgic power to the letter of the law, although it is us-starting with our own interpretation - who carry a creative capacity. Let me ask: has the law suddenly changed in the United States after September 11, 2003, or has the shock, mediated and even enhanced by the media, resulted in a reinterpretation from which an America differing in principles is now being formed by?

The dilemma with the ensuing debate around the very meaning of the transition is more active than ever, and social anxiety has not abated at all. New personal and social tragedies are being revealed 
daily. Questions emerge and are still to be answered because law cannot be abstracted from the practice ofeveryday life.

- Nevertheless, law may be formalized, impersonalized through its linguistic formulation, and even extended to whatever culture. However, as Oliver Wendell Holmes once construed, its life is still not logic alone by far: law is not merely an abstract, conceptual act. ${ }^{10}$ We, humans, have devised law as an autonomous mediator, and we try again and repeatedly to isolate it artificially. However, we are not living for the sake of complying with sheerly abstract formulas. The reason why we have law is the same why we have culture and, in it, morality: we wish to filter the contingencies of everyday life arising in the spur of the moment through standards that we have established according to our values. With culture and morality in it, law is seriously considered and mostly respected in the same way and for the same reason as our self-discipline. It is foolish to turn the instrument at one's disposal against oneself, but it is even more foolish to blame the instrument itself. The English say that law can only transform into a collective pact of suicide in a society that is suicidal anyway. Professionals of the abstract defense of human rights were already horrified at the thought of calling to account when the Argentinean junta collapsed. Because of them, the desire for any sensible resolution and its irradiating side effects has since reached global proportions; thus, the rhetoric of GEORGE SOROS's human rights watchers is also becoming more refined. While earlier they used to view any attempt by the successive government at probing into the affairs of its predecessor with suspicion of infringement upon human rights from the start, they now tend to regard the successor as bound to initiate even criminal proceedings if human rights violations on behalf of the predecessor are detected on a massive scale. Our path of transiting to democracy might have been more beneficial and also more convincing to the local populace had those human rights watchers become enlightened earlier.

\section{Perhaps, such an "enlightenment" may need some time, don't you think?}

- From the very outset, the external marshaling of all the key events of our transition was unfortunately a thoroughly theorized and ideologized act of political influencing guided by global forces' own interests predetermining the outcome instead of unbiased problem-solving. This is why it would be vital for society to recognize its own strength in both thought and action to neutralize missionary self-interest in professional human rights activism.

10 The famous opening sentence "The life of the law has not been logic: it has been experience" was already published elsewhere in an insignificant place and context a year earlier-[Anonymous, standing for Holmes] (1880) [Book notices], American Law Review, XIV, pp. 233 et seq. on p. 234-than usually marked in his first classic book: Holmes, jr., O. W. (1881) The Common Law. Boston : Little, Brown, and Co. xvi+422 pp. on p. 1 . 
In your recent books, you call attention to the fact that there is very little literature on the legal handling of post-dictatorship situations. As far as I know, the legality of the Nuremberg trials has also been raised recently. What do you think of all this?

- Did the Belgians act in the proper way when they refused to sentence their king for usurpation of power according to the letter of their Constitution, for having preserved the occupied country's legal continuity in exile during the world wars, thus necessarily omitting certain formalities, and greeted him as the nation's savior and legalized posteriorly his procedure as a gap in law? The Nuremberg procedures may be questioned indeed. Actually, this, for the most part, is a professional issue. Indisputably and all that notwithstanding, its direct message is that, back in those days, people had the courage to face questions posed by their times, forging out some kind of answer that they deemed ideal.

Law gets again monopolized by political power everywhere. For every regime in history has in fact interpreted its rules according to its understanding, adapting and/or deforming them so as to serve primarily as its own instrument. What can remain for us from the respect for law?

- Like anything else, laws and rights can also be used and misused, that is, overused and abused. There is no "royal path" in law either; any formal question can be answered by either "yes" or "no," but this is merely the surface, the formal ending of a responsibly and carefully creative proceeding by searching for balance in the whirl of rules, principles, and considerations running against or even extinguishing each other. This is why the classical Jewish and Arabic as well as the Anglo-Saxon legal mind focuses so little on sheerly formal logicism in decision-making; for genuine legal culture arises exactly from the sensitivity and relative openness of this search for a balance, from the realization that such a search may ensure reconsideration and even change within a relative legal permanence.

If the prevailing law and order is not protected by guarantees of the Rule of Law, what can the individual and society expect?

-When they meant "Rule of Law," the English did not put their trust into dead letters but into the disciplining force of public opinion instead. This is why English legal disputes are usually not only more edifying for the soul, more responsible, and more disciplined but also burdened by fewer contingencies. They are focused on the issues themselves and associate (by adapting) their legal considerations to these. They know that whatever is socially assumable, its legal form with proper justification can also be designed. They do not suggest that law is something that hovers above us, readily available. In a maturely developed culture, the assumption of responsibility for human concerns by humans is to ensure that words have a weight and deeds have consequences. 
Your reconsideration is not intended exclusively for lawyers: the purport of the issues surveyed extends well beyond the bounds of the legal profession. The questions it investigates are still unanswered, constantly generating strains. The negative effect of the way past and present are permitted to interact and interpenetrate in our present-day transition permeates our everyday lives. We have not yet come to terms with the past, and it will take a long time before we can reach the desired equilibrium.

- Postponing action aggravates the problem. In critical times, even a tiny error may cause shifts, leading to forced paths whose effect will be felt for generations to come. This is why we still feel compelled to reconsider, as a thought-inspiring drama, the American dilemma of bombing or further fighting Japan in the final period of the war. A human's greatest enemy is no one else but their cowardly self, if incapable of thinking and of determination, lost in uncertainty. At best, with our psychical father complex, we can cling on to nothing but whatever we generate out of ourselves, our culture, and morality. Lawyers carry huge responsibility in setting standards - even more so if they under-or over-perform. We should recall that in the Middle Ages, often condemned as "dark," virtue had to go hand in hand with temperance, moderation, and proportion.

What can society do for the future? What can law do?

- We live in a world controlled in a strange way. The debates we have scarcely started already lost their topicality when the intention of political transition was born. Being overzealous in adopting externally patterned models, we used to ponder solutions that were in fact formulated by others at their places and times to respond to their troubles, as if no particularity could survive our brave new world's universality. Consequently, we smoothly ignore dilemmas and/or chances which these canons, imposed upon us as ready-made and left unanswered. We should realize, at last, that insensitivity and lack of independence in thought and action will not lead us out of our problems. The willingness to take a risk by beating a new track in the jungle is needed to find the desired path. 


\section{MAY ONE COME TO TERMS WITH THE PAST UNDER THE RULE OF LAW? Principles and Constitutional Assessments in Hungary ${ }^{1}$}

1. When a Criminal Past is Over 2. Attempts at a Resolution in Hungary 3. A Constitutional Counterrevolution 4. Signs of a Livable Perspective

ABSTRACT A decade ago, the criteria were set at an international level, according to which "a legacy of grave and systematic violations generates obligations that the state owes to the victims and to society. They are in fact distinct duties, each one of which must be complied with to the best of the government's abilities (1) to investigate, prosecute, and punish the perpetrators - a right of the victim to see justice done; (2) to disclose to the victims, their families, and society all that can be reliably established about those events - a right to know the truth; (3) to offer the victims adequate reparations - an entitlement to compensation and also to nonmonetary forms of restitution; and (4) to separate known perpetrators from law enforcement bodies and other positions of authority - a right to new, reorganized, and accountable institutions" (MÉNDEZ). Drawing a balance of the implementations hitherto actualized, it can be ascertained that none of them have been fulfilled in Hungary during the first two decades labeled as "change of regimes" but resulting in "a regime re-instated" instead. For no justices of the Hungarian Constitutional Court sensed any difference in whether or not criminal prosecution failed, despite efforts being legally required or them having been intimidated or deterred from acting in the first place, that is, whether legal normality or abnormality of criminal terror over citizens and state machinery had operated the period of statutory prescription to be expired. For, from that time on, neighboring states in Central Europe had already edified from our inability by issuing specific laws with the prospective effect that dictatorial annihilation of law shall never be recognized by the Rule of Law, for fear that selflegalization of terrorism may end in its re-legitimation and also incite states in trouble to test it anew.

KEYWORDS Justitia program for transition in Hungary; state complicity in mass crimes; statutory limitation; elementary justice; Rule of Law; successor state's duty in mass crimes

1 A paper prepared for and presented at the 2009 international conference organized by SHING-I LIU and ULFRIED NeUmANN in memory of Professor ARTHUR KaUfmanN in Taipei. Originally, it was published in Liu, Shing-I, Neumann, Ulfried (ed.) (2011) Gerechtigkeit:Theorie und Praxis/Justice: Theory and Practice. Baden-Baden: Nomos 250 pp. on pp. 215-235; later on, also as (2009) 'May One Come to Terms with the Past under the Rule of Law? A Case Study of Principles and Constitutional Assessments in Hungary', Central European Political Science Review, 10(Nos.36-37), pp. 112-134 and as (2013) 'Transitional Justice: Philosophical Foundation and Constitutional Rejection in Hungary' in History of Communism in Europe. Vol. 4: 'Transitional Justice and Civil Societies after Dictatorial Regimes'. Bucharest: Zeta Books pp. 22-43 \&<http://www.pdcnet.org/85257DC10065CC7E/ file/949464782A886926C1257DC5005582A8/\$FILE/hce_2013_0004_0000_0022_0043.pdf> as well as in Varga, Csaba (2008) Transition? To Rule of Law? Constitutionalism and Transitional Justice Challenged in Central \& Eastern Europe. Pomáz: Kráter 292 pp. [PoLíSz sorozat könyvei 7] \&<http://mek.oszk.hu/14800/14851> on pp. 107-116. 


\section{When a Criminal Past is Over}

Almost 20 years ago, when after the collapse of the communist regime, the very first symposium addressing the issue had been organized in Hungary on January 12, 1990, ${ }^{2}$ I started my intervention on a rather skeptical note, aware of the fact that

it is always a potentially catastrophic practice to administer justice in the aftermath of political changes. At the same time, it would be likewise disastrous to eliminate the possibility of jurisdiction in such periods of history. We are clearly on the horns of a dilemma here. Our choice is that between the Devil and the deep sea. ${ }^{3}$

For it was clear right at that time that

it is a sine qua non of this process to grant, at least in principle, a minimal redress to the victims, and also to make certain that the related measures have a preventive effect on the public in general, and the offenders in particular. It is likewise necessary [...] to denounce the negative developments in history, at least symbolically. Among other things, this is important so that we can rule out communism, whose ingrained practices still appear to linger, as an acceptable political alternative. We must prevent communism from sneaking back in through the back door in the guise of a democratically legitimate political alternative. ${ }^{4}$

Back at the time when the trust in the honest feasibility of a Justitia program (as the governing party Hungarian Democratic Forum had named it) was still unbroken and aware of being right when also morally responsible, all this simply seemed to be a function of proper formulation justifiable for both sides in the parliament. The rather modest and defensible program developed by the governing party and put on its agenda only ascertained that the victims are entitled to (1) recognition by the National Assembly in representation of the whole nation, to (2) a judicial procedure through which those once victimizing deeds and perpetrators are qualifiedly named, and to (3) comprehensive documentation with the official

2 For the proceedings, cf. Bence, György, Chambre, Ágnes, Kelemen, János (eds.) (1990) Visszamenőleges igazságszolgáltatás új rezsimekben [Ex post facto justice in new regimes]. Budapest: ELTE BTK Társadalomfilozófia és Etika Tanszék 53 pp. [FIL 2 Gyorsszimpózium], with the author's contribution on pp. 20-24 \& 48-49.

3 As the contribution referred to above, cf. Varga, 'On Setting Standards' in the present volume (and originally quoted from <http://mek.oszk.hu/14700/14760/> p. 121), with the analogy taken over from Huyse, Luc (1994) 'A Devil's Choice: Dilemmas of Backward-looking Justice', European Journal of Crime, Criminal Law and Criminal Justice, 2(1), pp. 120-140.

4 Varga, 'On Setting Standards', 1995 on p. 122. 
clarification of all those facts relevant to past deeds, accompanied by (4) some cultivation, funded from guaranteed state resources, of the continued historiography of the acts of this criminal past. ${ }^{5}$

Within half a year, the Prime Minister of the Republic of Hungary set up a Committee for the Investigation of Unlawful Benefits, ${ }^{6}$ to which each member-professors of the Eötvös Loránd University in metropolitan Budapest-submitted a background paper to clarify respective positions. There and then, in my contribution, I formulated as a preliminary question:

What is the consequence if the state does not use [its prerogative] for fulfilling its punitive responsibility but rather as a perspective for avoiding fulfilment? What if the state itself becomes perpetrator? What if the politics of the state are backed only by committed crimes and rewarded state criminals?

By way of illustrating the underlying basic conditions that might offer a divide by which one must contextualize their response, I quoted

an example, apparently extreme but by far not unrealistic, from World War II Central European history. At incidences of rape, the commanders of the [Soviet] occupying forces when official notice was made, reacted abruptly under military law, by shooting the offender. It could only be established subsequently that nevertheless this was the exception. The average practice was to expose those making complaint (the victim and/or her relative) to immediate brutal, often murderous destiny. The

5 Files from personal archives (from May 1990). Cf., as a documentation, Varga, Csaba (2008) 'What has Happened and What Is Happening ever since (In Remembrance of Deportations to Forced Work Camps at Hortobágy)' in Varga, Csaba (2008) Transition? To Rule of Law? Constitutionalism and Transitional Justice Challenged in Central \&Eastern Europe. Pomáz: Kráter 292 pp. [PoLíSz sorozat könyvei 7] \& <http://mek.oszk.hu/14800/14851> on pp. 173-174. The Hungarian program has been caught up in endless and fruitless debates about the chances of legal justifiability and options as compared to other instances of "settling accounts"-see, for example, Orentlicher, Diane F. (1991) 'Settling Accounts: The Duty to Punish Human Rights Violations of a Prior Regime', Yale Law Journal, 100(8), pp. 2537-2615-where direct sociopolitical ends have been targeted and also served. The first of all of them was dissociation, that is, relocation and remapping of the nets of the kinds of formal and informal public auctoritases at both local and national levels. Cf. Nino, Carlos Santiago (1996) Radical Evil on Trial. New Haven \& London: Yale University Press xii+221 pp., para. 3: 'Political Aspects' and especially Karstedt, Susanne (1998) 'Coming to Terms with the Past in Germany after 1945 and 1989: Public Judgments on Procedures and Justice', Law \& Policy, 20(1), pp. 15-56.

6 Government Decision No. 1025 (30 August 1990). My own position was first published in (1991) Reggeli Pesti Hirlap [Morning Pest Newspaper], II(November 4)(No. 258), p. 8.

7 Varga, 'The Right to Judge the Past' in the present volume (and originally quoted from $<$ http://mek.oszk. $\mathrm{hu} / 14700 / 14760 />$ on $\mathrm{p} .133$. 
invaders preferred eradicating the trouble itself at once and for all; and only if it proved not to be feasible for any reason, they resorted to kinds of legal proceedings. In any case, the roles of the victim and the guilty were mixed, and the only secure way was not to take cognisance of the crime committed. Is it then reasonable, fitting within the morality of the Rule of Law, that those transgressing any [conceivable] law and order would be the first beneficiary of the protection extended by the new law and order [as restored]? That the new Rule of Law has to be tested [and corrupted] from the very beginning by granting unpunishability for state-organised murderers? And all this simply because the running amok did not last for a shorter period of time? Simply because they were unscrupulous enough to make their crimes officially unnoticeable? Because they held on long enough so that both their self-granted statutory limitation could pass and grant a pardon to make the rest unpunishable? ${ }^{8}$

With regard to the issue's pending constitutional adjudication at that time, a press call was also formulated by me, emphasizing that not even the declaration of the limitation period passed (as the apparent routine answer) could be without problems. For

in the final analysis, once the routine is questioned, the insistence on routine is just as much one of the choices for a genuinely creative, responsible and responsive decision as the one based upon substantive argumentation. Eventually, any of them is only justified by a political position. ${ }^{9}$

The issue I had sensed as burning had been reconsidered five weeks before the Constitutional Court was to take its decision. ${ }^{10}$ As to the alternatives one may choose from when giving an answer to the dilemma of statutory limitations, I concluded that

on the one hand, we may say that despite the honourable merits of the above [routine] arguments, they are legally irrelevant, they have no legal sense. This is the same stating that, in a legal sense, there is no difference whatsoever between an unmarried mother committing infanticide and the murders committed by, and for the sake of, the party-state within an institutional framework, for the benefit of the prevailing regime, thus openly rewarded by its political establishment, and whose prosecution was therefore blocked by the same state-all this only provided that

8 Ibid., pp. 133-134.

9 Ibid., p. 134.

10 First published in (1992) Új Magyarország [New Hungary; a daily], II(January23)(No.19), p. 9. 
since they were committed, the time prescribed in the law as statutory limitation had already passed. On the other hand, we may equally say that there is something intrinsically different between the two situations, namely, the differing state reactions to the crimes - and that this can be taken as a basis for differentiating between the two cases in a legally relevant way. That is to say that while prosecution was hindered, the mere physical passage of time could not initiate statutory limitations. ${ }^{11}$

As opposed to the recurrent claim forwarded by both those allegedly transubstantiated into social-democrats from rank-and-file, unscrupulous communists and also fellow travelers preaching cosmopolitan libertinism under the guise of Open Society liberalism, stating that all it could only stand for a witch-hunt and political justice, ${ }^{12}$ I added:

If, for example, we state that the Communist regime imposed by Moscow was based not on guaranteeing internationally accepted human rights but on neglecting them, not abiding even by its own declared set of rules-this is only an institutional statement at the most, as its meaning can only be understood in an institutional context. It is as party-neutral as if we would state: rain also falls in Socialism. Or, the same way: stating that the whole question of facing the past has political roots, as the flawed phenomenon of certain crimes remaining unprosecuted was caused by the political system - this is also a sort of classifying statement that describes the medium which was especially active in the previous regime. As we have already noticed, anything could have prevented the state from exercising its punitive power, and this wouldn't alter the characteristics of the problem one bit. ${ }^{13}$

Later on, in a compilation of works preparatory to the German Laws I and II on Statutory Limitations (with initiatives and drafts of, as well as Bundesrat-commissioned professorial opinions on them, followed by HANS-HEINRICH JESCHECK, interviewed on the topic), on the one hand, and the Czech Law on the illegality of the communist regime (with its reaffirming

11 As the above article in translation, see Varga, Csaba (1993) 'The Dilemma of Enforcing the Law' in Aarnio, Aulis, Paulson, Stanley L., Weinberger, Ota, von Wright, Georg Henrik, Wyduckel, Dieter (eds.) Rechtsnorm und Rechtswirklichkeit: Festschrift für Werner Krawietz zum 60. Geburtstag. Berlin: Duncker \& Humblot pp. 427-435 \{reprinted in <http://mek.oszk.hu/14700/14760/> on pp. 136-143 on p. 139\}.

12 Miller, Arthur (1996) 'Why I Wrote "The Crucible”: An Artist's Answer to Politics', New Yorker, (October21), p. 158 \& <https://www.newyorker.com/magazine/1996/10/21/why-i-wrote-the-crucible>. As usual in the dogmatism of Hungarian, post-communist, so-called "liberals," the equation was false as the case at stake by far not concerned "panic-induced searches for perceived wrong-doers." Cf. <http://en.wikipedia.org/wiki/ Witch-hunt>.

13 Varga (1993) 'The Dilemma', p. 140. 
constitutional court assessment), on the other, ${ }^{14}$ the alert was also formulated relatively late (even if not too late), saying that

it would be a rather cynical solution, and would also impair our prospects for the future, if we agreed to grant impunity (let alone anonymity) to the criminal minions of a state that throws obstacles in the way of fighting crime only because this fundamentally criminal state managed to throttle fight against its own crimes over a period of time specified by itself. An intact judicial sense would exclaim in protest against such an abnormal and preposterous manifestation of absolutism. Not even the most ancient and primitive laws would allow anyone to gain by his sin. Any temporal limitation of criminal persecution can be enforced only if in the preceding period the state's punitive mechanism had functioned properly, i.e., the obligation to fight against crime was observed, or at least the authorities were ready to meet that obligation. If the state's relevant mechanisms were unable to perform these duties, no starting date can be attached to statutory limitation. ${ }^{15}$

This is the position that supports the very ideal and ethos lurking behind the millenniaold institutionalization of Verjährung, or prescription, or statutory limitation in Europe. ${ }^{16}$ It is the position suitable for the law's proper social functioning, justifiable both according to the law's own analytical doctrine [Rechtsdogmatik] and morally. For any other constitutional response, indeed, "would clearly signal our total disrespect for the law's moral foundations, would slap in the face the principles behind the legal regulations, and would only serve to encourage the would-be dictators" with far-reaching consequences, hardly reparable even in the long term. For

should these ideals turn out to be unfit in helping us transcend the past, our initial enthusiasm would inevitably cool off, our constitutional ideals themselves would lose their moral cohesion and appeal, and would inevitably dry out, as it were, with our democratic pathos and perspective evaporating away. ${ }^{17}$

14 Varga, Csaba (ed.) (1994) Coming to Terms with the Past under the Rule of Law: The German and the Czech Models. Budapest xxvii+178 pp. [Windsor Klub] \& <http://mek.oszk.hu/14300/14310/14310.pdf> [including VerjährungsG (26 March 1993) \& 2. VerjährungsG (27 September 1993); Zákon... (9 July 1993) \& Sp. zn. Pl. ÚS 19/93 (21 December 1993); followed by expert opinions to the Hungarian Parliament].

15 Varga, Csaba (1994) 'Preface' in ibid., pp. xii-xviii.

16 See Varga, Csaba (1999) 'Ex Post Facto Legislation' in Gray, Christopher Berry (ed.) The Philosophy of Law: An Encyclopedia. New York \& London: Garland Publishing [Garland Reference Library of the Humanities 1743] \& <https://b-ok.xyz/book/2642769/8c5190> on pp. 274-276.

17 Varga, Coming to Terms..., 1994, pp. 155 \& 145. 
To wit, the practice of the master German Constitutional Court has ever excelled by its caring for, and awareness of the importance of, incessantly nurturing the demand for any popular support to Rechtsstaatlichkeit ${ }^{18}$ (i.e., their Rule of Law), being apparently abandoned by its Hungarian student.

\section{Attempts at a Resolution in Hungary}

Upon the push of internal tensions arising from the fact that the coalition in opposition of the forces of the ancien régime (communist, veteran ex-rulers and arriviste starters), on the one hand, and their generated antinomy doubleurs (those converted into overperforming proselytes of a limitlessly radical liberalism of principles from their one-time extremism in MAoism and anarchism, having once criticized socialism in Hungary to be too pragmatic vis-à-vis their then MARXist doctrinarism), on the other, contradicted any genuine facing or rupture with the past sharply by referring to the inviolability of human rights and the Rule of Law as they alleged meaning to it. This, as they pretended — and to the detriment of the once deniers of such noble ideals—would be endangered and transgressed upon by any act on behalf of the state or society if it were to touch, even the least slightly, the privacy that the new scheme had guaranteed also to them. Hungary thus became the first post-communism country to formulate a tentative legal answer.

Although the draft was written as a personal motion by the Hungarian Democratic Forum MP Dr ZsoLt ZÉTÉNYI (as helped by many from the legal profession and prepared through quite a few scholarly debates both in form of conferences and deliberations in the professional press), ${ }^{19}$ it had had support from international academia as well, such as M.

18 See, for instance, Varga, "Rechtsstaatlichkeit" and "Rule of Law"' in the present volume.

19 See, for example, (1990) 'Az igazságtétel nehézségei' [Problems arising when facing with the past], Világosság [The light], XXXI(8-9), pp. 661-677; as a summary of the work done by the Committee referred to above, Békés, Imre, Bihari, Mihály, Király, Tibor, Schlett, István, Varga, Csaba, Vékás, Lajos (1991) ‘Szakvélemény: Az 1949 és 1990 között elkövetett, a társadalmi igazságérzetet sértő magatartások, illetve előnyök megítélésének, a felelősség megállapításának elveiről és jogi feltételeiről' [Expert opinion on the principles and legal conditions of the establishment of responsibility for, and the judgment upon, behaviors and privileges in infringement of the social sense of justice, realized between 1949 and 1990], Magyar Jog [Hungarian law], XXXVIII(11), pp. 641-645 \& (1992) Társadalmi Szemle [Social review], XLVII(1), pp. 70-76; Szúk, László (1991) A szeptemberi tanácskozás dokumentumai [Proceedings of the September meeting of the Criminal Lawyers' Club]. [ms] Budapest 141 pp.; von der Bank, Erhard (ed.) (1992) A múlt feldolgozása a jogállam eszközeivel [Treatment of the past with the instrumentality of the rule of law]. Budapest: Konrad Adenauer Stiftung 96 pp. [Alapítványi kiadványok III] \{including papers by Wolfgang Brandstetter, von Bülow, B. Sharon Byrd, Joachim Hermann, Joachim Hruschka, Martin Kriele, Karl Heinz Schnarr \& Jacques Verhaegen\}; Lamm, Vanda, Bragyova, András (ed.) (1992) Visszamenôleges igazságszolgáltatás [Ex post facto justice]. Budapest: MTA Állam- és Jogtudományi Intézete 110 pp. [Institute for Legal and Political Sciences of the Hungarian Academy of Sciences Working Papers 1] \{including Christoph Mayerhofer, Giuseppe de Federico \& Vito Zincani as foreign invitees\}. 
Cherif BAssiouni, Professor of Law of De Paul University College of Law in Chicago, whoin his expert opinion sent on October 30, 1991 to the Hungarian Parliament at the Request of Deputies Dr. GÁBOR PERJÉs \& Dr. ZÉTÉNYI—held a strong stand, according to which

crimes against the person such as murder and torture which were criminal under existing laws could still be prosecuted, even if there is or was prescription. The basis for that conclusion is predicated on the assumption that the prescription is stopped by the deliberate non-enforcement of the criminal laws. ${ }^{20}$

Indeed, at its session on November 4, 1991, the National Assembly passed an Act on the Amenability to Prosecution of Grave Crimes Committed, But Not Prosecuted for Political Reasons, between 21 December 1944 and 2 May 1990, reading as follows:

Article 1 (1) The period of statutory limitation on the punishability of crimes committed between 21 December 1944 and 2 May 1990 and defined by laws in force at the time of their commission, which were specified as treason by Art. 144 (2) of the Act IV of 1978, as wilful homicide by Art. 166 (1) and (2), and as bodily injury causing death by Art. 170 (5) of the said Act, shall, where the State's failure to prosecute criminal offences was based on political reasons, start again on 2 May 1990. (2) The punishment imposed by application of para. (1) hereof may be mitigated without restriction.

Amidst the press (denationalized by its once nationalizers) campaigning on the scandal of the rise of evil ghosts witch-hunting again, the Constitutional Court reacted abruptly by declaring the bill unconstitutional, with objections, among others, that

5. Cases of failure by the State to have exercised its criminal jurisdiction cannot be constitutionally distinguished on political or other grounds. 6. Given its ambiguity, the decision to declare it a cause of suspension of the period of limitation that "the State did not exercise its criminal jurisdiction for political reasons" prejudices legal certainty and is consequently contrary to the Constitution.

Nevertheless, its drafter may have believed that the assurance given by the Council of Europe-in addition to the justification drawn from the elementary sense of justice shared by all those humiliated and subjected to the dictatorship of the Soviet agents' communism 
in Hungary for four and a half decades, and who had bloodily revolted against as early as in 1956-was enough to meet the requirements of the new sensitivity. In fact, MP ZÉTÉNYI's official quest for inquiry was favorably welcomed by the Council of Europe Committee on Legal Affairs and Human Rights Chairman, Lord KIRKHILL. As he explicated in his letter-copied, by office, to the then Director of Human Rights, Dr LEUPRECHT, dated on June 28, 1993-

the famous principle of von FEUERBACH Nullum delictum nulla poena sine previo lege penale, which is mentioned in Article 7 of the European Convention on Human Rights, is not absolute. The Convention itself, in the second section of this Article, mentions the possibility of making exceptions: "2. This Article shall not prejudice the trial and punishment of any person for any act or omission which at the time when it was committed, was criminal according to the general principles of law recognised by civilised nations."

As a stand in doctrine, he affirmed that "the statutory limitation of crimes is, however, not a matter of substantive law but concerns procedure [...]" and concluded accordingly:

Under these circumstances, it seems to me that a prolongation of the periods of statutory limitation or even a reopening of periods already expired, provided this is done in accordance with due legislative process, may be entirely justified and not contrary to the principles of human rights and the rule of law, ${ }^{21}$

notwithstanding the fact that both domestic and international representatives of the academia and universitas were in favor of the logic that the disqualified bill embodied. Most importantly, Professor Dr. jur. h.c. mult. HANS-HEINRICH JESCHECK, emeritus director of the Max-Planck-Institut für ausländisches und internationales Strafrecht at Freiburg im Breisgau, gave a Presseinterview, ${ }^{22}$ the main argumentation of which he developed again in a letter to Dr ZÉTÉNYI on April 30, 1992. According to its transcription in his letter addressed to me on January 20, 1994, he, the master, at his Freiburg Institute, of all the academically high-ranking criminal lawyers in Hungary (though not represented in person in the Constitutional Court itself ${ }^{23}$ but including, of course, the acting Chief Procurator of the country), also believed that

21 Reprinted as fac simile in ibid., pp. 175-176.

22 Zétényi, Zsolt, Tárkány-Szücs, Attila in (1991) Új Magyarország [New Hungary; a daily], I(November30)(185), pp. 2 \& 4, reprinted as fac simile in ibid., pp. 123-133.

23 Of those by whom the Constitutional Court was formed, as justices and advisers alike, ANDRÁs SzABó (19282011) was a criminalist alone but with an academic background in the criminology of juvenile delinquency and recidivism exclusively; cf. <https://hu.wikipedia.org/wiki/Szabó_András_(jogász)>. 
if you apply these legal principles to Hungary, it is not at all a retroactive provision on the statute of limitations that worsens the situation of those affected, but a provision that was already in effect at the time of the offense. Even if the regulation did not formally exist in Hungarian law, it must be said that it must be derived from the meaning of the statute of limitations, because the statute of limitations cannot begin or continue if the legal situation makes it impossible to prosecute a criminal offense. In this way, the government would be able to afford any crime without fear of prosecution later. The statute of limitations is therefore limited by the general legal concept of resting according to mandatory principles of justice. ${ }^{24}$

\section{A Constitutional Counterrevolution}

Throughout the formative years of the genuine process of transition, the Hungarian Constitutional Court ${ }^{25}$ acted under the pretext of constitutional adjudication, that is, albeit it was by far not authorized to creeping constitution-making yet exploiting the consequences of their founding constitutional statute having placed no forum of control or appeal above it and thereby each and every act having taken by it being built into the Hungarian constitutional order with undoubtable constitutional force-otherwise speaking, in want of any legal possibility to be held responsible either politically or legally-the activity of its justices could only be limited by their own moderation and self-control, far from being their prime virtue in this dramatic - transformative-time period.

This may explain the contrast and paradoxical contradiction by which the catchword "Rule of Law" became incontestable both legally and socio-politically, while it was exactly under the pretense of the Rule of Law that-according to a growing number of analyses, especially in the press-the sense and the merit of the entire transition process (integrating the nation in a manner ethically acceptable for generations) got lost. For at every crossroads, the

24 Reprinted as fac simile in ibid., pp. 134-136: "Wenn Sie diese Rechtsgrundsätze auf Ungarn anwenden, so handelt es sich gar nicht um eine rückwirkende, die Lage der Betroffenen verschlechternde Vorschrift über die Verjährung, sondern um eine Bestimmung, die schon zur Tatzeit gegolten hat. Selbst wenn es die Vorschrift im ungarischen Recht formell nicht gab, so wird man doch sagen müssen, daß sie aus dem Sinn der Verjährungsrechts zwingend abgeleitet werden muß, denn die Verjährung kann nicht beginnen oder weiterlaufen, wenn die Rechtslage die Verfolgung einer Straftat unmöglich macht. Die Regierung würde sich auf diese Weise jedes Verbrechen leisten können, ohne später eine Strafverfolgung befürchten zu müssen. Die Verjährung wird also durch den allgemeinen Rechtsgedanken des Ruhens nach zwingenden Grundsätzen der Gerechtigkeit eingeschränkt."

25 For a general overview, cf. Majoros, Ferenc (1993) Ungarische Verfassungsbarkeit seit 1990. Köln: Bundesinstitut für Ostwissenschaftliche und Internationale Studien iii+59 pp. [Berichte des Bundesinstituts für Ostwissenschaftliche und Internationale Studien 15]. 
hypnotizing siren's voice of a "revolution led by the rule of law" could be heard, and indeed, "the role of law was primordial in that each step in this process, no matter how unexpected, was controlled and accompanied by a legal response."26

In fact, "the Hungarian Constitutional Court adopted a formalistic and neutral approach to the rule of law that focussed on legal certainty."27 Accordingly, from the stand schemed by its founding first president stating that

the rule of law — as the key concept for the transition and also in a technical sensegained a meaning identical with legal safety that is regarded by the Constitutional Court [...] as the "conceptual element" of the rule of law, ${ }^{28}$

the practice followed that "the rule of law [...] is construable as exclusively a formal rule of law." ${ }^{29}$ As a matter of fact, this was "the approach with which the Constitutional Court could transform the great political-ideological debates of the transition into problems of constitutional law and thereby neutralise them." ${ }^{30}$

The result has had to be disputable merely because the unsuitable method itself has been disputable. Moreover, jurisprudents have long agreed that a normative construction based on the exclusivity of "not entirely normatively definable" concepts and principles can only prove the "political hypertrophy" of such a constitutional judiciary's interventionist activism. $^{31}$

In consequence, "the Court [...] never really addressed the past directly." When its inevitably over-politicized roleplaying forced it to do so, the result proved to be mostly a catastrophe: lifeless as quite a doctrinarian deduction can at all be.

26 Dupré, Catherine (2003) Importing the Law in Post-Communist Transitions: The Hungarian Constitutional Court and the Right to Human Dignity. Oxford \& Portland Oregon: Hart Publishing xx+217 pp. [Human Rights Law in Perspective] on p. 29.

27 Ibid., p. 31.

28 Sólyom, László (2001) Az alkotmánybíráskodás kezdetei Magyarországon [The beginnings of constitutional judiciary in Hungary]. Budapest: Osiris 799 pp. [Osiris tankönyvek] on p. 686.

29 Decision No. 31/1990 (15 December) of the Constitutional Court in (1990) Alkotmánybírósági Határozatok, pp. 136 et seq. on p. 141.

30 Sólyom, Azalkotmánybíráskodás kezdetei, 2001 at p. 689. The same sentence in authorial English translation has some substantive variations: "The existence of the Constitutional Court during the transition [...] allowed the transformation of political problems into legal questions that could be addressed with final, binding decisions." Sólyom, László (1994) 'The Hungarian Constitutional Court and Social Change', Yale Journal of International Law, 19(1), pp. 223-237 on p. 223.

31 Přibáň, Jiří (2001) 'Moral and Political Legislation in Constitutional Justice: A Case Study of the Czech Constitutional Court', The Journal of East European Law [Columbia University East European Law Center], 8(1), pp. 15-34 on pp. $28 \& 16$. 
In fact the Court seemed to make a point of considering that there was nothing particularly special nor problematic with this past and that its adjudication function was as normal as in any other Western country. ${ }^{32}$ [Thereby,] by repeating the mantra of the rule of law (without a textual anchor in the constitution, and under a highly arbitrary interpretation of the concept) [...] the Court decided that its own highly arbitrary interpretation of the rule of law should prevail over politically defined understandings of the right mix of legalism and substantive justice. ${ }^{33}$

This is merely the attraction to extremity with several sui generis fundamental differences effaced-albeit relevant enough to substantiate a formal distinction. This is the case of mistaken partisanship, ${ }^{34}$ referring to which a monographic stand may have already concluded that

not much is gained, and much is lost in terms of comprehending the complexity of the issue at hand, by »normalizing « such dilemmas through analogizing them to various routine constitutional dilemmas faced by consolidated constitutional systems in their day-to-day operations. ${ }^{35}$

The decision of the Constitutional Court on legality with justice silenced and on crimes followed by unpunishment, in terms of which making the prosecutory processing of the past "travesty of legality"36 is possibly contrasted with the "constitutionalisation of criminal law"37 as ultimately invalidated by it distinctly shows the Court's determination for formal interpretation by narrowing - and indeed, reducing - the very idea of the Rule of Law to a most positivistic understanding of legal security, which can only assume unbroken continuity with the past: a continuity that cannot any longer be either challenged, or intervened with, by legislatorial or other legal means. At stake was no less than the issue of whether, after the

32 Dupré, Importing the Law..., 2003, p. 192.

33 Sadurski, Wojciech (2005) Rights before Courts: A Study of Constitutional Courts in Postcommunist States of Central and Eastern Europe. Dordrecht: Springer xviii+377 pp. on p. 256.

34 For some parallelism, see, for instance, Posner, Eric A., Vermeule, Adrian (2004) 'Transitional Justice as Ordinary Justice', Harvard Law Review, 117(3), pp. 761-825 \& in <http.//www.law.uchicago.edu/academics/ publiclaw/resources/40.eap-av.transitional.both.pdf>.

35 Sadurski, Wojciech (2003) 'Decommunisation', 'Lustration', and Constitutional Continuity: Dilemmas of Transitional Justice in Central Europe. Badia Fiesolana, San Domenico [Firenze]: European University Institute Department of Law 52 pp. [EUI Working Paper Law 2003/15] on p. 50.

36 Ibid., p. 2.

37 Szabó, András (2000) Alkotmány és büntetőjog [Constitution and criminal law]. Budapest: MTA 11 pp. [Székfoglalók a Magyar Tudományos Akadémián] on p. 6, in terms of which "the nullum crimen sine lege principle as reflected [...] to a domain transcending the criminal law proper is now already the genuine provision for a guarantee." 
inglorious collapse of a state having become criminal itself by having offenses committed against its own properly enacted criminal code, then gratifying this criminal service while also criminally retributing for and repressing any eventual social or legal initiative at their effective prosecution, the successor state had to complete the criminal proceedings of such deeds (especially of homicide and torture), which had been previously made time-barred formally; or whether it has, in the name and under the seal of its "rule of law" but in fact belying any sound ideal of law, to assume and enforce in this new constitutional democracy the MACHIAVELLIst cynicism of the dictators' murderous logic, suggesting that one must safely continue doing the dirty work, taking care of only one thing, namely to always to be able to erect and solidify a state power that will be oppressing enough to last until the deeds implied by such a mission can be declared prescribed or pardoned by itself. However, such a decision inspired by this stunning logic, one-sidedly and disproportionately beneficial for the perpetrator's side, has at once gotten into the focus of critical debate both domestically and internationally.

For in its decision No. 11/1992 (March 5), the Constitutional Court stipulated, with an unprecedented sharpness, that

with respect to its validity, there is no distinction between "pre-Constitution" and "post-Constitution" law. The legitimacy of the different (political) systems during the past half century is irrelevant from this perspective; that is, from the viewpoint of the constitutionality of laws, it does not comprise a meaningful category.

What obviously follows-since, from now on, "constitutional review does not admit two different standards for the review of laws"38 - testifies to an utter "constitutional indifference" toward the legal actualities of a communist dictatorship.

From the correct description of what the statute of limitations is about-"the statute of limitations in the criminal law guarantees lawful accountability for criminal liability by imposing a temporal restriction on the exercise of the State's punitive powers," as reflected to the bill just voted for by the Parliament, which had declared the legal passing of the prescription's time interrupted in so far as (as termed by the bill) "the State's failure to prosecute for criminal offences was based on political reasons"- the Court concluded that "failure to apprehend [the criminal] or the dereliction of duties by the authorities which exercise the

38 Sólyom, László, Brunner, Georg (eds.) (2000) Constitutional Judiciary in a New Democracy: The Hungarian Constitutional Court. Ann Arbor: University of Michigan Press x+417 pp. at p. 220 \{cf. also Sólyom, László, Brunner, Georg (eds.) (1995) Verfassungsgerichtsbarkeit in Ungarn: Analysen und Entscheidungssammlung 1990-1993. BadenBaden: Nomos 634 pp.\}. 
punitive powers of the State is a risk borne by the State." Thus, as the judgment observed, given the lack of previous express statutory provisions to the contrary, the period of limitations can also expire through a lapse of time relieved from official procedure by a dictatorial (i.e., again, criminal) rétorsion of any victim's legal initiative at prosecution. Consequently, no subsequent differentiation whatever and no comprehension detached from the dictatorial past can now affront the reassessment of the cynicism implied by such an inhuman logical formalism, which may even degrade the future becoming captive of complicity, trampling the ethical foundation and humanity of the new scheme of an alleged Rule of Law under foot from the outset. For, as the verdict continues, "if the statute of limitations has expired, the person has a right to immunity from criminal punishment." ${ }^{139}$

This decision is remembered in the international professional press $^{40}$ as a veterinary horse, a strange mixture of formalistic hovering and uncontrolled rushing forward, whose main feature is that it has now lost all contact with what could still be meaningfully viable and acceptable.. As one author deems, "it is rather hard to see what values underlying the principle of legality support such a conclusion." For "failure to apprehend" and "dereliction of duties" as conditions referred to by the decision let the limitations expire as accidental occurrences of a society operating normally-as it is due-under the Rule of Law. In our case, however, the system itself degenerated by having silenced its law and order. With its flagrantly unlawful intervention brutally retaliating any lawful intention to retaliate, it annihilated the very chance of normality that the Constitutional Court discretion now claims to have existed. For all the underlying conditions did arise by far not by chance, "as if the 'risk' in question were a matter of the negligent behaviour of the state," but they "were part of the purposeful policy of the Communist state." Otherwise speaking,

here the non-identity of the "state" before and after the transition is most crucially relevant, and the fiction of continuity at its most absurd. For, in terms of the Communist state, it was not a matter of a "risk" at all but rather of deliberate and lawless protection of offenders, whiles on the part of the successor state the "price" in the form of non-prosecution is unrelated to its negligent criminal policy. ${ }^{41}$

Of course, no one thinks in terms of respectable principles allowed to be put aside but only of the necessity, of any genuine judicial event, of pondering and balancing values (either complementing or conflicting) held to be equally respected—as dichotomized only rarely

39 Idem., p. 223.

40 Sadurski, 'Decommunisation'..., 2003, reconsidered in Sadurski, Rights before Courts, 2005, ch. 9, pp. $223-262$.

41 Sadurski, Rights before Courts, 2005, pp. 253, 254, 254-255 \& 255. 
and never concluding by "prospectivity" and "equal justice," "legality" and "substantive justice,"43 or "legal security" and "material justice"44_with no side to be absolutized in a sober judgment. It is the more so as

a lawless and reprehensible refusal by the old regime to punish those who committed some of the most severe crimes as defined under the law valid at the time, seems to effectively vitiate the general moral reprobation of various forms of retroactivity in criminal law. Put simply, it would seem perverse if the crimes committed in the past were to go unpunished solely because those who committed them were part of the system that protected them, and made sure that, as long as the system lasted, their crimes would remain unpunished. ${ }^{45}$

Or, expressed in a reversed way, the stand taken by the above decision is a plain encouragement to crime as it places the grace into the perpetrator's hand from the outset, by allowing the latter to absolve itself at their own discretion by either proclaiming pardon or setting statutory limitation for their own deeds, irrevocable by any later development in principle. Moreover, in parallel, it inevitably charges the successor state as an accomplice to crime as it will leave the latter with the exclusive choice to declare all those wrongfully unprosecuted offenses unprosecutable as legally final.

Such an artificial solution was neither inevitable nor did it follow from the Constitution itself. For it is obvious that

by non-prosecution of these crimes, and by thus allowing them to become timebarred, the old regime successfully brought about a state of affairs practically identical to what it could have achieved by conferring upon itself and its members a blanket amnesty. Consistently with what has just been suggested, there is no special,

42 Teitel, Ruti (1997) ‘Transitional Jurisprudence: The Role of Law in Political Transformation', The Yale Law Journal, 106(7), pp. 2009-2080. On p. 2024, she reminds that "the Berlin court, the controlling rule-of-law value was what was 'morally' right, whereas for the Hungarian Court the controlling rule-of-law value was protection of preexisting 'legal' rights." The Hungarian Constitutional Court president's recollection refers exactly to such a moral/legal duality unduly cut into antinomy, presenting his one-time inclination to extremity as a paradox: "This debate is morally insoluble. I find it right to have, as a constitutional judge, put legal security first. It is a different issue that I shall never be able to reassuringly settle the question of conscience that I have not fulfilled the rightful claims of several victims." LÁszLó Sólyom as interviewed by Takács, Péter (2001) “'A morális alkotmányértelmezésnek a szöveghez kötöttnek kell lennie"' [Moral interpretation of the constitution needs to be bound by the text] Fundamentum [Budapest], (1), pp. $68-73 \&<$ https://epa.oszk. $\mathrm{hu} / 02300 / 02334 / 00005 / \mathrm{pdf} />$ on p. 71.

43 Sadurski, 'Decommunisation'..., 2003 and Sadurski, Rights before Courts, 2005.

44 This is the Hungarian Constitutional Court terminology.

45 Sadurski, Rights before Courts, 2005, p. 255. 
conclusive obligation deriving from the principle of legal continuity to meticulously observe those privileges, and no obvious reason why to prosecute despite them would be an outrage to the principle of non-retroactivity of justice.

Accompanied by the categoricalness of rigid inflexibility ending in empty formalism, extremism may have prevented the Court from any search for an in-between, compromising, or simply practical (genuinely responsible and responsive) solution. Indeed, "the range of options is much broader than either full observance of all the entitlement-conferring rules of the predecessor system or a revolutionary rupture with the legal past. ${ }^{\prime 46}$ According to a psychologically motivated political reconstruction, "the intervention of the Court [...] can be seen as an arrogation of the power, by the Court, to dictate the terms of the transition." ${ }^{24}$

The bitter dilemma may indeed arise, as a student of mine has in fact put it: "what is more important? Does man exist for the rule of law or does the rule of law exist for man? Or does the rule of law exist for its own self?" His generation can only conclude now that

our society was judged unsuited to face with the past by the Constitutional Court with its decisions from "above," while in Germany the wise and precise legal thought addressed the problem itself, thereby allowing space and opportunity for social debate as well. ${ }^{48}$

Indeed, all these inputs may have contributed to the actual survival of past power relations in Hungary, the failure of any hope for a brand-new start, in service and as a framework by which the early implementation of a fully-fledged Rule of Law was in fact heralded. For the Court's lasting contribution was the final recognition of continuity, with inviolability of past relations within the womb of the absolutization of new Rule-of-Law-schemed legal guarantees idealized as untouchable civic rights. ${ }^{49}$

Such an end result has even perplexed an American constitutional scholar, hypothesizing that the decision itself may have been not so much on prescription but on declaring, hardly hiding a political zeal, who is marshaling the transition in Hungary. As formulated, "the ZÉTÉNYI case stands for the proposition that the authority to assess the legality of the

46 Idem., pp. $261 \& 262$.

47 Idem., p. 256.

48 Rumi, Tamás (2005) 'Szembenézés a jogállam előtti múlttal - a német példa és tanulságai, különös tekintettel az elévülés kérdésére' [Confronting the past prior to the rule of law - the German example and lessons learned, with a special focus on the statute of limitations], Collega [Budapest], IX(4), pp. 45-51, quotes on 46 \& 51.

49 Cf. Sólyom, Az alkotmánybíráskodás kezdetei, 2001, pp. 542-544. 
prior regime does not lie with Parliament, but instead with the Constitutional Court." It may have stood as "a controversial power grab" that "enables the court to operate in a counterrevolutionary fashion while increasing judicial power," or the whole affair known as "the ZÉTÉNYI case could be less about the rule of law than about institutional distrust.".50

\section{Signs of a Livable Perspective}

If we consider the set of reform criteria stipulated in international literature as formulated with a decade of delay, the following requirements can be found:

a legacy of grave and systematic violations generates obligations that the state owes to the victims and to society. [...] [T] hey are in fact distinct duties, each one of which must be complied with to the best of the government's abilities [...] (1) to investigate, prosecute, and punish the perpetrators - a right of the victim to see justice done; (2) to disclose to the victims, their families, and society all that can be reliably established about those events - a right to know the truth; (3) to offer the victims adequate reparations - an entitlement to compensation and also to nonmonetary forms of restitution; and (4) to separate known perpetrators from law enforcement bodies and other positions of authority - a right to new, reorganized, and accountable institutions. ${ }^{51}$

Drawing a balance of all the implementations hitherto actualized, it must be ascertained that none of these four mutually complementary basic requirements have been fulfilled in Hungary during the almost two decades labeled as "change of regimes" but resulting rather in "a regime re-instated" instead. A question may arise: what would be the answer of our rule of law, if state terrorism in devastation of humans swept over our people again? Silence, incompetence, and impotence-however shameful they may be. After one and a half decades unchanged, the last word said on the issue is the same unique decision of the Hungarian Constitutional Court, with the legality of the self-prescription by the predecessor regime overwriting the chances of any successor regime. For no justices sensed any difference in whether

50 Teitel, Ruti (1994) 'Paradoxes in the Revolution of the Rule of Law', Yale Journal of International Law, 19(1), pp. 239-247 on pp. $246,244, \& 246$. It is amazing now to realize OWEN M. FIss's total ignorance of the very stake of the issue (in ibid., p. 220), when introducing TeITEL's criticism upon SóLYom's explanation, quoted in note 44.

51 Méndez, Juan E. (1997) 'Accountability for Past Abuses', Human Rights Quarterly, 19(2), pp. 255-282 on pp. 255 \& 261 (with emphasis placed by the recent author, also interpolating the respective rights back into the block of obligations). 
or not criminal prosecution failed despite the efforts required by the law or the fact that they had been intimidated since the beginning and deterred from acting, that is, whether legal normality or abnormality by a state based on criminal terror over both its citizens and state machinery had allowed the period of statutory prescription to expire. For, from that time on, neighboring states in Central Europe had already edified from our specific inability by having decreed specific laws with the prospective effect that the dictatorial annihilation of law should never be recognized by the Rule of Law, for fear that self-legalization of terrorism could end in its re-legitimation and incite states in trouble to test it anew..$^{52}$

All this is as if the negative prophecy of writer, resistance activist, and President of the Czech Republic, Václav Havel's counter-ideology, extended to the entire Central and Eastern European region, were to have been implemented as transferred from a moral terrain to the proper field of law, excluding any calling to account even conceptually. For, according to him, "we are all—though naturally to differing extents—responsible for the operation of the totalitarian machinery. None of us is just its victim. We are all also its co-creators." ${ }^{53}$ Such a false equalization in human responsibility by unifying all of its kinds has already led to the shameless revival of a then plainly criminal past transformed into the mainstream to be lived anew, with a constitutionally amoralized law serving at its background. ${ }^{54}$ Such challenges to the very ideal of the Rule of Law, questioning its root meaning, merits, and livability, ${ }^{55}$ may call for further research, extended to the dysfunctions encountered when the experience of globalization is also made. ${ }^{56}$

52 As an exhaustive overview of the underlying normative material, see Udvaros, Judit (2002) 'Landesbericht Ungarn' in Strafrecht in Reaktion auf Systemunrecht. Vol. 5: Weigend, Ewa, Zoll, Andrzej, Udvaros, Judit PolenUngarn. Freiburg im Breisgau: Iuscrim xii+361 pp. [Beiträge und Materialien aus dem Max-Planck-Institut für Ausländisches und Internationales Strafrecht Freiburg i. Br. 82:5], pp. 151-357.

53 As his first presidential speech, The New Year's Address to the Nation (Prague, January 1, 1990) in <http://old. hrad.cz/president/Havel/speeches/1990/0101_uk.html>.

54 Cf. Varga, 'Crossroads of Civil Obedience and Disobedience' in the present volume.

55 For a comparative analysis of transition-from-dictatorship schemes with the underlying rule-of-law ideals behind them involved, constrasting closing-the-WWII models and after-communism ones, on the one hand, and the German and Hungarian constitutional adjudicative patterns, on the other, see Varga, 'Rule of Law, or the Dilemma of an Ethos: To be Gardened or Mechanised?' in the present volume.

56 For some preliminary studies, cf. Varga, Csaba (2007) 'Reception of Legal Patterns in a Globalising Age' in Calera, Nicolás López (ed.) Globalization, Law and Economy / Globalización, Derecho y Economía: Proceedings of the $22^{\text {nd }}$ IVR World Congress. Vol. IV. Stuttgart: Franz Steiner Verlag, pp. 85-96 [ARSP Beiheft 109] \{reprinted in $<$ http://mek.oszk.hu/15300/15386>, pp. 181-207\} as well as, for the gradually but increasingly self-emptying Rule of Law coverage of globalization, with ample literary documentation, Varga, Csaba (2009) Jogrendszerek, jogigondolkodásmódok az európai egységesülés perspektivájában (Magyarkörkép-európai uniósösszefüggésben) [Legal systems and legal mentalities in the perspective of European unification: Hungarian overview in a European Union context]. Budapest: Szent István Társulat 282 pp. [Jogfilozófiák] \& <http://mek.oszk.hu/15100/15173>. 


\title{
RETROACTIVITY IN LAW ${ }^{1}$
}

1. Preliminaries 2 . The Neutrality of Legal Techniques

\begin{abstract}
Approaching retroactive measures as a purely legal technique, these do not differ from legal answers in general: they are neutral forms of regulation which, like medical scalpels that anyone can heal or kill with, can be used for any purpose. It is a tool that does not carry its qualities on its own. As an instrument, it is neither good nor bad; it is in the hands of its user that it will serve for this or that purpose.
\end{abstract}

KEYWORDS Ex postfacto legislation; nullum crimen / nulla poena sine lege; constitutions; neutrality of legal techniques; common law precedents; social engineering through law

\section{Preliminaries}

Ex post facto legislation is regulation in a style that usually prescribes a negative sanction with punitive consequences in law for an action performed prior to the law's coming into force. There is a technical, pragmatic, and, at the same time, deeply moral question behind the decision as to whether it is allowable and whether it is worthwhile.

For a long time, law had permitted this; jurisprudence could only conclude that the retroactive effect of a rule is not excluded by any legal assumption. ${ }^{2}$ Its validity cannot be disturbed by the fact that it declares an act to have been a crime after the fact. ${ }^{3}$

A decisive answer was first given on the European continent when criminal procedure was surrounded by legal guarantees. The recognition of the principles nullum crimen sine lege [no crime without legislation] and nulla poena sine lege [no punishment without legislation] expressly interdicted making a deed punishable or meting out a penal sanction without a prospective statutory decree. Some early modern constitutions, such as the Norwegian

\footnotetext{
1 Originally, Paragraph One is a part of the entry of Varga, Csaba (1999) 'Ex Post Facto Legislation' in Gray, Christopher Berry (ed.) The Philosophy of Law: An Encyclopedia. New York \& London: Garland Publishing [Garland Reference Library of the Humanities 1743] \& <https://b-ok.xyz/book/2642769/8c5190> on pp. 274-276, the Paragraph Two of which is part of a paper published only in Hungarian in 2012.

2 Somló, Felix (1917) Juristische Grundlehre. Leipzig: F. Meiner xv+556 pp. on p. 302.

3 Lyons, David (1984) Ethics and the Rule of Law. Cambridge: Cambridge University Press x+229 pp. on p. 76.
} 
Constitution and the 1784 New Hampshire Constitution, excluded retrospectivity with moral overtones: "Retrospective laws are highly injurious, oppressive, and unjust. No such laws, therefore, should be made, either for the decision of civil causes, or for the punishment of offences." The German Constitution restricts this prohibition and limits it exclusively to substantive criminal law. ${ }^{5}$ Moreover, German constitutional jurisprudence limits it to cases no longer under adjudication, distinguishing the original from the nonoriginal retroactive effect. As to common law, the analytical examination of the law embodied in precedents has proven long ago that judicial decisions that create a rule of decision also have an ex post facto. ${ }^{6}$

Theoretically, since it is a means of social engineering, law is mostly prospective and makes use of regulation that links legal consequences to future events. As a program for social reform, trying to influence with prohibition and repression is less successful than offering a model for behavior that includes advantages because it is surrounded by positive sanctions. Modern formal law is primarily the means for mediating relationships toward a network of ascriptions; thus, it is of primary importance to provide regulations promoting normative determination for behavior. A secondary consideration is that inasmuch as the regulation is kept secret, does not become cognizable or available or bears a retroactive effect, it will not have the chance to influence the behavior that law seeks.

\section{The Neutrality of Legal Techniques}

Today's heightened sensitivity is more an atavism than a considered response worthy of the emphatically rational consciousness of our times. It is an early stream-a passing fashion strongly fueled by the rigid doctrinalization of liberalism, which dominates public discourse, hiding its own thoughtlessness in surrogacy.

For, from a historical perspective, taking one instance, the grandiose meaning of the dividing line between retroactivity and proactivity, the absolutization of the prohibition of analogy in criminal and tax law, and the presentation of nullum crimen sine lege and nulla poena sine lege as the basic minimum of civilization are all peculiarly European things because they are only expressions of the sensitivity (and, by experiencing helplessness, also anti-church) that has been formed over centuries of blatant abuses by monarchs who claimed

4 New Hampshire Constitution (1784), Part I, Article 23.

5 German Constitution [Grundgesetz für die Republik Deutschland] (1949), Article 103, Paragraph 2.

6 Gray, John Chipman [1921] The Nature and Sources of the Law. 2nd ed. New York: Macmillan, 1948 xviii+348 pp. on pp. 89-101 \& 218-233. 
to be Christian in the course of European feudal development. ${ }^{7}$ It is a wounding reminder of the human misery and the sense of total subjugation that only the bloody chaos of the French Revolution, which was not only secular but downright persecutory, could end it all. ${ }^{8}$

This explains why in Anglo-American literature-and even in certain European schools of the nineteenth century-arguments for and/or against a retroactive legal solution to a dispute are usually put forward without prejudice, as a matter of pure practicality, while it is once again raised - rarely heard by champions of logical clarity with an ideal of consistencythat we always conceptually cross this rubric and fall into retroactivity when reconstructing a change in judicial practice or any precedential process in general and a logical picture of the actual course of Anglo-Saxon precedent law in particular.'

If we consider retroactive regulation as a purely legal technique, ${ }^{10}$ we should see it as nothing more than a technical legal response in general: it is a procedural form that is neutral in itself, which—like the medical scalpel, with which I can cure and kill—can be used for any purpose. It is a tool that does not carry qualities in itself. As an instrument, it is neither good nor bad; in the hands of its wielder and its user, it becomes merely a servant to one cause or another.

It is characteristic of the good faith of jurisprudence that, in earlier times, it was not even conceivable for the state to be confronted with itself-neither by its legal assumptions

7 Cf. the paper entitled 'In Want of New Balances in Transition: Lithuania Searching for its Own Path' in the present volume.

8 In contrast to the feudal practice of criminal law used for the destruction of the next opponent for explicitly political purposes, this is "the product of the natural law philosophy which reached the peak of its development at the end of the eighteenth century and was sanctioned by the French revolutionary legislation as a guaranteed subject of constitutional law." Angyal, Pál (1916) A visszaható erő az anyagi büntetójogban [Retroactive force in criminal substantive law]. Budapest: Magyar Tudományos Akadémia 84 pp. [Értekezések a philosophiai és társadalmi tudományok köréből I/9] on p. 52.

9 For me, the most recent-after having reviewed the common law components of this in Varga, Csaba (2009) 'A kontinentális és az angolszász jogi mentalitás jövője az Európai Unióban' [The future of Continental and Anglo-Saxon legal mentality in the European Union], Jura, 15(1), pp. 133-142-is a clear statement made more than three quarters of a century ago: "It is conceptually inconceivable that a change in judicial practice should not have a retroactive effect. In that case, it would never be possible to depart from the previous practice, because the facts of the particular case arose under the old judicial practice and thus, according to the principle of non-retroactivity, the new decision could never have any effect on them." Szászy, István (1938) 'A magánjogi jogszabályok időbeli hatálya: A törvény visszaható erejének problémája - Kísérlet egy új elmélet felállítására' [The temporal scope of private law provisions: The problem of the retroactivity of the statute - An attempt at a new theory], Magyar Jogászegyleti Értekezések és egyéb tanulmányok, VI(21), pp. 70-99 \& [off-print] Budapest: Attila Nyomda, 193818 pp.

10 Cf. Varga, Csaba, Szájer, József (1989) 'Legal Technique’ in Mock, Erhard, Varga, Csaba (eds.) RechtskulturDenkkultur: Ergebnisse des ungarisch-österreichischen Symposiums der Internationale Vereinigung für Rechts- und Sozialphilosophie 1987. Stuttgart: Franz Steiner Verlag Wiesbaden 175 pp. [Archiv für Rechts- und Sozialphilosophie, Beiheft 35] on pp. 136-147 \{reprinted in <http://mek.oszk.hu/15300/15333/\#>, pp. 187-198\} as well as Varga, Csaba (2008) 'Doctrine and Technique in Law', Iustum Aequum Salutare, IV(1), pp. 23-37 \& <http://ias. jak.ppke.hu/hir/ias/20081sz/02.pdf>. 
nor by its practice as law; for example, by using the apparatus of its own law in a cynically dishonest way to deceive the outside world ${ }^{11}$ or by denying in its actual practice what it had otherwise assumed to be the Rule of Law. ${ }^{12}$ It is for this reason-and not in the sense of the immorality of the Hungarian Constitutional Court, which refuses to serve justice in law and thus preempts the chances of a real systemic change-that the Hungarian monographer of the question a century ago could have said, for example, that

the limitation period is, as a rule, a continuum and not a utile tempus. And thus only the period during which the running of the limitation period is hindered by a legal obstacle which, according to the law, results in the suspension of the limitation period, shall not be counted in the limitation period, whereas if the criminal prosecution of the offender is hindered by factual obstacles, this does not suspend the running of the limitation period. This was already taught by ULPIAN. ${ }^{13}$

He must have been convinced that normativum and factum cannot directly meet and thus cannot conflict with each other. Most probably, that is why he built his work on the axiomatic illumination of the fact that "it is always only a right, a power, that expires." ${ }^{14}$ It is this that has led legal literature to reflect, in its problem of combining purely practical considerations with fairness, on the following:

11 For example, on the development of Soviet law, Varga, Csaba (1982) 'Lenin and Revolutionary Law-making' International Review of Contemporary Law [Brussels], (1), pp. 47-59 \{\& in <http://mek.oszk.hu/15300/15333/\#>, pp. 515-527\} as well as Varga, Csaba (2019) 'Lenin and the Law: A Case-study on the Borders of Legal Normality', Central European Political Science Review, 20(No.75), pp. 131-179.

12 The Czech Constitutional Court declared, without the statute of limitations having even begun, that for the crimes committed by the communist regime but rewarded instead of prosecuted, which they prevented from being held accountable until the collapse of their own regime, that

if we interpret the time passed since the commission of these crimes as a prescription period [...] this would be equivalent to confirming the "legal security" which the perpetrators had from the very beginning of their activity, and which was actually incorporated into their official immunity from prosecution.The "legal security" of the perpetrators, in this sense, would be equivalent to the legal unsecurity of the citizens [...]. Any solution different than this would inevitably mean that the regime of totalitarian dictatorship receives a certification for its "rule of law"; this would create a dangerous precedent for the future. More precisely, this would confirm that crime can go unpunished, if and insofar as it is committed in mass proportions, is well-organised, lasts for a long time, and falls under the protection of state authorisation.

The Czech Constitutional Court decision No. 19 on December 21, 1993, reprinted in extenso in Varga, Csaba (ed.) (1994) Coming to Terms with the Past under the Rule of Law: The German and the Czech Models. Budapest xxvii+178 pp. [Windsor Klub] \& <http://mek.oszk.hu/14300/14310/14310.pdf> on pp. 145-169.

13 Kováts, Andor (1922) A büntetöjogi elévülés dogmatikája [The dogmatics of the statute of limitations in criminal law]. Szeged: Városi Nyomda VIII+176 pp. on pp. 84-85.

14 Ibidem. 
without any room for criticism, laws which seek to punish acts committed in abuse of a law may also be declared retroactive by the legislature. It is necessary, after all, to have in its arsenal the means with which to combat abuses which take advantage of the inadequacy of the legislative work-all the more so since the legislative work of Parliament is rather long; it is therefore necessary that the need to rebuild the law can be foreseen..$^{15}$

There are also authors who argue that such a procedure (i.e., regulation with a retroactive scope), should be a natural possibility in tax law in the case of insufficient legal rigor or a regulatory gap. ${ }^{16}$ In situations that cannot be resolved by other means, this is why the classic of Hungarian criminal law could also have believed in good faith that "salus rei publicae suprema lex esto" [the welfare of the people should be the supreme law] must take a back seat to the lex non reagit, even if the latter rested on a basis recognized as scientifically indisputable. ${ }^{17}$ For we are dealing with an old Christian wisdom here: a value that embodies a bare instrumentality cannot be elevated above a fundamental value. ${ }^{18}$ However, this is independent of the fact that all three of the abovementioned procedural options inherently have technical foundations, which generally raise such serious objections to the use that they are usually resorted to-or at least considered for actual use-only in situations that are nevertheless

15 Roubier, Paul (1929) Les conflits de lois dans le temps: Théorie dite de la nonretroactivité des lois. Vol. I. Paris: Recueil Sirey pp. 520-521 ["Les lois qui tendent à sanctionner des commis en fraude de la loi peuvent également être déclarées rétroactives par le législateur, sans qu'il y ait lieu à critique. Il faut que le législateur conserve, dans l'arsenal de ses armes, des moyens de réagir contre des abus qui se seraient introduits à la faveur d'une insuffisance de l'œuvre législative, et delà d'autant plus que la procédure moderne de confection des lois par les assemblées est assez longue; il faut donc prévoir la nécessité d'un redressement."]

16 In tax matters, in order to plug an explicit abuse that repeatedly exploits a loophole in the law, an ex post provision that will be "treated as always having had effect" is not objectionable, according to several authors-for example, Redstone, Anne (2010) 'Will Retrospective Taxes Affect us All? Analysis' [online]. Available at: <http://news.bbc.co.uk/2/hi/business/8496921.stm>. Better yet, another author-Graetz, Michael J. (1977) 'Legal Transitions: The Case of Retroactivity in Income Tax Revision', University of Pennsylvania Law Review, 126(1), pp. 47-87 on p. 87-concludes that "the tax law must remain a flexible instrument of public policy. [...] People should make investments with the expectation that political policies may change."

17 Angyal, A visszaható erô, 1916 on p. 82 . He also writes, on p. 66, that

as a matter of public law, the offender cannot complain of a violation of rights because of a heavier penalty imposed under a new law any more than the owner of a house, on whom a higher tax has been imposed by a new law than that which was due at the time of purchasing the house, or a person subject to serve in the defence forces, who, after having entered the army, is required by a new provision to bear arms beyond the period of service prescribed by law, or to take part in the war. He must submit to the new rule, although he is more seriously affected by the more onerous duty and deserves more attention than the criminal.

18 See, for more details, Varga, 'Buts et moyens en droit', 2003 and, as expanded, Varga, Csaba (2005) 'Goals and Means in Law: or Janus-faced Abstract Rights' in Jurisprudencija [Vilnius: Mykolo Romerio Universitetas], 68(No.60), pp. 5-10 \& <https://intranet.mruni.eu/en/mokslo_darbai/jurisprudencija/ archyvas/?l=120712>. 
exceptional. ${ }^{19}$ In any case, their approach is always pragmatic, and their eventual selection is always based on considered expediency, in contrast to the feudal misery that our continent once experienced, where the abundance of exorcisms makes us dread even the raising of the matter. The issues that we are facing here and now may seem abstract, but that is precisely why they require a theoretical response. We must know, however, that the normal, balanced intellect, which is not hostile to reason, always tends toward balance in everything, including our subject. ${ }^{20}$ It is with this sensitivity, therefore, that we must also approach the possible inner balance and logic of our subject.

19 Fuller, Lon L. (1964) The Morality of Law. New Haven \& London: Yale University Press viii+202 pp. [Storrs Lectures on Jurisprudence 1963], reviewed by Varga, Csaba (1970) in Acta Juridica Academiae Scientiarum Hungaricae, XII(3-4) \& <http://real-j.mtak.hu/787/1/ACTAJURIDICA_12.pdf>, pp. 449-450 and theorised by Varga, Csaba (1985) 'Reflections on Law and on its Inner Morality', Rivista internazionale di Filosofia del diritto, LXII(3), pp. 439-451 \{reprinted in <http://mek.oszk.hu/15300/15333/\#>, pp. 77-89\}.

20 E.g. Fisch, Jill E. (1997) 'Retroactivity and Legal Change: An Equilibrium Approach', Harvard Law Review, $110(5)$, pp. 1055-1123. 


\title{
BORDERING ISSUES III
}

\author{
HUMAN RIGHTS
}




\title{
THE PROBLEMATICS OF HUMAN RIGHTS ${ }^{1}$
}

\author{
1. Historical outline of human rights 2 . The foundation of human rights 3 . The nature of human rights 4 . \\ The universality and/or particularity of human rights 5 . Conclusion
}

\begin{abstract}
The analysis of historical development, foundation, true nature as well as the universality/ particularity issue shows that human rights as such exist only by acting - speaking and doing —on and in their name. In our civilizational development, a task is articulated; in one or another way we posit it and then adjust our behavior to it. That is, in law as in case of any normative standard, the positivation of a linguistically expressed duty can become the factor of motivation for human action within a given receptive medium of humans (who are prepared through education and socialization to transform into a hermeneutic community), exerting influence so that it can actually shape behavior with some efficiency on a mass scale (or, more precisely, to channel mass behavior into the framework set by its patterns), according to the patterns it has forwarded. Consequently, in the ontology of social being, human rights, taken as intellectual representations that do usually function as ideologies, can also acquire genuinely real existence only provided that they actually influence social processes, intervening as intermediaries in(to) social mediation.
\end{abstract}

KEYWORDS historical roots of the idea of human rights; foundation of human rights; nature of human rights; cultural contexture of human rights; universality vs. particularity of human rights

One of the cornerstones of modern statehood and thus of any modern conception of state theory-including the constitutional question and, by definition, good governance and any acceptable formulation of the common good as an end, as well as of the rule of law as a means of achieving it -is the declaration of human rights and the assumption of its system of requirements. ${ }^{2}$ From a difficult struggle that once involved a confrontation with power in the name of the expression of humanity, it is safe to say that the cause of human rights has now realized a political victory. However, it is precisely this political victory of the generalized extension of human rights and their universalization that has made all the theoretical and profound problems that have arisen in the past and, in particular, in the present concerning the

1 Published earlier in Hungarian in 2013 (and later, shortened, in Russian) exclusively. Originally, it had been commissioned as a set of four entries to the encyclopedia of human rights in preparation in Budapest by an editor who, because of her own meainstream views and without further notice, replaced them with another author's entries in the end product. Lamm, Vanda (ed.) (2018) Emberijogi enciklopédia [Encyclopedia of human rights]. Budapest, HVG-Orac 747 pp.

2 Or, there is an "intimate relationship" between the fields of human rights and the Rule of Law. Sajó, András (2004) 'Universalism with Humility' in Sajó, András (ed.) Human Rights with Modesty: The Problem of Universalism. Leiden \& Boston: M. Nijhoff viii+382 pp. on p. 2. 
very justification of human rights, more acute than ever. Consequently, the quest to justify their existence-in other words, to rethink how they can be established, how they are defined in terms of their nature, and what, in the face of anything particular, is their universality and yet their sociohistorical specificity-therefore raises questions that touch upon the very heart of the law.

\section{The Historical Outline of Human Rights}

Western culture traces the human-centered conception of human rights back, almost arbitrarily, to at least one of the central expressions of the Old Testament, which is the first to record the divine constitution of our humanity. ${ }^{3}$ In SopHocles's drama, Antigone may oppose Creon because she is called upon to do so by a divine command, which is, so to speak, immutable in man. CICERo, on the other hand, declares the essential identity of all human beings to be natural, for among humans there is "nulla dissimilatudine [...] in genere."4 All these insights are reinforced by the theological development through St AugustinE and then St Thomas Aquinas on divine and natural law through the Middle Ages and modern times, anchoring in our consciousness the source-identical specific status of our humanity as a result of our eternal existence in the world. It is, of course, about humans, but far from being specific to the state or intended to derive entitlements emphatically independent of the fulfillment of any obligation. However, they do contain, on the one hand, the knowledge of inherent rights independent of human authority-on which GAIUs, in his Institutiones, also expresses the view that civil law may derogate from civil law but not from natural law ${ }^{5}$-and, on the other hand, the truth of what has only been eroded from the European legal tradition by the new and recent age of positivism, by which law is more than a mere legislative product because behind it lies - unwritten - a culture that unites a whole world of values (faith and morals), of which law is merely the tip of the iceberg, as a fragmentary but strikingly visible actualization. ${ }^{6}$

The English Magna Carta (1215) is a milestone in this development. At the same time, of course, it is nothing more than a legal statement of rights-with a practical, detailed

3 Or 'imago Dei' in The Book of Genesis 1:27, according to which "So God created humankind in his image, in the image of God he created them; male and female he created them." <http://www.vatican.va/archive/bible/ genesis/documents/bible_genesis_en.html>.

4 Cicero Delegibus I, X, 28.

5 'Civilis ratio civilia quidem iura corrumpere potest, naturalia vero non potest'; Gaius Institutiones I, 158.

6 On the ancient problematic issues, see also Juhász, Zita (2011) 'De iure non scripto, avagy a korai jogfogalom duplexivitása' [De iure non scripto, or the duplexivity of the early concept of law], De jurisprudentia et jure publico [Szeged], V(1), pp. 1-38 [online]. Available at: <http://www.dieip.hu/2011_1_06.pdf>. 
precision but far from being intended to or calling upon humans to provide an abstract catalog of rights. In this respect, the same can be said of the Hungarian Golden Bull (1222) as of the later English Petition of Rights (1627) or Bill of Rights (1679). All these are declarations in their own form but constitutions in substance, in so far as they record in writing a bilateral treaty.

In 1552, in response to the new challenges of the colonial era, a Dominican friar, BARTOLOMÉ DE LAS CASAS, spoke out in defense of the "natural rights" of the South American Indians. He was driven by the theological conviction that, in the eyes of Christianity, all human beings are entitled to freedom. He is the first to record in writing the existence of what he calls "human rights," which recur again with FRANCISCO SUAREZ in 1612 to form one of the most stable pillars of the modern version of the natural law tradition.

GEORG JELLINEK, who established the doctrine of the state at the turn of the nineteenth and twentieth centuries, already pointed out that Protestantism's emphasis on free individual conscience once helped shape, historically, the idea of human rights as attached to the individual. ${ }^{8}$ In terms of terminology, in English civic development, the Levellers in particular-and prominently RICHARD OVERTON's call (1647)-popularized the invocation of "natural human rights and freedoms" as the "fundamental rights and liberties" of revolutionary movements. ${ }^{9}$ From such roots grew the beliefs of the Anglo-American THOMAS PAINE at the end of the eighteenth century, according to whom the constitution is nothing more than the determination of the people to govern themselves on the basis of rights inherent in the people themselves, which no one can usurp and which cannot be legally limited even by a royal charter. ${ }^{10}$

The real breakthrough comes with the revolutionary wave sweeping the Western world. First in America, then in France-the most vibrant citadel of feudalism of absolute monarchy. The Enlightenment bore fruit in both countries; in the rationalistic creation of the world in both places, an almost religious fervor is at work. In America, public rights-Declaration of Independence (July 4, 1776) - and then liberties directly affecting the individual and the citizen-Bill of Rights (September 25, 1789)—are enshrined in constitutional legislation, while in France, the 17 articles of the Déclaration des droits de l'homme et du citoyen (August $18-27,1789$ ) are formulated, and in the latter, it is the revolutionary National Assembly that

7 Exactly as written: 'las reglas de los derechos humanos' in de las Casas, Bartolomé (1971) A Selection of his Writings. Trans. \& ed. George Sanderlin. New York: Knopf $\mathrm{x}+209$ pp. [Borzoi Books on Latin America].

8 Jellinek, Georg (1895) Die Erklärung der Menschen- und Bürgerrechte. Leipzig: Duncker \& Humblot 53 pp.

9 See Woodhouse, A. S. P. (ed.) (1938) Puritanism and Liberty, Being the Army Debates (1647-1649) from Clarke Manuscripts with Supplementary Documents. London: J. M. Dent 506 pp.

10 Paine, Thomas [1791-1792] The Rights of Man. London: Daniel Esaac Eaton, 1795 vii+151 pp. as well as London: J. M. Dent \& Rutland: Charles E. Tuttle, 1993 xviii+238 pp. [Everyman's Library]. 
"recognises and declares" [reconnaît et déclare] the fundamental rights attached to both qualities of the person. Another half century would pass before Henry David THOREAU, a lone warrior, would fight his battle for tax law. It is from this widely influential literary adaptation-The Rights and Duties of the Individual in Relation to Government (1848)- that the bipolar structure of human rights is imprinted in the consciousness of humanity; that they are not simply a list of the qualities of humans but a clarification at last of the extent of humans' autonomy, that is, the state's self-limitation of the fundamental freedom that every individual has to fulfill themselves.

Afterward, the history of Europe repeats itself. For in the same way that the feudal helplessness of humans, defenseless in itself, once gave birth to the revolution of reason and in it the doctrine of classical human rights, as the product of humans' rational self-reconstruction and at the same time of their new self-reconstitution, now, in the throes of the Second World War, as a reaction to the dictatorships between the two wars, it is slowly taking shape in the body of the Universal Declaration of Human Rights (December 10, 1948), one of the most influential documents of the United Nations, which, with the unanimous vote of 48 countries of the contemporary world (and the abstention of the socialist world, already heading toward a cold war, and South Africa and Saudi Arabia, for a total of eight states) will close the stage of development from the past and gradually open the way to the ever-widening positivization of the sense of entitlement resulting from humans' self-realization. It thus draws a dividing line between the belief, ideology, and doctrine of human rights, on the one hand, and the regulatory field of human rights as part of the written and formalized legal system, on the other. It is the same period that sanctions and popularizes the new vocabulary in English, which is also perceived as one of the most important meanings of the Second World War, proclaiming "freedom from fear and want" to "all the men in all the lands," which is confirmed a year later by the prophetic words of the British wartime prime minister, who in this new departure foresees the coming of "the enthronement of human rights."

In its origin, as we have seen, the idea of human rights was strongly linked to the Christian tradition. However, after the Renaissance, with the advance of industrialization and capitalization, they had to separate; for Christianity, the theological starting point and framework was and remained the dignity and freedom of the divine creature, the person destined to salvation, while the subject of the human rights movement became more and more clearly the individual, the human being emphasized in their uniqueness. All this is undoubtedly a product of Western civilization, rooted in European culture. This can be seen in the focus on the individual, in the opposition of the state as a public power to the individual,

11 In The Atlantic Charter (14 August 1941) and Winston Churchill in The Times (October 30, 1942); cf. Roshwald, Mordecai (1959) 'The Concept of Human Rights', Philosophy and Phenomenological Research, 19(3), pp. 354-379. 
and, of course, as a historical explanation, in the fact that both these developments were a response to the feudalism that European culture had suffered and precisely to radically transcend it and rule out any return to it.

There are, of course, efforts in other civilizations, cultures, and religious traditions that, taken as analogies, are functionally comparable to these. Current research attempts to unravel these Christian European roots in some kind of comparative and universalizing postmodernity-hoping to present human rights as truly universal, as a common tradition of humanity.

\section{The Foundation of Human Rights}

A complex social phenomenon which, in historically changing times, gives expression to changing human aspirations to recognize them-at least by ideological means-in their own community, obviously has a historically changing foundation as well.

Its first attempt to establish a foundation, which is still valid today in various forms, was essentially philosophical in nature. It was based on a convention of values (i.e., an agreement between people). Since its subject was not simply regarded as an arbitrary human choice or a chance arrangement but as a feature of the way in which our world is structured, it was conceived as natural law. This explains why, in SopHocles's drama, Antigone can be precise. For, according to her,

yes; for it was not Zeus that had published me that edict; not such are the laws set among men by the justice who dwells with the gods below; nor deemed I that thy decrees were of such force, that a mortal could override the unwritten and unfailing statutes of heaven. For their life is not of to-day or yesterday, but from all time, and no man knows when they were first put forth. ${ }^{12}$

The position here is clear. There are "unwritten statutes," and they are valid in their own right, for compared with the randomness of our earthly world, this validity is not only transcendent but also eternal. Since it does not come from anyone's own empire, its existence cannot be affected by worldly power. As to its root, this validity may rest either on the given arrangement of the world, which predetermines the nature of things, or, going further as to its source, on the divine creative will of the one who, by creating this world (and not others),

12 Sophocles [BCE 442] Antigone trans. R. C. Jebb in <http://classics.mit.edu/Sophocles/antigone.html>. 
has already preordained it for humans. It is therefore particularly significant that this is considered natural law: is not based on positive law (i.e., not on the will of humans or on the determination of individuals or generations) but on the intellectuality of taking note of our world - and precisely as it exists - and of seeking to discover, from its visible signs, its inner connections, which are not directly perceivable.

However, the answer to what this arrangement is, and above all what follows from it, depends on human reconstruction-on something that, like thinking, is an inherently human action; that is, despite the desirability of following the ideal model of pure rationality, it is always both more and different. Consequently, this human reconstruction will inevitably depend on the possible prior-and perhaps always decisive-ideological and even interest-driven control of the subject acting. To assert the above, it is therefore necessary to acknowledge that the entire history of natural law is a history of definitions-definitions of what nature is, what a human being is in it, and what requirements can be inferred from these as those which will be presented as a derived system of natural law.

The history of science also shows that the apologetic or reformist-critical versions of such definitions against the existing order were not simply reflexes of theological and/or natural concepts at work in the background, but they served mundane policies that were actually dominant or seeking to dominate. The result, from classical times to our own, has been either a catalog of pragmatic enumerations, a coherent system constructed with the precision of a geometer, or, alternatively, a set of systems fixed in the duality of divine order and humans' responsibility for their own determination. In it, recurring requirements were often formulated or directly deduced, which, in the continuity of a tradition that goes back almost two millennia, might have promised some kind of solid foundation for theorizing. Yet, the result to be drawn at any given time was (and could never be) nothing more than either a perpetual debate or the power/normative acceptance of one of the contested positions-without, however, the outcome always presented to this community being considered as agreed in the historical perspective. ${ }^{13}$

Methodologically, it is not significantly different if it is human needs from which human rights are attempted to be derived-although, in the case of natural law, they proceed in a speculative way while here they proceed in a sociological way. In both cases, they refer to empiricism - in other words, to everyday human experience. The efforts of MARX were essentially the same when he explained the duality of the rights of humans and citizens (with the political legitimation of capitalism) by the intertwined definition of an economic basis and a

13 KELSEN argued against the theologically based natural law on the basis of precisely such a banal historical fact. See Kelsen, Hans (1963) 'Positivisme juridique et doctrine du droit naturel' in Mélanges en l'honneur de Jean Dabin. Vol. I. Bruxelles: Bruylant \& Paris: Sirey pp. 141-148. 
political-legal superstructure. ${ }^{14}$ It is worth noting that legal anthropology has been doing the same ever since, seeking to establish the optimal conditions for human organization through comparative historical analysis. ${ }^{15} \mathrm{~A}$ similar basis was once the starting point for the covert attempt at natural law, which was once denied under socialism, when, in the person of a Polish social scientist, she attempted to deduce from the species-essence of humans [Gattungswesen] (in MARX's terms) the minimum conditions of sociality (i.e., of existence in society) by generalizing sociological experience. ${ }^{16}$ Today's equivalents of this broad direction try to infer the inevitability of human rights on the basis of universal socio-biological needs, ${ }^{17}$ human needs as distinct from social needs, ${ }^{18}$ or simply the provision of functional normality, ${ }^{19}$ according to the terminology used. However, a closer examination reveals that, despite their apparently similar aspirations, these are not homogeneous directions. While human derivation from socio-biological needs was expected to formulate absolute entitlements, MARxian economism and томіsm, wrapped in functional normality, both see what they call human rights as functional positionality (an operational function or, in other words, a determinant of the overall movement at any given time and therefore relative and variable).

It is no coincidence that the French revolutionary Declaration of the Rights of Man and of the Citizen in 1789 was the first to cause a shock in England, where there was a tradition of philosophical sobriety and purist realism in the use of language dating back to the early modern period-prompting thinkers such as EDMUND BURKE to formulate the creed of political conservatism-where a JOHN LOCKE or a JEREMY BENTHAM in the centuries of the modern age condemned the use of fictional language and the spread of pictorial, symbolic expressions

14 Marx, Karl [1859] 'Vorwort zur Kritik der politischen Ökonomie' in Marx, Karl, Engels, Friedrich (1961) Werke. Vol. 13. Berlin[-East]: Dietz Verlag pp. 7-11 \& <http://www.mlwerke.de/me/me13/me13_007.htm>. Cf. also Szabó, Imre (1966) 'Fundamental Questions concerning the Theory and History of Citizens' Rights' in Halász, József (ed.) Socialist Concept of Human Rights. Budapest: Akadémiai Kiadó 309 pp. on pp. 2-81.

15 For a related methodological critique, see Whyte, Jessica (2009) 'Particular Rights and Absolute Wrongs: Giorgio Agamben on Life and Politics', Law Critique 20(2), pp. 147-161 \& <http://www.academia. edu/325705/Particular_Rights_and_Absolute_Wrongs_Giorgio_Agamben_on_Life_and_Politics>, and for the dangers of using it for fundamentalist (contemporary American) politics see (2006) Against Human Rights - Slavoj Žižek. [Oct 9 13:33] [online]. Available at: <http://libcom.org/library/against-human-rightszizek>.

16 Borucka-Arctowa, Maria (1970) 'Koncepcja „natury ludzkiej” a wspólczene problemy oceny prawa', Etyka, (6), pp. 79-96 \&<http://etyka.uw.edu.pl/wp-content/uploads/2014/04/Etyka6_M_Borucka-Arctowa.pdf>.

17 Galtung, Johan (1994) Human Rights in Another Key. Oxford \& Cambridge, Mass.: Cambridge Polity Press vi+184 pp.

18 Miller, David (2012) 'Grounding Human Rights', Critical Review of International Social and Political Philosophy, 15(4), pp. 407-427.

19 Maritain, Jacques (1953) L'Homme et l'État. Paris: Presses Universitaires de France xiii+204 pp. Cf. also Fuller, Timothy, Hittinger, John P. (eds.) (2001) Reassessing the Liberal State: Reading Maritain's Man and the State. Washington, D.C.: American Maritain Association \& The Catholic University of America Press 260 pp. 
in general, suggesting a pseudo-metaphysical pseudo-depth, as a clear harm, a return from knowledge to superstition, and therefore a danger of destabilizing society. ${ }^{20}$

However, after a century and a half of labor, the French revolutionary manifesto became, in the wake of the revival following the Second World War, an international recognition of entitlement (1948) signed by the United Nations and declared universal in scope. The Universal Declaration of Human Rights thus led, after a few more decades, to a human rights culture formally protected and enforced by specialized interstate/state courts. Its concept gradually became an indispensable companion to the most sublime principles of Western civilization, democracy, and the Rule of Law, as a major factor in any overall political, social, or economic discourse on the future of world stability and self-sustainability. ${ }^{21}$ From an island country perspective, the Irishman EDMUND BURKE may have wondered how it is possible to simply proclaim as universal what is innate in man. According to him, these were "metaphysical rights" because a right was conceivable only in a concrete situation, after it had been carved out as the expression, that is, the result, of hard struggles. However, he continued, "You lay down [as] metaphysical propositions which infer universal consequences, ${ }^{22}$ revealing in such a designation both a contradiction and a trap. For in the face of all excitement, fervor, and accompanying eagerness, his sober self-control alone made him feel that, though we may talk of anything, to believe that we possess anything as a real possessio by it is childish.

Today, however, our world has changed; it is now dominated by the idea of human rights. We approach it as the sacrality of our time. Not only jurisprudence but also philosophy, political science, even historical research, talk about them all the time. The reconstruction of the past is also increasingly unhistorical because it is performed by means of extrapolation and retro-inspectio under its criterion, so to speak. These "scientific" reassessments and, in their wake, public discourse, as well as various party programs and international manifestos, explain its worldwide spread with the magical repetition of a kind of mantra and endeavor to deepen and extend its culture. It is surrounded by awe and pathos, together with the intention

20 Cf. Sweet, William (2001) 'Jeremy Bentham (1748-1832)' in Internet Encyclopedia of Philosophy [online]. Available at: <http://www.iep.utm.edu/bentham/>.

21 It is ironic that precisely because of this overuse and the generalization that went hand in hand with it as a substitute for many other considerations, the idea of human rights has become as empty as the Rule of Law. With regard to the above, for instance, Griffin, James (2008) On Human Rights. Oxford: Oxford University Press xiii 339 pp. on pp. 14-15 writes that 'the term 'human right' is nearly criterionless. [...] The language of human rights has, in this way, become debased." For a follow-up on the latter, see Varga, Csaba (2009) Jogrendszerek, jogi gondolkodásmódok az európai egységesülés perspektivájában (Magyar körkép-európai uniós összefüggésben) [Legal systems and legal mentalities in the perspective of European unification: Hungarian overview in a European Union context]. Budapest: Szent István Társulat 282 pp. [Jogfilozófiák] \& <http://mek.oszk. $\mathrm{hu} / 15100 / 15173>$, ch. I.

22 Burke, The Right Honourable Edmund (1887) The Works. Vol. III. [1790] Reflections on the Revolution in France. London: John C. Nimmo \& <http://www.gutenberg.org/files/15679/15679-h/15679-h.htm>, pp. $312 \& 528$. 
of endowing it with all the worldly embellishment of pseudo-metaphysics. However, even though they perceive its momentary acceptance as truly entitled to global ambitions, they are still working to at least build a foundation for it by going backward from the present.

Can it be established, can it be justified with scientific clarity, that we have-so to speak-human rights?

The existence of human rights is often simply taken for granted as something that is inherent in a person's particular quality or social practice, ${ }^{23}$ that is, it is self-evident. In more philosophically sophisticated terms, it is nothing more than an assertion of the self-evident self-worth of human existence. Following an early statement by IMMANUEL KANT, contemporary philosophy therefore defines a human being and all humanity as an end in itself that cannot be instrumentalized. ${ }^{24}$ This does not explain anything, but as an axiomatizing premise, it can convincingly offer itself as a common basis for any approach. We should also note, however, that there is also an implicit criticism of principle in this, in the spirit of the well-known and justified Marxist critique, against the fact that (as and how) capitalism reduces/can reduce humans, so to speak, as a matter of law, to a mere statistical unit of the market mechanism.

Others look behind the phenomenon, sensing the indefensibility and the unjustifiability in principle of the linguistic expressions claiming/asserting the existence of human rights. ${ }^{25}$ Thus, the increasing proclamation of human rights from the Atlantic and Western European centers is seen as nothing more than a declaration of values: the formulation of a goal to be pursued as a benefit to the community. ${ }^{26}$ Because the actual existence of human rights, as existing substances, can hardly be discussed in a rigorous analysis, science seems to be in retreat, only stating that we are witnessing something that is becoming a reality, so to speak. The truth of this can indeed be affirmed with sufficient wisdom since history itself testifies that entitlement always tends to go hand in hand with the consciousness of this entitlement, with the consciousness of entitlement itself. ${ }^{27}$ Thus, without a real ontological foundation,

23 For example, Alexy, Robert (2009) 'Law, Morality, and the Existence of Human Rights', Ratio Juris, 25(1), pp. 2-14; Beitz, Charles (2009) The Idea of Human Rights. Oxford: Oxford University Press xiii+235 pp.; Gardner, John (2008) "Simply in Virtue of Being Human": The Whos and Whys of Human Rights', Journal of Ethics \& Social Philosophy, 2(2), pp. 1-22 \& <http://www.jesp.org/PDF/Gardner.pdf> on p. 22; Gewirth, Alan (1982) Human Rights: Essays on Justification and Applications. Chicago: University of Chicago Press xiv+366 pp.; and Griffin, On Human Rights, 2008.

24 Polanyi, Karl (1944) The Great Transformation: The Political and Economic Origins of Our Time. New York: Rinehart \& Co. xiii+305 pp. [Human Relations Collection].

25 Beck, Gunnar (2008) 'The Mythology of Human Rights', Ratio Juris, 21(3), pp. 312-347.

26 Bobbio, Norberto (2007) Das Zeitalter der Menschenrechte: Ist Toleranz durchsetzbar? Berlin: Klaus Wagenbach 126 pp. on p. 11.

27 Pandeya, R. C. (1986) 'Human Rights: An Indian Perspective' in [UNESCO International Institute of Philosophy] (ed.) Philosophical Foundations of Human Rights. Paris: UNESCO 340 pp. at 267-277. 
the process becomes circular. From this perspective, then, all that can be said about human rights is the following apparent lapidarity, nothing more or less: faith in them generates a movement, and its success, by providing self-justification, further strengthens the faith that should have been its foundation. ${ }^{28}$ This is the reality of the pride of (post)modernity: a mutuality of communal psychology, a mass psychosis, which, in the spirit of this ethereality, will also be expressed in mass behavior, if it is given the right impetus. For-and here comes the paradox, which is also the reality of our time, the triumph of artificiality in this socialization-human rights, as such, exist, according to the above, only by acting about them and in their name: by speaking and doing. ${ }^{29}$ Beyond postponing the problem, therefore, science can only try to trace the basis of the obligatory nature of human rights either to the personal dignity of a human being or simply to the facts of human common consent-but in a practical way since it is entirely defensible in the sphere of practice. ${ }^{30}$ In our everyday thinking, one or the other may be convincing. At the same time, however, it is obvious that neither the former nor the latter can serve as sufficient justification. Hence, free of any ideological framing, the science of today only says this: human rights are given as a project. We are given a task; we live by it, we theorize accordingly, and then we adapt our behavior accordingly. Thus, its justification can only be-again — circular. In this way, stripped back to the bone, we are saying nothing more than that knowledge of human rights itself creates a human rights reality which will already correspond, to a large extent, to the description of the reality that it presupposes. ${ }^{31}$

It is not difficult to see a veritable enlightening of consciousness here, an ideology in the most comprehensive sense of the word. Indeed, the modern philosophy of languageand in it the speech acts theory-suggests a theoretical reconstruction of law where, in any formal normative (and thus in law), the linguistic representation of the bond within a given understanding (because socialization and education have made it suitable) of the human medium (as a hermeneutic circle) based on established social practice and the psychological conditioning of each individual participant is capable, as a factor in the motivational system of action, of influencing it in such a way that it can, on a mass scale, with a certain effectiveness, actually shape action according to its patterns (or more precisely, bring it into a

28 Kardos, Gábor (1999) 'A pozitivizmuson innen és túl' [Within and beyond positivism], Magyar Tudomány, XLIV(2), pp. 145-147.

29 Kelemen, János (1999) 'Válasz Ludassy Mária körkérdésére' [Response to the circulated quest], Magyar Tudomány, XLIV(2), pp. 148-151.

30 Beitz, The Idea, 2009.

31 For example, Sajó, András (2004) 'Az emberi jogok mint tudásrendszer' [Human rights as a set of knowledge], Állam-és Jogtudomány, XLV(1), pp. 3-38. 
framework set by its patterns). For we must realize that law does not exist as a physicality either. ${ }^{32}$ For in our way of speaking, in our social communication (or more precisely, as modern philosophy puts it, in our intellectual representations), where and how can coercive power be found? What we tend to experience as a coercive force accompanying the accepted binding character of law is not in fact in the law itself but in the totality of the social environment that presupposes and inevitably accompanies the law, evolving with humans' social existence since ancient times.

\section{The Nature of Human Rights}

In their basic structure, human rights are addressed directly to the solitary human being conceived as an individual. This gives them an unconditional right to claim, which at the same time gives rise-albeit indirectly-to an obligation toward all others. In the course of its development, this right of claim is always asserted against the state in order to guarantee the individual, in accordance with its original conception, inviolability against any possible state overriding power and its conceivable harms.

The scientific reconstruction is clear in that both poles: the state, with an advanced organizational system as the cause and the solitary human as the effect (as the party suffering possible harm), endowed with autonomy in their actions and existence and therefore treated as an individual, evoke the world view of modern Western development and its end product. Scientific reconstruction warns that this narrowness-and in particular the pervasive ideological and political predominance of human rights today-is also leading to a homogenization of the most diverse social tensions and problems, which is precisely the invasion of the concept and tools of human rights, in which the fundamental rights that directly guarantee the survival of the community no longer have a place, and in which, as a technical process, what is taking place under the aegis of human rights protection in the overdevelopment of our time can sometimes even be to the detriment of the community. Again, this whole development, which is typical of its Western civilizational roots, is not at all accidental since historically it was created precisely as a negative mirror of the authoritarianism of European feudalism, as a denial of and response to it, and as a paving the way for the future.

The prehistory/history of human rights is also a constant aspiration for the legal recognition of the requirements that they contain. This means a continuous shift from its prelaw, purely ideological-movement rhetoric to positivation (i.e., a state of protection now

32 E.g. Varga, Csaba (2012) The Paradigms of Legal Thinking. [1996/1999.] Enlarged 2nd ed. Budapest: Szent István Társulat 418 pp. [Philosophiae Iuris] \& <https://mek.oszk.hu/14600/14657/>. 
guaranteed by the law). Since the Universal Declaration of Human Rights (1948), political, diplomatic, jurisprudential, political science, and philosophical fora have been constantly working to expand and extend the catalog of human rights, and its international and national theorization is thus almost continuous and almost arbitrary, with no end in sight.

In the ideology and doctrine of human rights, the completeness and maturity of these socalled rights is attained by their inscription in the positive law and thus by their acquiring the status of a legal norm. The ideology and doctrine of human rights knows the completeness and maturity of these so-called rights. It is also a sign of this that the human rights movements do not ultimately appeal for, or long for, anything other than the protection of state power. It is already clear that, without being transformed into rules (issued/sanctioned) by the state, these rights can only be the evocations of some kind of recorded speech. This is best known to those who proclaim the presence of these rights as innate and indestructible qualities of humans (just like the preachers, who try to make their target community aware of the reality of what they claim, so that they may become their believers, confessors, and even institutionalizers and upholders), only to have the state give them de facto legal recognition (i.e., to assume them with the desired legal consequences, sanctioning them to the point of enforceability). For, without such a transformation, they are not part of the law, even though they are proclaimed as a "right," and consequently do not give rise to any entitlement; their assertion, therefore, as a de lege ferenda aspect toward the de lege lata, can mean little more than an expectation. In itself, however, it is no more than fictitious embellishment.

It is a debatable question whether human rights (whether ideologically asserted or transformed into real rights) are unilaterally conferred on human beings as an absolute right, independently of all other circumstances, regardless of whether they are under obligations to their fellow human, their community, their state, their world and whether they have actually fulfilled these obligations, perhaps as a precondition for making these rights respected. Sensing the moral descent of our times, one of the most influential Spanish thinkers ${ }^{33}$ warned almost a century ago against the proliferation of the dissipation of responsibility and above all, the disruptive effect that universal care, if it were to come (and there are more and more promises, as well as promises of wages without work), would lead us all back to a childlike (or more accurately, childish) state. Nowadays, this is embedded in a distinctly American problematic, namely the "rights language," which is also pervasive in our country. ${ }^{34}$ It is nothing other than a unilaterally expressed expectation (i.e., the expectation of I, You, Him, but always of another

33 For example, Ortega y Gasset, José (1930) La Rebelión de las masas. Madrid: Revista de occidente 315 pp. \{\& (1932) Revolt of the Masses. London: Allen \& Unwin \& New York: Norton 204 pp.; Moore, Kenneth (ed.) (1985) Trans. Anthony Kerigan. Notre Dame: University of Notre Dame Press xxxi+192 pp.\}.

34 E.g. Glendon, Mary Ann (1991) Rights Talk: The Impoverishment of Political Discourse. New York: Free Press xvi+218 pp. 
and never of oneself). It is nothing more than a mere reflection on the psychological-social consequences of the public's expected aid performance: a consideration of the possibility of entire groups becoming dependent on the support of other groups without their own performance, even becoming lifelong beneficiaries of others, thus showing parasitism in their interactions. It is a question of fairness and economic efficiency, ${ }^{35}$ but in today's "politically correct" ideocratization, it can also become a matter of human rights, if it leads to the confrontation of groups and thus to the unintentional or even deliberate breakdown - if not the dissolutionof the social integration that is a sine qua non.

In fact, from its moral theological point of view, the Catholic Church has always taught the complementarity of rights and duties and thus understood them not only as mutually complementary but in the context of a unity that is explicitly and only presupposed by the fulfillment of duties. ${ }^{36}$ Growing up in the same culture but not yet denying the primacy of social integration as a means of preserving the community, MARX also formulated a reciprocal presupposition that was no different. ${ }^{37}$ Human rights ideologies do not tend to respond to this assumption. In any case, the naturalness of its truth is adequately explained by its origin and source since human rights ideologies were not historically conceived as a force of social organization but as a means of overcoming feudal despotism and preventing situations of human vulnerability by neutralizing the overriding power of the state. The reason why human rights ideologies are shrouded in a silence expressing dislike at the idea of the unity of rights and duties is that-as a sort of forced conclusion-their implicit aim is no longer simply curative prevention but, more and more explicitly, the atomizing individualization of society into mere individuals. ${ }^{38}$

35 Of course, the social infantilization that is now becoming a psychiatric problem. See, for example, as a classic Jonas, Adolphe David \& Klein, Doris (1972) Man-child: A Study of the Infantilization of Man. New York: McGrawHill xvi+362 pp.

36 This is why it speaks of "[t]he mutual complementarities between rights and duties ...[which]... are indissolubly linked." [Pontifical Council for Justice and Peace] (ed.) (2004) Compendium of the Social Doctrine of the Church. [online]. Available at: <https://www.vatican.va/roman_curia/pontifical_councils/justpeace/documents/rc_ pc_justpeace_doc_20060526_compendio-dott-soc_en.html>, para. 156.

37 "[N]o rights without duties, no duties without rights" - Karl Marx inscribes in a movement protocol book, [International Workingmen's Association] (ed.) (October 1864) General Rules. London [online]. Available at: <http://www.marxists.org/archive/marx/works/1864/letters/64_11_04-abs.htm> \& <http://www.marxists. org/archive/marx/iwma/documents/1864/rules.htm>.

38 There is little sign that the scientific discussion of human rights is rising above human rights as a mere oppositional politics, as an ideology that is increasingly assuming a world-approving salvationist position. Nevertheless, an open sensitivity to the problem characterises, for example, the adaptation of Hodgson, Douglas (2003) Individual Duty within a Human Rights Discourse. Aldershot \& Burlington, VT: Ashgate xi+277 pp. [Applied Legal Philosophy], and the elaboration of Boot, Eric R. [2017] Human Duties and the Limits of Human Rights Discourse. Cham: Springer ix+183 pp. [Studies in Global Justice 17] as a system based on this complementarity. Yet, for two decades, the problematic issues have been systematically formulated in the Baltic States-not on theological grounds but on the basis of common sense. See, for example, Varga 'In Want of New Balances' in this volume. 
Today's critiques are already warning of the worldwide prevalence of the unilateral declaration of human rights entitlement, of the overwhelming nature of our public discourse and the way in which it is diverting our public affairs into a narrow channel (i.e., the overriding of heterogeneity in the name of a chosen homogeneity). As we know, the translation of human rights claims into law has now given rise to a specific set of legal concepts and procedural techniques that are compulsively used by anyone who deals with social policy, social advocacy, or the management of tensions. It has its place in the law, but it should not be allpervading since it limits the vast variety of instruments, conceptualizations, and techniques that can nevertheless be found in the law to a single response. A compulsively homogenized approach to complex problems can easily derail otherwise promising paths to a solution.

\section{The Universality and/or Particularity of Human Rights}

Human rights, as claims and demands with their legal specification, are indeed universal; however, philosophical reflection and diplomatic parleys promptly raise the question of universality versus particularity.

The very clarification of the conceptual basis implies the possibility of a two-way interpretation. Methodological reconstructions refer to human rights as "essentially contested concepts, ${ }^{39}$ where the presumed core of meaning is surrounded by inextricably divergent interpretative possibilities. This kind of ambiguity in the scope of the validity of human rights is therefore described by the literature in a flexible, figurative term: there is undoubtedly a "fundamental universality," it is argued, but it is nevertheless expressed in terms of "cultural variations. ${ }^{\text {"मo }}$ Alternatively, both halves of this self-contradictory statement prove true, in that it embodies, so to speak, nothing more than the "interlocking of universality and diversity." ${ }^{\text {"1 }}$

In any case, the overall picture is split, as is the idea itself. For its whole ideological edifice would collapse if it did not see its object as universal from the outset, while it has no empirical grip whatsoever on how to consistently universalize across space and time. Hence, whatever official pronouncements we turn to will be about universality and, to that

39 See Gallie, W. B. (1956) 'Essentially Contested Concepts', Proceedings of the Aristotelian Society, 56, pp. 167-198. 40 Donnelly, Jack (1984) 'Cultural Relativism and Universal Human Rights', Human Rights Quarterly, 6(4), pp. $400-419$ on p. 419.

41 'conjugaison de l'universalité et de la diversité'; Marie, Jean-Bernard (2004) 'Specificités culturelles versus universalité des droits de l'homme: Quel défi?' in Kuçuradi, Ioanna (ed.) Threats to Human Rights in the Beginning of the Twenty-first Century. Ankara: Hacettepe University Centre for Research and Application of the Philosophy of Human Rights pp. $75-85$ on p. 82. 
extent, about humanity's conversion to itself at last. This reassures us of the identity of our present, namely the knowledge that we are now living in "the age of rights." ${ }^{132}$ In the spirit of reason, however, science notes that most of our rights/entitlements to this/that can only be understood within an institutional context and therefore can only be imagined within a given social structure and development. It wonders, therefore, how it is possible to imagine universality in a historical space where everything depends on the changing circumstances since even the species-essence of man, as MARX defined it, is historical, that is, in principle, a formation subject to change. It is, moreover, an axiomatic premise of anthropology that any value judgment can only be validly justified within the paradigm of a given culture.

The American theoretician of The Clash of Civilizations ${ }^{43}$ already recorded a decade and a half ago that the buzzwords that dominate our world, such as "human rights," "democracy," "liberalism" or "political secularism," are the signifiers and fruits of Western civilization.

The recognition - and especially the admission — of this creates a tension between the universality of human rights in principle and the European roots that are thus being flattened. This is most often illustrated by examples that characterize our own human rights doctrine from a non-European perspective or describe a solution that we accept but which, from a foreign perspective, is already strikingly problematic.

Let us consider some examples.

From a BuDDHist perspective, it is simply inexplicable that our approach to human rights, based on nothing more than "division and segregation, struggle and contention," is rather barren as it is based on the very ground of dividing and opposing fellow human beings ${ }^{44}$ that because it is based on an artificial ingenuity/construction that has no natural counterpart, it is uninterested in the motives and inner motives within man, while only our external behavior becomes relevant to it; that it formulates an abstract rule in an abstract space and time, but in doing so it merely introduces an institutional mediation into our human processes; that by focusing on individuality—on the free will of the individual—it does not strengthen human dignity but destroys it into a plaything of momentary pleasure. For in its entirety,

42 For example, Bobbio, Norberto (1990) L'età dei diritti. Torino: Einaudi xxiv+252 pp. [Saggi brevi 16] \{(1996) The Age of Rights. Trans. Allan Cameron. Cambridge: Polity Press xix+168 pp.\} discusses it as an achievement of humanity that has finally arrived.

43 Huntington, Samuel P. (1996) The Clash of Civilizations and the Remaking of World Order. New York: Simon \& Schuster 367 pp. on 70-72.

44 Phra Dhammapidok, quoted by Hongladarom, Soraj (1994) 'Buddhism and Human Rights in the Thoughts of Sulak Sivaraksa and Phra Dhammapidok (Prayudh Prayutto)' in Keown, Damien V., Prebish, Charles S., Husted, Wayne R. (1998) Buddhism and Human Rights. Richmond, Surrey: Curzon Press xxi+239 pp. [Curzon Critical Studies in Buddhism] on p. 8. 
-in a "CARTESIan" mood and with no regard of the "fullness of existence"-it embodies "a hard relationship," which is none other than "a mechanistic treatment of human beings where the emphasis is on beings as such regardless of their inner nature and function in the fullest sense; it is an atomistic analysis of beings where the premium is placed on what is relatable and manipulable without regard for their true potentials for becoming. In a way it is externalization in the extreme. ${ }^{345}$

All this is, therefore, not a superior achievement but rather a crisis product of the West: having destroyed its god ${ }^{46}$ and thus-for lack of a criterion-its image of man, it has to concoct a substitute out of what it still has left, namely the ruins of its metaphysical materialism, its psychological reductionism, its nihilistic ethical relativism. ${ }^{47}$ For indeed, today, academic analysts all over the world are forced to admit that our human rights ideology is made up of fragments and therefore has no organic wholeness as a claim, and its fragments are formulated as extreme positions because-and this is again a development in the Westthey operate by litigation. Seen from this perspective, then, normality for the Western conception of law and human rights is itself a never-ending struggle. Moreover, it is an internal and persistent militant division that irreconcilably confronts the individual, proclaimed as the sole holder of the right, with public power-and with such a force that its specific "human rights medium" (its sensitivity, its receptivity) will exclude the public interest (the res publica as the sole source of justification for a state-organized existence) from its possible relevance.

Anthropology detects "structural equivalences" between different arrangements. ${ }^{48}$ However, the fundamental truth behind all human sciences (and thus all social products) is that the meaning/significance of any social fact can only be established as a framework of

45 Inada, Kenneth (1995) 'A Buddhist Response to the Nature of Human Rights', Journal of Buddhist Ethics, 2 \& $<$ https://blogs.dickinson.edu/buddhistethics/category/volume-02-1995/>, pp. 1-9 on p. 3.

46 Friedrich Nietzsche's Zarathustra-Also sprach Zarathustra (1885) - proclaims to the world what he first proclaimed in his Fröhliche Wissenschaft (1885) [(1974) The Gay Science with a Prelude in Rhymes and an Appendix of Songs. Trans. Walter Kaufmann. New York: Random House xviii+396 pp., sections 108, 125 \& 343], that "God is dead. God remains dead. And we have killed him." Cf. also <https://en.wikipedia.org/wiki/God_is_dead>, and Pfahl-Traughber, Armin (2000) 'Also sprach Nietzsche: “Gott ist tot!"', Diesseits, (2) [online]. Available at: $<$ http://www.dober.de/religionskritik/gott_ist_tot.html>.

47 Arslan, Zühtü (1999) 'Taking Rights Less Seriously: Postmodernism and Human Rights', Res Publica, 5(2), pp. 195-215<http://www.philosophy.ru/library/pdf/234617.pdf>.

48 Renteln, Alison Dundes (1990) International Human Rights: Universalism versus Relativism. London \& New Delhi: Sage Publications 205 pp. [Frontiers of Anthropology 6]. 
interpretation within a given civilization. ${ }^{49}$ In any case, on the occasion of the Universal Declaration of Human Rights, the American Anthropological Association once issued a manifesto, which is still valid today, to clarify that the individual cannot be conceived without taking into account the sociocultural fabric that is decisively behind it. ${ }^{50}$

The cultural diversity which, system by system, inherently rejects a European-rooted conception of human rights is astonishingly diverse. In the Confucian worldview, for example, there is no self as such. No one "acts" a role because there is nothing that can be attached to anything from the outside, like a clothes hanger. For every human being is a totality of roles by definition, in the hierarchical/paternal structure of the place and time in question, within the family community. The community of Africa seeks to mediate between communitarian and individualizing values in a spirit of mutual care, ${ }^{51}$ seeking to find the place of the anthropos between the cosmos and theos in a universe conceived as a moral unity. ${ }^{52}$ In contrast, in the case of Islam, for example, in a sacrality that encompasses and embraces all existence, everything that is mundane-including law—can only be part of this divinity, without the secularity of any carnal desire. The ancient traditions of the Far East see the key to the future in the further development of human virtues. They would consider it a loss to waste any energy on the free expression of individuality, as is done by other cultures that dictate themselves in a worldcentric, imperialistic way, above all by those who refer to Europe, to Western European-Atlantic culture, and ultimately to White civilization. This is why INDIRA GANDHI could declare with such striking simplicity that "it is not individuals who have rights but states." ${ }^{53}$

In the Islamic world, as we have seen, only the divine destiny is considered, which is not changeable and which is neither practical nor dynamic. The possible rethinking of the apparatus of worldly life can also only take place within the acceptance of the eternal perfection of this belief. ${ }^{54}$ In the same way, we can continue through the different civilizations. Thus,

49 The basic stance of historicism has become the cornerstone of anthropology, in addition to MARxism: "civilization is not something absolute, but [...] it is relative, and [...] our ideas and conceptions are true only so far as our civilization goes." Boas, Franz (1887) 'Museums of Ethnology and their Classification', Science, IX(No.228) (June 17), pp. 588-589 at p. 589 reprinted in Carbonell, Bettina Messias (2004) Museum Studies: An Anthology of Contexts. Malden, MA: Routledge pp. 139-142 on p. 142\}.

50 [Executive Board, American Anthropological Association] (1947) 'Statement on Human Rights', American Anthropologist, 49(4), pp. 539-543.

51 Ilesanmi, Simeon O. (1995) 'Human Rights Discourse in Modern Africa: A Comparative Religious Ethical Perspective', Journal of Religious Ethics, 23(2), pp. 293-322.

52 Benson, Igboin (2011) 'Human Rights in the Perspective of Traditional Africa: A Cosmotheandric Approach', Sophia, 50(1), pp. 159-173.

53 Quote from the New York Times (July 3, 1975) by Pollis, Adamantia, Schwab, Peter (1983) 'Human Rights: A Western Construct with Limited Applicability' in Pollis, Adamantia, Schwab, Peter (eds.) Human Rights: Cultural and Ideological Perspectives. New York: Praeger xvi+165 pp. on p. 14.

54 An-Na'im, Abdullahi Ahmad (2010) Islam and Human Rights, Selected Essays. Ed. Mashool A. Baderin. Farnham \& Burlington, VT: Ashgate $\mathrm{xxxox}+372 \mathrm{pp}$. 
the Indian mentality knows neither formal right nor entitlement by abstract claim. It can only experience anticipation if and to the extent that it has already been earned with fair proportionality by the party concerned..$^{55}$ In the Japanese world, the concept of entitlement was unknown until the end of the nineteenth century (when the term itself had to be coined in order to translate European codes). ${ }^{56}$ However, even since then, if they use it at all, it denotes a foreign culture; it is hardly used in their internal practice. Thus, how can we talk about selfadvocacy? In the spirit of some kind of justice? In the spirit of loving self-denial within the family, the very idea of doing so would be a contradiction in terms.

The proposition of universality versus particularity, or particularity versus universality, is therefore inherently polarizing. Consequently, this question is not to be answered dichotomously (i.e., with a kind of either/or exclusivity). If such an attempt were made, it could only generate a debate in which extremes would clash, even indefinitely. This is why research is underway worldwide to identify "cross-cultural universals" as a conceptual minimum. ${ }^{57}$

For it is indeed evident that in the process of concretizing definitions in abstract-universal terms, the question of actualization, or contextualization, in the given context of hic et nunc inevitably comes to the fore. This is tantamount to realizing that, although any of us can freely live with paper standards, when they are brought to life, they are interpreted and applied in a given context(s) because how else could they be interpreted $?^{58}$ We cannot get out of our own skin; we do not have a neutral perspective on reality.59

A declaration in Bangkok two decades ago could therefore confirm that

while human rights are universal in nature, they must be considered in the context of a dynamic and evolving process of international norm-setting, bearing in mind the significance of national and regional particularities and various historical, cultural and religious backgrounds. ${ }^{60}$

55 And this is the adhikarin. Pandeya 'Human Rights', 1986.

56 An intriguing story is presented by Hasegawa, Ko (2009) 'Between Rights and »Kenri«' in Ritaine, Eleanor Cashin (ed.) Legal Engineering and Comparative Law / L'ingenierie juridique et le droit comparé (Rapports du Colloque de $25^{\circ}$ anniversaire de l'Institut Suisse de droit comparé du 29 aôut 2008 à Lausanne). Vol. 2. Genève, etc.: Schulthess pp. 87-103 [Publications de l'Institut Suisse de droit comparé 64], providing a detailed chronology of the circumscriptions and experimental conceptualizations used by the Japanese to express in their own language and culture a hitherto unknown and, for them, confusingly abstract position of thought.

57 Renteln, International Human Rights, 1990, pp. 86-87. See also Renteln, Alison Dundes (1988) 'Relativism and the Search for Human Rights', American Anthropologist, 90(1), pp. 56-72.

58 Sajó, 'Universalism with Humility', 2004, pp. 19.

59 Varga The Paradigms, 2012.

60 Final Declaration of the Regional Meeting for Asia of the 1993 United Nations Conference on Human Rights, 29 March - April 1993 [online]. Available at: <https://www.hurights.or.jp/archives/other_documents/section1/1993/04/ final-declaration-of-the-regional-meeting-for-asia-of-the-world-conference-on-human-rights.html>, para. 8. 
In doing so, they are once again, in the service of what is seen as a good cause, doing no more than bringing particularities into a common framework under the banner of universality with a play on words. Thus, they save what can be saved and continue to play this game of words, and, because it is conceptualized, it seems reassuring, though not beyond its own scope.

\section{Conclusion}

As a final thought, our conclusion is that the realm of human rights is nothing more than a world of ideologies, values, and aspirations for the foundation of humanity. Because, by its very nature, it is a virtuality floating in thought, in imagination, it can only see the possibility of its realization or fulfillment in its institutionalization, and within this, ultimately in its transcription into law, and as law. This does not in the least change the fact that, as an artificial part of the ontology of existence that constitutes our world, the species of intellectual representations that can be designated as ideology in the ontology of the social being can also have a quasi-real existence with regard to human rights, insofar as they actually exert an influence on social processes-intervening in them, in an ontological sense, as mediators for mediation purposes. ${ }^{61}$ In addition to the values that they call for, this duality is/ may be the source of the (of course always relative) strength of what humanity has known and cultivated as human rights and as a human rights culture, especially since the second half of the twentieth century.

61 Cf., e.g., Varga, Csaba (2012) The Place of Law in Lukács' World Concept. [1981/1985.] 3rd (reprint) ed. with Postface. Budapest: Szent István Társulat 218 pp. \&<http://mek.oszk.hu/14200/14249/>. 


\section{PUZZLES AND THEORIES}




\title{
RULE OF LAW Or the Dilemma of an Ethos: to be Gardened or Mechanized ${ }^{1}$
}

\begin{abstract}
1. Diverging Patterns 2. Historical Particularism versus Abstract Universalism 3. With Diverging Structures and Paths 4. Imposition or Organic Development? 5. Rule of Law, Certainty of Law, and the Values Involved
\end{abstract}

\begin{abstract}
Post-dictatorship models for transition can be either total defeat with military control, breaking past continuity through preventing local practices to reorganize while re-educating for democracy (as in post-WWII), or just declaring full-pledged rule of law operating from now on (as in postcommunism). Practice may vary in whether or not the Rule of Law is a set of expectations categorically absolute and exhaustively codified or just a respectable ideal having once developed in response to particular challenges somewhere and somewhen, under given historical conditions. Then, it is an art of balancing conflicting values within its ethos: a strive never to end and close as it is a learning process surfacing new features once new challenges are to be met. Eventually, a choice must be made between attitudes characteristic of a circus trainer and a gardener. The temptation at substituting nihilism to a kind of fetishism is also to be faced as it may strengthen the dependence of target countries on patternfollowing by weakening their self-responsibility, which is vitally needed for a successful recovery.
\end{abstract}

KEYWORDS universalism vs. particularism; annihilation vs. fetishization; imposition vs. organicity

\section{Diverging Patterns}

One of the post-dictatorship models for transition is exemplified by total defeat with military administration and jurisdiction, breaking past continuity by preventing local practices to

$1 \mathrm{~A}$ paper commissioned by and presented at the international conference organized by the Umea University in 2007, and published as (2009) 'Rule of Law, or the Dilemma of an Ethos: Gardening versus Mechanisation' in Bergling, Per, Ederlöf, Jenny, Taylor, Veronica L. (ed.) Rule of Law Promotion: Global Perspectives, Local Applications. Uppsala: Iustus Förlag 377 pp. [Skrifter från juridiska institutionen vid Umeå universitet Nr 21] on pp. 213-230. Further versions include (2007), 'Rule of Law, or the Dilemma of an Ethos: To be Gardened or Mechanicised?', Central European Political Science Review, 8(No.27), pp. 46-69; (2010-2011) 'Rule of Law through Legal Transfer: Historical Patterns and Contemporary Dilemmas' in East European $\&$ Russian Yearbook of International and Comparative Law, 4-5, pp. 45-61; (2013) 'Rule of Law, or the Dilemma of an Ethos: Gardened or Mechanized' Law of Ukraine [Kiev], (4), pp. 54-65; (2014) 'The Changing Idea of »Rule of Law« and Post-totalitarian Impositions', Curentul Juridic [Tîrgu-Mureș], XVII(1)(No.56), pp. 64-77 \& https://ideas.repec.org/a/ $\mathrm{pmu} /$ cjurid/v56y2013p64-77.html \{reprinted in <http://mek.oszk.hu/14800/14851>, pp. 85-104\}. 
reorganize, while re-educating for democracy, as patterned by the Allied Powers after WWII in Germany, Italy, and Japan. Another model, at the other extreme, involves declaring a fullpledged rule of law scheme, operated from an artificial zero point on, as made to practice by Central Europe after the fall of communism. Almost opposite are the costs and benefits of either ideals, on behalf of both the party having generated the given solution and the party whom it was generated to. ${ }^{2}$ Notwithstanding that the legacies of bygone regimes-with their successors' task of selecting out one of the above ideal started to be implemented among them after their predecessors' fall—are hardly comparable to one another, the philosophical considerations (together with the relevant politico-cultural and anthropological pre-assumptions) that underlie the selected paths are already close to appear and actually work as mutually antagonistic.

With differences characterized by the following scheme, they are common in that both simply introduce a new regime never met and heard before from the next moment on, when the replacement of power control has been exacted. ${ }^{3}$

\begin{tabular}{|c|c|}
\hline $\begin{array}{c}\text { US w/ Allied Powers after WWII } \\
\begin{array}{c}\text { via military victory \&occupation } \\
\text { through brutal force of facts }\end{array}\end{array}$ & $\begin{array}{c}\text { US w/ global forces after collapse of communism } \\
\text { through mere declaration \& institutionalization }\end{array}$ \\
\hline military administration & experimentation \\
\hline $\begin{array}{c}\text { intervention imposed upon - } \\
\text { instead of democratic mobilization }\end{array}$ & no genuine transitory period \\
\hline military justice (Nuremberg/Tokyo) & past unfaced \\
\hline $\begin{array}{c}\text { discontinuation of the past } \\
\text { w/ dissociation, dissolution \& annihilation }\end{array}$ & $\begin{array}{c}\text { continuation of past getting reorganized, } \\
\text { re-patterned \& re-legitimized }\end{array}$ \\
\hline
\end{tabular}

2 For the above's first description in a context suggesting that there must be an explanation to why the United States of America changed in the meantime the patterns it offered, see Varga, Csaba (1993) 'Transformation to Rule of Law from No-law: Societal Contexture of the Democratic Transition in Central and Eastern Europe', The Connecticut Journal of International Law, 8(2), pp. 487-505.

3 See, for example, Friedmann, Wolfgang (1947) The Allied Military Government in Germany. London: Stevens x+362 pp.; Nobleman, Eli E. (1950) American Military Government Courts in Germany: Their Role in the Democratization of the German People. Ft. McPherson, Ga. x+261 pp. [U.S. Provost Marshal General's School, Camp Gordon]; Montgomery, John D. (1957) Forced to be Free: The Artificial Revolution in Germany and Japan. Chicago: The University of Chicago Press xiii+210 pp.; Redford, L. H. (ed.) (1977) The Occupation of Japan: Impact of Legal Reform. [The Proceedings of a Symposium.] Norfolk, Va.: MacArthur Memorial 212 pp.; Waibel, Dieter (1996) Von der Wohlwollenden Despotie zur Herrschaft des Rechts: Entwicklungsstufen der amerikanischen Besatzung Deutschlands, 1944-1949. Tübingen: Mohr xx+410 pp. [Beiträge zur Rechtsgeschichte des 20. Jahrhunderts]; Diestelkamp, Bernhard (ed.) (1996) Zwischen Kontinuität und Fremdbestimmung:Zum Einfluss des Besatzungsmächte aufdie deutsche und japanische Rechtsordnung, 1945 bis 1950. [Deutsch-Japanisches Symposium.] Tübingen: Mohr ix+398 pp. 
Their most striking difference is perhaps the in-built cynicism and utopianism (with reminiscences of some ahistorical all-mightiness, known mostly from revolutionary honeymoon periods, ${ }^{4}$ by the way) that dominates the solution adopted worldwide today. The very fact that a genuine transitory period is denied from this dramatic change in both theory and practice and that a full-pledged Rule-of-Law scheme is declared to have been rightly introduced from one moment to the next ${ }^{5}$ will inexorably result in a basically counterproductive effect. Namely, the new regime-certainly with abundance in limitations and scarcity of authorizations, and without being equipped with instruments of safe operation, suitable exclusively to develop through new conventionalization while facing everyday conflicts in practical implementation, that is, in a course demanding rather long periods of time-will, in the final analysis, only re-state its own negated past: though in new form and under new legitimacy but with the resurgence of many significant power relations, networks, and connections, waiting in the silent background exclusively for getting reorganized, so that after a while, they can re-pattern step by step and eventually take the lead over the entire political and socioeconomic process. Otherwise speaking, the likely outcome will be a dialectical Aufhebung, by sublating the past (in reminiscence of the HEGELian triad of negating / preserving / transcending its subject). This is why and how the past may have turned into present in a kind of presence able to also define the timely history of the region further on.

Diverging historical coincidences in why and under which conditions the challenge is to be faced may predetermine the approach to it, with the ideologization and overall effect of the whole transformation process as well.

Accordingly, military threat with the imperative of self-defense majored in the first case and profiteering from a given situation while extending control over the target countries was the prime motive in the second case. This was regardless of the fact that the long-voiced longing for returning to institutional Europe proper ${ }^{6}$ had, from the beginning, offered a

4 For the expression, see Sorokin, Pitirim A[leksandrovich] (1925) The Sociology of Revolution. Philadelphia \& London: J. B. Lippincott Company xii+428 pp. [Lippincott Sociological Series] \{reprint (1967) New York: H. Fertig\}.

5 Comp. with the declaration of the Hungarian Constitutional Court's first (founder) president, LÁszLó SóLYOM, messaging in sharp terms-as intervened to Grudzinska-Gross, Irena (ed.) (1994) Constitutionalism in East Central Europe: Discussions in Warsaw, Budapest, Prague, Bratislava. Bratislava: Czecho-Slovak Committee of the European Cultural Foundation 148 pp. on p. 51-that "I am upset and irritated by the term 'transition': for how long are we going to be in transit?! Three years is a very long time in a historic era of rapid change. From a legal point of view, transition was accomplished [...] on October 23, 1989 [...]. Hungary must be considered to have been a law-governed state since that time [...] so from a legal angle there is no further stage to transit to." 6 The countries concerned in Central Europe have in fact belonged to Europe/West (instead of the East) for the last thousand of years, even if political deals may have manoeuvred them to get subjected to powers of Europe/East, as it happened the last time as an issue of the Yalta Treaty in 1945. For the whole span of a historical 
general framework (patterned by the European Economic Community and fore-patterned by the North Atlantic Treaty Organization) for Hungary and the entire region, with the aim of being assimilated into this larger scheme by gradual steps. ${ }^{7}$ All in all, the twisted interest shared by at least one prominent side of the main partners in transformation is perhaps the main factor explaining why and how quite a plain artificiality of the entire setting has had to characterize the latter model of transition in depth.

\begin{tabular}{|c|c|}
\hline $\begin{array}{c}\text { own lives to be lost } \\
\text { being at stake }\end{array}$ & $\begin{array}{c}\text { taking control over target countries in power vacuum } \mathcal{1} \\
\text { amidst their financial dependence being at stake }\end{array}$ \\
\hline imposition of actors \& acts & lead by ancient régime survivors \\
\hline $\begin{array}{c}\text { military regime } \\
\text { military measures taken }\end{array}$ & $\begin{array}{c}\text { adoption of ready-made schemes } \\
\text { taken from EU and/or on sale }\end{array}$ \\
\hline $\begin{array}{c}\text { no issue of } \\
\text { domestic national interests }\end{array}$ & $\begin{array}{c}\text { almost dispreference of } \\
\text { domestic national interests }\end{array}$ \\
\hline thorough change provoked & $\begin{array}{c}\text { changeover of nothing but } \\
\text { power techniques on final account }\end{array}$ \\
\hline
\end{tabular}

After all, it has led mostly to the well-known scene being re-arranged, while almost the same play and assertion of interests were bound to be continued, with a partial replacement of the involved partners. The rather urging time schedule, as sped up during the transformation itself with the felt need to also re-join formally Europe proper again, conditioned huge masses of foreign normative materials to be simply implanted without either the proper care of or the sheer ability to adaptation and refinement. The Rule-of-Law framework that had developed at a relatively early period of transformation (by, literally speaking, preceding the total collapse of communism and thereby also the start of any Rule-of-Law scheme coming into genuinely full operation) with the overwhelming legalistic view and the accentuated juristic treatment of the process itself (in reaction to former legal nihilism, imbued with any dictatorship, and in response to the widely voiced popular longing for putting an

overview, see Szücs, Jenő (1983) 'The Three Historical Regions of Europe', Acta Historica Academiae Scientiarum Hungaricae, 29(1-2), pp. 131-184 rreprinted in Keane, John (1988) Civil Society and the State: New European Perspectives. London - New York: Verso 426 pp. on pp. 291-332 and in parts in Gessner, Volkmar, Hoeland, Armin, Varga, Csaba (eds.) (1996) European Legal Cultures. Aldershot, Brookfield USA, Singapore, Sydney: Dartmouth xviii+567 pp. [Tempus Textbook Series on European Law and European Legal Cultures I] on pp. 14-48\}.

7 Cf. Höland, Armin (1993) 'Évolution du droit en Europe centrale et orientale: Assiste-t-on à une renaissance du "Law and Development"?', Droit et société, (No.25), pp. 467-488.

8 Cf. Mattei, Ugo (1997) Introducing Legal Change: Problems and Perspectives in Less Developed Countries. [Manuscript of a lecture delivered at the Session of World Bank Workshop on Legal Reform in Washington D. C. on April 14, 1997.] Berkeley - Trento 19 pp. 
end to the over-politicization of daily issues, characteristic of the communist era) could only contribute to the timely outcome that after one or two terms of free-elected parliaments and governments heralding both the changeover and the foundational change of the past regime; old-new forces of the ancient régime may now take the lead again with renewed and seemingly legitimate catchwords but in fact exposing the country to the free market of the global capital without due (or duly negotiated) consideration of local interests to be anyhow asserted and protected.

In the final analysis, the reverse was the sense and the ratio of relative costs in investment and benefits gained therefrom, also in terms of which side was to take the burden for all this and had the most likely chance of profiteering from such a planned situation on.

\begin{tabular}{|c|c|c|}
\hline & huge costs of military intervention & almost no costs of control \\
\hline $\begin{array}{c}\text { in short-term } \\
\text { perspective }\end{array}$ & $\begin{array}{c}\text { no issue of impact } \\
\text { upon after-war living standards }\end{array}$ & $\begin{array}{c}\text { decrease of living standards } \\
\text { \& loss of national fortune }\end{array}$ \\
\hline $\begin{array}{c}\text { in long-term } \\
\text { perspective }\end{array}$ & $\begin{array}{c}\text { radical renewal } \\
\text { w/ success in return }\end{array}$ & $\begin{array}{c}\text { uncertainty about future } \\
\text { w/ hopes \& uncovered promises }\end{array}$ \\
\hline
\end{tabular}

From a broader historical perspective, all this may have had repercussions on the changing ways in which Rule of Law has been understood and in fact implemented in classical times and now, resulting in crucial crossroads, as far as the science-philosophical and science-methodological issue of how to conceptualize a historical idea evolved to play a fermentative role in channeling legal practice as an ultimate ideal (to be equally cultivated intellectually and treated as a part of the very ontology of social existence) ${ }^{9}$ is concerned. For quite opposite presuppositions can be reconstrued as two historical instances from those having prevailed then and now, in the process of transition to the Rule of Law.

\begin{tabular}{|c|c|}
\hline $\begin{array}{c}\text { concrete-historical understanding } \\
\text { of the Rule of Law }\end{array}$ & $\begin{array}{c}\text { abstract-absolutizing understanding } \\
\text { of the Rule of Law }\end{array}$ \\
\hline $\begin{array}{c}\text { as if CARL SCHMITT: }{ }^{10} \\
\text { history w/ideals is unique, } \\
\text { bound to conditions }\end{array}$ & $\begin{array}{c}\text { universalism } \\
\text { from the outset }\end{array}$ \\
\hline
\end{tabular}

9 For the ontological status and significance of the lawyers' professional deontology [juristische Weltanschauung] in the law's existence, see Varga, Csaba (2012) The Place of Law in Lukács' World Concept. [1981/1985.] 3rd (reprint) ed. with Postface. Budapest: Szent István Társulat 218 pp. \& <http://mek.oszk.hu/14200/14249/>.

10 Cf. Varga, Csaba (2005) 'Change of Paradigms in Legal Reconstruction (Carl Schmitt and the Temptation to Finally Reach a Synthesis)' in Peter Wahlgren (ed.), Perspectives on Jurisprudence: Essays in Honor of Jes Bjarup. Stockholm: Stockholm Institute for Scandinavian Law [= Scandinavian Studies in Law, 48] pp. 517-529 \& $<$ http://www.scandinavianlaw.se/pdf/48-31.pdf>. 


\begin{tabular}{|c|c|}
\hline $\begin{array}{c}\text { concrete-historical understanding } \\
\text { of the Rule of Law }\end{array}$ & $\begin{array}{c}\text { abstract-absolutizing understanding } \\
\text { of the Rule of Law }\end{array}$ \\
\hline $\begin{array}{c}\text { as if EDMUND BURKE: } \\
\text { achievements must have been } \\
\text { fought for \& through }\end{array}$ & $\begin{array}{c}\text { a case of nothing more than } \\
\text { mere will, determination, \& proclamation }\end{array}$ \\
\hline $\begin{array}{c}\text { as if sociologism: } \\
\text { we, individuals \& society, } \\
\text { are all culturally rooted products }\end{array}$ & $\begin{array}{c}\text { as if mechanical (quasi-biological) determinism: } \\
\text { for any society under any times \& conditions }\end{array}$ \\
\hline
\end{tabular}

Such a sharp difference in the underlying presuppositions explains why, in the former case, a true-and in many features-original democratic arrangement was the historical outcome, while, at least for the time being, a sham and from the very beginning defected politico-legal culture is on the way to being established in the latter case, as if it were to exemplify nothing but the leveling down of values when being drifted by streams at hand, accompanied by low efficiency in quality selection (prophesized by the once "revolution of the masses" described by ORTEGA Y GASSET almost 80 years ago). ${ }^{11}$

\section{Historical Particularism versus Abstract Universalism}

Practice in Central and Eastern Europe varies in terms of whether or not the Rule of Law is conceived as a set of expectations to be considered categorically absolute as quasi-exhaustively ready-made and gaplessly codified, or whether it is taken as a most respectable ideal having once developed in response to particular challenges in given cultures under given historical conditions, that is, as an art of how to balance differing and conflicting values and interests within its own ethos or, otherwise speaking, a strive never to end and close as it is nothing more ambitious than a never-to-stop learning process itself: a compound of various viewpoints and shifts, layers and levels, which re-repeatedly brings to the surface new features, once the field of everyday routine in either typical situations or mostly used solutions is left to meet new challenges. ${ }^{12}$

11 Ortega y Gasset, José (1930) La Rebelión de las masas. Madrid: Revista de occidente 315 pp. \{\& (1932) Revolt of the Masses. London: Allen \& Unwin \& New York: Norton 204 pp.; Moore, Kenneth (ed.) (1985) Trans. Anthony Kerigan. Notre Dame: University of Notre Dame Press xxxi+192 pp.\}.

12 For the perception of how much that what is now clearly seen-even if wrongly-as an unprecedented historical exception in a local (or regional, but in any case: epoch-making) context can be transposed into a modality further adapted from-when allegedly copying - a past exception made somewhere else, a modality which had already been amalgamated and pacified into routine, cf. Posner, Eric A., Vermeule, Adrian (2004) 'Transitional Justice as Ordinary Justice', Harvard Law Review, 117(3), pp. 761-825 \& in <https://chicagounbound. uchicago.edu/journal_articles/1742/>. 
Accordingly, the duality of understandings as portrayed above is to repeat itself here.

\begin{tabular}{|c|c|}
\hline $\begin{array}{c}\text { Rule of Law } \\
\text { as historically particular an ideal }\end{array}$ & $\begin{array}{c}\text { Rule of Law } \\
\text { as abstract-universal a claim }\end{array}$ \\
\hline $\begin{array}{c}\text { own achievement in response to } \\
\text { own challenges }\end{array}$ & $\begin{array}{c}\text { recipe once ready-made somewhere } \\
\text { as closed \& perfected by someone }\end{array}$ \\
\hline "not a pact of collective suicide"13 & to be enforced at any price \\
\hline part of the culture specific for us & a minimum condition to be meted out \\
\hline $\begin{array}{c}\text { to be cultivated } \\
\text { creatively \& responsively } \\
\text { to be suited to coexist with }\end{array}$ & $\begin{array}{c}\text { to be respected unconditionally } \\
\text { as number one criterion of survival } \\
\text { in membership of a given club }\end{array}$ \\
\hline
\end{tabular}

Only very few studies have had the vocation to call scholarly attention to the facts of the past, extremely rich in historical messages, warning against the type of "honeymoon period" a-historicism that is also to refute scholarly achievements of the last century, especially regarding the legal sociological and anthropological analysis of the classical cases of transplantation and of their well-developed Rezeptionslehre ${ }^{14}$-concluding that mere acts of will (i.e., of power imposition) cannot end in kinds of pattern borrowing, able to organically integrate into the working body of the law in a way suitable to exert an impact upon it as comparable to the efficiency of its functioning in its original context.

One trend was to relate ongoing processes and their ideologization to the criticism formulated on the "Law and Modernization" movement, ${ }^{15}$ that is, to the major factors of why it had been bound to (more overall than partial) failure in a mostly Latin American

13 "The Rule of Law is not, and cannot be taken as, a collective pact of suicide"-as taught by JoHn FinNis in Budapest on February 19, 1990 at an international conference on "Rule of Law / Rechtsstaatlichkeit" convened by the political party FIDESz (now the strongest in opposition to the old-new communists in the parliament), referring to the consideration above as practically the sole and exclusive message that our region (under quite new conditions never met before, as facing transition from a subversively brutal and lasting dictatorship) may draw as reasonably useful from the library-wide Western literature on the Rule of Law. For a background, see Finnis, John (1980) Natural Law and Natural Rights. Oxford: Clarendon Press xv+425 pp. [Clarendon Law Series], particularly at p. 175. For the context, cf. also Varga, Csaba (1995) Transition to Rule of Law: On the Democratic Transformation in Hungary. (Budapest: 'ELTE Comparative Legal Cultures' Project 190 pp. [Philosophiae Iuris] \& <http://mek.oszk.hu/14700/14760/>.

14 Cf. primarily Kulcsár, Kálmán (1992) Modernization and Law. Budapest: Akadémiai Kiadó 282 pp. as well as Sajó, András (1988) Társadalmi-jogi változás [Socio-legal change]. Budapest: Akadémiai Kiadó 211 pp., and the long series of case studies such as, for example, Starr, June (1978) Dispute and Settlement in Rural Turkey: An Ethnography of Law. Leiden: Brill xvi+304 pp. [Social, Economic, and Political Studies of the Middle East 23] and Scholler, Heinrich (ed.) (1996) Westliches Recht in der Republik Türkei: 70 Jahre nach der Gründung. Baden-Baden: Nomos 174 pp. [Arbeiten zur Rechtsvergleichung 181].

15 Cf., as an early monographic criticism upon it, Gardner, James A. (1980) Legal Imperialism: American Lawyers and Foreign Aid in Latin America. Madison: University of Wisconsin Press xii+401 pp. 
context ${ }^{16}$ and also to its survival and transposition in renaissance in the conceptualization and methodological preparation of the changes to be provoked by now in a new terrain, that of Central and Eastern Europe ${ }^{17}$-mostly and significantly because of its embeddings in a kind of ethnocentrism, standing for the abstract-universal view of global approaches, looking at societies as ones without their own past and tradition and therefore apt for being treated in a quasi-mechanical manner.

Another trend attempted to reconstruct what the need for a Rule of Law could at all be in history; where and how and as a result of what kind of challenges it has evolved, ending by responding to the dilemma of whether it is a cultural ideal to be aspired for, by measuring pros and cons and weighing and balancing amongst its conflicting aspects-even if never attainable in an airily full completion - or, as arrived at present-day conditions with well-established standards both internationally and domestically, whether it is just a preestablished set of clearly formalized normative requirements to be simply abided by, strictly and formally and under any condition.

In-between mitigation was perfected by a third direction, casting light on the basic differences in underlying mentalités juridiques ${ }^{18}$ between the two main historical manifestations of the same root idea, ${ }^{19}$ namely in the Rule of Law proper developed in cultures of the common law, on the one hand, and in form of Rechtsstaatlichkeit developed in arrangements of the civil law, on the other. For justice administered with an open ending, coupled with due

16 For the main pieces of criticism, see, for example, Trubek, David M. (1972) 'Toward a Social Theory of Law: An Essay on the Study of Law and Development', Yale Law Journal, 82(1), pp. 1-50; Franck, Thomas M. (1972) 'The New Development: Can American Law and Legal Institutions Help Developing Countries?', Wisconsin Law Review, 12(3), pp. 767-801; Trubek, David M., Galanter, Marc (1974) 'Scholars in Self-estrangement: Some Reflections on the Crisis in Law and Development Studies in the United States', Wisconsin Law Review, (4), pp. 1062-1102; Merryman, John Henry, Clark, David S., Friedman, Lawrence M. (1979) Law and Social Change in Mediterranean Europe and Latin America: A Handbook of Legal and Social Indicators for Comparative Study. Stanford: Stanford University Press - Dobbs Ferry, N.Y.: Oceana xvi+618 pp. [Stanford Studies in Law and Development].

17 Cf., as a most telling example, Linz, Juan J[osé], Stepan, Alfred (1996) Problems of Democratic Transition and Consolidation: Southern Europe, South America, and Post-Communist Europe. Baltimore: Johns Hopkins University Press $\mathrm{xx}+479 \mathrm{pp}$.

18 For the term - a fabulous stand to be taken nonetheless seriously—see Legrand, Pierre (1996) 'European Legal Systems Are not Converging', The International and Comparative Law Quarterly, 45(1), pp. 53-81 and as synthetized in Legrand, Pierre (1999) Le droit comparé. Paris: Presses Universitaires de France 127 pp. [Que sais-je? 3478].

Although hidden in reconstruction (by the example of German and English languages) of how differing terminologies coming from differing word uses and cultural understandings are to represent Civil Law and Common Law respectively, cf. the pioneering characterization by Sack, Peter (1987) 'Law \& Custom: Reflections on the Relations between English Law and the English Language', Rechtstheorie, 18(4), pp. 421-436.

19 Cf. Varga, Csaba (2005) 'Legal Traditions? In Search for Families and Cultures of Law', Acta Juridica Hungarica 46(3-4), pp. 177-197 and in Moreso, José Juan (2007) Legal Theory: Legal Positivism and Conceptual Analysis (Proceedings of the $22^{\text {nd }}$ IVR World Congress Granada 2005). Vol. I. Stuttgart: Steiner 263 pp. [ARSP Beiheft 106] on pp. 181-193 \{reprinted in <http://mek.oszk.hu/15300/15386>, pp. 77-97\}. 
process of law of course, stands for the former, while formal security of law trusting in the mere production of legal rules stands for the latter. Paradoxically, although completed perfection of the law as enacted without gaps and waiting for nothing in addition to quasi-mechanical an application spirit the latter ${ }^{20}$ the former is mostly used in global mass transfers as a closed set of requirements codified almost to its smallest details. ${ }^{21}$

\section{With Diverging Structures and Paths}

As it has since long been established by legal sociology and then by legal hermeneutics, a legal system in operation is by far more than a mere skeleton made up of formal enactments; in fact, it is a working unit of formal and informal components, upon the basis of some legal culture, with an adequate tradition in the background. ${ }^{22}$ As it has been argued for exactly by Scandinavian legal realism, ${ }^{23}$ rules-either enacted or casually reconstru(ct) ed-are sheer indicators of the kinds of underlying normativity already in operation, ${ }^{24}$ from which they can surface as icebergs' visible tops at the most. All in all, transfers and impositions risk being wedged in a contexture having been and maybe also remaining alien to them, either detaching themselves from - as an external interference with (and as cast out of) - the target system or decomposing the system itself, by rerouting its further development on an artificial (forced) path rendered from the system's original culture and tradition.

The illustration below clearly shows that no approach to a working legal system can be reduced to a given quantum of enacted rules as mappable out from any formal doctrine on the sources of the law. Rules provide only basic guidance and mark mere directions, specifying the terrains and channels of what would presumably (because obligatorily) follow in judicial weighing, argumentation, and reasoning. This is the average condition for all well-developed

20 Cf. Varga, "Rechtsstaatlichkeit" and "Rule of Law": Divergent Paths of a Corelated Ideal' in the present volume.

21 See Varga, Csaba (2007) 'Reception of Legal Patterns in a Globalising Age' in Calera, Nicolás López (ed.) Globalization, Law and Economy / Globalización, Derecho y Economía: Proceedings of the $22^{\text {nd }}$ IVR World Congress. Vol. IV. Stuttgart: Franz Steiner Verlag, pp. 85-96 [ARSP Beiheft 109] \{reprinted in <http://mek.oszk. $\mathrm{hu} / 15300 / 15386>$, pp. 181-207\}.

22 Cf. Varga, Csaba (ed.) (1992) Comparative Legal Cultures. Aldershot, Hong Kong, Singapore, Sydney: Dartmouth $\&$ New York: The New York University Press xxiv+614 pp. [The International Library of Essays in Law \& Legal Theory, Legal Cultures 1].

23 For a local overview (with some texts reproduced for textbook use), cf. Visegrády, Antal (ed.) (2003) Scandinavian Legal Realism / Skandináv jogi realizmus. Budapest: [Szent István Társulat] xxxviii+160 pp. [Philosophiae Iuris / Jogfilozófiák].

24 For the latest theory on the core of juridicity, cf. Pattaro, Enrico (2007) The Law and the Right: A Reappraisal of the Reality that Ought to be. Dordrecht: Springer xxxiii+457 pp. [A Treatise of Legal Philosophy and General Jurisprudence I]. 
legal arrangements stabilized and crystallized in practice, even if not apparent at first sight. Consequently, at dramatic times, when enacted rules are changed because of a revolutionary new start or massive law import, underlying social practices as well as skills, sensitivities, and adaptations in/through judicial practice also lose ground, while conventions and conventionalization destined to both fill their gaps and make such a skeleton of rules socially livable are to gain ground in years-perhaps decades, even centuries-until the working legal system can be said to fit to rightly expectable expectations.

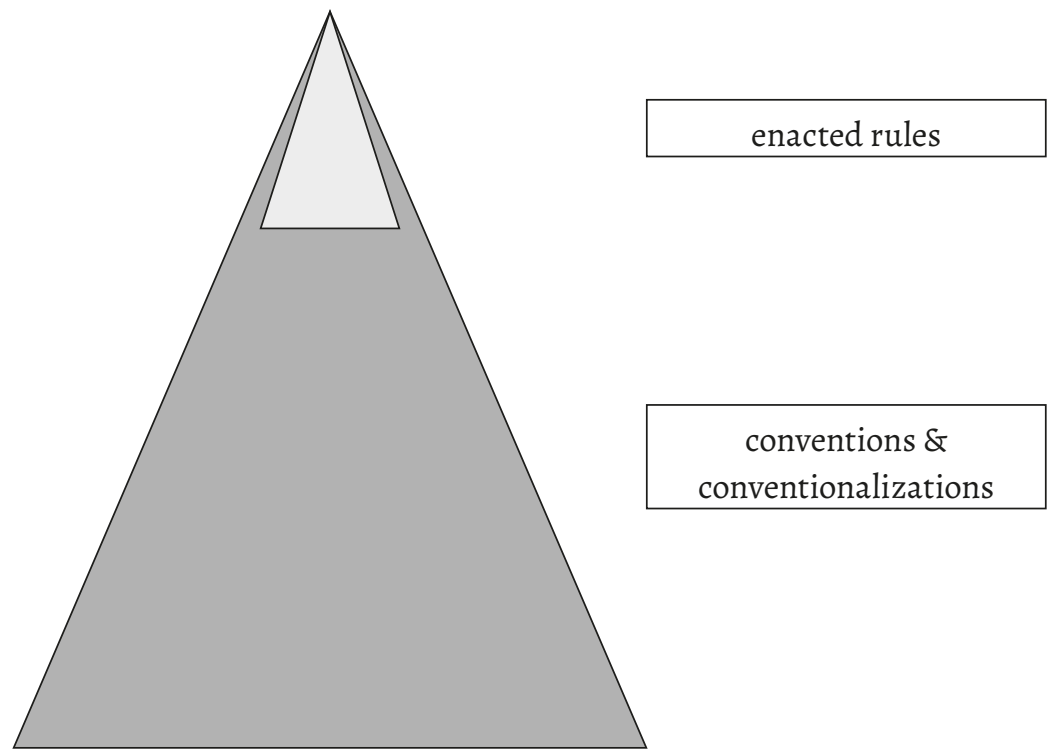

In the meantime, anything can happen on behalf of those who are determined enough to take advantage of any chance to avail, only provided they are endowed with less scruples. ${ }^{25}$ Partly, the overall tragedy of Russia after the fall of communism can also be attributed to the shaking of the regulation on the top and thereby to the collapse of the old regime, which, all if its Byzantic-Asiatic/Mongolian-Bolshevik complexity notwithstanding, may well have been rather meager but nevertheless in a position to assure the mere survival of the populace on a basic level. ${ }^{26}$

25 Cf. also, as mirrored by a Lithuanian case study, Varga, 'In Want of New Balances in Transition: Lithuania Searching for Its Own Path' in the present volume as well as Varga, 'Rule of Law - At the Crossroads of Challenges' in the present volume.

26 Cohen, Stephen F. Failed Crusade America and the Tragedy of Post-Communist Russia (New York \& London: W. W. Norton \& Company 2000) xiv +304 pp. and, as its essayistic review, by the present author in his 'Amerikai önbizalom, orosz katasztrófa: Kudarcot vallott kereszteshadjárat?' [Failed crusade: American self-confidence, Russian catastrophe] PoLíSz (2002. december-2003. január), No. 68, pp. 18-28\&<http://www.krater. $\mathrm{hu} / \mathrm{site} \cdot \mathrm{php}$ ? func $=$ polisz\&file $=$ cikkek\&cnr $=81>$. 
More to the point are some examples taken from Hungary's recent history. Namely, by the forceful push of a doctrinarian libertinist course during the early years of the first freeelected government after the fall of communism, the police was intimidated to use arms; it frequently happened that young policemen on night duty were killed by thieves of old cars of otherwise extremely low value. ${ }^{27}$ The legalistic overtone had pervaded government to such a depth that, after half a century of Soviet occupation, it had no effective means of controlling national security - for instance, by officially asking any of the Hungarian diplomats, army, and police generals in service whether or not they had ever been and/or continued being agents of any of the network of, say, Soviet secret agencies. Moreover, over-enrichment without legal title that might justify its volume could continue uncontrollably all through and practically up to our days as practically all of the successive bills presented until now to wedge at least posterior measures guaranteeing minimum transparency in the process of so-called privatization (ending, by the way, in the loss of two-thirds of the national fortune without due return in direct financial assets or indirect economic benefits) were equally rejected through an overactive constitutional adjudication.

It is much telling about the differences of the underlying mentalités juridiques in play that instead of the continental manner of approaching any issue as a problem to be solved directly in and just through the law, the most useful American suggestion ever addressed on my query ${ }^{28}$ to my government was exactly to evade searching for direct paths and especially ones formulated in and through the law. Only to mention two instances: instead of posterior cleansing, the introduction of a physical fitness test was advised to somewhat rejuvenate those in the highest army and police ranks with dubious past loyalty, on the one hand, and the US-modeled use of questionnaires in re of so-called national security sensible positions-that is, voluntary self-offering provision of all data needed to enable human resources management to begin on the relevant field and conceived as solving the problem outlined in the former paragraph-on the other.

All this stands for the following realization: while substantively formulated paths may easily be found to be problematic, procedural ways are by far more openly neutral as withstanding and excluding any questionability. Otherwise speaking, in cases at hand as those exemplified above, civil law methodology mixed with practices known in common law may prove to be by far

27 Especially in small towns at dawn, characteristically by criminals coming from our Eastern (Ukrainian) neighborhood, where used Zhigulis of a current Hungarian value of hardly more than US $\$ 2000$ still had a good market. For the brand, cf. <https://en.wikipedia.org/wiki/Zhiguli_(car_brand) $>\&<$ https://en.wikipedia.org/wiki/Lada $>$.

28 When, in addition to my positions at the academia and universitas, I served as a member of the Advisory Board to the Prime Minister of the Republic of Hungary between 1991 and 1994, such and similar were the most sparkling ideas we got during our frequent visits from our partners at the US Embassy in Budapest or, mostly, the US Department of State, the Head of the Joint Chiefs of Staff as well as the National Security Council in Washington. 
more practicable and smoothly functioning than just facing the issue as a challenge to anyone's right to be either extended or limited. That is, the same problematization in the pragmatism of an object-language as transposed into the law's normatively frameworked meta-language may feature up and, in fact, serve the most diverging and even antagonistic characters-goals, in function of the (substantive and procedural) directions and (institutional) channels chosen and used, thereby preselecting the legal technicality mastering the given field. ${ }^{29}$

\section{Imposition or Organic Development?}

Whether or not the new language happens to be predominantly American (i.e., formulated in one of rights and human rights) and how much the borrower's peculiar technicality and procedural approach segments and departmentalizes-or even dissolves-the common responsibility once born for the res publica's sake even vivid under the old (communist) regime, is another issue that needs to be examined alongside the scholarly treatment of the movements of law and development, law and modernization as well as within the scope of globalized legal transfers.

Accordingly, and most importantly for the region, a new reality risks having become the mainstream under the aegis of the new demands of the Rule of Law after the fall of the communist dictatorship, and this is the rivalry among state institutions. Under their new legitimacy, parts and branches exercising state power-Parliament and Constitutional Court, Government and the Supreme Court as well as the series of ombudsmen-are even now (after almost two decades past) to fully accomplish to the farthest extent (by over-exhausting what is inherent in) their legal status, while, step by step, extending their respective competences up to the point they can reach at all, with an exclusively sectoral and eminently narrowed view of their own chances and availabilities, but without any intent of either sensitively safeguarding overall common (i.e., national) interests or entering into cooperation with any other branches of the state machinery for such a (legally less definable and posteriorly less accountable) purpose. Having this solitary attitude in mind, the disappointing outcome cannot be but a kind of practical anarchy, casting a disfavorably ambiguous light on the popular understanding of what the Rule of Law is and can at all be. By now starting to be more liking to the once communist myth and propaganda about a better future than to what it appeared to be as serving for two decades ago, when it had become the rallying call as a counter-symbol

29 For the transforming magic built in law, cf. Varga, Csaba (2006) 'Theory and Practice in Law: On the Magical Role of Legal Technique', Acta Juridica Hungarica, 47(4), pp. 351-372 \{reprinted in <http://mek.oszk. hu/15400/15409>, pp. 263-286\}. 
by which the ultimate insupportability of all the forms what we had once known as the "actually existing system of socialism" could be demonstrably shown.

Eventually and in any case, as far as the way of mastering (or the caring for humility toward) the instrument is concerned, a choice must finally be made between the attitudes of a circus trainer and a gardener.

This very option concerns most directly the conclusion, by which the criticism upon the main relevant American trends has ended in its due deliberation. Notably, ethnocentrism and cultural imperialism have been only two instances of the keywords covering this ahistorical new utopianism, which is merely expressive of the contemporary tendencies toward globalization through all-thorough universalization..$^{30}$ The critical mass of papers collected by World Bank bibliographies is alternating in a basic choice to be made between two directions when taking a final stand: either the pattern of a circus trainer in an abstract understanding of the Rule of Law, transmitting and enforcing their own will as previously determined and decided because taken from their home, or the example of the gardener in a historically particular and locally singular understanding of the Rule of Law-a gardener who is (1) in respect of the target culture as given (by cultivating its soil and planting its plants); (2) to assist its particularities to further develop (instead of any of their fixed idea or experiment/ experience, they mediate as made/gained by others at some other place at another time, to be simply transferred and imposed upon); in conclusion of which (3) the Rule of Law as a scheme cannot be more than a continued learning program for all those involved (that is, equally for once pioneers of having historically formed it and past students having grown in the meantime to become masters themselves in equal status with the former) at the most.

\section{Rule of Law, Certainty of Law, and the Values Involved}

In any case-and especially in Central Europe with active constitutional adjudicationthere is a temptation at substituting past nihilism of the Rule of Law $^{31}$ to a kind of fetishism

30 As to the tendency of globalization through universalization, specified as inherently characteristic of the United States of America, an imperially large country-therefore far more sensitive to core issues than to small-size subtleties-cf. Varga, Csaba (2010) 'Rule of Law? Mania of Law? On the Boundary between Rationality and Anarchy in America' in Nótári, Tamás, Török, Gábor (eds.) Prudentia Iuris Gentium Potestate: Ünnepi tanulmányok Lamm Vanda tiszteletére [Festschrift to Vanda Lamm]. Budapest: MTA Jogtudományi Intézete 530 pp. on pp. 492-504 \{reprinted in <http://mek.oszk.hu/15300/15386>, pp. 165-180\}.

31 Cf. Varga, Csaba (1989) 'Liberty, Equality, and the Conceptual Minimum of Legal Mediation' in MacCormick, Neil, Bankowski, Zenon (eds.) (1989) Enlightenment, Rights and Revolution: Essays in Legal and Social Philosophy. Aberdeen: Aberdeen University Press pp. 229-251 \{reprinted in <http://mek.oszk.hu/14700/14760/>, pp. 38-61\}. 
of the same Rule of Law, ${ }^{32}$ which may further strengthen the dependence of target countries on pattern-following and thereby weaken their creative forces and sense of self-esteem and self-responsibility, which are vitally needed for their successful recovery.

After all, in present-day societies, the variations to the ideal of the Rule of Law as described in the first two paragraphs as characteristic of post-WWII developments can be best typified by the illustration below. This very typification is centered on the transition-to-Ruleof-Law understanding of the Rule of Law as a most purist and formalist, simplistic and excessive-proselyte-type exemplified by the path that the Constitutional Court of Hungary had chosen as unilaterally enforced upon the country, which is then compared to the by far more matured and balanced master type formed in the wake of transiting to Rule of Law after WWII, demonstrable by the jurisprudence of the Constitutional Court of Germany.

\begin{tabular}{|c|c|}
\hline German Constitutional Court & Hungarian Constitutional Court \\
\hline $\begin{array}{c}\text { balanced caring } \\
\text { for basic constitutional values }\end{array}$ & $\begin{array}{c}\text { past nihilism } \\
\text { changed over by fetishism }\end{array}$ \\
\hline bound to nothing but its Basic Law & "elegantly flying to and fro above" \\
\hline $\begin{array}{c}\text { coming from below } \\
\text { in respect of expectations }\end{array}$ & $\begin{array}{c}\text { partisan forum } \\
\text { prescribing ultimate choices \& values }\end{array}$ \\
\hline
\end{tabular}

32 In acknowledgment of the Central and Eastern European lawyerly nostalgic ideal of the Rule of Law as reflected back to its respective pre-war past and of the practical want of any impact upon it of the post-WWII continental (Western) developments in both judicial style and patterns of reasoning in respect of both the latter's ways and sources of inspiration (as exemplified particularly by the coming into fore of reasoning by principles, a renewed sensitivity toward the demands of natural law especially in form of "the nature of things," and the growing constitutionalization of issues), cf., in addition to the author's contribution-Varga, Csaba (2007) 'Development of Theoretical Legal Thought in Hungary at the Turn of the Millennium' in Takács, Péter, Jakab, András, Tatham, Allan F. (eds.) The Transformation of the Hungarian Legal Order 1985-2005: Transition to the Rule of Law and Accession to the European Union. Alphen aan den Rijn: Kluwer Law International xviii+673 pp. on pp. 632-654 \&<https://core.ac.uk/download/pdf/18405810.pdf>, on the one hand, and Varga, Csaba (2003) 'Meeting Points between the Traditions of English-American Common Law and Continental-French Civil Law (Developments and Experience of Postmodernity in Canada)', Acta Juridica Hungarica, 44(1-2), pp. 21-44 \& < https://akjournals.com/view/journals/026/44/1-2/article-p21.xml>, on the other-Kühn, Zdenek (2004) 'Worlds Apart: Western and Central European Judicial Cultures at the Onset of the European Enlargement', The American Journal of Comparative Law, 52(3), pp. 531-567.

As to the conflicted role played by the Hungarian Constitutional Court, arbitrarily stipulating what the Rule of Law must stand for in Hungary and then making its own unchallengeable but usurped outcome transubstantiated into an ultimate goal and sine qua non simultaneously, cf. Varga, Csaba (2008) 'Creeping Renovation of Law through Constitutional Judiciary?' in Varga, Csaba Transition? To Rule of Law? Constitutionalism and Transitional Justice Challenged in Central \& Eastern Europe. Pomáz: Kráter 292 pp. [PoLíSz sorozat könyvei 7] on pp. 117-160 \& < http://mek.oszk.hu/14800/14851>.

1 Quoted from one of the Constitutional Court Justices of the first term, reporting on their activity's fruits, IMRE VÖRÖs in [as interviewed by] Halmai, Gábor, Tordai, Csaba (1992) “kevesebb lesz az elegáns röpködés a jogrendszer fölött"' "There will be less elegant flying to and fro above the legal system"], Fundamentum, (2), pp. $60-68$ on p. 68 . 


\begin{tabular}{|c|c|}
\hline German Constitutional Court & Hungarian Constitutional Court \\
\hline $\begin{array}{c}\text { multilateral } \\
\text { democratic participation } \\
\text { w/ profession included if feasible }\end{array}$ & $\begin{array}{c}\text { unilateral } \\
\text { democratic participation } \\
\text { w/ profession excluded on principle }\end{array}$ \\
\hline $\begin{array}{c}\text { legitimacy searched for } \\
\text { incessantly }\end{array}$ & $\begin{array}{c}\text { legitimacy } \\
\text { drawn from mere status }\end{array}$ \\
\hline past discontinued & past continued \\
\hline $\begin{array}{c}\text { law is seen } \\
\text { in totality of its working } \\
\text { in implementation \& adaptability }\end{array}$ & $\begin{array}{c}\text { suggesting pattern-following } \\
\text { w/ weakened creative forces } \\
\text { in adaptation }\end{array}$ \\
\hline
\end{tabular}

Accordingly, on the one hand, in the after-WWII mature type, the idea of the Rule of Law comes-symbolically speaking - to the fore from the grass, as the outcome of a widely felt and consented need from below. Therefore, it preserves all through a rather sensitive relationship to the populace in the widened sense of democratic participation. Under the aegis of the Rule of Law, anything can be done in realization — and, after all, only providedthat practicing it is a function of its continued popular support. Its smooth functioning is inherently preconditioned by moving in parallel with rightly felt popular expectations, at least in the sense that the Rule of Law is not to become a self-conceited, partisan forum of predetermining political paths and national policies, of reforming morals and prescribing values, but it will remain cautious, neutral, and well-balanced by being bound solely to its Basic Law-not owned by the country's Constitutional Court but respected as the ultimate foundation stone for the lifespan of all of the citizens' common Republic - when decisions are to be taken. Therefore, the guardian of constitutionality does not dissociate itself either from the people and/or from the relevant profession(s).

On the other hand, the after-communism type-as favored mostly by Open Society specialists and forces of globalism-has unequivocally opted for formalism and strict rulepositivism whenever refuting the interpretation against its creative innovation is at stake. For instance, early enough to pre-define the entire course and the end result of the transition, the Hungarian Constitutional Court took a stand in what was an artificially erected contradiction between so-called legality and justice, ${ }^{2}$ in terms of which it preferred foreseeability as the sole guarantor of formale Rechtssicherheit-arriving from formal security in/of law to Rule-of-Law continuity with a past based upon the total denial of anything of the Rule of

2 For differing solutions reached by neighboring contries, cf. Varga, Csaba (ed.) (1994) Coming to Terms with the Past under the Rule of Law: The German and the Czech Models. Budapest xxvii+178 pp. [Windsor Klub] \& <http:// mek.oszk.hu/14300/14310/14310.pdf>. 
Law - to the detriment of any material or substantive value. Therefore, and in a rather unforeseeable way, it used to conclude the unconstitutionality of several dramatic issues (bills and laws) based upon nothing but its imagined virtual "invisible constitution," false references to solutions adopted by "civilized nations," or, if any constitutional clause was named and identified as a source at all, the mere description of the Republic of Hungary as "an independent, democratic state under the rule of law."3 Such a way could certainly become the marshaling power of after-communism transition in Hungary, forecasting its degeneration into unconditional continuity, which could, after all, solidify old political forces to come back as new ones, now also endowed by their new Rule-of-Law legitimacy.

Amidst changing times and political preferences in governance, such an approach to the Rule of Law never strove for popularity or participation in democratic processes. It was too contradictory to be able to convince anyone or to have its voice heard as positive feedback out of which a nation's destiny can be formed. In many cases, constitutional adjudication took a course running counter majorities in the public sector such as the parliament, government, political parties as well as academia and universitas, in full consciousness of only one single fact: it is not subjected to any control, as its decisions are of a constitutional force eo ipso; thus, its unilateral acts are made unquestionable from the outset.

The very idea of the Rule of Law is reduced here to the all-mightiness of its uncontrollably discretionary power. For instead of caring for common advance and destiny of a people, such a constitutional adjudication sufficed by proclaiming its positions as if it were to hammer on row materials, acting in such a granted security that the kind of constitutionality it presented as the last value for a nation's survival was inherent in and embodied with it from the very beginning.

Under such conditions, ${ }^{4}$ the rebirth of the vitality of Dicey's thought about public opinion as the ultimate support of any progress achieved in law ${ }^{5}$ is a lesson still to be learned; the fact notwithstanding that all various forms by which the idea of the Rule of Law have been institutionalized up until now do display a strong civilizational value.

3 Constitution as the Act XL (June 19, 1990), Section 2, Paragraph 1. The Hungarian Constitutional Court treated this clause as the basis from which to derive its arguments for a politically activist and interventionist decision, notwithstanding that the term defies any legally unambiguous definition. For the relative openness of the term taken as an ideal and a given solution, only weighable within individual balances hic et nunc and in concreto, see Fallon, Jr., Richard H. (1997) '»The Rule of Law« as a Concept in Constitutional Discourse', Columbia Law Review, 97(1), pp. 1-56.

4 The issue of whether or not the conditions developed do allow the consolidation of a democratic setup is analyzed in broader social science terms by Kulcsár, Kálmán (2006) ‘The New Political System and Hungarian Reality', Angewandte Sozialforschung, 24(3-4), pp. 187-200.

5 Dicey, A. V. (1885) Lectures Introductory to the Study of the Law of the Constitution. London: Macmillan vii+407 pp. \{reprinted as ed. J. W. F. Allison. Oxford: Oxford University Press, 2013 xlvii+522 pp. [The Oxford Edition of Dicey I]\} and Dicey, A. V. (1905) Lectures on the Relation between Law and Public Opinion in England during the Nineteenth Century. London: Macmillan and Co. $\mathrm{xx}+503$ pp. \{reprinted by Indianapolis: LibertyClassics $\mathrm{xx}+420 \mathrm{pp}$. 


\title{
TRANSITION IN HUNGARY Or What to Learn for Future Transformations ${ }^{1}$
}

\begin{abstract}
1. Introduction: On the Call for Early Pre-planning 2. The Assumption 3. Models: Post-communist vs. Post-WWil Ones I. The Hungarian Case of System Transformation 4. No Pattern to Follow 5. Models in Conflict and Flux 6. Lack of Balanced Planning 7. Multi-party Democracy with Opposition, Running Risks that the Needed Stability will Evaporate 8. The Prevalence of Lawyerly Considerations 9. Nothing but Western Self-interest Asserted as Guiding Help from »the West« 10. No Discontinuity with the Past: As a Natural Consequence, the Past is Becoming more Established than ever 11. Divided Country, where the Media as the Fourth Acting Branch of Power Instigate against all Three of the Rest 12. Academia/Universitas Unchallenged, only to be Switched off from Being a Vassal of Moscow onto Another Pole in Family Resemblance to the Same Extremity, the one that Amalgamates with US-dominated Global Universalism II. CONCLUSION III. POLICY DURING THE Process
\end{abstract}

\begin{abstract}
As a critical self-reflection of developments in Central and Eastern Europe in general and in Hungary in particular during the last half century, by calling for early pre-planning for future and presenting the post-WWII as well as the post-communist models of system change, the Hungarian case of system transformation is characterized by features such as no pattern to follow; models in conflict and flux; lack of balanced planning; multi-party democracy with opposition, running risks that the needed stability will evaporate; the prevalence of lawyerly considerations; nothing but Western selfinterest asserted as guiding help from "the West"; no discontinuity with the past, by which, as a natural consequence, the past is becoming more established than ever; a divided country, where the media as the fourth acting branch of power instigate all three of the rest; and academia/universitas being unchallenged, only to go from being a vassal of Moscow to another pole of the same extremity in family resemblance, the one amalgamating with US-dominated global universalism; ending with a conclusion and the policy during the system transformation process, which is proposed to any entity possibly facing the job again. To master the course, sovereignty must be regained, both to be able to elaborate proper responses to the challenge and to develop the mental and moral capacity to face problems in their due way.
\end{abstract}

KEYWORDS models of transition; balance between legal and in-substance considerations; continuity/ discontinuity with the past; need of transition of academia/universitas life; concurrence of own building and global integration

1 Invited contribution to a Korean Institute for National Unification Center for International and Strategic Studies project from which-published subsequently as Kim, Kyu-ryun (ed.) (2014) Lessons of Transformation for Korean Unification. Seoul: KINU xi+350 pp. [Research on Unification Costs and Benefits 2014-2] -I had to withdraw this case study because expectations changed retrospectively, with forcefully homogenizing intentions, during the preparation process.

Already published as (2014) 'What to Learn for Future Transformations? Lections from Central European Transition to Rule of Law', Central European Political Science Review, 15(No.58), pp. 9-38. 


\section{Introduction: On the Call for Early Pre-planning}

One may step onto various roads leading to diverging destinies, which, in the long run and at least retroactively, may also cause one's original identity to change. The same may also happen with nations and clubs of states. Further, as to the kind of consciousness involved, one may prepare for-by expressly engineering - them (in which case, whatever the eventual outcome shall be, it will prove to be the consequence of factors planned in advance to build in the process), or one may just be ready and determined enough to face any challenge when situations and chances are encountered, within and for which the foreseeability of any event requiring prompt action (or series of actions) emerges. In modern times and with nations built upon well-founded traditions as actors on the scene, when a war ends, perhaps already the next day, some early preparation to the conclusion of peace treaty will have had a start. To take a twentieth-century instance, planning and negotiations that had forerun, shaped, and eventually also defined-in both Europe and Asia-the conception of what would become known as the Nuremberg/Tokyo trials, denazification, and so on as a final product were all to progress step by step, by turning back and forth, over the whole span of the war years. All this to conclude that it is desirable to start thinking in alternatives of either action or reaction, but in both cases, covering the ends and means as well as effects and by-effects that may advance or hinder any course in due-rather early—time.

\section{The Assumption}

The basic assumption underlying the present discussion is the eventuality that a reformative regime in what is called the Democratic People's Republic of Korea may emerge at any time in the future of the Korean peninsula's ever-long common history, initiating, by the side of either this entity, North Korea, or the Republic of Korea (i.e., South Korea) the first steps for ending their antagonism through some sort of a unifying process. Under such a hypothesis, tiring political talks intermingled with mutual compromise solutions and ending in concessions may prove to be a prerequisite to being able to develop some joint trust in agreeing that continuing the discourse is worthwhile. When (1) the will of unification will have already been commonly shared, this agreement stage can be succeeded by (2) the integration stage, in terms of which both institutional and economic integration are taking place step by step, lasting as long as years to decades perhaps, depending upon the depth of the integration of the state and the society to be formed by the end. An imaginary step forward can be idealized as (3) the nation-building stage, whose aim at far-reaching, thorough, and up-tothe-depth social and psychological integration might only lend itself to a genuinely historical 
perspective, presupposing so long a period to reach an (often imperfect) achievement as the only realistic output and as the present-day (relative) end product of any actual nationbuilding that has ever taken place under the complex conditions of world history. Finally, (4) the closing point of the process might only be the unified Korea as a normal state, an end result that must be hypostasized as the might-be promise of future, after generations' untiring efforts at it. Properly speaking, this can only be a historical job, which is already placed beyond the perspective of all tactics and strategies that human planning, dedicated to its own historical time and imaginability as drawn and abstracted from the humanity's selfreflection upon experience cumulated from the comprehension of both the past as well as the present, can truly apprehend and master.

\section{Models: Post-Communist vs. Post-WWII Ones}

For Hungary and the other state entities in Central and Eastern Europe, ${ }^{2}$ the whole agenda of system transformation is most commonly known as "transition to Rule of Law," which used to have a tripartite stake consisting of (1) building multi-party constitutional democracy from a communist, one-party dictatorship; (2) helping capitalism to emerge from the ruins and out of the devastations of the centrally planned state economy; and (3) instituting the Rule of Law by overcoming its past denial. Such a complex challenge had to be faced by almost the entire region, which three of the victorious WWII Allied Powers left to the fourth of them, to the mercy of the mighty of Red Army (which had been led by Moscow party rule as assisted by local collaborationists) for more than four decades-except to Soviet Russia with regard to the Soviet Union itself, which had developed and then endured her own regime for nearly three-quarters of a century.

As to the past regime-both the patterning one and the patterned (or satellite) ones-the possibly deepest deformation that ensued from the communists' reign was not that institutions and structures had been turned upside down but that human souls had become deprived, step by step, of both civic virtues and civilian mentality. For this was done, indeed, so that those subjected could be homogenized as sharing the same politically over-ideologized and thoroughly instrumentalized partisan mentality, which, from the very beginning, was made ready to intervene in blocking and/or destroying any spontaneous development if, all that notwithstanding, one happened to emerge.

2 For a comparative overview, cf. Gessner, Volkmar, Hoeland, Armin, Varga, Csaba (eds.) (1996) European Legal Cultures. Aldershot, Brookfield USA, Singapore, Sydney: Dartmouth xviii+567 pp. [Tempus Textbook Series on European Law and European Legal Cultures I], part dedicated to »Transition to the Rule of Law«, pp. 413-490. 
Catchwords? Collectivism versus individualism (and either/both versus the person's dignity, as one of the ultimate values of CHRIsTianity, the one commanding unconditional respect under any conditions) as well as strict rank-and-file discipline versus the freedom of all kinds that must overarch, as a natural and absolute corollary, personality. Such and similar clashing opposites had to be abruptly changed and/or resolved in the course of any system transformation-a tremendous task that, with rotating governments and policies under new and democratic conditions, could only be completed through crisscrossing, in repeatedly reversed target directions, between the extremes.

Anyhow, the basic challenge was something hitherto unprecedented in all human history that had to be faced-especially by the European part of humanity-all and through the whole span of the twentieth century. For now, individual lives, together with living communities that they had once been anchored in, became a genuine race laboratory dedicated to experimenting and testing human behavior for that full scale social engineering (the ideal of modernism since the end of the nineteenth century, ordeal of mere rationalism emptied from classical humanistic values, deployed for planning a new society by a stroke of the pen, promising everything of the past to be left behind as a mere garbage) could eventually be launched on, in mass proportions. Accordingly, as an instrument helping the end to be reached, a strive, never heard before, accompanied it, in view of which humans themselves would be programmed following a strict code, erecting the psychological state of readiness for that they would behave-act and react-uniformly, even if faced with a variety of unexpected challenges and had to step in a succession of historically changing directions, in which only a superior in hierarchy was authorized to issue a directive.

Such and similar characteristics were in fact common to regimes born after that the Great War and its lethal consequences had become too apparent, those regimes once called "New Deals,"3 which, in confrontation with-and in order to overtake-the parliamentarian democracies of the time that failed to offer adequate responses to their epoch's main challenges, had in fact done nothing but nurture contributions to a new type of dictatorship. All that notwithstanding, as far as their underlying nature is concerned, there is a basic difference between the interwar re-formation (or de-formation) of, for instance, the destinies of Germany and Italy, with their interiorly felt need for abrupt destruction for that a new society could be built upon the predecessor's ruins once they were defeated, and of the postWWII extension of the Soviet Union's Asiatic barbarity to Central and Eastern Europe, with

3 Classically Lengyel, Emil (1934) The New Deal in Europe. New York \& London: Funk \& Wagnalls vi+312 pp. For one of the contemporary reviews, cf. Lynch, William O. (1934) in Indiana Magazine of History, 30(2), pp. 203204, and see, as a present-day reconsideration, Schivelbusch, Wolfgang (2006) Three New Deals: Reflections on Roosevelt's America, Mussolini's Italy, and Hitler's Germany, 1933-1939. New York: Metropolitan Books 242 pp. 
the search of those subjected to find a path they might wish undertaking, once the entire empire had been doomed and fallen apart. For what the Allied Powers sensed that they were facing after their military victory had been secured was nothing but almost insurmountable dimensions of a job to take: (1) neutralize past militarist dictatorship while—and partly also through-(2) re-educating a whole population's poisoned minds. Although it is to be noted that, in case of Germany at least, (a) capitalism remained unchallenged-neither overturned nor nationalized but somewhat state-monopolized and militarily marshaled-to be then channeled back to free market capitalism; (b) the alleged toxication, covering huge masses of society indeed, could be effective no longer than, all in all, 11 years; and (c) the besieged state was, as characterized even by its most ardent critics already in exile, operated as a "dual state" [Doppelstaat], ${ }^{4}$ with a simulacrum of the Rule of Law offered to what it treated as the "friend" part of it, counter-distinguished from the other part, the "enemy," within the dichotomized, two-strata society. ${ }^{5}$

In short, the Herculean task having awaited Central and Eastern Europe after the fall of communism can perhaps be best (though symbolically) characterized by an airplane that must undergo a complete changeover of its whole structuring and operating ensemble, including engines and piece-to-piece constituents, while flying with full cargo.

\section{THE HUNGARIAN CASE OF SYSTEM TRANSFORMATION}

\section{No Pattern to Follow}

Central and Eastern European experiences of system transformation are rather varied; at the same time, they are shadowed by the fact that there has been no available pattern to follow. Consequently, only some adaptation of the "trial and error method" could be used, namely in variation to classical models, inasmuch as the "insight, theory or organized methodology" were subject to changes by each round, alternating from one to another endlessly under the new conditions of parliamentary rotations.

4 Fraenkel, Ernst (1941) The Dual State: A Contribution to the Theory of Dictatorship. [Doppelstaat.] Trans. E. A. Shils. New York: Oxford University Press xvi+248 pp. The Rule of Law [Normenstaat] instituted for civic life with economy, commerce, etc. involved, and rule of measures [Maßnahmenstaat] with instrumental functionalism for power secured; cf. <http://www.lexikon-drittes-reich.de/Doppelstaat>.

5 Schmitt, Carl (1922) Politische Theologie: Vier Kapitel zur Lehre von der Souverenität. München \& Leipzig: Duncker \& Humblot 56 pp. resp. (1985) Political Theology: Four Chapter on the Concept of Sovereignty. Trans. George Schwab. Cambridge, Mass.: MIT Press xxv+70 pp. [Studies in Contemporary German Thought].

$6<$ http://en.wikipedia.org/wiki/Trial_and_error>. 
The only exception to this overall picture was afforded by Germany, where a state entity called East Germany [Deutsche Demokratische Republik] was unified by/to what was known as West Germany [Bundesrepublik Deutschland] in the course of a rather thoroughly planned and controlled process that was marshaled, on the unifying side, by a solidly strong democratic parliamentarian power and high level of state craftmanship, substantiated by a nationwide and long-nurtured commitment to the cause, and, last but not least, bolstered by outstandingly stable economic wealth. The West German preparation for a future unification was exemplary; its founding charter, the Basic Law of Bonn (1949), ${ }^{7}$ had once been drafted expressly in such a perspective.

Alas, considering the particularity of the German story, Germany's path could not offer too many lesson to other countries concerned, not because of its federal system but for consideration of the fact that none of the rest had "another" or "counter" part to it to patronizepolitically, logistically, financially, and with regard to the human skills needed-the whole process. Instead, the countries freed from the Soviet occupational empire were, without exception, almost fully drown in a deplorable state of being at the threshold of financial bankruptcy, facing unsustainability of a weak economy, operating a growingly ineffective and unjustifiable political, administrative, and economic structure-all adding up to form a general condition that was already to forecast a complete social/societal breakdown.

\section{Models in Conflict and Flux}

Consequently, for a long while-for instance, in Hungary for 20 years, until the present government won two-thirds of the seats for the first time-(a) parliamentarism as a political system also had the potential to mean that the entire conception devised-alongside the whole instrumentality erected-for system transformation had to begin as formatted anew in every fourth year, that is, to restart again as if from scratch; (b) a multi-party system favoring that during the whole span of the mandate of any given government, some sort of antagonism (with the opposition's questioning and disputing whatever measure taken endlessly and without the hope of anything resolved in good standing) would necessarily form to prevail on why, how, to what depths, and which of the state agencies were at all to proceed on; moreover, (c) the common call for the Rule of Law-with a particularly doctrinaire understanding of it, ordered as the dictate of the Hungarian Constitutional Court, of what exactly should stand for it as applied to the issue at hand in the given moment—could only assist

7 <https://www.btg-bestellservice.de/pdf/80201000.pdf>. 
first and most directly nothing but the renaissance of the ancien régime, that is, the old communist course, with its in-built network preserved, to survive in an even reinforced strength and vigor and, from now on, sealed by the new, reinstated, and genuinely authoritative Rule of Law legitimacy; last but not least, (d) even the past media monopoly of the party-state (sublated now as the old-new proprietor's media monopoly resulting from a "successful" privatization process, defensively actuated by the old forces in the last minutes of their reign) launched close scrutiny of, by agitating against, any effective action that envisaged (or could envisage, as a by-effect) limiting or interfering with politically or economically vested interests or, anyhow, diverting the country from the path taken hitherto.

The accumulation of such and similar factors and the adversary environment could not lead anywhere resembling to the original target but to a sham transformation alone, achieved and fulfilled more or less on a rather nominal plane, by renaming that what hasstructurally, functionally, operationally, even contextually-been the old. Accordingly, after more than 12 long years of a period of hardly 24 years since the communists' fall, the end product could be nothing but a de facto communist survival, intersected by another 12 years when the same could also go on somewhat mediated by, that is, within and through, a multiparty political structure.

As to the factors lurking behind the scene, this could materialize partly due to (a) the presence of old communists pressing their antiquated agenda disguised as socialist (Social Democratic) or Liberal program in the parliament, and partly due to the fact that (b) past party propriety (once separated, with no return, from the rest of the private property nationalized after WWII with no return again) remained untouched (never returned to or accounted for the public) and that (c) a huge part of the once nationalized property, which had therefore been state-owned all through the period of communism, became private propriety again—now having been privatized by rank-and-file communists (appearing as capitalist managers and/or liberal statesmen or public figures now) by the time their own (or their fathers') regime collapsed; finally, as already noticed, (d) mass media were also privatized mostly by the same old-new forces and, to top it all, early enough for being able to fully exploit them to hold on informal control over policies, thereby preventing models from both conclusively settled finalization and successful popularization.

\section{Lack of Balanced Planning}

After the initial search for a path had failed, what ensued was an uncertain course in itself-stopped, restarted, and diverted from original paths again in a sort of cycle. Consequently, government action could only be full of ambivalences, within the womb 
of which oscillation among kinds of proselytic overdoings and considerate-to-expectations-of-the-West underdoings with incompetences and gross misunderstandings often mixed. For that matter, what was missing was definitely not political or moral courage, or intellectual capacity of or due perspective in planning for system transformation. In Hungary, for instance, preparatory studies to and series of programs themselves were elaborated abundantly by both the governing parties and their oppositional counterparts. As to the National Renewal Program, ${ }^{8}$ it was well founded and consequent for most its parts. It is so much so that nowadays, almost a quarter of a century after the missed opportunity for an effective and thorough regime change, the present-day government (which is mandated by two-thirds of the votes for the third successive time now) is still endeavoring to implement some of its elements (or at least some variation of their original idea).

In sum, the coming to fruition of planning ideas has been blocked from the very beginning. The way things stood then was mostly the outcome of the timely (and certainly simply random) coincidence of many significant factors. Some of them are overviewed in the next few sections.

\section{Multi-party Democracy with Opposition, Running Risks that the Needed Stability will Evaporate}

The democratic arrangement operated by a multi-party parliamentary structure may be situated under rather harsh, sensitive, and hardly manageable conditions, especially when the job of dismantling a thoroughly centralized and dictatorial party-state system is to be effected; moreover, when this must be done at a time when offering "nothing but blood, toil, tears, and sweat" can be the exclusive option. For what was to be considered and weighed as the present state of nations concerned in Central and Eastern Europe in general and of Hungary in particular, was (a) a nearing bankrupt financial balance; (b) the evidence gained on the irrentability of the inherited state economy; (c) immediate exigency for that its assets shall be privatized, even if for an unproportionately low offer in return; (d) the widely shared unrest of population as natural reaction to their miserable condition, even aggravated by the lack of any promising perspective; accompanied by (e)

8 Cf., e.g., [Advisory Body to the Prime Minister of the Republic of Hungary] (1992) Hungary's National Renewal Program: The First Three Years (1990-1992) of the Republic. Budapest 197 pp. (with the present author's part taken in the elaboration).

$9<$ http://en.wikipedia.org/wiki/Blood,_toil,_tears,_and_sweat>. 
the want of any spiritual/symbolic/demonstratory and emotionally-mnemonically memorable moment that could seal the rupture with the past and open a perspective on the future-indeed, any event/act from the sensation of which further encouragement and determination could have been drawn-; and (f) what remains in all of the formers' absence, or ignorance, cannot be anything less utopian than life standard expectations rocketing to the heights overnight. Indeed, any of these occurrences (even if not a cumulation of them) could be used as an easy pretext for provocation, for instigation to withdrawal, resistance, or rebellion. For to pave the path to such bad turn, it might be enough to make airy—gratuitously irresponsible-siren voices (especially by opposition parties and hostile media) be heard, for that interference with coming events would be crowned by success. The rivalry of parties in moral and legal vacuity is, after all, a free space for marketing with free promises.

As a consequence, complex programming, which presumes long-term cooperation, may this way be deprived of chances from the beginning as it risks getting unwittingly intersected by four-year periods of governments' mandates-a situation especially difficult to overcome and almost impossible to manage when self-discipline and self-restraint (that is, self-denial, with practical renouncement of long-expected privileges) are among the first expectations that governments must demand from the populace as a prime precondition. Under difficult situations, when a genuine turn is the only option, any agenda for being successful may presuppose the complementarity of self-devotion as a popular virtue.

This is to claim that, generally speaking, the more the government recurrently faces the urgent economic-financial need to impose restrictions on the populace, the more the entire scheme becomes captive to media intentions-good or bad as they may be-of whether or not media moguls are willing to stir up against such restrictions and thereby against the credibility, stability, and even force of the government, also testing its power of resistance. An old wisdom may reiterate itself here: rightist and leftist governments succeed one another, with the one investing and the other squandering what the former has accumulated.

It is also to be added that under limiting conditions, when neither frameworks nor measures within frameworks are yet stably given, ideas themselves (wherever they were brought from) are usually interpreted discretionarily, that is, according to the fist law of mihi placet ["it pleases me"], dictated mostly by particular interests alone as the exclusive reason for the given variation. 


\section{The Prevalence of Lawyerly Considerations}

Popular disgust of and resistance against the never ceasing over-politicized, a-legal, and manifestly il-legal manipulations of the communist regime ${ }^{10}$ was most visibly expressed by the population-wide cry for the reestablishment of the Rule of Law as a prioritized agenda that has ever stood for the overall undertaking of a regime change, that is, a really public manifestation that has become the symbol of the wish to change. Indeed, in the late 1970-1980s and as a first reaction, the communists, who were initially themselves addressed by that, metamorphosed into a reformist party, hoping thereby to possibly extend their long institutional agony. This was a period lasting for several decades, with mostly one step forward and two steps back, until the communists had to acknowledge their final breakdown and regime collapse by 1989. On the one hand, what they aimed at was something fake and deceptive-and also abortive-from the beginning because they narrowed reformist action to the economic sphere alone, excluding the heretic idea of challenging the foundation of their power on party rule. On the other, even so, they hastily drafted a regulatory framework for simulacra of a democratic establishment, setting up, among others, a Constitutional Council, which was reminiscent of the French Conseil d'État but without any genuine commission.

Anyhow, in the meantime preceding the breakdown, "constitutionalism," "legalism" and "lawfulness" became a panacea for both curing and smashing the old at will. Accordingly, the Rule of Law was invoked to embody the very reason why and the prime criterion of how to destroy something and build up something else in its place.

Consequently, establishing a genuine Constitutional Court was decided as early as the tripartite talks amongst communist government and the pseudo-civil organizations it has set up, on the one side, and their civic opposition, on the other, which were reconfirmed statutorily the following year in late 1989. ${ }^{.1}$ The practice of constitutional adjudication, however, has forged, step by step, a major autotelic force, a new dictatorial center of sovereign control of any power and development in the country from an institution worthy of itself. The "invisible constitution" that the Court invented and steadily erected became the sole yardstick used as an all-purpose standard in substitution for everything else to measure constitutionalism. A privileged body of a handful of professors holding no responsibility but full power to enact what they deem to be feasible-a body limited only by its own (nonexistent)

10 As an ontological explanation of why such a law could only be the case of a wicked law, cf. Varga, Csaba (1989) 'Liberty, Equality, and the Conceptual Minimum of Legal Mediation' in MacCormick, Neil, Bankowski, Zenon (eds.) (1989) Enlightenment, Rights and Revolution: Essays in Legal and Social Philosophy. Aberdeen: Aberdeen University Press pp. 229-251 \{reprinted in <http://mek.oszk.hu/14700/14760/>, pp. 38-61\}.

11 For an overview by its first president, see Sólyom, László, Brunner, Georg (2000) Constitutional Judiciary in a New Democracy: The Hungarian Constitutional Court. Ann Arbor: University of Michigan Press x+417 pp. 
self-control-has necessarily degenerated into a politically interventionist and partisan decision-maker, judging any exercise and manifestation of national sovereignty at will..$^{12}$ Its decisions-often based on either mere discretion or apparent justification based on nothing but hardly operative constitutional platitudes (like the laconic formulation that "Hungary is an independent, democratic state under the rule of $l a w^{\prime 13}$ )— have prioritized formal certainty and foreseeability of the law to the neglect of anything else, including the most vital and acute considerations of justice. Such a politically regressive activism has, from the beginning, leveled down the chances of a successful break from the past. In addition, the constitutional justices' over-formalistic and reductionist understanding of the Rule of Law has also led to a catastrophic deformation of the jurisprudence of ordinary courts. What actually replaces the former became nothing more than (a) positivistic fetishism of the law in replacement of the law's annihilation, characteristic of the socialist past; (b) mechanical jurisprudence in substitution to the genuine task needed of the judicial process, namely weighing and balancing conflicting values equally protected by the law; and, as a consequence, (c) contentious and harmful issues, openly qualified as "immoral but lawful," used to win the day.

\section{Nothing but Western Self-interest Asserted as Guiding Help from "the West"}

Throughout centuries of political antagonism between the oppressed "We" and the oppressor "Them" in Central and Eastern Europe ${ }^{14}$ the formers' popular sympathy has unequivocally been extended to "the West," meaning both the Atlantic world and the Western hemisphere in the European continent (of course, with its Nordic Germanic and Southern Latinic parts included). Albeit twice betrayed by the same West in the near past-firstly by the Yalta Agreement and secondly when Berlin, Poznań, Budapest, and Gdańsk were left to fatal destiny during/after their successive uprisings against communism-they have continued to place their last hope in what they have regarded as the almost exclusive identity of or idealized master pattern for them. However, once the implementation of such an ideal can materialize, it may easily prove to be empty of whatever capacity of stimulation, activation,

12 E.g., Fletcher, George P. (1992) 'Searching for the Rule of Law in the Wake of Communism', Brigham Young University Law Review, (1), pp. 145-164 and Varga, Csaba (2008) 'Creeping Renovation of Law through Constitutional Judiciary?' in Varga, Csaba Transition? To Rule of Law? Constitutionalism and Transitional Justice Challenged in Central \& Eastern Europe. Pomáz: Kráter 292 pp. [PoLíSz sorozat könyvei 7] on pp. 117-160 \& <http://mek. oszk.hu/14800/14851>.

13 Constitution-Act XL (June 19, 1990)-Article 2, Section 1.

14 Cf. Torańska, Teresa (1987) »Them«: Stalin's Polish Puppets. [Oni (1985)] trans. Agnieszka Kolakowska. New York: Harper \& Row 384 pp. 
or simple channelization. In fact, Western self-interest has, as always, won again. Instead of practically anything offerable, demanding agendas have assertively been tabled for that their specific interest could again be served. Roughly speaking, no Western sympathy has been extended to helping proud, patriotically autotelic, self-serving nations rebuild. Instead, developments have rather been channeled so that these new-old states remain fragmented and easily manipulatable entities, subjected to their giant Western "friends." This has implied a new expectation: converse of subjugation. In fact, their elites, long at the forefront of Muscovite servilism, have suddenly shifted their trust (in form of over-loyalty) to the United States of America in the fields of business interests, capital expansion, political supercontrol, and so on. In due course, this shift has brought political interventionism by those now trusted as well, exerted by partisan forces using the language of human rights such as, for instance, Mr. GEORGE SOROs's Open Society Foundations. Accordingly, various Western programs prioritized, first of all,

(1) markets to be opened; guarantees afforded to capital investment; schemes favouring Western financial control introduced; and, as to the policy touching upon the future of local industry, components of the asset relating to which Western markets are simply extended (in case of Hungary, e.g., food industry) to be withered away, and other components, especially those assembling and merely finishing products (in case of Hungary, e.g., cars), further developed without any intellectual value or creative extra to be added to them any longer, that is, taking profit from the exploitation of cheap local labour force only;

(2) pretending fighting nationalism that did allegedly provoke already two World Wars in the past, making the target states resign from asserting own national interest, by beating - like a mantra, using both politico-ideological and historiographic channels - the involved local nations' past culpability in having caused grave human suffering by atrocities committed before/during/after the two World Wars;

(3) heralding the advancement of globalism, the effective curtailment of the remainder of national sovereignty, by reallocating its decisive parts (in case of Hungary, first of all, ones which are most sensitive to the country's financial control) to international agencies.

The issue of whether there should be disillusionment as a natural reaction has divided the two main political party directions and sympathies-alignments of which the boundaries have hardly changed since the 1956 revolution, conventionally (simplifyingly or mistakenly) called as rightist and leftist, respectively. 


\section{No Discontinuity with the Past: As a Natural Consequence, the Past is Becoming more Established than ever}

As a matter of fact, Hungary used to be the first country in the region to initiate and also draft a bill on coming to terms with the criminal past, ${ }^{15}$ making the legally relevant time period — what the statutory limitations, defined in the Criminal Code (1878/1950/1961) and assigned to those deeds involved (murder, torture as well as high treason)—have a start by the time when "politically motivated' obstruction to and ban of any initiative at launching legal procedure could already be over, that is, by the fall of communism-instead of the mere physical time period that may have passed since their commitment. ${ }^{16}$ As revealed, the historical search into the past has ascertained the well-known truth: the perpetrators were state agents; their deed, state-commissioned; those guilty in, state-rewarded for their deed; and with no exception, all of them, prevented from criminal prosecution up to their regime's end. Despite everything, the Constitutional Court of Hungary—by contrasting alleged formal legality to any consideration of material justice and by reference to the past and the present bridged over in full legal continuity-overturned the bill, based again on the constitutional clause stating that Hungary as a state entity "is under the rule of law." ${ }^{\text {"17 }}$

Accordingly, the demand that communism shall be opted out from the freely undertakable political currents (just in the way as the commitment to interwar criminal regimes was indicted by the Nuremberg/Tokyo trials) became thereby debilitated, and the

15 Few countries in the region followed this pioneering path. For the documentation of two successful implementation, see Varga, Csaba (ed.) Coming to Terms with the Past under the Rule of Law: The German and the Czech Models. Budapest xxvii+178 pp. [Windsor Klub] \&<http://mek.oszk.hu/14300/14310/14310.pdf>. The first Western reflexion (taken as a minute at Pécs, Hungary, June 1990) was also assertive, inasmuch as "retribution should not be carried out, except against those who had committed clear criminal acts (such as torture)." Elster, Jon (2004) Closing the Books: Transitional Justice in Historical Perspective. Cambridge - New York: Cambridge University Press xii+294 pp. at <http://assets.cambridge.org/97805218/39693/frontmatter/9780521839693_ frontmatter.pdf> p. x. Eventually, realizing the specific countereffects of their former policy, deterring from facing the past, which had become the barrier of any democratization furthering itself, Soros Foundations committed themselves to a volte-face. See, for example, Méndez, Juan E. (1997) 'Accountability for Past Abuses', Human Rights Quarterly, 19(2), pp. 255-282 \& <https://digitalcommons.wcl.american.edu/facsch_ lawrev/1696/>.

16 The Act on Amenability to Prosecution of Grave Crimes Committed, But Not Prosecuted for Political Reasons, Between December 21, 1944, and May 2, 1990, adopted by the National Assembly at its session of November 4 , 1991.

17 Constitutional Court decision No. 11 of (March 5) 1992. 
network inherited by communists from their past (including the channels of loyalty not dissociated, ${ }^{18}$ in contrast to post-WWII ambitions ${ }^{19}$ ) only reinforced as a counterweigh. ${ }^{20}$

\section{Divided Country, where the Media as the Fourth Acting Branch of Power Instigate against all Three of the Rest}

In a country where an oppressive dictatorial government (growingly drowning in economic unsustainability) starts negotiations with representative civic organizations (that start at once burgeoning) on the possibility of transiting state power by granting them green light to general election (to be organized as unrestrained by them), idealism, good will, and trust notwithstanding, the ancien régime remains fully equipped with chances and prospects to somewhat prolongate its own control. For instance, during the transitory time left to it, it may reorganize its past network, both institutional and informative, by the early privatization of media, which had been held by the state until then, extending it to both electronic and paper-bound carriers as well as TV/Radio channels, newspapers, magazines, and book publishers. Thereby, a quasi-institutional network may be unchanged in serving the old course by operators from reliable ex rank-and-file, who, from this moment on, must be considered fully pledged civilians of a new democratic entity.

For example, the cumulation of (a) the renewed media power and (b) the influx of financial and logistic schemes by international/foreign nongovernmental organizations (like SoRos's foundational empire) in order for pre-selected and biased political and axiological agendas (coded in the language of rights) to be cultivated and ultimately made to prevail may be decisive in setting in stone the fragmentation of society and maintaining it in the passing of time.

18 Cf., for example, Varga '»Radical Evil« on Trial' in the present volume.

19 Karstedt, Susanne (1998) 'Coming to Terms with the Past in Germany after 1945 and 1989: Public Judgments on Procedures and Justice', Law \& Policy, 20(1), pp. 15-56.

20 For the complexity of the issue, see Varga, Csaba (2011) 'Coming to Terms with the Past under the Rule of Law: Principles and Constitutional Assessments (A Case-study of Hungary)' in Liu, Shing-I, Neumann, Ulfried (eds.) Gerechtigkeit - Theorie und Praxis / Justice - Theory and Practice. Baden-Baden: Nomos 250 pp. on 215-235 \{\& <http://www.pdcnet.org/85257DC10065CC7E/file/949464782A886926C1257DC5005582A8/\$FILE/ hce_2013_0004_0000_0022_0043.pdf $>$. 


\section{Academia/Universitas Unchallenged, only to be Switched off from Being a Vassal of Moscow onto Another Pole in Family Resemblance to the Same Extremity, the one which Amalgamates with US- dominated Global Universalism}

Once upon the time, a Soviet Politburo member ${ }^{21}$ visiting Hungary was argued by his Hungarian partner JÁNOS BERECZ, answering the former's dissatisfaction with the low speed of communism's institutional self-reform in late 1989, by which, as remembered, "we have advanced the course by granting early autonomy to three public bodies-academia, universitas, as well as ecclesia-but now, regrettably, we have to conclude that these have become the entities most effectively withstanding any change and self-reform." Paradoxically, he was right in a direct and a figurative sense as well.

Even more paradoxical is that with the dividing lines practically unchanged-albeit loosely re-shifted and/or softened and tempered by various challenges of the coming times, within an autotelic line of development more or less in the same direction-there started some alternation between the doctrinarism of Soviet-type internationalism and its similarly rigid (but principledly liberal) antipode, universalism, just as if scientific voluntarism were to metamorphose into a new product of intellectualism called nominalism, universalizing what it can abstract from social reality.

A third paradoxical feature is that universalism is now far more inflexible, arrogantly dogmatic and normative, and insensitive to reality than MARxism's has ever been.

What else would social science be if not a well-ordered series of historico-comparative analysis, classification, and generalization of the historical experience of given communities? Which experience cannot be but hic et nunc, that is, drawn from the particularity of a given place and time? At the same time, Americanization/globalization is equal to losing the perspective and sensitivity of given communities - with the historical experience they have accumulated hitherto-to replace them with the functional equivalents of the perspective and sensitivity of some alien but giant community-either/or, with nothing re-gainable in return, or model ideas alone, taken as conceptually abstracted phantasies, can be projected onto genuine life lived through, but one cannot add an authentic fertilizing force to it. ${ }^{22}$

21 Политбюро; cf.<http://en.wikipedia.org/wiki/Politburo>.

22 For a summary of the experience of a quarter of a century, cf. Varga, Csaba (2011) Válaszúton-húszév múltán: Viták jogunk alapjairól és céljairól [At the crossroads again: After twenty years; Debating the foundations and destinations of our law]. Pomáz: Kráter 256 pp. [PoLíSz sorozat kötetei 7] \& <http://mek.oszk.hu/15100/15175>. 


\section{CONCLUSION}

The lesson that can be drawn from the case of system transformation in Central and Eastern Europe in general and in Hungary in particular is threefold. Curiously enough, all three conclusions are on the heights of universal wisdom as formulated in the language of the philosophy of history, and each of them, being cumulative, seems to point to the same direction.

Accordingly,

(1) World history and every instance of it are to be taken as a source of learning, rather than as a ready-made recipe of the path and ways to be followed. In consequence, human experience gathered wheresoever is to be treated in the same manner. We must learn from everything, but at the same time we must not make ourselves dependent on the experience of others. Amongst its components, routine is just one species out from a huge potential: one given particularity having been typified from a huge repository of further particularities, perhaps equally feasible and viable.

(2) What we call the Rule of Law is nothing but an ideal, far from being a finished recipe. Properly speaking, when referring to the rule of law, actually we mean some selected patterns/models of the Rule of Law. These are nothing but typified instances, summarising what has been the routine of a given country, region or continent, at a given period of time. All this is an aggregate of professionalised human experience, relevant to a given field, which originates from particular historical situations under particular historical conditions, where and when specific (individually defined and not other) challenges have elicited specific (individually defined and not other) responses. Therefore, forcing one's perception and consolidated understanding to be accepted by others as their own perception and consolidated understanding is sheer imperialism. There is no royal path; there are no chosen peoples and no chosen experiences either. No particularity can stand for the universality. Indeed, ideals and experiences are to serve as 'life's teachers': ${ }^{23}$ as parts of the humans' world history, they serve as brute material for reflection to everyone and everytime. ${ }^{24}$

23 Cf. <http://en.wikipedia.org/wiki/Magistra_vitae>.

24 Cf. Varga 'Varietes of Law and the Rule of Law' in the present volume as well as Varga, Csaba (2005) 'Rule of Law - At the Crossroads of Challenges', Iustum, Aequum, Salutare, I(1-2), pp. 73-88 \& < http://ias.jak.ppke.hu/ hir/ias/20051sz/20051.pdf>. 
(3) For a nation faced to make historically decisive strategic decisions, an own solution is to be fought through. As a combination of components, this is a sum of paths and ways decided from inside, from own conditions, after due deliberation of wherefrom to inspire and what to inspire is made. Available intellectual forces are to be mobilised for the search of arguments from the full body of law, involving historical and comparative tradition as well ${ }^{25}$ for that proper identification and justification will be crowned by success.

Needless to say, national self-consciousness and commitment cannot be equated with self-sufficiency or self-complacency. However, a sober nurturing process is needed for national causes to maturate.

\section{POLICY DURING THE PROCESS}

In sum, the best advice for Korea can only be a negative reflection of what has been the most destructive in the whole process of the Hungarian system change.

Here I must remind the reader that, in Hungary, the political vernacular no longer uses the term "regime change"; instead, it speaks—with a contemptuous tone-of a change of gang or of a change of method, which implies that the essence behind the changed appearance is unchanged. That is, the plundering of the nation's resources there and heremerely, perhaps, by refining the means.

Accordingly,

(1) start and continuation must be based upon some unitary and solid, multiply checked and verified program which is duly determined and widely agreed. Be sure that only refinement and/or adjustment, needed for details in execution, will be accepted/tolerated all through the course of action. At the same time, be conscious of the fact that any detour may lead to confusion, and this is usually worse than any less-than-optimum original determination.

25 For exemplification by the use of principles, see Dworkin, Ronald (1967-1968) 'The Model of Rules', University of Chicago Law Review, 35(1), pp. 14-46 \& <https://chicagounbound.uchicago.edu/uclrev/vol35/iss1/3/> as well as especially Perelman, Chaïm (1976) Logique juridique: La nouvelle rhétorique. Paris: Dalloz 193 pp. [Méthodes du droit]. For a kind of theoretical foundation, see Varga, Csaba (2008) 'Doctrine and Technique in Law', Iustum Aequum Salutare, IV(1), pp. 23-37 \& <http://ias.jak.ppke.hu/hir/ias/20081sz/02. pdf $>$. 
(2) Rule of Law considerations must be decided from within, substantiated by due lawyerly preparation upon the basis of an overall plan programmed also for cases when incidental controversies are to be solved. Only for the sake of self-defence are international experts to be called in, if at all.

(3) The favours the process will grant to the population at large must be detailed and timetabled as a forecast before anything else. 


\title{
IDOL, DEDUCED FROM AN IDEAL? Rule of Law, Universalization, Degradation ${ }^{1}$
}

\begin{abstract}
1. From Political Contingency to Attempts to Gain Political Power 2. Civilizing Idea as the Law's Instrumental Value 3. The Dangers of Homogeneities Over-homogenized 4. Who is to Rule the Law and How? 5. Final Queries
\end{abstract}

ABSTRACT Today, the Rule of Law is defined worldwide by one single legal culture in which the declaration of what the law is is done ex post facto (as in English common law) or in the one political pragmatism that relocates legal innovation from elected representative bodies to the administration of justice (as in the USA). Moreover, the Rule of Law used as a political catchword results in ideocratic idealization. The Rule of Law, embodying instrumental value (even if international pressure groups do their best to fundamentalize it), represents a particular culture in the play of hic et nunc challenges and responses (even if globalism does its best to universalize it). Developed under varied conditions particular to place and time, it cannot be more than a series of living cultures of countries concerned, based on their historically evolving civilizing and humanizing ideal. Law, as an aggregate of values to be defended equally, must face values that conflict with one another in daily enforcement, crying for weighing and balancing in a compromise solution at the most. Far from standing for all-or-nothing absolutism, one-sidedness or homogenization, idolizing legal certainty (as the Hungarian Constitutional Court did) or subjecting government action to judicial or human rights control may sacrifice justice, implying that popular support and raison d'être will vanish behind it. Moreover, fetishizing its own homogeneity may distort the merits that it claims to serve. A globalizing judgeocracy tries to monopolize the worldwide learning process at the price that it will isolate local developments from their natural context to enforce its own creation. After all, the quest for those who can master the law is crucial for that they call in the intervention by either international agencies or the European Union in local issues as well, under the aegis of the Rule of Law.

KEYWORDS Rule of Law; ideal; legal cultures; values; universalization

I In its first version, it served as an analysis at the book presentation of Varga, Zs. András (2015) Eszményból bálvány? A joguralom dogmatikája [Idol? from an ideal? The doctrine of the rule of law]. Budapest: Századvég 227 pp. [Szabadság] in the ceremonial hall of Pázmány Péter Catholic University in 2015; cf. <https://www.youtube. com/watch?v=prKcY6VkNUo>. Earlier versions in English include—abridged—(2016) 'Global Challenge, Rule of Law, and the National Interest' in Zapesotsky, A. S. (ed.) Contemporary Global Challenges and National Interests: The 16th International Likhachov Scientific Conference, May 19-21, 2016. St. Petersburg: St. Petersburg University of the Humanities and Social Sciences 243 pp. \& <http://www.lihachev.ru/pic/site/files/lihcht/Sbor_full/2016_ english.pdf> on pp. 146-150; (2016) 'Rule of Law, or Universalism/Particularism Debated in the Western World', Juridical Journal [Юридичний журнал] [Kiev], (August), No. 169, pp. 50-55 as well as-in full-(2016) 'Ideal or Idol? Traps in Understanding the Rule of Law', Central European Political Science Review, 17(Fall, No. 65), pp. 198-219; (2019) 'Rule of Law and Soft Law: Jolly Jokers' in Pokol, Béla, Téglási, András (ed.) Die Stufenweise entstehung des Juristokratischen Staates / The Gradual Emergence of the Juristocratic State. Budapest: Dialóg Campus 206 pp. on pp. 101-122; (2019) 'Idol, Deduced from an Ideal? Rule of Law, Universalization, Degradation', Фiıocoøir права ізагальна теорія права / Philosophy of Law and General Theory of Law [Kharkov], (2), pp. 192-214<http://phtl. nlu.edu.ua/article/view/204724> \& <https://doi.org/10.21564/2227-7153.2019.2.204724>. 
"All people of broad, strong sense have an instinctive repugnance to the men of maxims; because such people early discern that the mysterious complexity of our life is not to be embraced by maxims, and that to lace ourselves up in formulas of that sort is to repress all the divine promptings and inspirations that spring from growing insight and sympathy. And the man of maxims is the popular representative of the minds that are guided in their moral judgment solely by general rules, thinking that these will lead them to justice by a ready-made patent method, without the trouble of exerting patience, discrimination, impartialitywithout any care to assure themselves whether they have the insight that comes from a hardly-earned estimate of temptation, or from a life vivid and intense enough to have created a wide fellow-feeling with all that is human."

George Eliot ${ }^{2}$

"There is no need at all for different peoples, religions and cultures to adapt or conform to one another. [...] I think we help one another best if we make no pretenses, remain ourselves, and simply respect and honor one another, just as we are."

Václav Havel ${ }^{3}$

\section{Rule of Law: From Political Contingency to Attempts to Gain Political Power}

For more than a quarter of a century, the almost mechanical and unreflective reception of Western mainstream trends across the entire Central and Eastern European region has made the chance of any fresh start the function of a soullessly estranged doctrinarianism, declaring its newest inventions the law of the day, profoundly self-defeating for those countries

2 Eliot, George (1860) The Mill on the Floss. Book 6, chap. $2<$ https://www.gutenberg.org/files/6688/6688-h/6688-h. htm\#41>.

3 Quoted in Howard, Philip K. (2011) 'Vaclav Havel's Critique of the West' The Atlantic, (December 20) <http:// www.theatlantic.com/international/archive/2011/12/vaclav-havels-critique-of-the-west/250277/>. 
concerned. ${ }^{4}$ For whatever its present state-even if it appears obsolete, strange, or crude to an external observer at first glance-within a given civilizational level, it is only tradition, the accumulation of generations' lived experience-in other words, the historically evolving culture of each and every community-that can offer an integrative force to any given society and dignity to the persons belonging to it. ${ }^{5}$

To start with our central concept, it is a degrading paradox to realize how much the Anglo-American legal heritage strives to become the number one teacher of Europe in making it understand what the overemphasized and overused notion of "Rule of Law" means. For it is surprising to notice that-as to the English past-an ideal is extended to gain acceptance worldwide as a universal model that has from the beginning targeted the preservation of the autonomy (or independence from the royal power) of the judiciary. Ironically, the most essential feature, namely that common law has never been embodied in clear rules and that the incessantly growing mass of precedents cannot but be based on an ex post facto declaration of what the kingdom's law has always allegedly been-that is, plainly retroactive for the

4 Cf., as to the once Soviet Union's destiny, Varga, Csaba (2008) 'Failed Crusade: American Self-confidence, Russian Catastrophe' in Transition? To Rule of Law? Constitutionalism and Transitional Justice Challenged in Central \& Eastern Europe. Pomáz: Kráter 292 pp. [PoLíSz sorozat könyvei 7] on pp. 199-219 <http://mek.oszk. hu/14800/14851>. For a general overview, see Holmes, Stephen, Krastev, Ivan (2020) The Light that Failed: Why the West is Losing the Fight for Democracy. New York: Pegasus Books 246 pp.

5 Even if, perhaps, no one is hardly longing for reviving the nomadic life of the Steppe again, the political and social wisdom of its order may have been adequate and thoroughly balanced in its time. Nysanbayev, Abdumalik (2004) 'Kazakhstan. Cultural Inheritance and Social Transformation' in Kazakh Philosophical Studies I: Cultural Heritage and Contemporary Change Series IIIC Central Asia 2. Washington, D. C.: Council for Research in Values and Philosophy <http://www.crvp.org/book/Series03/IIIC-2/chap-2.htm>ch. II: Common Law Philosophy of the Kazakhs: Potentials for Democracy. Cf. also Varga, Csaba (2015) 'Ösnépeink jogszemlélete' [The legal mentality of our ancient ancestries], Hitel, 28(No. 11), pp. 83-96 \& <http://www.hitelfolyoirat.hu/sites/ default/files/pdf/17-varga.pdf>. While the Albanian Highland's blood feud [gjakmarrja] will scarcely be regarded positively today, nevertheless,

Albanians have a reverence for honesty and good faith that plays an almost sacred role in their customary law. These same values can bring justice to modernity, and control the atomism and the positivism that have defaced the rule of law in other, more modern, European societies.

Trnavci, Genc (2010) 'The Interaction of Customary Law with the Modern Rule of Law in Albania and Kosova' in Sellers, Mortimer, Tomaszewski, Tadeusz (eds.) The Rule of Law in Comparative Perspective. Dordrecht: Springer Science+Business Media B.V. xii+253 pp. [Ius Gentium: Comparative Perspectives on Law and Justice 3], pp. 201-221 at p. 215. Cf. also Iseni, Arburim, Sela, Ylber, Beadini, Adem (2013) 'A Comparative Study of Albanian Customary Law with the Code of the West and the Common Law of England. Lex Scripta vs. Lex Non Scripta' Journal of Law, Policy and Globalization 18, pp. 50-59 \&<http://www.iiste.org/Journals/index.php/ JLPG/article/viewFile/8498/8437>.

The first comparative attempt at drawing a legal map of the world based expressly on tradition is Glenn, Patrick (2014) Legal Traditions of the World: Sustainable Diversity in Law. Oxford: Oxford University Press. For the variety of roles tradition used to play, see Varga, Csaba (2012) Comparative Legal Cultures: On Traditions Classified, their Rapprochement \& Transfer, and the Anarchy of Hyper-rationalism. Budapest: Szent István Társulat 253 pp. [Philosophiae Iuris] \& <http://mek.oszk.hu/15300/15386> on pp. 83-85. 
contended case ${ }^{6}$-is not disputed by either its classic or contemporary jurisprudence. ${ }^{7}$ As to the United States of America's presence, its understanding of what the Rule of Law stands for is founded on the political and hierarchical supremacy of judicial power, in such a way that it amounts to the breakdown of what has been left from their founding fathers' ideas on democracy and representation. As to its motives, as domestic critics repeatedly claim, it is rooted in the short-term strive to win that is characteristic of American culture, including politics. In its main orientation of not losing, the state power's democratic (representative) machinery, legislation-cum-government, is oriented to attract voters' favor and therefore frequently passes on, obstinately, those issues that risk unanimous popular consent to readily available judicial fora. For this reason, instead of achieving the democratic consent of people's representatives, divisive issues - that is, those that would indeed need disputing at a demos level—are decided in camera by a judicial forum throughout homogenized and formalized in law-not exceptionally on crucial issues as well-pioneering over the stance of huge parts of massively shared popular values. ${ }^{8}$ As an added and self-multiplying effect, there is also constitutional adjudication imposed upon legislation: the law enacted by the sovereign representative is, if brought to judicial fora, dependent on reaffirmation by a professional body that is not representative nor easily accessible to democratic control either and that acts, again, in a legally homogenized and formalized way. In its own self-generating turn, this offered an invitation to the recently deceased RONALD DWORKIN to propose judicial review for assessing political party programs before a party may launch its agenda before the public. Moreover, even American rule-based law itself gets increasingly deformed in legislative practice so that it can easily serve juristocratic interests: ${ }^{9}$ laws are said to have been drafted in a manner to ease decisional options for the future judge, should the regulated issue be contested. ${ }^{10}$

In reaction to the above, scholarly literature on the other side addresses the destructive effects of this new "political religion,"11 calling attention, among others, to the intellectual

6 Ekins, Richard (2011) 'Rights, Interpretation and the Rule of Law' in Ekins, Richard (ed.) Modern Challenges to the Rule of Law. Wellington: LexisNexis NY pp. 165-187 on pp. 166-167 and 174-178.

7 For example, Reid, John Philip (2004) The Rule of Law: The Jurisprudence of Liberty in the Seventeenth and Eighteenth Centuries. DeKalb, Ill.: Northern Illionis University Press 150 pp. and Silkenat, James R., Hickey Jr., James E., Barenboim, Peter D. (eds.) (2004) The Legal Doctrines of the Rule of Law and the Legal State (Rechtsstaat). Heidelberg: Springer xii+367 pp. [Ius Gentium: Comparative Perspectives on Law and Justice 38].

8 "Legislation is far more likely to reflect majority sentiment while judicial activism is likely to represent an elite minority's sentiment." Bork, Robert H. (1990) The Tempting of America: The Political Seduction of the Law. New York: Simon and Schuster xiv+432 pp. on p. 17.

9 Cf. Pokol \& Téglási (eds.) Die Stufenweise, 2019.

10 Helland, Eric, Kick, Jonathan (2013) 'Regulation and Litigation: Complements or Substitutes?' in Buckley, F. H. (ed.) The American Illness: Essays on the Rule of Law. New Haven: Yale University Press xii+534 pp. on pp. 118-136.

11 Hirschl, Ran (2011) Constitutional Theocracy. Cambridge, Mass.: Harvard University Press 306 pp. 
climate in the womb of which unrestrained law professors rival each other to arrive at intellectually constructed extremes, in company of profit-hungry advocates skilled in filling available or artificially established gaps in the law, who construct their own Rule of Law to the detriment of the one-time ideals of its founding fathers.

What have they produced and what may have produced them? As a sign of the dissolution of social trust and the disintegration of the social network in American society over the last 50 years, divorce has multiplied by four times, birth out of wedlock by 12 times, and violent crime by 10 times at a short period when, as critics allege, the hypertrophically increasing curve of regulatory intervention and litigation had already corroded faith in the law. ${ }^{12}$ Instead of being a remedy, law has itself become the problem-a major pathogenic factor in the sickening of America, as repeatedly stated by home critics. ${ }^{13}$ Accordingly, at a stage when representative democracy is forced back by the triumphal judicial power ${ }^{14}$ and mainstream ideology (upheld by some from a minority partisan background) is estranged from basic human needs, the cry for "Government by real people, not theories" is also to surface as a new re-vindication. ${ }^{15}$ Proud and arrogant "American exceptionalism" (recognizing, in the mirror of America, the "end-of-history" typ $\mathrm{e}^{16}$ universal ideal of human existence) is already seen and diagnosed by some as a repressed impotence-cum-chauvinism characterized by an over-expensive legal order, artfully legalized wrangling, and an influential lawyer cast parasitic on corruption. ${ }^{17}$ It is usual to attribute this more and more to the proliferating easy and irresponsible brainchildren of elite universities acting as "short-sighted, self-interested groups" ${ }^{18}$ that social solidarity has molded. As has been concluded, "the legal foundation of the road to serfdom was devised by law professors," at a time when "social policy litigation has corroded democracy and contributed to public

12 Fukuyama, Francis (1999) The Great Disruption: Nature and the Reconstitution of the Social Order. New York: The Free Press xii+354 pp. Cf. also Varga, Csaba (2012) 'Humanity Elevating Themselves? Dilemmas of Rationalism in our Age' in Varga, Csaba Comparative Legal Cultures: On Traditions Classified, their Rapprochement \& Transfer, and the Anarchy of Hyper-rationalism. Budapest: Szent István Társulat 253 pp. [Philosophiae Iuris] \&<http:// mek.oszk.hu/15300/15386> on pp. 131-163.

13 Buckley, F. H. (2013) The American Illness: Essays on the Rule of Law. New Haven - London: Yale University Press xii+534 pp. is itself an inquiry into the quest, as stated in the Preface, "whether the U.S. legal system is contributing to the country's long post-war decline." As a reflection, see also Varga, 'Rule of Law? Mania of Law? Rationality and Anarchy in America' in the present volume.

14 Hirschl, Ran (2004) Towards Juristocracy: The Origins and Consequences of the New Constitutionalism. Cambridge, MA - London: Harvard University Press 286 pp.

15 Howard, Philip K. (2014) The Rule of Nobody: Saving America from Dead Law and Broken Government. New York: W. W. Norton \& Company $\mathrm{x}+244$ pp. with the quote heralded as a chapter title; cf. also Howard, Philip K. (1994) The Death of Common Sense: How Law is Suffocating America. New York: Random House 202 pp.

16 Cf. Fukuyama, Francis (1992) The End of History and the Last Man. New York: The Free Press xxiii+418 pp.

17 Buckley, F. H. (2013) 'The Rule of Law in America' in Buckley, The American Illness, pp. 3-39.

18 Howard, Philip K. (2002) The Collapse of the Common Good: How America's Lawsuit Culture Undermines our Freedom. New York: Ballantine Books $253 \mathrm{pp}$. 
polarization and the fiscal crisis." ${ }^{19}$ That is, thanks to both the overall mass of laws and the lawyers wedging themselves extensively into the available ongoing processes and movements of habitual social practices, medical expenditure is hypertrophically higher, and litigation costs have multiplied by four to nine times as compared to other countries; with the end result of an "overlawyered, overregulated country with multiple access points for bureaucrats and special interests to interfere with business decisions." ${ }^{20}$ It is no coincidence that shortly before his assassination, ROBERT F. KENNEDY expressed his view of perhaps the most popular American "value" as also standing for the mainstream conception of the Rule of Law ideal, namely that "the gross national product [...] measures everything, in short, except that which makes life worthwhile. And it tells us everything about America except why we are proud to be Americans."21

It now seems as if such new developments were at the same time anticipating European Union political and legal reality. For, as recently stated,

The European Union (EU) is not driven by the Rule of Law as an institutional ideal. Instead, the Union deploys the "Rule of Law", viewed to a large extent through the lens of the autonomy of the EU legal order, to shield its law from potential internal and external contestation. This is precisely the opposite of what the classical understanding of the Rule of Law would imply. The perverse semantics of the Rule of Law in the EU legal context would not be worthy of a lengthy investigation, if it were not for the fact that far-reaching destructive consequences of this perversion directly affect the very constitutional essence of the European Union and its Member States by undermining the values-the Rule of Law included —on which both constitutional levels are purportedly built. ${ }^{22}$

What happened? What were the consequences of all this? By now, on a widened scene, both domestic and international agencies (mostly not-in-law-educated representatives of

19 Randy E. BARnetT and Philip K. Howard quoted in Olson, Walter (2011) Schools for Misrule: Legal Academia and an Overlawyered America. New York: Encounter Books vi+428 pp. on pp. 427 and 428.

20 Reinsch II, Richard M. (2013) America's Rule of Law Sickness. <http://www.libertylawsite.org/2013/07/24/ americas-rule-of-law-sickness/>. For background, cf. Varga, Csaba (2012) 'The Law's Homogeneity Challenged by Heterogenisation through Ethics and Economics', Acta Juridica Hungarica, 53(2), pp. 165-174 \& <http://real-j.mtak.hu/767/1/ACTAJURIDICA_53.pdf>.

21 Robert F. KENNEDy at the University of Kansas on March 18, 1968, quoted by Majithia, Vishal (2006) 'Great Leaders are Made, not Born' (October 27) <https://www.flickr.com/photos/vm1757/280433501> from Kennedy, Robert F. (1998) Make Gentle the Life of the World: The Vision of Robert F. Kennedy. Ed. Maxwell Taylor Kennedy. New York: Harcourt Brace 188 pp.

22 Kochenov, Dimitry (2015) 'EU Law without the Rule of Law: Is the Veneration of Autonomy Worth It?', Yearbook of European Law, 34(1), pp. 74-96 \& <https://ssrn.com/abstract=2642689>. 
political bodies and international agencies, including ones of the United Nations ${ }^{23}$ ) use, overuse, and abuse catchwords such as "Rule of Law," "democracy," and "human rights" as if such sphinx-like expressions could stand for genuine legal authorities themselves. ${ }^{24}$ Almost like political slogans, these are appealed to as if they were to imply normatively well-defined and legally operative measures able to exhaustively offer exclusive and lawyerly manageable criteria. For that matter, they do this fully aware of the fact that, indeed, both their meaning and the consequences of what has been attributed to them by politically and legally maneuvering actors is ambiguously open. After all, this performance is a barely disguised and ill-concealed political rule, exercised manipulatively but, at the same time, as if they were merely following the clear and exclusive dictates of some kind of absolutism..$^{25}$ This is what makes the requirements behind such procedures over-generalized, emptying them of their historically developed contexture and original meaning. Finally, assuming that such a characterization will prove to be correct, the remainder will be no more than wasted (because false) conceptualization, transformed into a merely referential idol qualifiable only as "meaningless thanks to ideological abuse and general over-use."26

23 Fitschen, Thomas (2008) 'Inventing the Rule of Law for the United Nations', Max Planck Yearbook of United Nations Law, 12, pp. 347-380.

24 In the meantime, the once balance of duties/rights has been unilateralized, and the pattern of the "expansion of the language of rights [...] without boundaries and without responsibility"-Carozza, Paolo G. (2013) The Protean Vocabulary of Human Rights. [A lecture delivered at a United Nations event in Geneva, 3 June.] Chambésy: Caritas in Veritas Foundation Blueprint <http://www.fciv.org/downloads/Carozza.pdf> 7 pp.-has become almost exclusive. Glendon, Mary Ann (1991) Rights Talk: The Impoverishment of Political Discourse. New York: The Free Press xvi+218 pp. By today, it is human rights and the Rule of Law that are emphasized in pair as embodying the supreme human values to be guarded by law, whose activation-as claimed by Trujillo, Isabel 'Human Rights, Peace, and the Concept of Law: The Story of an Incomplete Legal Revolution', [Plenary lecture at the International Association for Philosophy of Law and Social Philosophy XXVIII World Congress, Lisboa (July 20, 2017)] published as Тружильо, I. (2019) 'Права людини, мир та поняття права. Історія незавершеної правової революції', Філособія права і загальна теорія права / Philosophy of Law and General Theory of Law [Kharkov], (1), pp. 175-200 \& <http://phtl.nlu.edu.ua/article/ view/186525>-can only be guaranteed by social participation wedged in through the various forms of soft law. Thereby, a new kind of legal pluralism seems to be born, ending in the flowless dissolution of what has ever been known as law.

25 Reminiscent of repeated times with "the intervenors [who], when challenged, always resort to a moral justification-natural law and Christianity in the sixteenth century, the civilizing mission in the nineteenth century, and human rights and democracy in the late twentieth and twenty-first centuries." Wallerstein, Immanuel (2006) European Universalism: The Rhetoric of Power. New York: New Press xv+94 pp. on p. 27.

26 Shklar, Judith (1987) 'Political Theory and the Rule of Law' in Hutchinson, Allan C., Monahan, Patrick (eds.) The Rule of Law: Ideal or Ideology. Toronto: Carswell xiv+167 pp.: pp. 1-16 on p. 1. Cf., as recently monographised, by a constitutional justice, a member of the Venice Commission, ex deputy procureur générale of Hungary, Varga, András Zs. (2019) From Ideal to Idol? The Concept of the Rule of Law. Budapest: Dialóg Campus 190 pp. 


\section{Civilizing Idea as the Law's Instrumental Value}

Three decades ago, those now in government (and my own university students in the Faculty of Law in Budapest then) organized an international conference on the understanding of the Rule of Law, at a time when they already perceived the dawn of the collapse of the communist regime. ${ }^{27}$ JoHN FinNIS of Oxford, invited by them to the conference, set the tone with a surprising but upbeat and pertinent admonition. There was an immense number of books dedicated to the topic - he said-addressing them in their endeavor in rebuilding their country after communism, though-he added-they should not have bothered with them as it would have been meaningless for them. There was only one single sentence-he continued-, one from my own book that may have had a particular message for them. It read: "Rule of law is not and cannot be a pact of collective suicide." ${ }^{\text {"28 }}$ What was meant by such a cryptic, sharp, and shocking formulation? As he explained, the Rule of Law stands for the culture of the exercise of state power. This has developed differently in differing countries, responding to local contingent challenges; as these are hic et nunc-that is, particular with varied emphases and cultural contexts-there is no exclusive response available. Whatever response eventually arises, there and then, it is solely a response to the urgently felt need in the first place, with no specific concern for the abstract posterity. That is, the Rule of Law is a civilizing idea of how state power can pacify and humanize: it is only one means of achieving the common good as a strategic end, but it is by no means an excuse for why we cannot approach it. All in all, in principle and having reached and within the framework of a degree of civilizational development, it is the function of any given state to define exactly what culture it cultivates and how it is to implement its measures in various situations.

This amounts to stating that the Rule of Law cannot become a fetish; moreover, it cannot even be treated like an artificially dichotomized duality, in the style of all-or-nothing without

27 For instance, Raz, Joseph (1990) 'The Politics of the Rule of Law', Ratio Juris, 3(3), pp. 331-339 refers expressly to the lecture he delivered in Budapest at the time, which he reformulated later as an academic paper.

28 Finnis, John (1980) Natural Law and Natural Rights. Oxford: Clarendon Press xv+425 pp. [Clarendon Law Series] holds that security of law being a public good and Rule of Law having the potential to secure all aspects or the essence thereof, by choosing between unconditional legality and a statesman's act, one may be forced to renounce the latter's full implementation.

By the way, since Justice JACKSON's dissent in Terminiello, 337 U.S. at 36 in 1949, calling the Court to temper its doctrinaire logic with a little practical wisdom, for it will not "convert the constitutional Bill of Rights into a suicide pact," this argument has been accepted by the Supreme Court of Israel, among others. As quoted by its president-Barak, Aharon (2003) 'The Role of a Supreme Court in a Democracy, and the Fight against Terrorism', University of Miami Law Review, 58, pp. 125-141 \& <https://repository.law.miami.edu/umlr/vol58/ iss1/12/> \& <http://www.antoniocasella.eu/archica/Aharon_Barak_2003.pdf> on p. 132-"A constitution is not a prescription for suicide, and civil rights are not an altar for national destruction. The laws of a people should be interpreted on the basis of the assumption that it wants to continue to exist. Civil rights derive from the existence of the State, and they should not be made into a spade with which to bury it." 
counting with gradualism ${ }^{29}$ and-of course, ethically and juristically also thoroughly balanced-practical issue. ${ }^{30} \mathrm{After}$ all, the Rule of Law is an ideal: it is not an operational concept, and it has no commonly accepted notion in law either. ${ }^{31}$ This is also to say that it belongs to those concepts that are, from the beginning, essentially contested. Such is the typical treat of conceptualization to which neither narrowing (or reductive dogmatism) nor widening (or open-ended eclecticism) can offer a solution. Expressive of value-content and very varied considerations by definition, their unending democratic disputation, controversy, polemics, and argumentation are-instead of making them sharp to induce one single conclusiononly selected from the variety of equally defendable understandings, in themselves each conceivable and viable in law. ${ }^{32}$ For what is at stake with the Rule of Law is not an accomplished and positivized system but a living culture, built step to step by each and every relevant occasional action. Developing through the unending chain and accumulation of challenges and responses, it draws from the hic et nunc historical experience of any given people. Moreover, taking into consideration the most intimate connection and overall embeddedness of any given stage within the cultural patterns prevailing there and then, it cannot-roughly

29 Cf., for example, Sampford, Charles (2006) Retrospectivity and the Rule of Law. Oxford: Oxford University Press $\mathrm{xvii}+308 \mathrm{pp}$. who holds that, to a certain extent, rectroactivity operates in practically all well-arranged societies, independently of whether this is noticed or not.

30 Hayek, F. A. (1944) The Road to Serfdom. Chicago: University of Chicago Press viii+248 pp. on p. 22 emphasizes, for instance, that "retrospective legislation can be beneficial when it corrects some legislative slip or permits the overcoming of some hardship to some persons without injury to the rights of others," and Chaturvedi, Kameshwar Nath (2013) 'Legislative Retrospectivity and Rule of Law', Statute Law Review, 34(3), pp. 207-220 adds that it may be legally quite unproblematic. However, what is the situation if it runs counter earlier expectations, perhaps just because the transition from dictatorship to democracy needs it? It is Marmor, Andrei (2004) 'The Rule of Law and its Limits', Law and Philosophy, 23(1), pp. 1-43 on p. 20 who responds (by reference to coming to terms with the past after a dictatorial regime) by saying that "if the legal system is profoundly corrupt, citizens are not morally entitled to assume that whatever is legal at the time is something that they are permitted to do."

31 "Firm adherents are locked in great disagreement about what the rule of law really is." This is a statement by which Dworkin, Ronald (2012) The Rule of Law as a Practical Concept. <http://www.venice.coe.int/webforms/ documents/default.aspx?pdffile $=$ CDL\%282013\%29016-e $>$ introduced his Keynote Speech to the Venice Commission Conference. Cf., as an already classical overview, Fallon, Jr, Richard H. (1997) "The Rule of Law" as a Concept in Constitutional Discourse', Columbia Law Review, 97(1), pp. 1-56, followed by, e.g., Rodriguez, Daniel B., McCubbins, Mathew B., Weingast, Barry R. (2010) 'The Rule of Law Unplugged', Emory Law Journal, 59(6), pp. 1455-1494 on p. 1493 \& <https://scholarship.law.duke.edu/cgi/viewcontent.cgi?referer=https:// www.google.hu/\&httpsredir=1\&article=5990\&context=faculty_scholarship $>$, concluding that "it is likely that no single definition of Rule of Law will ever achieve consensus among those who make Rule of Law promotion their central goal. Aggregating all of the existing measures into an ordinal scale or index, which is the most common approach, does little to overcome this definitional divide and only serves to violate every tenet of measurement theory."

32 Gallie, Walter Bryce (1955-1956) 'Essentially Contested Concepts', Proceedings of the Aristotelian Society, 56, pp. 167-198; cf. also <https://en.wikipedia.org/wiki/Essentially_contested_concept $>$. 
speaking - be more than a synthetic average of what is ordered from above and what its popular assistance dictates on a changing (perhaps daily) basis. ${ }^{33}$

As a cultural aspiration, the Rule of Law ideal widely spreads through peoples with whom there has evolved some demand for a mutual learning process. Thereby, on the one hand, kinds of assimilation may eventuate (in order to form types characteristic of given historical periods) and, on the other, common development can ensue (in order to form types characteristic mostly of, for instance, the common law or the civil law). However, the constant formation of how this ideal is implemented via actual moves, measures, and provisions that are necessary to meet current needs does not make it a universal (or universalizable) pattern either: it remains the living culture of the peoples concerned, responding to their own challenges according to their own ways as part of solely their own heritage-independently of whether or not, in the persistent whirling of imperialisms and globalisms on our globe, there are power centers endeavoring to impose their own routines, as if they were a universal pattern, on others. ${ }^{34}$ Now, what follows? It takes-in the meantime transubstantiated from what was in the past the myth of the civilizing "white man," followed by the Spanish/ English and French/Dutch colonizing "European superiority" and "cultural supremacy"-on the image of "American exceptionalism." ${ }^{35}$ Aggrandizing its great and sole global power ethno-

33 "The Rule of Law probably cannot exist in a society unless people engage in constant argument what the Rule of Law amounts to"-holds Waldron, Jeremy (2002) 'Is the Rule of Law an Essentially Contested Concept (In Florida)?', Law and Philosophy, 21(2), pp. 137-164 on p. 16. Therefore, as stated in the classic Hayek, F. A. (1960), The Constitution of Liberty. Chicago: University of Chicago Press $x+569$ pp. on p. 206, "many of the applications of the rule of law are also ideals which we can hope to approach very closely but can never fully realise. If the ideal of the rule of law is a firm element of public opinion, legislation and jurisdiction will tend to approach it more and more closely. But if it is represented as an impracticable and even undesirable ideal and people cease to strive for its realisation, it will rapidly disappear. Such a society will quickly relapse into a state of arbitrary tyranny." In other words, a sensitive balance needs to be drawn repeatedly.

34 Cf. Varga, Csaba (2007) 'Reception of Legal Patterns in a Globalising Age' in Calera, Nicolás López (ed.) Globalization, Law and Economy / Globalización, Derecho y Economía: Proceedings of the $22^{\text {nd }}$ IVR World Congress. Vol. IV. Stuttgart: Franz Steiner Verlag, pp. 85-96 [ARSP Beiheft 109]. Even pieces of historical particularity are universalized when a feature unreproducible elsewhere-Franck, Thomas M. (1972) 'The New Development: Can American Law and Legal Institutions Help Developing Countries?' Wisconsin Law Review, 12(3), pp. 767-801 on p. 783-is implemented in cultures beyond the Common Law like South-Africa and Israel. Cf. Hirschl, Towards Juristocracy, 2004.

On the ideological overgeneralization and universalization of the winner's interests at any time, see, classically, Marx, Karl, Engels, Friedrich (1932) Die deutsche Ideologie: Kritik der neuesten deutschen Philosophie in ihren Repräsentanten Feuerbach, B. Bauer u. Stirner u. des deutsches Sozialismus in seinen verschiedenen Propheten, 18451846. [Volksausgabe der ersten ungekürzten vollständigen Erstausgabe der Marx-Engels-Verlag im Auftrag der Marx-Engels-Lenin-Institut Moskau.] Hrsg. Vladimir V. Adoratskij. Wien-Berlin: Verlag für Literatur u. Politik $636 \mathrm{pp}$.

35 Cf. <https://en.wikipedia.org/wiki/American_exceptionalism> and <http://nationalinterest.org/about-thenational-interest $>$, respectively. 
centrism, ${ }^{36}$ it is now used to excel in denouncing even modest local assertions of others' national interests as hideous "nationalism."

By its nature, the Rule of Law withstands encapsulation into dogmas. Its guiding spirit is far from any clear-cut command as to how to proceed in a concrete case or take an individual decision. It is weighing and balancing in situations where equally legitimate, relevant considerations, values, and interests are in competition and/or conflict; in situations of which the optimum fulfillment can only be something of a middle course, a compromise solution.

After all, the most acute and vigorous idea of the "Rule of Law," "democracy," "human rights," and so on - as the Polish Pope of yesterday also reminded us ${ }^{37}$-embodies an instrumental value and nothing more. For law and language are categories of social mediation: they are neutral in themselves. What they mediate is taken over from other social complexes. ${ }^{38}$ Thus, they are to mediate fundamental values, among others, too, and the ultimate value of the instrumental value of "Rule of Law," "democracy," "human rights," and so on is dependent on what those values are in the occurrence that they actually mediate or allege to mediate. ${ }^{39}$

An excellent recapitulation has been given by the president of the Hungarian Curia [supreme court of justice], messaging that

values laying the foundations of legal order and substantiating why society is legally organised-like dignity, liberty, and the peace of persons and communities-have to be asserted and condensed in the very notion of the rule of law. But the implementation of such values is from the beginning impaired if other rule of law notional components-like legal security—are granted absolute priority. For legal security and rule by law embody values themselves, on the one hand. But values can conflict

36 For an early account drawn on one of the first major American interventions in aid policy, cf. Gardner, James A. (1980) Legal Imperialism: American Lawyers and Foreign Aid in Latin America. Madison: University of Wisconsin Press xii+401 pp.

37 Cf. Varga, Csaba (2003) 'Buts et moyens en droit' in Loiodice, Aldo, Vari, Massimo (eds.) Giovanni Paolo II: Le vie della giustizia - Itinerari per il terzo millennio (Omaggio dei giuristi a Sua Santità nel XXV anno di pontificato). Roma: Bardi Editore - Libreria Editrice Vaticana pp. 71-75 and, as expanded, Varga, Csaba (2005) ‘Goals and Means in Law: or Janus-faced Abstract Rights' in Jurisprudencija [Vilnius: Mykolo Romerio Universitetas], 68(60), pp. 5-10 \& <https://intranet.mruni.eu/en/mokslo_darbai/jurisprudencija/archyvas/?l=120712>. As ARISTOTLE formulated, there are 'things good in themselves' and 'things good for the sake of things good in themselves', which latter can only serve as 'instruments to them'; cf. Aristotle (2014) Nicomachean Ethics. Rev. trans. \& ed. Robert Crisp. Cambridge: Cambridge University Press xiii +210 pp. [Cambridge Texts in the History of Philosophy] Book I (para 10-15) on 8-9.

38 Varga, Csaba (2012) The Place of Law in Lukács' World Concept. 3rd (reprint) ed. with Postface. Budapest: Szent István Társulat 218 pp. <http://mek.oszk.hu/14200/14249/> and Varga, Csaba (2013) 'The Contemporaneity of Lukács' Ideas with Modern Social Theoretical Thought: The Ontology of Social Being in Social Science Reconstruction with Regards to Constructs like Law' Archiv für Rechts- und Sozialphilosophie 99(1), pp. 42-54 \{\& <http://elib.sfu-kras.ru/bitstream/2311/19820/4/01_Varga.pdf $>$ \}.

39 Varga, 'Goals and Means in Law', 2005. 
and therefore need balancing, on the other. Once instrumental value protecting the law's consistency conflicts with a fundamental value, this latter has priority. ${ }^{40}$

\section{The Dangers of Homogeneities Over-homogenized}

In such a perspective, it is not only the hyperactivity, doctrinarianism, and extreme formalism of some constitutional courts in the region that should be blamed as a real source of danger in the long term. Albeit the supreme illegality of their activism may have called into question why the Rule of Law is worthwhile at all and hindered (if not simply blocked) the chance of a true(r) transition, ${ }^{41}$ nowadays, what is even more troubling is the EU's manipulation, maneuvering with unfounded criticism on a daily basis as a quasi-legal intervention in order to marshal domestic issues as well. This is perhaps a postmodern imperialism, springing to the attack with sacred passion as if it were the incarnation of the final truth.

Ideologists today act as if judgeocracy were to rule, operating with soft law. ${ }^{42}$ Due to this, the benefits of representative power, parliamentary sovereignty, and the whole complex

40 Darák, Péter (2014) ‘Társadalmi problémák - jogi megoldások’ [Social problems - legal solutions] in Csehi, Zoltán, Koltay, András, Landi, Balázs, Pogácsás, Anett (eds.) (L)ex cathedra et praxis: Ünnepi kötet Lábady Tamás 70. születésnapja alkalmából. Budapest: Pázmány Press 633 pp. [Xenia], pp. 585-600 at 591, note 6. It is worthwhile to note that in a scandalous precedent made a quarter of a century ago, the Constitutional Court of Hungary practically declared all abuses of the past murderous regime no longer prosecutable, referring to the mere passing of time under statutory limitations, denying the relevance of the fact that an obstinately criminal state-organized police network as actor had also excluded-even retaliating brutally on their occurrence-any lawful intent at investigation according to the criminal and procedural codes made by the socialist state in force at the time. As declared in both justification and excuse, but setting its future tone, the Constitutional Court opined that "legal certainty based on formal and objective principles is more important than necessarily partial and subjective justice." Constitutional Court of the Republic of Hungary Decision No. 11/1992 in <https:// hunconcourt.hu/dontes/decision-11-1992-on-the-retroactive-prosecution-of-serious-criminal-offenses>.

41 Cf. Varga, Csaba (1995) Transition to Rule of Law: On the Democratic Transformation in Hungary. (Budapest: 'ELTE Comparative Legal Cultures' Project 190 pp. [Philosophiae Iuris] \&<http://mek.oszk.hu/14700/14760/>.

42 All over the world, the topic is feverishly cultivated, covering both its international and domestic dimensions as can be seen (as reduced to national uses) from, among others, Senden, Linda (2004) Soft Law in European Community Law. Oxford - Portland, Oregon: Hart Publishing lvi+533 pp. [Modern Studies in European Law 1]; Mörth, Ulrika (2004) Soft Law in Governance and Regulation: An Interdisciplinary Analysis. Cheltenham - Northampton: Edward Elgar ix+224 pp.; Haocai zhu bian, Lui (2010) Ruan fa de li lun yu shi jian [The theory and practice of soft law] Beijing Shi: Beijing da xue chu ban she 410 pp. [Ruan fa yan jiu xi lie \{Soft law series\}]; Haocai, Luo, Gongde, Song (2013) Soft Law Governance: Towards an Integrated Approach. [2009.] Trans. Ben Armour \& Tang Hailong. Buffalo, N.Y.: William S. Hein \& Co. xxvi+443 pp.; Wahlgren, Peter (ed.) (2013) 'Soft Law'= Scandinavian Studies in Law 58. Stockholm: Stockholm Institute for Scandinavian Law 308 pp.; Naoya cho, Endō (2014) Sofuto rō demokurashī ni yoru hōkaikaku. / Reform ofJapanese Law via Soft Law Democracy. Tōkyō: Ātodeizu 103+158 pp.; Weeks, Greg (2016) Soft Law and Public Authorities: Remedies and Reform. Oxford and Portland, Oregon: Hart Publishing xxxiii+280 pp. [Hart Studies in Comparative Public Law 11]; (2017) Soft law et droits fondamentaux: Actes du colloque du 4 et 5 février 2016. Paris: Pedone 318 pp. [Publications de l'Institut international des droits de l'homme 33]; Шопов, Ангел (2017) Soft law и съвременното право [Soft law and contemporary law]. София [Sofia]: Сиби 343 pp. 
quest for democracy may be impoverished and minimized..$^{43}$ Once law in action is freed from the law in books by the judiciary, widening or narrowing of the law's scope becomes discretionary, menacing by situations of sabotage judiciaire ou révolte as well. ${ }^{44} \mathrm{As}$ is known, balances and proportions that come to frame and structure institutions and ideologies at any time are confused by such new claims, if advanced and pushed under voluntarist pressure. This is the necessary outcome because all kinds of artificial and imposed developments enforce new kinds of homogenization that disfigure the original setting. The assertion of any single consideration-mostly alien to what the matter is about-may distort the whole process. ${ }^{45}$ For instance, a human rights-centered approach, as pressed by the Western mainstream nowadays, can corrupt and spoil any other consideration, reducing the complexity of adjudication to a single point of view, mostly extraneous to the matter. ${ }^{46}$ Similarly, introducing judicial control over government actions may easily lead to ignoring what the proper essence may have truly been. For social acceptance, economic gain, political rationality, and even national survival itself may be confronted with mere legality, which may prove to be socially and even politically irrelevant at the time. ${ }^{47}$ For, as is known, reductionism equals simplification, homogenization, and denaturation, implying falsification. Like a whitewash, a fourstar Pentagon general was told by the supreme commander on duty as an exoneration: "We don't know what to do [...], but we've got a good military, and we can take down governments. I guess if the only tool you have is a hammer, every problem has to look like a nail. ${ }^{148}$

Is this really the direction of "progress" we want to take? The one that we longed to reach after the destruction of peoples and countries brought by communism?

43 Hirschl, Towards Juristocracy, 2004; cf. also Tate, C. Neal, Torbjörn, Vallinder (1995) The Global Expansion of Judicial Power. New York - London: New York University Press xii+556 pp.; Olson, Walter K. (2003) The Rule of Lawyers: How the New Litigation Elit Threatens America's Rule of Law. New York: St. Martin's Press 358 pp.; Goldstein, Leslie Friedman (2004) 'From Democracy to Juristocracy?' Law \& Society Review 38(3), pp. 611-629; Sweet, Alec Stone (2010) Governing with Judges: Constitutional Politics in Europe. Oxford: Oxford University Press xii+232 pp.; Rüthers, Bernd (2014) Die heimliche Revolution vom Rechtsstaat zum Richterstaat: Verfassung und Methoden - Ein Essay. Tübingen: Mohr Siebeck ix+175 pp.

44 For a historical case study, cf. Hufteau, Yves-Louis (1965) Le référé législatifet le pouvoir du juge dans la silence de la loi. Paris: Presses Universitaires de France 159 pp. [Travaux et recherches de la Faculté de Droit et des Sciences économiques de Paris, Série Droit privé 2].

45 Howard, Collapse, 2002.

46 Varga 'The Problematics of Human Rights' in the present volume.

47 Cf., for example, Harlow, Carol (2003) 'European Governance and Accountability' in Bamforth, Nicholas, Leyland, Peter (ed.) Public Law in a Multi-layered Constitution. Oxford: Hart Publishing, $\mathrm{x}+433$ pp. on pp. 79-102. A telling series of instances were used from the World Bank's ample documentation for exemplification by Varga, 'Reception of Legal Patterns...', 2007. As to the basic change, even complete switch-off, of comingto-terms-with-the-past-in-law endeavors in post-dictatorship areas of the world, cf. Méndez, Juan E. (1997) 'Accountability for Past Abuses,' Human Rights Quarterly, 19(2), pp. 255-282.

48 In Clark, Wesley (2017) 'Gen. Wesley Clark Weighs Presidential Bid. I Think About It Every Day' [interview]. (March 2) <http://www.democracynow.org/2007/3/2/gen_wesley_clark_weighs_presidential_bid> and $<$ http://genius.com/General-wesley-clark-seven-countries-in-five-years-annotated $>$. 


\section{Who is to Rule the Law and How?}

In a brief overview of the historical development of what law in Europe has duly meant and consisted of from its earliest appearances to its present-day variations, the ancient dikaion justice stood for guidance as a springboard to arrive at a there-and-then just solution, with ius serving as an airy ideal. Later on, standardizing what the pattern is by positing it and thereby also exhaustively embodying it in the established form of lex, reduced the ideal to what could be realized therefrom within the realm of the lex. At the same time, that which was once regola, that is, a simplified summary characterization of ongoing decisional practice, became regula, that is, accurately drafted and specified normative building blocks of the body of the law. To make the law an aggregate of unquestionable rules, in European history, lawgivers repeatedly resorted to the prohibition of interpretation. All this notwithstanding, however, the inventiveness of lawyerly tricks were to erode original meanings so much in later times that MARTIN LUTHER, for instance, could only qualify the entire profession as Juristen, böse Christen. ${ }^{49}$ Not much later, processing and developing the law via logical means resulted in both conceptualizing it and arranging it into a coherent system, from which a formal conceptual doctrine, Rechtsdogmatik, would result, with an added new property never heard of in either Jewish or Islamic development or within the range of common law. Conceptualization and subsequent ratiocination would then turn into formal positivism, with a peak of extremity in the exegetic application of nothing but the given provisions of the freshly promulgated French Code civil.

Today's ontological knowledge informs us that even if law is a text consisting of signs, their message can only be drawn from their meaning, which necessarily leads us to the law's hermeneutic understanding. In turn, hermeneutics itself leads to recognizing society at large as the exclusive holder and player of law, giving by its hic et nunc understanding the actual contents by which it can at all exert whatever influence.

Law is usually seen as a specific text, objectified and externalized in its strictly regulated enacted form. However, with law in action distinguished from law in books, the overall picture of the legal phenomenon is certainly irreducible to posited law alone. According to the scheme I once proposed, ${ }^{50}$ the triple realm of law consists of components enacted and/or

49 'Lawyers, wicked Christians'; cf. Herberger, Maximilian (1978) 'Juristen, böse Christen' in Erler, Adalbert (ed.) Handwörterbuch zur deutschen Rechtsgeschichte. Vol. II. Berlin: Erich Schmidt Verlag pp. 482-483.

50 Varga, Csaba (1973) 'Quelques questions méthodologiques de la formation des concepts en sciences juridiques', Archives de Philosophie du Droit, XVIII, pp. 205-241 [reprinted in <http://mek.oszk.hu/15300/15333/\#>, pp. 7-33] and Varga, Csaba (1988) 'Anthropological Jurisprudence? Leopold Pospíšil and the Comparative Study of Legal Cultures' in Law in East and West: On the Occasion of the $30^{\text {th }}$ Anniversary of the Institute of Comparative Law. Tokyo: Waseda University Press pp. 265-285 \{reprinted in <http://mek.oszk.hu/15300/15333/\#>, pp. 437-457\}. 
enforced and/or socially lived in, and once visualized-all together forming three partially intersecting circles-which concludes that the question of what the law is now becomes a complex issue, depending upon at least four aspects of how to approach and name it. One, there are components of law figured as slices of the respective circles that do and do not overlap with others, respectively; consequently, any query as to "what is the law?" needs to be complemented by its qualifier "the law, but in what respect?" In consequence, from now on, legal phenomena can only be recorded as more or less having, or sharing with, the quality of the "distinctively legal," ${ }^{51}$ as compared to others. Two, the life of law represented by these three circles is, in principle, in constant movement as an unending process, onto which and from which new parts and particles are to enter and to recede ceaselessly. Three, independently of whether or not the prevailing ideology and legal machinery force the unitary view of the law as a single entity of what has been enacted in due form and procedure, those three slices of components and the generative factors behind them are in permanent rivalry, simply by pressing their presence to master the rest. Four, the professional deontology, characteristic of given legal cultures, is not something added to the law from outside as merely an external complement, but it forms part of the ontological being of said law. ${ }^{52}$

Today's challenge leads to a path with broken tradition. The relevancy test of rules against principles, described and prescribed by DworkIN, has already duplicated legal regimes unduly; practically, it has done so as a function of the extent of the lawyerly contribution to a case's judicial processing. Next, the practical focus on the primacy of the "human rights" approach has already led to the distortion of the very merits of the case through their homogenizing reductionism. Last but not least, the "Rule of Law" can do no more than remain a mere call to action, claiming more and better but with no sufficient rigor to be able to serve as an operative yardstick. After all, the organic construction of human societies with integrative forces as key elements cementing it is overshadowed by present-day hesitations on whether or not, and to what extent, individual rights are to be balanced by the rights of the collectivity, on the one hand, and by the complementarity of duties, ${ }^{53}$ on the other, while the chance of practical anarchy through society's atomization with

51 Selznick, Philip (1968) 'The Sociology of Law' in Sills, David L. (ed.) International Encyclopedia of the Social Sciences. Vol. 9. New York: MacMillan and The Free Press pp. 50-59 on p. 51.

52 For these developments, see Varga, Csaba (2012) The Paradigms of Legal Thinking. [1996/1999.] Enlarged 2nd ed. Budapest: Szent István Társulat 418 pp. [Philosophiae Iuris] \& <http://mek.oszk.hu/14600/14657/>.

53 Since the end of World War II, the human rights discourse has enriched with new kinds of rights and new families of rights continually put on the agenda. For "rights always agitate for more rights: they create ever new areas of claim and entitlement that again prove insufficient. We keep demanding and inventing new rights in an endless attempt to fill the lack, but desire is endlessly deferred." Douzinas, Costas (2007) Human Rights and Empire: The Political Philosophy of Cosmopolitanism. Abingdon - New York: Routledge and Cavendish $\mathrm{x}+32$ pp. on p. 49. 
ensuing disintegration is also to be kept in mind. Ending the list, soft law with discretionary guidelines as a basic constituent of a number of new civil codes around the world and law rendered soft by the manner it is used by power centers in many quarters, including the decision-making organs of the EU, may vary according to the users' explicit or hidden intentions; in any case, however, it contributes to eroding the traditional authority of the law.

To be sure, the prevailing juristocracy and the globalizing elites, with an army of internationalized foreign NGOs' partisan interventionism, may easily overcome local democracies, so that sooner or later, model legal regimes with model constitutions will be seen entering the scene, for the sake of which they will implement a new world in which old - genuine-states, constitutions, and legal regimes will be degraded into pseudo-entities than real ones. This may then lead to the establishment of the old dream of a global culture which, in its turn, may become the forum of final definition, effecting, through institutionalized cultural or sheer ideological pressure, a kind of contextual pre-determination and the latter's enforcement by the then law.

Thus, from the ancient dedication to the concrete (that is, a case and its just solution) step by step in the historical process of two millennia, we seem to have arrived at the cultivation of reducing the former's mass of casual instances to generalizable frameworks (common treatments, types, subsystems, governing principles) and, as a natural end, their sum and hierarchization in constitutions, codes, and individual laws. In opposition to the above, however, the history of adjudication is nothing other than the evolution of growing abstraction with an open invitation to any discretion, imbued with an innate logic of development leading to complete self-emptying and, perhaps, reaching also the point where and when consequences can already be imputed only arbitrarily. ${ }^{54}$

In the final analysis, the issue is on the divisive question of who the ultimate agent to master the law is. This has been an eternal query for centuries and millennia, from the earliest time in which human memory has been able to reconstruct intellectually at all. Therefore, the whole dilemma must also be examined from a political science perspective-whether or not we see it as a topic of power centralization or power dependence.

54 From the perspective of alleged reconstruction, it seems that the process of deconstruction is ultimately nothing more than the construction of a conceptual synthesis, from which traditional and living cultural context textualities have been extracted-whether historical or living in the present-by re-rationalizing them in a purely formal logical way into an abstract ideal system. 


\section{Final Queries}

The more it is characteristic of our epoch to learn from everyone and everything from the past and present alike and to recognize that continuous learning grows into a supradomestic softening of the law in an all the world's a courtroom-type of soft unification of world practices into a global corpus of available and stressed-for modes of judicial argumentation, ${ }^{55}$ the more the abuse of international agencies to use political slogans as operative terms in law will be generally practiced up to the point when big and forceful entities' daily routines will be seen as universal panaceas to impose on the rest. However, it should be noted that impositions usually impoverish the subject, depriving it of what should be a potential part of it. This is precisely the way in which benevolence turns into its opposite. External dictates are closer to following a circus trainer mentality with in-built interest projected onto its subject, while those taking pains just to assist are closer to a gardener type of passion about their plant alone, only ambitious for its well-being. ${ }^{56}$

Law is shaped by human needs and serves human interests. It must withstand both fetishization and reification with alienating ends. For, on the one hand, law is human adventure that transforms historical experience into ordering and planning tools, but on the other, "life is nonstandard," the fact notwithstanding that

"the modern era has been dominated by the culminating belief that the world [...] is a wholly knowable system governed by finite number of universal laws that man can grasp and rationally direct [...] objectively describing, explaining, and controlling everything." This is why "[t]he more systematically and impatiently the world is crammed into rational categories, the more explosions of irrationality there will be to astonish us. ${ }^{\text {"57 }}$

Considering the variability of situations of life and reactions to them, the commensurability of the law's regimes, too, is definitely limited. To assess any of them, wisdom experienced in long practice must be grounded in knowledge..$^{58}$

55 Abrahamson, Shirley S., Fischer, Michael J. (1997) 'All the World's a Courtroom: Judging in the New Millennium', Hofstra Law Review, 26(2), pp. 273-291.

56 Varga, 'Reception of Legal Patterns...', 2007.

57 Howard, 'Vaclav Havel's...', 2011.

58 Varga, Csaba (2005) 'Visszavont emberi teljesség? Eszmeuralom és tetszőlegesség' [Fullness of being withdrawn? Ideocracy \& arbitrariness], PoLíSz, (No.82), pp. 14-21 \{reprinted in \& <http://mek.oszk. hu/17900/17995/17995.pdf>, pp. 17-26\}. 


\title{
RULE OF LAW, RECHTSSTAATLICHKEIT, ÉTAT DE DROIT - CONTESTING AND CONTESTED ${ }^{1}$
}

\begin{abstract}
1. Post-WWII Rebirth and Transformation into a Catchword 2. Limitlessness in Today's Use 3. Roots and Development in Various Legal Cultures 4. The Genuine Content
\end{abstract}

\begin{abstract}
The rule of law movement is a by-product of the post-WWII rebirth of human rights, which turned into a key political issue by the turn of the millennium. By becoming part of the language and blackmailing practice of international politics, it has self-emptied as well. It is an ideal; historically a function of human experience at individual places and times, shaped by local traditions. As a complex of heterogeneous values and principles, its ethos can at best be respected and approached via the neverending balancing of compromise solutions.
\end{abstract}

KEYWORDS Rechtsstaat, État de droit, democracy, constitutionalism, judicialisation, UN, EU

\section{Post-WWII Rebirth and Transformation into a Catchword}

The end of World War II was followed by shocks in politics worldwide and of course, in law. Both victory and defeat questioned the continuability of the uncritical survival of legal positivism and reconsidered the tenet of Das Recht ist das Recht!, which had once given the impetus to the easy transition of dictatorial regimes born of the dramatic changes of power between the two world wars. They were forced to rethink the need to ensure the fundamentals of natural law as the basic living conditions of any human society. They reversed the accepted order of the ultimate values in law, prioritising justice over the search for legal certainty, as interwar experience had taught that in the event of total dehumanisation, no legal certainty could be of any value. Last, they breathed life into concepts that had earlier been dispersed on the margins of previous movements and literature, such as human rights and the barely cultivated notions of the rule of law and Rechtsstaatlichkeit.

1 Commissioned and published originally as (2021) 'Rule of Law - Contesting and Contested', Central European Journal ofComparative Law, 2(1), pp. 245-267<https://ojs3.mtak.hu/index.php/cejcl/article/view/6041/4723> for the Ferenc Mádl Institute Comparative Law, a new research centre under the auspices of the Ministry of Justice in Budapest. Thanks to their kind permission, its almost parallel edition appears in this volume. 
After the abovementioned cataclysm, human rights first had to be accounted for, and what they were and what kind of legal protection they needed clarified. Even the creation of the United Nations (1945) was an ordeal for the parties drifting towards the Cold War, and the adoption of the Universal Declaration of Human Rights (1948) implied a straightforward multiplayer factional struggle over what and how to name it. Back then, it seemed sufficient to edify a 'law + rule/state' conglomerate as the broadest framework for their safeguard so that they would actually be implemented and not forced out by popular rebellion. For this reason, the Declaration had to state that 'human rights should be protected by the rule of law' $^{2}$ (where the term may have stood for some rule(s) of the law, not the classical rule of law3): 'Il est essentiel que les droits de l'homme soient protégés par un régime de droit'. (Since the term État de droit was translated from German, it never occurred to the drafters that this could have anything to do with the Anglo-American rule of law).

Presumably, in the disorganised turmoil of antinomic thought traditions, the opposition of the Euro-Atlantic West to the Bolshevik East led the former to clarify its own identity and as a political option, embrace the positive-sounding tradition of 'rule of law', only to thereby exorcise Muscovite dictatorship. Regardless, it was discussed in Chicago in 1957. A year later, in response, the Soviet bloc produced a socialist legality in Warsaw as its own version, only so that a new synthesis would be summoned in New Delhi within a year that encompassed Asian aspirations. Chicago summed up the Western tradition as the supremacy of law, which the French tradition simply enshrined as légalité. In addition, participants could still add further content to it in New Delhi. All this has reportedly been defined, the results of which may perhaps be educed from the four-page questions and hundreds of answers. ${ }^{4}$ Under such con-

$2<$ https://www.un.org/en/udhrbook/pdf/udhr_booklet_en_web.pdf>, p. 2, resp. <https://www.un.org/fr/ udhrbook/pdf/udhr_booklet_fr_web.pdf>, p. 1 .

3 Perhaps due to American universalism, not even Harvard's excellent Catholic thinker, Glendon, Mary Ann (2004) 'The Rule of Law in the Universal Declaration of Human Rights', Northwestern Journal of International Human Rights, 2(1), pp. 1-19 \& <http://scholarlycommons.law.northwestern.edu/njihr/vol2/iss1/5> at p. 4 did notice that instead of an early use of the term, it may have simply been an occasional formula used by the drafters.

4 (1959) Rule of Law as Understood in Western Countries / Le concept de la légalité dans les pays occidentaux. = Annales de la Faculté de droit d'Istanbul, IX(No.12), pp. 1-349; and Katz, Milton, Schlesinger, Rudolf B., Rheinstein, Max (1957) 'International Association of Legal Science: The Colloquia at Chicago, September 8-16, 1957', American Journal of Comparative Law, 6(4), pp. 518-525; then (1961) Le concept de la légalité dans les pays socialistes: Colloque de l'AISJ, 10-16 septembre 1958. Wrocław-Warszawa: Zakład Narodowy imenia Ossolińskich, Wydawnictwo Polskiej Akademii Nauk 414 pp. [Cahiers de l'Académie Polonaise des Sciences / Zeszyty Problemowe Nauki Polskiej 21]; and Tóth, János (1965) 'Le droit comparé dans l'Europe de l'Est', Revue de la Commission Internationale des Juristes, $\mathrm{VI}(2) \&<\mathrm{https} / /$ www.icj.org/wp-content/uploads/2013/08/ICJ-Journal-VI-2-1965-fra.pdf>, pp. 274-278; in the end [International Commission of Jurists] Marsh, Norman S. (ed.) (1960) The Rule of Law in a Free Society. (A Report on the International Congress of Jurists, New Delhi, India, January 5-10, 1959.) Geneva xi+336 pp. \& <https://www.icj.org/wp-content/uploads/1959/o1/Rule-of-law-in-a-free-society-conferencereport-1959-eng.pdf>, in particular on pp. 183-186. 
ditions, from the end of World War II to the Soviet atomic bomb threat to the Western world, the notion of the rule of law as a fundamental element of a free society lurked. However, this happened without going beyond idealising what the Atlantic mainstream considered good and desirable in public affairs. ${ }^{5}$

With this, a legally immature term began its triumphant journey. It soon became fertilised in use by politics and political science; was transferred to international diplomacy; integrated into the language of the United Nations; and finally, into that of the World Bank and International Monetary Fund, set up as the latter's agencies. ${ }^{6}$ Therefore, it is no coincidence that even the most committed student of the notion of the rule of law can only characterise the turn-of-the-millennium situation by saying, 'One cannot get through a foreign policy debate these days without someone proposing the rule of law as a solution to the world's troubles'. ${ }^{7}$ More striking is that the memory of its Cold War use seems to have been preserved. It was first used as a symbol of the excellence of the West, then as an expression of opposition to the shame of the Bolshevik East, ${ }^{8}$ and finally by the UN international development financial organisations with explicitly blackmailing unilateralism to impose Western legal solutions on the rest of the world. ${ }^{9}$

This has already resulted in unspecified but rhetorical overuse, and the term has been inflated and wasted in international diplomacy and in the practice of the European Union,

5 The American statesman who served as an associate judge of the Supreme Court, then as one of the closest associates to Presidents Roosevelt and Truman, and as the Secretary of State in the end-Byrnes, James Francis (1947) Speaking Frankly. London-Toronto: William Heinemann xii+324 pp. at p. 314-uses the term 'a system of collective security that will develop and enforce the rule of law' in the epilogical summary of his remarks on the tasks of the United Nations in a manner standing for a rule of ideal law thought of as an airy desire rather than an elaborate concept.

6 In the e-world, 'rule of law' in company of 'United Nations' occurs 15,000,000 times and 13.300,000 times in company of 'European Union'; with 'World Bank' 6,150,000 times and with 'International Monetary Fund' 1,510,000 times. In German, 'Rechtsstaat' coupled with 'Vereinte Nationen' occurs 113,000 times and with 'Europäische Union' 167,000 times.

7 Carothers, Thomas (1998) 'The Rule of Law Revival', Foreign Affairs, 77(2), pp. 95-106 at p. 95.

8 As a leading human rights movement today, the International Commission of Jurists was established with the support of the CIA in West Berlin in 1952 (<https://www.icj.org/>), designed to become a "Cold Warrior against Socialist Legality"; cf. Tolley, Howard B. (1994) The International Commission of Jurists: Global Advocates for Human Rights. Philadelphia: University of Pennsylvania Press xvii+355 pp. [Pennsylvania Studies in Human Rights]', ch. I. It was made as a counterpart of the International Association of Democratic Lawyers established in Paris in 1946 (<https://iadllaw.org/>), with the foundational presidency of the Nobel Peace Prize winner RENÉ CASSIN (a future drafter of the Universal Declaration of Human Rights), after the latter started documenting US war crimes committed during the Korean War.

9 Cf., e.g., Varga, Csaba (2007) 'Reception of Legal Patterns in a Globalising Age' in Calera, Nicolás López (ed.) Globalization, Law and Economy / Globalización, Derecho y Economía: Proceedings of the $22^{\text {nd }}$ IVR World Congress. Vol. IV. Stuttgart: Franz Steiner Verlag, pp. 85-96 [ARSP Beiheft 109] \{reprinted in <http://mek.oszk. hu/15300/15386>, pp. 181-207\}. 
especially after its expansion by including countries of Central and Eastern Europe. ${ }^{10}$ This increase can be inferred from the growth that made the term a buzzword, as seen in its text frequency and use in book titles: ${ }^{11}$

\begin{tabular}{|c|c|}
\hline word & e-occurrence \\
\hline rule oflaw & 105.000 .000 \\
\hline Rechtsstaat & 4.000 .000 \\
\hline État de droit & 6.500 .000 \\
\hline jogállam [=Rechtsstaat] & 500.000 \\
\hline joguralom [=rule of law] & 150.000 \\
\hline
\end{tabular}

\begin{tabular}{|c|c|c|c|c|c|}
\hline books & 1944-1959 & 1960-1975 & 1976-1991 & 1992-2007 & 2008-2020 \\
\hline 'Rule of law' in title in English' & 32 & 96 & 64 & 544 & 1120 \\
\hline 'Rechtsstaat' in title in German & 30 & 120 & 180 & 180 & 270 \\
\hline
\end{tabular}

Interestingly, the term came to the fore when the two-power world order collapsed by making Central and Eastern Europe a confusing international problem (or trump) anew, reclaiming and regaining the region's old place in the world..$^{13}$

10 Cf., e.g., Varga, Csaba (2009) Jogrendszerek, jogi gondolkodásmódok az európai egységesülés perspektívájában (Magyar körkép - európai uniós összefüggésben) [Legal systems and legal mentalities in the perspective of European unification: Hungarian overview in a European Union context]. Budapest: Szent István Társulat 282 pp. [Jogfilozófiák] \& <http://mek.oszk.hu/15100/15173>, pp. 19-28.

11 Its occurrence as a title in the Hungarian language shows a different picture. It was once a current term because the journal Jogállam [Rechtsstaat] (1903-1938) used to publish case reports and book series. As a book title, it appears exclusively in Balogh, Arthur (1914) Jogállam. Budapest: Magyar Tudományos Akadémia 57 pp. [Értekezések a társadalmi tudományok köréből XIV:8], and then more recently, in the collection of Takács, Péter (ed.) (1995) Joguralom és jogállam: Antológia a rule oflaw és a Rechtsstaat irodalmának köréböl [Rule of law and Rechtsstaat: An Anthology]. Budapest: [Osiris-Századvég] 329 pp. [Jogfilozófiák / Philosophiae Iuris].

12 As a book title, 'rule of law' became widespread early because the International Commission of Jurists preferred to use it as a starting point and contrast in processing conflicting situations, such as in, for example, [International Commission of Jurists] (ed.) (1957) The Hungarian Situation and the Rule of Law. The Hague: International Commission of Jurists $144 \mathrm{pp}$.

13 Even on the seemingly not politically sensitive issue of why and how the notion of the rule of law could reach its period of consummation, we cannot meet with either disinterest or clairvoyance. Despite his Polish roots, Krygier, Martin (2014) 'The Rule of Law after the Short Twentieth Century: Launching a Global Career' in Nobles, Richard, Schiff, David (eds.) Law, Society and Community: Essays in Honour of Roger Cotterrell. Farnham, Surrey: Ashgate pp. 327-346 sees the term coming to the fore in the surfeit of ideologies of the post-Cold War Atlantic and Western European world, while another interpreter-Janse, Ronald (2019) 'Why Did the Rule of Law Revive?', The Hague Journal on the Rule of Law, 11(2-3) \& <https://link.springer.com/article/10.1007/s40803019-00132-Z\#Fn2>, pp. 341-348-says it originated from the changing eras of European communality. 
Thus, it has become a fashionably common catchword to express pride for the self and/or contempt for others. This lack of content, the fact that the word has become commonplace, is hitting those struggling for the underlying ideal to be implemented in the Third World, ${ }^{14}$ and who must identify the enemy of their cause in those who are cheating with it by punting it as a panacea. ${ }^{15}$ CARL SCHMITT despised the use of Rechtsstaat from the early 1930s, because it can mean the Recht and Staat separately. Its only trait is that it sounds promising, which when held accountable, makes us free to denigrate any opponent. ${ }^{16}$ Alternatively, as widely expressed,

\section{'the phrase "the Rule of Law" has become meaningless thanks to ideological abuse and general overuse. It may well have become just another of those self-congratulatory rhetorical devices that grace the utterances of Anglo-American politicians [...]. No intellectual effort need therefore be wasted on this bit of ruling-class chatter.' ${ }^{17}$}

However, at the same time, its indefiniteness in content, which sounded as a cry for others, has become an inspiring source of truly exploratory and not infrequently monographic works. These, the absence of a theoretically developed background and established doctrinal structure or dogmatics ${ }^{18}$ have in the name of scholarly analysis often become like a program or creed that ensures good governance to achieve the public good by supplying the adequate quality of legal background with the available institutional procedures and techniques.

14 Humphfreys, Stephen (2010) Theatre of the Rule of Law: Transnational Legal Intervention in Theory and Practice. Cambridge: Cambridge University Press xxx+295 pp. [Cambridge Studies in International and Comparative Law] on pp. 1-26 laments its 'magical, or at least talismanic, role'. Drawing conclusions, Flake, L. Gordon (2000) 'Preface and Acknowledgments' in The Mansfield Center for Pacific Affairs (ed.) The Rule of Law: Perspectives from the Pacific Rim. Findlay, Ohio: The Mansfield Center for Pacific Affairs $x+156$ pp. \&<https://biblioteca. cejamericas.org/bitstream/handle/2015/993/mcpa-rule-law-pacific.pdf?sequence=1\&isAllowed=y> on $\mathrm{pp}$. $\mathrm{i}-\mathrm{x}$ at p. vii states that "the "Rule of Law" has become a buzzword of today and an oft-prescribed panacea for the myriad challenges of development faced by Asian nations. Yet seldom in such discussions is the concept of the "Rule of Law" carefully defined'. Note that as synonyms for buzzword, expressions like 'hokum' and 'bunk' make it even more accurate to understand what the author may have meant by this wording.

15 E.g. Peerenboom, Randall (2004) 'Varieties of Rule of Law: An Introduction and Provisional Conclusion' in Peerenboom, Randall (ed.) Asian Discourses of Rule of Law: Theories and Implementation of Rule of Law in Twelve Asian Countries, France and the U.S. London \& New York: Routledge xxiii+479 pp. [Routledge Curzon Law in Asia 1] on pp. 1-53 at p. 33.

16 Schmitt, Carl (1932) Legalität und Legitimität. Berlin: Duncker \& Humblot 98 pp. [(1988) 4. \{reprint\} Ausgabe. Berlin: Duncker \& Humblot 98 pp. at p. 19.

17 Shklar, Judith N. (1987) 'Political Theory and the Rule of Law' in Hutchinson, Allan C., Monahan, Patrick (eds.) The Rule of Law: Ideal or Ideology. Toronto: Carswell xiv+167 pp. on pp. 1-16 at p. 1.

18 As characterised by Gárdos-Orosz, Fruzsina, Szente, Zoltán (2014) 'A Jó Állam jogállami követelményei' [The rule of law preconditions of a Good Government] in Kaiser, Tamás, Kis, Norbert (ed.) A JóÁllam mérhetôsége [The measurability of a Good Government]. Budapest: Nemzeti Közszolgálati Egyetem Jó Állam Kutatómúhely pp. 267-290 at p. 267, in such a complex deficiency, 'the main difficulty is not that there is no widely accepted general definition of the rule of law, but that there is no consensus on its components'. 


\section{Limitlessness in Today's Use}

The first finding jurisprudence can formulate is that the rule of law is a contested concept. ${ }^{19}$ Inherently, ${ }^{20}$ 'the meaning of the concept known as the rule of law is always open to debate ${ }^{21}$ as it belongs to those notions whose 'nature and meaning are contested and controversial. ${ }^{22}$ Or again, 'The rule of law is a flexible and contested concept that can be defined in different ways. [...] Its different definitions mean that the rule of law has no uniform accepted form. ${ }^{23}$ Considering it an undefined and uncertain notion from the beginning, ${ }^{24}$

19 According to Gallie, W. B. (1956) 'Essentially Contested Concepts', Proceedings of the Aristotelian Society, 56(1), pp. 167-198 at p. 169, those concepts are essentially contested, 'the proper use of which inevitably involve endless disputes'. This issue-Gray, John N. (1977) 'On the Contestability of Social and Political Concepts', Political Theory, 5(3), pp. 331-348 at p. 344 asserts - 'cannot be settled by appeal to empirical evidence, linguistic usage, or the canons of logic alone'. Furthermore, Garver, Eugene (1978) 'Rhetoric and Essentially Contested Arguments', Philosophy \& Rhetoric, 11(3), pp. 156-172 at p. 168 opines that a good answer is excluded from the beginning. Within a few decades, artistic and political categories (with rule of law included) had also been categorised as such. Cf. Waldron, Jeremy (2002) 'Is the Rule of Law an Essentially Contested Concept (in Florida)?', Law and Philosophy, 21(2), pp. 137-164 and Collier, David, Hidalgo, Fernando Daniel, Maciuceanu, Andra Olivia (2006) 'Essentially Contested Concepts: Debates and Applications', Journal of Political Ideologies, 11(3), pp. $211-246$.

20 See Bárd, Petra, Carrera, Sergio, Guild, Elspeth, Kochenov, Dimitry (2016) An EU Mechanism on Democracy, the Rule of Law and Fundamental Rights. Annex II: Assessing the Need and Possibilities for the Establishment of an EU Scoreboard on Democracy, the Rule of Law and Fundamental Rights. [Research paper.] Brussels: European Parliamentary Research Service 234 pp. [CEPS Paper in Liberty and Security in Europe 91] \& <https:// europatarsasag.hu/sites/default/files/open-space/documents/magyarorszagi-europa-tarsasag-eprsstud57 9328annexiicepseuscoreboard12april.pdf> \& <https:/www.academia.edu/24709057/Petra_Bárd_Sergio_ Carrera_Elspeth_Guild_and_Dimitry_Kochenov_with_thematic_contribution_by_Wim_Marneffe_An_EU_ mechanism_on_Democracy_the_Rule_of_Law_and_Fundamental_Rights_CEPS_Paper_in_Liberty_and_ Security_in_Europe_No_91_April_2016_234_p_ISBN_978_94_6138_520_8_> at p.80, who claim that 'defining it in the best possible way cannot cancel the nature of the rule of law, which is an essentially contested concept'.

21 Zimmermann, Augusto (2007) 'Rule of Law as a Culture of Legality: Legal and Extra-legal Elements for the Realisation of the Rule of Law in Society', Murdoch University Electronic Journal of Law, 14(1)(textNo.2), <http:// classic.austlii.edu.au/au/journals/MurdochUeJlLaw/2007/2.html>, pp. 10-31 at p. 10.

22 Allan, T. R. S. (1998) 'Rule of law (Rechtsstaat)' in Routledge Encyclopedia of Philosophy. <https://www.rep. routledge.com/articles/thematic/rule-of-law-rechtsstaat/v-1> [DOI 10.4324/9780415249126-To22-1].

23 Lautenbach, Geranne (2013) The Concept of the Rule of Law and the European Court of Human Rights. Oxford: Oxford University Press xxi+235 pp. at p. 19.

24 E.g. Ajani, Giovanni (2003) 'Navigatori e giuristi: A proposito del trapianto de nozioni vaghe' in Bertorello, Valentina (ed.) Io comparo, tu compari egli compara: Che cosa, come, perché. Milano: Giuffrè pp. 3-18; Costa, Pietro (2007) 'The Rule of Law: A Historical Introduction' in Costa, Pietro, Zolo, Danilo (eds.) The Rule of Law: History, Theory and Criticism. Dordrecht: Springer xiv+695 pp. [Law and Philosophy Library 80] on pp. 73-149 at p. 74; Fallon, Jr., Richard H. (2007) “The Rule of Law” as a Concept in Constitutional Discourse', Columbia LawReview, 97(1), pp. 1-56 at pp. 1 and 6; Mattei, Ugo, Nader, Laura (2008) Plunder: When the Rule of Law is Illegal. Oxford: Blackwell x+283 pp. at p. 10; Rodriguez, Daniel B., McCubbins, Mathew B., Weingast, Barry R. (2010) 'The Rule of Law Unplugged', Emory Law Journal, 59(6), pp. 1455-1494 \& <https://scholarlycommons.law.emory.edu/elj/vol59/iss6/2/>. As officially perhaps understated-[House of Lords Select Committee on the Constitution, $6^{\text {th }}$ Report of Session 2006-07] (2007) Relations between the Executive, the Judiciary and Parliament. London: The Stationary Office 128+104 pp. [HL Paper 151] at p. 12, para. 24-,'the rule of law remains a complex and in some respects uncertain concept'.

Selznick, Philip (2005) 'Democracy and the Rule of Law', Syracuse Journal of International Law and Commerce, 33(1) \& <https://surface.syr.edu/jilc/vol33/iss1/4/>, pp. 29-39 at p. 29. 
a 'mixture of implied promise and convenient vagueness', ${ }^{25}$ it is 'exceedingly elusive' with 'rampant divergence of understandings'. ${ }^{26}$ Thus, '[n]o one in the international community is quite sure' (as 'we are never quite sure') what it means at all, ${ }^{27}$ because 'scholars are not agreed on the desiderata that would define the Rechtsstaat ${ }^{28}$ and what its scattered generalities may mean without any central thought. ${ }^{29}$ 'In fact, the only thing that seems to consistently garner agreement within the "Rule of Law" discourse is that there is pervasive disagreement within this discourse'. ${ }^{30}$ Such characterisations are often formulated not as rejection or destructive criticism, but to justify new investigations in the hope of reaching a consensus some time in the future.

RONALD DWORKIN, who was astonishingly bold by basing his theorising on the values of a single time and place, ended his introductory speech at the London meeting of the Venice Commission on the Clarification of the Rule of Law in the European Union, perhaps the last public act of his life, by concluding:

'There is a paradox at the heart of the rule of law. That ideal demands certainty and condemns ambiguity in the law. But that is great uncertainty and alleged ambiguity in the ideal itself. Firm adherents are locked in great disagreement about what the rule of law really is'. ${ }^{31}$

25 Kirchheimer, Otto (1996) 'The Rechtsstaat as Magic Wall' in Scheuerman, William E. (ed.) The Rule of Law under Siege: Selected Essays of Franz L. Neumann and Otto Kirchheimer. Berkeley: University of California Press vii+268 pp. [Weimar and Now 9] at p. 244.

26 Tamanaha, Brian Z. (2004) On the Rule of Law: History, Politics, Theory. Cambridge \& New York: Cambridge University Press viii+180 pp. at p. 3 adds that it is like wishing for good: 'Everyone is for it, but have contrasting convictions about what it is'.

27 Bouloukos, Adam C., Dakin, Brett (2001) 'Toward a Universal Declaration of the Rule of Law: Implications for Criminal Justice and Sustainable Development', International Journal of Comparative Sociology, 42(1-2), pp. 145-162 at p. 145 as well as Fletcher, George P. (1966) Basic Concepts of Legal Thought. New York: Oxford University Press ix+213 pp. at p. 12 .

28 Borneman, John (2007) Settling Accounts: Violence, Justice, and Accountability in Postsocialist Europe. Princeton: Princeton University Press xii+197 pp. [Princeton Studies in Culture/Power/History] at p. 4.

29 Higgins, Rosalyn (2007) The ICJ and the Rule of Law. A speech given at the United Nations University (11 April). $<$ http://archive.unu.edu/events/fil les/2007/20070411_Higgins_speech.pdf> states this, referring mainly to UN documents.

30 Hamara, Courtney Taylor (2013) 'The Concept of the Rule of Law' in Flores, Imer B., Himma, Kenneth Eimar (eds.) Law, Liberty, and the Rule of Law. Dordrecht: Springer $\mathrm{x}+190 \mathrm{pp}$. [Ius Gentium: Comparative Perspectives on Law and Justice 18] on pp. 11-26 at p. 12.

31 Dworkin, Ronald (2012) 'Keynote Speech' in Conference on "The Rule of Law as a Practical Concept«. European Commission for Democracy through Law (Venice Commission) 92 pp. \& <http://www.venice.coe.int/ webforms/documents/default.aspx?pdffile=CDL\%282013\%29016-e $>$ on pp. $5-11$ at p. 11 . 
This is because it does not have an own object, and is largely an 'umbrella' or 'container' concept $\mathrm{t}^{32}$ used as an indicator when describing the law, the state, politics, or the general situation to disclose in respect of a given legal order that what is in is actually secure as regulated or in contrast, absent compared to its agreed minimum. However, this almost free capacity makes it a 'rhetorical balloon' that can be increasingly inflated and made almost unlimited. Here, as scholars claim, ${ }^{33}$ the more it says, the less it is worth.

Thus, it is not simply that we can understand a certain object in multiple ways, but that we mean different objects in different ways although we call them by one name as if talking about a single object. As a result, there is a cacophony of naming and understanding. Regarding American constitutional law, Harvard's expert explores its comprehensibility from various perspectives and a plethora of variations of each perspective..$^{34}$ Another author distinguishes between at least four approaches that differ in subject matter and have different characteristics. According to him,

'One could [...] define the rule of law in terms of the values which that institution is designed to serve, such as human dignity or individual fulfilment through the full development of one's capacities; or in terms of the several principles whereby those institutions are to be safeguarded, such as the rule that a legal basis must be shown for every government action interfering with the rights of the citizen; or in terms of the institutions, such as the courts, the bar, the parliaments and the police who are responsible for doing the safeguarding, in their own distinctive ways; or, finally, in terms of the procedures which those institutions use for that purpose, such as public hearings, jury trial, habeas corpus and the like'. ${ }^{35}$

In light of this multitude, ${ }^{36}$ we may have the impression that the term was a kind of desideratum, a set of desirable standards backed by a complete edifice of theses and criteria on

32 E.g. Bedner, Adriaan (2010) 'An Elementary Approach to the Rule of Law', Hague Journal on the Rule of Law, 2(1), pp. 48-74 \& <https://core.ac.uk/download/pdf/194433601.pdf> at pp. 48-74 and Belton, Rachel Kleinfeld (2005) Competing Definitions of the Rule of Law: Implications for Practitioners. Washington, D.C.: Carnegie Endowment for International Peace 38 pp. [Democracy and Rule of Law Project; Carnegie Papers 55] at p. 6.

33 Frändberg, Åke (1996) 'Begreppet rättsstat' in Sterzel, Fredrik (ed.) Rättsstaten: Rätt, politik och moral. (Seminarium 5 oktober 1994.) Stockholm: Rättsfonden 127 pp. [Rättsfondens skriftserie 31] at pp. 22-23 and Frändberg, Åke (2014) From Rechtsstaat to Universal Law-state: An Essay in Philosophical Jurisprudence. Cham: Springer xi+190 pp. [Law and Philosophy Library 109] p. 31.

34 Fallon, '“The Rule of Law"...', 2007.

35 Walker, Geoffrey de Q. (1988) The Rule of Law. Carlton, Victoria: Melbourne University Press xxvi+475 pp. at p. 9. 36 Cf. as well Møller, Jørgen, Skaaning, Svend-Erik (2014) The Rule of Law: Definitions, Measures, Patterns and Causes. London: Palgrave Macmillan xii+198 pp. and Yakushik, Valentin (2018) 'Varieties of a Law-Governed State', Ukrainian Policymaker, (No.3), pp. 72-84 \& <https://www.academia.edu/38103741/Yakushik_Valentin_ Varieties_of_a_Law_Governed_State_In_Ukrainian_Policymaker_2018_No_3_P_72_84>. 
the state-organised legal regime of society, based on a given social philosophy, and elaborated to the depths doctrinally. This is not the case-if not perhaps for some minds exclusively, for private use only, and with no obligatory institutionalisation or valid measurement standards.

Today, we are in turmoil, because the term can simultaneously mean nothing and anything, everything or anything. We are discussing a word that has long since become empty with its arbitrarily adaptable meaning-bearing capacity and inflated overuse, formed in response to conflicts of interest. It has no standardised meaning within the law; consequently, it has no legally assertable or defendable criterial functionality. It is political mud wrestling with millions of teammates in the world's thousands of political think tanks as well as scholarly and media workshops. In fact, any of us can enrich it with whatever we want. In addition, it has no dogmatics, and thus no solid structure, support frame, or boundaries. Why should its expandability know any limitation? The theoretical literature commonly notes that 'It is very difficult to talk about the "Rule of Law". There are almost as many conceptions of the "Rule of Law" as there are people defending it', ${ }^{37}$ as all kinds of authors 'use the term as a catch-all slogan for every desirable policy one might wish to see enacted'.$^{8}$ As an expert on the issue, one of New York's leading philosophical authorities paints as a tableaux vivant: 'Open any newspaper and you will see the "Rule of Law" cited and deployed-usually as a matter of reproach, occasionally as an affirmative aspiration, almost always as a benchmark of political legitimacy'.39

The analysis reveals not only the uncertainty surrounding the concept, but also the extent to which the product that takes incessantly changing shapes amid historical contingencies is variable and environment-dependent, because it develops differently according to culture, tradition, and local conditions. ${ }^{40}$ Thus, the rule of law is primarily and foremost a historical category. It is based on a wide variety of historical experiences that differ by nation and age, which define or condition its hic et nunc particularity. Consequently, as

'a product of historical development [..., the rule of law [...] cannot be seen in isolation from the constitutional theories and traditions [....as it...] is closely tied to the historical

37 Taiwo, Olufemi (1999) ‘The Rule of Law: The New Leviathan?', Canadian Journal of Law and Jurisprudence, 12(1), pp. 151-168 at p. 154 .

38 Bellamy, Richard (2007) Political Constitutionalism: A Republican Defence of the Constitutionality of Democracy. Cambridge \& New York: Cambridge University Press $x+270$ pp. at p. 54.

39 Waldron, Jeremy (2008) 'The Concept and the Rule of Law', Georgia Law Review, 43(1), pp. 1-61 \& <https:// digitalcommons.law.uga.edu/cgi/viewcontent.cgi?article=1028\&context=lectures_pre_arch_lectures_ sibley> at p. 1.

40 E.g. May, Christopher (2014) The Rule of Law: The Common Sense of Global Politics. Cheltenham \& Northhampton: Elgar xxxvii+234 pp. 
and institutional setting in which the rule of law has come to development'.41 'What it rules out, what it allows, what it depends on, and indeed what it is, are all matters of disagreement that stem from differences between political and legal histories and traditions, and reflect dilemmas and choices that recur in different forms and weights in many such histories and traditions'. ${ }^{42}$

We can generalise from these, but as the best-known French expert on the issue points out, then out of context, only an empty shell—une coquille vide - remains as the end-product. ${ }^{43}$

With this, we return to the specific problems of various national and other developments and to aspirations that inspire a solution, including their shoreless ambitions. However, what develops in this arbitrary and dispersed way locks down the chance of any orderly-or anyconceptuality, as the shape it takes will be a flow of continuous rearrangements. Moreover,

'The idea of the rule of law is characterised by its programmatic character, which means that it cannot be exclusively identified with one or another specific legal concept, but rather comprises a whole set of principles that govern the morality of the exercise of public authority in a society at a particular time of its history'.44

As a result, uncertainty characterises not only the term as a whole, but also, in addition to its internal context, each of its elements separately, since each will be the product of the characteristics of a given historical development, that is, the diversity determined by place and time. However, as the analysis continues, behind the disguised commonality of its wording is again the case of multiple concepts. The notion of the rule of law is from the outset

'elusive and controversial [..., for...] there is an "embeddedness" of this term with specific national historical diversities of a political, institutional, legal and imaginary nature. [...] This requirement of vagueness plays strongly against any Quichotean attempts to turn the rule of law into a shopping list of elements'. ${ }^{45}$

41 Lautenbach, The Concept of the Rule of Law, 2013, pp. 35 and 210.

42 Krygier, Martin Evald John (2015) 'Rule of Law (and Rechtsstaat)' in Wright, James D. (ed.) International Encyclopedia of the Social \& Behavioral Sciences. Vol. 20. 2nd edn. Oxford: Elsevier pp. 780-787 \& <https://www. researchgate.net/publication/278412328_Rule_of_Law_and_Rechtsstaat>at p. 780 .

43 Chevallier, Jacques (2003) L'État de droit. $4^{e}$ éd. Paris: Montchrestien 160 pp. [Clefs: Politique] at p. 52.

44 Grote, Rainer (2010) 'Rule of Law, Rechtsstaat y État de Droit', Pensamiento Constitucional, VIII(8), pp. 127$176 \&<$ https://www.researchgate.net/publication/27270699_Rule_of_Law_Rechtsstaat_y_Etat_de_Droit> at p. 175.

45 Bárd, Carrera, Guild, Kochenov, An EU Mechanism..., 2016, pp. 79, 80 and 80. 
Putting its building blocks together, the complete picture of an infinitely complex jigsaw puzzle emerges: elements with meaning and validity drawn from their historical hic et nunc formations, which in a given place and time, are stacked in an international space while preserving their generational local values to form a concept that can be widely shared and accepted in a given culture. Characteristically, when a Harvard constitutionalist analysed the components of how many innumerable perspectives can be identified only in legal practice in the US, with each of them having separate although equally defensible versions of the rule of law, he could do so simply by flinging them into the floating cloud of relativity, because each user is used to expecting to create his/her own version for his/her own use. ${ }^{46}$ Because, he continues, ${ }^{47}$

'It is a mistake to think of particular criteria as necessary in all contexts for the rule of law. Rather, we should recognize that the strands of the Rule of Law are complexly interwoven, and we should begin to consider which values or criteria are presumptively primary under which conditions'.

\section{Roots and Development in Various Legal Cultures}

Our age is characterised by a new ideocracy after the Christian mediaeval desire for spiritual brilliance. By surpassing both the historical past and human experience, it wants to see today's revolutionary thoughts (concerning our gender, skin colour, sexuality, growing up in a family, living as a nation, and so on), hoped to be world-shattering after the practice of millennia, as a latent but now discovered eternal quality of the universal human. The ideas that sparked the French Revolution also lead us back to our classical Greek predecessors, sometimes directly to the earliest traces of intellectual archaeology. However, we know that although 'human rights' were already mentioned-for example, in protest against the genocidal murder of natives in Latin America by a Spanish Dominican centuries ago— ${ }^{48}$ today's

46 Similar to case law, where the judge will draw the stare decisis from what he can learn from precedents he has considered to serve as a rule for his pending decision, but without publicly stating it.

47 Fallon, “'The Rule of Law"..., 2007, p. 6.

48 BARTOlOmÉ DE las CASAS was the first in 1552 to mention 'las reglas de los derechos humanos'. Las Casas, Bartolomé de (1971) A Selection of his Writings. Ed. Sanderlin, George. New York: Knopf x+209 pp. [Borzoi Books on Latin America] and Corres, Moisés Jaime Bailón (2014) Derechos Humanos de los pueblos indígenas: El debate colonial y las leyes de indias de 1681. México: Comisión Nacional de los Derechos Humanos 96 pp.; cf. also Pennington, Kenneth (2018) 'Bartolomé de Las Casas' in Domingo, Rafael Martínez-Torrón, Javier (eds.) Great Christian Jurists in Spanish History. Cambridge: Cambridge University Press xiii+395 pp. [Law and Christianity] on pp. 98-115. 
movement is not rooted in this but comes from the Enlightenment and post-World War II conscience test, and to a smaller extent, as the aftermath of the 1968 uprisings. Equally obvious is that the complexity of today's notion of the rule of law dates to the 19th century as a concept born mainly of German and English development.

The idea took shape largely because of the confrontation with feudal arbitrariness, specifically, with the omnipotence of the absolutist state. The recently deceased nestor of Italian jurisprudence called this a reversal, a rights-orientation surpassing the ethos of obligations by the advent of the age of individualism. ${ }^{49}$ Its background was clearly formulated by the American revolutionary THOMAS PAINE in 1776: 'In absolute governments the King is law, so in free countries the law ought to be King'. ${ }^{50}$ The notions maturing the root ideas of the rule of law can also be traced to classical Greek and Roman antiquity, and to early modern movements. However, it may be sufficient to recall the turn of the 18th and 19th centuries when the enlightened Prussian ruler had already included in the draft Allgemeines Landrecht that 'The laws and ordinances of the state may not restrict the natural freedom and rights of citizens more than the common end purpose requires'. To clarify further, the contemporary textbook added: 'All rights of the regent are to be regarded only as a means by which the state purpose is to be brought about'. . $^{\text {st }}$

The English version was moulded by DICEY, the father of British constitutionalism, who summarised his book-wide explanation in a few sentences. Accordingly,

'The rule of law [...] remains a distinctive characteristic of the English constitution. In England no man can be made to suffer punishment or to pay damages for any conduct not definitely forbidden by law; every man's legal rights or liabilities are almost invariably determined by the ordinary Courts of the realm, and each man's individual rights are far less the result of our constitution than the basis on which that constitution is founded'..$^{2}$

Its requirements, summed up in three theses, are the generalised principle of nulla poena sine lege, the right to bring any action before an independent court, and the recognition of the

49 Bobbio, Norberto (1990) L'età dei diritti. Torino: Einaudi xxiv+252 pp. [(1996) The Age of Rights. Trans. Allan Cameron. Cambridge: Polity Press xix+168 pp.] at pp. ix and 58.

50 Paine, Thomas (1776) Common Sense. <https://www.mtholyoke.edu/acad/intrel/paine.htm> \& <https:// sourcebooks.fordham.edu/mod/paine-common.asp>.

51 Entwurf eines Allgemeinen Gesetzbuchs für die Preußischen Staaten von 1791, Einleitung $\$ 79$ as well as Gönner, Nikolaus Thaddäus (1804) Teutsches Staatsrecht. Landshut: Krüll xx+844 pp. at p. 418.

52 Dicey, A. V. (1915) Introduction to the Study of the Law of the Constitution. [1885.] 8th edn. London: Macmillan [reprinted in ( 1982) Indiana: Liberty Fund cxlviii+435 pp. \& <https://files.libertyfund.org/files/1714/0125_ Bk.pdf>] at p. lv. 
quasi-natural law grounds ${ }^{53}$ of rights. Behind this, he saw on one hand, that an unwritten constitution with the affirmative seal of centuries is more difficult to move than any written charter, and on the other, the power of public opinion. The doctrine of the separation of the branches of state power, however, is known for him only in the case-law autonomy of the judiciary, ${ }^{54}$ but hardly applies to the relation between the legislature and executive. ${ }^{55}$ In addition, he entrusts the functions of constitutional control to the skill of the functioning of English parliamentarism for many centuries. ${ }^{56}$ Similarly, he records reliance on judicial decisions instead of legislation as an additional safeguard, which because it builds the wisdom of generations atop each other, is in his view the best guarantee of individual freedom and freedom from arbitrariness..$^{57}$

The first mention of the Rechtsstaat dates to the turn of the $18^{\text {th }}$ and $19^{\text {th }}$ centuries ${ }^{58}$ when a government's intention to reform was expressed. ${ }^{59}$ Classical political scientists such as ROBERT VON MOHL and FRIEDRICH JULIUS STAHL were already explicitly seeking to replace the administrative state (Polizeistaat) with enlightened changes. ${ }^{6}$ Contrary to the 'rule of law' as worded in English, the Germans could rely on the Staat, because unlike the English

53 Although topically expanded, this is discussed by Opałek, Kazimierz (1999) 'The Rule of Law and Natural Law' in Opałek, Kazimierz Selected Papers in Legal Philosophy. Ed. Woleński, Jan Dordrecht \& Boston: Kluwer Academic Publishing viii+344 pp. [Law and Philosophy Library 39] on pp. 91-98 \& <https://link.springer.com/chap ter/10.1007/978-94-015-9257-4_7> as a system of claims formulated in the name of humanity by natural law.

54 Or, Jennings, W. Ivor (1941) 'The Rule of Law in Total War', Yale Law Journal, 50(3), pp. 365-386 at p. 365 warns that "The English lawyer usually speaks of the "rule of law" where the American lawyer speaks of "due process of law".

55 Wade, William, Forsyth, Christopher (2009) Administrative Law. [1961.] 10th edn. Oxford \& New York: Oxford University Press lxxxix +898 pp. at p. 18 reassert that 'There is only a hazy borderline between legislation and administration, and the assumption that they are two fundamentally different forms of power is misleading'. See also Phillips, Owen Hood, Jackson, Paul, Leopold, Patricia (eds.) (2001) Constitutional and Administrative Law. London: Sweet \& Maxwell cxxvi+855 pp. at p. 26.

56 Zolo, Danilo (2007) 'The Rule of Law: A Critical Reappraisal' in Costa, Pietro, Zolo, Danilo (eds.) The Rule of Law: History, Theory and Criticism. Dordrecht: Springer xiv +695 pp. [Law and Philosophy Library 80] on pp. 3-71 at p. 9.

57 Hayek, Friedrich A. von (1982) Law, Legislation and Liberty: A New Statement of the Liberal Principles of Justice and Political Economy. [I-III in one vol.] London: Routledge \& Kegal Paul at pp. 55-56 \& 85-88.

58 Placidus [Petersen], Johan Wilhelm (1798) Litteratur der Staatslehre: Ein Versuch. Strasbourg: [no printer] xiv+164 pp. \& <https://babel.hathitrust.org/cgi/pt?id=mdp.39015070881084\&view=1up\&seq=186>; later and in a reactionary sense, Müller, Adam H. (1809) Die Elemente der Staatskunst: Oeffentliche Vorlesungen... Vol. IIII. Berlin: J. D. Sander, and in a liberal one Welcker, Carl Theodor (1813) Die letzten Gründe von Recht, Staat und Strafe philosophisch und nach den Gesetzen der merkwürdigsten Völker rechtshistorisch entwickelt. Gießen: Heyer 590 pp.; Christoph, Johann, Freiherr von Aretin (1824) Staatsrecht der konstitutionellen Monarchie: Ein Handbuch für Geschaftsmänner, studirende Jünglinge, und gebildete Bürger. Vol. I. Alternburg: Literatur-Comptoir ends this early series of using the term.

59 Bockenförde, E[rnst]-W[olfgang] (1969) 'Entstehungswandel des Rechtsstaatsbegriffs' in Festschrift für Adolf Arndt zum 65. Geburtstag. Frankfurt am Main: Europäische Verlagsanstalt pp. 53-76 at pp. 53-54.

60 von Mohl, Robert (1832) Die Polizeiwissenschaft nach den Grundsätzen des Rechtsstaates. Vol. I. Tübingen: Heinrich Laupp \& <https://babel.hathitrust.org/cgi/pt?id=uc1.b3132508\&view=1up\&seq=4> at p. 8 and Stahl, Friedrich Julius (1878) Rechts- und Staatslehre auf der Grundlage christlicher Weltanschauung. Heidelberg: Mohr 405 pp. \{reprinted (1963) Hildesheim: Olms [Philosophie des Rechts II]\} at p. 137. 
tradition, the state was a legal concept for them ${ }^{61}$ to the extent that the master of the Pure Theory of Law could simply refer to the Rechtsstaat as a pleonasm, as the Staat was already involved in the notional sphere of Recht. ${ }^{62}$ In today's German public law, however, the Rechtsstaat is no longer an independent but a substitute notion. The Basic Law uses it only in relation to the territories [Länder] that make up the Federal Republic of Germany, and even then does not afford it more of or a different meaning than the itemised requirements of the Basic Law. As the latter states, 'The constitutional order in the Länder must conform to the principles of the republican, democratic, and social state governed by the rule of law, within the meaning of this Basic Law'. ${ }^{63}$ This is tantamount to having no surplus over the law and order defined by the constitution. Consequently, as a surrogate, it is also a pleonasm in constitutional law-whether or not it is suitably used in other contexts and as a synonym in German jurisprudence and doctrine. However, it certainly has one proper message. That is, providing that Rechtsstaatlichkeit is expressive of already posited constitutional contents whose quality is part of constitutionalism itself, any idea or demand for its further substantive enrichment is already out of the professional profile of jurists. It cannot but be a direct political intention to amend the constitution. ${ }^{64}$

Compared to the previous ones, the French solution appeared late, as a translation from German, well after the First World War, although the institutional framework for its effective control was found half a century ago. The first wording of what is meant by État de droit- the State is subordinated to a rule of law which is superior to itself that it does not create and that it cannot violate ${ }^{65}$ - expresses Rousseau's live effect on la culte de la loi, ${ }^{66}$ and stemming from that, the tradition of le droit and most important, of la constitution and the repulsion of the gouvernement des juges from pre-revolutionary times. ${ }^{67}$ Interest was lacking

61 MacCormick, Neil (1984) 'Der Rechtsstaat und die rule of law', Juristenzeitung, 39(January20)(2), pp. 65-70 at p. 65.

62 Kelsen, Hans (1992) Reine Rechtslehre. [1960.] 2. Aufl. Wien: Österreichische Staatsdruckerei 534 pp. at p. 314 , reasserted by Troper, Michel (1993) 'Le Concept d'État de droit' Droits, (No.15), pp. 51-63 at pp. 51-63, upon which the Belgian legal historian Caenegem, R. C. van (1991) Legal History: A European Perspective. London - Rio Grande, Ohio: Hambledon Press xi+242 pp. at p. 185 can only dryly remark that here, 'the problems [...] start with the very word'.

63 Grundgesetz (1949), Article 28 (1).

64 Koetter, Matthias (2013) 'Rechtsstaat und Rechtsstaatlichkeit in Germany' <https://wikis.fu-berlin.de/ display/SBprojectrol/Germany>.

65 Duguit, Léon (1923) Traité de droit constitutionnel. [1911.] 2 éd. Vol. III. Paris: E. de Boccard \& <https://gallica. bnf.fr/ark:/12148/bpt6k932649r/f561.item.r=Duguit\%2oléon\%2odroit\%20constitutionnel\%203>, ch. VI, \$ 88: 'L'État de droit«, p. 547; somewhat differently, cf. also Carré de Malberg, Raymond (1920-1922) Contribution à la théorie générale de l'État, spécialement d'après les données fournies par le droit. Vol. II. Paris: Recueil Sirey.

66 Burdeau, Georges (1939) 'Essai sur l'évolution de la notion de la loi en droit français', Archives de Philosophie du Droit et de Sociologie Juridique, 8, pp. 7-55 at p. 9.

67 Zolo, 'The Rule of Law...', 2007, p. 14. 
for a long time because it had little or no distinct content.$^{68}$ However, Rousseau's tradition soon triumphed: In a democracy, law can be nothing more than an expression of la volonté générale, which has to take statutory form. ${ }^{69}$ The basis, source, and root of this expression is the current constitution. This is complemented and confirmed, sanctioned and checked by the establishment of the Constitutional Council (1971) and by the indisputability of its official wording, declaring, "The law as voted expresses the general will in so far as and to the extent it respects the Constitution'.70

What is expressed by these three legal traditions? First, we see the paradox that although due to random word usage, all three are historically marked by words that do not express what they say. Moreover, all three contradict the internal logic of language, since 'rule' stands here for either 'regula' or 'authority'.71 'Rule of law' is not the sum of 'rule' and 'law', just as the Rechtsstaat is not summed up from Recht and Staat. ${ }^{72}$ Regarding the third variation, an official clarification of the concept by the Council of Europe defines the content of État de droit not by either of the former terms, but as the primacy of the law [la prééminence du droit], noting that this concept is rarely used in the law itself. At most, it occasionally appears in professional literature only..$^{73}$

Overall, the different roots of background thinking are clearly visible in the world map of laws. In the English development, Parliament, the king, and the judiciary had separate, sometimes conflicting, places. Although Parliament drafted the law, the precedent used in court practice is considered law. Therefore, the desire for the rule of law has meant not simply submission to the law, but extended justiciability, that is, the availability of courts to judge any conflict. In the German development, legislation has always defined the law, so progress has been made by subordinating the ruling power and thus the state to it. Finally, the French version, though a mirror translation from German, focuses not on the state, but as the culmination of Rousseau's volonté générale expressed in legislated form, in the imperativeness

68 Dyevre, Arthur (2010) 'The Rule of Law in France' <https://wikis.fu-berlin.de/display/SBprojectrol/France>.

69 Rousseau, Jean-Jacques (1762) The Social Contract. [Du contrat social.] <https://www.marxists.org/reference/ subject/economics/rousseau/social-contract/cho2.htm>, vol. II, ch. 6, para. 6 .

70 Décision no 85-197 DC du 23 août 1985 in <https://www.conseil-constitutionnel.fr/decision/1985/85197DC. htm>, para. 27.

71 According to <https://www.etymonline.com/word/rule>, both meanings are known from the beginning of the 13 th century.

72 Flores, Imer (2013) 'Law, Liberty and the Rule of Law (in a Constitutional Democracy)' in Flores, Imre B., Himma, Kenneth Einar (eds.) Law, Liberty, and the Rule of Law. Dordrecht - New York: Springer $x+190$ pp. [Ius gentium: Comparative Perspectives on Law and Justice 18] on pp. 77-101 [reprint as Georgetown Public Law and Legal Theory Research Paper No. 12-161 <https://scholarship.law.georgetown.edu/cgi/viewcontent.cgi?ar ticle $=2125 \&$ context $=$ facpub $>\}$.

73 Jurgens, Erik (2007) The Principle of the Rule of Law. Committee on Legal Affairs and Human Rights Doc. 11343 Report. [Council of Europe] Parliamentary Assembly (6 July) in https://assembly.coe.int/nw/xml/XRef/X2HXref-ViewHTML.asp?FileID=11593\&lang=EN>, B-5 resp. Appendix I, I-b. 
that any operation of the state is constitutional. However, the variety of approaches seems to converge in the need for the chance of ending conflicts by judgement from an independent body. On the Anglo-American side, this is justiciability for both power representatives and individuals, and on the German-French side, this is guaranteed by a separate body entitled to review the constitutionality of the acts by which the state is operated.

At a basic level, therefore, although considered that in its origin, the underlying ideal may have been conceived by the English in the judiciary, while the French and German may have been inspired by their written constitution, ${ }^{74}$ there is some commonality. Specifically, for a good century in England, DICEY voiced the basic expression of both pertinent claims.

One is the availability of state rules that are formally capable of operating and enforcing law and order, as well as the law's normative force binding both the state and its population, that is, the primacy of law ensuring both address subordination. Nobel Prize-winner economist VON HAYEK gave a classic summary of this at the end of the Second World War:

'Stripped of all technicalities, this means that government in all its actions is bound by rules fixed and announced before-hand, rules which make it possible to foresee with fair certainty how the authority will use its coercive powers in given circumstances and to plan one's individual affairs on the basis of this knowledge'.75

The past Chief Justice of England used a similar tone:

'The core of the existing principle is [...] that all persons and authorities within the state, whether public or private, should be bound by and entitled to the benefit of laws publicly and prospectively promulgated and publicly administered in the courts' ${ }^{76}$

The other is justiciability, that is, the availability of an independent decision-making forum for practically all possible cases and conflicts. In Germany, there is clear reference to judicial review, since the current content of the Rechtsstaat is provided for by the Constitution and its protection ensured by the Verfassungsgerichtshof in reviewing the constitution. In France, the discursive path led straight from the contrat social to la volonté générale, to its

74 Wennerström, Erik O. (2007) The Rule of Law and the European Union. Uppsala: Iustus Förlag 354 pp. [Skrifter från Juridiska fakulteten i Uppsala 105] on pp. 60-61.

75 Hayek, F. A. (1994) The Road to Serfdom. [1944.] Chicago: University of Chicago Press xlvi+274 pp. at p. 80.

76 Bingham, Tom (2007) 'The Rule of Law', The Cambridge Law Journal, 66(1), pp. 67-85 at p. 69. 
embodiment in la constitution, and consequently, from the need for constitutionnalité to effectively controlling it by the Conseil constitutionnel. ${ }^{77}$

Assuredly, "The first necessary and inescapable desideratum of the rule of law is an independent judiciary' ${ }^{78}$ Currently, this is accepted and widespread not only in the United States, but also in Western Europe and elsewhere. Thus, the real issue is no longer the fact of it, ${ }^{79}$ but of how to find and determine the extent of adequate control. This is merely (we would say: again) the need for balance, namely that justiciability - which is used to gain increasing ground at the expense of various democratic representative institutions, that is, of further restrictions on popular sovereignty-shall not degenerate into juristocracy or judgeocracy, or perhaps the finality of the constitutionalisation of rights and judicialisation of politics. ${ }^{80}$

The dilemma in scientia iuris has been over for more than half a century, whether or not there are more layers added to the notion of rule of law beyond one, the availability of duly posited law, and two, the state's subordination to it, and in addition to three, justiciability. Only if the question arises at all-sharing the view that 'the rule of law is a multifaceted and layered concept' ${ }^{81}$ - the distinction between their strata is usually made between formal and substantive, or in the English language culture, thick and thin.

It is easy now to recall my visits to Oxford, when in the first half of the 1990s I was able to talk to perhaps the most influential leaders of both directions in physical proximity to one another, namely JOSEPH RAZ, who narrowed the concept to formalism, and RoNALD Dworkin, who needed it to be saturated with extra content. The former correctly argued that this concept is not about what is good (e.g. the public good, with the political and legal conditions thereof, including their desirable order and institutionalisation), since then it would be redundant. Moreover, such a demand would presuppose 'propounding a complete

77 Interestingly, we arrive at the same result if we approach it from a negative side, starting from the reason why the ideology of the rule of law leaves Asia insensitive. Hager, Berry M. (2000) 'Defining it and Defending it in an Asian Context' in The Mansfield Center for Pacific Affairs (ed.) The Rule of Law: Perspectives from the Pacific Rim. Findlay, Ohio: The Mansfield Center for Pacific Affairs $x+156$ pp. \& <https://biblioteca.cejamericas.org/ bitstream/handle/2015/993/mcpa-rule-law-pacific.pdf?sequence $=1$ \&isAllowed $=y>$ on $p$. $1-11$ at p. 2 answers that it would be a foreign imposition upon them, being 'a reflection of the American bent for legalism and litigiousness'.

78 Sellers, Mortimer (2016) 'What is the Rule of Law and Why is it so Important?' in Goudappel, Flora A. N. J., Hirsch Ballin, Ernst M. H. (eds.) Democracy and Rule of Law in the European Union: Essays in Honor of Jaap W. de Zwaan. Berlin \& Heidelberg: Springer / Asser Press pp. 3-14 at p. 10.

79 Or, as the Prime Minister of Slovenia explained in an open letter to the President of the European Council on 17 November 2020—<https://www.gov.si/assets/PV/November-2020/Letter-of-PM-Janez-Jansa-to-thePEUCO-Charles-Michel.pdf $>$ - By definition, "the rule of law" means that disputes are decided by an independent court and not by a political majority in any other institution'.

80 Cf. 'Ideal or Idol? Traps in Understanding the Rule of Law' in the present volume.

81 Lautenbach, The Concept of the Rule of Law..., 2013, p. 211. 
social philosophy'. ${ }^{82}$ This view is fairly general, ${ }^{83}$ including the British Supreme Justice's professional creed at the turn of the millennium:

'Law should be accessible, clear and predictable; Questions of legal right and liability should be decided by application of the law; The law of the land should apply equally to all, except when objective difference requires differentiation; Public officials should exercise their powers in good faith, and not exceed their powers; The law must protect fundamental rights; A method should be provided, at reasonable cost, to resolve civil disputes; Adjudicative procedures must be provided by the state should be fair; The rule of law requires the state to comply with its obligations in international law'. ${ }^{84}$

Notwithstanding, current liberalism still proclaims itself as the mainstream. As it advertises, the rule of law is not a 'rule-book', but a 'right-book', ${ }^{85}$ which it attempts to fill with content taken from the fields of either human rights or judicialisation. ${ }^{86}$

Thus, the intentions of 'improvement' may emerge, and various previously proposed resolutions, no matter how exaggerated, uninterruptedly exceed one another in an unceasing priority competition. This must lead to the free mixing of any desire with anything else, and ultimately, albeit with the intention of saying everything, proceed to the stage of saying

82 Raz, Joseph (1979) 'The Rule of Law and its Virtue' [originally The Law Quarterly Review, 93 (1977)(2), pp. 198-202] in Raz, Joseph The Authority of Law: Essays on Law and Morality. Oxford: Clarendon Press ix+292 pp. at p. 211.

83 See, as a classic in developing the internal technological minimal needs of law, Fuller, Lon L. (1964) The Morality of Law. New Haven: Yale University Press viii+202 pp. [Storrs Lectures on Jurisprudence 1963]; and in outlining another ideal, Bobbio, Norberto (1971) 'Le bon législateur', Logique et Analyse, 14(No.53/54) \& in Hubien, Hubert (ed.) (1971) Le raisonnment juridique / Legal reasoning / Die jurisdiche argumentation. Bruxelles: Établissements Emile Bruylant pp. 243-249; or MacCormick, 'Der Rechtsstaat...', 1984; Summers, Robert (1988) 'The Ideal Socio-Legal Order: Its »Rule of Law« Dimension', Ratio Juris, 1(2), pp. 154-161 and Summers, Robert (1993) 'A Formal Theory of Rule of Law', Ratio Juris, 6(2), pp. 127-142; and last, the original classic in reducing rule of law to 'rule of rules', Scalia, Antonin (1989) 'The Rule of Law as a Law of Rules', [Oliver Wendell Holmes Lecture at Harvard University (February 14, 1989)], University of Chicago Law Review, 56(4), pp. 1175-1188 \& <https:// chicagounbound.uchicago.edu/cgi $/$ viewcontent.cgi?article $=4632 \&$ context $=u c l r e v>$. Cf. Atienza, Manuel (1989) 'Contribución a la teoría de la legislación', Doxa, (No.6), pp. 385-403 \& <https://rua.ua.es/dspace/ bitstream/10045/10854/1/Doxa6_21.pdf> and Atienza, Manuel (1997) Contribucion a una teoria de la legislación. Madrid: Civitas 109 pp.; Borneman, Settling Accounts, 2007, pp. 40-41; Heydon, J. D. (2011) 'What do we Mean by the Rule of Law?' in Ekins, Richard (ed.) Modern Challenges to the Rule of Law. Wellington: LexisNexis NY xxvi+314 pp. on pp. 19-22; and Ekins, Richard (2011) 'Rights, Interpretation and the Rule of Law' in Ekins, Richard (ed.) Modern Challenges to the Rule of Law. Wellington: LexisNexis NY xxvi+314 pp. on pp. 165-166.

84 Bingham, 'The Rule of Law', 2007.

85 Dworkin, Ronald (1978) 'Political Judges and the Rule of Law', Proceedings of the British Academy, 64, pp. 259-287 $\&<$ http://publications.thebritishacademy.ac.uk/pubs/proc/files/64p259.pdf>, reasserted by Craig, Paul P. (1997) 'Formal and Substantive Conceptions of the Rule of Law: An Analytical Framework', Public Law, pp. $467-487$ at p. 479.

86 Jurgens, The Principle of the Rule of Law, 2007, Appendix I, I-c-3. 
nothing. ${ }^{87}$ 'Sacrificing too many social goals on the altar of the rule of law-asserts Oxford's authority - may make the law barren and empty' ${ }^{88}$ The other limiting position? 'Elided with justice, rule of law becomes an empty vessel into which each person pours his or her hopes for a better tomorrow'. ${ }^{89}$ However, as is usually the case, as soon as a flood ${ }^{90}$ or the free dreaming of the arrival of a new golden age is indeed to begin, ${ }^{91}$ the temptation of the gluttonous sphere always reappears: kneading itself until it bursts. This is because 'the "catalogue of rights" is constantly open to inflation by means of anomic accumulation through successive "generations" of rights or normative interpolations arising out of mere factual circumstances'.92

In addition, even the infinite path to the inclusion of a full social policy is in advance paved by accidental considerations, because as soon as any part of the rule of law project encounters sympathy, the surplus act of providing both an easy environment for it and the conditions for the community to live it becomes the express duty of the state to produce them in due time. This is because only the words are abstract-warns an author. However, the rights we propose to substantiate the words are no longer abstract entities: they are from this moment life pieces. Therefore,

'Any theory that understands rights outside the context of the community that gives them life will be blind to the meaning that those rights have and to implementing them in ways that can be effectively integrated into the everyday lives of people..93

Consequently, any effort to make it a reality must now include 'not only to safeguard and advance the civil and political rights of the individual in a free society, but also to establish

87 E.g. Sellers, 'What is the Rule of Law', 2016.

88 Raz, 'The Rule of Law...', 1979, p. 229. Or, as quasi officially reasserted by Craig, Paul P. (2007) 'The Rule of Law' $=\left[\right.$ Appendix 5] in [House of Lords Select Committee on the Constitution, $6^{\text {th }}$ Report of Session 2006-07] Relations between the Executive, the Judiciary and Parliament: Report with Evidence. London: The Stationary Office 128+104 pp. [House of Lords Paper 151] on pp. 97-106 at p. 100, 'if the rule of law is taken to encompass the necessity for "good laws" [...] then the concept ceases to have an independent function'.

89 Peerenboom 'Varieties of Rule of Law...', 2004, pp. 1 and 13.

90 According to Carothers, Thomas (2006) 'The Rule of Law Revival' in Carothers, Thomas (ed.) Promoting the Rule of Law Abroad: In Search of Knowledge. Washington, D.C.: Carnegie Endowment for International Peace $x v+363$ pp. at p. 4 , the rule of law should 'enshrine and up-hold the political and civil liberties that have gained status as universal human rights over the last half-century'.

91 E.g. Selznick, Philip (1999) 'Legal Cultures and the Rule of Law' in Krygier, Martin, Czarnota, Adam (eds.) The Rule of Law after Communism: Problems and Prospects in East-Central Europe. Aldershot \& Brookfield: Ashgate viii+344 pp. on pp. 21-38 and Bedner, 'An Elementary Approach...', 2010, pp. 71-72.

92 Zolo, 'The Rule of Law...', 2007, pp. 38.

93 Stewart, Cameron (2004) 'The Rule of Law and the Tinkerbell Effect: Theoretical Considerations, Criticisms and Justifications for the Rule of Law', Macquarie Law Journal, 4, pp. 135-164 \& <http://www5.austlii.edu.au/ au/journals/MqLJ/2004/7.html> at p. 7 . 
social, economic, educational, and cultural conditions under which his legitimate aspirations and dignity may be realised. ${ }^{94}$

The idea of the rule of law naturally appears in international law as well, in its globalising development in the company of human rights as a quasi-religious supplement. The terrain is twofold. In today's cult, the issue of the need for and attempt at implementation of any kind of 'rule of law' appears in the workings of international organisations and international jurisprudence, while rule of law demands for the domestic law of states are most often also mediated by international organisations.

The applicability of the rule of law to the domain of international law, and to its actors and acts, may be an interesting topic, since such an extension is in principle fully justified. Moreover, the search for the common root idea of the rule of law in justiciability also seems structurally conceivable in the international arena..$^{95}$ However, as sovereign states are the subject carriers of international law, it is difficult in general to imagine an appellate or arbitral forum capable of judging the stand of the rule of law concerned and of the global powers in particular, because the judiciary is part of what any rule of law control must address. However, if this is the case-because logically, anything else would not be conceivable-we must also rethink our answers to the English, German, and French versions. In principle, this objection applies to all domestic regimes.

It is clear from the English development that there may have been a creative antagonism between possible royal tyranny and a court that has always been considered independent, a division that may have had another bipolar version in Germany with the duality of the legislature and the executive powers. In both Germany and France, it may have taken decades (even after the need for Rechtsstaatlichkeit or État de droit was highlighted) to find the path to the special judicial control of constitutionality. According to this tenet, the applicability of the rule of law to a domestic state may long have been incomplete and partial from the outset, since it was only after a long time that a formula could be found for one branch or function of the state to be played off against another.

In the expansion of the concept, it is not singular states but international organisations and intellectuals as individual authors that excel. In the international arena, for example, the Secretary-General of the United Nations launched a campaign in honour of the rule of law at the turn of the millennium, with a definition attached to it. In his statement, venerable but

94 Declaration of Delhi (1959) <https://www.icj.org/wp-content/uploads/1959/o1/Rule-of-law-in-a-free-societyconference-report-1959-eng.pdf>. Subsequent interpretation-Lautenbach, The Concept of the Rule of Law..., 2013, p. 23-links the expectation of genuine implementation to an earlier commitment to involved values.

95 Lamm, Vanda (2010) 'Some Thoughts on the Rule of Law in International Law', Yасопис Київського університету права [Kyiv], (2), pp. 297-303 shows strong affirmation regarding the implementation of decisions already made, but strong reservation in respect of the role of states in the decision-making process. 
devoid of legal force, he crammed into his notion everything he could bring from the various aspects of law and the state. The rule of law-he orated ${ }^{96}$

'refers to a principle of governance in which all persons, institutions and entities, public and private, including the State itself, are accountable to laws that are publicly promulgated, equally enforced and independently adjudicated, and which are consistent with international human rights norms and standards. Measures to ensure adherence to the principles of supremacy of law, equality before the law, accountability to the law, fairness in the application of the law, separation of powers, participation in decision-making, legal certainty, avoidance of arbitrariness, and procedural and legal transparency.97

In contrast, the contemporary definitions issued by the World Bank ${ }^{98}$ and Organization for Economic Co-operation and Development ${ }^{99}$ are formal, reminiscent of Fuller's quasi legaltechnological requirements of a rule's efficiency ${ }^{100}$ formulated nearly four decades earlier.

96 Annan, Kofi (2004) The Rule of Law and Transitional Justice in Conflict and Post-conflict Societies. Report of the Secretary-General, Doc. S/2004/616, 23 August, para. 6.

97 It is noteworthy that by smuggling 'international human rights norms and standards' into the proposed requirements, the Secretary-General is also to sanction hardly standardisable indefiniteness. Note that the UN Member States' individual interests differ from each other, but some may unite in occasional groups for either regional or historical reasons. This may be exemplified by the division between emitting and hosting countries in recent migration trends, singling out those left out from becoming target countries.

98 [The World Bank Legal Vice Presidency] (2004) Initiatives in Legal and Judicial Reform. Washington, D.C.: The World Bank iii+101 pp. \& <http://documents1.worldbank.org/curated/en/139831468778813637/ pdf/250820040Edition.pdf> at pp. 2-3:

'The rule of law prevails where (1) the government itself is bound by the law; (2) every person in society is treated equally under the law; (3) the human dignity of each individual is recognized and protected by law; and (4) justice is accessible to all. The rule of law requires transparent legislation, fair laws, predictable enforcement, and accountable governments to maintain order, promote private sector growth, fight poverty, and have legitimacy'.

99 Equal Access to Justice and the Rule of Law OECD Development Assistance Committee (DAC) Mainstreaming Conflict Prevention (2005), quoted by European Commission, 2011, para. 27, p. 7:

'[T] he rule of law is composed of the following separate fundamental elements, which must advance together: (1) The existence of basic rules and values that a people share and by which they agree to be bound (constitutionalism). This can apply as much to an unwritten as to a written constitution. (2) The law must govern the government. (3) An independent and impartial judiciary interprets the law. (4) Those who administer the law act consistently, without unfair discrimination. (5) The law is transparent and accessible to all, especially the vulnerable in most need of its protection. (6) Application of the law is efficient and timely. (7) The law protects rights, especially human rights. (8) The law can be changed by an established process that is itself transparent, accountable and democratic'.

100 Fuller, The Morality of Law, 1964. For the interpretation of its requirements-which are regardless of any morality, purely efficiency-oriented (i.e. instrumental and as such, purely technological) preconditions see Varga, Csaba (1970) [review of Fuller, The Morality of Law, 1963], Acta Juridica Academiae Scientiarum Hungaricae, XII(3-4) \& <http://real-j.mtak.hu/787/1/ACTAJURIDICA_12.pdf>, pp. 449-450; cf. also Lyons, David (1984) Ethics and the Rule of Law. Cambridge: Cambridge University Press $\mathrm{x}+229$ pp. at p. 77. 
Last, not even the Venice Commission of the European Union, dedicated to 'democracy through law' clarifies the enigma of the rule of law beyond the former either in the general outline or when detailing the fundamentals. ${ }^{101}$

Regarding the European Union's perception of the rule of law, ${ }^{102}$ initially, the EU position seems reassuring, both by its clauses in the Treaty and its judicial decision-making practice. Its court exhaustively determined the basis of the EU mandatory rules and availabilities of judicial review, as a Luxembourg decision ascertained three and a half decades ago that

'the European Economic Community is a Community based on the rule of law, inasmuch as neither its member states nor its institutions can avoid a review of the question whether the measures adopted by them are in conformity with the basic constitutional charter, the treaty. In particular [...], the treaty established a complete system of legal remedies and procedures designed to permit the Court of Justice to review the legality of measures adopted by the institutions' ${ }^{103}$

The same reassuring effect may have been somewhat reinforced by the bipolarity of the construction and operation of European law, analogous to the solar and planetary systems, the true state of which at any time cannot be but the result of their mutual play. ${ }^{104}$ Moreover, the analysis of the EU case law has led to a reassuring conclusion according to which in the possible simultaneous co-effect of centrifugality and centripetality, the bilateral cooperation of the EU centre(s) with any given member state is preferable to positional confrontation in the long run, prospecting 'most success if it is built upon existing national rule of law traditions.'.05

101 European Commission, 2011, para. 37, then para. 41, 60, and also 15-16:

'(1) Accessibility of the law (that it be intelligible, clear and predictable); (2) Questions of legal right should be normally decided by law and not discretion; (3) Equality before the law; (4) Power must be exercised lawfully, fairly and reasonably; (5) Human rights must be protected; (6) Means must be provided to resolve disputes without undue cost or delay; (7) Trials must be fair, and (8) Compliance by the state with its obligations in international law as well as in national law'.

102 For an overview, see Pech, Laurent (2009) The Rule of Law as a Constitutional Principle of the European Union. New York: New York University School of Law 79 pp. [Jean Monnet Working Paper 03/09] \& <https:// jeanmonnetprogram.org/paper/the-rule-of-law-as-a-constitutional-principle-of-the-european-union/>.

103 E.C.J., April 23, 1986, Les Verts v. Parliament, 294/83, Rec. 1339, \$23.

104 Varga, Csaba (2011) 'The Philosophy of the Construction and Operation of European Law', Rivista internazionale di Filosofia del Diritto [Roma], LXXXVIII(3), pp. 313-344 \{reprinted in <http://mek.oszk.hu/15400/15409>, pp. 307-354\}.

105 Lautenbach, 2013, p. 217. Note that it is questionable who, and on whose behalf, can judge or override the sovereign in matters of domestic law and rule of law in matters belonging to the preservation of constitutional identity. In a criticism of the latter, Rosenfeld in Rosenfeld, Michel, Sajó, András (eds.) (2012) The Oxford Handbook of Comparative Constitutional Law. Oxford: Oxford University Press xix+1396 pp. [Oxford Handbooks in Law], Abstract, opines that "Constitutional identity" is an essentially contested concept as 
Finally, the fact that some states in Central and Eastern Europe define themselves as rule of law formations in their constitutions, and that their constitutional courts may have ruled by propagating their understanding of the term 'rule of law' in a manner the population resent, ${ }^{106}$ is relevant in the present context only as an illustration that the notion of the rule of law is powerless. The power of the rule of law can only rely on its overall societal support, owing to the society having experienced its blessings-in the manner that DICEY located its final strength in public opinion. Alternatively, formulated reversely,

'if [the ideal of the rule of law] is represented as an impracticable and even undesirable ideal and people cease to strive for its realization, it will rapidly disappear. Such a society will quickly relapse into a state of arbitrary tyranny'. ${ }^{107}$

\section{The Genuine Content}

It is difficult to think of something that we know almost nothing about. It is hard to talk about something we want. The nonsense of such an enterprise becomes absurd when we try to qualify something in this way. Qualification would presuppose that we are holding a standard before us, and by measuring our subject, we will find out whether it meets it. However, if the standard is arbitrary, then our measurement will also be arbitrary-a false measurement, since it hardly expresses more than our like or dislike. No matter how normal

there is no agreement over what it means or refers to'. It is only characterisable by 'an incurable lack of determinacy, which inevitably results in arbitrariness in its use [...]. [Its] practical use [...] is poised to weaken, if not undermine tout court, the process of European integration'. Cf. Fabbrini, Federico, Sajó, András (2019) 'The Dangers of Constitutional Identity', European Law Journal, 25(4), pp. 457-473 and Drinóczi, Tímea (2020) 'Constitutional Identity in Europe: The Identity of the Constitution - A Regional Approach', German Law Journal, 21(2), pp. 105-130 \& <https://www.cambridge.org/core/journals/german-law-journal/article/ constitutional-identity-in-europe-the-identity-of-the-constitution-a-regional-approach/83D8D1737788756F EFo98CF9485D7B1C/core-reader> as well.

106 Cf., Varga, Csaba (1995) Transition to Rule of Law: On the Democratic Transformation in Hungary. (Budapest: 'ELTE Comparative Legal Cultures' Project 190 pp. [Philosophiae Iuris] \&<http://mek.oszk.hu/14700/14760/> and Varga, Csaba (2008) Transition? To Rule of Law? Constitutionalism and Transitional Justice Challenged in Central \&Eastern Europe. Pomáz: Kráter 292 pp. [PoLíSz sorozat könyvei 7] \& <http://mek.oszk.hu/14800/14851>.

107 Hayek, Friedrich A. (1960) The Constitution of Liberty. Chicago: Chicago University Press x+569 pp. at p. 205. As expressed by Reynolds, Noel B. (1989) 'Grounding the Rule of Law', Ratio Juris, 1(1), pp. 1-16 \& < https://www. academia.edu/16851582/Grounding_the_Rule_of_Law $>$ at p. 7, 'If people do not expect the rule of law and insist on it when officials move to compromise its effect, it is soon corrupted and replaced by rule of will. This also includes recognising that the artificial meaning attributed to law cannot far precede what common sense suggests, because-as Pildes, Richard H. (1996) 'The Desctruction of Social Capital through Law', University of Pennsylvania Law Review, 155(5), pp. 2055-2077 at p. 2058 claims-laws will be self-defeating when they undermine social norms whose maintenance turns out to be necessary to make those very laws effective'. 
such a procedure may be, something similar has been going on in the European Union for a long time. In this Union-that is, to those nations grown in undisturbed peace and prospered hopefully in wisdom since World War II - we joined with a sincere heart and sense of legitimate historical return after the fall of the dictatorship imposed upon. As an echo of the former and as a whip, this is also happening in Hungary: a hostile, embarrassing, openly blackmailing quarrel, and an immeasurable yardstick for all loudmouths everywhere-as if there were some hidden knowledge of the subject beyond what the mood of the word may suggest to the user.

When we let exact science speak, what may be its message has definite meaning in any language, because it is based on observation, verified connections, and precise definitions. Would it be different in law? Where anything we say is not a description or intellectual reflection, but prescription and formal expectation, a normative standard binding and secured by state coercion?

However, in this case, the question is now about the subject itself. What is often substituted, partly intertwined with other concepts, and sometimes downright redundant? In today's German public law, as mentioned, the 'rule of law' is nothing more than the guaranteed implementation into practice of the itemised requirements of the Basic Law. This is almost a pun on the term, similar to what is happening with human rights, where outsiders besiege the gates of the law by claiming their alleged 'human rights' (tacitly engaging everyone else in tolerating and perhaps also funding their alleged need). However, as soon as they will have succeeded, it will be indifferent in the law's normative sea why and how admission has taken place. ${ }^{108}$

The content of this object is not something that is, but what it should be, that is, not a simple mirror of something existing or prevailing, but a desire, an ideal. ${ }^{109}$ Alternatively, this kind of perfection its confessors can only strive towards, since reaching it is impossible from the outset, and thus, only approaching it is possible. ${ }^{110}$

Now, back to our basic question: What are we talking about? In short, this is a set of rights and duties with values in the background, which are guaranteed to everyone as a chance visà-vis both the state power and any human fellow. Considering that it contains a variety of requirements, it is impossible to meet them simultaneously and with the same completeness

108 Cf. Varga, Csaba 'The Problematics of Human Rights' in the present volume.

109 E.g. Oakeshott, Michael (1983) 'The Rule of Law' in Oakeshott, Michael On History and Other Essays. Totowa, N.J.: Barnes \& Noble 198 pp. at p. 178. It is 'a legal ideal' for Lautenbach, 2013, pp. 23 \& 210 and 'an aspirational ideal, pointing the way toward a more just world' for Peerenboom, 2004, pp. 1 \& 13.

110 According to Hayek, The Constitution of Liberty, 1960, p. 205, 'many of the applications of the rule of law are also ideals which we can hope to approach very closely but can never fully realize'. 
and depth, as their competing support would lead to the extinction of the other. Thus, in any situation, consideration and balance with compromise are necessary for the relative totality of the requirements of the rule of law to be optimally approached and fulfilled." ${ }^{11}$

Thus, only provided we could use the concept as a benchmark, answering it would not be a simple 'yes' or 'no' even if considering it within a given section of time, culture, or tradition. Actually, it would presuppose a lengthy presentation, and a number of cases analysed with balanced arguments and counter-arguments. ${ }^{112}$ Therefore, we cannot speak of any sharp distinction between simple realisation and non-realisation, or of a more or less successful attempt at approximation in some kind of continuum, ${ }^{113}$ or gradualness among intermediate states of the process. This is because the balance of the practice or the state of any given legal arrangement does not lie in semi-stages between the extreme points of a definite 'yes' or 'no', but in the impossibility of reaching a resolute answer. Therefore, we need to know that in real-world concrete situations it is compromise characterisations and not complete sets of features attributed to this concept ${ }^{114}$ that are to be met. Essentially, what matters is the kind of compromise in the search between different notional directions, contents, and mutually extinguishing messages made, or simply, what is their ethos and value-orientation? This is what cannot be answered in a short way. ${ }^{115}$

Increasingly, the content itself is most often mixed and freely expandable. The main part of the notion of the rule of law is undoubtedly the proper formality and observance of the law, which is often supplemented with substantive content. Thus, it is filled with overarching

111 It is a fundamental tenet of jurisprudence-Varga, Csaba (2002) 'Structures in Legal Systems: Artificiality, Relativity, and Interdependency of Structuring Elements in a Practical (Hermeneutical) Context', Acta Juridica Hungarica, 43(3-4) \& in <http://real-j.mtak.hu/757/1/ACTAJURIDICA_43.pdf>, pp. 219-232-that everything in law is relative and cannot have but a position ascribed to it by the law or its doctrine, or a function assigned to it by the conventions prevailing in the given society. This is why the president of the Supreme Court of Israel could uphold-Barak, Aharon (2015) Human Dignity: The Constitutional Value and the Constitutional Right. Cambridge: Cambridge University Press xxxviii +360 pp. at pp. 6 and 119-that everything in law is 'dependent upon historical, cultural, religious, social and political contexts', condensed in such principles 'in state of constant conflict [...and which...] must be balanced'.

112 In these circumstances, should we consider it an honour that out of a population of 520 million, the European Union entrusted a Dutch person with no learned profession (cf. <https://en.wikipedia.org/wiki/Judith_ Sargentini>) to judge Hungary regarding her rule of law?

113 Gowder, Paul (2016) The Rule of Law in the Real World. New York: Cambridge University Press xii +275 pp. at p. 26 writes that 'The rule of law is a continuum, not a binary: states can satisfy it to a greater or lesser extent'.

114 Also practically nearly to all concepts, except those schematically projected to be found geometry and mathematics, for example.

115 As the German Constitutional Court has decreed, any situation can only be judged by considering all circumstances: 'dieser Verfassungsgrundsatz bedarf vielmehr der Konkretisierung je nach den sachlichen Gegebenheiten, wobei fundamentale Elemente des Rechtsstaates und die Rechtsstaatlichkeit im ganzen gewahrt bleiben müssen'. 1BVL14/76 [Urteil vom 21.06.1977] \& <https://openjur.de/u/60105.html>, para. 193. 
core values blending in with democracy, distribution of power, human rights, and the like. ${ }^{116}$ Therefore, the development of the German tradition, Rechtsstaat and Rechtsstaatlichkeit, came eerily close to the doctrine on the forms of the state [Staatsformenlehre] in continental Europe, almost as a developmental part thereof. ${ }^{117}$ However, the more generalised it is, the more it loses its distinctiveness from others, and thus the meaning of its use.

What does it cover? This is an ideal conception in the civilisational self-ennoblement of man on the terrain of what we project to and expect from our law and its practice. This is thought to be based on the state in Germany, concretised as case law by the judiciary in England, with emphasis on the constitution in France, and developed from their originalprimitive-stands into forms according to what and how countries, peoples, and cultures learn from each other in random encounters. Its name stems from the time it was first described, and understood. Once some nations gain hegemonic position, they are induced to proclaim their own version extended to a universal pattern for mankind.

The idea of the rule of law is not a type of constructed abstraction. It has never been or has become anything other than what has been shaped through value-sensitive responses to challenges posed to the laws and cultures of the countries concerned: this way in England, and that way in the Netherlands and Italy. While it may have been polished through cultural contacts and may have become more common under a common name, it remained only a demand or signpost: a medium for the collection of possibilities and paths of the civilisational

116 The Copenhagen Meeting of the Conference on the Human Dimension of the CSCE (29 June 1990) <https:// www2.ohchr.org/english/law/compilation_democracy/csce.htm>stipulated in para. 3 that 'democracy is an inherent element of the rule of law', with Jurgens, 2007, para. B/5 adding human rights to these two components, thereby producing a 'trinity of three concepts'. This is why Chesterman, Simon (2008) 'An International Rule of Law?', The American Journal of Comparative Law, 56(2), pp. 331-362 at p. 361 explicitly admitted that 'the rule of law sometimes plays as a Trojan horse to import other political goals such as democracy, human rights, and specific economic policies'. Moreover, resembling the colonial era, promoting the rule of law can easily turn into an act of imposing one's own law, involving 'a fairly complete vision of what society is and how it should look', which is also to be borrowed by the target country. Humphfreys, Theatre of the Rule of Law, 2010, xx, exposed by Humphfreys, Simon (2012) 'Laboratories of Statehood: Legal Intervention in Colonial Africa and Today', The Modern Law Review, 75(4), pp. 475-510.

117 E.g. Tiedemann, Paul (2014) 'The Rechtsstaat-Principle in Germany: The Development from the Beginning Until Now' in Silkenat, James R., Hickey, Jr., James E., Barenboim, Peter D. (eds.) The Legal Doctrines of the Rule of Law and the Legal State (Rechtsstaat). Cham: Springer xii+367 pp. [Ius gentium: Comparative perspectives on law and justice 38] on pp. 170-192. It is no coincidence that at a time preceding the overwhelming rule of law boom in the West, socialist literature in Hungary— Sztodolnik, László (1963) 'A jogállam eszméjének színeváltozásai' [The changing face of the idea of the rule of law], A Budapesti Eötvös Loránd Tudományegyetem Állam-és Jogtudományi Karának Actái, IV(1), pp. 143-163; Péteri, Zoltán (1973) 'Új törekvések a jogállam-eszme körül' [New aspirations around the idea of the rule of law], Jogtudományi Közlöny, XXVIII(6), pp. 309-316; Takács, Albert (1986) 'A jogállam társadalmi és jogi feltételei' ['Social and legal conditions of the rule of law], Jogtudományi Közlöny, XLI(11), pp. 521-530; Ficzere, Lajos (1988) 'Szocializmus és jogállamiság' [Socialism and the rule of law], Jogtudományi Közlöny, XLIII(3), pp. 105-111-treated the issue as one of the developmental aspects of the doctrine of the state [Staatslehre]. 
self-ennoblement of the nations that demand it, and not an inventory or a complete catalogue of items. ${ }^{118}$

In addition, the concept has evolved in recent times in the swamp fight that characterises today's political moves. It is used in the legal literature as part of an overabundant vocabulary. Mostly, it is a group marker expressing civilisatory progress. It could not have been used for anything else or more demanding, as it has never become an operational term in law. Perhaps this is an important word? Spanning 2oth-century Germany, it is mentioned three times only among the one thousand most important historical documents, and never with any emphasis. ${ }^{119}$ After the defeat of the Third Reich, the Basic Law of Bonn uses the word, but only to name the constitutional order of Länder and with no independent meaning: only those requirements already arranged in the Basic Law are assigned to it. This is why a constitutional court had to be established as the protector of Rechtsstaatlichkeit, the essence of which is already inherent in what is called constitutionality.

In post-World War II advancement, it played and continued to play a sublime role. The disgraceful blackmail via rule of law mantra serves to expand power. In our brave new peaceful world, owing to the prohibition of war, only occupying economic space and acquiring dominance through the capital market can come to the fore. Therefore, it will be launched worldwide to have a unified, transparent, and secure legal environment for international economic transactions, a common regime that can be mastered by easy routine. The best is to replicate one's own arrangement. Thus far, various acceleration and modernisation programs are spreading worldwide, especially to neglected landscapes. Moreover, even scholarship is helping this dissemination, developing a genuine theoretical trend to prove its interest-driven lies, saying there is a correlation between the rule of law and level of economic development and performance. ${ }^{120}$ That tested in transnational economic relations continues in international politics.

118 For Chesterman, 'An International Rule of Law?', 2008, p. 361, this 'political ideal' should be seen 'as a means rather than an end, as serving a function rather than defining a status'. It is astonishing that this recognition has only been formulated by a single author and as relating to the use of the notion in the international arena.

119 Altrichter, Helmut (ed.) (2020) 100(0) Schlüsseldokumente zur deutschen Geschichte im 20. Jahrhundert. <https:// www.10oodokumente.de/index.html?c=dokumente_de\&l=de\&viewmode $=2>$.

120 The World Bank, Initiatives..., 2004, p. 2 postulates 'the rule of law as a sine qua non of development', followed by among others, Dam, Kenneth W. (2006) The Law-growth Nexus: The Rule of Law and Economic Development. Washington, D.C.: The Brookings Institution xii+323 pp.; Haggard, Stephan, MacIntyre, Andrew, Tiede, Lydia (2008) 'The Rule of Law and Economic Development,' Annual Review of Political Science, 11 \& <https://www. annualreviews.org/doi/abs/10.1146/annurev.polisci.10.081205.100244>, pp. 205-234; and Gowder, The Rule of Law..., 2016, p. 3. Mere coincidence is observed by Matsuo, Hiroshi (2005) 'The Rule of Law and Economic Development: A Cause or a Result?' in Matsuura, Yoshiharu (ed.) The Role of Law in Development: Past, Present and Future. Nagoya: Nagoya University Center for Asian Legal Exchange viii+11o pp. [CALE Books 2] on pp. 59-70 and Haggard, Stephan, Tiede, Lydia B. (2011) 'The Rule of Law and Economic Growth: Where Are We?', World Development, 39(5) \& <https://gsdrc.org/document-library/the-rule-of-law-and-economic-growth-where-are- 
In vain does life refute, as interest is stronger. These two gigantic organisations are currently doing this to feature their most spectacular deficits with respect to democracy and the rule of law. After all, the literature on the United Nations and European Union shows that they refrain from accepting external influences. With their institutional structure and strength set in, they focus on protecting their own game of power from any counter-arguability in law. From the beginning, they rigidify and petrify their own law making by securing it from any provocation to change. Regarding the EU, by 'shield[ing] its law from potential internal and external contestation, [t]his is precisely the opposite of what the classical understanding of the Rule of Law would imply'. ${ }^{121}$

Thus, let us expand theoretically what we have simply named the rule of law so far. Its character, direction, and ontological nature were illuminated three decades ago by an Oxford celebrity invited by the recent graduates of Bibó College, ${ }^{122}$ who paradoxically called

we/>, pp. 673-685. Anything of direct interdependence is refuted by Ozpolat, Asli, Guven, Gulsum Gunbala, Ozsoy, Ferda Nakipoglu, Bahar, Ayse (2016) 'Does Rule of Law Affect Economic Growth Positively?', Research in World Economy, 7(1) \& <http://www.sciedu.ca/journal/index.php/rwe/article/view/9778>, pp. 107-117. As to further positions, Nedzel, Nadia E. (2014) 'Rule of Law v. Legal State: Where Have We Come from, Where Are We Going To?' in Silkenat, James R., Hickey, Jr., James E., Barenboim, Peter D. (eds.) The Legal Doctrines of the Rule of Law and the Legal State (Rechtsstaat). Cham: Springer xii+367 pp. [Ius gentium: Comparative perspectives on law and justice 38] on pp. 289-314 at p. 289 remarks that "Englishness" [...] has traditionally provided greater stability, greater protection for liberty, and incentives for economic development'. According to a particular position, Asia is keen to enter the path to achieving economic development but without adopting its corollary, the rule of law, which is viewed there as an alien construct threatening their identity. Clarke, David (1999) 'The Many Meanings of the Rule of Law' in Jayasuriya, Kanishka (ed.) Law, Capitalism and Power in Asia: The Rule of Law and Legal Institutions. London - New York: Routledge xooo+345 pp. [Asian Capitalisms] on pp. 28-44 \& <https://citeseerx.ist.psu.edu/viewdoc/download?doi=10.1.1.612.9223\&rep=r epi\&type=pdf>, and similarly Hager, 'Defining it...', 2000, pp. 2-5; Oshimura, Takashi (2000) 'In Defense of Asian Colors' in The Mansfield Center for Pacific Affairs (ed.) The Rule of Law: Perspectives from the Pacific Rim. Findlay, Ohio: The Mansfield Center for Pacific Affairs $x+156$ pp. \& <https://biblioteca.cejamericas.org/ bitstream/handle/2015/993/mcpa-rule-law-pacific.pdf?sequence=1\&isAllowed=y> on pp. 141-144 at p. 141; and Hong, Joon-Hyung (2000) 'The Rule of Law and its Acceptance in Asia' in The Mansfield Center for Pacific Affairs (ed.) The Rule of Law: Perspectives from the Pacific Rim. Findlay, Ohio: The Mansfield Center for Pacific Affairs x+156 pp. \& <https://biblioteca.cejamericas.org/bitstream/handle/2015/993/mcpa-rule-law-pacific. pdf? sequence $=1$ \&isallowed $=y>$ on pp. $145-153$ at $\mathrm{p} .149$.

121 Kochenov, Dimitry (2015) 'EU Law without the Rule of Law: Is the Veneration of Autonomy Worth It?', Yearbook of European Law, 34(1), pp. 74-96 \& <https://www.researchgate.net/publication/283866218_EU_Law_ without_the_Rule_of_Law_Is_the_Veneration_of_Autonomy_Worth_It $>\&<h t$ tps://papers.ssrn.com/sol3/ papers.cfm?abstract_id=2642689> at p. 74; Lietzmann, Hans J. (2004) 'Die Europäische Union als »defekte Demokratie«? Rechtsstaat und Pfadabhängigkeit in Europa', Österreichische Zeitschrift für Politikwissenschaft, 33(1), pp. 19-30 \& <https://webapp.uibk.ac.at/ojs/index.php/OEZP/article/view/1136/831>; for an overview, see Hegedős, Soma (2020) 'A jogállamiság fogalmának teoretikai problémái az Európai Unió jogfelfogásának vonatkozásában' [Theoretical problems relating to the notion of the rule of law with regards to the EU understanding of law], Külügyi Múhely, (2), pp. 5-24 \& <https://epa.oszk.hu/03800/03841/00003/pdf/EPA03841_ kulugyi_muhely_2020_02_005-024.pdf> at pp. 19-21.

$122<\mathrm{https} / / /$ bibo.elte.hu/> was the workshop of those students of law in Budapest who founded the political party governing Hungary from 1998 to 2002, and with a two-thirds majority, from 2010 presumably to 2022 , involving the early law-graduate elite. 
his audience to listen to common sense instead of scholarly books on the rule of law. For, he claimed, in their books, every nation of every age articulates idealisms filtered through their own hard-won experiences. Well, while knowing others is undoubtedly a respectable undertaking, every nation must first cope with its own task-the torturous question of how to deal with its own challenges so as not only to succeed in its cause, but also to serve its civilisational self-ennoblement. With our demand for the rule of law, we want a moral rise to be more humane and civilised, through and owing to it. We do not want a mystic mandarin above us who as in the first decade of our constitutional judiciary, may turn a symbolic hammer over our heads, making it impossible for us to meet national strategic priorities by falling victim to important matters of national progress. In short, therefore, as he explained, no claim to the rule of law can serve as a collective suicide pact. ${ }^{123}$ Not only have we become clear in this way, but it is also the Supreme Court of Israel, which as a state that takes its national strategic agenda seriously, does not forget the lessons of this. ${ }^{124}$

Consequently, the experience of a given place and time, its specific particularity, works in any of the variations to the rule of law. Once it is peculiar, it cannot be declared to have become universal, as anyone would try. What may be generalised from this is only the result of learning and interaction. Although we are learning to become somewhat more, the result will only be a newer, more advanced form of particularity.

It follows from this logic that when I fight for the rule of law, I assume an idea or the conventionalised core of something, which I contend is lacking. However, all monographs, textbooks, and kinds of practical guidance begin with the sober statement that nothing like this is available, only a handful of authorial opinions. From references to existing law and from the vast rule of law literature, it may be hoped that a common message will ultimately be unravelled. Think of what kind of magically tricky problem solving this insecurity assumes in a combat situation in the deadly moments of a battle from an operations commander who

123 For detail on FinNis' message-cf. Finnis, John (1980) Natural Law and Natural Rights. Oxford: Clarendon Press xv+425 pp. [Clarendon Law Series] —, see Varga, Csaba (2019) 'Idol, Deduced from an Ideal? Rule of Law, Universalization, Degradation', Філософбія права і загальна теорія права / Philosophy of Law and General Theory of Law [Kharkiv], (2), pp. 192-214 \& <http://phtl.nlu.edu.ua/article/view/204724> atp. 198 and note 28.

124 Barely a decade ago, Judge AsHeR GRUNIs declared-High Court of Israel (11 January 2012); cf., among others, <https://www.jurist.org/commentary/2012/02/jabareen-zaher-israel-citizenship/>-that 'Human rights do not prescribe national suicide'. Mitchell, Michael (2012) 'National Suicide', Harvard International Review, (July 7) <http://hir.harvard.edu/article/?a=2957> writes, "if Israel's commitment to human rights clashed with policies that seemed necessary for the preservation of its current identity, Israel could permissibly abrogate its rights commitments by enacting discriminatory policies'. Exactly the lack of such awareness in Hungary has made me wonder whether we are still a nation that can stand up for herself, or are we already lethargically tired of our difficult twentieth century. Cf. Varga, Csaba (2015) '"Méltón a sorshoz, alkalmas a küzdelemre» Szellemünk és tudományunk állapotáról' [»Dignified to fate, fit to fight« On the state of our spiritual and intellectual standing], Hitel, XXVIII(2), pp. 53-70 \& <http://www.hitelfolyoirat.hu/sites/default/files/pdf/o6varga_o.pdf> at p. 62. 
can only remember the nightmare when law professors used to teach him at the military academy. What is he expected to do? Should he, who lives the profession of military commands with 'yes' or 'no' answers, now chew on lists compiled here and there from a number of legal documents and self-honouring stands taken by authors whose works he had to toil through during his academic studies? Now, facing the dangerous moments of battle noise, he is expected to make a compass out of these himself, one he will be able to justify even when the smooth-faced headquarters of law may examine for years what he was forced to command in situations where each moment varied. This picture is absurd, but realistic. This is exactly what military law is about. ${ }^{125}$ Its latest handbook also provides no template solution. In the field of the rule of law, any briefing can be a benefit 'rather as a starting place and a supplement for other materials and, crucially, individual thought', for 'the difficulty may well be in knowing what to read, rather than in finding something to read'. ${ }^{226}$ One cannot hope any added message from the NATO-accredited international centre of rule of law at The Hague. 'Unfortunately, there is no common definition of the Rule of Law. Many IOs, NGOs, governments, lawyers and judges associations, policy think-tanks, and private foundations are engaged in promoting the Rule of Law and most of them view Rule of Law in different ways'. ${ }^{127}$

Perhaps not as drastically, but this is happening every day in the EU witches' kitchens of Brussels, Luxembourg, and Strasbourg, as well as in Venice. ${ }^{128}$

Generalising the situation, we could also say that everyone has some Jolly Jokers in their hands, and none of them will tell you in advance how much their card is worth. Maybe even they do not know. However, each will receive exactly as much of his card as he will announce when he strikes it.

125 In the field of military law, the quest for rule of law first appeared at the turn of the millennium. This is evident in the fact that the [US Department of the Army Field Manual 100-23] (1994) Peace Operations. (December.) vi+131 pp. \& <http://www.dtic.mil/doctrine/jel/service_pubs/fm100_23.pdf> ignores it, but the [US Department of the Army Field Manual 3-07 (Field Manual 100-20)] (2003) Stability Operations and Support Operations. (February.) [4-106.] <http://www.globalsecurity.org/military/library/policy/army/fm/3-07/fm307.pdf> stresses its importance. For an overview, cf. Lewis, Angeline (2010) 'Defining the Rule of Law for Military Operations', Australian Year Book of International Law, 29, pp. 155-200 \& <http://www.austlii.edu.au/ au/journals/AUYrBkIntLaw/2010/6.pdf>.

126 Bowman, Lt. Col., Helen, Child, Lt. Col., Tim (eds.) (2015) Rule of Law Handbook: A Practicioner's Guide for Judge Advocates 2015. Charlottesville, Virginia: The Judge Advocate General's Legal Center and School, US Army Center for Law and Military Operations vii+218 pp. <https:/www.loc.gov/rr/frd/Military_Law/pdf/rule-oflaw_2015.pdf > at p. vi.

127 (2012) Civil-Military Cooperation Centre of Excellence (The Hague) in <https://www.cimic-coe.org/branches/cic/ cimic-innovation/advanced-cultural-competence-aac/rule-of-law/>.

128 Or, 'In the context of the Convention, the rule of law is a multifaceted and layered concept. Yet, it is possible to distil a core contents of the rule of law from the case law, based on the frequency and consistency of the argumentations that are linked to the rule of law and the results that are obtained when the Court has interpreted the Convention in line with the rule of law'. Lautenbach, 2013, p. 211. 
For nearly a century and a half, it has been a familiar lesson from sociology and other social sciences that overdoing anything can turn into the opposite. As a classic example, the extreme pursuit of rationality can lead to irrationality and over-regulation to collapse ending in anarchy. ${ }^{129}$ It is no coincidence, therefore, that such unbridled over-cultivation of the notion of the rule of law leads to burnout and exhaustion from within. In addition to those who expect world redemption from the cult of the rule of law, an increasing numberparticularly from the United States-swear with bitterness that this once-hopeful concept has become a mere shell, a rhetorical chatter.

Law offers a special example to demonstrate how anything can be called anything, and as long as the legal effect of this designation lasts, this is undoubtedly so in the normative order. Let us remember that Roman law already 'knew' in what order members of a family died in a boat sunk at sea at any unknown place and time (of course, only in terms of inheritance). In classical Jewish law, a woman is sometimes a man, and vice versa, and the dog and cat might become equally substitutable in Islamic law. Of course, the legislator could have the power at any time to really determine-which has never been done anywhere-the criterion by reference to which a state can be called to account in the name of the rule of law. Either there is a definition available of those facts that constitute a case of the rule of law or not, but in the latter alternative, we remain at the amorphousness of a Mädchen für alles. On the other hand, once defined, it would be a subject, that is, a posited position in law. For its writing into the law would eo ipso transubstantiate it-in the manner we exemplified by human rights, transforming in nature when acknowledged by the law.

In conclusion, it would be a mistake to assume a different conception of the rule of law behind the conflict of opinions between Brussels and Budapest. All we can see is that as a fake card player, one party plays Jolly Joker with cards without definite value, and so there is actually no card game, and the other only warns of this as not an insignificant circumstance. Clearly, when the latter assumed the values of the rule of law, État de Droit, and Rechtsstaat when she joined, it was done so by tacitly accepting their understanding at the time, which no one could regard or mistake as an ever-at-please-refillable blank frame. Agreeing today that I will not war from now on, it will no longer mean tomorrow that I will also pass on my family and property. A new situation could only arise if States Parties had both the intention and legal option to prescribe qualities that could now be held accountable with a degree of accuracy that could be ascertained as a European Union definition of the facts that constitute

129 Cf., e.g. Schlag, Pierre (1998) The Enchantment of Reason (Durham \& London: Duke University Press vii + 160 pp. and as a Harvard case study reviewed, Varga, Csaba (2010) 'Rule of Law? Mania of Law? On the Boundary between Rationality and Anarchy in America' in Nótári, Tamás, Török, Gábor (eds.) Prudentia Iuris Gentium Potestate: Ünnepi tanulmányok Lamm Vanda tiszteletére [Festschrift to Vanda Lamm]. Budapest: MTA Jogtudományi Intézete 530 pp. on pp. 492-504 \{reprinted in <http://mek.oszk.hu/15300/15386>, pp. 165-180\}. 
what the rule of law is. With this, a yardstick could be created, and a measurement could be possible and available, which regardless of the name, would be a different object from the one we have just tried to outline. 


\section{BIBLIOGRAPHY}

Abrahamson, Shirley S., Fischer, Michael J. (1997) 'All the World's a Courtroom: Judging in the New Millennium', Hofstra Law Review, 26(2), pp. 273-291

Ackerman, Bruce (1991-2014) We the People. Vol. I-III. Cambridge, Ma.: Belknap Press of Harvard University Press

Ackerman, Bruce (1992) The Future of Liberal Revolution. New Haven \& London: Yale University Press viii+152 pp.

Aczél, Zsongor László (2005) Parázs a hamu alatt Dokumentumok és visszaemlékezések a pécsi cserkészek katakombaéletéből, (1947)-1951-1965... [Brand under ash: Documents and memories from the scouts' catacomb life at Pécs]. Budapest: Új Ember - Márton Áron Kiadó 339 pp.

(2006) Against Human Rights - Slavoj Žižek. [Oct 9 13:33] [online]. Available at:<http://libcom.org/library/ against-human-rights-zizek>

Ajani, Gianmaria (1994) 'La circulation des modèles juridiques dans le droit post-socialiste', Revue internationale du Droit comparé, 46(4), pp. 1087-1105 [or Ajani, Gianmaria (1995) 'By Chance and Prestige: Legal Transplants in Russia and Eastern Europe', The American Journal of Comparative Law, XLIII(1), pp. 93-117]

Ajani, Giovanni (2003) 'Navigatori e giuristi: A proposito del trapianto de nozioni vaghe' in Bertorello, Valentina (ed.) Io comparo, tu compari egli compara: Che cosa, come, perché. Milano: Giuffrè pp. 3-18

Alchourrón, Carlos E., Bulygin, Eugenio (1971) Normative Systems. Wien \& New York: Springer xviii+208 pp. [Library of Exact Philosophy 5]

Alexy, Robert (2009) 'Law, Morality, and the Existence of Human Rights', Ratio Juris, 25(1), pp. 2-14; Beitz, Charles (2009) The Idea of Human Rights. Oxford: Oxford University Press xiii+235 pp.

Allan, T. R. S. (1998) 'Rule of law (Rechtsstaat)' in Routledge Encyclopedia of Philosophy <https://www.rep. routledge.com/articles/thematic/rule-of-law-rechtsstaat/v-1>[DOI10.4324/9780415249126-To22-1]

Allen, Francis A. (1967) 'Civil Disobedience and the Legal Order', University of Cincinnati Law Review, 36(1), pp. 1-38

Altrichter, Helmut (ed.) (2020) 100(0) Schlüsseldokumente zur deutschen Geschichte im 20. Jahrhundert. $<$ https://www.10oodokumente.de/index.html?c=dokumente_de\&l=de\&viewmode=2>

(1995) 'America's Best Graduate Schools', U.S. News \&World Report (March 20, 1995)

Angyal, Pál (1916) A visszaható erő az anyagi büntetôjogban [Retroactive force in criminal substantive law]. Budapest: Magyar Tudományos Akadémia 84 pp. [Értekezések a philosophiai és társadalmi tudományok köréből I/9]

Annan, Kofi (2004) The Rule of Law and Transitional Justice in Conflict and Post-conflict Societies. Report of the Secretary-General, Doc. S/2004/616, 23 August

An-Na'im, Abdullahi Ahmad (2010) Islam and Human Rights, Selected Essays. Ed. Mashool A. Baderin. Farnham \& Burlington, VT: Ashgate xxxox+372 pp. 
Aristotle (2014) Nicomachean Ethics. Rev. trans. \& ed. Robert Crisp. Cambridge: Cambridge University Press xiii+210 pp. [Cambridge Texts in the History of Philosophy]

Arnold, Jörg (1998) 'Prinzipien und Grundsätze im deutschen Strafrecht und im Entwurf des Allgemeinen Teils des Litauischen Strafgesetzbuches', Jurisprudencija [Vilnius], 9(1), pp. 62-74

Aron, Robert (1967-1975) Histoire de l'épuration. Vol. 1-3(1-2). Paris: Fayard

Arslan, Zühtü (1999) 'Taking Rights Less Seriously: Postmodernism and Human Rights', Res Publica, 5(2), pp. 195-215 <http://www.philosophy.ru/library/pdf/234617.pdf>

Atienza, Manuel (1989) ‘Contribución a la teoría de la legislación', Doxa, (No.6), pp. 385-403 \& <https:// rua.ua.es/dspace/bitstream/10045/10854/1/Doxa6_21.pdf>

Atienza, Manuel (1997) Contribucion a una teoria de la legislación. Madrid: Civitas 109 pp.

Baecker, Dirk (2001) Wozu Kultur? 2nd enlarged ed. Berlin: Kadmos Kulturverlag 203 pp.

Baker, Paul R. (ed.) (1976) The Atomic Bomb: The Great Decision. 2nd rev. ed. Hindale, Ill.: Dryden Press viii+193 pp.

Bakshi, S. R. (1985) Gandhi and the Civil Disobedience Movement. New Delhi: Gitanjali 230 pp.

Balkin, Jack M. (1990) 'Tradition, Betrayal, and the Politics of Deconstruction', Cardozo Law Review, 11(5-6) pp. 1623-1630 in <http://digitalcommons.law.yale.edu/cgi/viewcontent.cgi?article=1282\& context=fss_papers $>$

Balla, Péter 1990) 'A jog funkciói körüli szerepzavar' [The trouble of roles around the functions of law], Magyar Nemzet [Hungarian Nation], LIII(29 November), p. 1

Balogh, Arthur (1914) Jogállam. Budapest: Magyar Tudományos Akadémia 57 pp. [Értekezések a társadalmi tudományok köréből XIV:8]

Barak, Aharon (2003) 'The Role of a Supreme Court in a Democracy, and the Fight against Terrorism', University of Miami Law Review, 58, pp. 125-141 \& <https://repository.law.miami.edu/umlr/vol58/ iss1/12/> \& <http://www.antoniocasella.eu/archica/Aharon_Barak_2003.pdf>

Barak, Aharon (2015) Human Dignity: The Constitutional Value and the Constitutional Right. Cambridge: Cambridge University Press xxxviii+360 pp.

Baxter, Simeon (1782) Tyrannicide Proved Lawful: From the Practice and Writing of Jews, Heathens, and Christians. (A Discourse delivered in the mines at Symsbury, in the colony of Connecticut to the Loyalists confined there by order of the Congress; On September 19, 1781.) [London]: Printed in America: reprinted for S. Bladon $31 \mathrm{pp}$.

Bay, Christian (1967) 'Civil Disobedience: Prerequisite for Democracy in Mass Society' in Spitz, David (ed.) Political Theory \& Social Change. New York: Atherton Press pp. 163-183

Bárd, Petra, Carrera, Sergio, Guild, Elspeth, Kochenov, Dimitry (2016) An EU Mechanism on Democracy, the Rule of Law and Fundamental Rights. Annex II: Assessing the Need and Possibilities for the Establishment of an EU Scoreboard on Democracy, the Rule of Law and Fundamental Rights. [Research paper.] Brussels: European Parliamentary Research Service 234 pp. [CEPS Paper in Liberty and Security in Europe 91] \& <https://europatarsasag.hu/sites/default/files/open-space/ documents/magyarorszagi-europa-tarsasag-eprsstud579328annexiicepseuscoreboard12april. pdf > \&<https://www.academia.edu/24709057/Petra_Bárd_Sergio_Carrera_Elspeth_Guild_and_ Dimitry_Kochenov_with_thematic_contribution_by_Wim_Marneffe_An_EU_mechanism_ on_Democracy_the_Rule_of_Law_and_Fundamental_Rights_CEPS_Paper_in_Liberty_and_ Security_in_Europe_No_91_April_2016_234_P_ISBN_978_94_6138_520_8_>

Beale, Joseph H. (1935) A Treatise on the Conflict of Laws. Vol. I. New York: Baker, Voorhis \& Co.

Beck, Gunnar (2008) 'The Mythology of Human Rights', Ratio Juris, 21(3), pp. 312-347 
Bedner, Adriaan (2010) 'An Elementary Approach to the Rule of Law', Hague Journal on the Rule of Law, 2(1), pp. 48-74 \&<https://core.ac.uk/download/pdf/194433601.pdf>

Bellamy, Richard (2007) Political Constitutionalism: A Republican Defence of the Constitutionality of Democracy. Cambridge \& New York: Cambridge University Press $x+270$ pp.

Belton, Rachel Kleinfeld (2005) Competing Definitions of the Rule of Law: Implications for Practitioners. Washington, D.C.: Carnegie Endowment for International Peace 38 pp. [Democracy and Rule of Law Project; Carnegie Papers 55]

Bence, György, Chambre, Ágnes, Kelemen, János (eds.) (1990) Visszamenóleges igazságszolgáltatás új rezsimekben [Ex post facto justice in new regimes]. Budapest: ELTE BTK Társadalomfilozófia és Etika Tanszék 53 pp. [FIL 2 Gyorsszimpózium]

Benda, Julien (1928) The Great Betrayal. [(1927) La trahison des clerks. Paris: B. Grasset 306 pp.] Transl. Richard Aldington. London: Routledge $\mathrm{x}+188 \mathrm{pp}$. / The Treason of the Intellectuals. Transl. Richard Aldington. New York: W. Morrow 1928. xii + 244 pp.

Benson, Igboin (2011) 'Human Rights in the Perspective of Traditional Africa: A Cosmotheandric Approach', Sophia, 50(1), pp. 159-173

Berlin, Isaiah (1991) The Crooked Timber of Humanity: Chapters in the History of Ideas. New York: Knopf xi+277 pp.

Bernstein, Barton J. (ed.) (1976) The Atomic Bomb: The Critical Issues. Boston: Little, Brown xix+169 pp.

Bernstein, Barton J., Matusow, Allen F. (1966) The Truman Administration: A Documentary History. New York: Harper \& Row viii+518 pp.

Bernstein, Richard J. (2002) 'Reflections on Radical Evil: Arendt and Kant', Soundings: An Interdisciplinary Journal, 85(1-2), pp. 17-30

Besenyei, Lajos, Érszegi, Géza, Gorlero, Maurizio Pedrazza (eds.) (1999) De bulla aurea Andreae II regis Hungariae, 1222. Verona: Valdonega 253 pp.

(1990) Beszélő [The Speaker], special issue (October28)(6)

Békés, Imre, Bihari, Mihály, Király, Tibor, Schlett, István, Varga, Csaba, Vékás, Lajos (1991) 'Szakvélemény: Az 1949 és 1990 között elkövetett, a társadalmi igazságérzetet sértő magatartások, illetve előnyök megítélésének, a felelősség megállapításának elveiről és jogi feltételeiről' [Expert opinion on the principles and legal conditions of the establishment of responsibility for, and the judgement upon, behaviours and privileges in infringement of the social sense of justice, realised between 1949 and 1990], Magyar Jog [Hungarian law], XXXVIII(11), pp. 641-645 \& (1992) Társadalmi Szemle [Social review], XLVII(1), pp. 70-76

Bigo, Pierre (1965) La doctrine sociale de l'Église: Recherche et dialogue. Paris: Presses Universitaires de France $540 \mathrm{pp}$.

Bihari, Ottó (1967) Összehasonlitó államjog: az állami szervezet felépitése és intézményei a mai kapitalista, szocialista és felszabadult, volt gyarmati országokban [Comparative state law: the structure and institutions of state organisation in today's capitalist, socialist and liberated former colonial countries]. [Textbook.] Budapest: Tankönyvkiadó 381 pp.

Bihari, Ottó (1970) Socialist Representative Institutions. Budapest: Akadémiai Kiadó 279 pp.

Bihari, Ottó (1979) The Constitutional Models of Socialist State Organization. Budapest: Akadémiai Kiadó $371 \mathrm{pp}$.

Bingham, Tom (2007) 'The Rule of Law', The Cambridge Law Journal, 66(1), pp. 67-85

Bloom, Allan David (1987) The Closing of the American Mind: How Higher Education has Failed Democracy and Impoverished the Souls of Today's Students. New York: Simon and Schuster xv+382 pp. 
Boas, Franz (1887) 'Museums of Ethnology and their Classification', Science, IX(No.228) (June 17), pp. 588-589 at p. 589 \{reprinted in Carbonell, Bettina Messias (2004) Museum Studies: An Anthology of Contexts. Malden, MA: Routledge pp. 139-142

Bobbio, Norberto (1971) 'Le bon législateur', Logique et Analyse, 14(No.53/54) \& in Hubien, Hubert (ed.) (1971) Le raisonnment juridique / Legal reasoning / Die jurisdiche argumentation. Bruxelles: Établissements Emile Bruylant pp. 243-249

Bobbio, Norberto (1990) L'età dei diritti discusses it as an achievement of humanity that has finally arrived. Torino: Einaudi xxiv+252 pp. [Saggi brevi 16] \{(1996) The Age of Rights. Trans. Allan Cameron. Cambridge: Polity Press xix +168 pp.\}

Bobbio, Norberto (2007) Das Zeitalter der Menschenrechte: Ist Toleranz durchsetzbar? Berlin: Klaus Wagenbach $126 \mathrm{pp}$.

Bockenförde, E[rnst]-W[olfgang] (1969) 'Entstehungswandel des Rechtsstaatsbegriffs' in Festschrift für AdolfArndt zum 65. Geburtstag. Frankfurt am Main: Europäische Verlagsanstalt pp. 53-76

Bolgár, Vera (1963) 'The Public Interest: A Jurisprudential and Comparative Overview of the Symposium on Fundamental Concepts of Public Law', Journal of Public Law [Emory University Law School], 12(1), pp. 13-52

The Book ofGenesis <http://www.vatican.va/archive/bible/genesis/documents/bible_genesis_en.html>

Boot, Eric R. [2017] Human Duties and the Limits of Human Rights Discourse. Cham: Springer ix+183 pp. [Studies in Global Justice 17]

Borges, Jorge Luis (2001) 'John Wilkins' Analytical Language' in Borges, Jorge Luis The Total Library: Non-Fiction 1922-86. Ed. Eliot Weinberger. London, Penguin Books pp. 229-232

Bork, Robert H. (1990) The Tempting of America: The Political Seduction of the Law. New York: Simon and Schuster xiv+432 pp.

Bork, Robert H. (1996) Slouching towards Gomorrah: Modern Liberalism and American Decline. New York: Regan Books xiv+382 pp.

Borneman, John (2007) Settling Accounts: Violence, Justice, and Accountability in Postsocialist Europe. Princeton: Princeton University Press xii+197 pp. [Princeton Studies in Culture/Power/History]

Borucka-Arctowa, Maria (1970) 'Koncepcja „natury ludzkiej” a wspólczene problemy oceny prawa', Etyka, (6), pp. 79-96 \&<http://etyka.uw.edu.pl/wp-content/uploads/2014/04/Etyka6_M_BoruckaArctowa.pdf>

Botero, Adolfo Jerónimo, Granobles, Yuliana Leal (2013) 'Radical Evil and Banality of Evil: Two Faces of Horror of Totalitarian Regimes from Hannah Arendt's Perspective', Universitas Philosophica, 30(No.60), pp. 99-126 <http://www.scielo.org.co/scielo.php?pid=SO120$53232013000100005 \&$ script $=$ sci_abstract $\&$ tlng $=$ en $>$

Bouloukos, Adam C., Dakin, Brett (2001) 'Toward a Universal Declaration of the Rule of Law: Implications for Criminal Justice and Sustainable Development', International Journal of Comparative Sociology, 42(1-2), pp. 145-162

Bourdrel, Philipe (2002) L'épuration sauvage: 1944-1945. Paris: Perrin 698 pp. [Collection Tempus 227]

Bowman, Lt. Col., Helen, Child, Lt. Col., Tim (eds.) (2015) Rule of Law Handbook: A Practicioner's Guide for Judge Advocates 2015. Charlottesville, Virginia: The Judge Advocate General's Legal Center and School, US Army Center for Law and Military Operations vii+218 pp. <https://www.loc.gov/rr/frd/ Military_Law/pdf/rule-of-law_2015.pdf>

Bragyova, András (2005) 'Constitutional Law as Limit to Legal Change: The Constitutional Court and the Backward-looking Laws in Hungary' in The Role of Judicial Review Bodies in Countries in 
Transition. [International Symposium, Nagoya University Center for Asian Legal Exchange, 29-30 July.] [multipl.] pp. 1-10

Brewster, Sir David (1855) Memoirs of the Life, Writings, and Discoveries of Sir Isaac Newton. Vol. II. Edinburgh: T. Constable

Brietzke, Paul H. (1994) 'Designing the Legal Frameworks for Markets in Eastern Europe', The Transnational Lawyer, 7, pp. 35-63

Brinton, Crane (1935) The Anatomy of Revolutions. New York: W. W. Norton 326 pp.

Brunner, Georg (1992) 'Development of a Constitutional Judiciary in Eastern Europe', Review of Central and East European Law, 18(6), pp. 535-553

Buckley, F. H. (2013) The American Illness: Essays on the Rule of Law. New Haven - London: Yale University Press xii+534 pp.

Buckley, F. H. (2013) 'The Rule of Law in America' in Buckley, The American Illness, 2013 on pp. 3-39.

Buñuel, Luis Viridiana (1961); cf. <https://en.wikipedia.org/wiki/Viridiana>

Burdeau, Georges (1939) 'Essai sur l'évolution de la notion de la loi en droit français', Archives de Philosophie du Droit et de Sociologie Juridique, 8, pp. 7-55

Burke, The Right Honourable Edmund (1887) The Works. Vol. III. [1790] Reflections on the Revolution in France. London: John C. Nimmo \& <http://www.gutenberg.org/files/15679/15679-h/15679-h.htm>

Bükkösdi, László (2003) 'Az egyház nem rehabilitál' [The Church is not to rehabilitate] [originally: (1989) A Helyzet (September 15)] in Bükkösdi, László Szeressétek a macskát! Egy öregember emlékiratai [Love the cat! Memoirs of an old man]. Pécs: Pro Pannonia 357 pp. [Pannonia] on pp. 99-107

Byrnes, James Francis (1947) Speaking Frankly. London-Toronto: William Heinemann xii+324 pp.

Caenegem, R. C. van (1991) Legal History: A European Perspective. London - Rio Grande, Ohio: Hambledon Press xi+242 pp.

Campos, Paul F. (1994) 'Secular Fundamentalism', Columbia Law Review, 94(6), pp. 1814-1827

Campos, Paul F. (1998) Jurismania: The Madness of American Law. New York \& Oxford: Oxford University Press xi+198 pp.

Carbonnier, Jean (1981) 'Le Code Napoléon en tant que phénomène sociologique', Revue de la Recherche juridique: Droit prospectif, (3), pp. 327-336

Cardenas, Sonia (2000) [review on Nino (1993)], Latin American Research Review 35(2)

Carothers, Thomas (1998) 'The Rule of Law Revival', Foreign Affairs, 77(2), pp. 95-106

Carothers, Thomas (2006) 'The Rule of Law Revival' in Carothers, Thomas (ed.) Promoting the Rule of Law Abroad: In Search of Knowledge. Washington, D.C.: Carnegie Endowment for International Peace $\mathrm{xv}+363 \mathrm{pp}$.

Carozza, Paolo G. (2013) The Protean Vocabulary of Human Rights. [A lecture delivered at a United Nations event in Geneva, 3 June.] Chambésy: Caritas in Veritas Foundation Blueprint <http://www.fciv. org/downloads/Carozza.pdf> 7 pp.

Carré de Malberg, Raymond (1920-1922) Contribution à la théorie générale de l'État, spécialement d'après les données fournies par le droit. Vol. II. Paris: Recueil Sirey

Celsus in D 1.1.1. pr. Ulp I Inst (Pal. 278).

Chaffee, Wilber A. (2000) [review on Nino (1993)], Hispanic American Historical Review, LXXX(1), pp. $217-218$

Chaturvedi, Kameshwar Nath (2013) 'Legislative Retrospectivity and Rule of Law', Statute Law Review, 34(3), pp. 207-220

Chesterman, Simon (2008) 'An International Rule of Law?', The American Journal of Comparative Law, 56(2), pp. 331-362 
Chevallier, Jacques (2003) L'État de droit. 4 éd. Paris: Montchrestien 160 pp. [Clefs: Politique]

Christoph, Johann, Freiherr von Aretin (1824) Staatsrecht der konstitutionellen Monarchie: Ein Handbuch für Geschaftsmänner, studirende Jünglinge, und gebildete Bürger. Vol. I. Alternburg: Literatur-Comptoir Churchill, Winston in The Times (30 October 1942)

Cicero Delegibus

(2012) Civil-Military Cooperation Centre of Excellence (The Hague) in <https://www.cimic-coe.org/ branches/cic/cimic-innovation/advanced-cultural-competence-aac/rule-of-law/>

Clark, Wesley (2017) ‘Gen. Wesley Clark Weighs Presidential Bid. I Think About It Every Day’ [interview]. (March 2) <http://www.democracynow.org/2007/3/2/gen_wesley_clark_weighs_presidential_bid> and <http://genius.com/General-wesley-clark-seven-countries-in-five-years-annotated>

Clarke, David (1999) 'The Many Meanings of the Rule of Law' in Jayasuriya, Kanishka (ed.) Law, Capitalism and Power in Asia: The Rule of Law and Legal Institutions. London - New York: Routledge xooo+345 pp. [Asian Capitalisms] on pp. 28-44 \&<https://citeseerx.ist.psu.edu/viewdoc/downloa d?doi=10.1.1.612.9223\&rep=repi\&type $=p d f>$

Cohen, Stephen F. (2000) Failed Crusade: America and the Tragedy of Post-Communist Russia. New York \& London: W.W. Norton \& Company xiv+304 pp.

Cointet, Jean-Paul (2008) Expier Vichy: L'épuration en France (1943-1958). Paris: Perrin 522 pp.

Collier, David, Hidalgo, Fernando Daniel, Maciuceanu, Andra Olivia (2006) 'Essentially Contested Concepts: Debates and Applications', Journal of Political Ideologies, 11(3), pp. 211-246

(1961) Le concept de la légalité dans les pays socialistes: Colloque de l'AISJ, 10-16 septembre 1958. WrocławWarszawa: Zakład Narodowy imenia Ossolińskich, Wydawnictwo Polskiej Akademii Nauk 414 pp. [Cahiers de l'Académie Polonaise des Sciences / Zeszyty Problemowe Nauki Polskiej 21]

Conklin, William A. (1998) The Phenomenology of Modern Legal Discourse: The Judicial Production and the Disclosure of Suffering. Aldershot, etc.: Ashgate xii+285 pp.

Cooper, Judith (1974) Ubu roi:An Analytical Study. New Orleans: Tulane University Department of French and Italian 120 pp. [Tulane Studies in Romance Languages and Literature 6]

Corres, Moisés Jaime Bailón (2014) Derechos Humanos de los pueblos indígenas: El debate colonial y las leyes de indias de 1681. México: Comisión Nacional de los Derechos Humanos 96 pp.

Costa, Pietro (2007) 'The Rule of Law: A Historical Introduction' in Costa, Pietro, Zolo, Danilo (eds.) The Rule of Law: History, Theory and Criticism. Dordrecht: Springer xiv+695 pp. [Law and Philosophy Library 80] on pp. 73-149

Coville, Alfred (1932) Jean Petit: La question du tyrannicide au commencement du XVe siècle. Paris: A. Picard $\mathrm{xi}+613 \mathrm{pp}$.

Craig, Paul P. (1997) 'Formal and Substantive Conceptions of the Rule of Law: An Analytical Framework', Public Law, pp. 467-487

Craig, Paul P. (2007) 'The Rule of Law' = [Appendix 5] in [House of Lords Select Committee on the Constitution, $6^{\text {th }}$ Report of Session 2006-07] Relations between the Executive, the Judiciary and Parliament: Report with Evidence. London: The Stationary Office 128+104 pp. [House of Lords Paper 151] on pp. 97-106

Curran, Charles E., McCormick, Richard A. (eds.) (1986) Official Catholic Social Teaching. New York: Paulist Press xi+459 pp. [Readings in Moral Theology 5]

Dam, Kenneth W. (2006) The Law-growth Nexus: The Rule of Law and Economic Development. Washington, D.C.: The Brookings Institution xii+323 pp. 
Darák, Péter (2014) 'Társadalmi problémák - jogi megoldások' [Social problems - legal solutions] in Csehi, Zoltán, Koltay, András, Landi, Balázs, Pogácsás, Anett (eds.) (L)ex cathedra et praxis: Ünnepi kötet Lábady Tamás 70. születésnapja alkalmából. Budapest: Pázmány Press 633 pp. [Xenia], pp. 585-600

Dawisha, Karen (1997) 'Introduction' to Dawisha, Karen, Parrot, Bruce (eds.) The Consolidation of Democracy in East-Central Europe. Cambridge \& New York: Cambridge University Press xx+389 [Democratization and authoritarianism in postcommunist societies 1]

de Berg, Henk (2007) Das Ende der Geschichte und der bürgerliche Rechtsstaat: Hegel - Kojève - Fukuyama. Tübingen: Francke Verlag $285 \mathrm{pp}$.

de Castro, Marcus Faro (1997) [review on Nino (1993)], The Law and Politics Book Review, VII(6), pp. 262-265 (1828) De la doctrine du tyrannicide. Paris: chez Mlle Carié de la Charie 129 pp.

de las Casas, Bartolomé (1971) A Selection of his Writings. Trans. \& ed. George Sanderlin. New York: Knopf $\mathrm{x}+209$ pp. [Borzoi Books on Latin America]

Delmas-Marty, Miraille (2006) 'Le pluralisme ordonné et les interactions entre ensembles juridiques', Recueil Dalloz, $1^{\text {er }}$ Cahier (rouge) 182(14;No.7243), pp. 951-957 \& in <http://www.ieim.uqam.ca/IMG/ pdf/article_Dalloz.pdf>

Delpeuch, Thierry (2005) [compte rendu], Droit et Société, (No.60), p. 593

Dicey, A. V. (1885) Lectures Introductory to the Study of the Law of the Constitution. London: Macmillan vii+407 pp. \{reprinted as ed. J. W. F. Allison. Oxford: Oxford University Press, 2013 xlvii+522 pp. [The Oxford Edition of Dicey I]\}, resp. (1915) Introduction to the Study of the Law of the Constitution. [1885.] 8th edn. London: Macmillan [reprinted in (1982) Indiana: Liberty Fund cxlviii+435 pp. \& <https://files.libertyfund.org/files/1714/0125_Bk.pdf> and (1923) Introduction to the Study of the Law of the Constitution. $2^{\text {nd }}$ edn. London: Macmillan vii+407 pp. / with translations (1902) Bevezetés az angol alkotmányjogba. Budapest: Magyar Tudományos Akadémia, xv+412 pp. [Új folyam LII] \& <http://real-eod.mtak.hu/3303/> \& <https://archive.org/details/bevezetsazangolookautgoog/ page/n193/mode/2up> / (1902) Introduction à l'étude du droit constitutionnel. Paris: V. Giard et E. Brière xxxii+474 pp. [Bibliothèque internationale de droit public] / (2002) Einführung in das Studium des Verfassungsrechts. Baden-Baden: Nomos 483 pp.

Dicey, A. V. (1905) Lectures on the Relation between Law and Public Opinion in England during the Nineteenth Century. London: Macmillan and Co. $x x+503$ pp. \{reprinted by Indianapolis: LibertyClassics $\mathrm{xxx}+420 \mathrm{pp}$.

Diestelkamp, Bernhard (ed.) (1996) Zwischen Kontinuität und Fremdbestimmung: Zum Einfluss des Besatzungsmächte auf die deutsche und japanische Rechtsordnung, 1945 bis 1950. [Deutsch-Japanisches Symposium.] Tübingen: Mohr ix+398 pp.

DiPalma, Giuseppe (1982) 'Italy: Is there a Legacy and is it Fascist?' in Herz (ed.), From Dictatorship..., 1982, pp. 107-134

Дойчев, Момчил (2010) Политическата коректност срещу либералната толерантност: Есе за идейните битки след комунизма. [Political correctness against liberal tolerance: An essay on the ideological battles after Communism.] София [Sofia]: Фабер 160 pp.

Donnelly, Jack (1984) 'Cultural Relativism and Universal Human Rights', Human Rights Quarterly, 6(4), pp. 400-419

Dorandeu, Renaud (1993) 'Les Pélerins constitutionnels: Éléments pour une sociologie des influences juridiques' in Mény, Yves (ed.) Les politiques du mimétisme institutionnel: La greffe et le rejet. Paris: L'Harmattan 285 pp. [Logiques politiques] on pp. 83-112

Douzinas, Costas (2007) Human Rights and Empire: The Political Philosophy of Cosmopolitanism. Abingdon - New York: Routledge and Cavendish $\mathrm{x}+32 \mathrm{pp}$. 
Drahomaniv, Mykhǎlo Petrovych (1881) Le tyrannicide en Russie et l'action de l'Europe occidentale. Genève: Rabotnik et de la Hromada 16 pp.

Drinóczi, Tímea (2020) 'Constitutional Identity in Europe: The Identity of the Constitution - A Regional Approach', German Law Journal, 21(2), pp. 105-130 \& <https:/www.cambridge.org/core/journals/ german-law-journal/article/constitutional-identity-in-europe-the-identity-of-the-constitution -a-regional-approach/83D8D1737788756FEF098CF9485D7B1C/core-reader>

Duguit, Léon (1923) Traité de droit constitutionnel. [1911.] 2 $2^{\mathrm{e}}$ éd. Vol. III. Paris: E. de Boccard \& <https://gallica.bnf.fr/ark:/12148/bpt6k932649r/f561.item.r=Duguit\%2oléon\%20droit\%20 constitutionnel\%203>

Duprat, Jean-Pierre (2006) [review of Dupré (2003)] in Revue internationale de Droit comparé, 56(3), pp. 734-737

Dupré, Catherine (1995) 'Le droit à la dignité humaine, emblême de la transition constitutionnelle?' in Tóth, Károly (ed.) System Transformation and Constitutional Developments in Central and Eastern Europe / Changement de régime politique et le développement de la constitution en Europe centrale et orientale. Szeged-Kecskemét: József Attila Tudományegyetem - Károli Gáspár Reformed University Press 298 pp. on pp. 51 et seq.

Dupré, Catherine (2000) 'Importing German Case Law: The Right to Human Dignity in Hungarian Constitutional Case Law' in The Constitution Found? The First Nine Years of Hungarian Constitutional Review on Fundamental Rights. Budapest: INDOK pp. 215 et seq.

Dupré, Catherine (2000) 'Importing German Law: The Interpretation of the Right to Human Dignity by the Hungarian Constitutional Court', Osteuropa-Recht, 46(2), pp. 144-157

Dupré, Catherine (2003) Importing the Law in Post-Communist Transitions: The Hungarian Constitutional Court and the Right to Human Dignity. Oxford \& Portland Oregon: Hart Publishing xx+217 pp. [Human Rights Law in Perspective 1]

Dupré, Catherine (2003) 'Anticipating Membership: Importing the Law of the West'<http://www.iue. it/LAW/Events/WSWorkshopNov2003/Dupre_paper.pdf>

Dworkin, Ronald (1967-1968) 'The Model of Rules', University of Chicago Law Review, 35(1), pp. 14-46 \& https://chicagounbound.uchicago.edu/uclrev/vol35/iss1/3/

Dworkin, Ronald M. (1968) 'On Not Prosecuting Civil Disobedience', The New York Review of Books X(6 June) p. 14

Dworkin, Ronald M. (1977) Taking Rights Seriously. London: Duckworth xv+293 pp.

Dworkin, Ronald (1978) 'Political Judges and the Rule of Law', Proceedings of the British Academy, 64, pp. 259-287 \& <http://publications.thebritishacademy.ac.uk/pubs/proc/files/64p259.pdf>

Dworkin, Ronald M. (1982) 'Law as Interpretation', Texas Law Review, 60(3), pp. 527-550

Dworkin, Ronald M. (1986) Law's Empire. London: Fontana xiii+470 pp. [Fontana Masterguides]

Dworkin, Ronald M. (1988) Law's Empire. Cambridge, Mass.: Belknap Press of Harvard University Press xiii+470 pp.

Dworkin, Ronald (2012) 'Keynote Speech' in Conference on »The Rule of Law as a Practical Concept«. European Commission for Democracy through Law (Venice Commission) 92 pp. \& <http://www. venice.coe.int/webforms/documents/default.aspx?pdffile=CDL\%282013\%29016-e > on pp. 5-11

Dworkin, Ronald (2012) The Rule of Law as a Practical Concept. <http://www.venice.coe.int/webforms/ documents/default.aspx?pdffile=CDL\%282013\%29016-e>

Dyevre, Arthur (2010) 'The Rule of Law in France' <https://wikis.fu-berlin.de/display/SBprojectrol/ France> 
Edgerton, Robert B. (1985) Rules, Exceptions, and Social Order. Berkeley: University of California Press ix+328 pp.

Einstein, Albert (1922) 'Geometry and Experience' in Einstein, Albert Sidelights on Relativity. London: Methuen \& <https://mathshistory.st-andrews.ac.uk/Extras/Einstein_geometry/>

Ekins, Richard (2011) 'Rights, Interpretation and the Rule of Law' in Ekins, Richard (ed.) Modern Challenges to the Rule of Law. Wellington: LexisNexis NY xxvi+314 pp. on pp. 165-166

Eliot, George (1860) The Mill on the Floss. <https:/www.gutenberg.org/files/6688/6688-h/6688-h.htm\#41>

Elshlain, Jean Belhhe (1998) [review on Nino (1993)], Political Theory, XXVI(3), pp. 419-422

Elster, Jon (2004) Closing the Books: Transitional Justice in Historical Perspective. Cambridge - New York: Cambridge University Press xii+294 pp. at <http://assets.cambridge.org/97805218/39693/ frontmatter/9780521839693_frontmatter.pdf>

Endo, Ken (2001) Subsidiarity and its Enemies: To what Extent is Sovereignty Contested in the Mixed Commonwealth of Europe? San Domenico/Firenze: European University Institute 42 pp. [EUI Working Paper RSC 2001/24]

Engelmann, Frederick C. (1982) 'How Austria has Coped with Two Dictatorial Legacies' in Herz (ed.), From Dictatorship..., 1982, pp. 135-160

Engels, Friedrich, Krautsky, Karl 'Juristen-Sozialismus' (1887) in Marx, Karl, Engels, Friedrich (1962) Werke. Vol. 21. Berlin[-East]: Dietz Verlag pp. 491-509 \& <http://www.mlwerke.de/me/me21/ me21_491.htm>

(1995) 'Ex occidente lux?', Transit: Europäische Review, (9) \{for the contents, cf. <https://www.iwm.at/ publication/transit/heft-09-ex-occidente-lux>\}

[Executive Board, American Anthropological Association] (1947) 'Statement on Human Rights', American Anthropologist, 49(4), pp. 539-543

Fabbrini, Federico, Sajó, András (2019) 'The Dangers of Constitutional Identity', European Law Journal, 25(4), pp. 457-473

Fallon, Jr, Richard H. (1997) “'The Rule of Law” as a Concept in Constitutional Discourse', Columbia Law Review, 97(1), pp. 1-56

Fehér, Ferenc (1995) 'Imagining the West', Thesis Eleven, 42(1), pp. 52-68

Ficzere, Lajos (1988) 'Szocializmus és jogállamiság' [Socialism and the rule of law], Jogtudományi Közlöny, XLIII(3), pp. 105-111

Finnis, John (1980) Natural Law and Natural Rights. Oxford: Clarendon Press xv+425 pp. [Clarendon Law Series]

Fisch, Jill E. (1997) 'Retroactivity and Legal Change: An Equilibrium Approach', Harvard Law Review, 110(5), pp. 1055-1123

Fish, Stanley (1989) Doing What Comes Naturally: Change, Rhetoric and the Practice of Theory in Literary and Legal Studies. Durham-London: Duke University Press $\mathrm{x}+613$ pp. [Post-contemporary interventions]

Fiss, Owen M. (1982) 'Objectivity and Interpretation', Stanford Law Review, 34(4) pp. 739-763 \& <http:// www.law.yale.edu/documents/pdf/objectivity_and_interpretation.pdf>

Fitschen, Thomas (2008) 'Inventing the Rule of Law for the United Nations', Max Planck Yearbook of United Nations Law, 12, pp. 347-380

Flake, L. Gordon (2000) 'Preface and Acknowledgments' in The Mansfield Center for Pacific Affairs (ed.) The Rule of Law: Perspectives from the Pacific Rim. Findlay, Ohio: The Mansfield Center for Pacific Affairs x+156 pp. \& <https://biblioteca.cejamericas.org/bitstream/handle/2015/993/mcpa-rulelaw-pacific.pdf? sequence $=1 \&$ isAllowed $=y>$ on $p p . i-x$ 
Fleck, Zoltán (2010) Változások és változatlanságok: A magyar jogrendszer a rendszerváltás után [Changed and unchanged: Hungarian legal system after the change of regimes]. Budapest: Napvilág 162 pp. [20 év után]

Fletcher, George P. (1966) Basic Concepts of Legal Thought. New York: Oxford University Press ix+213 pp.

Fletcher, George P. (1992) 'Searching for the Rule of Law in the Wake of Communism', Brigham Young University Law Review, (1), pp. 145-164

Flores, Imer (2013) 'Law, Liberty and the Rule of Law (in a Constitutional Democracy)' in Flores, Imre B., Himma, Kenneth Einar (eds.) Law, Liberty, and the Rule of Law. Dordrecht - New York: Springer $\mathrm{x}+190$ pp. [Ius gentium: Comparative Perspectives on Law and Justice 18] on pp. 77-101 \{reprint as Georgetown Public Law and Legal Theory Research Paper No. 12-161 <https://scholarship.law. georgetown.edu/cgi/viewcontent.cgi?article $=2125 \&$ context $=$ facpub $>$ \}

Ford, Franklin L[ewis] (1985) Political Murder: From Tyrannicide to Terrorism. Cambridge, Mass: Harvard University Press xii+440 pp.

Formosa, Paul (2007) 'Is Radical Evil Banal? Is Banal Evil Radical?', Philosophy \& Social Criticism, 33(6), pp. $717-735$

Fortas, Abe (1968) Concerning Civil Disobedience and Dissent. New York: The New American Library 64 pp. [Signet Special Broadside 3]

Foucart, Jacques (2000) Le mythe du 'bon juge' de Château-Thierry: Le Président Magnaud. Amiens: Bibliothèque municipale d'Amiens $286 \mathrm{pp}$. [Eklitra 84]

Fraenkel, Ernst von (1941) The Dual State: A Contribution to the Theory of Dictatorship. Trans. E. A. Shils. New York \& London: Oxford University Press xvi +248 pp., resp. (1974) Der Doppelstaat. Frankfurt am Main: Europe Verlag-Anstalt 257 pp. [Studien der Gesellschaftstheorie]

Franck, Thomas M. (1972) 'The New Development: Can American Law and Legal Institutions Help Developing Countries?', Wisconsin Law Review, 12(3), pp. 767-801

Frankena, William K. (1963) Ethics. Englewood Cliffs, N.J. xiii+109 pp. [Prentice-Hall Foundations of Philosophy Series]

Frändberg, Åke (1996) 'Begreppet rättsstat' in Sterzel, Fredrik (ed.) Rättsstaten: Rätt, politik och moral. (Seminarium 5 oktober 1994.) Stockholm: Rättsfonden 127 pp. [Rättsfondens skriftserie 31]

Frändberg, Åke (2014) From Rechtsstaat to Universal Law-state: An Essay in Philosophical Jurisprudence. Cham: Springer xi+190 pp. [Law and Philosophy Library 109]

Freeman, Harrop A. (1966) 'Moral Preemption Part I: The Case for the Disobedient', Hastings Law Journal, 17(3), pp. 425-437

Freeman, Harrop A. (1966) 'The Right of Protest and Civil Disobedience', Indiana Law Journal, 41(2), pp. $228-254$

Friedmann, Wolfgang (1947) The Allied Military Government of Germany. London: Stevens x+362 pp.

Friedmann, Wolfgang (1955) 'Übergesetzliche Rechtsgrundsätze und die Lösung von Rechtsproblemen', Archiv für Rechts- und Sozialphilosophie, 41(3), pp. 348-371

Frivaldszky, János (2003) 'Gondolatok az emberi jogok radikális szemléletéból fakadó problémákról' [Thoughts on problems arising from the radical approach to human rights] in Frivaldszky, János (ed.) Egy európai alkotmány felé: A nizzai Alapvető Jogok Chartája és a Konvent. [Towards a European constitution: the Charter of Fundamental Rights and the European Convention on Human Rights.] Budapest: JTMR Faludi Akadémia - OCIPE Magyarország 99 pp. [Agóra II] on pp. 63-74 Fukuyama, Francis (1992) The End of History and the Last Man. New York: The Free Press xxiii+418 pp. Fukuyama, Francis (1999) The Great Disruption: Nature and the Reconstitution of the Social Order. New York: The Free Press xii+354 pp. 
Fuller, Lon L. (1964) The Morality of Law. New Haven \& London: Yale University Press viii+202 pp. [Storrs Lectures on Jurisprudence 1963]

Füzér, Katalin (1997) 'The Invisible Constitution: The Construction of Constitutional Reality in Hungary', International Journal of Sociology, 26(4), pp. 48-65 \& <https:/www.researchgate.net/ publication/310757509_The_Invisible_Constitution_The_Construction_of_Constitutional_ Reality_in_Hungary>

Gaius Institutiones

Gallie, Walter Bryce (1955-1956) 'Essentially Contested Concepts', Proceedings of the Aristotelian Society, 56(1), pp. 167-198

Galtung, Johan (1994) Human Rights in Another Key. Oxford \& Cambridge, Mass.: Cambridge Polity Press vi+184 pp.

Gardner, James A. (1980) Legal Imperialism: American Lawyers and Foreign Aid in Latin America. Madison: University of Wisconsin Press xii+401 pp.

Gardner, John (2008) "Simply in Virtue of Being Human": The Whos and Whys of Human Rights', Journal of Ethics \& Social Philosophy, 2(2), pp. 1-22 \& <http://www.jesp.org/PDF/Gardner.pdf>

Garro, Alejandro M. (1993) 'Nine Years of Transition to Democracy in Argentina: Partial Failure or Qualified Success?', Columbia Journal of Transnational Law, 31(1), pp. 1-102

Garver, Eugene (1978) 'Rhetoric and Essentially Contested Arguments', Philosophy \& Rhetoric, 11(3), pp. $156-172$

Gaudemet, Jean (1976) 'Les transferts de droit', L’Année sociologique, 27, pp. 29-59

Gárdos-Orosz, Fruzsina, Szente, Zoltán (2014) 'A Jó Állam jogállami követelményei' [The rule of law preconditions of a Good Government] in Kaiser, Tamás, Kis, Norbert (ed.) A Jó Állam mérhetősége [The measurability of a Good Government]. Budapest: Nemzeti Közszolgálati Egyetem Jó Állam Kutatómühely pp. 267-290

Gessner, Volkmar, Hoeland, Armin, Varga, Csaba (eds.) (1996) European Legal Cultures. Aldershot, Brookfield USA, Singapore, Sydney: Dartmouth xviii+567 pp. [Tempus Textbook Series on European Law and European Legal Cultures I]

Gewirth, Alan (1982) Human Rights: Essays on Justification and Applications. Chicago: University of Chicago Press xiv+366 pp.

Giovannitti, Len, Freed, Fred (1965) The Decision to Drop the Bomb. New York: Coward-MacCann 348 pp. Glaser, Stefan (1964) in Le Monde (December17), p. 10

Glendon, Mary Ann (1991) Rights Talk: The Impoverishment of Political Discourse. New York: The Free Press xvi+218 pp.

Glendon, Mary Ann (1994) A Nation under Lawyers: How the Crisis in the Legal Profession is Transforming American Society. Cambridge, Mass.: Harvard University Press 331 pp.

Glendon, Mary Ann (2004) 'The Rule of Law in the Universal Declaration of Human Rights', Northwestern Journal of International Human Rights, 2(1), pp. 1-19 \& < http://scholarlycommons.law.northwestern. $\mathrm{edu} / \mathrm{njihr} / \mathrm{vol} 2 / \mathrm{iss} 1 / 5>$

Glenn, H. Patrick (2000) Legal Traditions of the World: Sustainable Diversity in Law. Oxford - New York: Oxford University Press xxiv+371 pp.

(2001-) Global Civil Society Yearbook, I-, London \& New York: Oxford University Press

Goldstein, Leslie Friedman (2004) 'From Democracy to Juristocracy?' Law \& Society Review 38(3), pp. $611-629$

Goodman, Nelson (1955) Fact, Fiction and Forecast. Cambridge: Harvard University Press 126 pp. 
Goti, Jaime Malamud (1991) 'Punishment and a Rights-based Democracy', Criminal Justice Ethics, 10(2), pp. 3-13

Gowder, Paul (2016) The Rule of Law in the Real World. New York: Cambridge University Press xii+275 pp. Gönner, Nikolaus Thaddäus (1804) Teutsches Staatsrecht. Landshut: Krüll xx+844 pp.

Graetz, Michael J. (1977) 'Legal Transitions: The Case of Retroactivity in Income Tax Revision', University of Pennsylvania Law Review, 126(1), pp. 47-87

Grant, Robert (1990) Oakeshott. London: The Claridge Press 128 pp. [Thinkers of our Time]

Gray, John N. (1977) 'On the Contestability of Social and Political Concepts', Political Theory, 5(3), pp. 331-348

Greskovits, Béla (2017) Rebuilding the Hungarian Right through Civil Organization and Contention: The Civic Circles Movement. San Domenico di Fiesole: European University Institute Robert Schuman Centre for Advanced Studies 30 pp. [EUI Paper RSCAS 2017/37]

Griffin, James (2008) On Human Rights. Oxford: Oxford University Press xiii+339 pp.

Grote, Rainer (2010) 'Rule of Law, Rechtsstaat y État de Droit', Pensamiento Constitucional, VIII(8), pp. 127-176 \& < <htps://www.researchgate.net/publication/27270699_Rule_of_Law_Rechtsstaat_y_ Etat_de_Droit>

Grudzinska-Gross, Irena (ed.) (1994) Constitutionalism in East Central Europe: Discussions in Warsaw, Budapest, Prague, Bratislava. Bratislava: Czecho-Slovak Committee of the European Cultural Foundation $148 \mathrm{pp}$.

Grugel, Jean (1999) Democracy without Borders: Transnationalisation and Conditionality in New Democracies. London \& New York: Routledge xv+189 pp. [Routledge/ECPR Studies in European Political Science 10]

Hager, Berry M. (2000) 'Defining it and Defending it in an Asian Context' in The Mansfield Center for Pacific Affairs (ed.) The Rule of Law: Perspectives from the Pacific Rim. Findlay, Ohio: The Mansfield Center for Pacific Affairs x+156 pp. \& <https://biblioteca.cejamericas.org/bitstream/ handle/2015/993/mcpa-rule-law-pacific.pdf?sequence=1\&isAllowed=y $>$ on pp. $1-11$

Haggard, Stephan, Tiede, Lydia B. (2011) 'The Rule of Law and Economic Growth: Where Are We?', World Development, 39(5) \& <https://gsdrc.org/document-library/the-rule-of-law-and-economicgrowth-where-are-we/>, pp. 673-685

Haggard, Stephan, MacIntyre, Andrew, Tiede, Lydia (2008) 'The Rule of Law and Economic Development,' Annual Review of Political Science, 11 \& <https:/www.annualreviews.org/doi/ abs/10.1146/annurev.polisci.10.081205.100244>, pp. 205-234

Hall, Robert T. (1971) The Morality of Civil Disobedience. New York, etc.: Harper \& Row xiii+162 pp. [Torchbook Library Edition]

H[almai], G[ábor] (2004) [review of Dupré (2003)] 'Alkotmány és alkotmánybíráskodás a rendszerváltozások után' [Constitution and constitutional judiciary after the political transitions], Fundamentum, (1), pp. 211-215

Halmai, Gábor (2007) 'Ez nem polgári engedetlenség’ [This is not civil disobedience], Népszabadság [People's Liberty: a daily], (February3)

Halmai, Gábor, Tordai, Csaba (1999) '»kevesebb lesz az elegáns röpködés a jogrendszer fölött«' ['There will be less elegant flying to and fro above the legal system'], Fundamentum, 3(2), pp. 60-68

Hamara, Courtney Taylor (2013) 'The Concept of the Rule of Law' in Flores, Imer B., Himma, Kenneth Eimar (eds.) Law, Liberty, and the Rule of Law. Dordrecht: Springer x+190 pp. [Ius Gentium: Comparative Perspectives on Law and Justice 18] on pp. 11-26 
Hamvas, Béla (1938) A világválság [World crisis]. Budapest: Budapest Székesfőváros Házinyomdája 69 pp. [=(1937) A Fôvvárosi Könyvtár évkönyve, VII, pp. 39-105]

Hankiss, Elemér (2016) 'Europe between Two Worlds' in Jensen, Jody, Miszlivetz, Ferenc (eds.) Reframing Europe's Future: Challenges and Failer of the European Construction. New York - London: Routledge pp. 237-248. \{in German: (1990) 'Zwischen zwei Welten. Wertewandel in Ungarn’ Transit, (1), pp. 167-184\}

Hanuš, Libor (2007) 'Jsou obecné právní principy pramenem práva v právním řádu ČR?' [Are general principles of law a source of law in the legal system of the Czech Republic?], Právník, CXLVI(1), pp. $1-12$

Haocai zhu bian, Lui (2010) Ruan fa de li lun yu shi jian [The theory and practice of soft law] Beijing Shi: Beijing da xue chu ban she $410 \mathrm{pp}$. [Ruan fa yan jiu xi lie \{Soft law series\}]

Haocai, Luo, Gongde, Song (2013) Soft Law Governance: Towards an Integrated Approach. [2009.] Trans. Ben Armour \& Tang Hailong. Buffalo, N.Y.: William S. Hein \& Co. xxvi+443 pp.

Harlow, Carol (2003) 'European Governance and Accountability' in Bamforth, Nicholas, Leyland, Peter (ed.) Public Law in a Multi-layered Constitution. Oxford: Hart Publishing, $\mathrm{x}+433 \mathrm{pp}$.

Harvey, Colin (2003) 'Series Editor's Preface' in Dupré, Importing, p. vii.

Hasegawa, Ko (2009) 'Between Rights and »Kenri«' in Ritaine, Eleanor Cashin (ed.) Legal Engineering and Comparative Law / L'ingenierie juridique et le droit comparé (Rapports du Colloque de $25^{\circ}$ anniversaire de l'Institut Suisse de droit comparé du 29 â̂ut 2008 à Lausanne). Vol. 2. Genève, etc.: Schulthess pp. 87-103 [Publications de l'Institut Suisse de droit comparé 64]

Havel, Václav (1990) ‘The New Year's Address to the Nation’ (Prague, January 1, 1990) in <http://old.hrad. cz/president/Havel/speeches/1990/0101_uk.html>

Hayek, F. A. (1944) The Road to Serfdom. Chicago: University of Chicago Press viii+248 pp.

Hayek, F. A. (1960), The Constitution of Liberty. Chicago: University of Chicago Press x+569 pp.

Hayek, Friedrich A. von (1982) Law, Legislation and Liberty: A New Statement of the Liberal Principles of Justice and Political Economy. [I-III in one vol.] London: Routledge \& Kegal Paul

Hayek, F. A. (1994) The Road to Serfdom. [1944.] Chicago: University of Chicago Press xlvi+274 pp.

Hegedős, Soma (2020) 'A jogállamiság fogalmának teoretikai problémái az Európai Unió jogfelfogásának vonatkozásában' [Theoretical problems relating to the notion of the rule of law with regards to the EU understanding of law], Külügyi Mühely, (2), pp. 5-24 \& <https://epa.oszk. hu/03800/03841/00003/pdf/EPA03841_kulugyi_muhely_2020_02_005-024.pdf>

Helland, Eric, Kick, Jonathan (2013) 'Regulation and Litigation: Complements or Substitutes?' in Buckley, F. H. (ed.) The American Illness: Essays on the Rule of Law. New Haven: Yale University Press xii+534 pp. on pp. 118-136

Hempel, Carl G., Oppenheim, Paul (1936) Der Typusbegriff im Licht der neuen Logic. Leyden: Sijthoff vii+130 pp.

Herberger, Maximilian (1978) 'Juristen, böse Christen' in Erler, Adalbert (ed.) Handwörterbuch zur deutschen Rechtsgeschichte. Vol. II. Berlin: Erich Schmidt Verlag pp. 481-484

Herder, Johann Gottfried (1791) Ideen zur Philosophie der Geschichte der Menschheit. in Herder, Johann Gottfried (2002) Werke. Ed. Wolfgang Pross. Vol. III/1. Munich: Carl Hanser Verlag Book 16

Herz, John H. (1982) 'Denazification and Related Policies' in Herz, John H. (ed.) From Dictatorship to Democracy: Coping with the Legacies of Authoritarianism and Totalitarianism. Westport, Conn.: Greenwood xii+311 pp. [Contributions in Political Science 9] on pp. 15-38

Heydon, J. D. (2011) 'What do we Mean by the Rule of Law?' in Ekins, Richard (ed.) Modern Challenges to the Rule of Law. Wellington: LexisNexis NY xxvi+314 pp. on pp. 19-22 
Higgins, Rosalyn (2007) The ICJ and the Rule of Law. A speech given at the United Nations University (11 April). <http://archive.unu.edu/events/fil les/2007/20070411_Higgins_speech.pdf>

Hinghofer-Szalkay, Stephan G. (2019) 'The Austrian Constitutional Court: Kelsen's Creation and Federalism's Contribution?' Fédéralisme Régionalism, 17, <https://popups.uliege.be/1374-3864/index. php?id=1671>

Hirschl, Ran (2004) Towards Juristocracy: The Origins and Consequences of the New Constitutionalism. Cambridge, MA - London: Harvard University Press $286 \mathrm{pp}$.

Hirschl, Ran (2011) Constitutional Theocracy. Cambridge, Mass.: Harvard University Press 306 pp.

Hodgson, Douglas (2003) Individual Duty within a Human Rights Discourse. Aldershot \& Burlington, VT: Ashgate xi+277 pp. [Applied Legal Philosophy]

[Anonymous, standing for Holmes, jr., O. W.] (1880) [Book notices], American Law Review, XIV, pp. 233 et seq.

Holmes, Oliver Wendell (1881) The Common Law. Boston: Little, Brown xvi+422 pp. \& <http://www. constitution.org/cmt/owh/commonlaw.txt>

Holmes, Stephen (2001) 'Transitology', London Review of Books, 23(8)(19 April) pp. 32-35

Holmes, Stephen, Krastev, Ivan (2020) The Light that Failed: Why the West is Losing the Fight for Democracy. New York: Pegasus Books 246 pp.

Holmes, Stephen, Sunstein, Cass R. (1999) The Cost of Rights: Why Liberty Defends on Taxes. New York: Norton 255 pp.

Hong, Joon-Hyung (2000) 'The Rule of Law and its Acceptance in Asia' in The Mansfield Center for Pacific Affairs (ed.) The Rule of Law: Perspectives from the Pacific Rim. Findlay, Ohio: The Mansfield Center for Pacific Affairs x+156 pp. \& <https://biblioteca.cejamericas.org/bitstream/handle/2015/993/mcparule-law-pacific.pdf?sequence=1\&isAllowed=y> on pp. $145-153$

Hongladarom, Soraj (1994) 'Buddhism and Human Rights in the Thoughts of Sulak Sivaraksa and Phra Dhammapidok (Prayudh Prayutto)' in Keown, Damien V., Prebish, Charles S., Husted, Wayne R. (1998) Buddhism and Human Rights. Richmond, Surrey: Curzon Press xxi+239 pp. [Curzon Critical Studies in Buddhism]

Horovitz, Joseph (1972) Law and Logic: A Critical Account of Legal Argument. New York, Vienna: Springer $\mathrm{xv}+213$ pp. [Library of Exact Philosophy]

Horvath, Michael J. (1972) Golden Bull (Bulla aurea), 1222, of Hungary and the Magna carta, 1215: A Selected Bibliography Commemorating the Former One's 750th Anniversary. College Park, University of Maryland Library $28 \mathrm{pp}$.

[House of Lords Select Committee on the Constitution, $6^{\text {th }}$ Report of Session 2006-07] (2007) Relations between the Executive, the Judiciary and Parliament. London: The Stationary Office $128+104 \mathrm{pp}$. [HL Paper 151]

Howard, Philip K. (1994), The Death ofCommon Sense: How Law is Suffocating America. New York: Random House $202 \mathrm{pp}$.

Howard, Philip K. (2002) The Collapse of the Common Good: How America's Lawsuit Culture Undermines our Freedom. New York, Ballantine Books 253 pp.

Howard, Philip K. (2011) 'Vaclav Havel's Critique of the West' The Atlantic, (December 20) <http://www. theatlantic.com/international/archive/2011/12/vaclav-havels-critique-of-the-west/250277/>

Howard, Philip K. (2014) The Rule of Nobody: Saving America from Dead Laws and Broken Government. New York, W. W. Norton \& Co. $\mathrm{x}+244 \mathrm{pp}$.

Howe, Daniel Walker (1990) Henry David Thoreau on the Duty of Civil Disobedience: An Inaugural Lecture Delivered before the University of Oxford on 21 May 1990. Oxford: Clarendon Press $32 \mathrm{pp}$. 
Höland, Armin (1993) 'Évolution du droit en Europe centrale et orientale: Assiste-t-on à une renaissance du "Law and Development"?', Droit et société, (No.25), pp. 467-488

Humphfreys, Simon (2012) 'Laboratories of Statehood: Legal Intervention in Colonial Africa and Today', The Modern Law Review, 75(4), pp. 475-510

Humphfreys, Stephen (2010) Theatre of the Rule of Law: Transnational Legal Intervention in Theory and Practice. Cambridge: Cambridge University Press $\mathrm{xxx}+295$ pp. [Cambridge Studies in International and Comparative Law]

(1992) Hungary's National Renewal Program: The First Three Years (1990-1992) of the Republic. Budapest: [Advisory Body to the Primer Minister of the Republic of Hungary] $197 \mathrm{pp}$.

Huntington, Samuel P. (1991) The Third Wave: Democratization in the Late Twentieth Century. Norman \& London: University of Oklahoma Press xvii+366 pp.

Huntington, Samuel P. (1996) The Clash of Civilizations and the Remaking of World Order. New York: Simon \& Schuster $367 \mathrm{pp}$.

Hufteau, Yves-Louis (1965) Le référé législatif et le pouvoir du juge dans la silence de la loi. Paris: Presses Universitaires de France 159 pp. [Travaux et recherches de la Faculté de Droit et des Sciences économiques de Paris, Série Droit privé 2]

Hyde-Price, Adrian G. V. (1994) 'Democratization in Eastern Europe, the External Dimension' in Pridham, Geoffrey, Vanhanen, Tatu (eds.) Democratization in Eastern Europe: Domestic and International Perspectives. London: Routledge xiv+274 pp. on pp. 220-254

(1990) 'Az igazságtétel nehézségei' [Problems arising when facing with the past], Világosság [The light], XXXI(8-9), pp. 661-677

Ilesanmi, Simeon O. (1995) 'Human Rights Discourse in Modern Africa: A Comparative Religious Ethical Perspective', Journal of Religious Ethics, 23(2), pp. 293-322

Inada, Kenneth (1995) 'A Buddhist Response to the Nature of Human Rights', Journal of Buddhist Ethics, 2 \&<https://blogs.dickinson.edu/buddhistethics/category/volume-02-1995/>, pp. 1-9

[International Commission of Jurists] (ed.) (1957) The Hungarian Situation and the Rule of Law. The Hague: International Commission of Jurists $144 \mathrm{pp}$.

[International Commission of Jurists] Marsh, Norman S. (ed.) (1960) The Rule of Law in a Free Society. (A Report on the International Congress of Jurists, New Delhi, India, January 5-10, 1959.) Geneva xi+336 pp. \& <https://www.icj.org/wp-content/uploads/1959/o1/Rule-of-law-in-a-free-societyconference-report-1959-eng.pdf>

Iseni, Arburim, Sela, Ylber, Beadini, Adem (2013) 'A Comparative Study of Albanian Customary Law with the Code of the West and the Common Law of England. Lex Scripta vs. Lex Non Scripta' Journal of Law, Policy and Globalization 18, pp. 50-59 \& <http://www.iiste.org/Journals/index.php/ JLPG/article/viewFile/8498/8437>

Ivasivka, Mátyás, Arató, László (2006) Sziklatábor - A katakombacserkészet története: Visszaemlékezések és dokumentumok, (1945-)1948-1988 [Rock camp: History of catacomb scouting; Remembrance and documents]. Budapest: Új Ember - Márton Áron Kiadó 517 pp.

Jajodia, Sushil, Shakarian, Paulo, Subrahmanian, V.S., Swarup, Vipin, Wang, Cliff (eds.) (2015) Cyber Warfare: Building the Scientific Foundation. Cham: Springer International Publishing xiii+321 [Advances in Information Security 56]

Jakab, András (2004) [review of Dupré (2003)] in Zeitschrift für ausländisches öffentliches Recht und Völkerrecht, 64(1), pp. 243-246

Janse, Ronald (2019) 'Why Did the Rule of Law Revive?', The Hague Journal on the Rule of Law, 11(2-3) \& $<$ https://link.springer.com/article/10.1007/s40803-019-00132-Z\#Fn2>, pp. 341-348 
Janša, Janez (2020) 'Prime Minister of Slovenia explained in an open letter to the President of the European Council on 17 November 2020' <https://www.gov.si/assets/PV/November-2020/Letter-ofPM-Janez-Jansa-to-the-PEUCO-Charles-Michel.pdf>

Jarry, Alfred [1896] Ubu roi, Drama in 5 Acts. In French \& English, transl. Barbara Wright. $3^{\text {rd }}$ ed. [1961.] London: Gaberbocchus P., 1966 xi+175 pp.

Jászi, Oszkár, Lewis, John D. (1957) Against the Tyrant: The Tradition and Theory of Tyrannicide. Glencoe, Ill.: The Free Press ix+288 pp.

Jean, Jean-Paul (ed.) (2018) Juger sous Vichy, juger Vichy. Paris: La Documentation française 451 pp. [Histoire de la justice 29]

Jed, Stephanie (1982) Tyrannicidae Imago: Lorenzino de'Medici and the Imprint of Human Action. [Microform dissertation.] Connecticut: Yale University Department of Italian Language and Literature

Jellinek, Georg (1895) Die Erklürung der Menschen-und Bürgerrechte. Leipzig: Duncker \& Humblot 53 pp.

Jennings, W. Ivor (1941) 'The Rule of Law in Total War', Yale Law Journal, 50(3), pp. 365-386

Jillek, Ilona (2002) 'A világot nem tudom elképzelni Isten nélkül' [I cannot imagine the world without God], Új Ember, LVIII(February 24,8[No.2795])

Johnson, Frank M. (1969) 'Civil Disobedience and the Law', Tulane Law Review, XLIV(1), pp. 1-13

Jonas, Adolphe David \& Klein, Doris (1972) Man-child: A Study of the Infantilization of Man. New York: McGraw-Hill xvi+362 pp.

Jones, D. (1998) [review on Nino (1993)], Ethics \& International Affairs, 12(1), pp. 227-228

Jones, Drolay (1998) [review on Nino (1993)], Ethics and Jal's Affairs, XII, pp. 227-228

Jupine, Joseph, Helmke, Gretchen (2002) [review on Nino (1993)], Comparative Political Studies, 34(2), pp. $120-126$

Jurgens, Erik (2007) The Principle of the Rule of Law. Committee on Legal Affairs and Human Rights Doc. 11343 Report. [Council of Europe] Parliamentary Assembly (6 July) in https://assembly.coe.int/nw/ xml/XRef/X2H-Xref-ViewHTML.asp?FileID=11593\&lang=EN>

Juhász, Zita (2011) 'De iure non scripto, avagy a korai jogfogalom duplexivitása' [De iure non scripto, or the duplexivity of the early concept of law], De jurisprudentia et jure publico [Szeged], V(1), pp. 1-38 [online]. Available at:<http://www.dieip.hu/2011_1_06.pdf>

(2008) La justice de l'épuration: À la fin de la Seconde Guerre mondiale. Paris: La Documentation française 285 pp. [Collection Histoire de la justice 18]

(2001) La justice des années sombres: 1940-1944. Paris: La documentation française 335 pp. [Collection Histoire de la justice 14]

Kaganas, I. (1993) Lietuvos Respublikos valdymo forma - Lietuvos valstybingumo teisines problemos: Pirmojo pasaulio leituviu teisininku kongreso straipsniu ir teziu rinkinys [The form of government of the Republic of Lithuania - Legal problems of Lithuanian statehood: A collection of articles and theses of the First World Congress of Lithuanian Lawyers]. Vilnius

Kardos, Gábor (1999) 'A pozitivizmuson innen és túl' [Within and beyond positivism], Magyar Tudomány, XLIV(2), pp. 145-147

Karstedt, Susanne (1998) 'Coming to Terms with the Past in Germany after 1945 and 1989: Public Judgments on Procedures and Justice', Law \& Policy, 20(1), pp. 15-56

Katz, Milton, Schlesinger, Rudolf B., Rheinstein, Max (1957) 'International Association of Legal Science: The Colloquia at Chicago, September 8-16, 1957', American Journal of Comparative Law, 6(4), pp. 518-525

[Kárpáthy-]Kravjánszky, Miksa Mór (1914) Tanulmányok a zsarnokölés tanának történetéhez [Studies to the history of tyrannicide]. Nagyvárad \{now: Oradea in Romania\}: [Szent László Rt.] 155 pp. 
Kelemen, János (1999) 'Válasz Ludassy Mária körkérdésére' [Response to the circulated quest], Magyar Tudomány, XLIV(2), pp. 148-151

Kelsen, Hans (1911) Hauptprobleme der Staatsrechtslehre entwickelt aus der Lehre vom Rechtssatze. Tübingen: Mohr xxvii+709 pp.

Kelsen, Hans (1931) Wer soll der Hüter der Verfassung sein? Berlin-Grunewald: Rotschild 56 pp.

Kelsen, Hans (1942) 'Judicial Review of Legislation: A Comparative Study of the Austrian and the American Constitution', The Journal of Politics, 4(2), pp. 183-200

Kelsen, Hans (1963) 'Positivisme juridique et doctrine du droit naturel' in Mélanges en l'honneur de Jean Dabin. Vol. I. Bruxelles: Bruylant \& Paris: Sirey pp. 141-148

Kelsen, Hans (1992) Reine Rechtslehre. [1960.] 2. Aufl. Wien: Österreichische Staatsdruckerei 534 pp.

Kende, Pierre (1992) 'Reflexion sur l'optimisme institutionnel des élites postcommunistes' [Communication présentée au $4^{\text {ème }}$ congrès de l'Association Française de Science Politique, 23-26 septembre] 16 pp. \{\& Kende, Péter (1993) 'L'optimisme institutionnel des élites postcommunistes' in Mény (ed.), Les politiques du mimétisme, 1993, pp. 237-248\}

Kennedy, Robert F. (1998) Make Gentle the Life of the World: The Vision of Robert F. Kennedy. Ed. Maxwell Taylor Kennedy. New York: Harcourt Brace 188 pp.

Kilényi, Géza (1989) 'Ungarn schreitet in Richtung Rechtsstaatlichkeit', Europäische GrundrechtsZeitschrift, (No.23-24), pp. 513-518

Kirchheimer, Otto (1961) Political Justice: The Use of Legal Procedure for Political Ends. Princeton, New Jersey: Princeton University Press 452 pp.

Kirchheimer, Otto (1996) 'The Rechtsstaat as Magic Wall' in Scheuerman, William E. (ed.) The Rule of Law under Siege: Selected Essays of Franz L. Neumann and Otto Kirchheimer. Berkeley: University of California Press vii+268 pp. [Weimar and Now 9]

Kochenov, Dimitry (2015) 'EU Law without the Rule of Law: Is the Veneration of Autonomy Worth It?', Yearbook of European Law, 34(1), pp. 74-96 \&<https://www.researchgate.net/publication/283866218_ EU_Law_without_the_Rule_of_Law_Is_the_Veneration_of_Autonomy_Worth_It $\quad \&<$ https:// papers.ssrn.com/sol3/papers.cfm?abstract_id=2642689>

Koetter, Matthias (2013) 'Rechtsstaat und Rechtsstaatlichkeit in Germany'<https://wikis.fu-berlin.de/ display/SBprojectrol/Germany>

Komenský, Jan Amos (1663) Labyrint sveta a ráj srdce. Amsterdam ch. 15 in <http://www.oldlandmarks. com/labi5.htm>:

Kommers, Donald P. (ed.) (1997) The Constitutional Jurisprudence of the Federal Republic of Germany. 2 nd ed. Durham \& London: Duke University Press [xxi]+620 pp.

Kondor, Katalin (2005) Névjegy 2: Válogatás Kondor Katalin müsorából [Name card: selection from her \{radio\} programme]. Budapest: Masszi Kiadó 397 pp.

Konopczyński, Ladislas (1930) Le liberum veto: Étude sur le développement du principe majoritaire. Paris: Librairie Ancienne Honoré Champion \& Varsovie, etc.: Librairie Gebethner et Wolff 297 pp. [Institut d'Études slaves de l'Université de Paris, Bibliothèque polonaise II]

Kováts, Andor (1922) A büntetőjogi elévülés dogmatikája [The dogmatics of the statute of limitations in criminal law]. Szeged: Városi Nyomda VIII+176 pp.

Kovrig, Bennett (1995) 'Marginality Reinforced' in Barany, Zoltán, Völgyes, Iván (eds.) The Legacies of Communism in Eastern Europe. Baltimore \& London: Johns Hopkins University Press pp. 23-41

Krawietz, Werner, Varga, Csaba (eds.) (2003) On Different Legal Cultures, Pre-Modern and Modern States, and the Transition to the Rule of Law in Western and Eastern Europe. Berlin: Duncker \& Humblot xi+139-531 pp. [=(2002) Rechtstheorie, 33(2-4): II. Sonderheft Ungarn] 
Kronman, Anthony T. (1983) Max Weber Stanford: Stanford University Press 214 pp. [Jurists: Profiles in Legal Theory]

Kronman, Anthony T. (1993) The Lost Lawyer: Failing Ideals of the Legal Profession. Cambridge, Mass.: Belknap Press of the Harvard University Press viii+422 pp.

Kronman, Anthony T. (2007) Education's End: Why our Colleges and Universities have Given up on the Meaning of Life. New Haven, Conn.: Yale University Press xi+308 pp.

Krygier, Martin (2014) 'The Rule of Law after the Short Twentieth Century: Launching a Global Career' in Nobles, Richard, Schiff, David (eds.) Law, Society and Community: Essays in Honour of Roger Cotterrell. Farnham, Surrey: Ashgate pp. 327-346

Krygier, Martin Evald John (2015) 'Rule of Law (and Rechtsstaat)' in Wright, James D. (ed.) International Encyclopedia of the Social \& Behavioral Sciences. Vol. 20. 2nd edn. Oxford: Elsevier pp. 780-787 \& $<$ https://www.researchgate.net/publication/278412328_Rule_of_Law_and_Rechtsstaat>

Kubinyi, Ferenc (1994) Fekete lexikon: 1945-1956 [Black lexicon]. Budapest: [Malomfalvi] 303 pp.

Kulcsár, Kálmán (1992) Modernization and Law. Budapest: Akadémiai Kiadó 282 pp.

Kulcsár, Kálmán (2006) 'The New Political System and Hungarian Reality', Angewandte Sozialforschung, 24(3-4), pp. 187-200.

Kunstler, William (1969) 'Dissent and the Jury' in Berrigan, Daniel et al. (eds.) Delivered Into Resistance. New Haven, Conn.: The Advocate Press pp. 50-59

Kühn, Zdenek (2004) 'Worlds Apart: Western and Central European Judicial Cultures at the Onset of the European Enlargement', The American Journal of Comparative Law, 52(3), pp. 531-567

Lamm, Vanda, (2010) 'Some Thoughts on the Rule of Law in International Law', Yасопис Kиївського університету права [Kyiv], (2), pp. 297-303

Lamm, Vanda, Bragyova, András (ed.) (1992) Visszamenóleges igazságszolgáltatás [Ex post facto justice]. Budapest: MTA Állam- és Jogtudományi Intézete 110 pp. [Institute for Legal and Political Sciences of the Hungarian Academy of Sciences Working Papers 1]

Landor, Walter Savage (1851) Tyrannicide. [Published for the benefit of the Hungarians in America.] Bath: Meyler and son, printers [3 pp.]

Laquièze, Alain (2000) 'Le débat de 1964 sur l'imprescriptibilité des crimes contre l'humanité', Droits, (No.31), pp. 18-40

Las Casas, Bartolomé de (1971) A Selection of his Writings. Ed. Sanderlin, George. New York: Knopf x+209 pp. [Borzoi Books on Latin America]

Lautenbach, Geranne (2013) The Concept of the Rule of Law and the European Court of Human Rights. Oxford: Oxford University Press xxi+235 pp.

Lee, Leon H. (1990) The Historical and Literary Context of Henry David Thoreau's 'Civil Disobedience'. [D.A. thesis.] Murfirsboro, TN: Middle Tennessee State University 190 pp. [HOLLIS number: 990049006270203941]

Legrand, Pierre (1996) 'European Legal Systems Are not Converging', The International and Comparative Law Quarterly, 45(1), pp. 53-81

Legrand, Pierre (1999) Le droit comparé. Paris: Presses Universitaires de France 127 pp. [Que sais-je? 3478] Lehmann, Hartmut (2009) Die Entzauberung der Welt: Studien zu Themen von Max Weber. Göttingen: Wallstein $149 \mathrm{pp}$.

Lengyel, Emil (1934) The New Deal in Europe. New York \& London: Funk \& Wagnalls vi+312 pp.

Lenin, V. I. (1996) Imperialism, the Highest Stage of Capitalism (A Popular Outline). [1917.] London: Junius \& Chicago: Pluto lviii+132 
Lenoir, Yves (1993-1994) 'Bibliographie de Denijs Dille', Studia Musicologica Academiae Scientiarum Hungaricae, 35(1-3:Denijs Dille Nonagenario), pp. 7-33

Lewis, Angeline (2010) 'Defining the Rule of Law for Military Operations', Australian Year Book of International Law, 29, pp. 155-200 \& <http://www.austlii.edu.au/au/journals/AUYrBkIntLaw/2010/6.pdf>

Lewis, Anna Lisa Merklin (1990) Tyrannicide: Heresy or Duty? The Debates at the Council of Constance. Dumbarton Oaks vi+223 pp.

Leyret, Henry (ed.) (1900) Les jugements du président Magnaud. Paris: P.-V. Stock 346 pp. [Recherches sociales 4]

Leyret, Henry (ed.) (1903) Les nouveaux jugements du président Magnaud. Paris: Librairie C. ReinwaldSchleicher 246 pp. [Eklitra 84]

Lévai, Imre (2003) [review of Dupré (2003)] in Central European Political Science Review, 4(No.12), pp. 177-179

Lietzmann, Hans J. (2004) 'Die Europäische Union als »defekte Demokratie«? Rechtsstaat und Pfadabhängigkeit in Europa', Österreichische Zeitschrift für Politikwissenschaft, 33(1), pp. 19-30 \&<https:// webapp.uibk.ac.at/ojs/index.php/OEZP/article/view/1136/831>

Linz, Juan J[osé], Stepan, Alfred (1996) Problems of Democratic Transition and Consolidation: Southern Europe, South America and Post-Communist Europe. Baltimore: Johns Hopkins University Press $\mathrm{xx}+479 \mathrm{pp}$.

Livezeanu, Irina (?) 'Transcript of the closed “trial” of Nicolae and Elena Ceausescu, December, 1989' Making the History of 1989, Item \#690 <https://chnm.gmu.edu/1989/items/show/690>

Líndal, Sigurđur (1993) 'Law and Legislation in the Icelandic Commonwealth', Scandinavian Studies in Law, 37, pp. 55-92

Lomax, Bill (1997) 'The Strange Death of Civil Society in Post-communist Hungary', Journal of Communist Studies and Transition Politics, pp. 41-63

Lukács, Georg Prinzipienfragen einer heute möglich gewordenen Ontologie. [The last MS typed with autograph corrections in the Georg Lukács Archives of the Hungarian Academy of Sciences in $\mathrm{Bu}-$ dapest; <https://konyvtar.mta.hu/index_en.php?name=v_1_4_lukacs_archivum>], LAK M/153

Lukács, György (1976) A társadalmi lét ontológiájáról. \{On the Ontology of the Social Being\} Vol. I-III. Budapest: Magvető / Lukács, Georg (1984-1986) Zur Ontologie des gesellschaftlichen Seins. Vol. I-II. Darmstadt: Luchterhand [Georg Lukács Werke 13-14]

Lutaud, Olivier (1973) Des révolutions d'Angleterre à la Revolution française: Le tyrannicide \& Killing no murder: Cromwell, Athalie, Bonaparte. La Haye: Martinus Nijhoff xvi+463 pp. [Archives internationales d'histoire des idées 56]

Luzkow, Jack Lawrence (2003) The Revenge of History - Why the Past Endures: A Critique of Francis Fukuyama. Lewiston, N.Y.: Edwin Mellen Press ix+268 pp. [Problems in Contemporary Philosophy 57]

Lynch, William O. (1934) [review on Lengyel, 1934] Indiana Magazine of History, 30(2), pp. 203-204

Lyons, David (1984) Ethics and the Rule of Law. Cambridge: Cambridge University Press x+229 pp.

Łetowska, Ewa, Łetowski, Janus (1996) 'Poland: In Search of the "State of Law" and its Future Constitution' in Łetowska, Ewa, Łetowski, Janus (ed.) Poland: Towards to the Rule of Law. Warszawa: Wydawnictwo Naukowe Scholar 176 pp. [Institute of Legal Studies, Polish Academy of Sciences] on pp. 10-22

Macaulay, Thomas Babington (1895) 'Frederick the Great' [1842] in Macaulay, Thomas Babington Essays. [Popular edn.] London: Longmans pp. 791-834

MacCormick, Neil (1984) 'Der Rechtsstaat und die rule of law', Juristenzeitung, 39(January20)(2), pp. $65-70$ 
Macridis, Roy C. (1982) 'France: From Vichy to the Fourth Republic' in Herz (ed.), From Dictatorship..., 1982, pp. 161-178

Madách, Imre (1860) The Tragedy of Man. Trans. George Szirtes in <http://mek.oszk.hu/00900/00918/ html/madach15.htm>:; Trans. Ottó Tomschey in <https://mek.oszk.hu/00800/00876/00876.htm>; Trans. J. C. W. Horne in <https://mek.oszk.hu/00900/00915/html/madach15.htm

Majithia, Vishal (2006) 'Great Leaders are Made, not Born' (October 27) <https://www.flickr.com/ photos/vm1757/280433501>

Majoros, Ferenc (1993) Ungarische Verfassungsbarkeit seit 1990. Köln: Bundesinstitut für Ostwissenschaftliche und Internationale Studien iii+59 pp. [Berichte des Bundesinstituts für Ostwissenschaftliche und Internationale Studien 15]

Majtényi, László (2002) 'Lesz-e magánéletünk?' [Will we have a private life?] Élet és Irodalom, XLVI (29March), p. 13

Malamud-Goti, Faime 'Punishing Human Rights Abuses in Fledgling Democracies: The Case of Argentina' in Roht-Arriaza, Naomi (ed.) (1995) Impunity and Human Rights in International Law and Practice. New York: Oxford University Press xiii+398 pp. on pp. 160-170

Mann, Thomas (1933) 'Frederick the Great and the Grand Coalition: An Abstract for the Day and the Hour' [1914] in Mann, Thomas Three Essays. London: M. Secker 231 pp.

Marie, Jean-Bernard (2004) 'Specificités culturelles versus universalité des droits de l'homme: Quel défi?' in Kuçuradi, Ioanna (ed.) Threats to Human Rights in the Beginning of the Twenty-first Century. Ankara: Hacettepe University Centre for Research and Application of the Philosophy of Human Rights pp. $75-85$

Maritain, Jacques (1953) L'Homme et l'État. Paris: Presses Universitaires de France xiii+204 pp. Cf. also Fuller, Timothy, Hittinger, John P. (eds.) (2001) Reassessing the Liberal State: Reading Maritain's Man and the State. Washington, D.C.: American Maritain Association \& The Catholic University of America Press 260 pp.

Marmor, Andrei (2004) 'The Rule of Law and its Limits', Law and Philosophy, 23(1), pp. 1-43

Marx, Karl [1859] 'Vorwort zur Kritik der politischen Ökonomie' in Marx, Karl, Engels, Friedrich (1961) Werke. Vol. 13. Berlin[-East]: Dietz Verlag pp. 7-11 \&<http://www.mlwerke.de/me/me13/me13_007. htm>

Marx, Karl (1864) in [International Workingmen's Association] (ed.) (October.) General Rules. London [online]. Available at: <http://www.marxists.org/archive/marx/works/1864/letters/64_11_04-abs. htm> \& <http://www.marxists.org/archive/marx/iwma/documents/1864/rules.htm>204 pp.

Marx, Karl, Engels, Friedrich (1845-1846) The German Ideology [Die deutsche Ideologie]. Vol. I-II. 3rd rev. ed. Moscow: Progress Publishers, 1976. In original German, <http://www.mlwerke.de/me/ me03/me03_009.htm>

Marx, Karl, Engels, Friedrich (1932) Die deutsche Ideologie: Kritik der neuesten deutschen Philosophie in ihren Repräsentanten Feuerbach, B. Bauer u. Stirner u. des deutsches Sozialismus in seinen verschiedenen Propheten, 1845-1846. [Volksausgabe der ersten ungekürzten vollständigen Erstausgabe der MarxEngels-Verlag im Auftrag der Marx-Engels-Lenin-Institut Moskau.] Hrsg. Vladimir V. Adoratskij. Wien-Berlin: Verlag für Literatur u. Politik 636 pp.

Matsuo, Hiroshi (2005) 'The Rule of Law and Economic Development: A Cause or a Result?' in Matsuura, Yoshiharu (ed.) The Role of Law in Development: Past, Present and Future. Nagoya: Nagoya University Center for Asian Legal Exchange viii+110 pp. [CALE Books 2] on pp. 59-70

Matsuura, Y[oshihasu] (ed.) (2005) The Role of Law in Development: Past, Present and Future. Nagoya: Nagoya University viii+113 pp. [CALE Books 2] 
Mattei, Ugo (1997) Introducing Legal Change: Problems and Perspectives in Less Developed Countries. [Manuscript of a lecture delivered at the Session of World Bank Workshop on Legal Reform in Washington D. C. on April 14, 1997.] Berkeley - Trento 19 pp.

Mattei, Ugo, Nader, Laura (2008) Plunder: When the Rule of Law is Illegal. Oxford: Blackwell x+283 pp.

May, Christopher (2014) The Rule of Law: The Common Sense of Global Politics. Cheltenham \& Northhampton: Elgar xxxvii+234 pp.

McWilliams, Wilson Carey (1969) 'Civil Disobedience and Contemporary Constitutionalism: The American Case', Comparative Politics, I(2), pp. 11-27

Melkevik, Bjarne (1998) 'Penser le droit québécois entre culture et positivisme: Quelques considérations critiques' in Melkevik, Bjarne (ed.) Transformation de la culture juridique québecoise. Québec: Presses de l'Université Laval pp. 9-21

Melson, Robert (1996) Revolution and Genocide: On the Origins of the Armenian Genocide and the Holocaust. Chicago: The University of Chicago Press xxi+363 pp.

Merryman, John Henry, Clark, David S., Friedman, Lawrence M. (1979) Law and Social Change in Mediterranean Europe and Latin America: A Handbook of Legal and Social Indicators for Comparative Study. Stanford: Stanford University Press - Dobbs Ferry, N.Y.: Oceana xvi+618 pp. [Stanford Studies in Law and Development]

Meyer, Frank S. (1969) 'Libertarianism and Libertinism?', National Review, 21(September9), p. 910

Méndez, Juan E. (1997) 'Accountability for Past Abuses', Human Rights Quarterly, 19(2), pp. 225-282 \& $<$ https://digitalcommons.wcl.american.edu/facsch_lawrev/1696/>

Mihalicz, Csilla (1998) 'Interjú Sólyom Lászlóval, az Alkotmánybíróság volt elnökével' [Interview with László Sólyom, the ex-president of the Constitutional Court], BUKSz [Budapesti Könyvszemle], 10(4) \& <https://epa.oszk.hu/00000/00015/00012/09int.htm>, p. 437

Millán, Juan A. (1999) [review on Nino (1993)], The American Journal of International Law, 93, pp. 548-551

Miller, Arthur (1996) 'Why I Wrote “The Crucible”: An Artist's Answer to Politics', New Yorker, (October21), p. 158 \& <https://www.newyorker.com/magazine/1996/10/21/why-i-wrote-the-crucible>

Miller, David (2012) 'Grounding Human Rights', Critical Review of International Social and Political Philosophy, 15(4), pp. 407-427

Millon-Delsol, Chantal (1992) L'État subsidiaire - Ingérence et non-ingérence de l'État: le principe de subsidiarité aux fondements de l'histoire européenne. Chicago-London-Toronto: Encyclopaedia britannica 232 pp. [Léviathan]

Millon-Delsol, Chantal (1993) Le principe de subsidiarité. Paris: Presses Universitaires de France 127 pp. [Que sais-je? 2793]

Mirot, Léon (1933) L'assassinat de Louis duc d'Orléans et la théorie du tyrannicide au XV'e siècle. Paris: A. Picard $14 \mathrm{pp}$.

Mitchell, Michael (2012) 'National Suicide', Harvard International Review, (July 7) <http://hir.harvard. edu/article/?a=2957>

Molière (1668) L'Avare

Montesquieu [1748] De l'esprit des lois

Montgomery, John D. (1957) Forced to be Free: The Artificial Revolution in Germany and Japan. Chicago: The University of Chicago Press xiii+210 pp.

Moreso, J. J. (2012) 'Kelsen on Justifying Judicial Review' in Ramírez, Gonzalo Ecos de Kelsen: Vidas, obras y controversias. Bogotá: Editorial Universidad Externado de Colombia pp. 354-378 \{\&<https://ssrn. com/abstract $=2595560>$ \} 
Morton, Louis (1960) 'The Decision to Use the Atomic Bomb' in Greenfield, Kent Roberts, Office of the Chief of Military History (ed.) Command Decisions. Washington: U.S. Army viii+565 pp.

Mousnier, Roland (1973) The Assassination of Henry IV: The Tyrannicide Problem and the Consolidation of the French Absolute Monarchy in the Early Seventeenth Century. Trans. Joan Spencer. London: Faber and Faber 428 pp.

Møller, Jørgen, Skaaning, Svend-Erik (2014) The Rule of Law: Definitions, Measures, Patterns and Causes. London: Palgrave Macmillan xii+198 pp.

Mörth, Ulrika (2004) Soft Law in Governance and Regulation: An Interdisciplinary Analysis. Cheltenham Northampton: Edward Elgar ix+224 pp.

Müller, Adam H. (1809) Die Elemente der Staatskunst: Oeffentliche Vorlesungen... Vol. I-III. Berlin: J. D. Sander

Nagy, Péter N. (2007) 'A tőkétől a kerítésig' [From the capital to the fence], Népszabadság [People's Liberty - a daily], (February11) in <http://nol.hu/cikk/434884/>

Naoya cho, Endō (2014) Sofuto rō demokurashī ni yoru hōkaikaku. / Reform of Japanese Law via Soft Law Democracy. Tōkyō: Ātodeizu 103+158 pp.

Nedzel, Nadia E. (2014) 'Rule of Law v. Legal State: Where Have We Come from, Where Are We Going To?' in Silkenat, James R., Hickey, Jr., James E., Barenboim, Peter D. (eds.) The Legal Doctrines of the Rule of Law and the Legal State (Rechtsstaat). Cham: Springer xii+367 pp. [Ius gentium: Comparative perspectives on law and justice 38] on pp. 289-314

Newman, Jeffrey (2014), 'Hannah Arendt: Radical Evil, Radical Hope', European Judaism: A Journal for the New Europe, 47(1), pp. 60-71

Nietzsche, Friedrich (1891) Thus spake Zarathustra. [(1883) Also sprach Zarathustra.] Trans. Thomas Common. <http://eserver.org/philosophy/nietzsche-zarathustra.txt>]

Nietzsche, Friedrich (1885) Fröhliche Wissenschaft. [(1974) The Gay Science with a Prelude in Rhymes and an Appendix of Songs. Trans. Walter Kaufmann. New York: Random House xviii+396 pp.]

Nino, Carlos Santiago (1985) 'The Human Rights Policy of the Argentine Constitutional Government: A Reply', Yale Journal of International Law, 11(1), pp. 217-230

Nino, Carlos Santiago (1991) 'The Duty to Prosecute Past Abuses of Human Rights Put into Context: The Case of Argentina', Yale Law Journal, 100(8), pp. 2619-2640 \& <https://digitalcommons.law.yale. edu/ylj/volioo/iss8/11/>

Nino, Carlos Santiago (1993) 'When Just Punishment is Impossible' in Teitel, Ruti et al. (1993) Truth and Justice: The Delicate Balance (The Documentation of Prior Regimes and Individual Rights). Budapest: CEU Budapest College Legal Studies Program: The Institute for Constitutional and Legislative Policy 164 pp. [Working Paper 1] on pp. 67-74

Nino, Carlos Santiago (1996) Radical Evil on Trial. New Haven \& London: Yale University Press xii+221 pp.

Nisbet, Robert (2010) The Quest for Community: A Study in the Ethics of Order and Freedom. Wilmington, Del.: Isi Books xxxiii+330 pp.

Nobleman, Eli E. (1950) American Military Government Courts in Germany: Their Role in the Democratization of the German People. Ft. McPherson, Ga. X+261 pp. [U.S. Provost Marshal General's School, Camp Gordon]

Nojiri, Taketoshi (1999) 'Values as a Precondition of Democracy' in Zacher, Hans F. (ed.) Democracy: Some Acute Questions. (The Proceedings of the Fourth Plenary Session of the Pontifical Academy of Social Sciences, 22-25 April 1998.) Vatican City 450 pp. [Pontificiae Academiae Scientiarum Socialium Acta 4] on pp. 89-106

Novick, Peter (1968) The Resistance versus Vichy: The Purge of Collatorators in Liberated France. New York: Columbia University Press xv+245 pp. 
Nysanbayev, Abdumalik (2004) 'Kazakhstan. Cultural Inheritance and Social Transformation' in Kazakh Philosophical Studies I: Cultural Heritage and Contemporary Change Series IIIC Central Asia 2. Washington, D. C.: Council for Research in Values and Philosophy <http://www.crvp.org/book/ Serieso3/IIIC-2/chap-2.htm>

Oakeshott, Michael (1983) 'The Rule of Law' in Oakeshott, Michael On History and Other Essays. Totowa, N.J.: Barnes \& Noble 198 pp.

Offe, Claus (1997) 'Cultural Aspects of Consolidation: A Note on the Peculiarities of the Post-communist Transformation', East European Constitutional Review, 6(4), pp. 64-68

Olson, Walter K. (2003) The Rule of Lawyers: How the New Litigation Elit Threatens America's Rule of Law. New York: St. Martin's Press 358 pp.

Olson, Walter (2011) Schools for Misrule: Legal Academia and an Overlawyered America. New York: Encounter Books vi+428 pp.

Opałek, Kazimierz (1964) 'The Rule of Law and Natural Law' in Festskrift tillägnad Karl Olivecrona. Stockholm: Almquist and Wiksell 765 pp. on pp. 497-507

Opałek, Kazimierz (1999) 'The Rule of Law and Natural Law' in Opałek, Kazimierz Selected Papers in Legal Philosophy. Ed. Woleński, Jan Dordrecht \& Boston: Kluwer Academic Publishing viii+344 pp. [Law and Philosophy Library 39] on pp. 91-98 \& <https://link.springer.com/chapter/10.1007/978-94015-9257-4_7>

Oppenheim, Paul (1937) 'Von Klassenbegriffen zu Ordnungsbegriffen' in Bayer, Raymond (ed.) Travaux du IX ${ }^{e}$ Congrès International de Philosophie: Congrès Descartes. Vol. 9. Paris: Hermann [Actualités scientifiques et industrielles 530] pp. 69-76

Orentlicher, Diane F. (1991) 'Settling Accounts: The Duty to Punish Human Rights Violations of a Prior Regime', Yale Law Journal, 100(8), pp. 2537-2615

Orentlicher, Diane F. (1991) 'A Reply to Professor Nino', Yale Law Journal, 100(8), pp. 2641-2643 \&<https:// digitalcommons.law.yale.edu/ylj/volioo/iss8/12/>

Ortega y Gasset, José (1930) La Rebelión de las masas. Madrid: Revista de occidente 315 pp. \{\& (1932) Revolt of the Masses. London: Allen \& Unwin \& New York: Norton 204 pp.; Moore, Kenneth (ed.) (1985) Trans. Anthony Kerigan. Notre Dame: University of Notre Dame Press xxxi+192 pp.\}

Oshimura, Takashi (2000) 'In Defense of Asian Colors' in The Mansfield Center for Pacific Affairs (ed.) The Rule of Law: Perspectives from the Pacific Rim. Findlay, Ohio: The Mansfield Center for Pacific Affairs x+156 pp. \& <https://biblioteca.cejamericas.org/bitstream/handle/2015/993/mcpa-rule-lawpacific.pdf?sequence $=1 \&$ isAllowed $=y>$ on $p p .141-144$

Ozpolat, Asli, Guven, Gulsum Gunbala, Ozsoy, Ferda Nakipoglu, Bahar, Ayse (2016) 'Does Rule of Law Affect Economic Growth Positively?', Research in World Economy, 7(1) \& <http://www.sciedu.ca/ journal/index.php/rwe/article/view/9778>, pp. 107-117

Paine, Thomas (1776) Common Sense. <https://www.mtholyoke.edu/acad/intrel/paine.htm> \& <https:// sourcebooks.fordham.edu/mod/paine-common.asp>

Paine, Thomas [1791-1792] The Rights of Man. London: Daniel Esaac Eaton, 1795 vii+151 pp. as well as London: J. M. Dent \& Rutland: Charles E. Tuttle, 1993 xviii+238 pp. [Everyman's Library]

Pandeya, R. C. (1986) 'Human Rights: An Indian Perspective' in [UNESCO International Institute of Philosophy] (ed.) Philosophical Foundations of Human Rights. Paris: UNESCO 340 pp. at 267-277

Papp, Zsolt (1980) 'Bibó István: Társadalomelemzés és politika' [Social analysis and politics], Kritika, (11), pp. 11-15

Pasternak, Boris (1957) Доктор Живаго. Milan: Feltrinelli 
Patil, V.T. (1988) Mahatma Gandhi and the Civil Disobedience Movement: A Study in the Dynamics of the Mass Movement. Delhi: Renaissance Publishing House vi+224 pp.

Pattaro, Enrico (2007) The Law and the Right: A Reappraisal of the Reality that Ought to be. Dordrecht: Springer xxxiii+457 pp. [A Treatise of Legal Philosophy and General Jurisprudence I]

Pech, Laurent (2009) The Rule of Law as a Constitutional Principle of the European Union. New York: New York University School of Law 79 pp. [Jean Monnet Working Paper 03/09] \&<https://jeanmonnetprogram. org/paper/the-rule-of-law-as-a-constitutional-principle-of-the-european-union/>

Peerenboom, Randall (2004) 'Varieties of Rule of Law: An Introduction and Provisional Conclusion' in Peerenboom, Randall (ed.) Asian Discourses of Rule of Law: Theories and Implementation of Rule of Law in Twelve Asian Countries, France and the U.S. London \& New York: Routledge xxiii+479 pp. [Routledge Curzon Law in Asia 1] on pp. 1-53

Pennington, Kenneth (2018) 'Bartolomé de Las Casas' in Domingo, Rafael Martínez-Torrón, Javier (eds.) Great Christian Jurists in Spanish History. Cambridge: Cambridge University Press xiii+395 pp. [Law and Christianity] on pp. 98-115

Pereira, Anthony (1998) [review on Nino (1993)], The Americas: A Quarterly Review of Inter-American Cultural History, 54(3)

Perelman, Chaïm (1968) Droit, morale et philosophie. Paris: Librairie Générale de Droit et de Jurisprudence 149 pp. [Bibliothèque de Philosophie du Droit VIII]

Perelman, Ch[aïm] (1976) Logique juridique-Nouvelle rhétorique. Paris: Dalloz 193 pp. [Méthodes du droit]

Pérez-Díaz, Victor (1999) Spain at the Crossroads: Civil Society, Politics, and the Rule of Law. Cambridge, Mass.: Harvard University Press $\mathrm{x}+214 \mathrm{pp}$.

Péteri, Zoltán (1973) 'Új törekvések a jogállam-eszme körül' [New aspirations around the idea of the rule of law], Jogtudományi Közlöny, XXVIII(6), pp. 309-316

Pfahl-Traughber, Armin (2000) 'Also sprach Nietzsche: “Gott ist tot!”, Diesseits, (2) [online]. Available at: <http://www.dober.de/religionskritik/gott_ist_tot.html>

Phillips, Owen Hood, Jackson, Paul, Leopold, Patricia (eds.) (2001) Constitutional and Administrative Law. London: Sweet \& Maxwell cxxvi+855 pp.

Pildes, Richard H. (1996) 'The Desctruction of Social Capital through Law', University of Pennsylvania Law Review, 155(5), pp. 2055-2077

Placidus [Petersen], Johan Wilhelm (1798) Litteratur der Staatslehre: Ein Versuch. Strasbourg: [no printer] xiv+164 pp. \& <https://babel.hathitrust.org/cgi/pt?id=mdp.39015070881084\&view=1up\&seq=186>

Pokol, Béla (1995) Médiahatalom: Válogatott írások [Media Power: Selected writings]. Budapest: Windsor Kiadó 198 pp.

Pokol, Béla, Téglási, András (ed.) Die Stufenweise Entstehung des juristokratischen Staates / The Gradual Emergence of the Juristocratic State. Budapest: Dialóg Campus 206 pp.

Polanyi, Karl (1944) The Great Transformation: The Political and Economic Origins of Our Time. New York: Rinehart \& Co. xiii+305 pp. [Human Relations Collection]

Pollis, Adamantia, Schwab, Peter (1983) 'Human Rights: A Western Construct with Limited Applicability' in Pollis, Adamantia, Schwab, Peter (eds.) Human Rights: Cultural and Ideological Perspectives. New York: Praeger xvi+165 pp.

[Pontifical Council for Justice and Peace] (ed.) (2004) Compendium of the Social Doctrine of the Church. [online]. Available at: <https://www.vatican.va/roman_curia/pontifical_councils/justpeace/ documents/rc_pc_justpeace_doc_20060526_compendio-dott-soc_en.html>

Portalis, J. E. M. (1820) De l'usage et de l'abus de l'esprit philosophique durant le XVIII' siècle. $3^{e}$ éd. Paris, 1834 lxiii+404 pp. 
Portalis, Jean-Étienne-Marie (1836) 'Discours préliminaire' in Fenet, F. A. Recueil complet des travaux préparatoires du Code civil. Vol. I. Paris: Videcoq

Portalis, J. E. M. (1988) Écrits et discours juridique et politique. Aix-Marseille: Presses Universitaires d'AixMarseille $406 \mathrm{pp}$.

Posner, Eric A., Vermeule, Adrian (2004) 'Transitional Justice as Ordinary Justice', Harvard Law Review, 117(3), pp. 761-825 \& <https://chicagounbound.uchicago.edu/journal_articles/1742/>

Posner, Richard A. (1983) The Economics of Justice. Cambridge, Mass.: Harvard University Press xiii+415 pp.

Posner, Richard A. (1998) Economic Analysis of Law. New York: Aspen Law \& Business xxi+808 pp.

Pospíšil, Leopold (1974) Anthropology of Law: A Comparative Theory. New Haven: HRAF xiii+385 pp. at pp. $87-95$

Power, Paul F. (1970) 'On Civil Disobedience in Recent American Democratic Thought', The American Political Science Review, LXIV(1) pp. 35-47

Presa, Conceptión Gimena (1998) [review on Nino (1993)], Droit et Société, (No.38), pp. 145-149

Přibáň, Jiř́ (2001) 'Moral and Political Legislation in Constitutional Justice: A Case Study of the Czech Constitutional Court', The Journal of East European Law [Columbia University East European Law Center], 8(1), pp. 15-34

Pribán, Jiri (2003) [review of Dupré (2003)] in Legal Studies, 23(4), pp. 721-723

Prochazka, Radoslav (2002) Mission Accomplished: On Founding Constitutional Adjudication in Central Europe. Budapest - New York: Central European University Press xiv+358 pp.

Psomiades, Harry J. (1982) 'Greece: From the Colonels' Rule to Democracy' in Herz (ed.) (1982) From Dictatorship..., 1982, pp. 251-273

Radbruch, Gustav (1938) 'Klassenbegriffe und Ordnungsbegriffe im Rechtsdenken', Revue internationale de la Théorie du Droit, XII(1), pp. 46-54

Radin, Margaret Jane, Michelman, Frank (1991) 'Pragmatist and Poststructuralist Critical Legal Practice' University of Pennsylvania Law Review 139(4) pp. 1019-1058

Rau, Zbigniew, Grajewski, Przemysław Żurawski vel, Tracz-Tryniecki, Marek (eds.) (2016) Magna Carta: A Central European Perspective of our Common Heritage of Freedom. Abingdon, Oxon: Routledge xix+233 pp.

Rawls, John (1971) A Theory of Justice. Cambridge, Mass.: The Belknap Press of the Harvard University Press xv+607 pp.

Raz, Joseph (1979) 'The Rule of Law and its Virtue' [originally The Law Quarterly Review, 93 (1977)(2), pp. 198-202] in Raz, Joseph The Authority of Law: Essays on Law and Morality. Oxford: Clarendon Press ix+292 pp.

Raz, Joseph (1990) 'The Politics of the Rule of Law', Ratio Juris, 3(3), pp. 331-339

Redford, L. H. (ed.) (1977) The Occupation of Japan: Impact of Legal Reform. [The Proceedings of a Symposium.] Norfolk, Va.: MacArthur Memorial $212 \mathrm{pp}$.

Redstone, Anne (2010) 'Will Retrospective Taxes Affect us All? Analysis' [online]. Available at: <http:// news.bbc.co.uk/2/hi/business/8496921.stm>

Reid, John Philip (2004) The Rule of Law: The Jurisprudence of Liberty in the Seventeenth and Eighteenth Centuries. DeKalb, Ill.: Northern Illionis University Press 150 pp.

Reinsch II, Richard M. (2013) America's Rule of Law Sickness. <http://www.libertylawsite.org/2013/07/24/ americas-rule-of-law-sickness/>

Reményik, Sándor (1941) ‘Templom és iskola’ in Reményik, Sándor Összesversei [Complete Poems]. Vol. II. Budapest: Révai p. 334 \& <http://www.geocities.com/erdelyilobby/htm/remenyik.htm\#nehagyd> 
\& in <http://www.hungarianreview.com/article/20200121_a_nation_dismembered_selected_ poetry_part_i>.

Renteln, Alison Dundes (1988) 'Relativism and the Search for Human Rights', American Anthropologist, 90(1), pp. 56-72

Renteln, Alison Dundes (1990) International Human Rights: Universalism versus Relativism. London \& New Delhi: Sage Publications 205 pp. [Frontiers of Anthropology 6].

Reynolds, Noel B. (1989) 'Grounding the Rule of Law', Ratio Juris, 1(1), pp. 1-16 \&<https://www.academia. edu/16851582/Grounding_the_Rule_of_Law>

Reynolds, Noel B. (1994) 'Rule of Law in Legal and Economic Theory' in Kotsiris, L. E. (ed.) Law at the Turn of the Twentieth Century: International Conference Thessaloniki 1993. Thessaloniki: Sakkoulas v+404 pp. on pp. 357-376

Rodriguez, Daniel B., McCubbins, Mathew B., Weingast, Barry R. (2010) 'The Rule of Law Unplugged', Emory Law Journal, 59(6), pp. 1455-1494 \& <https://scholarlycommons.law.emory.edu/elj/vol59/ iss6/2/> \&<https://scholarship.law.duke.edu/cgi/viewcontent.cgi?referer=https://www.google.hu /\&httpsredir $=1 \&$ article $=5990 \&$ context=faculty_scholarship $>$

Rommen, Heinrich (1959) 'Natural Law in the Decisions of the Federal Supreme Court and of the Constitutional Courts in Germany', Natural Law Forum, IV, pp. 1-25 \& < https://scholarship.law. nd.edu/nd_naturallaw_forum/37/>

Rosenfeld, Michel, Guerra, Luis López, Geremek, Bronislaw, Neier, Aryeh (et al.) (1998) 'Conference on Peaceful Transition to Constitutional Democracy: Jacob Burns Institute for Advanced Legal Studies, April 8, 1997', Cardozo Law Review, 19(6), pp. 1891-1985

Rosenfeld, Michel, Sajó, András (eds.) (2012) The Oxford Handbook of Comparative Constitutional Law. Oxford: Oxford University Press xix+1396 pp. [Oxford Handbooks in Law]

Rosenzweig, Paul (2013) Cyber Warfare: How Conflicts in Cyberspace are Challenging America and Changing the World. Santa Barbara, Calif.: Praeger xi+290 [Changing Face of War]

Roshwald, Mordecai (1959) 'The Concept of Human Rights', Philosophy and Phenomenological Research, 19(3), pp. 354-379

Rothwax, Harold J. (1996) Guilty: The Collapse of Criminal Justice. New York: Random House xiv+238 pp.

Roubier, Paul (1929) Les conflits de lois dans le temps: Théorie dite de la nonretroactivité des lois. Vol. I. Paris: Recueil Sirey pp. 520-521

Rousseau, Jean-Jacques (1762) The Social Contract. [Du contrat social.] <https://www.marxists.org/ reference/subject/economics/rousseau/social-contract/cho2.htm>

Rowen, Herbert H. (1961) “L'État c'est à moi”: Louis XIV and the State', French Historical Studies [Duke University Press], II(1), pp. 83-98

Römeris, Mykolas (1928) 'Teisinès valstybès organizacija' [Organisation of the rule of law] in Lietuvos universitetas: 1927-1928 mokslo metais. [University of Lithuania: The academic year of 1927-1928.] Kaunas pp. 6-31

Rucker, Darnell (1966) 'The Moral Grounds of Civil Disobedience', Ethics, 76(2), pp. 142-145

(1959) Rule of Law as Understood in Western Countries / Le concept de la légalité dans les pays occidentaux. = Annales de la Faculté de droit d'Istanbul, IX(No.12), pp. 1-349

Rumi, Tamás (2005) 'Szembenézés a jogállam előtti múlttal - a német példa és tanulságai, különös tekintettel az elévülés kérdésére' [Confronting the past prior to the rule of law - the German example and lessons learned, with a special focus on the statute of limitations], Collega [Budapest], IX(4), pp. 45-51 
Rückert, Adalbert (1980) The Investigation of Nazi Crimes 1945-1978: A Documentation [Die Strafverfolgung nationalsozialistischer Verbrechen 1945 bis 1978]. Hamden, Conn.: Achron Book 145 pp.

Rüthers, Bernd (2014) Die heimliche Revolution vom Rechtsstaat zum Richterstaat: Verfassung und Methoden - Ein Essay. Tübingen: Mohr Siebeck ix+175 pp.

Sack, Peter (1987) 'Law \& Custom: Reflections on the Relations between English Law and the English Language', Rechtstheorie, 18(4), pp. 421-436.

Sadakata, 2006 = Sadakata, Mamoru (ed.) (2006) Hungary's Legal Assistance Experiences in the Age of Globalization. Nagoya: Nagoya University Graduate School of Law Center for Asian Legal Exchange $312 \mathrm{pp}$.

Sadoun, Mohamed (2011) Paul Magnaud, Ou le bon juge au service du pot de terre. Paris: Riveneuve 153 pp.

Sadurski, Wojciech (2003) 'Decommunisation', 'Lustration', and Constitutional Continuity: Dilemmas of Transitional Justice in Central Europe. Badia Fiesolana, San Domenico [Firenze]: European University Institute Department of Law 52 pp. [EUI Working Paper Law 2003/15]

Sadurski, Wojciech (2005) Rights before Courts: A Study of Constitutional Courts in Postcommunist States of Central and Eastern Europe. Dordrecht: Springer xix +377 pp.

Sajó, András (1995) 'Reading the Invisible Constitution: Judicial Review in Hungary', Oxford Legal Studies, 15(2), pp. 253-267\&<https://academic.oup.com/ojls/article/15/2/253/1446818?login=true>

Sajó, András (1997) 'Universal Rights, Missionaries, Converts and »Local Savages«', East European Constitutional Review, 6, pp. 44-49

Sajó, András (2004) 'Az emberi jogok mint tudásrendszer' [Human rights as a set of knowledge], Államés Jogtudomány, XLV(1), pp. 3-38

Sajó, András (2004) 'Universalism with Humility’ in Sajó, András (ed.) Human Rights with Modesty: The Problem of Universalism. Leiden \& Boston: M. Nijhoff viii+382 pp

Sajó, András (ed.) (1996) Western Rights? Post-communist Application. The Hague: Kluwer Law International xviii+386 pp.

Sampford, Charles (2006) Retrospectivity and the Rule of Law. Oxford: Oxford University Press xvii+308 pp.

Sanderson, M. A. (2004) [review of Dupré (2003)] in The Modern Law Review, 67(4), pp. 537-540

Santamaría, Julian (1982) 'Transición controlada y dificultades de consolidación: El ejemplo español' in Santamaría, Julian (ed.) Transición a la democracia en el sur de Europa y America Latina. Madrid: Centro de Investigaciones Sociologicas vii+421 pp. [Colección 'Monografias' 49] on pp. 371-417

Scalia, Antonin (1989) 'The Rule of Law as a Law of Rules', [Oliver Wendell Holmes Lecture at Harvard University (February 14, 1989)], University of Chicago Law Review, 56(4), pp. 1175-1188 \& <https:// chicagounbound.uchicago.edu/cgi/viewcontent.cgi?article $=4632 \&$ context=uclrev>

Schanda, Balázs (1995) 'Rechtsstaatlichkeit in Ungarn' in Hofmann, Rainer, Marko, Joseph, Merli, Franz, Wiederlin, Ewald (eds.) Rechtsstaatlichkeit in Europa. Heidelberg: Müller viii+340 pp. [Motive, Texte, Materialien 75] on pp. 219-235

Schivelbusch, Wolfgang (2006) Three New Deals: Reflections on Roosevelt's America, Mussolini's Italy, and Hitler's Germany, 1933-1939. New York: Metropolitan Books 242 pp.

Schlag, Pierre (1996) Laying down the Law: Mysticism, Fetishism, and the American Legal Mind. New York: New York University Press $\mathrm{x}+195 \mathrm{pp}$.

Schlag, Pierre (1997) 'Law as a Continuation of God by Other Means', California Law Review, 85(2) pp. 427-440 \& <http://scholarship.law.berkeley.edu/cgi/viewcontent.cgi?article=1625\&context=califo rnialawreview>

Schlag, Pierre (1998) The Enchantment of Reason. Durham: Duke University Press vii+160 pp. 
Schmitt, Carl (1922) Politische Theologie: Vier Kapitel zur Lehre von der Souverenität. Berlin \& Leipzig: Duncker \& Humblot 56 pp. <http://de.scribd.com/doc/81214206/schmitt-politische-theologie>

Schmitt, Carl (1932) Legalität und Legitimität. Berlin: Duncker \& Humblot 98 pp. [(1988) 4. \{reprint\} Ausgabe. Berlin: Duncker \& Humblot 98 pp.

Schneider, Peter (1956) 'Naturrechtliche Strömungen in deutscher Rechtssprechung' Archiv für Rechtsund Sozialphilosophie, 42(1), pp. 98-111

Scholler, Heinrich (ed.) (1996) Westliches Recht in der Republik Türkei: 70 Jahre nach der Gründung. BadenBaden: Nomos 174 pp. [Arbeiten zur Rechtsvergleichung 181]

Schwartz, Howard S. (2010), Society against Itself: Political Correctness and Organizational Self-destruction. London: Karnac Books xiv+216 pp.

Schooyans, Michel (1991) La dérive totalitaire du libéralisme. [Paris]: Éditions universitaires 358 pp. \{\& (1997) The Totalitarian Trend of Liberalism. St. Louis, Mo.: CCVA Central Bureau xi+262 pp.\}

Schooyans, Michel (1999) 'Droits de l'homme et démocratie à la lumière de l'enseignement social de l'Église' in Zacher, Hans F. (ed.) Democracy: Some Acute Questions. (The Proceedings of the Fourth Plenary Session of the Pontifical Academy of Social Sciences, 22-25 April 1998.) Vatican City 450 pp. [Pontificiae Academiae Scientiarum Socialium Acta 4] on pp. 47-56

Schooyans, Michel (2000) La face cachée de l'ONU. Paris: Le Sarment 283 pp. \{\& (2001) The Hidden Face of the United Nations. St. Louis, Mo.: CCVA Central Bureau xv+188 pp.

Schwartz, Herman (2000) The Struggle for Constitutional Justice in Post Communist Europe. Chicago: University of Chicago Press $\mathrm{xx}+347 \mathrm{pp}$. [Constitutionalism in Eastern Europe]

Sellers, Mortimer (2016) 'What is the Rule of Law and Why is it so Important?' in Goudappel, Flora A. N. J., Hirsch Ballin, Ernst M. H. (eds.) Democracy and Rule of Law in the European Union: Essays in Honor of Jaap W. de Zwaan. Berlin \& Heidelberg: Springer / Asser Press pp. 3-14

Selznick, Philip (1959) 'The Sociology of Law' in Merton, Robert K., Broom, Leonard, Cottrell, Leonard S. (ed.) Sociology Today: Problems and Prospects. New York: Basic Books pp. 125-127

Selznick, Philip (1968) 'The Sociology of Law' in Sills, David L. (ed.) International Encyclopedia of the Social Sciences. Vol. 9. New York: MacMillan and The Free Press pp. 50-59

Selznick, Philip (1999) 'Legal Cultures and the Rule of Law' in Krygier, Martin, Czarnota, Adam (eds.) The Rule of Law after Communism: Problems and Prospects in East-Central Europe. Aldershot \& Brookfield: Ashgate viii+344 pp. on pp. 21-38

Selznick, Philip (2005) 'Democracy and the Rule of Law', Syracuse Journal of International Law and Commerce, 33(1) \&<https://surface.syr.edu/jilc/vol33/iss1/4/>, pp. 29-39

Senden, Linda (2004) Soft Law in European Community Law. Oxford - Portland, Oregon: Hart Publishing lvi+533 pp. [Modern Studies in European Law 1]

Sereg, András (2005) Alkotmánybírák talár nélkül [Constitutional justices without robe]. Budapest: KJKKerszöv 299 pp. on pp. 165-197

Shklar, Judith N. (1986) Legalism: Law, Morals, and Political Trials. Cambridge, Ma.: Harvard University Press xiv+246 pp.

Shklar, Judith (1987) 'Political Theory and the Rule of Law' in Hutchinson, Allan C., Monahan, Patrick (eds.) The Rule of Law: Ideal or Ideology. Toronto: Carswell xiv+167 pp. on pp. 1-16

Shlapentokh, Vladimir (1995) Russia: Privatization and Illegalization of Social and Political Life. Michigan State University Department of Sociology [September 25] 44 pp. [NATO CND \{Chris Donally\} (95 459)] 
Silkenat, James R., Hickey Jr., James E., Barenboim, Peter D. (eds.) (2004) The Legal Doctrines of the Rule of Law and the Legal State (Rechtsstaat). Heidelberg: Springer xii+367 pp. [Ius Gentium: Comparative Perspectives on Law and Justice 38]

Slaughter, Anne-Marie (1994) 'A Typology of Transjudicial Communication', University of Richmond Law Review, 29(1), pp. 99-137 \& <https://scholarship.richmond.edu/lawreview/vol29/iss1/6/>

Smith, Steven D. (1993) 'Idolatry in Constitutional Interpretation', Virginia Law Review, 79(3) pp. 583-631 (2017) Soft law et droits fondamentaux: Actes du colloque du 4 et 5 février 2016. Paris: Pedone 318 pp. [Publications de l'Institut international des droits de l'homme 33]

Solzhenitsyn, Alexander I. (1978) A World Split Apart. (Commencement Address Delivered at Harvard University, June 8, 1978.) New York: Harper \& Row 61 pp. \& <https://www.solzhenitsyncenter. org/a-world-split-apart>

Sophocles [BCE 442] Antigone trans. R. C. Jebb in <http://classics.mit.edu/Sophocles/antigone.html>

Шопов, Ангел (2017) Soft law и съвременното право [Soft law and contemporary law]. София [Sofia]: Сиби 343 pp.

Sorokin, Pitirim A[leksandrovich] (1925) The Sociology of Revolution. Philadelphia \& London: J. B. Lippincott Company xii+428 pp. [Lippincott Sociological Series] \{reprint (1967) New York: H. Fertig\}.

Sólyom, László (1994) 'The Hungarian Constitutional Court and Social Change', Yale Journal of International Law, 19(1), pp. 223-237 \& <https://digitalcommons.law.yale.edu/yjil/volig/iss1/12/>

Sólyom, László (1995) 'Az Alkotmánybíróság hatáskörének sajátossága' [The specificity of the competence of the Constitutional Court] in Tanulmányok Benedek Ferenc tiszteletére [Festschrift for Ferenc Benedek]. Pécs: [Janus Pannonius Tudományegyetem Állam- és Jogtudományi Kar] pp. 5-34 [Studia Iuridica Auctoritate Universitatis Pécs publicata 123] as well as Sólyom, Azalkotmánybíráskodás kezdetei..., 2001, pp. 157-182

Sólyom, László (1996) 'Sur la coopération des cours constitutionnelles: Introduction à la Xème conférence des cours constitutionnelles européens' in Rapports généraux sur la séparation des pouvoirs et la liberté d'opinion dans la jurisprudence des cours constitutionnelles [Budapest, 6-9 mai] [ms]

Sólyom, László [interviewed] (1996) 'Teljesen átpolitizált lett a választás' [The elections became totally politicised], Magyar Narancs, VIII(November21), p. 47 in <http://www.mancs.hu/index. php?gcPage=/public/hirek/hir.php\&id=653>

Sólyom, László (2000) 'Introduction to the Decisions of the Constitutional Court of the Republic of Hungary' in Sólyom and Brunner, Constitutional Judiciary... pp. 41 et seq.

Sólyom, László (2001) Az alkotmánybíráskodás kezdetei Magyarországon [The beginnings of constitutional judiciary in Hungary]. Budapest: Osiris 799 pp. [Osiris tankönyvek]

Sólyom, László (2002) ‘Alkotmányértelmezés az új alkotmánybíróságok gyakorlatában’ [Constitutional interpretation in the practice of the new constitutional courts], Fundamentum, 6(2), pp. 18-28

Sólyom, László, Brunner, Georg (2000) Constitutional Judiciary in a New Democracy: The Hungarian Constitutional Court. Ann Arbor: The University of Michigan Press $\mathrm{x}+417 \mathrm{pp}$.

Sólyom, László, Brunner, Georg (eds.) (1995) Verfassungsgerichtsbarkeit in Ungarn: Analysen und Entscheidungssammlung 1990-1993. Baden-Baden: Nomos 634 pp.\}

Spengler, Oswald (1931) Der Mensch und die Technik: Beitrag zu einer Philosophie des Lebens. München: Beck v+88 pp. \{(1932) Man and Technics: A Contribution to a Philosophy of Law. Trans. Charles Francis Atkinson. New York: Knopf 104 pp.\}

Stahl, Friedrich Julius (1878) Rechts- und Staatslehre auf der Grundlage christlicher Weltanschauung. Heidelberg: Mohr 405 pp. \{reprinted (1963) Hildesheim: Olms [Philosophie des Rechts II]\} 
Stammler, Rudolf (1896) Wirtschaft und Recht nach der materialistischen Geschichtsauffassung: Eine sozialphilosophische Untersuchung. Leipzig: Veit viii+668 pp.

Starr, June (1978) Dispute and Settlement in Rural Turkey: An Ethnography of Law. Leiden: Brill xvi+304 pp. [Social, Economic, and Political Studies of the Middle East 23]

Stein, Ekkehart (1993) Staatsrecht. 14., völlig neu bearb. Aufl. Tübingen: Mohr xv+497 pp.

Stewart, Cameron (2004) 'The Rule of Law and the Tinkerbell Effect: Theoretical Considerations, Criticisms and Justifications for the Rule of Law', Macquarie Law Journal, 4, pp. 135-164 \& <http://www5. austlii.edu.au/au/journals/MqLJ/2004/7.html>

Stintzing, Johann August Roderich von (1875) Das Sprichwort »Juristen böse Christen « in seinen geschichtlichen Bedeutungen (Rede gehalten beim Antritt des Rectorates der Universität Bonn am 18. October 1875). Bonn: Adolph Marcus 32 pp.

Strasser, Christine (1983) August von Pettenkofen: Die Szolnoker Bilder. Salzburg 185 pp. [Salzburg Universität, geisteswissenschaftliche Dissertation]

Summers, Robert (1988) ‘The Ideal Socio-Legal Order: Its »Rule of Law« Dimension’, Ratio Juris, 1(2), pp. 154-161

Summers, Robert (1993) 'A Formal Theory of Rule of Law', Ratio Juris, 6(2), pp. 127-142

Swain, N[igel] (1992) Hungary: The Rise and Fall of Feasible Socialism. London: Verso 264 pp.

Sweet, Alec Stone (2010) Governing with Judges: Constitutional Politics in Europe. Oxford: Oxford University Press xii+232 pp.

Sweet, William (2001) 'Jeremy Bentham (1748-1832)' in Internet Encyclopedia of Philosophy [online]. Available at: <http://www.iep.utm.edu/bentham/>

Szabó, András (2000) 'Alkotmány és büntetôjog' [Constitution and criminal law. Budapest: MTA 11 pp. [Székfoglalók a Magyar Tudományos Akadémián]

Szabo, Denis (1995) Intégration normative et évolution de la criminalité. \{Lecture at a conference on value, behaviour, development, modernity, or the cultural factors of development and backwardness in development, as organised by the Institut de France [Paris] on September 16-17; manuscript [with the same title published in Boudon, Raymond, Chaunu, Pierre (eds.) (1996) Valeurs et modernité autour d'Alain Peyrefitte. Paris: Odile Jacob pp. 202-230]\}

Szabó, Imre (1966) 'Fundamental Questions concerning the Theory and History of Citizens' Rights' in Halász, József (ed.) Socialist Concept of Human Rights. Budapest: Akadémiai Kiadó 309 pp. at pp. 2-81

Szamuely, Tibor (1974) The Russian Tradition. Ed. Robert Conquest. London: Secker \& Warburg xi+443 pp.

Szászy, István (1938) 'A magánjogi jogszabályok időbeli hatálya: A törvény visszaható erejének problémája - Kísérlet egy új elmélet felállítására' [The temporal scope of private law provisions: The problem of the retroactivity of the statute - An attempt at a new theory], Magyar Jogászegyleti Értekezések és egyéb tanulmányok, VI(21), pp. 70-99 \& [off-print] Budapest: Attila Nyomda, 193818 pp.

Sztodolnik, László (1963) 'A jogállam eszméjének színeváltozásai' [The changing face of the idea of the rule of law], A Budapesti Eötvös Loránd Tudományegyetem Állam-és Jogtudományi Karának Actái, IV(1), pp. $143-163$

(1975) Die Szolnoker Malerschule. Wien: G. Gistel 126+40 pp.

Szücs, Jenő (1983) 'The Three Historical Regions of Europe', Acta Historica Academiae Scientiarum Hungaricae, 29(1-2), pp. 131-184 \{reprinted in Keane, John (1988) Civil Society and the State: New European Perspectives. London - New York: Verso 426 pp. on pp. 291-332 and in parts in Gessner, Volkmar, Hoeland, Armin, Varga, Csaba (eds.) (1996) European Legal Cultures. Aldershot, Brookfield USA, Singapore, Sydney: Dartmouth xviii+567 pp. [Tempus Textbook Series on European Law and European Legal Cultures I] on pp. 14-48\} 
Szúk, László (1991) A szeptemberi tanácskozás dokumentumai [Proceedings of the September meeting of the Criminal Lawyers' Club]. [ms] Budapest 141 pp.

Šejvl, Michal (2008) 'European Identity and European Citizenship: the Case of Missing Polis?', International Journal of Public Administration in Central and Eastern Europe [Budapest], 2(2), pp. 49-56

Taiwo, Olufemi (1999) 'The Rule of Law: The New Leviathan?', Canadian Journal of Law and Jurisprudence, 12(1), pp. 151-168

Takács, Albert (1986) 'A jogállam társadalmi és jogi feltételei' ['Social and legal conditions of the rule of law], Jogtudományi Közlöny, XLI(11), pp. 521-530

Takács, Péter (2001) “'A morális alkotmányértelmezésnek a szöveghez kötöttnek kell lennie”' [Moral constitutional interpretation has to be bound by the text], Fundamentum, 5(1) \&<https://epa.oszk. hu/02300/02334/00005/pdf/>, pp. 68-73

Takács, Péter (ed.) (1995) Joguralom és jogállam: Antológia a rule oflaw és a Rechtsstaat irodalmának köréból [Rule of law and Rechtsstaat: An Anthology]. Budapest: [Osiris-Századvég] 329 pp. [Jogfilozófiák / Philosophiae Iuris]

Tamanaha, Brian Z. (2004) On the Rule of Law: History, Politics, Theory. Cambridge \& New York: Cambridge University Press viii+180 pp.

Tate, C. Neal, Torbjörn, Vallinder (1995) The Global Expansion of Judicial Power. New York - London: New York University Press xii+556 pp.

Teitel, Ruti (1994) 'Paradoxes in the Revolution of the Rule of Law', Yale Journal of International Law, 19(1), pp. 239-247 \& <https://digitalcommons.law.yale.edu/yjil/volis/iss1/13/>

Teitel, Ruti (1997) 'Transitional Jurisprudence: The Role of Law in Political Transformation', The Yale Law Journal, 106(7), pp. 2009-2080\&<https://digitalcommons.law.yale.edu/ylj/volio6/iss7/2/>

Teubner, Gunther (1998) 'Legal Irritants: Good Faith in British Law or How Unifying Law Ends up in New Divergences,' The Modern Law Review, 61(1), pp. 11-32

Thoreau, Henry David (1966) Walden, and Civil Disobedience. Authoritative Texts, Background, Reviews, and Essays in Criticism. Ed. Owen Thomas. New York: W. W. Norton vi+424 pp. [A Norton Critical Edition]

Tiedemann, Arthur E. (1982) 'Japan Sheds Dictatorship' in Herz (ed.), From Dictatorship..., 1982, pp. $179-214$

Tiedemann, Paul (2014) 'The Rechtsstaat-Principle in Germany: The Development from the Beginning Until Now' in Silkenat, James R., Hickey, Jr., James E., Barenboim, Peter D. (eds.) The Legal Doctrines of the Rule of Law and the Legal State (Rechtsstaat). Cham: Springer xii+367 pp. [Ius gentium: Comparative perspectives on law and justice 38] on pp. 170-192

Tilk, Péter (2003) 'A jogállamiság és a jóerkölcs viszonya a Ptk. semmisségi szabályában' [The relationship of the rule of law to good morals in the nullity rule of the Civil code], Cég és jog, V(12), pp. 4-6

Tocqueville, Alexis de (1839) Democracy in America. [1840.] Transl. Henry Reeve in <https://www. marxists.org/reference/archive/de-tocqueville/democracy-america/ch16.htm>

Tolley, Howard B. (1994) The International Commission of Jurists: Global Advocates for Human Rights. Philadelphia: University of Pennsylvania Press xvii+355 pp. [Pennsylvania Studies in Human Rights]

Toranska, Teresa (1987) Oni: Stalin's Polish Puppets. [Oni (1985)] trans. Agnieszka Kolakowska. London: Collins Harwill 384 pp. / Torańska, Teresa (1987) »Them«: Stalin's Polish Puppets. [Oni (1985)] trans. Agnieszka Kolakowska. New York: Harper \& Row 384 pp. 
Tóth, János (1965) 'Le droit comparé dans l'Europe de l'Est', Revue de la Commission Internationale des Juristes, VI(2) \& <https://www.icj.org/wp-content/uploads/2013/08/ICJ-Journal-VI-2-1965-fra.pdf>, pp. $274-278$

Trnavci, Genc (2010) 'The Interaction of Customary Law with the Modern Rule of Law in Albania and Kosova' in Sellers, Mortimer, Tomaszewski, Tadeusz (eds.) The Rule of Law in Comparative Perspective. Dordrecht: Springer Science+Business Media B.V. xii+253 pp. [Ius Gentium: Comparative Perspectives on Law and Justice 3] on pp. 201-221

Troper, Michel (1993) 'Le Concept d'État de droit' Droits, (No.15), pp. 51-63

Trubek, David M. (1972) 'Toward a Social Theory of Law: An Essay on the Study of Law and Development', Yale Law Journal, 82(1), pp. 1-50

Trubek, David M., Galanter, Marc (1974) 'Scholars in Self-estrangement: Some Reflections on the Crisis in Law and Development Studies in the United States', Wisconsin Law Review, (4), pp. 1062-1102

Trujillo, Isabel 'Human Rights, Peace, and the Concept of Law: The Story of an Incomplete Legal Revolution', [Plenary lecture at the International Association for Philosophy of Law and Social Philosophy XXVIII World Congress, Lisboa (July 20, 2017)] published as Тружильо, I. (2019) 'Права людини, мир та поняття права. Історія незавершеної правової революції', Філособія nрава і загальна теорія права / Philosophy of Law and General Theory of Law [Kharkov], (1), pp. 175-200 \&<http://phtl.nlu.edu.ua/article/view/186525>

Turchetti, Mario (2001) Tyrannie et tyrannicide de l'Antiquité à nos jours. Paris: Presses Universitaires de France 1044 pp. [Fondements de la politique: Essais]

Udvaros, Judit (2002) 'Landesbericht Ungarn' in Strafrecht in Reaktion aufSystemunrecht. Vol. 5: Weigend, Ewa, Zoll, Andrzej, Udvaros, Judit Polen-Ungarn. Freiburg im Breisgau: Iuscrim xii+361 pp. [Beiträge und Materialien aus dem Max-Planck-Institut für Ausländisches und Internationales Strafrecht Freiburg i. Br. 82:5] on pp. 151-357

Uitz, Renáta (2004) [review of Dupré (2003)] 'Az emberi méltósághoz való jog és a magyar demokratikus átmenet' [The right to human dignity and the Hungarian democratic transition], Fundamentum, (1), pp. 216-220

[US Department of the Army Field Manual 100-23] (1994) Peace Operations. (December.) vi+131 pp. \& <http://www.dtic.mil/doctrine/jel/service_pubs/fm10o_23.pdf>

[US Department of the Army Field Manual 3-07 (Field Manual 100-20)] (2003) Stability Operations and Support Operations. (February.) [4-106] <http://www.globalsecurity.org/military/library/policy/ army/fm/3-07/fm3-07.pdf>

Utz, Arthur Fridolin (1975) Zwischen Neoliberalismus und Neomarxismus: Die Philosophie des Dritten Weges. Cologne: P. Hanstein 184 pp. [Gesellschaft, Kirche, Wirtschaft 8]

Vaišvila, Alfonsas (1999) 'Место наказания в правовом государстве' [Place of punishment in a legal state] in Проблеми вдосконаления законодавства та практика його застосувания з урахуванням прогнозу злочинности. Vol. 1. Луганськ pp. 44-49 [Вісник Луганського інституту внутрішніх справ МВС Украіни]

Vaišvila, Alfonsas (2000) 'Социальное правовое государство: Приобретаемая и теряемая реальность' [Welfare legal state as acquired and lost reality] in Конституиионно-правовое проблемы бормирования социального правового государства. (Материалы международной конференции.) Минск: Белорусский государственный университет рр. 24-28

Vaišvila, Alfonsas (2000) Teisinés valstybès koncepcija lietuvoje. [The Lithuanian approach to rule of law.] Vilnius: Litimo 647 pp. [summary: 'Law-governed State and its Problems of the Formation in Lithuania: The Outline of State Ideology', pp. 611-631] 
Vaišvila, Alfonsas (2001) Conception of the State Ruled by Law in Lithuania. (Summary of the research report presented for habilitation.) Vilnius: The Law University of Lithuania 50 pp.

Vaišvila, Alfonsas (2004) 'The Historical Input of Lithuania in the Creation of the Concept of the State under the Rule of Law', Jurisprudencija, 50(No.42), pp. 74-87

Vaišvila, Alfonsas (2005) 'Legal Personalism: A Theory of the Subjective Right' in Szilágyi, István H., Paksy, Máté (eds.) Ius unum, lex multiplex - Liber Amicorum: Studia Z. Péteri dedicata. (Studies in Comparative Law, Theory of State and Legal Philosophy. Budapest: Szent István Társulat 573 pp. [Philosophiae Iuris / Bibliotheca Iuridica: Libri amicorum 13] on pp. 557-572

Vaišvila, Alfonsas (2008) 'Dviguba Pilietybè - ne tik dvigubos teisès' [Double citizenship - not only Rights are Double] Jurisprudencija, 7(No.109), pp. 7-13

Vaišvila, Alfonsas (2009) 'Human Dignity and the Right to Dignity in Terms of Legal Personalism (from Conception of Static Dignity to Conception of Dynamic Dignity)' Jurisprudencija, 3(No.117), pp. 111-127 \& <https://search.proquest.com/openview/fadb79d2ea998601ffeoered9421265d/1. pdf?pq-origsite $=$ gscholar\&cbl $=2026708>$

Vaišvila, Alfonsas (2012) "Other Forms of Family", or an Attempt to Tailor the Notion of Family to an Individual's Subjectivity' Socialiniu Mokslu Studijos, 4(3), pp. 953-972

Vanwelkenhuyzen, A. (1968) 'De quelques lacunes du droit constitutionnel belge' in Perelman, Ch[ä̈] Le problème des lacunes en droit. Brussels: Bruylant pp. 339-360 [Travaux du Centre de Recherches de Logique] at pp. 347-350

Varga, Csaba (1970) [review of Fuller, The Morality of Law, 1963], Acta Juridica Academiae Scientiarum Hungaricae, XII(3-4) \&<http://real-j.mtak.hu/787/1/ACTAJURIDICA_12.pdf>, pp. 449-450

Varga, Csaba (1970) [reviews] Jogi Tudósító [Legal reporter] [Budapest], I(13-14), pp. 27-32

Varga, Csaba (1973) 'On the Socially Determined Nature of Legal Reasoning' in Perelman, Ch[aïm] (ed.) Études de logique juridique. Vol. V. Bruxelles: Établissements Émile Bruylant 296 pp. [Travaux de Centre National de Recherches de Logique] on pp. 21-78 \{reprinted in <http://mek.oszk. hu/15300/15333/\#>, pp. 317-374\}

Varga, Csaba (1973) 'Quelques questions méthodologiques de la formation des concepts en sciences juridiques', Archives de Philosophie du Droit, XVIII, pp. 205-241 \{reprinted in <http://mek.oszk. hu/15300/15333/\#>, pp. 7-33\}

Varga, Csaba (1979) 'Law and its Approach as a System', Acta Juridica Academiae Scientiarum Hungaricae, 21(3-4), <http://real-j.mtak.hu/769/1/ACTAJURIDICA_21.pdf>, pp. 295-319 \{reprinted in (1981) Informatica e Diritto, VII(2-3) \& <http://www.ittig.cnr.it/EditoriaServizi/AttivitaEditoriale/Informa ticaEDiritto/1981_02-03_177-199_Varga.pdf>, pp. 177-199\}

Varga, Csaba (1981) 'Logic of Law and Judicial Activity: A Gap between Ideals, Reality, and Future Perspectives' in Péteri, Zoltán, Lamm, Vanda (eds.) Legal Development and Comparative Law. Budapest: Akadémiai Kiadó 365 pp. on pp. 45-76 \{reprinted in <http://mek.oszk.hu/15300/15333/\#>, pp. $257-288\}$

Varga, Csaba (1981) 'Towards a Sociological Concept of Law', International Journal of the Sociology of Law, 9(2), pp. 157-176

Varga, Csaba (1982) 'Lenin and Revolutionary Law-making' International Review of Contemporary Law [Brussels], (1), pp. 47-59 \{reprinted in <http://mek.oszk.hu/15300/15333/\#>, pp. 515-527\}

Varga Csaba, (1984) 'Moderne Staatlichkeit und modernes formales Rechts', Acta Juridica Academiae Scientiarum Hungaricae, 26(1-2), pp. 235-241 \{reprinted in <http://mek.oszk.hu/15500/15540>, 116-122\} Varga, Csaba (1985) 'Reflections on Law and on its Inner Morality', Rivista internazionale di Filosofia del diritto, LXII(3), pp. 439-451 \{reprinted in <http://mek.oszk.hu/15300/15333/\#>, pp. 77-89\} 
Varga, Csaba (1986) 'Macrosociological Theories of Law: From the "Lawyer's World Concept" to a Social Science Conception of Law' in Kamenka, Eugene, Summers, Robert S., Twining, William (eds.) Soziologische Jurisprudenz und realistische Theorien des Rechts. Berlin: Duncker \& Humblot xvi+381 pp. [Rechtstheorie Beiheft 9] pp. 197-215 \{reprinted in <http://mek.oszk.hu/15300/15333/\#>, pp. 43-76\}

Varga, Csaba (1987) 'Leibniz und die Frage der rechtlichen Systembildung' in Mollnau, Karl A. (ed.) Materialismus und Idealismus im Rechtsdenken: Geschichte und Gegenwart. Stuttgart: Franz Steiner Verlag Wiesbaden 195 pp. [Archiv für Rechts- und Sozialphilosophie, Beiheft 31] on pp. 114-127 \{reprinted in <http://mek.oszk.hu/15500/15540/>, pp. 123-136\}

Varga, Csaba (1988) 'Anthropological Jurisprudence? Leopold Pospíšil and the Comparative Study of Legal Cultures' in Law in East and West: On the Occasion of the $30^{\text {th }}$ Anniversary of the Institute of Comparative Law. Tokyo: Waseda University Press pp. 265-285 \{reprinted in <http://mek.oszk. hu/15300/15333/\#>, pp. 437-457\}

Varga, Csaba (1989) 'Liberty, Equality, and the Conceptual Minimum of Legal Mediation' in MacCormick, Neil, Bankowski, Zenon (eds.) (1989) Enlightenment, Rights and Revolution: Essays in Legal and Social Philosophy. Aberdeen: Aberdeen University Press pp. 229-251 \{reprinted in <http://mek. oszk.hu/14700/14760/>, pp. 38-61\}

Varga, Csaba (1992) 'The Law and its Limits' Acta Juridica Academiae Scientiarum Hungaricae, 34(1-2), pp. 49-56 \{reprinted in <http://mek.oszk.hu/15300/15333/\#>, pp. 91-96\}

Varga, Csaba (1993) 'The Dilemma of Enforcing the Law' in Aarnio, Aulis, Paulson, Stanley L., Weinberger, Ota, von Wright, Georg Henrik, Wyduckel, Dieter (eds.) Rechtsnorm und Rechtswirklichkeit: Festschrift für Werner Krawietz zum 60. Geburtstag. Berlin: Duncker \& Humblot pp. 427-435 \{reprinted in <http://mek.oszk.hu/14700/14760/> on pp. 136-143 at p. 139\}

Varga, Csaba (1993) 'Transformation to Rule of Law from No-law: Societal Contexture of the Democratic Transition in Central and Eastern Europe', The Connecticut Journal of International Law, 8(2), pp. 487-505

Varga, Csaba (1994) 'Kelsen's Theory of Law-application: Evolution, Ambiguities, Open Questions', Acta Juridica Hungarica, 36(1-2) \& <http://real-j.mtak.hu/784/1/ACTAJURIDICA_36.pdf>, pp. 3-27

Varga, Csaba (1994) Law and Philosophy: Selected Papers in Legal Theory. (Budapest: ELTE 'Comparative Legal Cultures' Project xi +530 pp. [Philosophiae Iuris] \& <http://mek.oszk.hu/15300/15333/\#>

Varga, Csaba (1994) 'Preface' in Varga, Csaba (ed.) Coming to Terms with the Past under the Rule of Law: The German and the Czech Models. Budapest xxvii+178 pp. [Windsor Klub] \& <http://mek.oszk. $\mathrm{hu} / 14300 / 14310 / 14310 . p d f>$ on pp. xii-xviii

Varga, Csaba (1995) 'The Nature of the Judicial Application of Norms (Science- and Language-philosophical Considerations)' in Varga, Csaba (1994) Law and Philosophy: Selected Papers in Legal Theory. (Budapest: ELTE 'Comparative Legal Cultures' Project xi + 530 pp. [Philosophiae Iuris] \& <http:// mek.oszk.hu/15300/15333/\#>, pp. 295-314

Varga, Csaba (1995) Transition to Rule of Law: On the Democratic Transformation in Hungary. (Budapest: 'ELTE Comparative Legal Cultures' Project 190 pp. [Philosophiae Iuris] \& < http://mek.oszk. $\mathrm{hu} / 14700 / 14760 />$

Varga, Csaba (1999) 'Ex Post Facto Legislation' in Gray, Christopher Berry (ed.) The Philosophy of Law: An Encyclopedia. New York \& London: Garland Publishing [Garland Reference Library of the Humanities 1743] \& <https://b-ok.xyz/book/2642769/8c5190> on pp. 274-276

Varga, Csaba (2002) 'Structures in Legal Systems: Artificiality, Relativity, and Interdependency of Structuring Elements in a Practical (Hermeneutical) Context', Acta Juridica Hungarica, 43(3-4) \& in <http://real-j.mtak.hu/757/1/ACTAJURIDICA_43.pdf>, pp. 219-232 
Varga, Csaba (2003) 'Buts et moyens en droit' in Loiodice, Aldo, Vari, Massimo (eds.) Giovanni Paolo II: Le vie della giustizia - Itinerari per il terzo millennio (Omaggio dei giuristi a Sua Santità nel XXV anno di pontificato). Roma: Bardi Editore - Libreria Editrice Vaticana pp. 71-75 and, as expanded, Varga, Csaba (2005) 'Goals and Means in Law: or Janus-faced Abstract Rights' in Jurisprudencija [Vilnius: Mykolo Romerio Universitetas], 68(60), pp. 5-10 \& <https://intranet.mruni.eu/en/mokslo_darbai/ jurisprudencija/archyvas/?l=120712>

Varga, Csaba (2003) 'Búcsúírás' [Farewell letter] in Boros, Emese, Ohlendorff, Nóra (eds.) Pázmány Péter Katolikus Egyetem Jog-és Államtudományi Kar: 2003-ban végzettek évkönyve. [Yearbook of the class graduating at the Faculty of Law of Pázmány Péter Catholic University in 2003.] Budapest:Alumni pp. 119-122 \{reprinted in <http://mek.oszk.hu/18900/18995/18995.pdf>, 563-566\}

Varga, Csaba (2003) 'Meeting Points between the Traditions of English-American Common Law and Continental-French Civil Law (Developments and Experience of Postmodernity in Canada)', Acta Juridica Hungarica, 44(1-2), pp. 21-44 \& <https://akjournals.com/view/journals/026/44/1-2/ article-p21.xml>

Varga, Csaba (2003) 'What is to Come after Legal Positivisms are Over? Debates Revolving around the Topic of "The Judicial Establishment of Facts"' in Atienza, Manuel, Pattaro, Enrico, Schulte, Martin, Topornin, Boris, Wyduckel, Dieter (eds.) Theorie des Rechts und der Gesellschaft: Festschrift für Werner Krawietz zum 70. Geburtstag. Berlin: Duncker \& Humblot pp. 657-676 \{reprinted in <http:// mek.oszk.hu/15500/15540>, pp. 271-301\}

Varga, Csaba (2005) 'Change of Paradigms in Legal Reconstruction (Carl Schmitt and the Temptation to Finally Reach a Synthesis)' in Peter Wahlgren (ed.), Perspectives on Jurisprudence: Essays in Honor ofJes Bjarup. Stockholm: Stockholm Institute for Scandinavian Law [= Scandinavian Studies in Law, 48] pp. 517-529 \&<http://www.scandinavianlaw.se/pdf/48-31.pdf>

Varga, Csaba (2005) 'Legal Traditions? In Search for Families and Cultures of Law', Acta Juridica Hungarica 46(3-4), pp. 177-197 and in Moreso, José Juan (2007) Legal Theory: Legal Positivism and Conceptual Analysis (Proceedings of the $22^{\text {nd }}$ IVR World Congress Granada 2005). Vol. I. Stuttgart: Steiner 263 pp. [ARSP Beiheft 106] on pp. 181-193 \{reprinted in <http://mek.oszk.hu/15300/15386>, pp. 77-97\}

Varga, Csaba (2005) 'Rule of Law - At the Crossroads of Challenges', Iustum, Aequum, Salutare, I(1-2), pp. 73-88 \& <http://ias.jak.ppke.hu/hir/ias/20051sz/20051.pdf>

Varga, Csaba (2005) 'Visszavont emberi teljesség? Eszmeuralom és tetszőlegesség' [Fullness of being withdrawn? Ideocracy \& arbitrariness], PoLiSz, (No.82), pp. 14-21 \{reprinted in \& <http://mek. oszk.hu/17900/17995/17995.pdf>, pp. 17-26\}

Varga, Csaba (2006) 'Transition to Rule of Law: A Philosophical Assessment of Challenges and Realisations in a Historico-comparative Perspective' in Varga, Csaba On Transfers, Transition, and Renovation of Law. [Papers in Sadakata, Mamoru (ed.) Hungary's Legal Assistance Experiences in the Age of Globalization. Nagoya: Center for Asian Legal Exchange \{of the\} Graduate School of Law, Nagoya University.] \& <http://mek.oszk.hu/17500/17543> on pp. 185-214

Varga, Csaba (2007) 'Development of Theoretical Legal Thought in Hungary at the Turn of the Millennium' in Takács, Péter, Jakab, András, Tatham, Allan F. (eds.) The Transformation of the Hungarian Legal Order 1985-2005: Transition to the Rule of Law and Accession to the European Union. Alphen aan den Rijn: Kluwer Law International xviii+673 pp. on pp. 632-654 \& <https://core.ac.uk/download/ pdf/18405810.pdf>

Varga, Csaba (2007) 'Differing Mentalities of Civil Law and Common Law? The Issue of Logic in Law', Acta Juridica Hungarica, 48(4), pp. 401-410 \& <https://akjournals.com/view/journals/026/48/4/ article-p401.xml> 
Varga, Csaba (2007) 'Reception of Legal Patterns in a Globalising Age' in Calera, Nicolás López (ed.) Globalization, Law and Economy / Globalización, Derecho y Economía: Proceedings of the $22^{\text {nd }}$ IVR World Congress. Vol. IV. Stuttgart: Franz Steiner Verlag, pp. 85-96 [ARSP Beiheft 109] \{reprinted in $<$ http://mek.oszk.hu/15300/15386>, pp. 181-207\}

Varga, Csaba (2008) 'Creeping Renovation of Law through Constitutional Judiciary?' in Varga, Csaba Transition? To Rule of Law? Constitutionalism and Transitional Justice Challenged in Central \& Eastern Europe. Pomáz: Kráter 292 pp. [PoLíSz sorozat könyvei 7] on pp. 117-160 \& <http://mek.oszk. $\mathrm{hu} / 14800 / 14851>$

Varga, Csaba (2008) 'Doctrine and Technique in Law', Iustum Aequum Salutare, IV(1), pp. 23-37 \&<http:// ias.jak.ppke.hu/hir/ias/20081sz/02.pdf>

Varga, Csaba (2008) 'Failed Crusade: American Self-confidence, Russian Catastrophe' in Varga, Csaba Transition? To Rule of Law? Constitutionalism and Transitional Justice Challenged in Central \& Eastern Europe. Pomáz: Kráter 292 pp. [PoLíSz sorozat könyvei 7] on pp. 199-219 \& <http://mek.oszk. $\mathrm{hu} / 14800 / 14851>$

Varga, Csaba (2008) 'Jogi kultúránk - európai és globális távlatban' [Our legal culture in a European and global perspective] in Paksy, Máté (ed.) Európai jog és jogfilozófia: Tanulmányok az európai integráció ötvenedik évfordulójának ünnepére [European law and legal philosophy: Papers to the fiftieth anniversary of European integration]. Budapest: Szent István Társulat 397 pp. [Jogfilozófiák] on pp. 13-42 \{reprinted in <https://mek.oszk.hu/15100/15173>, pp. 5-32\}

Varga, Csaba (2008) 'Judicial Black-box and the Rule of Law in the Context of European Unification and Globalisation', Acta Juridica Hungarica, 49(4) \& in <http://real-j.mtak.hu/763/1/ACTAJURIDICA_49. pdf>, pp. 469-482

Varga, Csaba (2008) Transition? To Rule of Law? Constitutionalism and Transitional Justice Challenged in Central \& Eastern Europe. Pomáz: Kráter 292 pp. [PoLíSz sorozat könyvei 7] \& <http://mek.oszk. $\mathrm{hu} / 14800 / 14851>$

Varga, Csaba (2008) 'Transition Marshalled by Constitutional Court Dicta under the Cover of a Formal Rule of Law (A Case-study of Hungary)', Central European Political Science Review, 9(No.32), pp. 9-48 \{reprinted in \& <http://mek.oszk.hu/14800/14851>, pp. 117-160\}

Varga, Csaba (2008) 'What has Happened and What Is Happening ever since (In Remembrance of Deportations to Forced Work Camps at Hortobágy)' in Varga, Csaba (2008) Transition? To Rule of Law? Constitutionalism and Transitional Justice Challenged in Central \& Eastern Europe. Pomáz: Kráter 292 pp. [PoLíSz sorozat könyvei 7] \& <http://mek.oszk.hu/14800/14851> on pp. 173-174

Varga, Csaba (2009) Jogrendszerek, jogi gondolkodásmódok az európai egységesülés perspektívájában (Magyar körkép - európai uniós összefüggésben) [Legal systems and legal mentalities in the perspective of European unification: Hungarian overview in a European Union context]. Budapest: Szent István Társulat 282 pp. [Jogfilozófiák] \&<http://mek.oszk.hu/15100/15173>

Varga, Csaba (2009) 'Kényszeredetten bolyongunk' [Constrained, we are wandering], de Jure, X(11), pp. 2-7 \{reprinted in <http://mek.oszk.hu/15100/15175>, pp. 163-174\}

Varga, Csaba (2009) 'A kontinentális és az angolszász jogi mentalitás jövője az Európai Unióban' [The future of Continental and Anglo-Saxon legal mentality in the European Union], Jura, 15(1), pp. 133-142

Varga, Csaba (2009) 'The Quest for Formalism in Law: Ideals of Systemicity and Axiomatisability between Utopianism and Heuristic Assertion', Acta Juridica Hungarica, 50(1), pp. 1-30 \& <https:// akjournals.com/view/journals/026/50/1/article-p1.xml> 
Varga, Csaba (2010) 'Rule of Law? Mania of Law? On the Boundary between Rationality and Anarchy in America’ in Nótári, Tamás, Török, Gábor (eds.) Prudentia Iuris Gentium Potestate: Ünnepi tanulmányok Lamm Vanda tiszteletére [Festschrift to Vanda Lamm]. Budapest: MTA Jogtudományi Intézete 530 pp. on pp. 492-504 \{reprinted in <http://mek.oszk.hu/15300/15386>, pp. 165-180\}

Varga, Csaba (2011) Codification as a Socio-historical Phenomenon. [1979/1991.] 2nd \{reprint\} edn. with an Annex \& Postscript. Budapest: Szent István Társulat viii+431 pp. \& <http://mek.oszk. $\mathrm{hu} / 14200 / 14231 />$

Varga, Csaba (2011) 'Coming to Terms with the Past under the Rule of Law: Principles and Constitutional Assessments (A Case-study of Hungary)' in Liu, Shing-I, Neumann, Ulfried (eds.) Gerechtigkeit-Theorie und Praxis / Justice-Theory and Practice. Baden-Baden: Nomos 250 pp. on 215-235 \{\& <http://www.pdcnet.org/85257DC10065CC7E/file/949464782A886926C1257DC5005582A8/ \$FILE/hce_2013_0004_0000_0022_0043.pdf>\}

Varga, Csaba (2011) 'The Philosophy of the Construction and Operation of European Law', Rivista internazionale di Filosofia del Diritto [Roma], LXXXVIII(3), pp. 313-344 \{reprinted in <http://mek.oszk. $\mathrm{hu} / 15400 / 15409>$, pp. 307-354\}

Varga, Csaba (2011) Theory of the Judicial Process: The Establishment of Facts. [1992/1995.] $2^{\text {nd }}$ \{reprint\} ed. with Postfaces I and II (Budapest: Szent István Társulat 2011) viii + $308 \&<$ http://mek.oszk. $\mathrm{hu} / 15500 / 15540>$

Varga, Csaba (2011) Válaszúton - húsz év múltán: Vitákjogunk alapjairólés céljairól [At the crossroads again: After twenty years; Debating the foundations and destinations of our law]. Pomáz: Kráter 256 pp. [PoLíSz sorozat kötetei 7] \& <http://mek.oszk.hu/15100/15175>

Varga, Csaba (2012) Comparative Legal Cultures: On Traditions Classified, their Rapprochement \& Transfer, and the Anarchy of Hyper-rationalism. Budapest: Szent István Társulat 253 pp. [Philosophiae Iuris] \& <http://mek.oszk.hu/15300/15386>

Varga, Csaba (2012) The Paradigms of Legal Thinking. [1996/1999.] Enlarged 2nd ed. Budapest: Szent István Társulat 418 pp. [Philosophiae Iuris] \& <https://mek.oszk.hu/14600/14657/>

Varga, Csaba (2012) The Place of Law in Lukács' World Concept. [1981/1985.] 3rd (reprint) ed. with Postface. Budapest: Szent István Társulat 218 pp. \&<http://mek.oszk.hu/14200/14249/>

Varga, Csaba (2012) '...csak múlásunk törvény...' Varga Csaba jogfilozófussal beszélget Mezei Károly ['...only our passing away is a law...: The legal philosopher is interviewed...]. Budapest: Kairosz Kiadó 142 pp. [Magyarnak lenni CIII] \& <https://mek.oszk.hu/19800/19835/>

Varga, Csaba (2012) 'Humanity Elevating Themselves? Dilemmas of Rationalism in our Age' in Varga, Csaba Comparative Legal Cultures: On Traditions Classified, their Rapprochement \& Transfer, and the Anarchy of Hyper-rationalism. Budapest: Szent István Társulat 253 pp. [Philosophiae Iuris] \&<http:// mek.oszk.hu/15300/15386> on pp. 131-163

Varga, Csaba (2012) 'The Law's Homogeneity Challenged by Heterogenisation through Ethics and Economics', Acta Juridica Hungarica, 53(2), pp. 165-174 \& <https://akjournals.com/view/ journals/026/53/2/article-p165.xml>

Varga, Csaba (2012) 'Humanity Elevating Themselves? Dilemmas of Rationalism in our Age' in Varga, Csaba Comparative Legal Cultures: On Traditions Classified, their Rapprochement \& Transfer, and the Anarchy of Hyper-rationalism. Budapest: Szent István Társulat 253 pp. [Philosophiae Iuris] \&<http:// mek.oszk.hu/15300/15386> on pp. 131-163

Varga, Csaba (2012) The Paradigms of Legal Thinking. [1996/1999.] Enlarged 2nd ed. Budapest: Szent István Társulat 418 pp. [Philosophiae Iuris] \&<https://mek.oszk.hu/14600/14657/> 
Varga, Csaba (2012) The Place of Law in Lukács' World Concept. [1981/1985.] 3rd (reprint) ed. with Postface. Budapest: Szent István Társulat 218 pp. \& <http://mek.oszk.hu/14200/14249/>

Varga, Csaba (2012) '»Thing" and Reification in Law' [1978.] in Varga, Csaba (2012) The Place of Law in Lukács' World Concept. [1981/1985.] 3rd (reprint) ed. with Postface. Budapest: Szent István Társulat 218 pp. \& <http://mek.oszk.hu/14200/14249/> in Appendix, pp. 160-184

Varga, Csaba (2013) 'The Contemporaneity of Lukács' Ideas with Modern Social Theoretical Thought: The Ontology of Social Being in Social Science Reconstruction with Regards to Constructs like Law' Archiv für Rechts- und Sozialphilosophie, 99(1), pp. 42-54 \{reprinted in <http://elib.sfu-kras.ru/ bitstream/2311/19820/4/01_Varga.pdf $>$ \}

Varga, Csaba (2013) 'Az emberi jogok problematikája' [The problematics of human rights], Társadalomkutatás, 32(2), pp. 1-15 \{reprinted in <http://mek.oszk.hu/17900/17995/17995.pdf>, pp. 351-369\}

Varga, Csaba (2015) '»Méltón a sorshoz, alkalmas a küzdelemre« Szellemünk és tudományunk állapotáról' [»Dignified to fate, fit to fight « On the state of our spiritual and intellectual standing], Hitel, XXVIII(2), pp. 53-70 \& <http://www.hitelfolyoirat.hu/sites/default/files/pdf/o6-varga_o.pdf>

Varga, Csaba (2015) 'Ósnépeink jogszemlélete' [The legal mentality of our ancient ancestries], Hitel, 28(11), pp. 83-96 \& <http://www.hitelfolyoirat.hu/sites/default/files/pdf/17-varga.pdf>

Varga, Csaba (2016) '2oth-century Legal Philosophy in Hungary' in Pattaro, Enrico, Roversi, Corrado (ed.) Legal Philosophy in the Twentieth Century: The Civil Law World. Tome 1: Language Areas. Dordrecht: Springer xxxix+1062 pp. [A Treatise of Legal Philosophy and General Jurisprudence 12] \{\& $<$ https://b-ok.xyz/book/2742951/573fcd $>$ \}

Varga, Csaba (2019) 'Idol, Deduced from an Ideal? Rule of Law, Universalization, Degradation', Філособіiя права і загальна теорія права / Philosophy of Law and General Theory of Law [Kharkiv], (2), pp. 192-214 \& <http://phtl.nlu.edu.ua/article/view/204724>

Varga, Csaba (2019) 'Lenin and the Law: A Case-study on the Borders of Legal Normality', Central European Political Science Review, 20(No.75), pp. 131-179 \{radically shortened as (2020) 'Lenin, Vladimir I.' in Sellers, Mortimer, Kirste, Stefan (eds.) Encyclopedia of the Philosophy of Law and Social Philosophy. Dordrecht: Springer <https://doi.org/10.1007/978-94-007-6730-0_435-1>\}

Varga, Csaba (2020) 'Comparative Law and Multicultural Legal Classes: Challenge or Opportunity?' in Varga, Csaba (ed.) Comparative Law and Multicultural Legal Classes: Challenge or Opportunity? Cham, Springer x+212 pp. [Ius Comparatum - Global Studies in Comparative Law 46] \& <https://libgen. is/book/index.php?md5=0431D79329CDDF3B32B3AA506615CE73> on pp. 3-42

Varga, Csaba (2021) 'Encountering Comparative Law in Hungary', Journal of Comparative Law [London, Wiley], 16(1), pp. 243-264

Varga, Csaba (ed.) (1977) Modern polgári jogelméleti tanulmányok [Studies from modern western legal theory]. Budapest: Magyar Tudományos Akadémia Állam- és Jogtudományi Intézete 145 pp.

Varga, Csaba (ed.) (1981) Jog és filozófia: Antológia a század elsô felének polgári jogelméleti irodalma köréból [Law and philosophy: Anthology from western legal theory of the first part of the 2oth century]. Budapest: Akadémiai Kiadó 383 pp.

Varga, Csaba (ed.) (1992) Comparative Legal Cultures. Aldershot, Hong Kong, Singapore, Sydney: Dartmouth \& New York: The New York University Press xxiv+614 pp. [The International Library of Essays in Law \& Legal Theory, Legal Cultures 1]

Varga, Csaba (ed.) (1994) Coming to Terms with the Past under the Rule of Law: The German and the Czech Models. Budapest xxvii+178 pp. [Windsor Klub] \& <http://mek.oszk.hu/14300/14310/14310.pdf>

Varga, Csaba (ed.) (1998) Kiáltás gyakorlatiasságért a jogállami átmenetben [A cry for practicality in transition to the rule of law]. Budapest: [AKAPrint] 122 pp. [A Windsor Klub könyvei II] 
Varga, Csaba (ed.) (1999) Felix Somló: Schriften zur Rechtsphilosophie. Budapest: Akadémiai Kiadó xx+114 pp. [Philosophiae Iuris: Excerpta Historica Philosophiae Hungaricae] \& <http://mek.oszk. $\mathrm{hu} / 14800 / 14830 /$ index.phtml>

Varga, Csaba, Szájer, József (1989) 'Legal Technique' in Mock, Erhard, Varga, Csaba (eds.) Rechtskultur - Denkkultur: Ergebnisse des ungarisch-österreichischen Symposiums der Internationale Vereinigung für Rechts- und Sozialphilosophie 1987. Stuttgart: Franz Steiner Verlag Wiesbaden 175 pp. [Archiv für Rechts- und Sozialphilosophie, Beiheft 35] on pp. 136-147 \{reprinted in <http://mek.oszk. hu/15300/15333/\#>, pp. 187-198\}

Villey, Michel (1967) 'Histoire de la logique juridique', Annales de la Faculté de Droit et des Sciences économiques de Toulouse, XV(1), pp. 65-82

Vinx, Larx (2015) The Guardian of the Constitution: Hans Kelsen and Carl Schmitt on the Limits of Constitutional Law. Cambridge: Cambridge University Press ix+279 pp. [Cambridge Studies in Constitutional Law]

Varga, András Zs. (2019) From Ideal to Idol? The Concept of the Rule of Law. Budapest: Dialóg Campus 190 pp. Visegrády, Antal (ed.) (2003) Scandinavian Legal Realism / Skandináv jogi realizmus. Budapest: [Szent István Társulat] xxxviii+160 pp. [Philosophiae Iuris / Jogfilozófiák]

von der Bank, Erhard (ed.) (1992) A múlt feldolgozása a jogállam eszközeivel [Treatment of the past with the instrumentality of the rule of law]. Budapest: Konrad Adenauer Stiftung 96 pp. [Alapítványi kiadványok III]

von Mohl, Robert (1832) Die Polizeiwissenschaft nach den Grundsätzen des Rechtsstaates. Vol. I. Tübingen: Heinrich Laupp \&<https://babel.hathitrust.org/cgi/pt?id=uc1.b3132508\&view=1up\&seq=4>

Wade, William, Forsyth, Christopher (2009) Administrative Law. [1961.] 10th edn. Oxford \& New York: Oxford University Press lxxxix+898 pp.

Wahlgren, Peter (ed.) (2013) 'Soft Law' = Scandinavian Studies in Law 58. Stockholm: Stockholm Institute for Scandinavian Law 308 pp.

Waibel, Dieter (1996) Von der Wohlwollenden Despotie zur Herrschaft des Rechts: Entwicklungsstufen der amerikanischen Besatzung Deutschlands, 1944-1949. Tübingen: Mohr xx+410 pp. [Beiträge zur Rechtsgeschichte des 20. Jahrhunderts]

Waldron, Jeremy (2002) 'Is the Rule of Law an Essentially Contested Concept (In Florida)?', Law and Philosophy, 21(2), pp. 137-164

Waldron, Jeremy (2008) 'The Concept and the Rule of Law', Georgia Law Review, 43(1), pp. 1-61 \& $<$ https://digitalcommons.law.uga.edu/cgi/viewcontent.cgi?article=1028\&context=lectures_ pre_arch_lectures_sibley>

Walker, Geoffrey de Q. (1988) The Rule of Law. Carlton, Victoria: Melbourne University Press xxvi+475 pp. Wallerstein, Immanuel (2006) European Universalism: The Rhetoric of Power. New York: New Press xv+94 pp. Weber, Max (1919) Wissenschaft als Beruf. München \& Leipzig: Duncker \& Humblot 38 pp. \{reprinted in Weber, Max (1988) Gesammelte Aufsätze zur Wissenschaftslehre. [1922.] 7. Aufl. Tübingen: Mohr $\mathrm{xi}+613$ pp.\}

Weeks, Greg (2016) Soft Law and Public Authorities: Remedies and Reform. Oxford and Portland, Oregon: Hart Publising xxxiii+280 pp. [Hart Studies in Comparative Public Law 11]

Welcker, Carl Theodor (1813) Die letzten Gründe von Recht, Staat und Strafe philosophisch und nach den Gesetzen der merkwürdigsten Völker rechtshistorisch entwickelt. Gießen: Heyer 590 pp.

Wennerström, Erik O. (2007) The Rule of Law and the European Union. Uppsala: Iustus Förlag 354 pp. [Skrifter från Juridiska fakulteten i Uppsala 105] 
Weschler, Lawrence (1990) A Miracle, A Universe: Settling Accounts with Torturers. New York: Pantheon ix+293 pp.

West, Robin L. (1994) 'The Constitution of Reasons' [a review article on Cass R. Sunstein The Partial Constitution], Michigan Law Review, 92(6) pp. 1409-1437

Weyden, Peter (1984) Day One: Before Hiroshima and After. New York: Simon and Schuster 414 pp.

White, James Boyd (1973) The Legal Imagination: Studies in the Legal Thought and Expression. Boston: Little Brown xxxv+986 pp.

Whittaker, Charles E., Coffin, Jr., William Sloane (1967) Law, Order and Civil Disobedience. Washington, D.C.: American Enterprise Institute for Public Policy Research viii+156 pp. [Rational Debate Seminars 2]

Whyte, Jessica (2009) 'Particular Rights and Absolute Wrongs: Giorgio Agamben on Life and Politics', Law Critique 20(2), pp. 147-161 \& <http://www.academia.edu/325705/Particular_Rights_and_ Absolute_Wrongs_Giorgio_Agamben_on_Life_and_Politics>

Wirthné, Diera Bernadett (2015) Katolikus hitoktatás és elitképzés a Kádár-korszakban: Az 1961-es 'Fekete Hollók' fedőnevü ügy elemzése. [PhD Diss.] Budapest: Eötvös Loránd Tudományegyetem Bölcsészettudományi Kar 249 pp.

Woltag, Johann-Christoph (2014) Cyber Warfare: Military Cross-border Computer Network Operations under International Law. Mortsel: Intersentia xviii+314 pp. [International Law 14]

Woodhouse, A. S. P. (ed.) (1938) Puritanism and Liberty, Being the Army Debates (1647-1649) from Clarke Manuscripts with Supplementary Documents. London: J. M. Dent 506 pp.

[The World Bank Legal Vice Presidency] (2004) Initiatives in Legal and Judicial Reform. Washington, D.C.: The World Bank iii+101 pp. \& <http://documents1.worldbank.org/curated/en/139831468778813637/ pdf/250820040Edition.pdf>

Wronkowska, Sławomira (ed.) Polskie dyskusje o państwie prawa: Zarys koncepcji państwa prawnego w polskiej literaturze politicznej i prawnej. [Polish discussions on the state of law: summary of the concepts of the state of law in the Polish political and legal literature.] Warszawa: Wydawnictwo Sejmowe 140 pp.

Wyrzykowski, Mirosław (1995) 'Selected Problems of System Transformation' in Aregger, Josef, Poczobut, Jerzy, Wyrzykowski, Mirosław (eds.) Rechtsfragen der Transformation in Polen: Schweizerischpolnisches Kolloquium. Kraków: Wydawnictwo Baran i Suszczyńsi 317 pp. on pp. 9-33

Zétényi, Zsolt, Tárkány-Szücs, Attila (1991) in Új Magyarország [New Hungary; a daily], I(November30) (185), pp. $2 \& 4$

Zhu sha bao jun, Lu (1990) Diquan li: Bao jun fang fa li lun xin tan [The right of tyrannicide]. Chu ban / Taibei Shi: Shi ying chu ban she: zong jing xiao San min shu ju, Min guo 79 10+250 pp.

Zimmermann, Augusto (2007) 'Rule of Law as a Culture of Legality: Legal and Extra-legal Elements for the Realisation of the Rule of Law in Society', Murdoch University Electronic Journal of Law, 14(1) (textNo.2), <http://classic.austlii.edu.au/au/journals/MurdochUeJlLaw/2007/2.html>, pp. 10-31

Zlinszky, János (2003) 'Nyertesek és vesztesek a rendszerváltás során' [Winners and losers in the course of political transition] in Kiss, Daisy, Varga, István (eds.) Magister artis boni et aequi: Studia in honorem Németh János. Budapest: ELTE Eötvös Kiadó 1071 pp. on pp. 1015-1027

Zolo, Danilo (2007) 'The Rule of Law: A Critical Reappraisal' in Costa, Pietro, Zolo, Danilo (eds.) The Rule of Law: History, Theory and Criticism. Dordrecht: Springer xiv+695 pp. [Law and Philosophy Library 80] on pp. 3-71 
Yakushik, Valentin (2018) 'Varieties of a Law-Governed State', Ukrainian Policymaker, (No.3), pp. 72-84 \& <https://www.academia.edu/38103741/Yakushik_Valentin_Varieties_of_a_Law_Governed_ State_In_Ukrainian_Policymaker_2018_No_3_P_72_84>

Yale, D. E. C. (1971) 'Ex Turpi Causa Non Oritur Actio', The Cambridge Law Journal, 29(1), pp. 17-19

\section{SOURCES OF LAW}

\section{England}

Bridges v. Hawkesworth (1851), 21 LJ Queen's Bench 75

South Staffordshire Water Co. v. Sharman (1896), 2 Queen's Bench 44

Hannah v. Peel (1945), 1 King's Bench 509

\section{Czech Republic}

Constitution amended <https://www.psp.cz/en/docs/laws/1993/1.html>

Zákon... (9 July 1993)

Czech Constitutional Court decision No. 19 [Sp. zn. Pl. ÚS 19/93] on December 21, 1993, reprinted in extenso in Varga, Csaba (ed.) (1994) Coming to Terms with the Past under the Rule of Law: The German and the Czech Models. Budapest xxvii+178 pp. [Windsor Klub] \&<http://mek.oszk.hu/14300/14310/14310. pdf > on pp. 145-169

\section{European Union}

E.C.J., April 23, 1986, Les Verts v. Parliament, 294/83, Rec. 1339, \$ 23.

McCann and Others $v$ United Kingdom Series A, No 324, Application No 18984/91(1995) <https://hudoc. echr.coe.int/fre\#\{\%22itemid\%22:[\%22001-57943\%22]\}>

[European Commission for Democracy through Law (Venice Commission)] Report on the Rule of Law Adopted by the Venice Commission at its 86th plenary session (Venice, 25-26 March 2011) [Study No. 512 / 2009 CDL-AD(2011)003revOr. Engl.] \& <https:/www.venice.coe.int/webforms/documents/ default.aspx?pdffile $=\mathrm{CDL}-\mathrm{AD}(2011) 003 \mathrm{rev}-\mathrm{e}>$

\section{France}

Décision n85-197 DC du23août 1985 in <https://www.conseil-constitutionnel.fr/decision/1985/85197DC. htm>

\section{Hungary}

Constitution (1989)Act XL (June 19, 1990) Amending the Constitution of the Republic of Hungary $\{<$ https://oxcon.ouplaw.com/view/10.1093/law:ocw/cd405.regGroup.1/law-ocw-cd405?rskey=Etbt $\mathrm{CV} \&$ result $=179 \& \mathrm{prd}=\mathrm{OXCON}>\}$

Act on Amenability to Prosecution of Grave Crimes Committed, But Not Prosecuted for Political Reasons, Between December 21, 1944, and May 2, 1990, adopted by the National Assembly at its session of November 4, 1991

Constitutional Court decision no. 9/1990 (April 25) 
Constitutional Court decision no. 21/1990 (October 4) in <https://hunconcourt.hu/translations -summaries-old>

Constitutional Court decision no. 23/1990 (October 31) <https://hunconcourt.hu/dontes/decision-23 -1990-on-capital-punishment>

Constitutional Court decision no. 31/1990 (December 18) in Alkotmánybirósági Határozatok (1990), 136 et seq.

Constitutional Court decision no. 15/1991 (April 13) <http://jogiportal.hu/index.php?id=ued4efv12lnxii 6uy\&state $=19941224 \&$ menu $=$ view $>$

Constitutional Court decision no. 57/1991 (November 8) <http://www.codices.coe.int/NXT/gateway. dll/CODICES/precis/eng/eur/hun/hun-1991-c-001?fn=document $>$ frameset.htm $\$ f=$ templates $\$ 3.0$

Constitutional Court decision no. 11/1992 (March 5) <https://hunconcourt.hu/dontes/decision-11-1992 -on-the-retroactive-prosecution-of-serious-criminal-offenses $>$

\section{Germany}

Entwurfeines Allgemeinen Gesetzbuchs für die Preußischen Staaten von 1791

Grundgesetz (1949)

BVergGE 65, 1<https://www.servat.unibe.ch/dfr/bv065001.html>

1BVL14/76 [Urteil vom 21.06.1977] \& <https://openjur.de/u/60105.html>

VerjährungsG (26 March 1993)

2. VerjährungsG (27 September 1993)

\section{Israel}

Grunis, Asher, Judge in High Court of Israel (January 11, 2012) <https://www.jurist.org/ commentary/2012/02/jabareen-zaher-israel-citizenship/>

\section{Rome}

Ulpianus in D.50.17.54

\section{Switzerland}

Schweizerisches Zivilgesetzbuch (1907)

\section{USA}

Terminiello, 337 U.S. at 36 in 1949

Forman v. City Montgomery 245 F. Supp. 17, 24-5 (M.D. Ala. 1965) [Middle District of Alabama]

Williams v. Walace 240 F. Supp. 100, 106 (M.D. Ala. 1965)

Forti v. Suarez-Mason, 672 F. Supp. 1531, 1550 (N.D. Cal. 1988).

\section{Vatican}

Leo XIII, Pope (1891) On the Condition of the Working Classes / Rerum Novarum. Encyclical. \& <http://www. vatican.va/content/leo-xiii/en/encyclicals/documents/hf_l-xiii_enc_15051891_rerum-novarum. html>

Pius XI, Pope (1931) Quadragesimo Anno. Encyclical. \& <http://www.vatican.va/content/pius-xi/en/ encyclicals/documents/hf_p-xi_enc_19310515_quadragesimo-anno.html> 
John XXIII, Pope (1963) Pacem in Terris. Encyclical. \& <http://www.vatican.va/content/john-xxiii/en/ encyclicals/documents/hf_j-xxiii_enc_11041963_pacem.html>

John Paul II, Pope (1991) Centesimus Annus. Encyclical. <http://www.vatican.va/content/john-paul-ii/en/ encyclicals/documents/hf_jp-ii_enc_01051991_centesimus-annus.html>

\section{others}

United Nations

The Atlantic Charter (14 August 1941)

Final Declaration of the Regional Meeting for Asia of the 1993 United Nations Conference on Human Rights, 29 March - April 1993 [online]. Available at: <https://www.hurights.or.jp/archives/other_documents/ section1/1993/04/final-declaration-of-the-regional-meeting-for-asia-of-the-world-conferenceon-human-rights.html>

Commission on Security and Cooperation in Europe

The Copenhagen Meeting of the Conference on the Human Dimension of the CSCE (29 June 1990) $<$ https://www2.ohchr.org/english/law/compilation_democracy/csce.htm>

International Congress of Jurists

Declaration of Delhi (1959) <https:/www.icj.org/wp-content/uploads/1959/o1/Rule-of-law-in-a-free -society-conference-report-1959-eng.pdf $>\quad \& \quad<$ https://en.wikisource.org/wiki/Declaration of_Delhi>

Organisation for Economic Co-operation and Development (OECD)

Equal Access to Justice and the Rule of Law OECD Development Assistance Committee (DAC) Mainstreaming Conflict Prevention (2005) 



\section{INDEX}

'administration of justice' 27

Albania, see tradition

alienation of/by law 179

alternatives in law 199

American exceptionalism 309

amnesty, self- $210-211$

assistance, legal 101

auditoire universelle 62

Ausdifferenzierung 133

authority in law 92

autopoiesis 68

axiomatism in law $21-22$

bellum omnium contra omnes 76

Bible 181, 247

blockading in Hungary, taxi 158-159, 166-167

cahiers de doléance 65

Catholic social teaching 92-94, 97

Central Europe, the notion of 268-269

certainty of law vs justice in law in constitu-

tional adjudication in Hungary 124, 128,

$153,231,280,311$

civil disobedience 169-173, 174-178

- -, definition of $172-173$

- -, logic of 177-178

- society, dead, in Hungary 113

concept, see 'essentially'; Systembegriffe

conservatism vs reformism in law 80

constitutional court as negative Gesetzgeber 107

- courts' transjudicial communication 111

Constitutional Court of Germany 226-227, 279-280

- - - Hungary, activism of 104-131, 150,

$279-280$
- - - -, continuity with the past made by 123-127, 153

- - - -, decisionmaking of, referring to the

clause on 'rule of law' 108-111

- - - -, law importation by $105,108,114-116$

- - - -, private vs public law approach in 152

- - - -, usurpation by $112-113,151$

- - - - as power arrogator 127, 236

- - - - unfacing the past 231-232, 237-238

see also 'flying to and fro above law'

'constitutional criminal law' 117, 123, 232

constitutional identity 338-339

continuity of law 194-195

see also Constitutional Court of Hungary

cosmos/theos 262

criminal law, see 'constitutional criminal law'

cult de la loi, le 330

culture, legal, American 303-305

democracy, multi-party 290

- procedural, in Hungary 113

dignity, human 92-93

dissociation 295

'distinctively legal' 314

Doppelstaat 286

duplication of law 154

'end of history' 11

Entzauberung der Welt 148

'esprit philosophique' 150

'essentially contested concepts' 259, 322

exceptionality, see normality

expost facto $185,188,302$

- - - legislation 204, 239-240, 242-244, 308 
facing the past 294-295

- - -, German vs Hungarian approaches 126, 127, 235

- - -, legal defenses of 209-211

- - -, the moral background of 207

- - -, the politics of 206

-- , Spanish way 201

- - - failured in Hungary $123-127,129,140-141$

- - - - - - effects of $226-227$

- - - in Austria 203

- - - Belgium 204

- - - France 204

- - - Germany 203

- - - - Greece 205

- - - - Hungary, efforts at 222-224

- - - Italy 203

- - - - Israel 206

- - - Japan 204

- - - Portugal 205

- - - - Spain 205

fetishization of law, see nihilization

feudalism, reaction to 250

fight, real vs sublimed 181

'flying to and fro above law' in Hungary 131

friend vs enemy 286

gap in law, function of 189

Gattungswesen 63, 252

globalism in law 11, 63, 278

'Gott ist tot!' 48, 83, 261

gouvernment des juges 330

government in exile during WWI 189, 219

health as homeostasis 147

Hiroshima's bombing 98, 220

historicity 86

homogenization by/in law 155, 311-312

see also human rights

honeymoon period $13,79-80,120,268,272$

human rights $246-264$

- -, Buddhism on 260-261

- -, Confucianism on 262

- -, foundation of $250-256$

- -, Islamism on $262-263$

- -, nature of 256-259
- -, self-propelling of 255

- -, universality vs particularity of 259-264

- - as signifier of the West 260

- - homogenization of law 259

- - violations, the rights/duties of the successor state in case of 211,237

see also rule of law

ideology of juristic profession, see juristische imago Dei 94, 247

'immoral but lawful' 292

impacting like circus trainer vs gardener 156, 278,316

importation of law, see Constitutional Court of Hungary; transfer

individual vs the State in Hungarian constitutional court practice 117-121, 153

intellectuals 168

International Association of Democratic

Lawyers 319

International Commission of Jurists 319, 320

international humanitarian law 64

'invisible constitution' 78

ius vs lex 54, 84, 148, 162

'ius est ars boni et aequi' 85

ius resistendi 167

judicialization 47

'Juristen böse Christen' 154, 313

juristische Weltanschauung/Weltbild 66, 270, 314

justice, see certainty

Kazakhstan, see tradition

Korea, see transition

lagsaga 186

language of law 273

law, complexity of 212

-, definition of 134-135, 193

-, modern formal 148, 194

-, senses of 314

law's function $66,84,159$

- future 63-69

'Law \& Development' 90, 102 
law as art 85

- - game 69

- - means 182

legal force 24

legality, see rule of law

legalization by processualization $39-40$

Legislation, All-Soviet Institute of 65

libertinism 56

liberum veto 55

Lithuanian history 53,54

- trust in institutions $56-58$

localism of experience $59-60$

logic in law 218

logical submission in law 22-26, 81-82

lost property in law 41-42

media power 295

mentalité juridique 273, 276

method of distinguishing 27

mihi placet 290

modernization via law 90, 272

morality taken out of law 153

- within law 175

nationalism 293

natural law 63, 193, 251, 279, 329

- - exemplified by German law in Hungary 115

Natur der Sache, see natural law

nemo plus iuris 112

New Deal 57

nihilization vs fetishization of law 178 , 278-279, 307

normality presuming statutory limitation 190

- vs exceptionality $63,154,163,176,197,217$,

224-225

see also statutory limitation

nulla poena sine lege $207,239,240,328$

nullity of immoral transaction questioned 153

Nullum delictum nulla poena sine previo lege penale 229

nullum crimen sine lege 123, 207, 239, 240

nullum crimen sine lege constitutionali 117

Nuremberg trials 206, 219, 294

-- , effect of 203 obedience, due 209

ontology of law 134-135

- - societal totality $132-133$

open society / Open Society 51, 280, 293

optimum for law 38

order out of chaos 69,84

Ordnung vs Sonderordnung 154

ordo idea in law 34,92

pardon, self-, see amnesty

parliamentocracy 57

past to be faced, see Constitutional Court of

Hungary

permission in law 208

personalism, legal 58

Pécs, post-WWII 213-214

popular support, see rule of law

positionality of law 341

positivism, see socio-positivism

principles of law, overdomination by 77

--- , relativity of $67-68$

see also rule

prohibition, lack of 208

prophets' function 186

public, general clauses for protecting 96-97

public opinion supporting rule of law 181, 309

Quis custodiet ipsos custodes? 78

'radical evil' 200-202

radicalism in social transition 149

rationality, excessive, leading to irrationality

316

realism, see Scandinavian

Das Recht ist das Recht 10, 140, 317

Rechtsdogmatik 313

Rechtsstaat as Staatsform 9342

Rechtsstaatlichkeit 18-19, 20-26, 81, 82-83, 95, $162,329-330,331-332$

reciprocity in law 58

're-education to democracy' 98, 143-144, 267

reflective equilibrium 31, 63, 196

'reglas de los derechov humanos, las' 248, 327

regola transforming into regula 313

relativism, see value 
relevance, legal, questioned 161

responsibility avoided 306

- evaded 45

-, human 93, 173

retroactive, see ex post facto

revolution of 1956 in Hungary and aftermath

135-140

'right' in Japanese 263

rights complemented by duties $54-55,93,153$,

$258,306,314$

- , cost of 76

rule of law $81,85,163,195-196,220,297$,

307-310, 329

see also transition

rule of law, genuine content of 339-348

--- , definition of 337

- - -, English/German/French 330-333

- - -, military 34

- - - , senses of 324,336

- - - , uncertainty of 109-110, 322-323, 326, 346

- - - abandoned 339

- - - and human rights 53, 246, 253, 306, 342

- - - after WWII 318

- - - as ethos 53

- - - - historically particular ideal vs abstract universal claim 272

- - - justiciability 333

- - - legality 318

- - - means of blackmailing 319

- - - open ending 53,109

- - - - task 91

- - - unattainable 53

- - - weighing 85, 273

- - emptying $17,80,320-321$

- - - failures $75-78$

- - - in 1960s 9-10

- - - - Asia 333

- - - Cold War 318

- - - English past 302-303, 334

- - - European Commission 338

- - - - European Union 305

- - - - Organization for Economic Co-oper-

ation and Development 337

- - - - rejection of socialism 10

- - - - United Nations 336-337
- - - - World Bank 337

- - - limitlessness 322-327

- - - revolution 291

- - - to be defined by facts that constitute its case in law 347

- - - triumphing 320

- - - troubles in Hungary 276

- - - with/without popular support 217 see also 'suicide'

rule vs principle $31-32,198,314$

Russia, see tradition

sabotage judiciaire 312

salus rei publicae suprema lex esto 242

Scandinavian legal realism 274

social contract 163

socialist law as law 162

see also rule of law

societal totality, see ontology

socio-positivism, legal 64

soft law 311

Sozialrechtsstaat 54

stare decisis 327

statutory limitation 189, 197-198, 209-210

- - according to Act of 1991 of Hungary 228-230

- - - - - Constitutional Court of Hungary $228-237,311$

- - formalized $125-127$

- - in case of normality only $216-217$ see also normality

Stufenbautheorie 23

'suicide, rule of law cannot act as collective pact of' $218,272,307,345$

Systembegriffe vs Ordnungsbegriffe 28-31

systemicity vs pragmatism 150-151, 301

Szolnok artists' colony 96

tertium non datur in law 160, 165, 170-171, 194

tradition, legal, of Albanians 302

-, -, - Kazakhs 302

-, -, - Russia 275 
transfer of law, global 13, 101-102, 272

- - - into Hungary 105-106 see also Constitutional Court of Hungary

transformations in law 277

transition expectations $\quad 72-75$

- from dictatorship after WWII vs communism 143-144, 215

- - - - - - models of 267-270, 285-286

- - - imagined in Korea 283-284

- improvised 289

- to rule of law in Hungary $50-51,87-90$, 103-104, 112-113, 282-298

------- , burdening quests during 276

-------- denied as a period 268

- - - - - - preceded/hindered by academia, universitas, ecclesia 296

- - - - - programmed for 283, 299

-, American priorities for 293

trust in future 182

'turpit causa non oritur actio, Ex' 198

tyrannicide 138-139 universalism vs particularism 12

see also human rights; rule of law

'unjust but lawful' 154

USA interventionism 106

see also American; culture; transition

value conflicts in law 164, 310

- relativism 92

values, fundamental and instrumental 155

verbal magic $42-43$

veto right 57

Vorverständnis 62

Weltkrise 70

'West is best' 113, 169

wicked law 291

'worse for the facts, the' 59 


\section{INDEX OF SOURCES OF LAW}

\section{Babylon}

Codex Hammurapi 65

\section{Czech Republic}

Constitution (1993), Art. 1108

Zákon (9 July 1993) 226

Constitutional Court decision 19/1993 (December 21) 226, 242

\section{England}

Magna Carta (1215) 65, 248

Petition of Rights (1627) 248

Bill of Rights (1679) 248

Bridges v. Hawkesworth (1851), 21 LJ Queen's Bench 7541

South Staffordshire Water Co. v. Sharman (1896), 2 Queen's Bench 4441

Hannah v. Peel (1945), 1 King's Bench 50941

\section{European Union}

E.C.J., April 23, 1986, Les Verts v. Parliament, 294/83, Rec, 1339338

McCann and Others v. United Kingdom Series A, No 324, Application No 18984/91 (1995) 64

\section{France}

Déclaration des droits de l'homme et du citoyen (1789) 248-249, 252

Code civil (1804) 150, 313

Conseil constitutionnel decision 85/197 (23 août) 131

Conseil constitutionnel decision (December 29, 1998) 118

\section{Germany}

Allgemeine Gesetzbuch für die Preußischen Staaten, Entwurf (1791), Einleitung, Art. 79328

Grundgesetz (1949) 287, 343

-, Art. 2120

-, Art. 28(1) 330

- Art. 103(2) 240

VerjährungsG (26 March 1993) 226

2. VerjährungsG (27 September 1993) 226

1BVL14/76 (21. 05. 1977) 341

BVergGE (1983) 65118

\section{Hungary}

Magna Carta 65, 248

Golden Bull (1222) 180

Constitution (1989), Art. 1108

Constitution (1990) 281

- , Art. 1(2)/Art. 2(1) 108, 139, 151, 281, 290, 292

Constitution (1990), Art. 32110

Act IV of 1978228

Act on the Amenability to Prosecution... (November 4, 1991), Art. 1(1) 228, 294-295

Constitutional Court decisions 9/1990 \& 21/1990 116

Constitutional Court decision 23/1990 (October 31) 128

Constitutional Court decision 31/1990 (December15) 109, 231

Constitutional Court decision 57/1991 (November 8131

Constitutional Court decision 11/1992 (March 5) 123-127, 140, 228, 233, 294, 311, 233, 311

Government Decision No. 1025 (30 August 1990) 


\section{Israel}

Mosaic Law 26

High Court of Israel decision (11 January 2012) 345

\section{Lithuania}

Lithuanian Statutes $(1529,1566,1588) 53$

Constitution (1928), Art. 5157

Constitution (1992), Preamble 52

-, Art. 72-73 57

-, Art. 109(3) 54

Civil Code, Art. 47156

Criminal Code, Art. 10555

Constitution Court decision (December 9, 1998) 55

\section{New Hampshire}

Constitution (1784), Part I, Art. 23240

\section{Norway}

Constitution 239-240

\section{Rome}

Leges Duodecim Tabularum 65

\section{Switzerland}

Schweizerisches Zivilgesetzbuch (1907), Art. 1 (2) $82-83$

\section{United States of America}

Declaration of Independence (1776) 248

Bill of Rights (1789) 248

Constitution 44

Terminiello, 337 U.S. (1949) 307

Forman v. City Montgomery 245 F. Supp. 17,

24-5 (M. D. Ala. 1965) [Middle District of

Alabama] 172

Williams v. Wallace 240 F. Supp. 100, 106 (M. D. Ala. 1965) 172

Forti v. Suarez-Mason, 672 F. Supp 1531, 1550 (N.

D. Cal. 1988) 210

\section{International Documents}

The Atlantic Charter (1941) 249

Universal Declaration of Human Rights (1948)

$249,253,262,318,319$

European Convention of Human Rights (1953), Art. 2 \& 7229

Declaration of Delhi (1959) 336

International Covenant on Civil and Political Rights (1976) 116

Declaration on Fundamental Rights and Freedoms (1983) 116

Sixth Additional Protocol to the European Convention on the Protection of Human Rights and Fundamental Freedoms (1989) 116 Final Declaration of the Regional Meeting for Asia of the 1993 United Nations Conference on Human Rights, 29 March - April 1993 263

UN Secretary-General report (2004) (August 23) 337 


\section{INDEX OF NAMES}

Aarnio, Aulis 146

Abrahamson, Shirley S. 316

Ackerman, Bruce 126, 201, 206

Aczél, Zsongor László 136

Adamkus, Valdas 57

Adenauer, Konrad 137

Ajani, Gianmaria 90, 322

Alchourrón, Carlos E. 208

Alexa, Robert 254

Allan, T. R. S. 322

Allen, Francis A. 169

Altrichter, Helmut 343

Angyal Pál 241, 243

An-Na'im, Abdullahi Ahmad 262

Annan, Kofi 337

Antall, József 149, 215

Apáczai Csere, János 139

Arató, László 136

Arendt, Hannah 201

Aristotle 310

Aron, Robert 160

Arslan, Zühtü 261

Atienza, Manuel 334

Badoglio, Pietro 203

Baecker, Dirk 62

Bahar, Ayse 344

Baker, Paul R. 98

Bakshi, S. R. 175

Balkin, Jack M. 49

Balla, Péter 158

Balogh, Arthus 320

Barak, Aharon 307, 341

Barenboim, Peter D. 303

Barnett, Randy E. 305

Bartók, Béla 12-13
Bassiouni, Cherif 216, 228

Baxter, Simeon 138

Bay, Christian 173

Bayley, D. H. 93

Bárd, Petra 322, 326

Bárdfalvi, Ferenc 136

Beadini, Adem 302

Beale, Joseph H. 49

Beck, Gunnar 254

Bedner, Adriaan 324

Beitz, Charles 254, 255

Bellamy, Richard 325

Belton, Rachel Kleinfeld 324

Bence, György 184-185, 222

Benda, Julien 168

Benkő, Samu 185

Benson, Igboin 262

Bentham, Jeremy 252

Berecz, János 296

Berlin, Isaiah 43

Bernstein, Barton J. 98

Bernstein, Richard J. 201

Békés, Imre 227

Bibó, István 112, 163

Bigo, Pierre 92

Bihari, Mihály 227

Bihari, Ottó 9

Bingham, Tom 332, 334

Bloom, Allen David 36

Boas, Franz 262

Bobbio, Norberto 254, 260, 328, 334

Bockenförde, Ernst-Wolfgang 329

Bolgár, Vera 97

Boot, Eric R. 258

Borges, Jorge Luis 43

Bork, Robert H. 11, 95, 303 
Borneman, John 323, 334

Borucka-Arctowa, Maria 252

Botero, Adolfo Jerónimo 201

Bouloukos, Adam C. 323

Bourdrel, Philipe 160

Bowman, Helen 346

Bragyova, András 129, 227

Brandstetter, Wolfgang 227

Brazauskas, Algirdas 57

Brewster, David 43

Brietzke, Paul H. 90

Brinton, Crane 13

Brunner, Georg 107, 110, 120, 124, 128, 140-141, 233-234, 291

Buckley, F. H. 304

Bulygin, Eugenio 208

Buñuel, Luis 83

Burdeau, Georges 330

Burke, Edmund 252, 253, 271

Bükkösdi, László 136

Byrd, B. Sharon 227

Byrnes, James Francis 319

Caenegem, R. C. van 330

Calvin, Jean 139

Campos, Paul F. $38-48,84$

Carbonnier, Jean 150-151

Cardenas, Sonia 202

Cardozo, Benjamin N. 82, 112

Carothers, Thomas 319, 335

Carozza, Paolo G. 306

Carrera, Sergio 322, 326

Carré de Malberg, Raymond 330

Carroll, Lewis 119

Cassin, René 319

Ceaușescu, Elena 188

Ceaușescu, Nicolae 185, 188

Celsus 85

Chaffee, Wilber A. 202

Chambre, Ágnes 185, 222

Chaturvedi, Kameshwar Nath 308

Chesterman, Simon 342, 343

Chevallier, Jacques 326

Child, Tim 346

Chondzinskis, Jonas 53
Christoph, Johann, Freiherr von Aretin 329

Churchill, Winston 249, 289

Cicero, Marcus Tullius 247

Cimkauskas, Mykolas 54

Clark, David S. 273

Clark, Wesley 312

Clarke, David 344

Coffin, William Sloane, Jr. 170

Cohen, Stephen F. 51, 90, 180, 275

Cointet, Jean-Paul 160

Collier, David 322

Comenius, see Komenský

Confucius 262

Cooper, Judith 156

Copernicus, Nikolaus 68

Corres, Moisés Jaime Bailón 327

Costa, Pietro 322

Coville, Alfred 138

Craig, Paul P. 334, 335

Curran, Charles E. 153

Dakin, Brett 323

Dam, Kenneth W. 343

Darák, Péter 311

Dawisha, Karen 113

de Berg, Henk 11

de Castro, Marcus Faro 202

de Federico, Giuseppe 227

de Gaule, Charles 204

de las Casas, Bartolomé 248, 327

Delmas-Marty, Miraille 11

Delpeuch, Thierry 115, 121

del Vecchio, Giorgio 112

Descartes, René 261

Dhammapidok, Phra 260

Dicey, Albert Venn 10, 26, 81, 180, 281, 328

Diestelkamp, Bernhard 267

Dille, Denijs 13

DiPalma, Giuseppe 203

Дойчев, Момчил 48

Donnelly, Jack 259

Dorandeu, Renaud 105

Douzinas, Costas 314

Drahomaniv, Mykhaǐlo Petrovych 138

Drinóczi, Tímea 339 
Duguit, Léon 330

Duprat, Jean-Pierre 130

Dupré, Catherine 95, 104, 105-109, 111, 113, 114-122, 130, 231-232

Dworkin, Ronald M. 29-30, 40, 44, 60, 116, 170, 206, 298, 308, 323, 334

Dyevre, Arthur 331

Eagleburger, Lawrence S. 106

Eanes, Antonio Ramalho 205

Edgerton, Robert B. 84

Ehrlich, Eugen 23, 82, 112

Einstein, Albert 43

Ekins, Richard 303, 334

Eliot, George 301

Elslahin, Jean Belhhe 202

Elster, Jon 294

Endo, Ken 97

Engelmann, Frederick C. 203

Engels, Friedrich 62, 66, 252, 309

Fabbrini, Federico 339

Fallon, Richard H. 17, 80, 109, 281, 308, 322, 324, 327

Farkas Mihály 137

Fehér, Ferenc 113

Feuerbach, Paul Johann Anselm Ritter von 229

Ficzere, Lajos 342

Finnis, John 272, 307, 345

Fisch, Jill E. 244

Fischer, Michael J. 316

Fish, Stanley 30

Fiss, Owen M. 49, 202, 237

Fitschen, Thomas 306

Flake, L. Gordon 321

Fleck, Zoltán 145

Fletcher, George P. 292, 323

Flores, Imer 331

Ford, Franklin Lewis 139

Formosa, Paul 201

Forsyth, Christopher 329

Fortas, Abe 171

Foucart, Jacques 164

Franck, Thomas M. 273, 309

Frändberg, Åke 324
Fraenkel, Ernst von 137, 286

Franco, Francisco 205

Frank, Jerome 112

Frankena, William K. 172

Frederick II of Prussia 40

Freed, Fred 98

Freeman, Harrop A. 169, 173

Friedman, Lawrence S. 273

Friedmann, Wolfgang 98, 114, 267

Frivaldszky, János 60

Fukuyama, Francis 11, 304

Fuller, Lon L. 244, 334, 337

Fuller, Timothy 252

Füzér, Katalin 128

Gaius 247

Galanter, Marc 273

Gallie, Walter Bryce 259, 308, 322

Galtung, Johan 252

Gandhi, Indira 262

Gandhi, Mahatma 175, 177

Gardner, James A. 13, 215, 272, 310

Gardner, John 254

Garro, Alejandro M. 202

Garver, Eugene 322

Gaudemet, Jean 13

Gárdos-Orosz, Fruzsina 321

Geremek, Bronisław 202

Gessner, Volkmar 284

Gewirth, Alan 254

Gény, François 23, 112

Giovannitti, Len 98

Glaser, Stefan 210

Glendon, Mary Ann 38, 257, 306318

Glenn, H. Patrick 91, 302

Goldstein, Leslie Friedman 312

Gondge, Song 311

Goodman, Nelson 31

Goštautas, Albertas 53

Goti, Maime Malamud 207

Gowder, Paul 341, 343

Gönner, Nikolaus Thäddeus 328

Grajewski, Przemysław Żurawski vel 180

Granobles, Yuliana 201

Grant, Robert 93 
Gray, John Chipman 240

Gray, John N. 322

Greskovits, Béla 113

Griffin, James 253, 254

Groot, Hugo de 139

Grote, Rainer 326

Grotius, see Groot

Grudzinska-Gross, Irena 269

Grugel, Jean 117

Grunis, Asher 345

Guerra, Luis López 202

Guild, Elspeth 322, 326

Guven, Gulsum Gunbala 344

Habermas, Jürgen 60

Hager, Berry M. 333, 344

Haggard, Stephan 343

Hall, Robert T. $170,171,172$

Halmai, Gábor 130, 131, 177, 279

Hamara, Courtney Taylor 323

Hamvas, Béla 70

Hankiss, Elemér 70

Haocai zhu bian, Lui / Haocai, Luo 311

Harlow, Carol 312

Hart, H. L. A. 112

Harvey, Colin 105

Hasegawa, Ko 263

Havel, Václav 206, 238, 301, 316

Hayek, Friedrich August von 308, 309, 329, 332, 339,340

Hägerström, Axel 112

Hegedős, Soma 344

Hegel, Georg Wilhelm Friedrich 59

Helland, Eric 303

Helmke, Gretchen 202

Hempel, Carl G. 28

Henry IV French king 139

Herberger, Maximilian 154, 313

Herder, Johann Gottfried 185-186

Hermann, Joachim 227

Herz, John H. 203

Heydon, J. D. 334

Hickey, James E., Jr. 303

Hidalgo, Fernando Daniel 322

Higgins, Rosalin 323
Hinghofer-Szalkay, Stephan G. 110

Hirschl, Ran 303, 304, 309, 312

Hitler, Adolf 203

Hittinger, John P. 252

Hodgson, Douglas 258

Holmes, Oliver Wendell 18, 218

Holmes, Stephen 51, 60, 302

Hong, Joon-Hyung 344

Hongladarom, Soraj 260

Horovitz, Joseph 22

Horthy, Miklós 149

Horvath, Michael J. 180

Horváth, Sándor [Alexander] 112

Horváth, Barna 112

Howard, Philip K. 38, 48, 301, 304, 305, 312, 316

Howe, Daniel Walker 175

Höland, Armin 90, 269, 284

Hruschka, Joachim 227

Hufteau, Yves-Louis 312

Humphfreys, Stephen 321, 342

Huntington, Samuel F. 201, 216, 260

Huxley, Aldous 69

Huyse, Luc 222

Hyde-Price, Adrian G. V. 106

Ilesanmi, Simeon O. 262

Illyés, Gyula 185-186

Inada, Kenneth 261

Iseni, Arburim 302

Ivasivka, Mátyás 136

Jackson, Paul 329

Jackson, Robert H. 307

Jakab, András 130

Jajodia, Sushil 64

Jansa, Janez 333

Janse, Ronald 320

Jarry, Alfred 119, 156

Jászi, Oszkár 138

Jean, Jean-Paul 160

Jed, Stephanie 138

Jellinek, Georg 112, 248

Jennings, W. Ivor 329

Jescheck, Hans-Heinrich 216, 229

Jillek, Ilona 136 
John XXIII Pope 92, 93

John Paul II Pope 92, 94

Johnson, Frank M. 168, 171, 172

Jones, Dorothy V. 202

Jonas, Adolphe David 258

Jones, Drolay 202

Jörg, Arnold 55

Juhász, Zita 247

Jupine, Joseph 202

Jurgens, Erik 331, 334, 342

Kaganas, I. 57

Kalinowski, Georges 22

Kant, Immanuel 69, 201

Kantorowicz, Hermann 82, 112

Karamanlis, Constantine 205

Kardos, Gábor 255

Karstedt, Susanne 223, 295

Katz, Milton 318

Kaufmann, Arthur 221

Kautsky, Karl 66

Kádár, János 141

[Kárpáthy-]Kravjánszky, Miksa Mór 138

Kelemen, János 185, 222, 255

Kelsen, Hans 23, 107, 110, 112, 144, 155, 251, 330

Kende, Péter [Pierre] 112

Kennedy, Robert F. 305

Kick, Jonathan 303

Kilényi, Géza 108, 131

King, Martin Luther 177

Király, Tibor 227

Kirchheimer, Otto 188, 323

Kirkhill, Lord 216, 229

Klebelsberg, Kunó 149

Kelin, Doris 258

Kochenov, Dimitry 305, 322, 326, 344

Koestler, Arthur 69

Koetter, Matthias 330

Komenský, Jan Amos 179

Kommers, Donald P. 118, 120

Kondor, Katalin 103

Konopczyński, Ladislas 53

Kováts, Andor 242

Kovrig, Bennett 119

Krastev, Ivan 302
Kriele, Martin 227

Kronman, Anthony T. 38, 46, 47

Krygier, Martin Evald John 320, 326

Kubinyi, Ferenc 187

Kulcsár, Kálmán 38, 147, 214, 272, 281

Kuncze, Gábor 153

Kunstler, William 172

Kühn, Zdenek 279

Lamm, Vanda 227, 336

Landor, Walter Savage 138

Laquièze, Alain 210

Lautenbach, Geranne 322, 326, 333, 336, 338, 340,346

Lee, Leon H. 175

Legrand, Pierre 273

Lehmann, Hartmut 148

Lengyel, Emil 285

Lenin, V. I. 9, 146

Lenoir, Yves 12-13

Leo XIII Pope 92

Leonas, Petras 54

Leopold, Patricia 329

Leuprecht, Peter 229

Lewis, Angeline 346

Lewis, Anna Lisa Merklin 139

Lewis, John C. 138

Leyret, Henri 164

Lévai, Imre 130

Lietuvis, Mykolas 53

Lietzmann, Hans J. 344

Líndal, Sigurđur 186

Linz, Juan J. 12, 105, 113273

Liu, Shing-I 221

Livezeanu, Irina 188

Locke, John 252

Lomax, Bill 113

Losonczy, István 112

Lukács, György [George] 133, 134, 147

Lundstedt, Vilhelm 112

Lutaud, Olivier 138

Luther, Martin 154, 313

Lynch, William O. 285

Lyons, David 239, 337

Łetowska, Ewa 91, 143 
Macaulay, Thomas Babington 40

MacCormick, Neil 330, 334

Machiavelli, Niccolò 123, 233

MacIntyre, Andrew 343

Maciuceanu, Andra Olivia 322

Macridis, Roy C. 204

Madách, Imre 182

Magnaud, Paul 164

Majithia, Vishal 305

Majoros, Ferenc 230

Majtényi, László 117

Malamud-Goti, Faime

Mani prophet 121

Mann, Thomas 40

Mariana, Juan de 139

Marie, Jean-Bernard 259

Maritain, Jacques 252

Marmor, Andrei 308

Marsh, Norman S. 318

Marx, Karl 9, 62, 63, 86, 252, 254, 258, 260, 262, 296, 309

Matsuo, Hiroshi 343

Matsuura, Yoshihasu 101

Mattei, Ugo 90, 269, 322

Matusow, Allen F. 98

May, Christopher 325

Mayerhofer, Christoph 227

Mádl, Ferenc 149

McCormick, Richard A. 153

McCubbins, Mathew B. 308, 322

McVeigh, Timothy 39

McWilliams, Wilson Carey 168, 171, 172

Melkevik, Bjarne 12, 67, 200

Melson, Robert 64

Merkl, Adolf 23

Merryman, John Henry 273

Meyer, Frank S. 56

Méndez, Juan E. 126, 237, 294, 312

Mihalicz, Csilla 130

Michelman, Frank 49

Millán, Juan A. 202, 211

Miller, Arthur 225

Miller, David 252

Millon-Delsol, Chantal 97
Mirot, Léon 138

Mitchell, Michael 345

Molière 151

Montesquieu 22

Montgomery, John D. 98, 267

Moór, Gyula [Julius] 112

Moreso, J. J. 110

Morton. Louis 98

Moses 26

Mousnier, Roland 138

Mörth, Ulrika 311

Møller, Jørgen 324

Müller, Adam H. 329

Nader, Laura 322

Nagel, Thomas 207

Nagy, Péter N. 180

Naoya cho, Endō 311

Nedzel, Nadia E. 344

Neier, Aryeh 202

Neumann, Ulfried 221

Newman, Jeffrey 201

Newton, Isaac 43, 68

Nietzsche, Friedrich 48, 62, 83, 121, 261

Nino, Carlos Santiago 200-212, 223

Nisbet, Robert 92

Nobleman, Eli E. 267

Nojiri, Taketoshi 89

Nostradamus [Michel de Nostradame] 44

Novick, Peter 160

Nysanbayev, Abdumalik 302

Oakeshott, Michael 340

Offe, Claus 12

Olivecrona, Karl 112

Olson, Walter 305, 312

Opałek, Kazimierz 10, 329

Oppenheim, Paul 28

Orbán, Viktor 70, 150, 177, 184

Orentlicher, Diane F. 201, 211, 223

Ortega y Gasset, José 83, 257, 271

Orwell, George 69

Oshimura, Takashi 344

Overton, Richard 248

Ozpolat, Asli 344 
Ozsoy, Ferda Nakipoglu 344

Paine, Thomas 248,328

Pandeya, R. C. 254, 263

Papp, Zsolt 163

Pasternak, Boris 137

Patil, V. T. 175

Pattaro, Enrico 274

Pech, Laurent 338

Peerenboom, Randall 321, 335, 340

Pennington, Kenneth 327

Pereira, Anthony 202

Perelman, Chaïm 22, 62, 189, 298

Perjés, Gábor 228

Petrazicky, Leo 112

Pettenkofen, August von 96

Pérez-Díaz, Victor 205

Péteri, Zoltán 342

Phillips, Owen Hood 329

Pildes, Richard H. 339

Pius XI Pope 92

Placidus [Petersen], Johan Wilhelm 329

Pokol, Béla 95, , 303

Polanyi, Karl 254

Pollis, Adamantia 262

Portalis, Jean-Étienne-Marie 80, 150

Posner, Eric A. 122, 232, 271

Posner, Richard A. 60

Pospíšil, Leopold 187

Pound, Roscoe 112

Power, Paul F. 168, 172

Presa, Conceptión Gimena 202

Přibán̆, Jiří 109, 130, 231

Psomiades, Harry J. 205

Prochazka, Radoslav 10

Radbruch, Gustav 28, 112, 137

Radin, Margaret Jane 49

Rau, Zbigniew 180

Rawls, John 31, 46, 60, 63, 196

Raz, Joseph 307, 334, 335

Rákosi, Mátyás 141

Redford, L. H. 267

Redstone, Anne 243

Reid, John Philip 303
Reinsch II, Richard M. 305

Reményik, Sándor 137

Renteln, Alison Dundes 261, 263

Reynolds, Noel B. 84, 339

Rheinstein, Max 318

Rodriguez, Daniel B. 308, 322

Roht-Arriaza, Naomi 210

Roizijus, Petras 53

Rommen, Heinrich 114

Ronen, Dov 152

Roosevelt, Franklin Delano 57, 319

Rosenfeld, Michel 202, 338

Rosenzweig, Paul 64

Roshwald, Mordecai 249

Ross, Alf 112

Rothwax, Harold J. 38

Rotundas, Augustinas 53

Roubier, Paul 243

Rousseau, Jean-Jacques 66, 331

Roven, Herbert H. 149

Römeris, Mykolas 54, 53

Rucker, Darnell 169

Rumi, Tamás 127, 236

Rückert, Adalbert 203

Rüthers, Bernd 312

Sack, Peter 273

Sadoun, Mohamed 164

Sadurski, Wojciech 106, 117, 122, 123, 124-127, 129, 232, 234-236

Sajó, András 60, 105, 128, 246, 255, 263, 272, 338, 339

Salisbury, John of 139

Sampford, Charles 308

Sanderson, M. A. 130

Santamaría, Julian 205

Sapiega, Leonas 53

Scalia, Antonin 334

Schanda, Balázs 108

Schivelbusch, Wolfgang 285

Schlag, Pierre 48, 49, 347

Schlesinger, Rudolf B. 318

Schlett, István 227

Schmitt, Carl 62, 63, 112, 137, 270, 286, 321

Schnarr, Karl Heinz 227 
Schneider, Peter 114

Scholler, Heinrich 272

Schooyans, Michel 93, 94, 106

Schwab, Peter 262

Schwartz, Herman 114

Schwartz, Howard S. 48

Sela, Ylber 302

Sellers, Mortimer 333, 335

Selznick, Philip 62, 314, 322, 335

Senden, Linda 311

Sereg, András 122

Sforza, Carlo 203

Shakarian, Paulo 64

Shakespeare, William 142-143

Shklar, Judith N. 206, 306, 321

Shlapentokh, Vladimir 90

Silkenat, James R. 303

Simpson, O. J. 39

Skaaning, Svend-Erik 324

Skarga, Petras 53

Slaughter, Anne-Marie 111

Smith, Steven D. 48

Soares, mario 205

Solzhenitsyn, Alexander I. 47

Somló, Bódog [Felix] 112, 185, 239

Sophocles 250

Шопов, Ангел 311

Sorokin, Pitirim Aleksandrovics 268

Soros, George 292, 294

Sólyom, László 103, 107, 108, 109, 116, 117, 120, $122,124,126,128,129-131,140-141,149,155$, 209, 231, 233-235, 237, 268, 291

Spengler, Oswald 64

Stahl, Friedrich Julius 329

Stalin, J. V. 11, 17, 152, 168

Stammler, Rudolf $63,82,112$

Starr, June 272

Stein, Ekkehart 54

Stepan, Alfred 12, 105, 113, 273

Stewart, Cameron 335

Stintzing, Johann August Roderich von 154

Strasser, Christine 96

Suarez, Francisco 248

Subrahmanian, V. S. 64

Summers, Robert 334
Sunstein, Cass R. 60

Swain, Nigel 177

Swarup, Vipin, 64

Sweet, Alec Stone 312

Sweet, William 253

Šejvl, Michal 12

Szabo, Denis 93

Szabó, András 117, 123, 232

Szabó, Imre 214, 252

Szabó, József 112

Szamel, Lajos 9

Szamuely, Tibor 145

Szájer, József 241

Szászy, István 241

Szente, Zoltán 321

Szotáczky, Mihály 9

Sztodolnik, László 9, 342

Szû́cs, Jenő 268

Szûk, László 227

Taiwo, Olufemi 325

Takács, Albert 342

Takács, Péter 126, 128, 235, 320

Tamanaha, Brian Z. 323

Tate, C. Neal 312

Tárkány Szücs, Attila 229

Téglási, András 303

Teitel, Ruti 108, 109, 119, 121, 126, 128, 129, 235, 237

Teubner, Gunther 69

Thomas Aquinas, St 112, 252

Thoreau, Henry David 175, 177, 249

Tiede, Lydia 343

Tiedemann, Arthur E. 204

Tiedemann, Paul 342

Tilk, Péter 153

Tito, Josip Broz 137

Tocqueville, Alexis de 47

Tocsik, Márta 153

Tolley, Howard B. 319

Torańska, Teresa 137, 292

Torbjörn, Vallinder 312

Tordai, Csaba 131, 279

Tóth, János 318 
Tracz-Tryniecki, Marek 180

Trnavci, Genc 302

Troper, Michel 330

Trubek, David M. 273

Trujillo, Isabel 306

Truman, Harry S. 319

Turchetti, Mario 139

Udvaros, Judit 238

Uitz, Renáta 130

Ulpianus 112

Utz, Arthur Fridolin 89, 97

Vaišvila, Alfonsas $52-54,58-60,93$

Vanwelkenhuyzen, A. 189

Varga, Zs. András 300, 306

Vas, Tibor 112

Verhaegen, Jacques 227

Vermeule, Adrian 122, 232, 271

Vékás, Lajos 152, 227

Villey, Michel 28

Vinx, Larx 110

Visegrády, Antal 274

Vitoria, Francisco de 139

Volanas, Andrius 53

Von Bülow, Claus 227

von der Bank, Erhard 227

von Mohl, Robert 329

Vörös, Imre 131, 279

Vyshinsky, A. Y. 11

Wade, William 329

Wahlgren, Peter 311
Waibel, Dieter 267

Waldron, Jeremy 309, 322, 325

Walker, Geoffrey de Q. 324

Wallerstein, Immanuel 306

Wang, Cliff 64

Weber, Max 23, 46, 112, 148

Weeks, Greg 311

Weingast, Barry R. 308, 322

Welcker, Carl Theodor 329

Wennerström, Erik O. 332

Weschler, Lawrence 207

West, Robin L. 44

Weyden, Peter 98

White, James Boyd 63

White, Jessica 252

Whittaker, Charles E. 170

Wiesenthal, Simon 216

Wirthné, Diera Bernadett 136

Woltag, Johann-Christoph 64

Woodhouse, A. S. E. 248

Wronkowska, Sławomira 52

Wyrzykowski, Mirosław 131

Zétényi, Zsolt 129, 216, 227-229

Zhu sha bao jun, Lu 139

Zimmermann, Augusto 322

Zincani, Vito 227

Zlinszky, János 131

Zolo, Danilo 329, 330, 335

Žižek, Slavoj 252

Yakushik, Valentin 324

Yale. D. E. C. 198 

The rule of law has become a watchword in international politics over the last few decades. It has been transformed from a descriptum into a prescriptum, a criterion for judging legal orders, transferred from the legal to the political sphere. For Hungary, its impact coincided with the dissolution of the Soviet empire and the advance of globalization in our unipolar world. But what did not become, could not become, an operative term in law, since it is not linked to a definition of facts that would allow it to become legally ascertained and established as a set of facts constituting a legal case. Because, by its very nature, it is not a class concept with sharp boundaries, but a concept of order that can only be clarified by characterization and through examples. It is what literature calls essentially contested, and what institutions and authors are constantly expanding with competing formulations, which has long since led to its internal emptying out. In its origin and development, it has never been anything other than the accumulated experience of civilizational self-growth in the operation of the law by the state, which has evolved in responses to the challenges of various places and times. That is, it is particular. And the way in which our present attempts to universalize this-in which, of course, mutual learning processes between nations and ages are also involved-is a mere artificial projection, which conceals the West's urge to export the values that guide it. Not a yes or no category, but an ideal towards which we strive. Contradictory, with compromises, because if we attempted to satisfy it in its entirety, the conflicting values within it could extinguish each other; consequently, only a caseby-case weighing up of these values can ensure that a balance, optimally satisfactory there and then, is achieved.

The volume contains the author's writings from three decades of searching for a way forward and a response.

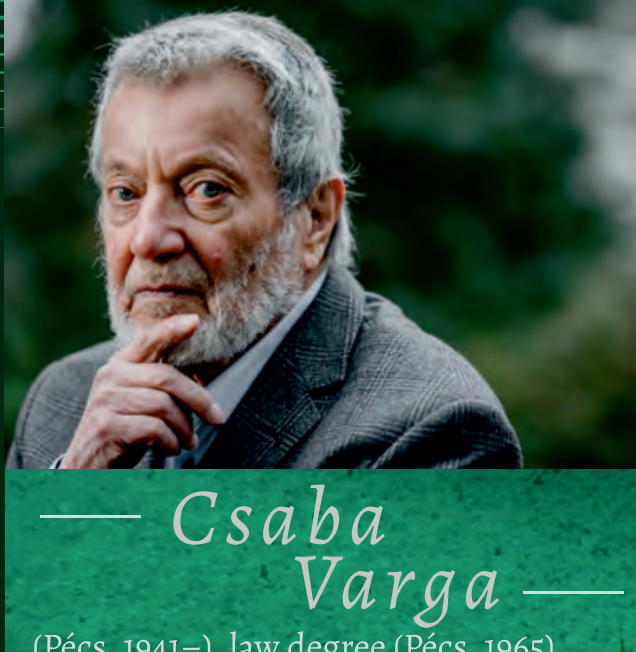

(Pécs, 1941-), law degree (Pécs, 1965). Researcher at the Institute for Legal Studies of the Hungarian Academy of Sciences (1965-), presently Research Professor Emeritus (2011-). Associate Professor, then Professor at the Faculty of Law of Eötvös Loránd University (1982-2002). Professor at the Faculty of Law of Pázmány Péter Catholic University (1995-), founder director of its Institute for Legal Philosophy (with honor as a 'Place of Excellence' in Hungary), presently Professor Emeritus (2011-). CSc (1976), DSc (1992); Széchenyi-prize (2013). Member of the Advisory Board to the Prime Minister of the Republic of Hungary (1992-1994); member of the International Academy of Comparative Law (2002-).

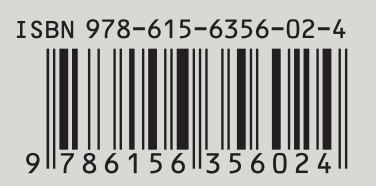

